\title{
Poticaji za bioetičko promišljanje odnosa kulture i prirode u djelu Nikole Viskovića
}

Guć, Josip

Doctoral thesis / Disertacija

2021

Degree Grantor / Ustanova koja je dodijelila akademski / stručni stupanj: University of Zagreb, Faculty of Humanities and Social Sciences / Sveučilište u Zagrebu, Filozofski fakultet

https://doi.org/10.17234/diss.2021.8879

Permanent link / Trajna poveznica: https://urn.nsk.hr/urn:nbn:hr:131:464410

Rights / Prava: In copyright/Zaštićeno autorskim pravom.

Download date / Datum preuzimanja: 2023-04-26

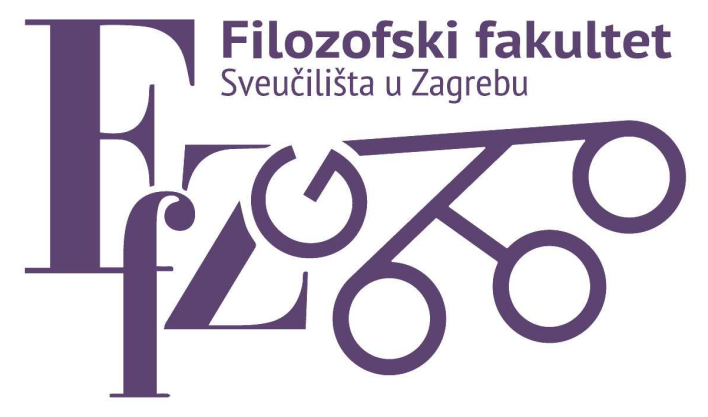

Repository / Repozitorij:

ODRAZ - open repository of the University of Zagreb Faculty of Humanities and Social Sciences
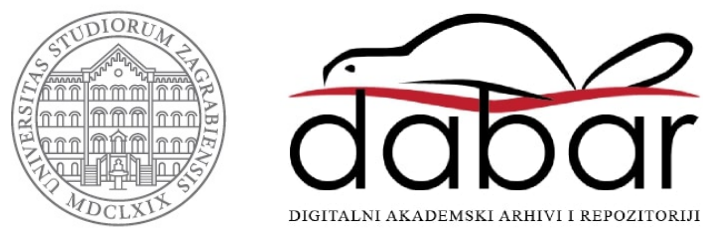


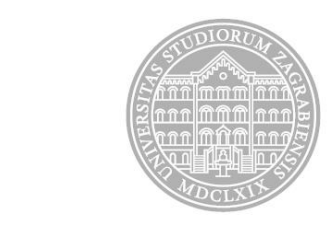

Sveučilište u Zagrebu

Filozofski fakultet

Josip Guć

\section{POTICAJI ZA BIOETIČKO \\ PROMIŠLJANJE ODNOSA KULTURE I \\ PRIRODE U DJELU NIKOLE VISKOVIĆA}

DOKTORSKI RAD

Zagreb, 2021. 


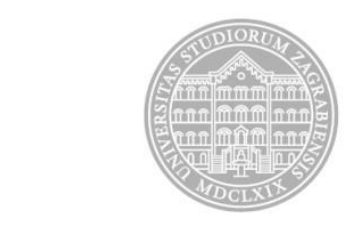

Sveučilište u Zagrebu

Filozofski fakultet

Josip Guć

\section{POTICAJI ZA BIOETIČKO PROMIŠLJANJE ODNOSA PRIRODE I KULTURE U DJELU NIKOLE VISKOVIĆA DOKTORSKI RAD}

Mentor: prof. dr. sc. Hrvoje Jurić

Zagreb, 2021. 


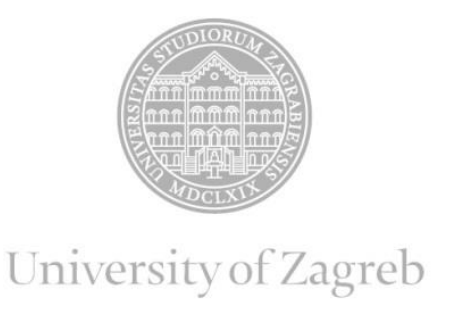

Faculty of Humanities and Social Sciences

Josip Guć

\section{INCENTIVES FOR THE BIOETHICAL CONSIDERATION OF REATIONSHIP BETWEEN CULTURE AND NATURE IN NIKOLA VISKOVIĆ'S WORK} DOCTORAL THESIS

Supervisor: Prof. Hrvoje Jurić, Ph.D. 


\section{PODACI O MENTORU}

Prof. dr. sc. Hrvoje Jurić* (Bihać, Jugoslavija / Bosna i Hercegovina, 1975.) redoviti je profesor na Odsjeku za filozofiju Filozofskog fakulteta Sveučilišta u Zagrebu. Nakon završene osnovne i srednje škole u rodnom gradu, od 1993. do 1998. studira filozofiju i komparativni studij hrvatske kulture na Hrvatskim studijima Sveučilišta u Zagrebu, a od 1998. filozofiju na poslijediplomskom doktorskom studiju na Filozofskom fakultetu Sveučilišta u Zagrebu. Studij završava 2007. obranom doktorske disertacije Etika odgovornosti Hansa Jonasa. Na Filozofskom fakultetu Sveučilišta u Zagrebu zaposlen je od 2000., gdje je do 2019. napredovao od znanstvenog novaka do redovitog profesora.

Jurić je od samih začetaka ideje i projekata vezanih uz koncept integrativne bioetike jedna od središnjih figura u njezinu razvoju. U institucionalnom pogledu, od 2013. (tj. od osnivanja) do 2018. obnaša dužnost glavnog tajnika, a od 2018. voditelja Centra za integrativnu bioetiku Filozofskog fakulteta Sveučilišta u Zagrebu, od 2014. (tj. od proglašenja) suradnik je, zatim glavni tajnik i zamjenik voditelja Znanstvenog centra izvrsnosti za integrativnu bioetiku, od 2017. (tj. od osnivanja) voditelj je Sveučilišnog centra za integrativnu bioetiku Sveučilišta u Zagrebu. Dužnost predsjednika Hrvatskog bioetičkog društva obnaša od 2016. do 2020. Izvršni je urednik biblioteke »Bioetika« u izdavačkoj kući Pergamena od 1998. do 2004., a pomoćni urednik biblioteke »Filozofska istraživanja« u izdanju Hrvatskog filozofskog društva te časopisā Filozofska istraživanja i Synthesis philosophica.

Sudjeluje u mnoštvu projekta, organizacijskih i programskih odbora međunarodnih simpozija i u njihovoj izvedbi kao predavač. Pored pedesetak znanstvenik i više od dvjesto stručnih, esejističkih i publicističkih članaka, objavljuje pet autorskih knjiga i tri suurednička znanstvena zbornika:

- [suurednice Gordana Bosanac i Jasenka Kodrnja] Filozofija i rod, Hrvatsko filozofsko društvo, Zagreb 2005.

- Etika odgovornosti Hansa Jonasa, Pergamena, Zagreb 2010.

- [suurednik Sead Alić] Filozofija i mediji, Hrvatsko filozofsko društvo - Centar za filozofiju medija i mediološka istraživanja, Zagreb 2014.

\footnotetext{
* Podaci o mentoru preuzeti s: »Prof. dr. sc. Hrvoje Jurić«, Odsjek za filozofiju Filozofskog fakulteta Sveučilišta u Zagrebu. Dostupno na: https://filoz.ffzg.unizg.hr/nastavnici/hrvoje-juric/ (pristupljeno 21. 2. 2021.).
} 
- Izazovi humanizma, Hrvatsko filozofsko društvo, Zagreb 2018.

- Tekst i kontekst bioetike, Pergamena - Znanstveni centar izvrsnosti za integrativnu bioetiku, Zagreb 2019.

- Euforija i eutanazija. Akutni zapisi o kroničnim problemima, Sandorf - Mizantrop, Zagreb 2019.

- $\quad$ [suurednik Ante Čović] Integrativno mišljenje i nova paradigma znanja, Pergamena Hrvatsko filozofsko društvo - Znanstveni centar izvrsnosti za integrativnu bioetiku, Zagreb 2019.

- Pandemija kao simptom, DAF, Zagreb 2021. 


\section{ZAHVALE}

Imao sam sreću da za vrijeme izrade ove disertacije imam čest kontakt s jednim od njezinih središnjih »predmeta«, samim Nikolom Viskovićem. Premda sam izbjegavao da druženje i razgovori s njim utječu na samo pisanje ovog rada, niti je on takvu želju ikada izrazio, ne mogu reći da mu ne dugujem zahvale zbog brojnih poticaja za nj, prvenstveno u pogledu uzoritog, sveobuhvatnog i odgovornog pristupa materiji koji nije samo objedinjen u objavljenim tekstovima (čega sam se gotovo u potpunosti držao pri obradi njegove misli), nego ne izostaje ni u razgovorima i uopće u njegovu životnom duhu.

Zahvalu dugujem i svima ostalima koji su dali svoj neizostavan doprinos izradi ove disertacije putem sugestija, savjeta, pribavljanja materijala i usluga raznih vrsta. Tih je osoba zaista mnogo i bojim se da bih njihovim poimeničnim navođenjem vlastitom krivnjom uvrijedio one od njih koje bi nepravedno bile izostavljene. No nadam se da se nespomenute osobe neće naljutiti ako ovdje ipak istaknem jedno ime, a riječ je o Hrvoju Juriću, neumornom mentoru, ali prije svega prijatelju, koji je pružao nebrojene intelektualne poticaje tijekom pisanja ove disertacije, kao i pomoć u radu koji je se neizravno doticao. Bez njegove podrške, izrada ovog rada bila bi znatno otežana. 


\section{SAŽETAK}

Cilj je ovog rada ukazati na određene elemente u bioetički relevantnom djelu hrvatskoga pravnika, kulturologa, političkog aktivista i intelektualca Nikole Viskovića (1938.), kao i u samom bioetičkom diskursu, koji su plodni za ponovno filozofsko promišljanje pojmova kulture i prirode te njihova međusobnog odnosa. Viskovićevo djelo, a posebno radovi koji razvijaju koncepte kulturne zoologije i kulturne botanike, poslužit će kao osnova za sagledavanja vrste i intenziteta bliskosti odnosno udaljenosti u odnosu prirodnog i kulturnog. Posebna pozornost bit će posvećena etičkim implikacijama ovog odnosa, tj. potencijalnim doprinosima Viskovićeve misli izgradnji koncepta integrativne bioetike te razmatranju etičkih argumenata o smislenosti moralnog obzira spram ne-ljudskih živih bića i prirode u cjelini. Temeljna je hipoteza da je Viskovićev doprinos promišljanju ovih problema moguć na temelju njegova svestranog sagledavanja međuodnosa čovjeka i drugih živih bića, kao i plodnih elemenata za značenjsko obogaćivanje koncepta bioetičkog senzibiliteta. Pri tome se dodatno sistematiziraju neki razdvojeni dijelovi Viskovićeva rada, ali se i na idejnom poticaju njegovih koncepata i ideje integrativne bioetike nadograđuju njihovi misaoni dosezi.

Ključne riječi: Nikola Visković, integrativna bioetika, kultura, priroda, kulturna zoologija, kulturna botanika, etika, bioetički senzibilitet. 


\section{STRUCTURAL SUMMARY}

Nikola Visković (1938) is one of the Croatian pioneers in bioethics, particularly regarding the introduction of non-human living beings into bioethical considerations. His contribution to these considerations is not only contained in the so-called fields of animal or environmental ethics and law (his main vocation being legal theorist), but in a complex pluriperspective insight into the relationship between culture (human being) and nature, mostly presented in the books Animal and Man and Tree and Man. Throughout these Visković (mostly implicitly) demonstrated that comprehensive insight into the moral issue of regard toward nature and other living beings cannot be done without an understanding of this complex relationship, i.e. without the contribution of different scientific and non-scientific perspectives. In that manner, Visković's work follows a similar path as integrative bioethics. Hence, this paper has two main aims: to locate the incentives for re-thinking the culture-nature relationship in Visković's work and to demonstrate how it can contribute to the construction of the stillyoung field of integrative bioethics.

After Visković's biography, in which his actions in the Zelena akcija Split (Green Action, Split) organization are specially considered, the paper reflects on the concepts of culture and nature. Culture is defined formally, as the specific mode of human existence or the specific mode in which they mediate the object (including themselves) they relate to, and not substantially as a number of certain traits. It is also shown that Visković's idea of culture in most parts follows this determination, namely as a specificity of what man builds out of and above nature, or as the process of denaturalization. The concept of nature is further explained through the historical shifts of its understanding, where one of the main ideas is Visković's notion of forgetfulness of nature.

In order to overcome this phenomenon, Visković forms the concepts of cultural zoology and cultural botany (under the common name of cultural biology), which are presented in detail. Both of them are explained through spiritual and material aspects, as well as through the aspect of maltreatment. The spiritual aspects of both cultural zoology and cultural botany are explained through scientific and philosophical reflections of the nature of animals and plants respectively. Special regard is then given to the examination of anthropomorphism, zoomorphism, and fitomorphism, as well as to the places which animals and plants occupy in myths, religions, 
arts, and politics. In the cultural-zoological part, the paper also reflects on the thesis that animals can have language and culture, which are both discredited regarding conclusions made earlier. However, in the cultural-botanical part additional reflections on forgetfulness of nature are made, more precisely through the presentation of Visković's detection of forgetfulness of wood as the matter. Other material aspects of cultural zoology are the usage of wood as fuel and weapons, usage of plants for healing and their cultivation. Material aspects of the human-animal relationship are presented through the phenomena of diet and domestication. Finally, maltreatment of non-human living beings is reflected through war, hunting, entertainment, scientific experiments, industrial farms and slaughterhouses, exterminations of species, forests, and individual animals and plants.

Following the fact that Visković opened his concept of culture not only for destruction but also for the appreciation of nature, the paper examines Visković's ethical position, tries to find the connections between his the mostly Marxist approach of the earlier and biocentric approach of the later phase, presents philosophical influences on his position by examining and criticizing ethical theories of Arthur Schopenhauer, Peter Singer, Tom Regan, Aldo Leopold, and Arne Næss, etc. Visković often discredits Marxism due to the lack of appreciation for nature. However, the paper tries to partly rehabilitate Marxist thought for bioethical purposes, primarily as a valuable tool for recognizing shortcomings of techno-scientific rationality and material conditions which make moral regard toward every living being more difficult. It can also be helpful for ethics which is focused on the concept of self-realization. Some other concepts, as moral rights and sustainable development, are also reflected and criticized in this chapter. One of its main goals is not only to criticize Visković's position but to make it more coherent and to demonstrate which incentives for all-encompassing ethical theory (here based on the concept of self-realization and various traditions) can be found in his thoughts.

Finally, the paper presents the history of the idea of bioethics and particularly integrative bioethics. It shows that Visković's potential contribution to the latter can be especially found in the enrichment of the concept of bioethical sensibility, through Visković's reflections on the familiarity of culture toward nature (with all of its desirable and undesirable consequences), anthropomorphism, and the relationship between sensibility and rationality, which both must be employed in order to heal human being's relationship with nature. Visković's contribution can also be observed by recognizing many similarities which his concept of bioethics shares not only with the integrative bioethics but also with the two fathers of bioethics: Van Rensselaer Potter and Fritz Jahr. This chapter also includes Visković's reflections on medical ethics and erotica, both examined through a wider bioethical viewpoint, as well as the question: should 
Visković be held a postmodernist and integrative bioethics a postmodernist endeavor? The paper stresses that both would not be adequate, even though there are certain reasons for the former conclusion.

The last part of the paper tries to summarize the issue of the culture-nature relationship by examining the normative dimension of both these concepts. One of the main conclusions is that culture and nature should be distinguished exactly in order to make a foundation for moral regard toward the latter.

Key words: Nikola Visković, integrative bioethics, culture, nature, cultural zoology, cultural botany, ethics, bioethical sensibility. 


\section{SADRŽAJ}

UVOD 1

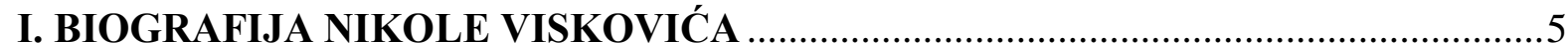

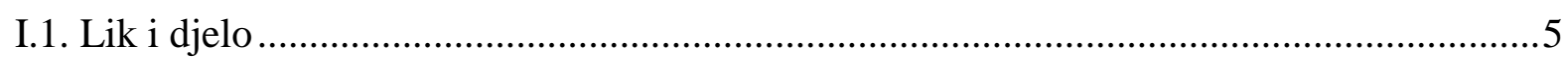

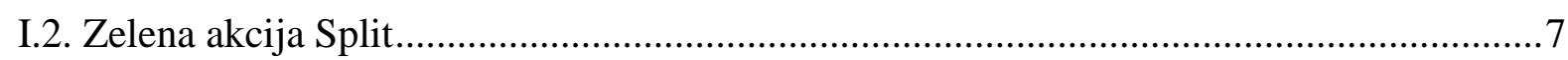

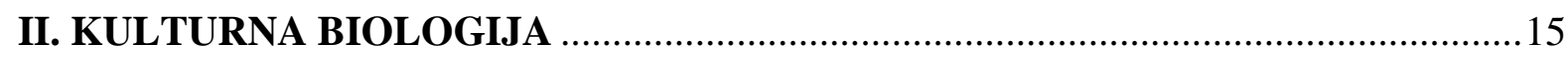

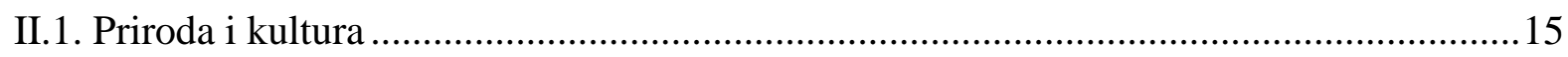

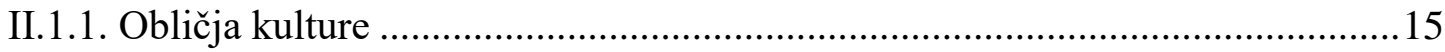

II.1.2. Viskovićevo poimanje kulture kao otprirođenja..........................................24

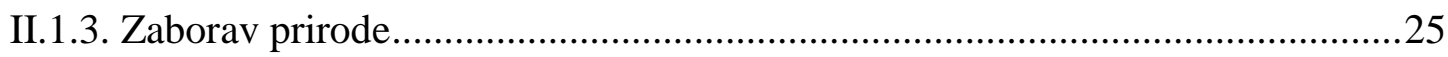

II.1.4. Kulturna biologija kao odgovor na zaborav prirode ...................................44

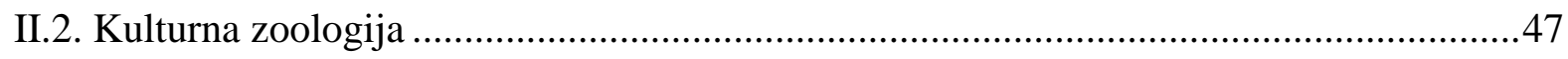

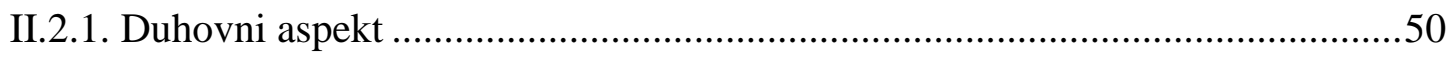

II.2.1.1. Antropomorfizam i zoomorfizam …..........................................52

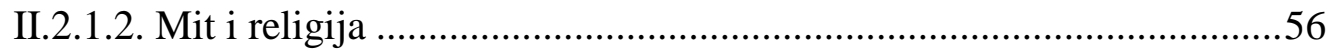

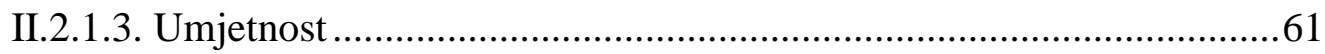

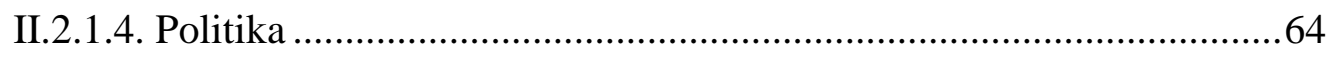

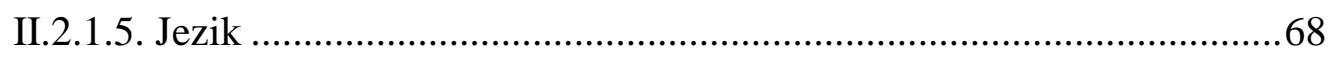

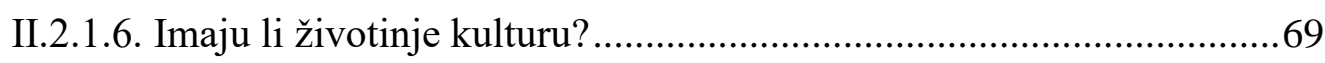

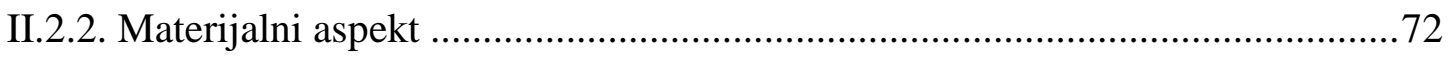

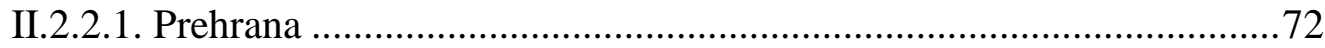

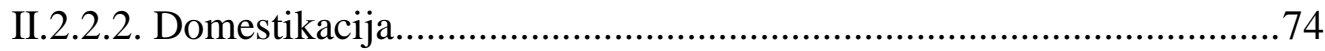

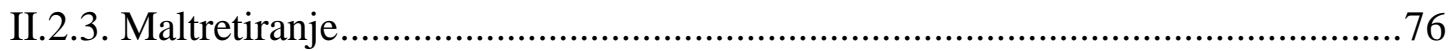

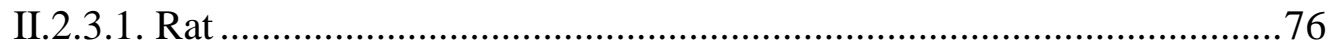

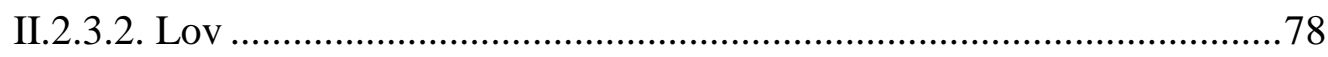

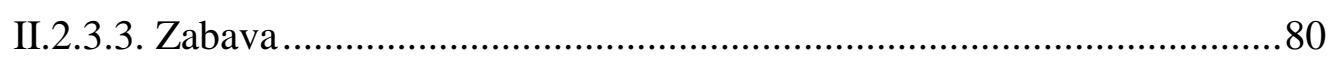

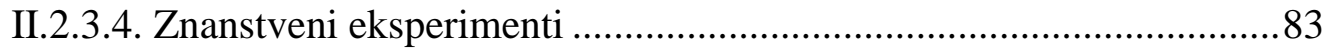

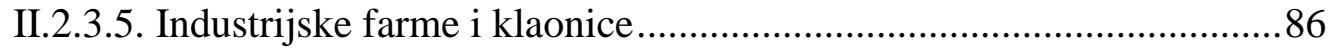

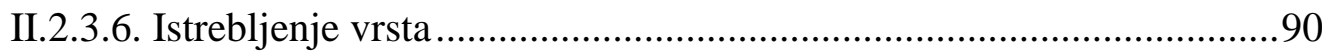

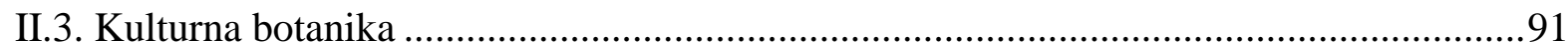




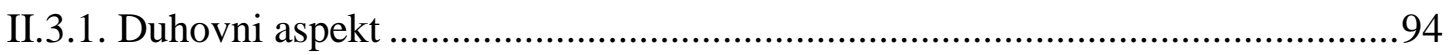

II.3.1.1. Antropomorfizam i fitomorfizam................................................98

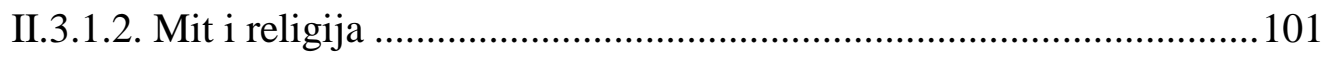

II.3.1.3. Ljepota i ostale estetičke kategorije ............................................. 104

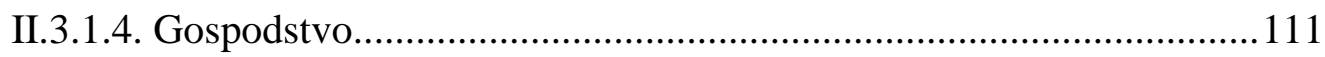

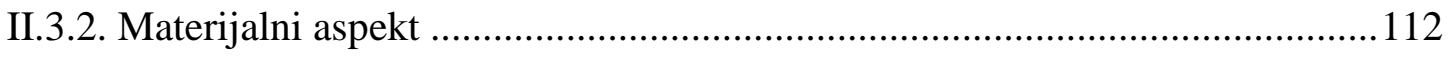

II.3.2.1. Zaborav drva kao materije ......................................................... 113

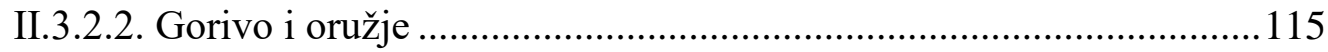

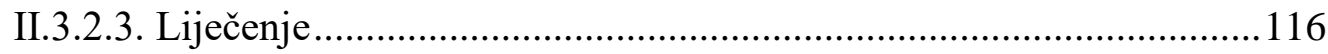

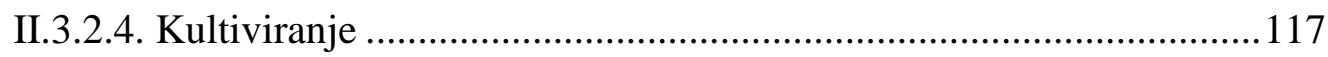

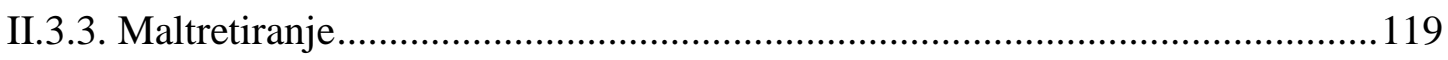

II.3.3.1. Uništavanje šuma ............................................................... 120

II.3.3.2. Uništavanje vrsta................................................................. 122

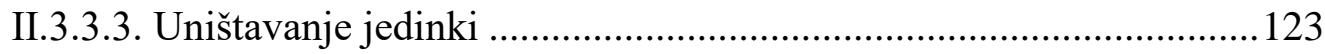

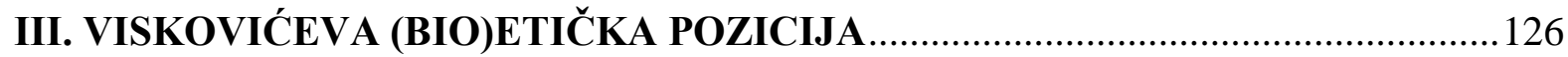

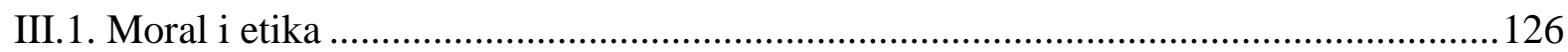

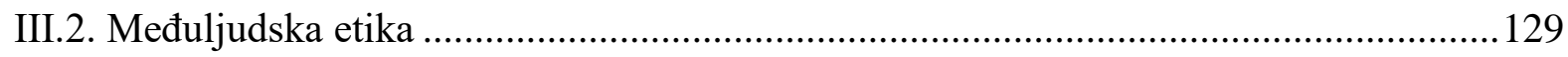

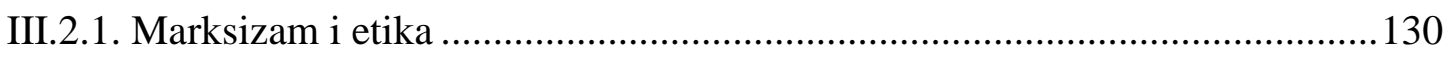

III.2.1.1. Prevladavanje etike u filozofiji prakse Milana Kangrge ............... 131

III.2.1.2. Visković i marksizam ................................................................ 137

III.2.2. Viskovićevo pozicioniranje u okviru tradicionalne etike ............................142

III.2.2.1. Moral kao poredak................................................................... 143

III.2.2.2. Kontinuitet i diskontinuitet moralnog poretka............................ 144

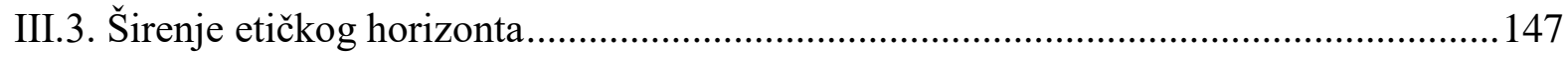

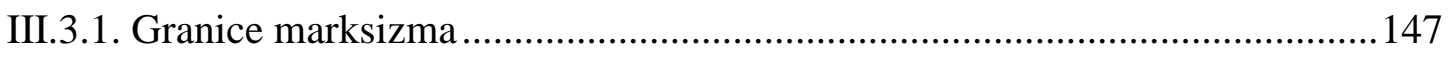

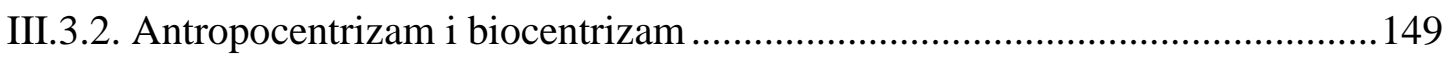

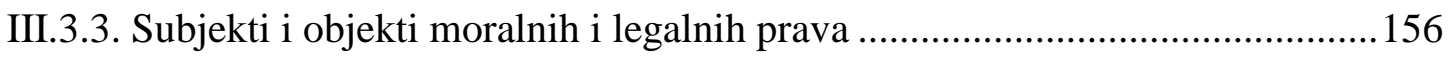

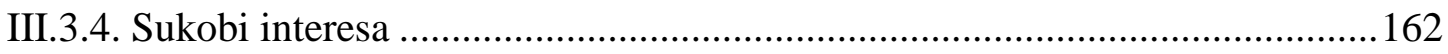

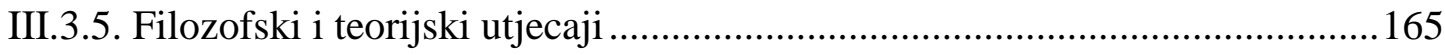

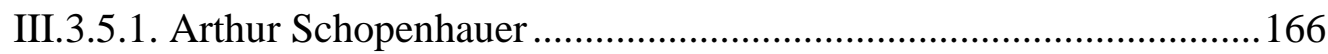

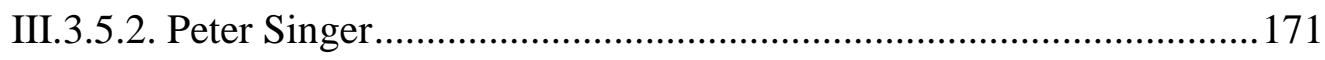

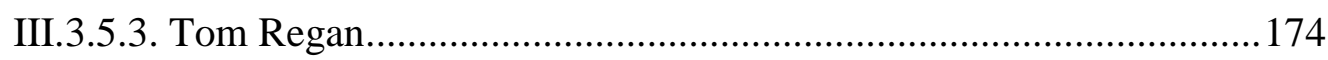

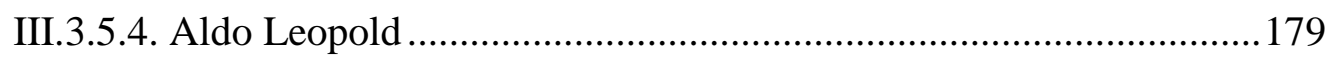

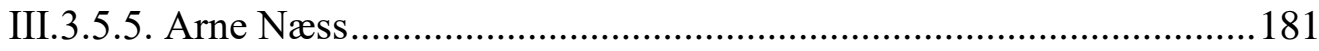


III.4. Kritički osvrt i pokušaj doprinosa utemeljenju biocentričke pozicije 191

III.4.1. Može li ne-ljudsko živo biće biti moralni subjekt?

III.4.1.1. Samoostvarivanje

III.4.1.2. Izleti u fiziocentrizam: prava neživog .........................................202

III.4.1.3. Smislenost koncepta moralnih prava i sukob dužnosti...................209

III.4.1.4. Održivi razvoj kao odgovor na ekološku krizu............................2214

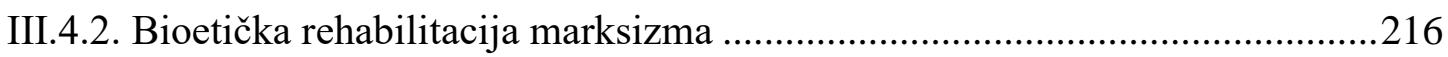

III.4.2.1. Znanstveno-tehnološka racionalnost, osjetila i potrebe..................218

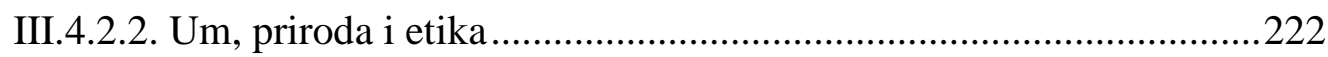

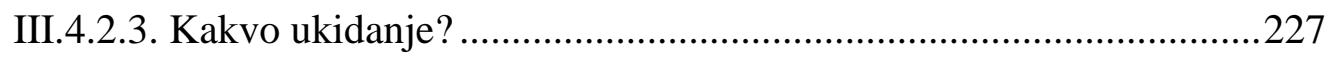

IV. DOPRINOS NIKOLE VISKOVIĆA INTEGRATIVNOJ BIOETICI...................229

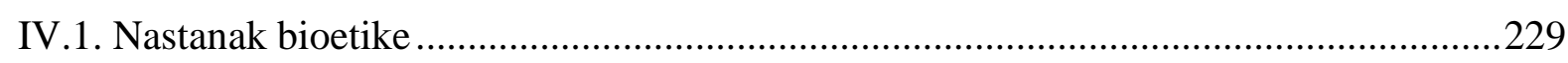

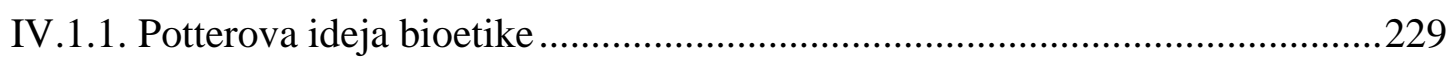

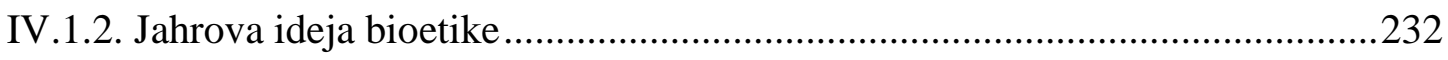

IV.2. Integrativna bioetika kao produbljivanje prvih impulsa ...........................................224

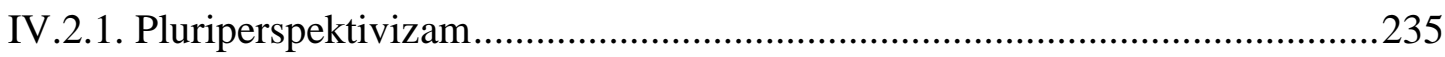

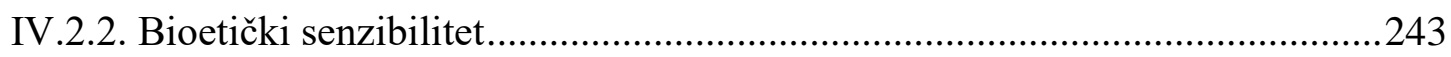

IV.3. Plodni elementi Viskovićeva djela za izgradnju integrativne bioetike .......................246

IV.3.1. Obogaćivanje koncepta bioetičkog senzibiliteta .......................................246

IV.3.1.1. Prisnost kulture prirodi i njene posljedice ....................................246

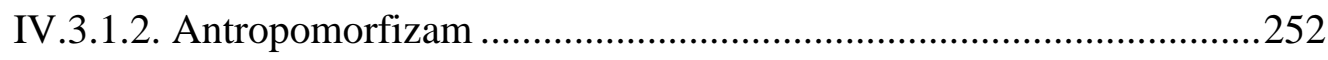

IV.3.1.3. Senzibilitet i racionalnost .....................................................25

IV.3.2. Ideja bioetike: Visković - očevi bioetike - integrativna bioetika .................256

IV.3.2.1. Znanje i moralnost ...................................................................260

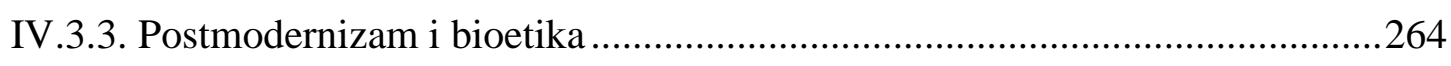

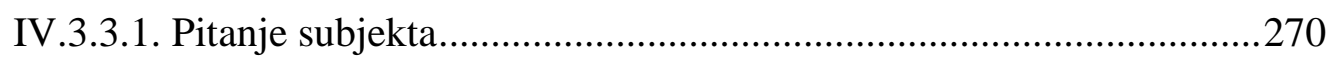

IV.3.3.2. Viskovićev postmodernizam? .................................................2 273

IV.3.3.3. Integrativna bioetika i postmodernizam ....................................277

IV.3.4. Viskovićevi osvrti na ostale bioetičke probleme.......................................281

IV.3.4.1. Medicinska etika..................................................................28

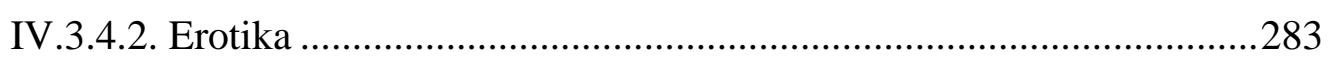

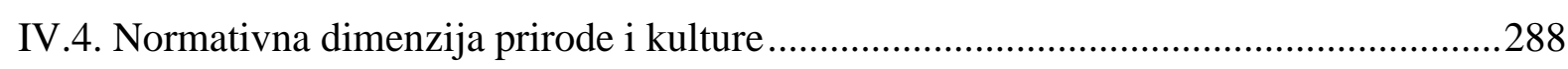

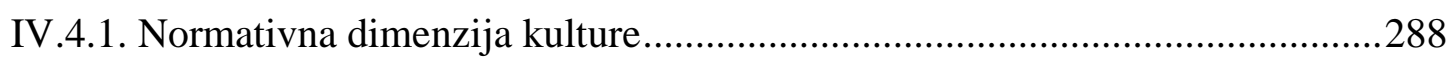

IV.4.1.1. Potreba razlikovanja prirode i kulture ......................................2290 
IV.4.1.2. Moralna relevantnost pripisivanja kulture ne-ljudskim bićima......293

IV.4.2. Normativna dimenzija sagledavanja prirode..............................................294

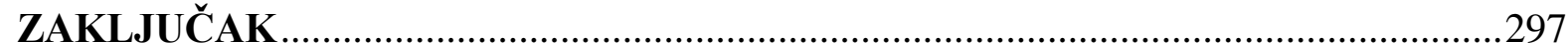

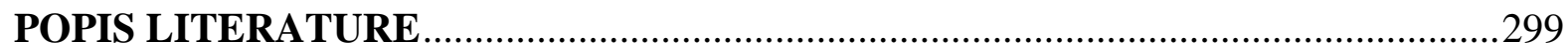

ŽIVOTOPIS AUTORA S POPISOM OBJAVLJENIH DJELA ..................................... 


\section{UVOD}

Nikola Visković svojoj je matičnoj instituciji, Pravnom fakultetu Sveučilišta u Splitu, donirao bogatu hemeroteku, od koje je jedan bioetički relevantan dio (i uopće posvećen živom svijetu), tzv. »bio-hemeroteka«, kasnije prebačen u Centar za integrativnu bioetiku Filozofskog fakulteta Sveučilišta u Splitu, u čijim se prostorijama nalazi i danas. ${ }^{1}$ Ova ne sadrži samo novinske članke, nego i razne zabilješke i slične materijale. Tako se u jednoj od 253 fascikle potonje nalazi dio izvjesne prepiske u kojoj Ante Čović Viskoviću spominje kako mu je Hrvoje Jurić natuknuo da bi bilo vrijedno izraditi studiju o uporištima za integrativnu bioetiku u djelu Nikole Viskovića. ${ }^{2}$ Takvom bi se studijom zasigurno pokazalo da pored integrativne bioetike, kao uvelike »izvornom hrvatskom proizvodu«, domaća bioetička misao također raspolaže, u izvjesnom smislu, njezinim pretečom i suputnikom, čiji su dosezi i poticaji kadri da postanu »izvoznim proizvodom« uslijed značajne »potražnje« za orijentacijom u životu suvremenog čovjeka - takvom koja će, među ostalim, ovakve ekonomske metafore učiniti zastarjelima. Upravo je ukazivanje na još uvijek nedovoljno istraženi potencijal Viskovićeve bioetičke misli za prijeko potrebno suočenje s ugrozom života i kulturnim nasiljem nad prirodom, a onda i doprinos sveobuhvatnom pristupu integrativne bioetike, zadatak kojemu se ovaj rad nastoji približiti.

Ovdje su korišteni dijelovi i naših prije objavljenih radova. U tekstu ćemo ukazivati na nekoliko onih čije manje dijelove koristimo, no one koje prenosimo u velikom obimu ovdje nećemo posebno denotirati jer je njihov sadržaj, kako u direktnom preuzimanju teksta, tako i u parafrazama, razasut $u$ fragmentima i natruhama po čitavom ovom radu, pa bi bilo nezahvalno minuciozno naznačavati svaku misao ili rečenicu koja je u njima objavljena. Riječ je o sljedećim tekstovima:

- »Ekološka kriza između kulture i prirode«, u: Ana Štrkalj, Zoran Glavaš, Sanja Kalambura (ur.), $1^{\text {st }}$ International Conference The Holistic Approach to Environment.

\footnotetext{
${ }^{1}$ Nemali broj u ovom radu korištenih novinskih i ostalih materijala pronađen je posložen u bio-hemeroteci, no na nju se referiramo samo onda kada se radi o materijalu koji se ne može pronaći na drugom mjestu ili barem nama drugdje nije bio dostupan. Na nju se referiramo u obliku: BH [Bio-hemeroteka] - F [fascikl, uz dodatak broja]. Klasifikacija je ostala ista onakva kakvom ju je u nasljedstvo ostavio Visković.

${ }^{2} \mathrm{BH}-\mathrm{F} 45$
} 
Proceedings Book, Association for Promotion of Holistic Approach to Environment, Sisak 2018., str. 211-221.

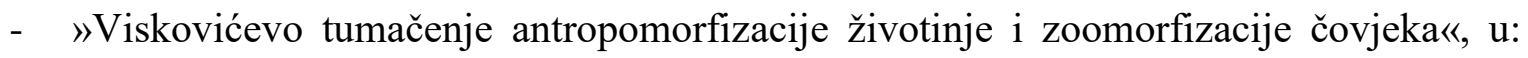
Snežana Voštinarov (ur.), Drugi kongres o zaštiti životinja. Zbornik radova, Animal Rescue Serbia, Beograd 2018., str. 9-12. ${ }^{3}$

- NNikola Visković, integrativna bioetika i očevi bioetike«, u: Josip Guć, Hrvoje Jurić (ur.), Nikola Visković: pravo - politika - bioetika. Zbornik povodom osamdesetog rođendana, Pergamena - Filozofski fakultet Sveučilišta u Splitu, Centar za integrativnu bioetiku - Pravni fakultet Sveučilišta u Splitu - Znanstveni centar izvrsnosti za integrativnu bioetiku, Zagreb - Split [u pripremi].

Bit će potrebno odmah na početku jasno odrediti prirodu ovog rada. Iako Viskovićeva misao u njemu zauzima središnje mjesto, on se ne ograničava na nju. To sugerira i sam naslov, jer ovdje je prije svega riječ o poticajima koje nalazimo kod Viskovića, a u svrhu rasvjetljavanja odnosa kulture i prirode u bioetičkom ključu. Pri tome pod bioetičkim prvenstveno mislim na ono integrativno-bioetičko, a razlozi za takvo usmjerenje postat će jasni u daljnjem tijeku rada. Iako su temelji integrativne bioetike već postavljeni, ponajprije u radovima naših bioetičara $(\mathrm{u}$ prvom redu Ante Čovića i Hrvoja Jurića), ali i nekih inozemnih autora (prvenstveno Thomasa Sörena Hoffmanna), još uvijek se radi o mladom području koje zahtijeva trud na njegovoj daljnjoj izgradnji. Stoga ovaj rad nije samo pregled bioetički relevantnih spisa Nikole Viskovića, nego i pokušaj doprinosa izgradnji integrativne bioetike. Štoviše, u njemu se upravo u Viskovićevoj misli pokušavaju detektirati plodni momenti za tu izgradnju. Stoga Viskovićeva misao neće biti predstavljena $\mathrm{u}$ »čistom obliku«, nego će često biti nadopunjivana našim refleksijama potpomognutima dijelom bogate literature o obrađenim temama, što neće $\mathrm{u}$ jednakoj mjeri vrijediti za svako poglavlje. Sudeći po razgovorima (a ponekad i žustrim raspravama) koje sam imao sa samim Viskovićem, neki će se moji zaključci bez sumnje protiviti njegovima, pa će u tom pogledu oslanjanje na njegovu misao biti u izvjesnom smislu heretično. U našim razgovorima, on bi rekao da je svako veliki i zaokruženi rad »umjetničko djelo«. Viskovićevo djelo svakako spada u tu kategoriju, ${ }^{4}$ pa ćemo ovdje biti toliko nepravedni

\footnotetext{
${ }^{3}$ Ovdje treba napomenuti da je onaj tko je pripremao ovu publikaciju za tisak nehotično izbacio bilješku/referencu na samom kraju ovog kratkog teksta (radi se o bilješki br. 149 u ovom radu), no u njemu je ostalo jasno istaknuto da je riječ o Viskovićevu citiranju Vittorija Höslea.

${ }^{4}$ Visković velika područja svog djelovanja kojima se bavimo u nastavku uistinu zaokružuje i odbija da se dublje pozabavi s njima u nastavku svog znanstvenog rada. To pak ne znači, čemu smo se u osobnim druženjima uvjerili, da odbija raspravu o svojim zaključcima. Ovdje će upravo zbog nezaokruženosti biti izostavljena šira rasprava o erotici, kojom se Visković trenutno bavi (njegov rukopis Toposi erotike još uvijek nije u procesu objavljivanja, iako se može reći da je u bitnome dovršen), a koje ćemo se dotaknuti tek u jednom manjem poglavlju ovoga rada.
} 
da uzmemo same njegove riječi i odgovorimo da i mi imamo pravo interpretirati njegovo »umjetničko djelo« na svoj način, bivajući barem malo pošteni utoliko ukoliko u citiranju i parafraziranju nećemo namjerno izobličavati samu njegovu materiju, tj. »goli tekst«.

U tom smo pogledu osobito pazili da referencama obilježimo točna mjesta iz kojih crpimo Viskovićeve misli, kako bismo ih jasno ogradili od nekih stavova koje pripisujemo sebi ili nekim drugim navedenim autorima. To ne znači ni da u onim dijelovima u kojima pokušavamo vjerno oslikati Viskovićevu misao ispunjavamo svoju zadaću. Interpretacija, naime, nije samo interioriziranje autorovih misli u svoje, nego i unošenje svojih misli u one autora. Već je i sam akt selektiranja određenih elemenata djela koje se interpretira svojevrsno iskrivljavanje njegove slike. Međutim, na te manjkavosti interpretacije u odslikavanju njenog objekta ne treba gledati kao na slabost, nego upravo kao na njeno »poslanje«, njezin doprinos daljnjem obogaćivanju misli. Stoga bi svaki čitatelj trebao znati da se tu radi upravo o interpretaciji - neuspješnom pokušaju odslikavanja određene misli, ali i mogućem doprinosu nekom misaonom sklopu ili barem poticaju za njega. Štoviše, moglo bi se reći da je njena skrivena bit u tome da nevjerno odslika svoj objekt - inače gubi na svojoj svrhovitosti. Ovo je, dakle, naš pokušaj doprinosa, uz nadu da na onim mjestima na kojima smo pokušali interpretirati Viskovića nismo otišli suviše daleko od njega. Barem se nadamo da idemo u smjeru onoga što je on sam zamislio kao željenu recepciju bioetičkog dijela njegova opusa, naime, »da ovo predstavljanje životinjstva i stabala u kulturi konačno potakne sektorska proučavanja tih tema u znanostima mitologije, religije, filozofije, književnosti, likovnosti, politike... $\ll^{5} \mathrm{Mi}$ ćemo pokušati pružiti jedno primarno filozofsko proučavanje ovih tema, s naglaskom na etički problem, a koliko ćemo u njemu biti uspješni, procijenit će čitatelji. Ovdje se, nažalost, nećemo opširnije baviti Viskovićevim doprinosom pravnoj teoriji. Osim što se radi o temi koja se ne veže direktno uz filozofski aspekt bioetičke problematike, ne smatramo se dovoljno kompetentnima da procjenjujemo njegov doprinos na tom području. Uopće je malo ljudi koji imaju toliku polihistorsku širinu da mogu kompetentno pristupiti svakom području u kojem je Visković stvarao.

Općenito, ovaj se rad u pravilu ne bi smio shvatiti kao kritika (pozitivna ili negativna) Viskovićeva djela, ponajprije iz razloga spomenutog nedostatka kompetencije i sposobnosti baratanja instrumentarijem mnogih znanosti i perspektiva koje ulaze u Viskovićev polihistorski interes. Važnu iznimku od tog pravila činit će, kako je rečeno, filozofska, a u tom okviru ponajprije etička problematika. Filozofskim pristupom pokušat ćemo konceptualizirati neke

\footnotetext{
${ }^{5}$ Nikola Visković, »U inat vladajućim idiotarijama«, Zarez 5.6.2003., intervju (razgovarao: Hrvoje Jurić), str. 810 , ovdje str. 8 .
} 
elemente Viskovićeva obimnog i ponekad nesređenog djela. Treba naglasiti da će to sređivanje nerijetko ići i u smjeru, kako sam naslov sugerira, prepoznavanja poticaja u Viskovićevu djelu za nešto što uključuje elemente koje sam Visković jamačno ne bi prihvatio.

Etika ima ključnu ulogu u ovom radu, kao i u samoj integrativnoj bioetici, koja usmjeravanjem pažnje na neke druge horizonte čovjekova djelovanja, često zanemarene od strane tradicionalne etike, nipošto ne odbacuje etiku kao filozofsku disciplinu. Štoviše, po mišljenju koje ćemo unutar ovog rada braniti, ona joj pridaje središnju važnost, ponajprije u vidu poimanja morala kao strogo formalne normativne odrednice čovjekova djelovanja. 


\title{
BIOGRAFIJA NIKOLE VISKOVIĆA
}

\section{I.1. LIK I DJELO}

Nikola Visković ${ }^{6}$ rođen je u Splitu 6. ožujka 1938. godine. Dio mladosti, od 1948. do 1956., provodi u Santiago de Chileu, a ta će »čileanska epizoda«, kako sam ističe, biti uvelike presudna za njegovo intelektualno i političko formiranje, u pogledu odbojnosti prema partijskoj birokraciji i političkog radikalizma, ali i u pogledu nekih tvrdih doktrinarnih crta kojih se, po vlastitu priznanju, godinama oslobađao. Tu ga lokalni trockisti uključuju u jedan omladinski studijski kružok gdje se upoznaje s marksizmom, a već s trinaest godina kolportira list Komunističke partije El Siglo i obilazi ponekad nasilne radničke demonstracije. Godinu dana nakon povratka u Jugoslaviju bit će primljen u partijsku organizaciju na Pravnom fakultetu u Zagrebu. No tada se nije odviše bavio politikom, a u mjeri u kojoj jest, to je činio, kako tvrdi, na jedan kozmopolitski način (na koji je svakako traga ostavio latinski svijet gdje »politika i umjetnost uvijek idu ruku pod ruku«), što nije oduševljavalo ni naše komuniste, ni naše antikomuniste, isto kao što su oni Viskovića ostavljali ravnodušnim.

\begin{abstract}
»Upravo to proživljeno iskustvo latinoameričke ljevice omogućilo mu je određeni odmak od teorije i prakse istočnoeuropskog real-socijalizma - zbog čega je u partijskim krugovima ponekad bio doživljavan kao »egzotični komunist« - ali je možda isto tako utjecalo da krajem 80-ih i početkom 90-ih realnije sagleda uzroke sloma socijalizma u Europi, kao i da bez obzira na taj slom ostane vjeran marksističkim idejama koje su ga formirale u čileanskim adolescentskim godinama. « ${ }^{7}$
\end{abstract}

\footnotetext{
${ }^{6}$ Podaci za poglavlje koje slijedi, a na koje se direktno ne referiramo, preuzeti su iz sljedećih izvora: Iva Rinčić, Amir Muzur, Fritz Jahr i rađanje europske bioetike, Pergamena, Zagreb 2012., str. 99; »Prof. dr. sc. Nikola Visković, umirovljeni profesor«, Pravni fakultet, Sveučilište u Splitu. Dostupno na: http://www.pravst.unist.hr/ljudi.php?p=26\&s=1008 (pristupljeno 19. 4. 2020.); Nikola Visković, Sumorne godine. Nacionalizam - bioetika - globalizacija, Kultura\&Rasvjeta, Split 2003., str. 76-82, 311; Boris Pavelić, »Nikola Visković pristupio RF-u: 'Hrvatska ljevica treba se udružiti u frontu'«, Novi list 3. 6. 2016. Dostupno na: http://www.novilist.hr/Vijesti/Hrvatska/Nikola-Viskovic-pristupio-RF-u-Hrvatska-ljevica-treba-se-udruziti-ufrontu (pristupljeno: 6. 2. 2019.); Ivan Cifrić, Leksikon socijalne ekologije. Kritičko promišljanje, Školska knjiga, Zagreb 2013., str. 432; Ivan Padjen, »Viskovićevo integralno poimanje prava: problemi i rješenja«, u: Josip Guć, Hrvoje Jurić (ur.), Nikola Visković: pravo - politika - bioetika. Zbornik povodom osamdesetog rođendana, Pergamena - Filozofski fakultet Sveučilišta u Splitu, Centar za integrativnu bioetiku - Pravni fakultet Sveučilišta u Splitu - Znanstveni centar izvrsnosti za integrativnu bioetiku, Zagreb - Split [u pripremi].

${ }^{7}$ Damir Pilić, »Professor emeritus Nikola Visković: 'potporni stup splitske ljevice'«, u: Josip Guć, Hrvoje Jurić (ur.), Nikola Visković: pravo - politika - bioetika. Zbornik povodom osamdesetog rođendana, Pergamena -
} 
Pored studija prava u Zagrebu, specijalizirao je usporedno pravo u Strasbourgu i Helsinkiju, a teoriju prava u Rimu. Pravo je diplomirao na Pravnom fakultetu u Zagrebu 1961., a usporedno pravo i europske studije na Međunarodnom fakultetu za komparativno pravo $\mathrm{u}$ Strasbourgu 1963. Doktorirao je 1974. na Pravnom fakultetu Univerziteta u Beogradu tezom Integralna teorija prava. Zaposlio se 1961. na Pravnom fakultetu Sveučilišta u Splitu, gdje je 1985. stekao zvanje redovnog profesora. Na tom je fakultetu do umirovljenja 2008. predavao teoriju prava i države. Godine 2009. postaje professor emeritus Sveučilišta u Splitu.

Od 1969. do 1970. bio je jedan od urednika splitskog časopisa Gdje, a od 1974. do 1975. glavni urednik časopisa Vidik. Redovito je u novinama i časopisima pisao i davao izjave o društveno-političkim i bioetičkim pitanjima.

Pored mnogih znanstvenih tekstova objavio je i knjige iz područja prava (Pojam prava, 1976.; Osnove prava, 1986.; Jezik prava, 1989.; Pravo kao kultura. Egokološka teorija prava Carlosa Cossija, 1990.; Država i pravo, 1995.; Argumentacija i pravo, 1997.; Teorija države i prava, 2001. - navedena su samo prva izdanja). Pored toga, objavljuje i dvije kod nas pionirske knjige iz područja kulturne biologije, tj. iz kulturne zoologije ili animalistike (Životinja i čovjek. Prilog kulturnoj zoologiji, 1996.) i kulturne botanike (Stablo i čovjek. Prilog kulturnoj botanici, 2001.). Svoje izabrane, uglavnom društveno-političke refleksije sabire u dvije knjige (Politički ogledi, 1990.; Sumorne godine. Nacionalizam - bioetika - globalizacija, 2003.). Bavio se i prevođenjem, čemu je poslužila činjenica da govori engleski, francuski, talijanski i španjolski jezik, a služi se njemačkim i portugalskim jezikom. Trenutno se bavi erotikom, prvenstveno u vidu opsežnog neobjavljenog rukopisa Toposi erotike.

Ovaj kratki pregled Viskovićeva djela ne smije zaobići ni nekoliko bogatih dokumentacija znanstvenih i publicističkih tekstova, tj. hemeroteka, koje je 2003. donirao Pravnom fakultetu u Splitu, da bi spomenuta »bio-hemeroteka« konačno bila pohranjena $\mathrm{u}$ Centru za integrativnu bioetiku Filozofskog fakulteta u Splitu. Na Pravnom fakultetu ostale su hemeroteke iz pravne teorije te jugoslavike-kroatike. One sveukupno broje preko 700 fascikala i stotinjak tisuća jedinica.

Prosudba Ivana Padjena »da je Visković jedan od autora koji je dao odlučujući prinos promjeni teorije prava i države u socijalističkoj Jugoslaviji i najznačajniji hrvatski teoretičar prava u dvadesetom stoljeću « ${ }^{8}$ bila je u izvjesnom smislu najavljena već Nagradom grada Splita

Filozofski fakultet Sveučilišta u Splitu, Centar za integrativnu bioetiku - Pravni fakultet Sveučilišta u Splitu Znanstveni centar izvrsnosti za integrativnu bioetiku, Zagreb - Split [u pripremi].

${ }^{8}$ I. Padjen, »Viskovićevo integralno poimanje prava: problemi i rješenja 
za znanost 1976., a za znanstveni rad dobio je i Nagradu Slobodne Dalmacije za znanost »Cvito Fisković« 2002. Počasnim predsjednikom Hrvatske udruge za pravnu i socijalnu filozofiju te teoriju prava i države bio je proglašen od njezinog osnutka 2007., a 2010. uručena mu je i nagrada Slobodne Dalmacije za životno djelo. Za afirmaciju antifašističkih vrijednosti 2011. dobio je Priznanje Srpskog narodnog vijeća »Gojko Nikoliš«. To je posljedica Viskovićeva bogatog građanskog i političkog angažmana, koji, kao ni na početku, nikada nije bio posve uobičajen. Sam će reći da se zbog svojih govora o autocenzuri 1978. i tvrdnji o klasnosti jugoslavenskog društva 1980. našao na udaru političkih komesara, no isto će tako samokritički istaknuti da, pored spomenute doktrinarnosti, nije bio dovoljno osjetljiv na povrede ljudskih prava tijekom političkih obračuna 70 -ih godina. U svakom slučaju, Visković ostaje pripadnikom kritičke ljevice sve do danas, pa se tako 2016. uključuje u Radničku frontu. No njegov je angažman ostavio osobitog traga u Zelenoj akciji Split, s kojom je ušao u prvi saziv višestranačkog Hrvatskog sabora, te u udrugama za ljudska prava: Dalmatinskom odboru solidarnosti, Dalmatinskoj akciji i Hrvatskom helsinškom odboru.

\section{I.2. ZELENA AKCIJA SPLIT}

Viskovićev angažman u (najprije građanskoj inicijativi, a zatim i političkoj stranci) Zelenoj akciji Split, najkonkretniji je okvir u kojem se može sagledati njegov ekološki aktivizam. Uostalom, njegova uloga u toj organizaciji bila je nezaobilazna, tako da se osim konkretnog aktivizma isticao i kao »neimenovani ideolog splitskih zelenih «. ${ }^{9}$ To se očituje i u novinskim člancima u kojima pojašnjava poslanje Zelene akcije Split, imajući u vidu znatno širi pogled na problemsko područje od samog pitanja zagađenja čovjekove okoline, odnosno površnog gledanja na problem ekološke krize. On smatra da se tadašnja kriza »strukturno i uzročno« smješta »u jednu mnogo širu, svjetsku krizu humaniteta i odnosa čovjeka prema prirodnoj okolini«, u kojoj je zapravo riječ o »ekološko-kulturnoj krizi«. S obzirom na tadašnje stanje smatra da je unutar Jugoslavije naročito pogođena Dalmacija, zahvaljujući industriji, turizmu, ali i većim zagađivačima s druge strane Jadrana, tj. visoko industrijaliziranoj Padskoj dolini. Počevši od problema zaštite prirode, sužava pogled na pitanje ljudskog kulturnog okoliša, gdje govori o »propadanju gradskih jezgri u svim njihovim komunalnim, ljudskim i

\footnotetext{
${ }^{9}$ Dražen Gudić, »Naprid zeleni«, Danas 15. 8. 1989., str. 73-75, ovdje str. 73.
} 
estetskim vidovima«, otvarajući i pitanje »zagađenja moralnih i političkih odnosa koji pripadaju tzv. 'ljudskoj ekologiji'«. ${ }^{10}$ Ove misli pokazat će se važnima u okviru Viskovićevih bioetički relevantnih spisa. Njihova prisutnost u ovom, novinskom obliku, svjedoči o stilu njegova života i rada, među kojima nema stroge podjele. Njegov život je neumoran rad, a njegov rad je najčešće oda životu i trud na njegovoj zaštiti. Njegova misao ne prebiva u »kuli bjelokosnoj«, nego stoji u službi razrješavanja konkretnih problema, ne samo u knjigama, znanstvenim radovima i u novinskim stupcima, nego i na prosvjedima, govornicama i drugim mjestima društvene $\mathrm{i}$ političke akcije. Stoga ovakav način izvođenja ovog rada, u kojemu se Viskovićeva biografija odvaja od njegova intelektualnog stvaralaštva, zasigurno ne priliči njegovu predmetu.

Zelena akcija Split, društvo koje je prije toga djelovalo kao neformalna ekološka inicijativa, službeno je osnovana 23. veljače 1989. u prostorijama Muzeja revolucije u Splitu, pri čemu je Visković zauzeo mjesto u neformalnom upravnom odboru. ${ }^{11}$ Već krajem 1989. organizacija sprovodi akcije čišćenja grada, a poseban angažman pokazala je u pokretanju akcija za čišćenje splitske park-šume Marjan, u kojima se konkretnim, manualnim radom Visković naročito isticao. ${ }^{12}$ Društvo se također osobito angažiralo na zaštiti Jadrana, ${ }^{13}$ izrađivalo je ankete o kvaliteti hrane, ${ }^{14}$ upućivalo mnogobrojne apele itd. Odlikovala ga je i iznimna šarolikost članstva, ali i područja djelovanja, a to se široko-ekološko usmjerenje odslikavalo u njegovih devet sekcija: za zaštitu mora i voda, za zdravu hranu, za čisti zrak, za zaštitu zelenih površina, za čistoću grada, za zaštitu proizvoda kulture, zatim protiv zvučnog zagađivanja, protiv zagađivanja pušenjem te sekcija prijatelja životinja. ${ }^{15}$ Upravo se za potonju Visković osobito založio pri neformalnom upravnom odboru, kakav je bio primjeren jednoj u

\footnotetext{
${ }^{10}$ Usp. Nikola Visković, »Zašto 'zeleni' u Dalmaciji?«, Slobodna Dalmacija 11. 11. 1988., str. 3. - U svojim bilješkama, Visković dijeli kulturnu i političku ekologiju s jedne i prirodnu ekologiju s druge strane, opravdavajući ovo proširenje pojma ekologije na sljedeći način: »Proširenje na društvo, ne kao iskonstruirana analogija nego po tome što je i društvo dio ekosistema i samo po sebi sistem bitno srodnih mehanizama...«(BH F34/1 [Naslovljeno »Na TV Marjanu 31. IV 90«.]).

${ }^{11}$ BH - F34/2 [Zapisnik osnivačke skupštine »Zelene akcije« Split, 23. veljače 1989., br. 1/89].

${ }^{12}$ Usp. Ante Kuštre, »Koliko je Split 'zelen'«, Nedjeljna Dalmacija 20. 11. 1988., str. 4; »Ipak akcija, 'zeleni' kreću! «, Slobodna Dalmacija, 9. 12. 1988., str. 7; Jasenka Leskur, »Velo Misto sad je čisto«, Slobodna Dalmacija 11. 12. 1988., str. 9; Zlatko Gall, »Split se oprao«, Danas 20. 12. 1988., 72-73; A. J., »Na meti Marjan i more«, Slobodna Dalmacija 30. 1. 1989., str. 8; A. J., »'Veliko spremanje' Marjanske šume«, Slobodna Dalmacija 5. 2. 1989., str. 7; A. J., »Povratak Marjanu«, Slobodna Dalmacija 12. 3. 1989., str. 4; A. J., »'Zeleni' na vrhu Marjana«, Slobodna Dalmacija 19. 3. 1989., str. 13; A. P. »Najmlađi sportaši na Marjanu«, Slobodna Dalmacija 9. 4. 1989., str. 4; A. J., »Pitomci najbolji«, Slobodna Dalmacija 23. 4. 1989., str. 6; J. Dadić, »Na Marjanu opet dobrovoljci«, Slobodna Dalmacija 19. 10. 1990., str. 8; E. V., »Slab odaziv građana«, Slobodna Dalmacija 11. 11. 1990., str. 8. ${ }^{13}$ Usp. M. Pejković Kaćinski, »Jadran treba zaštitu«, Večernji list 23. 5. 1990., str. 6; O. I. Grizelj, »Kresovi 'zelenih'«, Slobodna Dalmacija 24. 6. 1990., str. 32.

${ }^{14}$ Usp. Anđelka Petrović, »Kakav kruh jedemo«, Nedjeljna Dalmacija 19. 3. 1989., str. 14-15; Anđelka Petrović, »Prodavači kriju narodni kruh!«, Nedjeljna Dalmacija 26. 3. 1989., str. 14-15.

${ }^{15}$ Usp. A. Jakaša, »Više 'zelenih' nego čistoće«, Slobodna Dalmacija 12. 2. 1989., str. 8; Ž. R., »Četrnaest za«, Slobodna Dalmacija 25. 2. 1989., str. 9.
} 
ideji nehijerarhijskoj organizaciji kakva je bila Zelena akcija Split. ${ }^{16}$ Visković je uz to bio i jedna od važnih figura unutar Društva prijatelja životinja - Split, osnovanog 6. ožujka 1990. na Pravnom fakultetu u Splitu. ${ }^{17}$

Zelena akcija Split organizirala je i veće akcije, koje su izazvale veliku pažnju javnosti, ali i potaknule na pokretanje nekih koraka u rješavanju gorućih ekoloških problema. Vrijedi istaknuti neke od zapaženijih. Prva je »Biciklistički ekološki miting« održan 28. svibnja 1989., posredstvom koje je Zelena akcija Split ukazala na probleme vezane za uništavanje ozonskog omotača, a pri čemu je potpisivana peticija o prihvaćanju Montrealskog sporazuma o ograničenju proizvodnje freona na osnovu koje je Komisija Skupštine SFRJ pokrenula pitanje pristupanja Jugoslavije tom sporazumu. ${ }^{18}$ Druga istaknuta akcija bio je protestni tjedan zbog propadanja Dioklecijanove palače održan od 5. do 10. prosinca 1989., u sklopu kojega su upriličeni okrugli stol, demonstracije, izložba ekološkog plakata itd. ${ }^{19}$ Nedugo nakon toga, 27. siječnja 1990., održana je i akcija stvaranja ljudskog prstena oko Dioklecijanove palače, u sklopu koje je Ante Kuštre osmislio umjetnički događaj »Zeleni Peristil«. ${ }^{20}$

Djelovanje Zelene akcije Split bilo je obilato medijski popraćeno. Tjednik Nedjeljna Dalmacija pokrenuo je rubriku »Ekološki pressing«, u kojoj su članovi Zelene akcije Split često objavljivali priloge. Dnevna novina Slobodna Dalmacija, osim što je otvorila značajnu količinu prostora za ekološke teme i priopćenja članova Zelene akcije Split, u svom je novogodišnjem broju s 1988. na 1989. godinu proglasila tu organizaciju jednim od kulturnih podviga godine. ${ }^{21}$

Zelena akcija Split brzo je od neformalne ekološke skupine izrasla u snažan pokret s neskrivenim političkim ambicijama. ${ }^{22}$ Međutim, njen put prema upisu u registar udruženja građana nije tekao glatko, čemu svjedoče brojni prosvjedi protiv njegova odgađanja od strane Republičkog sekretarijata unutrašnjih poslova Hrvatske, u kojima je i Visković aktivno

\footnotetext{
${ }^{16}$ Usp. Zoran Matić, »Mrtvo, mrtvo Jadransko more«, Polet 24. 2. 1989., str. 17.

${ }^{17} \mathrm{BH}$ - F34/1 [Informacija iz lista Zaštita rada, ožujak 1990.] - Na istom mjestu Visković »navodi da su agroindustrijska postojenja - životinjski Aušvici«. (Ibid.)

${ }^{18}$ Usp. B. J. Oreb, »Uskoro startni brojevi BEM-a«, Slobodna Dalmacija 15. 5. 1989., str. 9; B. J. Oreb, »Šokantni eksponati«, Slobodna Dalmacija 27. 5. 1989., str. 8; B. J. Oreb, »Danas svi na bicikle!«, Slobodna Dalmacija 28. 5. 1989., str. 6; B. J. Oreb, »Zadovoljstvo sa zadrškom«, Slobodna Dalmacija 30. 5. 1989., str. 9; D. Mikulandra, »Fronta i sedam patuljaka«, Slobodna Dalmacija 24. 6. 1989., str. 14-15.

${ }^{19}$ Usp. M. Jč., »Protestni tjedan za Dioklecijanovu palaču«, Slobodna Dalmacija, str. 10; J. Ls. »Protestni tjedan za gradsku jezgru«, Slobodna Dalmacija 2. 12. 1989., str. 10; Jadranka Čoloković-Sviličić, »Car, prosjaci i rentijeri«, Slobodna Dalmacija 7. 12. 1989., str. 12; Jadranka Čoloković-Sviličić, »Potemkinova sela ili grad s naličja«, Slobodna Dalmacija 8. 12. 1989., str. 14; A. J., »Demonstracija 'zelenih'«, Slobodna Dalmacija 10. 12. 1989., str. 8; A. K., »Zeleno oko«, Slobodna Dalmacija 11. 12. 1989., str. 14.

${ }^{20}$ Usp. S. T., »Prsten oko palače«, Slobodna Dalmacija 27. 1. 1990, str. 9; Blažo Davidović, »S rukom u ruci za bolje 'stađune'«, Slobodna Dalmacija 28. 1. 1990., str. 7.

${ }^{21}$ Usp. »'Statuti' podvig, Salona ruglo, Zeleni nada«, Slobodna Dalmacija 31. 12. 1988. - 3. 1. 1989., str. $26-27$.

${ }^{22}$ Usp. D. Gudić, »Naprid zeleni«, str. 73.
} 
sudjelovao. ${ }^{23}$ Organizacija je čak dobila nagradu »Sedam sekretara SKOJ-a« za oblast ekologije prilikom prve dodijele te nagrade, a da još nije bila registrirana, pa su se njezini članovi šalili da su u ilegali poput SKOJ-evaca. ${ }^{24}$ Zelena akcija Split aktivno je pozivala i na ujedinjenje zelenih organizacija u Hrvatskoj i Jugoslaviji, a u tu je svrhu u Splitu 26.-27. siječnja 1990. organiziran prvi jugoslavenski skup zelenih iz svih republika na kojemu je osnovan Koordinacioni odbor ekologističkih skupina Jugoslavije, a donesena je i »Splitska izjava ekologističkih skupina Jugoslavije « u kojoj su istaknuti zahtjevi za ustavnom i obrazovnom implementacijom ekološki nastrojenih odredbi, za uspostavljanje pravne države i parlamentarne demokracije te za proporcionalni izborni sistem. ${ }^{25}$ Splitska delegacija u Savezu zelenih Hrvatske predstavljala je najodlučnijeg zagovornika osnivanja te udruge kao političke organizacije, pa iako Savez zelenih Hrvatske nije želio sudjelovati na izborima, lokalnim je organizacijama dopušteno da samostalno sudjeluju na njima. ${ }^{26}$ Odlukom o izlasku Zelene akcije Split na izbore usprotivili su se neki od članova, koji su u ožujku 1990. izašli iz pokreta, a kasnije su iskrenja po pitanju politizacije pokreta izbila između Zelene akcije Split i Saveza zelenih Hrvatske. ${ }^{27}$ Visković je, iako na strani »političke« opcije, smatrao da se u zelenom pokretu mora naći mjesta i za »ambijentaliste«, pri čemu se ne radi o većoj ili manjoj vrijednosti jednih ili drugih, jer je tu riječ samo o različitim metodama borbe za prispijeće istom cilju. ${ }^{28}$ Njegovo raspoloženje u vidu »ideološkog određenja« zelenih bilo je od početka jasno:

\begin{abstract}
»Najzad, dilema o ideološkoj pripadnosti 'Saveza zelenih' djelomično je pojednostavljena njegovom političkom samostalnošću i može biti u potpunosti razriješena samo praksom slobodnog opredjeljenja njegovih članova u borbi za ekološke vrijednosti; mislimo ipak da će po prirodi stvari ta praksa implicirati jedno novo, danas još ne posve definirano, ekosocijalističko shvaćanje društva.« $\ll^{29}$
\end{abstract}

\footnotetext{
${ }^{23}$ Usp. M. Dragičević, »Dva modela organiziranja«, Večernji list 7. 6. 1989., str. 5; A. Jakaša, »'Zeleni' još izvan zakona«, Slobodna Dalmacija 29. 6. 1989., str. 10; Ratko Aleksa, »Problemi splitske 'Zelene akcije'«, Vjesnik 4. 8. 1989., str. 4.

${ }^{24}$ Usp. Azra Jakaša, »Od SKOJ-a do 'Zelenih' - u ilegali«, Slobodna Dalmacija 11. 10. 1989., str. 9; Željko Rogošić, »Nagrada ne čeka registraciju «, Večernji list 15. 10. 1989., intervju (razgovarao Želimir Žanko), str. 7.

${ }^{25}$ Usp. Nikola Visković, »Ujedinjavanje 'zelenih'«, Zaštita rada 30 (1989) br. 353, str. 5; BH - F34/2 [Splitska izjava ekologističkih skupina Jugoslavije, 26.-27. 1. 1990.]; M. I., »Hitno mijenjati izborne zakone«, Vjesnik 28. 1. 1990., str. 3; Sergije Šelamov, »Pred ekološkim ponorom«, Slobodna Dalmacija 28. 1. 1990., str. 4; Dragan Jovanović, »Jajce u 'Lavu'«, NIN 4. 2. 1990., str. 28-30; Zoran Oštrić, »Ekološki pokreti u Jugoslaviji. Građa za proučavanje razdoblja 1971-1991.«, Socijalna ekologija 1 (1992) 1, str. 83-104, ovdje str. 97.

${ }^{26}$ Usp. Inge Perko-Šeparović, »Pogrešne percepcije«, Vjesnik 7. 7. 1990., str. [u prilogu Panorama subotom] 22.

${ }^{27}$ Usp. Ivan Cvitanović, Dada Lerotić, Jure Miličić, Matko Trebotić, »Da ne bude zabune«, Slobodna Dalmacija 27. 3. 1990., str. 18; D. F., »Tko se od 'zelenih' mora zacrvenjeti?«, Slobodna Dalmacija 26. 3. 1991., str. 11.

${ }^{28}$ Usp. Nikola Visković, »Većinski protiv razuma«, Borba 2. 2. 1990., intervju (razgovarao Živko Cerović), str. 8.

${ }^{29}$ Nikola Visković, »Prema političkom Savezu zelenih«, Nedjeljna Dalmacija 12. 11. 1989., str. 27.
} 
Visković je i na širem planu sudjelovao u ekološkoj politici, čemu svjedoči i sastavljanje izvještaja o političkoj situaciji u vezi ekologije u Jugoslaviji, koji je pisan za poslaničku grupu »Rainbow « u Europskom parlamentu. ${ }^{30}$

Kandidati Zelene akcije Split za Sabor SR Hrvatske bili su Ankica Luetić, Joško Niskota, Ante Jelavić i Nikola Visković, a planirano je i sudjelovanje na izborima za skupštine općina Kaštela, Solin i Split te na izborima za Skupštinu ZO Dalmacije i saveznu Skupštinu, premda je organizacija često prosvjedovala protiv zakonā o udruživanju i izborima, držeći ih nedemokratskima. ${ }^{31}$ Osobito je interesantan izborni program Zelene akcije Split, koji sažima njeno ekološko-demokratsko usmjerenje. Uz to, u njemu se naznačava i povezanost potrebe zaštite prirodne i kulturne okoline, kao i povezanost brige za lokalno i globalno. Bit će dovoljno istaknuti naglašene parole:

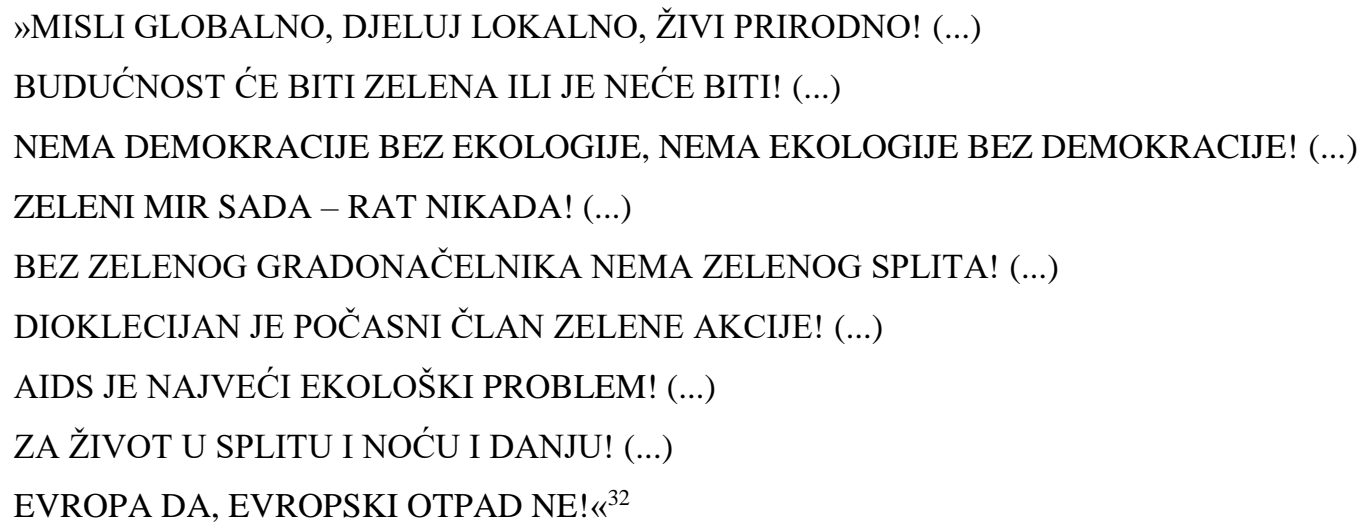

Njegov zaključak osobito je ilustrativan, ne samo za djelatnost i poslanje Zelene akcije Split, nego i za samo životno usmjerenje Nikole Viskovića:

»Zelena akcija se zalaže za jedinstvo u različitosti u cjelini svekolikog života na planeti, za čovjeka koji je jedinstvo racionalnog i osjetilnog, za eros života, a protiv pornografije!

Isteklo je vrijeme za zelenu retoriku, vrijeme je za ZELENU AKCIJU!

BUDUĆNOST JE GLASALA ZA ZELENE, A VI?«33

Zelena akcija Split izazvala je veliko zanimanje javnosti. Prema izbornim anketama Slobodne Dalmacije iz prosinca 1989. u Splitu, Zelena akcija Split predvodila je u broju glasova

\footnotetext{
${ }^{30}$ Usp. Nikola Visković, »Jugoslavija jučer i danas. A sutra?«, Nedjeljna Dalmacija 10. 9. 1989., str. $27-28$.

${ }^{31}$ Usp. Željko Bukša, »Obmana i ignoriranje demokratske javnosti«, Vjesnik 17. 11. 1989., str. 6; BH - 34/2 [Prijedlog odluke o sudjelovanju Zelene akcije na izborima; Zaključci]; »Zelena akcija Split. Naši kandidati za Sabor SR Hrvatske«, Slobodna Dalmacija 19. 4. 1990., str. 29.

${ }^{32}$ Zelena akcija, »Zeleni mir sada, rat - nikada«, Slobodna Dalmacija 15. 3. 1990., str. 11.

33 Ibid.
} 
(22,8\%), ali ubrzo je podrška opala, pa u ožujku 1990. ona iznosi tek 7,2\%. ${ }^{34}$ Radilo se uistinu o zanimljivom političkom pokretu, naročito ako se gleda iz perspektive začetka višestranačja u Hrvatskoj, odnosno Jugoslaviji. Zeleni pokreti u Hrvatskoj vjerojatno nikada nisu dosegnuli toliku popularnost. Međutim, Zelena akcija Split nije bila samo zanimljiv pokret jer se bavila ekološkim temama, nego i zbog svoje proeuropske ili internacionalne usmjerenosti, koja je često neodvojiva od ekološkog pristupa. Time se pokret svrstao u zanimljiva politička gibanja na splitskoj političkoj sceni, kakvu iz udaljenije perspektive u to doba dobro opisuje novinar Bogdan Tirnanić:

\begin{abstract}
»Split se u politička 'novopartijska gibanja' nije uključio kao regionalni (ili nacionalni) centar, već naprotiv, osnivanjem 'trans' partije - Zelene inicijative i Saveza građana za ujedinjenu Evropu. Premda obje ove inicijative mogu realnom političkom umu izgledati tek kao pikanterije jedne polivalentne političke situacije, ipak se ne može olako prijeći preko činjenice da, nasuprot ostalim 'partijama', koje se polomiše objašnjavajući načine, puteve i 'kako da zaslužimo' naše 'priključenje' Evropi, Savez građana za ujedinjenu Evropu polazi od proste istine kako Split već jest u Evropi.

Iz te svijesti o prisutnosti na evropskoj duhovnoj mapi proizlazi da se u programskim osnovama ovih splitskih 'partija' ne raspravlja o 'nacionalnom preporodu' i sličnim maglinama. Upravo suprotno: polazi se od toga da grad treba prvo očistiti od smeća. «35
\end{abstract}

Kada govorimo o jugoslavenskim ekološkim pokretima, valja imati na umu da se kod njih ne radi o, takorekuć, »'post-političkim' pokretima kao u razvijenim zemljama liberalne demokracije, nego prije o 'pred-političkim' $« .{ }^{36}$ Zeleni pokret tako nastupa kao nositelj ideja za reformaciju društva i u ne-zelenim kontekstima. Zelena akcija Split obećavala je kao skupina koja ima biti jedna od predvodnica pluralizacije jugoslavenskog političkog sistema, čega je izravno bio svjestan i sam Visković, tvrdeći da »stvaranje pokreta - stranke 'zelenih' jest jedan od najracionalnijih i društveno najhitnijih zadataka $u$ otvaranju političkog pluralizma $u$ Jugoslaviji i u izvlačenju Jugoslavije iz njenih sadašnjih zaostalosti«. ${ }^{37}$ Visković je krajem osamdesetih godina 20. st. naglašavao potrebu pluralizacije političkog života u Jugoslaviji, zagovarajući ponajprije postupni razvoj (opravdano se plašeći zaoštravanja unutarnjih sukoba u slučaju nagle promjene), odnosno prijelazne modele (unutarpartijski pluralizam) prema, dugoročno neizbježnom, višestranačkom sustavu. ${ }^{38}$ Međutim, pokušaji reforme jugoslavenskog

\footnotetext{
${ }^{34}$ Usp. Ivica Milivončić, »Vode Tuđman i Račan, slijede Savka i Miko«, Slobodna Dalmacija 8. 4. 1990., str. 1617 , ovdje str. 16.

${ }^{35}$ Bogdan Tirnanić, »Topla voda i hladni vetrovi«, NIN 25. 6. 1989., str. 12-13, ovdje str. 13.

${ }^{36}$ Z. Oštrić, »Ekološki pokreti u Jugoslaviji«, str. 84.

${ }^{37}$ N. Visković, »Prema političkom Savezu zelenih«, str. 27.

${ }^{38}$ Usp. Nikola Visković, Politički ogledi, Književni krug, Split 1990., str. 134-137.
} 
sistema došli su prekasno, a političko djelovanje moralo se snaći u novim okolnostima nadolaska višestranačja, stvaranja neovisnih nacionalnih država i izbijanja rata.

Na prvim višestranačkim izborima u Hrvatskoj, Visković je, kao predstavnik Zelene akcije Split na listi Socijal-demokratske partije, dobio saborski mandat. Tu se prvenstveno zalagao za uzimanje u obzir ekoloških pitanja, pri čemu se naročito ističe njegov istup protiv Tuđmanova formuliranja temeljnih i povijesnih zadataka hrvatske politike, u kojima je izostala zaštita prirode, čime se, prema njegovu mišljenju, dodatno potvrdila devetnaestostoljetna priroda takvih političkih pogleda. ${ }^{39}$ Riječ je o Tuđmanovu govoru o »deset neposrednih zadaća hrvatskog naroda i države« održanom na prvoj sjednici višestranačkog Sabora (30. svibnja 1990.), na koji je reagirao jedino Visković. ${ }^{40}$ Visković je ipak uspio u Komisiji za ustavna pitanja progurati prijedlog o unošenju zaštite biljnog i životinjskog carstva u članak 54. Ustava Republike Hrvatske. ${ }^{41}$

»Nastup posve prikladan predodžbi o zelenom poslaniku, ali za većinu u ekološkom pokretu prežestok. Zbog radikalnog stava i ironije koju su mnogi smatrali za uvredu nacionalnih osjećaja, od njegovih se istupa već nakon konstitucione sjednice novog Sabora (krajem svibnja 1990), ogradio i Izvršni odbor Saveza zelenih Hrvatske. ${ }^{42}$

Kako piše Zoran Oštrić, nije se radilo o posljednjem takvom prosvjedu i ograđivanju ovog tijela. Konačno su u ožujku 1991. iz Saveza zelenih Hrvatske zbog političkog djelovanja, premda takvo što nije bilo u proturječju sa statutom, isključene Zelene akcije Split, Zagreb i Šibenik. Aktivnost Saveza zelenih Hrvatske ubrzo prestaje. ${ }^{43}$

Visković navodi tri razloga iznenadnog gašenja, nakon isto tako iznenadnog uzleta, Zelene akcije Split. Prvo, raspadu je kumovala tadašnja politička situacija koja je kod samih članova potaknula zaoštravanje međusobnih nesuglasica po pitanjima koja nisu bila ekološka. Drugo, istupanje članstva zbog odluke Zelene akcije Split da se angažira na parlamentarnim izborima također je negativno utjecalo na perspektivu udruženja. Konačno, njegovo je vezivanje »zelenoga« uz »crveno« izazvalo iritaciju javnosti i stvorilo percepciju o političkoj zavisnosti Zelene akcije. ${ }^{44}$ No raspadu ovog pokreta svakako je kumovala i tadašnja politička situacija, o čemu se Visković jasno izrazio u jednom intervjuu iz rujna 1990.: »Ekološki pokreti

\footnotetext{
${ }^{39}$ Usp. N. Visković, Sumorne godine, str. 89.

${ }^{40}$ Usp. ibid., str. 195-196.

${ }^{41}$ Usp. ibid., str. 89.

${ }^{42}$ Z. Oštrić, »Ekološki pokreti u Jugoslaviji«, str. 100.

${ }^{43}$ Usp. ibid., str. 97.

${ }^{44}$ Usp. N. Visković, Sumorne godine, str. 91.
} 
u Jugoslaviji, rođeni tako kasno prije par godina, izgledaju osuđeni na smiješne ili ukrasne intelektualističke uloge kraj sadašnjih mobilizacija za tribalne sukobe. Oni su računali s civilnim društvom i demokratskim sposobnostima kakvi se u nas potpuno onemogućuju. « ${ }^{45}$

Tijekom rata koji je nedugo zatim nastupio, Visković se zauzeo za ekološke prijetnje, tražeći podršku i europskih »zelenih «. ${ }^{46}$ Među rijetkima je govorio i o stradavanju životinja tijekom tog razdoblja. ${ }^{47}$ No to ne znači da je u ratu zanemario ljudske stradalnike, počevši od organiziranja akcija za prikupljanje pomoći izbjeglicama iz Bosne i Hercegovine, ${ }^{48}$ pa sve do prosvjeda protiv zločina i spašavanja pojedinih osoba srpske nacionalnosti u gradu Splitu. I za svrhe potonjeg, Visković je, u okviru Dalmatinske akcije, koristio svoje kontakte sa »zelenima« Europe, domogavši se tako pomoći za izbjeglice i žrtve otkaza s posla po nacionalnom ključu. ${ }^{49}$ Osim što se zalagao za obespravljene, na više je mjesta pisao o konkretnim slučajevima njihova maltretiranja: izbacivanja iz stanova, premlaćivanja i ubijanja u svojoj sredini, a onda posebno i na čitavom ratom zahvaćenom i nezahvaćenom prostoru Hrvatske i Bosne i Hercegovine, nimalo pri tom ne štedeći političke prvake zemalja bivše Jugoslavije. ${ }^{50}$

\footnotetext{
45 Ibid., str. 12.

${ }^{46}$ Usp. B. Oreb, »I zelene kacige u Hrvatskoj?«, Slobodna Dalmacija 22. 3. 1992., str. 8.

${ }^{47}$ Usp. Nikola Visković, Kulturna zoologija. Što je životinja čovjeku i što je čovjek životinji, Naklada Jesenski i Turk, Zagreb 2009., str. 207; N. Visković, Sumorne godine, str. 97-98.

${ }^{48}$ Usp. L. G., »Donesite hrane!«, Slobodna Dalmacija 18.-20. 4. 1992., str. 20.

${ }^{49}$ Usp. Mašenjka Bačić, »Heroji mira: Aktivizam pod čizmama HOS-a«, Novosti 9. 8. 2019., str. $22-23$.

50 Vidi npr. članke: »Split - grad bezakonja?« iz lipnja 1992., »Riječ je o odgovornosti« iz siječnja 1994. i »Vjerovati Tuđmanu?« iz studenog 1993. u: N. Visković, Sumorne godine, str. 47-51, 62-72.
} 


\section{II.1. PRIRODA I KULTURA}

Prije no što krenemo u detaljnije propitivanje odnosa kulturnog i prirodnog u djelu Nikole Viskovića, pa i prije no što pružimo općenitu sliku o njegovim projektima kulturne zoologije i kulturne botanike, koji nam ovdje stoje u centru pažnje, bit će potrebno pružiti barem osnovni uvid u značenje pojmova kulture i prirode te načine njihova međuodnosa, čemu ćemo se više puta vraćati u toku i na kraju ovog rada.

\section{II.1.1. Obličja kulture}

Kultura je sve samo ne jednoznačan pojam. On je različito definiran u različitim vremenima, različitim sredinama i različitim kontekstima. Istovremeno, radi se o jednom od ključnih pojmova čovjekova samoodređenja, posredstvom kojega on određuje i sve ono što ga okružuje. S obzirom na to, poimanje kulture ima osobitu važnost, ono nije nimalo benigno i ne može biti prihvaćeno kao samorazumljivo (što je najčešće slučaj). Pokušat ćemo pokazati da o tom poimanju ne ovisi samo čovjekova, nego i sudbina svega bivstvujućeg što dolazi u odnos s njim. Promišljenost koja nas u ovom određivanju pojma kulture obavezuje ne nalaže nužno da se upustimo u minuciozno raščlanjivanje svih njenih nabačenih značenja, što lako može stvoriti nejasnu zbrku u kojoj je orijentacija gotovo nemoguća, nego bi prije označavala izdvajanje nekoliko onih jasnije određenih, kako bismo njihovu nit mogli provlačiti kroz ovaj rad. ${ }^{51}$

Kulturni antropolog Alfred Kroeber pobrojao je oko 250 definicija kulture, koje bi se mogle podvesti pod pet tipova definicija: pozitivističke, normativističke, metafizičke,

\footnotetext{
${ }^{51}$ Za raznolika određenja kulture vidi npr.: Ivan Cifrić, Pojmovnik kulture i okoliša, Visoka škola za poslovanje i upravljanje s pravom javnosti »Baltazar Adam Krčelić«, Zaprešić 2009., str. 124-126.; Terry Eagleton, Ideja kulture, prevela Gordana V. Popović, Naklada Jesenski i Turk, Zagreb 2014.; Terry Eagleton, Kultura, preveo Damir Biličić, Naklada Ljevak, Zagreb 2017. S obzirom na ovu raznolikost, može se, zajedno s Edgarom Morinom, reći da je termin 'kultura' »pravi konceptualni kameleon«. (Edgar Morin /suradnik Nelson VallejoGómez/, Odgoj za budućnost. Sedam temeljnih spoznaja nužnih u odgoju za budućnost, prevela Ingrid Šafranek, Educa, Zagreb 2002., str. 105.)
} 
kulturalističke i naturalističke. ${ }^{52}$ Već se tu otvara čitav mozaik problema koje bi i puno veće studije od ove teško mogle u potpunosti obuhvatiti. Ovdje si, stoga, postavljamo puno skromniji zadatak, naime, zadatak ocrta nekih vidova kompleksnog pojma kulture polazeći od onih uobičajenih i svakodnevnih. Suočavajući se s pojedinim problemima koji izviru iz takvih shvaćanja pokušat ćemo doći do nešto koherentnijeg određenja ovog pojma.

Promatramo li, tako, kulturu po pitanju nasljedovanja, kako se ona nerijetko razumijeva, onda se možemo poslužiti sljedećom definicijom: »Kultura obuhvaća one aspekte ljudske aktivnosti koji su prije društveno negoli genetički preneseni. « ${ }^{53}$ Kultura je, u tom smislu, nešto naučeno, a ne nešto puko naslijeđeno, nešto za što treba uložiti odgojni trud od strane one osobe koja je već u kulturi, što onome tko u kulturu ulazi ne pridolazi instinktivno. To nam je jasno već iz empirijskih primjera ljudske djece koja su odrastala uz divlje (ne-kulturne) životinje, a koja se povratkom u svoju biološku zajednicu nisu uspjela uklopiti u njezinu kulturu. Odavde možemo vidjeti i to da se kulturno često suprotstavljalo onom divljem, ne-kulturnom. Međutim, već se pri toj odredbi počinju javljati određeni problemi u razgraničenju kulturnog i nekulturnog. Jasno je da orao ili hijena pripadaju divljemu ili prirodi, a ne kulturi. Ali kako stoje stvari s ovcom ili psom, domaćim životinjama koje nisu divlje, nego su putem domestikacije postale sastavnim dijelom kulture? Premda je kultura gotovo nezamisliva bez uloge tih životinja, one samim time nisu kulturne. Njihovo bivanje objektima kulture ne čini ih ujedno i njenim subjektima. Kako bi se došlo do biti kulture, valjalo bi se upravo usredotočiti na djelatnost subjekta kulture, pa se u tom pogledu čini kako bi je najadekvatnije bilo odrediti kao oplemenjivanje (što sugerira i etimologija: lat. colere = gajiti, oplemenjivati). Tako je ona, prema jednoj drugoj definiciji, »u najširem smislu: preradba i usavršavanje nečega, neke građe, nekog materijala za određenu svrhu. U tom se smislu i govori npr. o kulturi tla, kulturi bilja (agrikulturi) i sl. I u tom smislu već ta riječ znači zapravo oplemenjivanje. « ${ }^{54}$ Ovakva odredba vodi k ideji, odnosno proizlazi iz ideje čovjeka kao bića čije djelovanje izvodi prirodu iz zaostalosti u plemenito postojanje, čije djelovanje time ima veću vrijednost od onog puko prirodnog. Konačno, sam taj djelatnik sebe (u generičkom smislu) postavlja kao vrjednijeg od onoga nad čime djeluje. Ono što ćemo kod ovih definicija primijetiti jest da kultura uvijek stoji naspram nečega. To ne znači da ona samim time ne ovisi o tome nečemu, a ne znači niti to da

\footnotetext{
${ }^{52}$ Vidi: Nikola Skledar, Čovjekov opstanak. Uvod u antropologiju, Hrvatsko filozofsko društvo, Zagreb 1996., str. $105-107$.

53 Anthony O'Hear, »Culture«, u: Edward Craig (ur.), The Shorter Routledge Encyclopedia of Philosophy, Routledge, New York 2006., str. 159.

${ }^{54}$ Vladimir Filipović, »Kultura«, u: Vladimir Filipović (ur.), Filozofijski rječnik, Nakladni zavod Matice hrvatske, Zagreb 1989., str. 183.
} 
ona ponekad ne ulazi u blisku vezu ili prožimanje sa svojom suprotnošću. Vladimir Filipović će to jasno izraziti u natuknici o kulturi u Filozofijskom rječniku upravo na mjestu gdje kulturu postavlja kao antitezu prirodi:

»Pod prirodom se kod čovjeka razumijevaju sve njegove urođene osobine, a pod kulturom njegova ličnim zalaganjem i stvaralaštvom ostvarena ličnost. To doduše nisu odijeljena područja njegove osobnosti, ali se ipak mogu i moraju diferencirati iako su u zbilji neodvojivo spojena i međusobno prožeta. « ${ }^{55}$

Definiranje pojma kulture nemoguće je bez refleksije o samom čovjeku, a izgleda da se to u velikoj mjeri odnosi i na njemu nasuprot stojeći pojam prirode. ${ }^{56} \mathrm{U}$ tom se kontekstu ne može tvrditi da je isključivo tvori ono što pojedinac vlastitim snagama izgradi iz sebe. Svaki pojedinac koji postaje kulturan, kako je rečeno, mora proći kroz proces odgoja ili, bolje, učenja unutar pojedine kulture. Stoga kultura, uz individualni, nužno posjeduje i nadindividualni aspekt, bilo da se odnosi na određenu zajednicu, bilo na određenu epohu. U ovom se kontekstu kultura može odrediti na način na koji to radi Alexander Ulfig, prema kojemu je ona »suma duhovnih ostvarenja jedne zajednice, odnosno jedne epohe «. ${ }^{57}$ Međutim, ako ovu definiciju dovedemo u odnos s gore navedenim određenjima, pojavljuje se nekoliko nedoumica, od kojih posebno možemo izdvojiti pitanje statičnosti odnosno aktivnosti te pitanje obuhvatnosti.

Ulfig navedeni pojam kulture zapravo izjednačava s pojmom kulturnih ostvarenja (Kulturleistungen), pa u nastavku navodi: »Kulturu čini ukupnost ljudskih ostvarenja i otkrića. Kulturna ostvarenja su npr. jezik, religija, znanost, umjetnost, pravo, odgoj, gospodarstvo, državno uređenje, osiguranje mira. $\ll^{58}$ Time je kultura označena kao nešto postalo, ono što je djelatnošću ljudskog duha stvoreno. Međutim, čini se da to sačinjava samo jedan aspekt kulture. Poimanje kulture kao nečeg statičnog ne može objasniti niti sam njen nastanak, odnosno iskakanje iz samoniklosti prirode. Štoviše, tada bi i kultura bila tek dio prirodne samoniklosti, samo one ljudske. Ona bi, ukratko, bila samo jedno od predodređenja, ne doduše kao urođeno

\footnotetext{
55 Ibid., str. 183.

${ }^{56}$ Ova se teza može zasnovati već u čuvenom Kantovu kopernikanskom obratu: »Dakle, red i pravilnost u pojavama, koje nazivamo prirodom, unosimo mi sami u njih, pa ih u njima ne bismo ni mogli naći, da ih mi ili priroda naše duše nije iskonski stavila u njih. «(Immanuel Kant, Kritika čistoga uma, preveo Viktor D. Sonnenfeld, Nakladni zavod Matice hrvatske, Zagreb 1984., str. 81). Sličan stav, koristeći pojam kulture, izreći će i Claude Lévi-Strauss: »To je, čini se, krajnje naivno poimanje, jer nema prirodnih pojava u čistom stanju; prirodne pojave za čovjeka postoje samo pojmovno i filtrirane logičkim i afektivnim normama koje pripadaju u područje kulture.« (Claude Lévi-Strauss, Strukturalna antropologija 2, preveli Daniel Bučan i Vjekoslav Mikecin, Školska knjiga, Zagreb 1988., str. 214.)

57 Alexander Ulfig, Lexikon der Philosophischen Begriffe, Bechtermünz, Eltville am Rhein 1993., str. 245.

${ }^{58}$ Ibid., str. 245.
} 
(gensko), ali svakako kao prirođeno (memsko), što se bitno kosi s mogućnošću stvaralaštva, novoga, drugačijega - slobode, kao njenog ključnog svojstva. ${ }^{59}$

\begin{abstract}
»U užem smislu kultura znači ostvarivanje humanih vrednota u čovjeku i njegovim djelima koja, za razliku od djela civilizacije (koju nazivamo materijalnom kulturom!), nose svoje vrednote same u sebi. Ona znači u isti mah i akt, stvaralački proces i ono što je tim procesom stvoreno. To bi bili npr. moralni čini, umjetničko stvaralaštvo, ali i ostvarena djela, za razliku od tvorevina tehnike koja služe svrhama izvan sebe. No i kulturne tvorevine (kulturna dobra!) mogu se nasljedovati i prenositi samo svojom izvanjštinom, bez unutrašnjih vrednota koje su temeljne za ostvarenje kulturnih dobara. Ova izvanjština kulture tvori zajedno s tehnikom ono što nazivamo civilizacijom. « ${ }^{60}$
\end{abstract}

Ova odredba pruža odgovor na postavljeni problem. Kultura nije postalost, već je i postalost i nastajanje. Ona se dodatno određuje time da su vrijednosti od kojih je sačinjena vrijednosti u sebi samima, čime se bitno razlikuju od tehnike, čija vrijednost leži izvan nje same. Tu je kultura, naime, shvaćena kao duhovna kultura, kojoj se onda suprotstavlja civilizacija kao materijalna kultura. Potonja se sastoji od same vanjštine, koja nema vrijednost u sebi. Tako, primjerice, Michelangelova statua Davida nema vrijednost u sebi, nego je stvar u tome da joj mi (od njenog stvaraoca pa nadalje) pridajemo vrijednost. Ta vrijednost i ne može biti puko naslijeđena ili prirođena - kako je rečeno, nasljeđuje se samo vanjština (sama statua), a unutarnja vrednota nije zauvijek postala, ona mora biti održavana. Naravno, u cjelokupnosti kulture ne radi se, kako kaže Milan Polić, samo o održavanju, nego prije svega o stvaralaštvu, kojega je svaka kultura izraz i koje je oduvijek bilo moguće samo na izvjesnoj kulturnopovijesnoj podlozi. Svaka pak kultura drži na životu samo čuvanjem onog nagovjesnog, a s prestankom stvaralaštva ona egzistira tek prividno, kao opetovanje. ${ }^{61}$

Ovdje se sada otvara i drugi postavljeni problem, onaj obuhvata. Radi li se kod kulture o nečemu što je pripadno jednom narodu (ili nekoj drugoj grupaciji), pa da time postoji više kultura, ili o tome da postoji više kultura koje pripadaju različitim epohama? Konačno, postoji li nešto kao jedinstvo ljudske kulture?

Dio odgovora svakako treba tražiti i u genezi pojma kulture. Upravo gore navedeno razlikovanje kulture i civilizacije nastaje u doba prosvjetiteljstva u razmimoilaženju svjetonazora francuske i njemačke misli. Kako objašnjava Terry Eagleton, ideja civilizacije razvijena je u kontekstu francuskog prosvjetiteljskog duha, sa značenjem općeg duhovnog i materijalnog napretka. Međutim, sam pojam civilizacije u francuskom se obično odnosio na

\footnotetext{
${ }^{59}$ Usp. Milan Polić, »Kultura kao sudbina«, Filozofska istraživanja 28 (2008) 1, str. 3-11, ovdje str. 10.

${ }^{60}$ V. Filipović, »Kultura«, str. 183.

${ }^{61}$ Usp. Milan Polić, Odgoj i svije(s)t, Hrvatsko filozofsko društvo, Zagreb 1993., str. 22.
} 
politički, ekonomski i tehnički aspekt života, dok je njemački pojam kulture, koji je u francuskom zapravo trebao označavati nešto slično civilizaciji u prvom iznesenom značenju, ograničio svoje značenje na religijski, umjetnički i intelektualni aspekt života. Osim toga, »njemačka kultura« podrazumijevala je uvećavanje nacionalnih razlika, dok je »francuska civilizacija« poprimila univerzalističku tendenciju. Dok je potonja bila upravo građanska tekovina, prva je zadobivala patricijske i populističke (volkisch) oblike. ${ }^{62}$

»Rođen na vrhuncu prosvjetiteljstva, pojam kulture sada se edipovskom silovitošću obara na svoje roditelje. Civilizacija je bila apstraktna, otuđena, razlomljena, mehanička, utilitarna, sužanj sirove vjere u materijalni napredak; kultura je bila holistička, organska, osjetilna, samosvrhovita, obuhvatna. «63

U takvom se kontekstu može učvrstiti teza da se ne može raditi o kulturi u singularu, nego samo o pojedinačnim kulturama pojedinačnih naroda i sl. Međutim, historijska razdioba kulture i civilizacije je, kako se dade vidjeti iz posljednje Filipovićeve definicije, zadobila jedno značenje koje odudara od izvornoga utoliko što prihvaća dio kritike njemačkog romantizma. Stoga se tu kultura može razumijevati u svojevrsnom »reformirano-prosvjetiteljskom« smislu, ali se, isto tako, može imenovati i potpuno prosvjetiteljskom, ako se prepoznaju zajednički elementi Filipovićeva određenja kulture s idejom kulture filozofa koji do vrhunca dovodi ono najplodnije iz prosvjetiteljstva, a riječ je o Immanuelu Kantu:

\footnotetext{
»Mi smo civilizirani i pretovareni raznim društvenim uljudnostima i pristojnostima. Ali još vrlo mnogo nedostaje da bismo se smatrali već moraliziranima. Jer, ideja moralnosti još spada u kulturu; ali primjena te ideje, svedena samo na častoljublje i vanjsku pristojnost koji nalikuju moralu, sačinjava samo civilizaciju. $\ll^{64}$
}

\footnotetext{
${ }^{62}$ Usp. T. Eagleton, Ideja kulture, str. 16-19. - O genezi podjele na (njemačku) kulturu i (englesku i francusku) civilizaciju vidi i: Norbert Elias, O procesu civilizacije. Sociogenetska i psihogenetska istraživanja, preveli Silvija Bosner i Marijan Bobinac, Izdanja Antibarbarus, Zagreb 1996., str. 55-98.

${ }^{63}$ T. Eagleton, Ideja kulture, str. 19.

${ }^{64}$ Immanuel Kant, »Ideja opće povijesti s gledišta svjetskog građanstva«, u: Immanuel Kant, Pravno-politički spisi, preveo Zvonko Posavec, Politička kultura, Zagreb 2000., str. 17-32, ovdje str. 27. - Norbert Elias također ističe ovo mjesto, dodajući tome historijsku kontekstualizaciju u vidu sukoba srednjeg staleža i plemstva: »Ovdje, dakle, imamo sloj koji je poprilično istisnut iz političkih aktivnosti, koji jedva da razmišlja u političkim, a tek vrlo bojažljivo u nacionalnim kategorijama, i čija sva legitimacija uglavnom proizlazi iz njegovih duhovnih, njegovih znanstvenih ili umjetničkih dostignuća; njemu nasuprot stoji gornji sloj koji ne 'stvara' ništa u smislu drugih slojeva, već se u središtu njegove samosvijesti i njegova samoopravdanja nalazi oblikovanje distingviranog i distingvirajućeg ponašanja. Upravo je to onaj sloj na koji Kant misli kada govori o 'civiliziranosti do zasićenja', o pukoj 'društvenoj učtivosti i uglađenosti', o onom 'ćudoređu sličnom u častoljublju'. Ovdje se zapravo radi o polemici njemačke inteligencije srednjeg staleža protiv uglađenosti postojećega, dvorskoga gornjeg sloja, o polemici presudnoj pri stvaranju suprotnosti pojmova kultura - civilizacija u Njemačkoj.« (N. Elias, O procesu civilizacije, str. 60.)
} 
Civilizacija se, stoga, odnosi samo na ono izvanjsko kulture, pa od tu izjednačavanje tog pojma s pojmom materijalne kulture u Filipovićevoj definiciji. S obzirom na to da u okviru onog duhovnoga za Kanta ključno mjesto zauzima ono moralno, ne treba posebno ukazivati na njegovu naglašeno univerzalističku narav. Filipovićevo poimanje kulture također sadrži univerzalističku tendenciju koja se očituje u sljedećem: »Kultura pojedinaca i čitavih zajednica teži svagda jedinstvu, pa se različita kulturna (vrijednosna) područja povezuju u raznolika jedinstva, jer kultura ne podnosi proturječnosti. « ${ }^{65}$

Ne može se poricati da postoji više različitih kultura u ovom pogledu. Međutim, bez obzira tendiraju li one jedinstvu ili ne, kultura se može poimati na generički način, kao nešto što pripada čovjeku kao čovjeku. Iako postoji više kultura u sadržajnom smislu, radi se o jednoj kulturi po pitanju same forme. Ona se, u tom pogledu, može promatrati kao specifični način čovjekova bivstvovanja (uz onaj prirodni) ili kao specifični način čovjekova posredovanja onoga što ga okružuje (ili bolje: s čime ulazi u odnos). Ona je, kao čovjeku specifičan način posredovanja postojećeg, istovremeno i mjesto na kojem se rađa moguće i buduće, što je jasno prisutno u moralitetu i stvaralaštvu, koji opet nužno podrazumijevaju neki odnos spram postojećeg, tj. posredovanje postojećeg. Kultura se onda u svom sadržajnom smislu konkretizira kod pojedinih kulturnih zajednica i u pojedinim epohama. U tom smislu, Zygmunt Bauman razlikuje dva načina poimanja kulture $\mathrm{u}$ društvenim zajednicama. Kultura $\mathrm{u}$ atributivnom smislu odnosila bi se na kulturu kao bitan atribut ljudske vrste kao takve, dok bi se kultura u distributivnom smislu odnosila na kulturu koja je lokalizirana u prostoru i vremenu. Prva bi se odnosila na jedinstvo ljudske vrste, druga na njene unutarnje duhovne razlike. ${ }^{66}$

Jedno široko određenje kulture koje bi nam moglo biti od pomoći u pokušaju sintetiziranja dijela navedenih izvoda nalazimo kod Nikole Skledara:

»Kultura je univerzalni ljudski fenomen, antropološka danost i bitna generička značajka čovjeka kao društvenoga i individualnog, duhovnoga i stvaralačkog bića. « ${ }^{67}$

Čini se da ova odredba najbolje odgovara poimanju kulture kao čovjeku specifična načina posredovanja onoga s čime ulazi u odnos, tj. kulture kao pripadne čovjeku kao čovjeku.

\footnotetext{
${ }^{65}$ V. Filipović, »Kultura«, str. 183.

${ }^{66}$ Usp. Zigmunt Bauman [Zygmunt Bauman], Kultura i društvo, preveo Radoslav Đokić, Prosveta, Beograd 1984., str. 27-28. - Bauman, doduše, kulturu u prvom redu promatra kao suprotstavljenu društvu, postavljajući interiorizaciju ili njenu mogućnost za kriterij kulturnih pojava. Tako bi ona bila sfera ciljeva, vrijednosti, značenja i tipova, dok bi društvo bila sfera zavisnosti u koju čovjek ulazi u procesu zadovoljenja svojih potreba. (Usp. ibid., str. 7-12.)

${ }^{67}$ N. Skledar, Čovjekov opstanak, str. 103.
} 
Prije svega, važna je pripomena da se tu radi o čovjeku kao duhovnom biću, tj. o njegovom duhovnom aspektu koji postoji uz onaj prirodni. Takvo određenje ne dolazi u konflikt s postojanjem materijalne kulture. Iako ona ne pripada duhovnoj kulturi, njeno je izvorište u duhu. Kako slikovito (iako možda s odveć pojednostavljenim shvaćanjem životinjske kognicije) objašnjava Karl Marx:

»Pauk vrši radove slične tkalčevim, a gradnjom svojega saća pčela postiđuje ponekog ljudskog graditelja. Ali što unaprijed odvaja i najgoreg graditelja od najbolje pčele, jest da je on svoju gradnju izgradio u glavi prije nego što će je izraditi u vosku. Na završetku procesa rada izlazi rezultat kakav je na početku procesa već postojao u radnikovoj zamisli, dakle idealno. Ne postizava on samo promjenu oblika prirodnih stvari; on u njima ujedno ostvaruje i svoju svrhu koja mu je znana, koja poput zakona određuje put i način njegova rađenja, i kojoj mora da podčini svoju volju. ${ }^{68}$

Nadalje, spomenuto određenje kulture ne ulazi u pitanje statičnosti i dinamičnosti kulture, što je svakako bolji put od jednoznačnog pristajanja na jednu ili na drugu opciju. Međutim, i jedno i drugo određenje daju se pronaći u nekima od pojmova koji su ovdje naznačeni. Svojevrsna uvjetovanost kulturom proizlazi iz činjenice da je ona naša antropološka danost. Mi smo, stoga, »osuđeni na kulturu« ${ }^{69}$ kao što smo i u poznatoj Sartreovoj tezi »osuđeni na slobodu«, ${ }^{70}$ što pak nikako ne znači da smo osuđeni na nekakav gotov sadržaj kako jedne, tako i druge. To, doduše, vrijedi do određene mjere, jer smo putem odgoja pod bitnim utjecajem određenog načina na koji se kultura upojedinjuje - sama naša misao odvija se u određenom jeziku - a bez odgoja nije moguće postati (ili, možda radije, postajati) kulturno biće. S druge strane, pojam stvaralaštva, tj. čovjeka kao stvaralačkog bića, jasno ukazuje na dinamičku prirodu kulture, iako ono ne isključuje ono što je stvarano od drugih stvaralačkih bića, a što mi nasljeđujemo. Ova se odredba, kako ćemo vidjeti, ne može potpuno jasno i jednoobrazno odrediti kao antropološka danost, naročito kada se u obzir uzmu pojedine suvremene tehnološke prijetnje mogućnosti ljudskog stvaralaštva, a tako i njegovoj slobodi i njegovoj kulturi. Dovođenjem u pitanje danosti dvaju potonjih pojmova za određenje čovjeka, spomenuta bi ga ugroza ozbiljno dovela u pitanje.

Stvaralaštvo se može promatrati kao ključan element za nastanak samog čovjeka, pri čemu su antropološke teze Arnolda Gehlena osobito instruktivne. Gehlen čovjeka primarno

\footnotetext{
${ }^{68}$ Karl Marx, Kapital. Kritika političke ekonomije, sv. 1, Proces proizvodnje kapitala, preveli Moša Pijade i Rodoljub Čolaković, Kultura, Zagreb 1947., str. 135.

${ }^{69}$ »Kakva god bila, kultura nas ljudski određuje. Kakva god bila, tek nas kultura ljudski omogućuje. Stoga, kakva god bila, kultura je čovjekova sudbina.« (M. Polić, »Kultura kao sudbina«, str. 8.)

${ }^{70}$ Usp. Jean-Paul Sartre, Egzistencijalizam je humanizam, Veselin Masleša, Sarajevo 1964., str. 16-17.
} 
određuje kao djelatno biće, što proizlazi iz njegove neustanovljenosti, a iz čega slijedi da je on bitno biće (samo)odgajanja. On je stvaralačko biće već u tom smislu što neustanovljenost njegova bića tvori od njega stalan zadatak. Nedovršivost čovjekova bića ne odnosi se samo na njegov duhovni aspekt, nego je on u puko morfološkom smislu uglavnom obilježen nedostatcima, $\mathrm{tj}$. on je morfološki nespecijalizirano biće, što onda nadoknađuje sposobnošću rada, odnosno pomoću ruku i inteligencije. Neprilagođenost i nespecijaliziranost nagone ga na preobrazbu dane stvarnosti u stvarnost koja će omogućiti odvijanje njegova života - kultura nije ništa drugo do sveukupnost prirode koju je čovjek preradio tako da služi njegovu životu, »druga priroda « u kojoj on jedino može opstojati. Njegova neprilagođenost okolišnom miljeu čini ga otvorenim prema svijetu, a istovremeno se postavlja na distancu spram svoje okoline, što mu omogućava orijentaciju, ali ga također izlaže silnoj količini podražaja i utisaka. Čovjek se, stoga, samo svojim snagama mora rasteretiti, a upravo iz rasterećenja izrastaju sve više djelatnosti, tj. djelovanja bez neposredne vrijednosti ispunjenja, komunikativne i od potreba slobodne akcije, kao i simbolizacija. Visoki stupanj stvaralaštva svojstven je jeziku, maksimumu orijentiranja i simboliziranja, upravo zbog njegove rasterećujuće uloge. Radi se o obliku komunikacije koji je najbezmučniji, a istovremeno uvećava osjetilnu puninu svijeta. ${ }^{71}$

Pored osnovnih (antropološka danost, stvaralaštvo...), moguće je navoditi i neka dodatna svojstva kulture, koja Skledar sintetizira u sljedećem određenju:

»Kultura u modernijem značenju te riječi (Puffendorf, 18. st) kao univerzalni ljudski fenomen (individualni i generički) jest njegovanje, usavršavanje čovjekovih naravnih (urođenih) datosti i svojstava, oplemenjivanje njegova svijeta, uljuđivanje cjelokupne organizacije njegova života, u jednu rečenicu, ozbiljenje humaniteta. Preneseno, to je cjelokupnost i rezultat materijalnog i duhovnog proizvođenja i stvaralaštva (poiesis) i njihovih rezultata i tvorevina, kojima čovjek u povijesti namiruje svoje složene potrebe, osmišljuje, tj. kultivira svoje življenje.

Kultura je skup svih procesa i tvorevina što su nastale kao rezultat materijalne i duhovne intervencije čovjeka (ljudskog roda) u prirodi, društvu i ljudskom duhu. Osnovni smisao kulture jest održavanje i napredak (humaniziranje) čovjeka, njegova društva i života. $\ll^{72}$

Kultura se, dakle, ne shvaća primarno kao skup karakteristika ili vrsta djelatnosti određenog živog bića, nego upravo kao čovjeku specifičan modus bivanja i djelovanja. No

\footnotetext{
${ }^{71}$ Usp. Arnold Gehlen, Čovjek. Njegova priroda i njegov položaj u svijetu, preveo Aleksa Buha, Veselin Masleša, Sarajevo 1974., str. 30-39, 47. - Ovdje slijedimo Gehlenovo korištenje pojma svijet, kao što je slučaj i kod drugih autora koji ga koriste u kolokvijalnom ili nekom drugom značenju, iako ga u ostatku rada tretiramo drugačije. Naime, barem u slučaju čovjeka, svijet nastaje upravo u onom kulturnom posredovanju. Stoga, iako se čini zgodno, nije primjereno kulturu nazivati načinom na koji čovjek sebi posreduje svijet, nego na koji posreduje ono što ga okružuje, postojeće, s čime ulazi u odnos i sl., a upravo se u tom posredovanju proizvodi čovjekov svijet.

${ }^{72}$ N. Skledar, Čovjekov opstanak, str. 107.
} 
ovdje se uz određenje kulture nadovezuje još jedan, dosad neistaknuti, iako prisutni problem. Riječ je o njenom normativnom odnosno deskriptivnom određenju. To postaje posebice očito nedugo nakon navedenog mjesta, gdje se određuje nekulturno i antikulturno:

»I suprotno: kao nekulturne ili antikulturne (ne potkulturne), znači i nehumane moraju se vrednovati sve one pojave i procesi koje su suprotne osnovnim potrebama i interesima održanja i napretka čovjeka i ljudskog društva $(..) \ll^{73}$

Ako bi se stajalo na ovakvom putu definiranja kulture, čini se da bi se pored kulture i prirode trebao uvesti i treći element - ono nekulturno (koje, za razliku od ne-kulturnog ili, analogno moralu, »akulturnog«, nema neutralno normativno značenje). Druga je opcija da se nekulturno kao zlo podvede pod prirodno (poistovjećenje nekulturnog i ne-kulturnog), što nije nepoznato zapadnoj misli. Treba primijetiti i da ovo prvo normativno određenje ne unosi u svoj obzor ne-kulturna živa bića, dakle ona ne-ljudska. Ovih nekoliko nabačaja mogućih problema zasad će ostati samo pod upitnikom, pošto je normativno odnosno deskriptivno određenje kulture kompleksniji problem no što se može činiti, a kako etički aspekt sačinjava ključan dio čitavog ovog rada, ovi će problemi biti razrješavani (koliko je to moguće) »u hodu« i na kraju rada.

Konačno, valjalo bi barem pružiti okvir u kojem ovdje mislimo promatrati pojam kulture. Po našem mišljenju, najbolji je način da se kultura pojmi onaj najobuhvatniji, a riječ je o pojmu kulture kao specifičnog načina čovjekova posredovanja onoga što ga okružuje i s čime ulazi u odnos (uključujući i sama sebe), što u širem značenju podrazumijeva i materijalne proizvode tog posredovanja. Riječ je, ukratko, o svim onim karakteristikama i proizvodima duhovnog i materijalnog stvaralaštva kojima čovjek izgrađuje svoj svijet, a koje ne nalazimo kod ne-ljudskih bića. Premda uvelike formalno, ovakvo određenje kulture zadaje donekle jasno polazište za propitivanje koje slijedi. Također, ovdje je važno istaknuti da ovo propitivanje pojma kulture u prvom redu postavljamo nasuprotno pojmu prirode. U ovom će kontekstu biti raspravljana i specifična određenja kulture koja nalaze svoje mjesto unutar ovog formalnog pojma. Ona će, dakle, biti promatrana i u svojim konkretiziranim momentima unutar pojedinih zajednica i epoha. Isto tako, razmatrat će se i u njenim pasivnim, kao i u njenim aktivnim aspektima. Konačno, propitivat ćemo i značenja njezinih dvaju temeljnih oblika: duhovne kulture i materijalne kulture. Kod pojedinih pitanja vraćat ćemo u raspravu i neka druga

\footnotetext{
${ }^{73}$ Ibid., str. 107.
} 
navedena određenja kulture, ali, kao i kod ostalih, jedino po pitanju središnjeg problema ovog rada - odnosa kulture i prirode.

\section{II.1.2. Viskovićevo poimanje kulture kao otprirođenja}

Udaljavanje kulture od prirodne osnove motiv je koji primarno zaokuplja pažnju Viskovićeve kulturologije. Prije svakog daljnjeg ispitivanja svakako će biti uputno da se ukaže na neka mjesta gdje Visković daje eksplicitna određenja kulture, naročito u njenom sagledavanju kao specifično čovjekova načina bivstvovanja.

»... polazim od fundamentalnog uvida da je kultura po svojoj najdubljoj biti proces odprirođivanja. To je posebnost onoga što čovjek čini od prirode i nadgrađuje na prirodu, mijenjajući je ili ništeći, a što modernom tehnologijom ide do neslućenih razmjera. Treba biti načisto s tim da je kultura, ma koliko bila i velebna (ali u nju spadaju i rat, zločini i bolesti!), uvijek razaranje, gutanje i ništenje primarne, biljne, životinjske i anorganske prirode. Kultura je uvijek ono naše umjetno. I tu se javlja, među ostalim, silan paradoks. Čovjek najprije preoblikuje, muči i ništi prirodu, ali odmah zatim tu svoju žrtvu vrednuje, osjeća za njom nostalgiju i krivnju, strah od gubitaka, strah od vlastite ugroženosti zbog takva razaranja, pa onda na različite načine svoj odnos s prirodom pokušava etički osmisliti i prirodu barem donekle zaštititi. Tako je kultura istovremeno ništenje prirode i htijenje da se ona sačuva i obnovi. « ${ }^{74}$

Dodajmo tome još jedno slično određenje:

»Kultura je ono što Homo faber stvara iz prirode ili protiv prirode. To je čovjekova intervencija u svijet, srazmjerna moći njegovih znanja i tehnologije, kojom i priroda postaje dijelom povijesti - trošeći se ili odprirođujući se pod ljudskim radom. $^{75}$

Visković kulturu primarno određuje spram prirode, tj. naspram nje. Priroda čini njen nužan materijal, nešto iz čega ona stvara, odnosno protiv čega ona stvara. U najmanju ruku, radi se o nezaobilaznoj podlozi kulture, nad čime ona stvara. Ono što na prvi pogled razlikuje Viskovićev pristup fenomenu kulture od odredbi klasičnih filozofskih poimanja, oduzimanje je kulturi oplemenjivačke funkcije, tj. oplemenjivanje joj nikako ne pripada kao supstancijalno svojstvo, nego tek kao mogući atribut. Štoviše, kod Viskovića je češće naglašenija razarajuća, ništeća narav kulture.

\footnotetext{
${ }^{74}$ N. Visković, »U inat vladajućim idiotarijama«, str. 8.

${ }^{75}$ Nikola Visković, Životinja i čovjek. Prilog kulturnoj zoologiji, Književni krug, Split 1996., str. 343.
} 
$\mathrm{U}$ istom smislu, ni čovjek nije samorazumnjivo dobar ili plemenit. Visković zamjera brojnim definicijama čovjeka to što se mahom osvrću na njegova pozitivna svojstva, potpuno zanemarujući činjenicu da je čovjek jedino živo biće koje može biti i zlo, jedino živo biće koje razara - homo destructor. ${ }^{76}$ Naravno, on to nije isključivo, što je jasno iz Viskovićeva preferiranja nabrajajućih definicija naspram ovakvih, per genus proximum et differentiam specificam, što posebno naglašava pri problematici definiranja života, ${ }^{77}$ a što će na više mjesta u ovom radu biti očitovano.

Paradoksalan modus bivstvovanja kulture otvara prostor koji Viskoviću omogućava da uz temeljno pitanje svoje kulturno-biološke misli: što je priroda (konkretno: životinja/stablo) čovjeku i što je čovjek prirodi, može postavljati i pitanje: što čovjek treba biti prirodi? Istovremeno, u ovome se sastoji jedan od bitnih uvida u podvojen odnos čovjeka prema prirodi posredstvom kulture. Njeno ništenje, koje se u poželjnim rezultatima zove oplemenjivanje, čini samu bit kulture, ali ona istovremeno pruža i etičku refleksiju nad ljudskim djelovanjem, koje se protivi smjeru u kojem to ništenje ide. Ova napetost bit će tematizirana u više svojih vidova kroz čitav rad.

\section{II.1.3. Zaborav prirode}

Možda je sâmo pitanje o određenju pojma prirode, kako navodi Branko Pavlović, lišeno kognitivnog smisla. Čini se da je određivanje nečega kao prirodnog samoevidentno, naprosto putem njegova suprotstavljanja onome što je načinjeno od strane čovjeka. ${ }^{78}$ Priroda je, naime: »Beskrajno promjenljiv termin, koji se mijenja kako se mijenja naša znanstvena koncepcija svijeta, a njegovo značenje se često bolje shvaća u suprotnosti prema nečemu što se smatra da nije dio prirode. $\ll^{79} \mathrm{U}$ tom bismo svjetlu, a slijedom gore iznesenog, prirodu mogli naprosto

\footnotetext{
${ }^{76}$ Nikola Visković et al., »Okrugli stolovi«, u: Bože Vuleta, Ante Vučković (ur.), Odgovornost za život. Zbornik radova sa znanstvenog simpozija održanog u Baškoj Vodi, 1. - 3. listopada 1999., Franjevački institut za kulturu mira, Split 2000., str. 643-667, ovdje str. 644-645.

${ }^{77}$ N. Visković et al., »Rasprave«, u: Bože Vuleta, Ante Vučković (ur.), Odgovornost za život. Zbornik radova sa znanstvenog simpozija održanog u Baškoj Vodi, 1. - 3. listopada 1999., Franjevački institut za kulturu mira, Split 2000., str. 621-642, ovdje str. 622. - Postupak definiranja per genus proximum et differentiam specificam »upućuje na odviše apstraktna i spoznajno nedovoljna svojstva zbilje. Stoga je za pojmovno određenje života, kao i za određenje drugih složenih pojava, primjerenija tzv. nabrajajuća definicija - koja punije oblikuje pojam nabrajanjem niza svojstava predmeta bez pretenzije da ih sve iscrpno zahvati. Tako znanstvenici kažu da je život organizam ili takva pojava koja ima: a) staničnu građu, b) metabolizam ili primanje i izmjenu tvari i energije, c) aktivan rast jedinke, d) razmnožavanje ili rađanje s nasljeđivanjem vrsnih svojstava jedinki, e) osjetilnost ili reagiranje na podražaje, f) veću ili manju pokretljivost, g) prilagodljivost okolini i evoluciju jedinki i njihovih vrsta.«(Nikola Visković, Stablo i čovjek, Izdanja Antibarbarus, Zagreb 2001., str. 22.)

${ }^{78}$ Usp. Branko U. Pavlović, Filozofija prirode, Naprijed, Zagreb 1978., str. 111.

${ }^{79}$ Sajmon Blekburn [Simon Blackburn], Oksfordski filozofski rečnik, preveli Ljiljana Petrović et al., Svetovi, Novi Sad 1999., str. 343.
} 
označiti kao ono ne-kulturno, ono što nije specifično ljudsko, mada ne izlazi iz konstitucije čovjeka, a sadrži i elemente koji čovjeku nisu pripadni (primjerice, autotrofno hranjenje kod biljki).

Priroda pak nije samo jedna od sastavnica čovjekova bića, ona koju dijeli s drugim bićima. Način na koji čovjek promatra prirodu, tj. način na koju je posreduje kulturom, čini ključnu sastavnicu njegova samotumačenja. Ako nikako drugačije, onda barem u tom vidu da je priroda kulturi ono najosnovnije drugo. Naravno, objašnjenje ovog odnosa ne treba ići u smjeru isključivanja. Postoji značajna »siva zona« u određivanju obuhvatnosti kulturnog i prirodnog, čije će nijanse činiti jednu od okosnica ovog rada.

Priroda nije ni puki materijal kulture. Da se kultura i priroda ne odnose isključujuće svjedoči već simbolotvorstvo kao jedna od osnovnih, a prema nekim tumačenjima

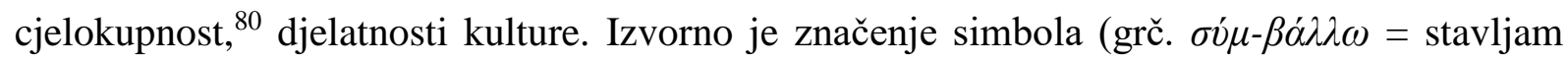
zajedno) znak prepoznavanja, koje se konkretno odvijalo na način spajanja dvaju dijelova razlomljenog predmeta od strane različitih donositelja, odakle je proizašlo predstavničko značenje, u smislu »stajanja namjesto «. ${ }^{81}$ Zanimljivo je da takvo značenje nalikuje jednoj uobičajenoj praksi prisutnoj u svakodnevnom životu. Mislimo na običaj nošenja polovice prelomljenog srca na ogrlici, kao simbola ljubavi između dvoje ljudi, čije spajanje sačinjava potpuno srce. Ipak, koliko god ta praksa izgledala banalnom, poruka koju ona nosi nije takva, već se u njoj krije čitavo bogatstvo značenjā. Ne radi se, naime, samo o tome da se polovice razlomljenog srca skladno sklapaju i upotpunjuju. Polovica srca nalikuje bezvrijednoj krhotini, dok konkretan organ, koji je u tom simbolu stiliziran, ne može u tom obliku održavati svoju funkciju, naime, funkciju održavanja čovjeka na životu, pa tako i zaista predstavlja tek bezvrijednu krhotinu nekad neprocjenjivog organa. Puka materija, koliko god da je konstitutivna za sam simbol, ima za nas značenje kao i polovica srca, naime nema vrijednosti ako nije posredovana značenjem kojega je simbol nosioc. No moglo bi se kazati i obrnuto materija ili sadržaj simbola ključan je u njegovoj konstituciji, a odabiranje upravo određenog sadržaja gotovo nikada nije slučajno (pa tako za simbol ljubavi nije odabrano slijepo crijevo, nego srce): »Simboli su uveliko uvjetovani važnošću i sustavom predmeta koji su im

\footnotetext{
${ }^{80}$ Najreprezentativnije tumačenje ove vrste ono je Ernsta Cassirera: »Razum je vrlo neprimjeren pojam da bismo njime obuhvatili cijelo bogatstvo i raznovrsnost oblika čovjekova kulturnog života. Međutim, svi su ti oblici simbolički. Stoga, umjesto da čovjeka definiramo kao animal rationale, trebali bismo ga definirati kao animal symbolicum. (Ernst Cassirer, Ogled o čovjeku. Uvod u filozofiju ljudske kulture, preveli Omer Lakomica i Zvonimir Sušić, Naprijed, Zagreb 1978., str. 43.)

${ }^{81}$ Usp. Anto Mišić, Rječnik filozofskih pojmova, Verbum, Split 2000., str. 238.
} 
supstrat. « ${ }^{82}$ To sačinjava jednu od temeljnih Viskovićevih teza na temelju koje ukazuje na ključnu ulogu živih bića i prirode uopće u izgradnji našeg kulturnog univerzuma. Priroda je tako, gledano iz rakursa same kulture, konstitutivna za samorazumijevanje čovjeka. Time shvaćanje onoga što priroda jest nije neutralno određivanje onog puko drugoga.

S obzirom na to da je pojam prirode bremenit različitim značenjima koja su joj pridavana u različitim historijskim momentima, nije ju moguće preliminarno odrediti, već se prije mora izvesti jedan pregled načina odnosa spram nje, u kojem se vrši i njezina refleksija. U ovom ćemo poglavlju svakako naznačiti i neka osnovna razmišljanja o novoj situaciji po pitanju odnosa čovjeka (kulture) i prirode, a generalno ćemo se voditi poglavljem »Zaborav prirode« Viskovićeve knjige Stablo i čovjek, uz dodatna obrazloženja (koja nisu nužno na liniji njegovih razmišljanja) iz manjeg dijela obimne literature koja se tiče ove nezaobilazne teme.

Pri razmatranju suvremenog odnošenja čovjeka spram prirode najčešće se ukazuje na način na koji se taj odnos odvijao u arhaičnim kulturama. Tim putom polazi i Visković u svojim projektima. To nije tek proizvoljna metodološka manira, nego on služi tome da se činjenična situacija osvijetli zajedno s povijesnim kontekstom, kao neizostavnim momentom u objašnjenju iste te situacije - njenih uzroka, značenja, konačno i otvorenih prostora transcendiranja postojećeg stanja. Ovdje ćemo, stoga, kombinirati uvid u suvremenu situaciju s ukazivanjem na genezu pojedinih elemenata te situacije.

Bliskost arhaične kulture prirodi uvelike počiva na ograničenoj moći i osvještenju ovisnosti o prirodnim dobrima, pri čemu se rađalo ključno saznanje da čovjek nije gospodar svoje okoline. ${ }^{83}$ Osim toga:

»Mnoga drevna vjerovanja nosila su, sa svim tim što bijahu prožeta prividima i predrasudama, vrijedna kolektivna iskustva o prirodnim temeljima života, o značaju sunca, vodâ, godišnjih doba, biljaka i životinja, o biljnim terapijama (...), i šumi, moru i planini kao vrelima fizičkog i duhovnog preporoda. $\ll^{84}$

Visković ističe da suvremeni čovjek nije ništa manje ovisan o prirodi negoli arhaični "primitivac«, što ne znači da se način i percepcija te ovisnosti nisu drastično izmijenili. Odnos s prirodom više je no ikad posredovan tehničkom obradom stvari, što uz rast naše moći (koja se upliće u njezine sve intimnije tokove) prikriva činjenicu te ovisnosti. Tu se ponajprije radi o

\footnotetext{
${ }^{82}$ N. Visković, Stablo i čovjek, str. 293. - „Simbol je duhovna tvorba, redovito drevnog i kolektivnog porijekla, kojoj je supstrat prirodna pojava (sunce, voda, boje, stablo, lav itd.) ili ljudska tvorevina (slovo, broj, križ, glazba, srp i čekić itd.), a značenje ideja što se ne može do kraja racionalno izraziti i što potiče na emotivne, spoznajne i vrijednosne stavove i na djelovanje.« (Ibid.) Simbolizacija je, također, »duhovno stvaranje značenja svijeta«. (Ibid.)

${ }^{83}$ Usp. ibid., str. 11.

${ }^{84}$ Ibid.
} 
materijalnoj ovisnosti: čovjek i dalje ne može bez vode ili bez biljki, no on materijale za svoje preživljavanje više ne uzima iz bliske prirode. Štoviše, on uslijed sve intenzivnije zamjene izvorne prirode tehnostrukturom i antropiziranom prirodom više i ne prepoznaje izvore svojih materijalnih dobara. Tehnologijom pogonjeno otuđenje od prirode rezultira opadanjem pridavanja vrijednosti, simboličkog tumačenja i poštivanja prirode. Očaranost tehnologijom zauzela je mjesto očaranosti prirodom. ${ }^{85}$ Taj proces vodi $\mathrm{k}$ još jednom problematičnom fenomenu:

»Sve je manje znanja o biljkama i životinjama čak i kod njihovih uzgajivača, jer se oni sada specijaliziraju za pojedine vrste i brinu o njima po istim mehaničkim (kemijsko-fizičkim) pravilima održavanja i rentabilnosti koje primjenjujemo na tvorničke strojeve. ${ }^{86}$

Time se svakako ukazuje na to da je čovjek nerijetko promatrao prirodu na način na koji su njegova sredstva kojima ju je obrađivao bila udešena. Prije je spomenuto da tehnika ne pripada području duhovne kulture, no ona u obliku tehnologije izrasta iz puke materijalne kulture u sastavni dio ove duhovne. Drugim riječima, prestaje služiti tek za svrhe izvan sebe i u izvjesnom smislu postaje samosvrha. Riječ je o procesu koji svoje zasade ima $u$ mehanicističkom poimanju prirode koji se formira početkom moderne misli, da bi danas doživio svoje mnogo intenzivnije ostvarenje.

Uzmimo tek terminologiju i značenja koja ona nosi unutar biologije u posljednjih stotinu godina. Jezik biologije stalno poprima termine, a zajedno s njima i poimanja vladajuće tehnologije (upravo kao slike svijeta, a ne tek sredstva). To zorno prikazuje Jeremy Rifkin, ukazujući na prevladavajući utjecaj strojarskih idioma u pedesetim godinama 20. st. (tako je, primjerice, 'performansa' djelomično stupila na mjesto 'ponašanja'), a potom i na suvremenu tendenciju u kojoj biologija sve više postaje informatička znanost. To se ponajprije očituje u bliskoj vezi genetike i informacijske tehnologije, gena i računala, koje u biotehnološkom stoljeću svoj uzlet dobiva zahvaljujući projektu kartiranja i sekvencioniranja ljudskog genoma. $\mathrm{Na}$ to se nastavlja genetička izmjena živog svijeta, koja vodi u smjeru komercijalnih dobitaka. ${ }^{87}$ Treba imati na umu da je integracija biologije, informatike i ekonomije, zajedno s ostalim znanostima koje s ovima dolaze u vezu (a uglavnom potaknutima posljednjom), integracija reduktivnog tipa. Tako, primjerice, biologija ne stupa u ravnopravan položaj s tehnologijom,

\footnotetext{
${ }^{85}$ Usp. ibid., str. 12.

${ }^{86}$ Ibid.

${ }^{87}$ Usp. Jeremy Rifkin, Biotehnološko stoljeće. Trgovina genima u osvit vrlog novog svijeta, prevela Ljerka Pustišek, Naklada Jesenski i Turk - Hrvatsko sociološko društvo, Zagreb 1999., str. 231, 237.
} 
nego se svodi na nju ili stoji potpuno u njenoj službi. Na djelu nije pokušaj svestranog pogleda na problem, u kojem bi više perspektiva moglo pružati svoje vrijedne uvide, nego o reduciranju znanosti na primjenjivo znanje, koje ima služiti tehnološkoj mašineriji, a najčešće u svrhu profita.

Rifkin uz to ističe da svaki novi koncept prirode služi opravdanju neizbježnosti načina na koji ljudi organiziraju svijet. Za to daje primjer u Darwinovu tumačenju prirodne evolucije, koja legitimira pretpostavke industrijskog društva Engleske njegova vremena, što se ponajprije ogleda u postavljanju stjecanja i nasljednosti kao osnovnih načina opstanka. Stoga nije tako, kako se često misli, da je socijalni darvinizam primjena neutralne teorije o prirodi na društvo, nego se upravo društvena situacija projektira na onu prirodnu. ${ }^{88}$ Ako je Rifkin na ovom mjestu u pravu, ako se ovdje ne radi o pretjeranom sociologiziranju (a može se reći i: u mjeri u kojoj se ne radi o tome), naša mogućnost zauzimanja jedne meta-pozicije spram ovakvih načina tumačenja prirode otvara izvjestan prostor neovisnosti u smislu da se priroda ne odslikava naprosto u naš spoznajni aparat, pri čemu nismo potpuno odriješeni od naših ne-znanstvenih sredstava i svrha. Čini se da je takva vrsta ovisnosti, ipak, neizbježna, međutim ona ne treba označavati slabost. Ovdje se može anticipirati da ovaj uvid otvara potencijalnu normativnu dimenziju unutar onog dijela našeg znanja za koji smo često držali da je isključivo deskriptivan. Ako naše tumačenje prirode nosi sa sobom određene svrhe i namjere te ako mi iste možemo osvijestiti, tada je ono barem indirektno moralno relevantno. Međutim, na moralni aspekt čitavog problema osvrnut ćemo se na kraju rada.

Zanimljiv je i Rifkinov opis suvremenog scenarija ove tendencije. Prema njegovu mišljenju, današnja razmišljanja o evoluciji postaju sukladna novom trgovinskom i gospodarskom uređenju. U tržišnom nadmetanju veliku vrijednost zadobiva mogućnost predviđanja i brzog snalaženja u stalno promjenjivom komercijalnom okolišu, za što je od iznimne važnosti sposobnost upravljanja podacima i stvaranja operativnih mreža. Kada taj koncept prebacimo u područje biologijskih tumačenja, tada našu želju da genetički prepravljamo organizme pravdamo time da se organizmi u prirodi ionako sami prepravljaju, pri

\footnotetext{
${ }^{88}$ Usp. ibid., str. 243, 248-250. - Ovo je već prije jasno uočio Karl Marx, za kojega, kako ističe Alfred Schmidt, upravo darvinizam otkriva kako su iskazi o prirodi u velikoj mjeri uvjetovani pretpostavkama koje nisu prirodoznanstvene. (Usp. Alfred Šmit [Alfred Schmidt], Pojam prirode u Marksovom učenju, preveo Danilo Basta, Vuk Karadžić, Beograd 1981., str. 61.) Na istom se mjestu referira i na u ovom pogledu važno mjesto iz jednog Marxova pisma Engelsu: »Značajno je kako Darwin među životinjama i biljkama otkriva svoje englesko društvo s njegovom podjelom rada, konkurencijom, otvaranjem novih tržišta, 'pronalascima' i Malthusovom 'borbom za opstanak'. To je Hobbesov bellum omnium contra omnes i podsjeća na Hegela u Fenomenologiji, gdje građansko društvo figurira kao 'duhovno životinjsko carstvo', dok kod Darwina životinjsko carstvo figurira kao građansko društvo. « (Karl Marx, »141, Marx Engelsu u Mančester, 18. juna 1862.«, u: Karl Marx, Friedrich Engels, Pisma. Januar 1960 - Septembar 1964, preveli Mara Fran i Ivan Ivanji, u: Dela, sv. 37, Institut za međunarodni radnički pokret - Prosveta, Beograd 1979., str. 229-230, ovdje str. 230.)
} 
čemu evolucija nije, kako se to mislilo, spor proces, nego se osnovne biološke promjene zbivaju brzo i iznenadno. Tu racionalizaciju prati i umrtvljenje empatičke veze spram predmeta manipulacije (prirode), kako bi se on lakše eksploatirao. Tako živa bića postaju tek »snopovi genetičkih podataka«, a kartezijansku predstavu o njihovoj bezdušnoj, mehaniziranoj prirodi zamjenjuje ideja o životu kao podacima. ${ }^{89} \mathrm{U}$ kontekstu primarne motivacije, prije se radi o zamjeni naglasaka, jer odnos spram živih bića kao pukih predmeta ljudske uporabe ostaje nepromijenjen. Promijenjen je samo način intervencije u njihov život unutar istog, puko instrumentalnog odnosa.

\begin{abstract}
»Problem je, još jednom, u tome da u našim kozmologijama napuhujemo sićušne vidove prirodne stvarnosti koje u jednom trenutku uvodimo u univerzalnu kozmologiju pa zatim tvrdimo da čitava priroda djeluje na isti način koji se slaže s našim djelovanjem. Mi stalno prepravljamo prirodu kako bi odgovarala našim vlastitim potrebama, a zatim zaključujemo da tehnološki postupci kojima se sada služimo moraju biti slični postupcima korištenima u prvobitnom stvaranju. « ${ }^{90}$
\end{abstract}

U sličnom smislu, Visković ne govori samo o udvajanju, nego i o trostrukom značenju prirode, kao one prve (izvorna priroda), druge (kulturno preoblikovanje izvorne prirode), a onda i treće (teorijsko-modelska priroda). Naše doba gotovo ne poznaje »pravu prirodu«, a stvaranje »druge prirode« uočava već »ponosna humanistička samosvijest«. ${ }^{91} \mathrm{O}$ novovjekovnom antropocentrizmu možemo posebno govoriti počevši od Govora o dostojanstvu čovjeka Pica della Mirandole, na koji se, kao izvorišni tekst renesansnog humanizma, oslanja novovjekovna misao, a ova čovjekovu uzdignutost spram prirode shvaća znatno zaoštrenije od onih ranijih. ${ }^{92}$ Međutim, taj proces početkom moderne poprima obilježja koja su se s vremenom pokazala kao razarajuća. Kultura je u svojem izdizanju iz prirode sve više počela poprimati obilježja samostalnosti, štoviše, potpune odvojenosti od prirode, te je na »razdvojenosti jedinstva prirode i kulture, nastalo projektiranje i razumijevanje čovjeka kao subjekta. Priroda je postala raspoloživi resurs, objekt povećanja i potvrde čovjekove subjektivnosti. « ${ }^{93}$ No rast subjektivnosti, primjećuju Max Horkheimer i Theodor Adorno, istovremeno je bio samodestruktivan, tako da se »svjetsko ovladavanje prirodom okreće (...) protiv samog mislećeg subjekta, od njega ne ostaje do onaj uvijek isti 'Ja mislim', koji mora pratiti sve svoje predstave. Subjekt i objekt postaju jednako ništavni. Nasuprot apstraktnome jastvu pravnoj

\footnotetext{
${ }^{89}$ Usp. J. Rifkin, Biotehnološko stoljeće, str. 258-261.

${ }^{90}$ Ibid., str. 263.

${ }^{91}$ N. Visković, Stablo i čovjek, str. 37.

${ }^{92}$ Usp. Tomislav Krznar, Znanje $i$ destrukcija. Integrativna bioetika i problemi zaštite okoliša, Pergamena Učiteljski studij Sveučilišta u Zagrebu, Zagreb 2011., str. 85.

${ }^{93}$ Ivan Cifrić, Bioetička ekumena. Odgovornost za život susvijeta, Pergamena, Zagreb 2007., str. 35.
} 
osobi protokoliranja i sistematiziranja, ne stoji ništa do apstraktni materijal bez ikakvih drugih osobina do da bude supstrat takvog posjedovanja. «" Kako oni tvrde, povećanje moći nad prirodom čovjek plaća otuđenjem od onoga što je u njegovoj moći. Stvar se, naime, priznaje samo manipuliranjem, što jasno vodi ukidanju svakog afiniteta između subjekta koji pripisuje smisao i objekta koji je tek puki nosioc značenja, a sam u sebi besmislen. ${ }^{95}$ Time se potvrđuje važnost prirodnog supstrata za ono kulturno, ovdje u vidu nemogućnosti da osiromašenje objekta proizvede suprotan učinak na subjekt.

Priroda je, premda u sve neravnopravnijem položaju, nastavila suopstojati s kulturom, a obje su imale svoju zasebnu vrijednost, pa se čovjek istovremeno mogao diviti »moralnom zakonu u sebi« i »zvjezdanom nebu nad sobom «. ${ }^{96}$ Čuđenje koje je bilo na djelu omogućilo je i štovanje prirode kao cjeline, a u ponekim kulturama i izraženi moralni obzir spram njenih pojedinih sastavnica. Čovjeku je priroda stajala na dispoziciji za njegove raznovrsne pristupe: čuđenje, promatranje i spoznavanje (theoria), stvaralaštvo (poiesis), a ponegdje i moralno odnošenje (praxis). Premda ti pristupi nisu uvijek bili aktualizirani i premda sa strane moralnog gledišta ne treba idealizirati »čovjeka stvaratelja«, koji ponekad harmonično stupa u odnos s prirodom, ali joj ponekad u svome stvaralaštvu škodi, samo-stalnost prirode ostavljala je otvoren prostor za samo-vrijednost prirode. Međutim, onda kada se priroda u posvemašnjem čovjekovu koloniziranju potpuno pretvara u njegov izum, u predmet nebrojenih manipulacija, naročito onda kada ona to nije samo u smislu izvanjske preobrazbe, nego i one intimne (pomoću genetičkih modifikacija), tada nije samo ugroženo štovanje prirode, nego u krizu dolazi i, kako je pokazano, čovjekovo (subjektovo) samovrednovanje.

Čovjek je danas stekao toliku moć nad prirodom da je gotovo potpuno negira, ali priroda mu isti slijepi, nesvrhoviti mehanizam koji joj je pripisao »uzvraća kao osvetu«. U tome leži čovjekovo prokletstvo izrastanja iz stvaratelja u stvoritelja (ili Tvorca kao božanske figure).

\footnotetext{
${ }^{4}$ Max Horkheimer, Theodor Adorno, Dijalektika prosvjetiteljstva. Filozofijski fragmenti, prevela Nadežda Čačinović-Puhovski, Veselin Masleša, Sarajevo 1974., str. 40. - No, u konačnici, šteta koju su subjekt, um, pa onda i prosvjetiteljstvo, počinili može se sanirati samo s više, a ne manje subjekta, uma, prosvjetiteljstva, a emancipacijski zaokret potonjega moguć je samo uz uvjet pomirenja s prirodom i izmicanja logici gospodarenja. (Usp. Predrag Krstić, Subjekt protiv subjektivnosti. Adorno i filozofija subjekta, Institut za filozofiju i društvenu teoriju - I. P. »Filip Višnjić«, Beograd 2007., str. 11, 45-46, 54-56.)

${ }^{95}$ Usp. M. Horkheimer, Th. Adorno, Dijalektika prosvjetiteljstva, str. 23. - Ovo mjesto ističe i Visković. (Usp. N. Visković, Stablo i čovjek, str. 16.)

${ }^{96}$ Slično zaključuje i Vittorio Hösle: »Čak i kod Kanta, koji je uveo dualizam etike i prirode radikalniji od ijednoga drugoga, poštovanje prema moralnom zakonu stapa se sa zadivljenošću pred zvjezdanim nebom. « (Vittorio Hösle, Filozofija ekološke krize. Moskovska predavanja, prevela Darija Domić, Matica hrvatska, Zagreb 1996., str. 135.) Kantov radikalizam zasigurno nije takav kakvim se mnogim komentatorima i kritičarima činio. Kako ovdje ne možemo ulaziti u raspravu o tome, upućujemo na studiju koja s pravom odbija takvo gledište, pozivajući se prvenstveno na treću kritiku, u kojoj Kant pokušava pomiriti teorijski i praktički um posredstvom moći suđenja (suda ukusa i teleologije): Igor Eterović, Kant i bioetika, Pergamena - Centar za integrativnu bioetiku Filozofskog fakulteta Sveučilišta u Zagrebu, Zagreb 2017.
} 
Smisao koji karakterizira čovjeka stvaratelja potpuno se gubi u čovjeku stvoritelju, koji u tim okvirima gubi sposobnost osmišljavanja i određenja sebe samog. To je svakako mogao dok je stajao »naspram nečega/drugoga«, gdje su i njegova kultura (kao uzvišena pozicija) i nasuprot stojeća priroda (kao osnova za kulturu - kao nužan uvjet njenog postojanja u materijalnom vidu i, slijedimo li Gehlena, u vidu biološke manjkavosti s obzirom na koju je započeo duhovni razvoj - i predmet čuđenja) imale specifični smisao i vrijednost, dok se sada u odnosu spram svojeg besmislenog svijeta može odrediti samo kao obesmišljen stvoritelj. Ironija je u tome što se on kao stvoritelj ponaša tek po diktatu apstrakcija poput kapitala ili tehnologije koje je sam u jednom momentu stvorio - gotovo kao bog koji stvaranjem prirodnih zakona ne može djelovati u suprotnosti s njima.

Destruktivnost posvemašnjeg oponašanja Tvorca na svoj način zapaža i Visković kada slijedeći genezu rascjepa između izvorne i od čovjeka preoblikovane prirode ukazuje na renesansni duh koji nastoji stvoriti vlastiti umjetni i samostalni svijet. Ta tendencija očituje se i u alkemiji, kao pokušaju izvornog stvaranja po uzoru na Tvorca. Kako humanizam, tako i kasnije prosvjetiteljstvo, pored velikih doprinosa čovjekovoj emancipaciji, zadobivanja misaone punoljetnosti i osvještenja čovjekova dostojanstva, istovremeno bivaju ravnodušni i nasilni prema prirodi. Tu je na djelu »malodobna ili neuračunljiva tehnokratska svijest o ljudskom odnosu prema okolnom svijetu «. ${ }^{97}$

Visković, zajedno s većinom onih koji izražavaju obzir spram ne-ljudskog života, naglašava kako nema smisla divinizirati prirodu niti sotonizirati tehnologiju, nego je stvar samo u tome da obnovimo poštovanje spram prirode, kako ne bismo dalje plaćali preveliku cijenu povijesnom napretku, odnosno kako bismo spriječili ostvarivanje razornih ideja prepotentnog homo fabera. ${ }^{98}$ Uskraćivanjem obzira ne-ljudskoj prirodi

\)... upada se u onaj opći zaborav svijeta života, uključujući uvjete opstanka toga svijeta i opstanka čovječanstva u njemu, koji bismo i na sadašnjoj razini tehnologije možda mogli izbjeći s nešto više spoznajne i moralne discipline. Ta nevolja se svakodnevno i kao na dlanu pokazuje u obrnutom razmjeru zbiljske važnosti prirodnih dobara i pozornosti koju im mi posvećujemo. «99

Pored spomenutog izostanka ovog razmjera, kod arhaičkog čovjeka priroda se zasigurno poima manje tuđom s obzirom na to da se ona u svojoj cjelokupnosti tumači u kategorijama

\footnotetext{
${ }^{97}$ Usp. N. Visković, Stablo i čovjek, str. 15.

${ }^{98}$ Usp. ibid., str. 13.

${ }^{99}$ Ibid., str. 13.
} 
života. ${ }^{100}$ Ono se u izvjesnom smislu zadržava i u antičkoj grčkoj filozofiji, u kojoj je, kako tvrdi Branko Despot, »biti i živjeti jedno te isto«. U tom duhu tvrdi da se može reći kako Aristotelova fizika nema čak ni zajednički predmet s modernom fizikom - u prvoj je priroda živa, u drugoj pak mrtva. ${ }^{101}$ Mnogi grčki mislioci prirodu ne shvaćaju kao nešto izvanjsko, pa su samim time svjesni da u spoznaji prirode spoznaju sami sebe i obrnuto. ${ }^{102}$ No dok su predsokratovci, prema Viskoviću, još čuvali znanje o jedinstvu čovjeka i prirode, tendencija povećanja jaza između čovjeka i njegove okoline može se pratiti od kasnije grčke filozofije i židovsko-kršćanske misli. Sličnost ovih pristupa ogleda se u stavu Aristotela i Tome Akvinskog, prema kojima biljke postoje radi životinja, a ove radi čovjeka. ${ }^{103}$ Premda tu ostaje na djelu svojevrsna harmonija, bilo prirodnog uređenja, bilo Božje zamisli, istovremeno se otvara problem tumačenja svrhe postojanja ne-ljudskih živih bića, koja lako može biti potpuno podređena onim čovjekovim. Aristotelovi stavovi možda i nisu toliko utjecali na rascjep koji će između čovjeka i prirode nastati u novom vijeku, pošto se filozofija tada pretežito okreće upravo protiv aristotelizma, a onda i protiv skolastike. Međutim, veću težinu ima promišljanje ovih problema unutar kršćanske filozofske misli, koja će onda doživjeti svoj (opravdani ili neopravdani) izraz u Baconovoj zamisli o čovjekovu pravu na prirodu:

»Neka ljudski rod samo opet stekne svoje pravo na prirodu, što mu pripada po božjoj namjeni, i neka to pravo potpuno izvršava; ispravni razum i zdrava religija već će odrediti pravu upotrebu. «104

Početak moderne znanosti, pored ostalih, bitno obilježavaju misli Renéa Descartesa i Francisa Bacona, s naglašenom notom ovladavanja prirodom, što ne znači da su mogli biti u stanju predvidjeti ono što će njihovi programi proizvesti u znanstveno-tehnološkoj epohi, pa ih time nije umjesno ni kriviti za takva stanja stvari. ${ }^{105}$ Tražeći genezu nekog duhovnog stanja

\footnotetext{
${ }^{100}$ Usp. Hans Jonas, The Phenomenon of Life. Toward a Philosophical Biology, Northwestern University Press, Evanston 2001., str. 8.

${ }^{101}$ Despotove misli prenesene iz: Hrvoje Jurić, Etika odgovornosti Hansa Jonasa, Pergamena, Zagreb 2010., str. 293.

102 Usp. B. Pavlović, Filozofija prirode, str. 20.

${ }^{103}$ Usp. N. Visković, Stablo i čovjek, str. 13. - U procjeni kršćanskog (biblijskog) stava o čovjekovu obziru spram prirode, Visković navodi i onu drugu stranu, u kojoj je čovjek staratelj nad prirodnim, međutim, osim što to ne uklanja misao o čovjeku kao najvišoj svrsi stvaranja, koji se paternalistički postavlja spram ostalog stvorenja, ta stajališta biocentričkim stavovima pristupaju posredstvom teocentrizma. Tu navodi i klasične primjere kršćanskih autora koji pokazuju brigu za druga živa bića: Aurelije Augustin, Franjo Asiški, srednjovjekovni mističari te suvremeni enfant terrible (barem kao bivši svećenik) Katoličke crkve Eugen Drewermann. (Usp. ibid., str. 36.) ${ }^{104}$ Francis Bacon, Novi organon, preveo Viktor D. Sonnenfeld (redigirao Vladimir Vratović), Naprijed, Zagreb 1986., str. 118. - Čović primjećuje kako Bacon ovdje izbjegava da se suoči s etičkim problemom upotrebe moći, čije rješavanje prepušta neodređenim instancijama. (Usp. Ante Čović, Etika i bioetika. Razmišljanja na pragu bioetičke epohe, Pergamena, Zagreb 2004., str. 49-50.)

${ }^{105}$ Usp. N. Visković, Stablo i čovjek, str. 15.; N. Visković, Životinja i čovjek, str. 301.
} 
često se nailazi na mislioce koji u svom vremenu ne mogu do kraja pojmiti koje su dugoročne posljedice vlastite misli. Odgovornost prije leži na svakoj idućoj generaciji koja mora pomno reflektirati različite konzekvence znanja koje upija od autoriteta. Čini se da je na tom tragu upravo sam Bacon, jedan od začetnika naše, znanstveno-tehnološke epohe, kada upozorava na idola theatri, zablude u koje upadamo ako se nekritički odnosimo spram nasljeđa priznatih autoriteta, a istjerivanjem kojih bi danas najvjerojatnije »platila« i Baconova »velika obnova«.

»Ima konačno idola, koji su ušli u duše ljudske iz različitih filozofijskih dogma, a također i iz naopakih zakona dokazivanja. Njih nazivamo idolima teatra (...) U te opet ne ubrajamo samo univerzalne filozofije, nego i većinu principa i aksioma pojedinih znanosti koji su se učvrstili na osnovu tradicije, vjere $\mathrm{i}$ nemarnosti. «106

Upravo se ta nova znanstvena metodologija prisutna u Baconovoj teoriji i u daljnjem znanstvenom eksperimentalnom idealu, prema kojem se »priroda stvari više otkriva u mučenju umijećem nego u vlastitoj slobodi «, ${ }^{107}$ može označiti kao ona koja je postala idol teatra. Kod nje se često zaboravlja da je eksperiment umjetna konstrukcija, koja u takvoj prisili prirode (ona pak sama od sebe ne eksperimentira) vrši promjene na samom tom prirodom. ${ }^{108}$ Time se dovodi u pitanje je li priroda uopće predmet prirodnih znanosti, kako s aspekta metode, tako i s aspekta rasta ljudske moći nad prirodom, kako to u pogledu suvremene prirodne znanosti jasno iskazuju Heisenberg odnosno Pavlović:

»Ako se može govoriti o slici prirode kakvu daje egzaktna prirodna nauka u naše vrijeme, onda se zapravo ne radi o slici prirode nego o slici naših odnosa prema prirodi. (...) Prirodna nauka ne stoji više pred prirodom kao promatrač nego spoznaje sebe kao dio uzajamnog utjecaja čovjeka i prirode. Naučna metoda izlučivanja, tumačenja i koordinacije postaje svjesna granica koje su joj postavljene time što je zahvat metode promijenio i preoblikovao njen predmet, dakle što se metoda više ne može odvojiti od predmeta. Time prirodnonaučna slika svijeta prestaje zapravo da bude prirodnonaučna. ${ }^{109}$

»Osim toga, rastom svoje moći nad prirodom, ljudi se sve više udaljuju od onoga što je u njima prirodno; njihova proizvodna moć se razilazi s proizvodnjom moći prirode. Ovo stvara osnove za sumnju u to da je svijet suvremenih eksperimentalnih znanosti još uvijek prirodni svijet, da su ove znanosti još uvijek 'znanosti o prirodi'. «110

\footnotetext{
${ }^{106}$ F. Bacon, Novi organon, str. 48.

${ }^{107}$ Ibid., str. 22.

${ }^{108}$ Usp. B. Pavlović, Filozofija prirode, str. 128.

${ }^{109}$ Werner Heisenberg, Slika svijeta suvremene fizike, preveo Drago Dujmić, Epoha, Zagreb 1961., str. 20.

${ }^{110}$ B. Pavlović, Filozofija prirode, str. 128-129.
} 
Upravo je posljednji gore navedeni razlog učvršćenja ovih dogmi - iz nemarnosti - ono o čemu je poglavito riječ u odnosu spram prirode u znanstveno-tehnološkoj epohi: radi se kako o nemarnosti spram same prirode, tako i o intelektualnoj nemarnosti koja zanemaruje svu širinu uvidā potrebnu za dosezanje istine. Redukcionizam o kojem je ovdje riječ javlja se kao »lijenost uma« koja kumuje neodgovornom postupanju prema prirodi. Druga dva razloga učvršćenja tih dogmi - iz tradicije i vjere - nekad se više, a nekad manje koriste kao podupiratelji ovom nemaru. Ovo pokazuje da se ponekad kod velikih mislioca lijek za boljke njihove teorije nalazi u njoj samoj - osobito onda kada je kritički nastrojena. Uostalom, u ukupnom sagledavanju misli određenog mislioca, potrebno je obratiti pažnju na njegove osnovne intencije:

\begin{abstract}
»Ono što treba imati na umu kada je riječ o ovim problemima jest to da je ovladavanje prirodom u korist čovjeka, i to cjelokupnog ljudskog roda, dakle generička korist, u Baconovom djelu dimenzionirano kao moralni prihvatljivi koncept. Drugim riječima, destrukcija kojoj danas svjedočimo, nije intencionalno zacrtana kao učinak procesa ovladavanja. Ona se javlja kao negativna popratna pojava koja sve jače prijeti životu na Zemlji, paradoksalno, kao negativna pojava izuzetno učinkovitog sustava. «111
\end{abstract}

Kada je riječ o Descartesovim intencijama, Visković na sličnom tragu jasno ističe da, usprkos raširenom stavu među animalistima o Descartesu kao »filozofskoj Babarogi«, on čak i ne poriče osjetilnost i osjećajnost kod životinja (premda ih naziva automatima) te ne stoji eksplicitno na liniji opravdanja okrutnosti spram životinja. ${ }^{112}$ Descartesova misao u dugoročnom je smislu naškodila životinjama više u svojim implikacijama negoli u eksplicitnim stavovima. Naime, kako tvrdi Visković, upitno je bi li se Descartes složio sa zaključkom njegova sljedbenika Malebranchea o cviljenju životinje kao rezultatu škripe kotačića u mehanizmu. Pa ipak, on je u svojoj ontologiji jaz ljudskog i animalnog doveo do krajnosti. ${ }^{113}$ Tu nije riječ samo o isključenju životinja iz etičkih razmatranja, na što Visković prvenstveno aludira, nego i o stvaranju nove slike svijeta koja će sveobuhvatnost svojih pogubnih potencijala

\footnotetext{
111 T. Krznar, Znanje i destrukcija, str. 97. - Bjelodanu činjenicu da Bacon nije mogao predvidjeti današnju ekološku situaciju kao posljedicu znanstvene paradigme ovladavanja prirodom ističe i Visković. (Usp. N. Visković, Životinja i čovjek, str. 301.)

${ }^{112}$ Usp. N. Visković, Životinja i čovjek, str. 157-158. - Visković se u obrani Descartesa ovdje poziva na jedan članak Johna Cottinghama u kojemu autor prvenstveno pobija učestalu predodžbu o Descartesovu nijekanju sposobnosti životinje da pati. Cottingham tvrdi da nema razloga, naročito u novovjekovnoj racionalističkoj misli, izjednačavati ustrojstvo na način automata i nesposobnost osjećanja. Tako, primjerice, Leibniz opisujući slobodni spontanitet čovjekove duše, govori o njoj kao o vrsti duhovnog automata, što hoće reći da impulse za pokretanje dobiva iznutra. Cottingham tomu pridodaje eksplicitne Descartesove tvrdnje (iz pisama Newcastleu i Moreu) o postojanju kako osjećajnosti, tako i osjetilnosti kod životinja. Pa ipak, neriješenim ostaje problem smještanja životinjske osjećajnosti i osjetilnosti između misleće (kojoj ne pripada) i protežne (kojoj po ovom opisu ne odgovara) supstancije, koji odražava neke od osnovnih problema kartezijanske dualističke ontologije. (Usp. John Cottingham, »'A Brute to Brutes?': Descartes' Treatment of Animals «, Philosophy 53 (1978) 4, str. 551-559., ovdje str. 553, 556-558.)

${ }^{113}$ Usp. N. Visković, Životinja i čovjek, str. 158.
} 
pokazati tek u našem dobu. Prvenstvena Descartesova »krivnja« nije sam dualizam, nego prije takav dualizam u kojem je onaj ne-oduševljeni (pri čemu duša nije više princip života, ${ }^{114}$ već među smrtnicima pripada još samo čovjeku) element sveden na puki mehanicistički kvantitet (kao protežna supstancija - res extensa). Njegova misao, među ostalima, uvodi mehanicistički svjetonazor u zapadnu misao, ${ }^{115}$ pa iako on sam odvaja duhovnu, misleću supstanciju od ove protežne i mehaničke, neće proći dugo dok ova druga ne »proguta« onu prvu. Pa i bez toga, redukcija koja se tu rađa, i koje se do dana današnjeg nismo u potpunosti otarasili, pokušava obuhvatiti i fenomen života. Tu se posebno očituje obrat od panvitalističkog svjetonazora primitivnog čovjeka, kojemu je život prva neupitna datost, a smrt prva enigma, prema panmehanicističkom svjetonazoru, u kojem život postaje enigma, pa se pokušava objašnjavati iz mrtve i mjerljive materije - moderna je fizika napuštanjem starog koncepta težnje izbacila život iz sfere postojećeg. ${ }^{116}$

Takav svjetonazor kasnije će dalje odvesti Julien Offray de La Mettrie, odajući priznanje Descartesu za svođenje životinja na strojeve, ali ipak šireći taj model i na ljude, u duhu mehanicističkog materijalizma. ${ }^{117} \gg$ Ljudsko je tijelo stroj, koji sam navija svoje opruge $«,{ }^{118}$ reći će tako La Mettrie, no rezultat njegove mehanicističke filozofije bit će upravo suprotan Descartesovu u pogledu procjene (a nekad i precjene) životinjskih sposobnosti s obzirom na to da sada nema principijelne osnove za kvalitativno razlikovanje čovjeka i životinje. ${ }^{119}$ »Čovjek nije umiješen od nekoga dragocjenijega blata; Priroda je upotrijebila jedno te isto tijesto, kojemu je samo mijenjala kvasac. ${ }^{120}$ Da između čovjeka i životinje kod La Mettrieja, što ovaj ekslicitno tvrdi, nema naglog prijelaza istaknut će i Visković. Razliku poglavito čini odgoj, a ni on nije presudan za mišljenje, pa čak ni za ponašanje prema moralnom prirodnom zakonu za

\footnotetext{
${ }^{114}$ Usp. H. Jonas, The Phenomenon of Life, str. 60.

$115 \mathrm{O}$ mehanicističkom se svjetonazoru u izvjesnom smislu može govoriti još od početaka ljudske kulture (vidi: Lewis Mumford, Mit o mašini, sv. 1, Tehnika i razvoj čovjeka, preveo Nikica Petrak, Grafički zavod Hrvatske, Zagreb 1986.), ali on se eksplicitno otkriva tek od začetaka moderne znanosti te zadobiva oblik koji u velikoj mjeri nasljedujemo danas. U tom pogledu valja zamijetiti da ideja životinje-stroja nije prvi put formulirana kod Descartesa: »Ovo načelo, možemo dodati, nije izvorno Descartesovo, nego ga je potanko bio izložio španjolski liječnik Gómez Pereira u glomaznom svesku na latinskom koji nosi čudan naslov Antoniana Margarita opus nempe physicis, medicis ac theologis non minus utile quam necessarium (Antoniana Margarita, djelo nesumnjivo $i$ korisno i neophodno učenjacima, liječnicima i teolozima), a koji je tiskan 1554. godine, gotovo jedno stoljeće prije objave Descartesovih Meditationes de prima philosophia (Razmišljanja o prvoj filozofiji) i Principia philosophiae (Načela filozofije). (Edward Payson Evans, Životinje pred sudom. Kazneni progon i smrtna kazna za životinje, preveo Hrvoje Gračanin, TIM press, Zagreb 2014., str. 42-43.) Pereiru u pogledu ovih rasprava spominje i Visković (usp. N. Visković, Životinja i čovjek, str. 159.

${ }_{116}$ Usp. H. Jonas, The Phenomenon of Life, str. 8-10, 61.

${ }^{117}$ Usp. N. Visković, Životinja i čovjek, str. 159.

118 Julien Offray de La Mettrie, »Čovjek stroj (1747.)«, u: Julien Offray de La Mettrie, Čovjek stroj / Rasprava o duši / Čovjek biljka, preveo Josip Balabanić, ArTresor naklada, Zagreb 2004., str. 167-254, ovdje str. 191.

${ }^{119}$ Vidi: ibid., str. 199-203.

${ }^{120}$ Ibid., str. 217. - Životinjama je »možda uzmanjkao samo jedan stupanj vrenja da budu posvema izjednačene s ljudima«. (Ibid., str. 218.)
} 
koje su i neke životinje sposobne. ${ }^{121}$ Konačno, La Mettrie drži da prihvaćanje ovakve ideje o jednolikosti prirode (gdje se analogije traže i između čovjeka/životinje i biljke), u kojoj postoji samo jedna raznoliko modificirana supstancija, rezultira nastrojstvom punim poštivanja i nježnosti spram nje te nevoljkošću da je uništava kako u sebi, tako ni u drugim bićima. ${ }^{122}$ Usprkos naivnosti pristupa, iz La Mettriejeva dosljednog provođenja mehanicizma, ali uz pretpostavku da čovjek poštiva prirodu, »ne hoteći činiti drugomu ono što ne bi htio da njemu drugi čini, sukladno Naravnomu zakonu, koji je dat svim životinjama«, ${ }^{123}$ proizlazi suprotan stav onome većine ranijih i kasnijih mehanicista, čiji je izričiti ili prešutni dualizam materiji oduzeo vrijednost i izručio je čovjeku na bespoštednu upotrebu.

Naime, kod potonjih iz mehanicističkog uprošćavanja prirode proizlaze osobito opasne posljedice za prirodu upravo onda kada se ono upari s idealom ovladavanja njome, ali pogubne posljedice takvog čina ne zaobilaze ni čovjeka, ne samo zbog spomenutog fenomena njegova »gutanja« od strane osiromašene materije, nego upravo putem same ideje ovladavanja. »Priroda se naime pobjeđuje samo pokoravajući joj se«, ${ }^{124}$ jedna je od čuvenih Baconovih teza, koja je odredila put novovjekovne znanosti i upravo oslikala našu sadašnjost. Ako se priroda shvaća kao instrument ljudske moći, tj. puko sredstvo, te ako se čovjek prirodi mora podrediti ako je Želi podrediti, tada čovjek mora postati sluga svog sredstva. Fenomen čovjeka kao održavatelja stroja ili tehnologije, koji danas uočavamo, rezultat je izvođenja samog duhovnog zadatka novovjekovlja.

Međutim, počeci novovjekovlja poznaju i još neke drugačije nastrojene mislioce, za što je Michael de Montaigne zoran primjer. Visković visoko drži do Montaignea, pa iako smatra da je njegovo djelo opterećeno »dosta naivnim prirodnim teleologizmom«, istovremeno ističe važnost njegova anticipiranja nekih otkrića etologije te pristupa obilježenog dubokom očaranošću prirodom i osjećajem odgovornosti za život. Ono što ga posebice na određen način čini našim suvremenikom, sumnja je u uvjerenje o čovjeku kao krajnjoj svrsi evolucije, koja se danas očituje u njegovu destruktivnom pristupu spram biosfere. ${ }^{125}$ Čovjek je, naime, sposoban konkretnim uništenjem uvjeta vlastitog opstanka na Zemlji praktično dokazati pogrešnost te pretpostavke.

\footnotetext{
${ }^{121}$ Usp. N. Visković, Životinja i čovjek, str. 159; J. O. de La Mettrie, »Čovjek stroj«, str. 213-222. - Visković ne zastaje samo pri tome da La Mettriejev materijalizam ocijeni kao grubo površan, već u njemu, oslanjajući se na Morusa, prepoznaje najavu evolucionističkog shvaćanja života. (Usp. N. Visković, Životinja i čovjek, str. 159.)

${ }^{122}$ Usp. J. O. de La Mettrie, »Čovjek stroj«, str. 249-254.

${ }^{123}$ Ibid., str. 253.

${ }^{124}$ F. Bacon, Novi organon, str. 37-38.

${ }^{125}$ Usp. N. Visković, Životinja i čovjek, str. 154.
} 
Znanstveni preokret poimanja sličnosti odnosno razlika između čovjeka i drugih živih bića nastupa tek s darvinizmom. Pa ipak, Visković je svjestan da njegova otkrića sama od sebe ne vode većem (moralnom) uvažavanju životinja, štoviše, da su imala sasvim suprotne motive:

\begin{abstract}
»Naime, nedvojbeno je znanstveno i moralno progresivno u darwinovskoj revoluciji to što ona teorijski definitivno prevladava ponor koji nas je odvajao od životinjskog. Ali pored sve pozornosti koju su izazvale njegove postavke o zajedničkom podrijetlu i o mnogostrukim sličnostima životinja i čovjeka, to ipak nije doprinijelo poboljšanju položaja životinja u modernom svijetu. Dapače, Darwin je znao i pristajao da u tom svijetu svekolike zloupotrebe znanosti u svrhu dominacije 'jedinstvena mjera čovjeka i životinje, ta njihova nova familijarnost, ide zajedno sa sustavnim postvarenjem životinje kao sirovine i uskoro kao proizvoda u preobražaju'. Na početku 'Porijekla vrsta' Darwin kaže da evolutivna fiziologija mora započeti proučavanje posljedica domestikacije radi toga da bi pronašla svoju primjenu u proizvodnoj eugenici. Tako je 'nadmoć nad svijetom sličnih bila ujedno izvor i svrha darwinovskih ispitivanja, isto kao što su prva sustavna ispitivanja specifičnih osobina rasa bila vezana za održavanja prevlasti bijelaca'. « ${ }^{126}$
\end{abstract}

Ovi se problemi, naravno, ne zadržavaju u filozofskim i znanstvenim »bjelokosnim kulama«, nego u konkretnim društvenim kretanjima prerastaju u ideologije, koje onda povratno djeluju na filozofske pozicije i znanstvena shvaćanja stvarnosti. Antropocentrizam i beskrajan materijalni rast pogonjen bezobzirnom tehnološkom nastrojenošću spram svijeta života Visković naziva nadideologijama, koje se podrazumijevaju unutar najutjecajnijih svjetonazora, kako liberalizma i socijalizma, tako i znanstvenog pozitivizma »sve oštrijeg tehnokratskog usmjerenja «. ${ }^{127}$ Tome se pridodaje spomenuto fragmentiranje znanosti, koje, prema Viskoviću, rezultira gubitkom uvida u cjelinu zbilje te odvajanjem svijesti i rada, a sve pod imperativom rasta učinkovitosti, kako bi se priroda (ali i društvo) kolonizirala za kratkovidne ekonomske ili pak scijentističke svrhe. Otprirođenje nije zahvatilo samo rascjepkane prirodne, nego i one društvene znanosti (s izuzetkom etnologije): ekonomiju, pravo, sociologiju, historiju. ${ }^{128}$

\footnotetext{
${ }^{126}$ Ibid., str. 163-164. - Visković se ovdje referira na P. R. Hallalija. Da se u niveliranju kulture i prirode u ovom pogledu ne radi o praksi koja samorazumljivo vodi obziru spram potonje, jasno iskazuje i Horkheimer: »To što se um smatra prirodnim organom ne lišava ga težnje vladavini, niti mu daje veće mogućnosti pomirbe. Naprotiv, abdikacija uma u popularnom darvinizmu povlači za sobom odbacivanje svih sastojaka mišljenja koji prelaze ulogu prilagodbe, i prema tome nisu oruđa samoopstanka. Um se odriče vlastitog prvenstva i propovijeda kako je običan sluga prirodnog izbora. Na površini, taj novi empirijski um čini se ponizniji prema prirodi nego um metafizičke predaje. U stvari, međutim, to je arogantan, praktičan razum koji tiranizira 'bespotrebno duhovno' i odbacuje svako shvaćanje prirode u kojoj se ono smatra nečim višim od poticaja ljudskoj djelatnosti. « (Max Horkheimer, »Pomrčina uma«, preveo Tomislav Ladan, u: Max Horkheimer, Kritika instrumentalnog uma. Iz predavanja i zabilježaka nakon svršetka rata, Globus, Zagreb 1988., str. 3-131, ovdje str. 90.)

${ }^{127}$ Usp. N. Visković, Stablo i čovjek, str. 16. - Ovdje se Visković poziva na Alda Leopolda, za kojega se sve moderne ideologije »natječu u jedinstvenoj vjeri: spasenje putem strojeva« (Usp. ibid., str. 37; i Aldo Leopold, »The Conservation Ethics«, u: Lloyd C. Irland (ur.), Ethics in Forestry, Timber Press, Portland 1994., str. 251263 , str. 258).

${ }^{128}$ Usp. N. Visković, Stablo i čovjek, str. 16.
} 
Viskovićeve kritike nije pošteđena ni tradicionalna ni moderna svijest zapadnog svijeta, koje se ne obaziru na ono što priroda, i kao osnova i kao sadržaj, znači za kulturu, reducirajući sve fenomene na duh, što za posljedicu ima uzimanje u obzir samo međuljudskih odnosa i interesa. $^{129}$

»Duhovne osnove takvog redukcionizma jesu nadasve kršćanski antropocentrizam i s njime u skladu kasniji znanstveni pozitivizam, koji se također odnosi prema prirodi kao prema po sebi bezvrijednoj tvari i neograničeno raspoloživom objektu djelovanja Homo fabera. «130

Zanimljivo je što Visković duhovno-redukcionističkim i antropocentričkim pristupom naziva i znanstveni pozitivizam, koji se sam upravo nastoji predstaviti kao objektivan i neovisan o ljudskim svrhama, pa u tome smislu i neduhovan. Iako pozitivizam pretendira na objektivnu istinu, a samo onu pozitivno-znanstvenu drži takvom, upravo zbog toga ne može izbjeći prigovoru za redukcionizam. Međutim, on iz samoga sebe ne može sagledati pogubnost i faličnost svoga redukcionizma, čemu će zasigurno uspješnije doskočiti višedimenzionalni pristupi kakvi su, kako ćemo vidjeti, kulturna zoologija i kulturna botanika, ali svakako i integrativna bioetika.

Ideološke konstrukcije nikako nisu strane ni raznim »naturalizmima« na koje Visković upozorava. Tu se ponajprije radi o proizvoljnoj ideološkoj upotrebi raznih »prirodnih prava«, kao i o socijalnom darvinizmu (prebivao on u pseudoliberalnom ili u rasističkom ruhu) koji utemeljuje agresivnost $\mathrm{u}$ preslikavanju tobože prirodi inherentne borbe za opstanak na ljudsko društvo. ${ }^{131}$ Time Visković implicitno ističe isti onaj ključan moment koji nalazi Rifkin kod same koncepcije prirodne borbe za opstanak, kao koncepcije koja pokušava na dubljoj razini legitimirati i konzervirati postojeće stanje stvari. Tu leži jedna od najznačajnijih opasnosti spomenutog nekritičkog diviniziranja prirode. Stoga:

»... svaka buduća rehabilitacija vrijednosti prirode mora pažljivo i kritički pretresati ta dva tobožnja 'naturalizma', kako bi od sebe otklonila opasnosti ideoloških kontaminacija i neosnovanih poistovjećivanja s njima. Dok prirodnopravne doktrine potvrđuju samo ljudska prava, a ne i prava prirode u obrani od ljudske razornosti, socijalni darvinizam tumači prirodne zakonitosti u ideološke svrhe čak i protiv ljudskih prava. ${ }^{132}$

\footnotetext{
${ }^{129}$ Usp. Nikola Visković, »Uvodna riječ«, u: Nenad Cambi, Nikola Visković (ur.), Kulturna animalistika. Zbornik radova sa znanstvenog skupa održanog 29. rujna 1997. godine u Splitu, Književni krug, Split 1998., str. 5-7, ovdje str. 5.

${ }^{130}$ Ibid.

${ }^{131}$ Usp. N. Visković, Stablo i čovjek, str. 18.

132 Ibid., str. 18. - Viskovićev bi se ambivalentan stav spram darvinizma adekvatno mogao opisati i dodatno obogatiti jednim mjestom iz Pomrčine uma Maxa Horkheimera: »Zbog svoje inherentne poniznosti prema prirodi,
} 
Potpuno zatiranje života i njegova potpunog podređivanja ljudskim svrhama vrhuni u današnjim opasnim tendencijama klimatskih promjena i genetičkih manipulacija, kao jasnim pokazateljima posvemašnjeg ljudskog otprirođenja ili »zaborava bitka« u Viskovićevoj reinterpretaciji klasičnog Heideggerova stavka, odnosno zaborava čitave prirode koja je uistinu "pri-rođena« čovjeku. ${ }^{133}$ Preformulacija upravo te sintagme nije slučajna. Ona se oslanja na analizu Georgea Steinera, koji iz Heideggerove misli izvlači sljedeći zaključak:

»Mi smo prisilili prirodu da nam izruči znanje i energiju, ali mi nismo pomno slušali i nismo dali da u nama boravi ono što je u prirodi živo i u njoj skriveno. Tako naša tehnologija zakriva Bitak umjesto da ga rasvjetljava. $\ll^{134}$

Dok s jedne strane, ističe Steiner, imamo stvaranje koje više nije skrb, a ljudska tvorevina više nije ono što potiče i udomljuje vrela bitka, s druge strane tehnika za seosku egzistenciju (u klasičnom, idiličnom smislu, »gdje je u slozi sa svijetom«) nije provokacija zemlje, nego darivanje i prihvaćanje (sijanje i žetva), skrb i obnova. Umjesto da udomljuje prirodni svijet, on je protivno naravi stvari njegove snage i stvorenja pretvorio u beskućnike. Ako se stvar pretvara u puki objekt čija svrha leži samo u ljudskoj koristi, tada se ukida njihova suradnička naklonost spram ljudskog stvaranja. Naime, sama njemačka riječ za objekt (Gegenstand) ne znači ništa drugo nego »stoji nasuprot«, tj. ono što se suprotstavlja. ${ }^{135}$ I ovdje se stvaralaštvo pretvara u stvorilaštvo time što priroda »odbija suradnju« za izgrađivanje kulturnog.

Pokušajima reinterpretacije Heideggerove filozofije u ekologističkom diskursu također su osobito doprinijeli radovi Michaela E. Zimmermana o njenoj poveznici s dubinskom ekologijom. Pripadnici tog pokreta nalaze zajedničku crtu s Heideggerom u kritici metafizičkih pretpostavki koje drže odgovornima za destrukciju prirode, pri čemu smatraju da je otkrivanje onoga što priroda i čovjek zaista jesu dovoljno za spontanu transformaciju društva, a to bi u

\footnotetext{
darvinizam bi mogao pomoći u zadaći njene pomirbe s čovjekom. Kad god ta teorija ohrabruje duh poniznosti (a ona je to učinila u mnogim prigodama), odlučno je nadmoćnija negoli oprečni nauci, i odgovara sastojku otpora (...) u odnosu na ego. Međutim, popularni darvinizam, koji prožima mnoge vidove masovne kulture i javnog ethosa našeg vremena, ne pokazuje tu poniznost. Nauk o 'opstanku najprilagodljivijih' nije više teorija organskog razvoja koji ne teži nametnuti etičke naloge društvu.« (M. Horkheimer, »Pomrčina uma«, str. 88.)

${ }^{133}$ Usp. N. Visković, Stablo i čovjek, str. 18-19.

${ }^{134}$ George Steiner, Martin Heidegger. With a New Introduction, The University of Chicago Press, Chicago 1992., str. 139; citirano prema: N. Visković, Stablo i čovjek, str. 41. - O »modernoj tehnici« kao načinu raskrivanja, kao i o mogućnosti da vladavina njezine biti manifestirane u po-stavu (Ge-stell) uskrati izvornije raskrivanje i početniju istinu, vidi: Vesna Batovanja, Martin Heidegger. Mišljenje koje se više ne razumije kao metafizika, Naklada Breza, Zagreb 2007., str. 111-112.

${ }^{135}$ Usp. G. Steiner, Martin Heidegger, str. 136-139; usp. N. Visković, Stablo i čovjek, str. 41.
} 
ovom slučaju značilo odbacivanje antropocentričkog, odnosno dualističkog i utilitarnog razumijevanja prirode. ${ }^{136}$ Često se kao izraz potrebnog obrata našeg odnosa spram prirode naglašava Heideggerova uzrečica »pustiti bivstvujuće biti (lassen Seiendes sein)«, pri čemu se ne radi o prestanku korištenja prirode, nego o »načelu suprirodnosti« u čovjekovu odnošenju s njom, koje se očituje u neagresivnom i neizazivajućem načinu suradnje. ${ }^{137}$ Visković će u pogledu ekologističkog čitanja Heideggera posebno istaknuti posljednje dijelove njegova eseja »Prevladavanje metafizike«. Tehnika je tu sažeto opisana na sljedeći način:

»Osnovna forma pojavljivanja, putem koje volja za volju u nepovijesnosti svijeta dovršene metafizike organizira i izračunava samu sebe, može se sažeto nazvati 'tehnikom'. Pri tom, ovaj naziv obuhvaća sva područja bivstvujućeg, koja pripremaju cjelinu bivstvujućeg: opredmećenu prirodu, stvari kulture, vođenu politiku i nagrađene ideale. ${ }^{138}$

Heidegger drži da je takva konstelacija, u kojoj se svi materijali (uključujući samog čovjeka) iskorištavaju za tehničko stvaranje, određena prazninom bitka u kojoj se bivstvujuće nalazi i koja mu je skrivena. Rad na ispunjenju te praznine pokazuje se kao jalov, jer se nju ne da ispuniti punoćom bivstvujućeg. Stoga se tehnika tu javlja tek kao organizacija nedostatka, kao ispomoć volji za volju, koja kronično pati od manjka bivstvujućeg, a za koju tehnika onda stalno masovno proizvodi stvari i troši resurse. ${ }^{139}$ Ovdje istaknute misli nalazimo sumiranima u odlomku eseja na koji se Visković referira:

»Pastiri, daleko od naših očiju, stanuju van pustopoljina opustošene zemlje koja ima služiti još samo osiguranju dominacije čovjeka čije se djelovanje ograničava na procjenjivanje je li nešto važno ili nije važno za život, život što kao volja za volju unaprijed zahtijeva da se svako znanje kreće na način osiguravajućeg računanja i vrednovanja. (...)

Breza nikad ne prekoračuje svoju mogućnost. Pčele stanuju u svojoj mogućnosti. Tek volja, svuda se organizirajući u tehniku, razdire zemlju i napada je zajedno s neprirodnošću, iznurivanjem, iskorištavanjem i promjenom. Tehnika primorava zemlju da iskorači preko naraslog kruga svoje mogućnosti i goni je k onom što više nije moguće i što je zato nemoguće. «140

\footnotetext{
${ }^{136}$ Usp. Michael E. Zimmerman, »Rethinking the Heidegger-Deep Ecology Relationship«, Environmental Ethics 15 (1993) 3, str. 195-224, ovdje str. 196.

137 Usp. Andrej Kirn, »Između ontološke i antropološke opasnosti: Martin Heidegger i 'usuda biti'«, Socijalna ekologija 7 (1998) 4, str. 331-341, ovdje str. 334. - Na ovaj članak upućuje i Visković u: N. Visković, Stablo $i$ čovjek, str. 41.

${ }^{138}$ Martin Heidegger, »Prevladavanje metafizike«, u: Martin Heidegger, Mišljenje i pevanje, preveo Božidar Zec, Nolit, Beograd 1982., str. 7-40, ovdje str. 18.

${ }^{139}$ Usp. ibid., str. 35.

${ }^{140}$ Ibid., str. 38; usp. N. Visković, Stablo i čovjek, str. 40.
} 
Ove riječi, prema Viskoviću, »mogu biti valjane pretpostavke za ekološke i ekološkoetičke razloge $\ll .{ }^{141}$ Dodajmo: uz dva uvjeta. Prvi je da ne počinimo neopravdano ograničavanje prekoračivanja mogućnosti na tehničku akciju, čime bismo mogli ispustiti iz vida onaj netehnički aspekt volje iz kojeg se generira čovjekova potreba prevladavanja postojećeg, potrebe koja čini sastavni dio kulture (čime se, uostalom, jedino i može suprotstaviti pošastima kojima je zaborav prirode rezultirao). Drugi je da ne slijedimo Heideggera u podizanju biti tehnike kao postava »na rang bitkovno-povijesne sudbe«, da je ne shvatimo kao ono na što čovjek »ne može ni pozitivno ni negativno utjecati«, da, konačno, ne svedemo čovjeka na pastira bitka, koji njegovu istinu tek očekuje. ${ }^{142} \mathrm{~S}$ jedne strane, moglo bi se s Danilom Pejovićem reći da je »rani Heidegger evropskog čovjeka suviše opteretio prepuštajući mu odluku o sudbini zapada«, a da »ga kasni Heidegger gotovo lišava svake odgovornosti i prikraćuje svođenjem povijesti na bitak «. ${ }^{143}$ No, s druge strane, treba imati na umu da u jednom Pejovićevu intervjuu Heidegger izričito tvrdi da se odlučnost (kao osobito istaknut egzistencijal u ranoj fazi) ne razlikuje od puštanja bivstvujućeg da jest (što se naglašava u kasnijoj fazi) time što se oboje misle kao »otvorenost tubitka za istinu kao svjetlo bitka«, a čovjek ne može »ništa pospješiti već samo čekati, jer mi nismo gospodari povijesti nego samo čuvari istine bitka «. ${ }^{144}$ Time se Heideggerovo puštanje bivstvujućeg da bude javlja unutar (potrebne) kritike građanskog svijeta, ali istovremeno kao (štetna) konzervativna i očajnička kritika. ${ }^{145}$ Međutim, prihvaćanje ove opaske ne otklanja važnost Viskovićeva implicitnog ukazivanja da se vrijedne misli za višedimenzionalan problem odnosa kulturnog i prirodnog daju izvući i iz filozofskih učenja koje u punini i ne trebaju odgovarati zadanom cilju.

Nije prošlo dugo dok se nisu pojavili neki mislioci koji su osvijestili zabrinjavajuću razarajuću tendenciju kulturnog odnosa spram prirode, koja se sasvim konkretno odvija pred našim očima u vidu ekološke krize. Osim Hansa Jonasa, Heideggerova učenika i jednog od ključnih mislioca po pitanju odgovornosti spram prirode, Visković posebno ističe Günthera Altnera, Eugena Drewermanna i Fritjofa Capru, mislioce koji se osvrću na malignosti antropocentričnog svjetonazora zapadne civilizacije. On osobito cijeni mislioce poput

\footnotetext{
${ }^{141}$ N. Visković, Stablo i čovjek, str. 40.

142 Ova Heideggerova određenja prenesena su iz: V. Batovanja, Martin Heidegger, str. 113.

143 Danilo Pejović, Suvremena filozofija Zapada. I odabrani tekstovi, Nakladni zavod Matice hrvatske, Zagreb 1983., str. 158.

${ }^{144}$ Usp. Martin Heidegger, »Razgovor s Martinom Heideggerom« (razgovarao Danilo Pejović), u: Danilo Pejović, Sistem i egzistencija, Zora, Zagreb 1970., str. 116-127, ovdje str. 123.

${ }^{145}$ Usp. Mihailo Marković, »Čovek danas«, u: Čovek danas. Zbornik filozofskih ogleda, Nolit, Beograd 1964., str. 9-30, ovdje str. 11. - U konkretnom je Heideggerovu slučaju, s obzirom na to da se svojim poimanjem povijesnosti vodio u sudjelovanju u nacional-socijalističkom pokretu (usp. Goran Gretić, »Heideggerova kritika boljševizma i liberalizma«, Anali Hrvatskog politološkog društva 13 (2016) 1, str. 37-50, ovdje str. 38), dešperatstvo ipak sretnije rješenje.
} 
Drewermanna, koji usprkos neodstupanju od kršćanstva uspijevaju iznaći snage da se usprotive nekim neodgovornim crkvenim doktrinama. Tako teolog Drewermann osobito kritizira natalitetnu doktrinu, upozoravajući na prirast svjetskog stanovništva kao na jedan od važnih uzroka ekološke krize. Međutim, kritici antropocentrizma doprinijeli su i autori koji ciljaju na jedan njegov vid u okviru ekofeminističkih postavki prema kojima androcentrizam stoji u analogiji s antropocentrizmom. Takva razmišljanja usvaja i Capra, a ključni poticaj promišljanju analogije instrumentaliziranja prirodnog s instrumentaliziranjem žene pružili su još Horkheimer i Adorno u Dijalektici prosvjetiteljstva. ${ }^{146}$

Pokušaji buđenja iz zaborava prirode i poticanja na alternativu mehanicističkoj slici prirode ipak nisu izostajali u drugim sferama čovjekova stvaralaštva, nego su često upravo prethodili znanstvenim i filozofskim refleksijama:

\».. uvijek je bilo otpora takvoj vladajućoj slici svijeta, tom padu iz priznanja i poštovanja prirode u raščaranost, ogoljeli utilitarizam i nipodoštavanje naše prirodne matrice. Prije svega, temelji toga otpora nalaze se u elementarnim stanjima čuđenja, divljenja i sanjarenja koje u svakom normalnom čovjeku pobuđuju tajne, veličina, ljepota i plodovi mora, neba, planina, rijeka, biljaka i životinja. ${ }^{147}$

Ova nas razmišljanja ponovno vraćaju na ono što smo istaknuli na početku. Naime, čovjekovo iskakanje iz prirode uvijek je ostavljalo prostora za ova elementarna stanja naspram same prirode kao onog drugog koje također zavrjeđuje poštivanje i uvažavanje. Ona su se prvenstveno izražavala u umjetnosti. Stoga, unutar našeg cjelokupnog odnosa spram prirodnoga, a onda i spram kulturnoga, osobitu važnost imaju kako umjetničke i sl. perspektive, koje bi u izvjesnom smislu trebale biti poticajne i samoj racionalnoj refleksiji.

\footnotetext{
»Iako su neki dijelovi toga fronta otpora vladajućem zaboravu prirode znanstveno naivni, romantičarski i antropomorfni, dakle ili nerealistični ili takvi da ne-ljudskim bićima pripisuju specifična ljudska svojstva, oni ipak svjedoče o sretno očuvanoj sposobnosti čovjeka da se uzdigne do spoznajnih i etičkih stavova koji nisu isključivo instrumentalno-ekonomski prema prirodi. Ovo posljednje se nadasve postiže u onom osebujnom prepoznavanju i priznanju prirode koje nose sadašnji duhovni i politički pokreti ekologizma i bioetike, a koji se od mističnih i romantičarskih načina povratka prirodnom svijetu razlikuju po tome što propituju zbiljske mogućnosti solidarnog odnosa čovjeka spram okolnog svijeta postupcima racionalno-argumentativne spoznaje i rasuđivanja: znanstvene spoznaje bioloških i ekoloških zakonitosti i etičko-estetskog rasuđivanja po kojima čovjek nije jedina 'svrha' svijeta, već su i sva druga bića i svijet
}

\footnotetext{
${ }^{146}$ Usp. N. Visković, Stablo i čovjek, str. 19, 42.

${ }^{147}$ Ibid., str. 19.
} 
uopće vrijedni po sebi, značajni, neponovljivi i lijepi, te stoga moraju biti predmetom našeg uživljavanja, brige i zaštite. $\ll^{148}$

Poglavlje o bliskoj i dalekoj prirodi, ključno u okviru refleksije o zaboravu prirode, Visković završava citirajući Höslea: »Filozofija prirode koja nastoji autonomiju uma povezati sa samostalnim dostojanstvom prirode čini mi se jednim od glavnih desiderata našega vremena. $\ll^{149}$

\title{
II.1.4. Kulturna biologija kao odgovor na zaborav prirode
}

Duh vremena obilježen zaboravom i tehnološkim posredovanjem prirode bitno se odrazio na pojedine znanosti, kako smo to u prethodnom tekstu već naznačili. Čovjekovo otprirođenje, smatra Visković, popraćeno je otprirođenjem znanosti. Tu se najčešće misli na prirodne znanosti, koje »porađaju tehnologiju« i bezobzirno tlače prirodu za čovjekove utilitarne svrhe. Međutim, njegova osuda za zaborav prirode u izvjesnom je smislu više uperena prema duhovnim znanostima, jer upravo one imaju dužnost »radikalne refleksije« nad čovjekovim djelovanjem spram svijeta života. Niti prirodne niti duhovne znanosti u pravilu prirodu ne shvaćaju kulturalistički i etički, što zapravo znači da ih se priroda uopće ne tiče. ${ }^{150}$ Važnu iznimku sačinjava etnologija:

\begin{abstract}
»Zato što je etnologija struka koja ne može pobjeći od prirode. Ona je silom svoga predmeta upućena na nju kao neposrednu osnovu kulture. I prirodne znanosti upućene su na prirodu, ali sa zadatkom stvaranja tehnologije radi osvajačkih ciljeva, a oni su toliko opsesivni i sebični da pred njima postojanje i opstanak prirode jednostavno padaju u zaborav. Etnologija je tradicionalno zaokupljena seoskom i pučkom kulturom, a ona je toliko pozitivno isprepletena s prirodom da je etnolozi ne mogu podcijeniti, a kamoli mimoići. «151
\end{abstract}

Potreba za kulturnom biologijom kod Viskovića se prvenstveno javlja kao prilog prevladavanju zaborava prirode $\mathrm{i}$ otprirođenja znanosti, a načine na koji to prevladavanje

\footnotetext{
${ }^{148}$ Ibid., str. 20.

${ }^{149}$ V. Hösle, Filozofija ekološke krize, str. 11; N. Visković, Stablo i čovjek, str. 21.

${ }^{150}$ Usp. N. Visković, »U inat vladajućim idiotarijama«, str. 9.

${ }^{151}$ Ibid., str. 9. - U ovom smislu nije neoubičajeno to što su kod nas Viskovićevu kulturnozoološku misao u prvom redu nastavljale etnologinje sa zagrebačkog Instituta za etnologiju i folkloristiku, prije svega Suzana Marjanić i Antonija Zaradija Kiš. Pored ostalih, vrijedi spomenuti njihov projekt Kulturna animalistika pokrenut 2008., kojemu pripada i godinu ranije objavljen zbornik Kulturni bestijarij. (Usp. Suzana Marjanić, »Pokret za prava životinja u RH: pokušaj pregleda«, Ekonomska i ekohistorija 10 (2014), str. 113-132, ovdje str. 114; Suzana Marjanić, Antonija Zaradija Kiš (ur.), Kulturni bestijarij, Hrvatska sveučilišna naklada - Institut za etnologiju i folkloristiku, Zagreb 2007.)
} 
njezine subdiscipline trebaju izvršiti, kao i ciljeve njihova ispitivanja, izložit ćemo u njima posvećenim poglavljima. Riječ je o dvije discipline: kulturnoj zoologiji ili kulturnoj animalistici te kulturnoj botanici, koje kao osnovna pitanja postavljaju što je čovjek životinji/biljci i što je životinja/biljka čovjeku. Njihovo postavljanje sačinjava i jedan od razloga korištenja pridjevka kulturnog:

»Uz zoološko i botaničko stavljam kultura, kao prvo, radi označavanja da nemam nikakvih pretenzija u prirodoznanstvenim disciplinama zoologije i botanike. Drugo, time najkraće naznačavam temeljno pitanje koje me u tim radovima motivira: što su životinja i stablo čovjeku, a što je čovjek životinji i stablu? «152

Ovi bi se projekti mogli podvesti pod kulturologiju, ali u sasvim specifičnom smislu:

»Kulturologija se vrlo različito definira u pragmatici nomenklature znanosti, pa tu nema njezina jedinstvenog i obvezujućeg određenja. No kada bi postojala borgesovska ili kalvinovska znanost kulturologije, ona bi se posvećivala ama baš svemu što čovjek na prirodi radi i dograđuje. Sve ljudsko je kultura i predmet takve kulturologije, uključivo prirodne znanosti, domestikacija prirode i razaranje prirode. Ipak, nemoguće je da se kulturologija u takvu opsegu oblikuje kao prava znanstvena disciplina, čak i kao ovako ili onako shvaćena antropologija, jer bi joj tada prijetila svaštarska (bes)plodnost. Znanost se mora specijalizirati, ali onda je svaka posebna znanost ipak segment takva ideala kulturologije. Kulturna zoologija i kulturna botanika dvije su od bezbrojnih mogućnosti znanstvenih interdisciplinarnih križanja. $\ll^{153}$

Viskovićev pristup se postavlja skromno, bez obzira na širinu horizonata ispitivanja koje si zadaje. No njih je, upravo zbog spominjane opasnosti od rascjepkavanja različitih uvida po ovom pitanju ili, još gore, reduciranja jednoga na drugi, upravo u tom razmjeru i potrebno postaviti. Okvirna metodologija na koju se Visković pri tom oslanja proizlazi iz pravničke teorije i prakse:

»Dakle, nalazeći se vazda pred nekim sporom, pravnik mora najprije utvrditi relevantne fakte, potom te vrijednosno ocijeniti i na kraju ih normativno kvalificirati u pravilu ili pojedinačnoj odluci. Slično tome razvijale su se i priče kulturne zoologije (...) One su prije svega velike zbirke sređenih činjenica, zatim etičko vrednovanje tih činjenica, i konačno prijedlozi za moralno i pravno normiranje odnosa čovječanstva prema prirodi. Zanimljivo je da kritika nije uočila da je takva struktura Životinja i Stabla analogna strukturi moje davne doktorske disertacije Pojam prava, prilog integralnoj teoriji prava, koja

${ }^{152} \mathrm{~N}$. Visković, »U inat vladajućim idiotarijama«, str. 8.

${ }^{153}$ Ibid., str. 9. 
objašnjava pravo kao sustav činjeničnih odnosa, vrijednosti i normi, koji su predmet povijesnog iskustva pravnika. Tu trojnu strukturu transponirao sam u razmatranje životinjstva i bilja u kulturi $(. ..) \ll^{154}$

Tri su, dakle, predmeta nužan sastojak pravnog iskustva: 1) društvene vrijednosti, 2) pravne norme i 3) društveni odnosi. ${ }^{155}$ Ove sastavnice, navodi Visković, odgovaraju onome što se tradicionalno u pravnoj znanosti naziva 1) idejnim izvorima prava (tu pravednost slovi za dominantnu vrijednost), 2) formalnim izvorima prava (gdje je zakon dominantan normativni akt) i 3) materijalnim izvorima prava (pri čemu je riječ o dominantnim ekonomskim, političkim, ali i biološkim odnosima). Potonji, materijalni izvori prava, u nastanku pravne pojave prethode prije navedenima, tako da se prvo javlja izvjesni društveno značajan i konfliktan odnos koji se dade kontrolirati. Nakon njegova spoznavanja slijedi njegovo vrednovanje ovisno o interesima s kojima on ima veze. Konačno, provodi se pravno normiranje tih odnosa, čime se, polazeći od društveno prevladavajućih vrednovanja, taj odnos disciplinira. ${ }^{156}$

No sve do 60-ih godina 20. st., nastavlja Visković, priroda, tj. odnosi međuzavisnosti njenih organskih i anorganskih sastojaka, nije spoznata kao materijalni izvor prava. Razlozi za to leže u dotadašnjem nedostatku očitovanja štetnog civilizacijskog utjecaja (s obzirom na nedovoljnu tehnološku razvijenost) na prirodu (osim na užim lokacijama), tj. ranjivosti prirode uslijed tehnološko-privredne uzurpacije, kao ni ograničenosti prirodnih bogatstava. Barem je svijest o ugroženosti vlastita života potaknula svijest o potrebi promjene na ovom planu. U tom je pogledu ugroženost prirode među osnovnim brigama čovječanstva, pa postaje materijalni izvor prava. No, s obzirom na to da ovi objektivno važni društveni odnosi ostaju dijelom nespoznati, a kada se prepoznaju normativni akti vezani uz njih bivaju površni i neučinkoviti, oni znatnim dijelom ostaju pravne praznine, tj. odnosi koji nisu zahvaćeni ili su tek nepotpuno ili nedjelotvorno zahvaćeni od strane pravne regulacije. ${ }^{157}$

Kako bi se te praznine popunile, ne samo u tom, nego i širem pogledu brige za sva živa bića radi njih samih, osnovni su zadaci koje Visković postavlja pred sebe i nastavljače kulturne biologije: osvijestiti odnose čovjeka i ne-ljudskih živih bića (u svim njihovim aspektima, od materijalne i simboličke upotrebe do njihova maltretiranja), zatim pokazati da su oni uvelike u vrijednosnom smislu neprihvatljivi i time dati doprinos društvenom prepoznavanju tog suda te

\footnotetext{
${ }^{154}$ Ibid., str. 8-9.

${ }^{155}$ Usp. Nikola Visković, Pojam prava. Prilog integralnoj teoriji prava, Logos, Split 1981., str. 23.

${ }^{156}$ Usp. Nikola Visković, »Ekologija i pravo«, u: Bože Vuleta, Ante Vučković (ur.), Odgovornost za život. Zbornik radova sa znanstvenog simpozija održanog u Baškoj Vodi, 1. - 3. listopada 1999., Franjevački institut za kulturu mira, Split 2000., str. 455-476, ovdje str. 455-456.

${ }^{157}$ Usp. ibid., str. 456-459, 461-462.
} 
konačno predložiti načine na koje će se oni koji ne prihvate te nove društvene vrijednosti disciplinirati. U nastavku ove glave poglavito će biti riječ o prvom zadatku.

\section{II.2. Kulturna zoologija}

Zoologija, grana biologije koja proučava životinjsko carstvo, svoju historijsku pozadinu gradi već od samog procesa domestikacije životinja, kada se javlja potreba sistematskog i mjerljivog sagledavanja njihova života, što se uslijed urbanizacije posebno intenzivira rastom zahtjeva za životinjskim proizvodima. ${ }^{158}$ Moglo bi se reći da već time, prije no što je nastala kao znanost, nastupa »protootprirođenje« zoologije, što osobito ne čudi s obzirom na bjelodano izvanznanstvene svrhe u koje u ovom slučaju metode nalik znanstvenima nastaju. No, kako navodi Earl Dorchester Hanson u jednom enciklopedijskom članku, tek s Grcima, osobito Aristotelom, možemo govoriti o racionalnijem, gotovo u modernom smislu znanstvenom studiju životinja. Na Mediteranu će upravo aristotelijanska tradicija oblikovati proučavanje životinja u dugom razdoblju koje slijedi, gdje će se uz ono što možemo nazivati znanstvenim pristupom akumulirati obilježja vezana uz folklor, predrasude i moralnu simboliku. Ona će posebno biti odstranjivana iz zoološkog istraživanja usvajanjem mehanicističkih sagledavanja životnih procesa. Tako je, primjerice, William Harvey (bez obzira na njegov načelno aristotelijanski stav) uključio mehaniku hidrauličkih sistema u objašnjenje načina na koji cirkulira krv. U 18. i početkom 19. st. nastupaju reforme u vidu nomenklature (Carl von Linné), obuhvatnih djela o prirodnoj prošlosti (Georges-Louis Leclerc de Buffon) i spisa iz komparativne anatomije (Georges Cuvier). Oko tog razdoblja formulira se i pojam stanice, praćen razvojem tehničkih naprava poput mikroskopa. Još jedna ozbiljna reforma svakako je ona Darwinova, a konačno je razvoj genetike u 20. st. bitno uvjetovao sve biološke discipline. Konačno se $\mathrm{s}$ ekologijom i etologijom zoološka istraživanja sve više uključuju u interdisciplinarni dijalog. Istovremeno se (već od teorije stanica, preko teorije evolucije i otkrića sličnosti genetičkog materijala kod svih organizama, do shvaćanja prijenosa materije i energije kroz ekosisteme) naglasak s empirijskog ispitivanja sve više prebacuje na konceptualni pristup. ${ }^{159}$

158 Usp. Earl Dorchester Hanson, »Zoology«, Encyclopaedia Britannica 13. 3. 2019. Dostupno na: https://www.britannica.com/science/zoology (pristupljeno 21. 4. 2020.).

${ }^{159}$ Usp. ibid. 
Naravno, klasična zoološka znanost, ako kreće s pretpostavkom pozitivne prirodne znanosti, ne smije sebi dopustiti samostalne izlete u holističko obuhvaćanje značenja životinje. Iako je uopće iluzorno isključivati subjekta promatranja (čovjeka) iz pozitivne znanosti, kako bi se postigla tobožnja objektivnost, moguće je donekle održati tu distancu, makar u smislu isključivanja određenih tema iz područja koja neka znanost obuhvaća.

Pa ipak, u zoologiji je došlo do nekih odstupanja od naprosto pozitivno-znanstvenog biološkog pristupa problemu, ponajprije u djelima Richarda Lewinsona Morusa i Roberta Deltona, ali usprkos njihovim pokušajima prikaza utjecaja životinja na ljudsku kulturu, sustavan prikaz kulturne historije životinja tek je na svome začetku. ${ }^{160}$ Upravo se na takvim punktovima rađaju prva odstupanja od pozitivno-znanstvenog pristupa stvarnosti, osobito ako je riječ o nečemu toliko kompleksnom i toliko premreženom kulturnim značenjima kao što je životinja. Naravno, ostaje pitanje što bi kulturna historija životinja ili kulturna zoologija uopće bila?

Visković ne daje izravnu definiciju kulturne zoologije, ${ }^{161}$ ali zato detaljno navodi sva područja kojima se ona bavi, o čemu svjedoči i čitav njegov rad na ovom polju - ili bolje: ne daje klasičnu definiciju per genus proximum et differentiam specificam, nego onu nabrajajuću. Osnovu za njeno određenje Visković nalazi u bliskoj svezi s etnozoologijom, čiju definiciju navodi prema Raymondu Pujolu, koji »će u jednom enciklopedijskom članku ${ }^{162}$ etnozoologiju odrediti kao graničnu biološko-socijalnu znanost koja spoznaje stvarne i imaginarne odnose kultura pojedinih pučkih skupina s pojedinim vrstama životinja«. ${ }^{163}$ Međutim, kulturna zoologija ima pretenziju na znatno šire područje istraživanja, kako bi obuhvatila sve razine odnosa čovjeka i životinje:

»Pored 'pučke kulture', ona bi trebala istraživati i zoo-pojave u 'visokoj kulturi' - urbanoj, književnoj,
likovnoj, političkoj, znanstvenoj, filozofskoj. Ona bi trebala pokazivati na koje sve načine ljudi u
pojedinim epohama, dijelovima svijeta i društvenim skupinama zavise o životinjama i percipiraju i
upotrebljavaju životinje u ekonomskom, vjerskom, umjetničkom, moralnom, osjećajnom, ratnom,
znanstvenom, pravnom i drugom smislu; kako je čovjek ugrožen od nekih životinjskih vrsta i kako on

\footnotetext{
${ }^{160}$ Usp. N. Visković, Kulturna zoologija, str. 10.

161 Premda bi se iz Viskovićeva teksta dala izvući definicija kakvu prepoznaje Bruno Ćurko. Tako je kulturna zoologija »prikaz mnogostranih i mnogoznačnih relacija životinja - čovjek u jedinstvenoj povijesti života na Zemlji«. (Usp. Bruno Ćurko, »Kulturna animalistika Nikole Viskovića - s primjerom vuka (Canis lupus)«, u: Josip Guć, Hrvoje Jurić (ur.), Nikola Visković: pravo - politika - bioetika. Zbornik povodom osamdesetog rođendana, Pergamena - Filozofski fakultet Sveučilišta u Splitu, Centar za integrativnu bioetiku - Pravni fakultet Sveučilišta u Splitu - Znanstveni centar izvrsnosti za integrativnu bioetiku, Zagreb - Split [u pripremi]; ovaj citat izvlači iz: N. Visković, Životinja i čovjek, str. 19.

162 To se odnosi, kako navodi Visković, na članak »L'Homme et l'Animal« u: Encyclopadié de la Pleiade: Historie des moeurs, vol. 1, Paris, 1990, str. 1307 i d.
}

${ }^{163}$ N. Visković, Kulturna zoologija, str. 11. 
njih ugrožava; kako su mu i koje životinje konkurenti, a kako i koje prijatelji i suradnici; koliko je on sam sličan životinjama i koliko se od njih razlikuje; koliko je spoznao animalno i svoje međuzavisnosti s njima koliko pati od neznanja i predrasuda spram njemu... $\ll^{164}$

Već ovaj poduži, čak i nedovršeni popis, pokazuje smjer kojim kulturna animalistika želi pristupiti svojoj osnovnoj temi - međuodnosu čovjeka i životinje. Njezin prikaz u ovom ćemo poglavlju uglavnom ograničiti na prvu sastavnicu spomenutog metodološkog ustrojstva, činjenice (a to će biti slučaj i u prikazu kulturne botanike koji mu slijedi), a izvođenju ćemo se dijelom osloniti i na tipologiju osnovnih pristupa odnosa čovjeka i životinje koju iznosi sam Visković. Kod njega se radi o sljedećim pristupima: ekonomski, simbolički, umjetnički, osjećajni, znanstveni i etički. Po sebi je jasno, ali autor to ipak daje do znanja, da se tu svakako ne može raditi o odvojenim pristupima. Tako daje primjer pećinskog slikarstva, koje nosi simboličke, umjetničke, pa i ekonomske elemente. ${ }^{165}$ Fokus ovog rada prvenstveno je na etičkom aspektu, tako da ćemo u ovome dijelu dati pregled ostalih pet ponešto modificiranih pristupa, bez pretenzije na dublje, kritičke uvide, kako bismo u posebnom odjeljku raspravili Viskovićevu (bio)etičku poziciju, izveli bitne filozofske utjecaje koji su doprinijeli njezinu formiranju, a konačno pružili i kritički osvrt na nju.

Elemente za pregled odabranih tema iz kulturne zoologije ovdje ponajprije crpimo iz Viskovićeva djela Životinja $i$ čovjek, odnosno njegova novijeg, skraćenog izdanja pod naslovom Kulturna zoologija. Drugo, skraćeno izdanje, ovdje ćemo koristiti kad god je to moguće, kako zbog veće dostupnosti same knjige, tako i zbog nekih sitnih izmjena i osvježenja koje je autor unio u nju. Na isti ćemo način postupati u čitavom radu. Nemogućnost obuhvata svih tema Viskovićeva kulturno-zoologijskog djela, tj. potreba selekcije pojedinih tema, postaje jasna nakon samog uvida u popis poglavlja (od kojih su neka napisali i drugi autori) knjige Životinja $i$ čovjek, djela gotovo enciklopedijskih razmjera. ${ }^{166}$

\footnotetext{
164 Ibid., str. 13.

${ }^{165}$ Usp. Nikola Visković, »Šest načina odnosa prema životinji«, u: Nenad Cambi, Nikola Visković (ur.), Kulturna animalistika. Zbornik radova sa znanstvenog skupa održanog 29. rujna 1997. godine u Splitu, Književni krug, Split 1998., str. 11-15, ovdje str. 11.

${ }^{166}$ Radi se o sljedećim poglavljima: Kulturna zoologija; Podjele životinja; Trenutak čovjeka; Antropomorfizam i zoomorfizam; Prva umjetnost; Egipatski i grčki panteon; Aristotel; Životinje u mitologiji. Reinkarnacija; Biblija i životinje; Kuran i Ihvanu-s-Safa; Dobro za jesti; Put do viših sila; Fantastične životinje. Jednorog; Jezik i životinje; Naši zoonimi (autor: Petar Šimunović); Haiku život; Likovna animalistika u Hrvatskoj (autor: Duško Kečkemet); Leonardova po-etika; Političke životinje; Heraldika; Montaigne; Descartes, kartezijanci i antikartezijanci; Darwin; Etologija i sociobiologija; Pamet; Spolnost; Igra i ljenčarenje; Mirisi; Majmuni i Gasset; Pas, mačka, gospodari; Equus caballus; Živjeli kukci!; Uljezi i susjedi; Čovjek čovjeku tovar (autor: Anatolij Kurdjavcev); Ptice i pjesnik; Dijete i životinja; Filmski zoo; Stare i nove upotrebe; Bionika; Šatrovački Zoo; Lov; Domestikacija; Zmijsko pitanje; Suđenje miševima; Svijet poglavice Seattle; Istrebljenje vrsta; Vuk i antiekološka Crvenkapica; Pismo slonu; Bitka za medvjeda; Močvarni biotopi; Ptice grabljivice (autori: Zvjezdana Mikulić, Nikola Visković); Umiranje Mediterana; Znanstveni masakri; Odprirođene životinje; Bestijalnost; Sporni Zoo parkovi; Industrija
} 


\section{II.2.1. Duhovni aspekt}

Visković prije svega postavlja pitanje o tome što životinja uopće jest, pitanje koje nije nimalo samorazumljivo kakvim se ono može na prvi pogled činiti. Štoviše, odgovori na to pitanje sve se više čine spornima. Iako se životinja najlakše sagledava kao pripadnica carstva Animalia, a u razlici spram biljke, tj. unutar još kod starih Grka prisutne podjele živog svijeta na biljke i životinje, znanost sve više osporava takvu jednostavnu podjelu, nalazeći njihovo temeljno jedinstvo, koje se lako uviđa kod bičaša i algi. U svakom slučaju, na djelu je zajedničko podrijetlo jednih i drugih. Razlika je uočljiva kod većeg dijela pripadnika ovih carstava, pa tako postoje klasične podjele na heterotrofne (one koji se hrane gotovim organskim tvarima) i autotrofne (one koji proizvode svoju hranu) organizme, pri čemu su prvi (životinje) slabije uvjetovani prirodnom sredinom, nesputanije se kreću itd. Međutim, probleme zadaju mnogi granični primjeri. Problemi se javljaju i u podjeli unutar životinjskog carstva, čije je razvrstavanje uvjetovano i kulturnim obrascima i interesima ljudi. Prvi ozbiljniji klasifikator životinja bio je Aristotel, nakon kojega vrijedi istaknuti spomenutog tvorca moderne taksonomije flore i faune Carla von Linnéa, da bismo kasnije došli do klasifikacije životinja na temelju njihovih morfoloških osobina i položaja koji zauzimaju u evoluciji. Iako iz današnje perspektive izgleda kako su nove taksonomije uvelike nadmašile one stare po pitanju objektivnosti, čini se da ipak nikada ne može biti riječ o potpuno objektivnom poslu, jer pored toga što su nove podjele također uvjetovane nekakvim interesom, pa makar to bio samo interes znanstvenika da potvrdi vlastito shvaćanje istine i društveni status, klasifikacije su manjkave s obzirom na mnoštvo još nedokumentiranih vrsta. Izvan strogo znanstvenih podjela stalno opstaju one koje radimo u svakodnevnom iskustvu. Životinje nam mogu biti: drage i mrske, korisne i nekorisne, lijepe i ružne, svete i demonske, čiste i nečiste, opasne i bezopasne, jestive i nejestive, ukusne i neukusne, divlje i pripitomljene itd. U tim podjelama često je prisutno i međupodručje životinja prema kojima smo ravnodušni. ${ }^{167}$

patnje i održivi razvoj; Borbe životinja. Tauromahija; Žrtve rata; Čudne farme; Kućni ljubimci; Antropocentrična i biocentrična etika; Imovina i sustvorenje; Zoofilija; filantropija i mizantropija; Žene su s vama; Imaju li dušu?; Vegetarijanstvo; Slavni prijatelji; Zaštitna udruženja; Animal liberation; Životinjska prava; Sukobi interesa; Kasna i nejednaka pravna zaštita; Angloamerički Animal law; Njemački Tierschutzgesetz; Talijansko iskustvo; Miljenici pred zakonom: Francuska; Zaštita životinja u Hrvatskoj; Međunarodna pravna zaštita; Nacionalni parkovi i rezervati. (Usp. N. Visković, Životinja i čovjek, str. 5-7.)

${ }^{167}$ Usp. ibid., str. 23-25, 27. - »U suvremenoj biologiji uvriježilo se definirati životinju kao višestanični organizam koji nema sposobnost fotosinteze, hrani se i hranu probavlja u crijevima.« (Lars Fr. H. Svendsen, Razumijemo li životinje? Filozofijski pristup, preveo Mišo Grundler, TIM press, Zagreb 2019., str. 141.) Po pitanju klasifikacije Lars Fr. H. Svendsen slično Viskoviću konstatira da su »naše klasifikacije uvjetovane, što se odnosi i na klasifikaciju svijeta sa životinjskim carstvom na jednoj, a ljudima na drugoj strani. Važno je naglasiti da takve 
Već sam intenzitet određenih znanstvenih istraživanja, u kojima prevladavaju ona vezana uz domestikaciju, govori o primarno utilitarnom interesu homo economicusa za životinje. ${ }^{168} \mathrm{Ne}$ treba, stoga, čuditi ni to što su podjele životinja više ili manje antropocentrički nastrojene.

Pitanje podjele živog svijeta neizostavno povlači pitanje o čovjekovu mjestu unutar njega. On se već kao animal rationale ili kao animal symbolicum postavlja u carstvo Animalia, a da ipak prema njemu čini određen odmak u vidu svoje vrsne razlike. Naravno, različita su tumačenja zaoštravala ovaj vid u jednu ili drugu stranu, postavljajući čovjeka kao umno ili oduševljeno biće izvan ovakvih podjela, kao i poričući njegovo kvalitativno razlikovanje od ostatka živog svijeta, odnosno prepoznavajući kod njega samo kvantitativne razlike spram drugih životinja.

Visković se također kreće između kvalitativnog i kvantitativnog određenja razlika između čovjeka i životinje. U jednom se trenutku čini da se više priklanja kvantitativnom razlikovanju, iako ne drži da se u razlikovanju čovjeka i životinje radi isključivo o takvoj vrsti:

»Etologija čini načelno upitnim čuveno razlikovanje čovjeka i životinje iz Rousseauove Rasprave o podrijetlu i nejednakosti među ljudima, po kojemu čovjek ima 'sposobnost da se usavršava', za razliku od životinje, 'koja je nakon nekoliko mjeseci ono što će biti čitava života, a njena vrsta bit će za deset tisuća godina ono što je bila prve godine od tih deset tisuća godina'. Evolucionistička biologija i etologija pokazuju združeno ispravnost Darwinove misli da je i u ovome razlika između čovjeka i životinje više u stupnju nego u kvaliteti.«169

Iako Darwin svojom teorijom o postanku vrsta daje jedan od najozbiljnijih udaraca shvaćanjima koja se trude otvoriti nesagledivi jaz između čovjeka i životinje, takva razmišljanja pojavljuju se još kod predsokratovaca, primjerice kod Anaksimandra, koji tvrdi da je čovjek nastao iz ne-ljudskih živih bića. ${ }^{170}$ No tek se Homo sapiens može sa sigurnošću odrediti kao »biće kulture u većoj mjeri neovisno o ekološkim uvjetima ili prilagodljivo promjenama okoline

\footnotetext{
klasifikacije oblikuju našu sliku svijeta. Podjelom svijeta po kojoj su životinje bitno različite od nas, mi ćemo ih uglavnom početi doživljavati kao bitno različite.« (Ibid., str. 143.) Tako i Hrvoje Jurić drži pojam 'životinje' konstruktom: »To nam pokazuje činjenica da se nereflektirano govori o 'životinji' (i 'životinjama'), usprkos diferenciranosti i nevjerojatnom rasponu kompleksnosti unutar tzv. 'životinjskog svijeta' (od kišne gliste do psa, od grinje do čimpanze), kao kad bi se nediferencirano govorilo o 'ne-bijelim ljudima' kao jedinstvenoj vrsti pored i naspram 'bijelih ljudi'.«(H. Jurić, Etika odgovornosti Hansa Jonasa, str. 295.)

${ }^{168}$ N. Visković, Životinja i čovjek, str. 199.

${ }^{169}$ N. Visković, Kulturna zoologija, str. 21-22.

${ }^{170}$ Usp. N. Visković, Životinja i čovjek, str. 29. - Historija znanstveno utemeljenog osporavanja vrsne razlike između čovjeka i drugih životinja (u prvom redu majmuna) započinje najkasnije u 18. st., odnosno s von Linnéom. (Usp. Predrag Krstić, Filozofska životinja. Zoografski nagovor na filozofiju, Službeni glasnik - Institut za filozofiju i društvenu teoriju, Beograd 2008., str. 164-166.)
} 
i ujedno minimalno specijalizirano u svojim sposobnostima - upravo kako čovjeka definira filozofska antropologija od Pica della Mirandole do Arnolda Gehlena «. ${ }^{171}$ Na njegovu polaganu biološku evoluciju nadodaje se (ponekad i kao njen pokretač) sve brža »kulturno-tehnološka evolucija« u kojoj se množe čovjekove specifične osobine, kao što su simbolotvorstvo, apstraktno mišljenje, upotreba vatre, otvorenost prema svijetu i distanciranje spram njega, samosvijest, religioznost itd. ${ }^{172}$ Ovdje je kvalitativna razlika čovjeka i životinje bitno naglašenija. Visković upravo ističe liniju razmišljanja o čovjeku koja potvrđuje postalost Homo sapiensa evolucijom iz reda primata, ali ga istovremeno određuje kao višu životinju koja poprima odliku nespecijaliziranosti, kao biološke slabosti i kulturne prednosti. On također slijedi i jedan od osnovnih uvida filozofske antropologije, da je čovjekovo samopoimanje bitno uvjetovano njegovom predstavom životinje. ${ }^{173}$

\section{II.2.1.1. Antropomorfizam i zoomorfizam}

Visković ističe da pripisivanje ljudskih osobina životinjama (antropomorfizam) i pripisivanje životinjskih osobina ljudima (zoomorfizam) ukazuju na duboku povezanost čovjeka i životinje. Dakako, antropomorfizam nije ograničen samo na životinje, nego je povezan i s načinom na koji čovjek oduvijek shvaća svijet, prirodu i bogove. Međutim, upravo su životinje »povlašteni predmet antropomorfizacije, prije svega u primitivnim kulturama i u svijetu djetinjstva«. ${ }^{174}$

Najpoznatija preplitanja čovjeka i životinje u imaginaciji prvoga, kako navodi Visković, prisutna su u mitološkoj svijesti, u likovima Kentaura, Minotaura, Sfinge itd. Osim iznimne važnosti životinje za ljudsku kulturu koju ti likovi oslikavaju, oni nešto govore i o zbiljskoj čovjekovoj konstituciji obilježenoj prožetošću animalnih nagona i umne samokontrole. Antropomorfizacije su najpoznatije u okviru bajki i basni, gdje životinje progovaraju, pokazuju ljudsku narav, stanja, misli i osjećaje. Tako životinje poprimaju i neke stalne osobine poput lukavosti kod lisice, brutalnosti i prijetvornosti kod vuka, radišnosti kod mrava, hrabrosti kod lava, oholosti kod žabe itd. Osim što takvim slikama obiluje dječja književnost,

\footnotetext{
${ }^{171}$ N. Visković, Životinja i čovjek, str. 31.

172 Usp. ibid., str. 31-32.

${ }^{173}$ Usp. N. Visković, Kulturna zoologija, str. 13. - Uz Viskovićevo često pozivanje na filozofsku antropologiju, valja u okviru ove teme primijetiti da je ona odbila »bilo da, poput dotadašnje umišljenosti, pripiše inteligenciju samo čovjeku, bilo da, poput nadirućeg biologizma, otkloni ma kakvu bitnu razliku između čovjeka i životinje. Za razliku od vremena ustanovljenja prirodnih znanosti, kada je glavna točka otpora bio teološki potkrijepljen antropocentrizam, oni se sada uglavnom suočavaju s obrnutom opasnošću, opasnošću potpune naturalizacije i zoologizacije čovjeka.«(P. Krstić, Filozofska životinja, str. 167.)

${ }^{174}$ Usp. N. Visković, Kulturna zoologija, str. 50-51.
} 
antropomorfizirane životinje postale su i predmet masovne kulture, ponajprije zahvaljujući Disneyjevim crtanim filmovima. ${ }^{175}$

Nadalje, Visković navodi da životinje ponekad nose i vjersko-moralna značenja, kako je to slučaj kod La Fontainea. Nekim životinjama sasvim se ozbiljno pripisivala religioznost, pa tako, primjerice, Plutarh i Montaigne pišu o vjerskim osjećajima slonova. ${ }^{176} \mathrm{U}$ religiji je antropomorfizacija životinja učestala pojava, što se ne ograničava samo na animizam. Interesantan je po tom pitanju spis Razgovor čovjeka sa životinjama, koji pripada enciklopediji Iskrene braće (Ihvanus-Safa), muslimanske sekte iz 10. st., u kojem životinje u okviru svoje moralne argumentacije stalno ukazuju na svoju pobožnost nasuprot ljudskom kršenju Božjih zakona. ${ }^{177}$

Visković navodi i da se intenzivna antropomorfizacija životinja zbiva i u čovjekovu odnosu prema kućnim ljubimcima, s kojima razgovara, za koje se brine kao za djecu, koje pokapa itd. Upravo se u jeziku antropomorfizacija životinja javlja na brojnim mjestima. Tu se ponajprije radi o tome da ne nazivamo životinje samo po njihovoj vrsti, nego im nadijevamo i individualna imena, naravno, opet sukladno njihovoj bliskosti čovjeku. ${ }^{178}$

Antropomorfizacija životinja nije ograničena samo na ove, uglavnom benigne prakse. U tom je pogledu suđenje životinjama i njihovo kažnjavanje jedan od zanimljivijih primjera. Visković ističe da se tu radi o gruboj antropomorfizaciji, koja potječe od čovjekove prepotentnosti i neznanja, ali ipak postupku koji u značajnom razdoblju historije nije izazivao sumnje, pa se, pored bizarnih srednjovjekovnih i ranonovovjekovnih suđenja životinjama, još u Starom zavjetu nalaze odredbe o kažnjavanju životinja za određenu štetu koju počine. Spomenuta suđenja pripisivala su im kako individualnu, tako i kolektivnu krivnju, prvu uglavnom domaćim, a drugu divljim životinjama. ${ }^{179}$ Radi li se tu samo o potvrdi Nietzscheove teze da suština kazne kroz najveći dio historije ne leži u ideji slobode volje, pravednosti ili

\footnotetext{
175 Usp. ibid., str. 51-52.

${ }^{176}$ Usp. ibid.

177 Vidi: Ihvanus-Safa, Razgovor čovjeka sa životinjama, preveo Enes Karić, V.B.Z., Zagreb 2008.

${ }^{178}$ Usp. N. Visković, Kulturna zoologija, str. 52, 123-124.

${ }^{179}$ Usp. N. Visković, Životinja i čovjek, str. 294-296. - Za mnoštvo primjera kažnjavanja životinja, kao i za problematiziranje tog fenomena, vidi: E. P. Evans, Životinje pred sudom. Vidi i temeljitu studiju o biopolitičkim aspektima ove problematike: Anita Lunić, »Životinja između biopolitike i bioetike: tehnike reguliranja životinjskog tijela i života. Od suđenja životinjama do više-nego-ljudske biopolitike«, u: Josip Guć, Hrvoje Jurić (ur.), Nikola Visković: pravo - politika - bioetika. Zbornik povodom osamdesetog rođendana, Pergamena Filozofski fakultet Sveučilišta u Splitu, Centar za integrativnu bioetiku - Pravni fakultet Sveučilišta u Splitu Znanstveni centar izvrsnosti za integrativnu bioetiku, Zagreb - Split [u pripremi]. Da formalno suđenje životinjama nije stvar daleke prošlosti potvrđuje jednim primjerom Visković: »U New Jerseyju je pet godina trajao spor oko psa koji je ugrizao djevojčicu, da bi nakon dvije presude o njegovu smaknuću guvernerka Christine Whitman pomilovala životinju ukazujući na to da je od žrtve bila izazvana, ali je istovremeno naredila izgon psa iz New Jerseyja.« (N. Visković, Životinja i čovjek, str. 466.)
} 
odgovornosti, nego u bijesu zbog pretrpljene štete? ${ }^{180}$ Možda ona ima težinu što se tiče samog historijskog nastanka kazne, koja se onda kasnijim razvijanjem pojma slobode (i njegovim dovođenjem u vezu s odgovornošću) sintetizira u značenjski bogatiji pojam, ali s obzirom na jaz između čovjeka i životinje po pitanju njihove slobode koji započinje vrlo rano u razvoju zapadne kulture, njeno je puno značenje upitno. Prije će biti slučaj da su ljudi imali potrebu legitimirati svoje iracionalne težnje moralnim i pravnim pojmovima i procedurama, a ona je utoliko brža ukoliko je legitimacija površnija i dovoljna da pruži privid racionalnosti. Visković tako ističe i reakcije na spomenute procese nekih autora 15. i 16. st., kao što su Leonardo Vairo i Pierre Ayrauld, koji jasno uviđaju da životinje ne mogu biti moralno odgovorne. Ono što pokriva barem dio istine $\mathrm{u}$ interpretaciji ovog fenomena jest uvid $\mathrm{u}$ funkciju zastrašivanja gospodara životinja i heretika, kojemu su ovi procesi svakako služili i čime se strahovlada nad životinjama funkcionalno povezala sa strahovladom nad ljudima. ${ }^{181}$ Sudbina životinje tako je često bila isprepletena sa sudbinom čovjeka, iako je razina okrutnosti kod jedne i druge uglavnom bila u disbalansu. Njihova veza možda se još jasnije očituje u suprotnom fenomenu, naime, zoomorfizaciji čovjeka.

Visković tvrdi da je zoomorfizam »naličje antropomorfizma, s bitno istim uzrocima i učincima«, pa je često teško razlučiv od njega. Naime, kod njega se često radi o izvorno antropomorfnom činu, kao što je, primjerice, pridavanje plemenitosti ili hrabrosti lavovima, koji se onda povratno odnosi na pojedinca ili skupinu ljudi, koje opisujemo hrabrima kao lavovima i sl. Zoomorfizam se, kako u čistom, tako i u navedenom posredovanom smislu, posebno očituje u totemizmu, ali i u mnogim simbolima naroda i država. Zanimljive su i kombinacije antropomorfnih bogova i životinja, kao što se, primjerice, Zeus pretvara u bika, a Višnu reinkarnira u ribu, kornjaču, medvjeda i sl. Upravo vjera u reinkarnaciju sačinjava jednu od najtješnjih veza čovjeka i životinje. ${ }^{182}$ Naravno, postoje i mnogi načini na koje se bez takvih predodžbi ljudi pretvaraju u životinje:

\footnotetext{
»Životinjska preoblačenja urođenika, ratnika i sudionika u dionizijskim, luperkalijskim i karnevalskim svečanostima beskrajna je povijesna galerija maski, plesova i gestualnih oponašanja što govori o čežnjama i strahovima pred zoo-silama i o stalnoj potrazi čovjeka za vlastitim animalnim korijenima i za životinjskom tjelesnom i duhovnom snagom. ${ }^{183}$
}

\footnotetext{
${ }^{180}$ Fridih Niče [Friedrich Nietzsche], Genealogija morala. Polemički spis, preveo Božidar Zec, Grafos, Beograd 1990., str. 59.

${ }^{181}$ Usp. N. Visković, Životinja i čovjek, str. 296.

${ }^{182}$ Usp. N. Visković, Kulturna zoologija, str. 55-56. - Za više informacija o reinkarnaciji vidi: N. Visković, Životinja i čovjek, str. 67-71.

${ }^{183}$ N. Visković, Kulturna zoologija, str. 56-57.
} 
Ne radi se ovdje samo o priredbama koje dijelom ili potpuno iskaču iz racionalnosti, nego i o tome da je naš konceptualni pristup samima sebi, kako naglašava Visković, bitno posredovan onim životinjskim. Naravno, to je očito i onda kada se to životinjsko postavlja kao negativ: kao nehumano, okrutno, seksualno neobuzdano, ali i kao čovjekovo »sramotno podrijetlo«. Metamorfoze ljudi u životinje u mitološkoj misli služe kao kazne, ali i u modernoj i suvremenoj misli one imaju svoje specifično značenje, vezano i uz kaznu, poput pretvorbe čovjeka u kukca (Kafka) ili u muhu (Langelaan/Neumann/Cronenberg) kao rezultat znanstvenih zloupotreba. ${ }^{184}$ Obje su ove pretvorbe označile početke važnih prekretnica u zapadnoj misli, prva kao ključno djelo jednoga od preteča egzistencijalizma, druga kao jedan od prvih uvida u pogubnost znanstveno-tehnološkog (i)racionaliteta.

Zanimljiv je još jedan put kojim je znanost čovjeka pretvarala u životinju. Radi se o, navodi Visković, staroj i danas mahom odbačenoj disciplini fiziognomike. Poznato je da je ona pokušavala očitati narav određene osobe s njenog lica i tijela, ali manje je poznato da su važnu ulogu u tom iščitavanju imale sličnosti s određenim životinjama. S druge strane, umjetnici su također prikazivali čovjekove psihičke i moralne osobine tako da su crte i pokrete njihove glave i tijela prilagođavali izgledu određenih životinja. Tako je i moderna karikatura u djelima Grandvillea i Daumiera na sličan način koristila životinjske atribute. ${ }^{185}$

Poživotnjenje čovjeka danas je možda najraširenije u obliku psovke, a sama riječ, ističe Visković, ima isti korijen kao i riječ 'pas'. Povlašteno mjesto u psovanju imaju domaće životinje, uz dodatak majmuna kao čovjeku fizički najbliskije. Izvori toga mogu biti različiti. Istaknimo tek dva: tu može biti riječ o domaćim životinjama kao oličenju ropstva, ali i o čovjekovoj primarnoj upućenosti na njih, tj. bliskosti s njima, na koje stoga prenosi vlastite osobine. Tu je posebice interesantna percepcija određenih životinja kao nositelja nekih svojstava, a koja su se pojavila zahvaljujući domestikaciji. ${ }^{186}$ Svinja je tu paradigmatičan primjer:

\footnotetext{
${ }^{184}$ Usp. ibid., str. 57-58. - Kako navodi Visković, kod uprisutnjenja metamorfoze u mitologiji najčešće je riječ o preobrazbama čovjeka u životinju, ali postoje i nešto rjeđi slučajevi preobražavanja životinje u čovjeka. Metamorfoze se najčešće provode kao kazne, ali ne isključivo. Primjerice, u Ovidijevim Metamorfozama 31 preobrazba ima značenje kazne, 11 značenje pomoći i spašavanja, a 7 značenje žalosti. (Usp. N. Visković, Životinja i čovjek, str. 66-67.)

${ }^{185}$ Usp. N. Visković, Kulturna zoologija, str. 58-59. - Prema Lambrosu i njegovim učenicima: »Zločinac je jednostavno divljak pušten na slobodu u uljuđenoj zajednici koji zanemaruje etičke predodžbe što su ih razvili vjekovi kulture i čini djela koja bi se u očima naših prapovijesnih predaka činila savršeno prikladnima $\mathrm{i}$ hvalevrijednima. (...) Zločinački tip nije ništa doli povratak na primitivni tip rase, a predstavnici ove antropološke škole neumorni su u svojim naporima da otkriju fizičke i moralne karakteristike zajedničke jednom i drugom: dugačke ruke slične čimpanzinim, četiri cirkumvolucije čeonog režnja mozga nalik onima velikih mesoždera, malen kapacitet lubanje nalik onom pećinskog čovjeka, pseći zubi nalik onima antropoidnih majmuna i majmunski nos. Ova se analogija širi na oči, kosu, čak i na unutarnje organe, jetra, srce i želudac te na bolesti koje ih pogađaju.« (E. P. Evans, Životinje pred sudom, str. 158.)

${ }^{186}$ Usp. N. Visković, Kulturna zoologija, str. 59-60.
} 
»Naime, svinja potječe od divljih vrsta koje žive u šumama i vlažnim područjima i koje nemaju ćelije za znojenje. (...) Ali budući da joj ljudi ne mogu ili ne žele omogućiti takvo, njoj neophodno hlađenje, ona se mora valjati, za razliku od njenih rođaka veprova, u bilo kakvoj vlažnoj tvari - pa i u vlastitim izmetima ako nema drugoga. Dakle, čovjek prisiljava svinju da bude 'prljava' čim je izvlači iz njenih biotopa i zatvara u uske, zagrijane, suhe obore... Tko tu zapravo čini 'svinjarije'?«187

\section{II.2.1.2. Mit i religija}

Imamo li u vidu Viskovićev naglasak na supstratu izvjesnog simbola u pogledu važnosti životinje za izgradnju kulture, simbolički jezik mita privilegiran je među ostalima, što se naročito ističe u njegovoj usporedbi s bliskim jezikom umjetnosti. Za razliku od potonjeg, koji je (prema Kantu) sasvim ravnodušan prema postojanju svog objekta, mit bi bez vjerovanja u postojanje svog objekta, tvrdi Cassirer, izgubio osnovu. No taj objekt bitno je različit od objekta suvremene znanosti. Uvijek je emotivno obilježen, onako kako ga nalazimo u elementarnom obliku ljudskog iskustva. Duh koji upotrebljava mit nema analitičan, onaj koji pravi razgraničenja (tako ni između čovjeka i drugih živih bića), nego sintetičan pogled na život. ${ }^{188}$

»Životinje su sadržaj i ujedno među najznačajnijim protagonistima mitova. Postoji u tome i jedna pravilnost: što su mitovi stariji, tj. što su arhaičnije kulture kojima pripadaju, to je u njima važnija i češća uloga životinja kao protagonista. «189

Već mitovi o nastanku svijeta imaju jedan važan životinjski element. Pri tome posebno mjesto zauzima, navodi Visković, najuniverzalniji kozmogonijski mit, naime, onaj o nastanku

svijeta iz jajeta. Životinje su ponekad protagonisti samog stvaranja, a ponekad simboliziraju presudne elemente u nastanku života. Ptica je, tako, čest simbol duše i uskrsnuća, a jedan od najupečatljivijih simbola vječnog rađanja je ptica feniks. Nasuprot tome, životinje igraju ključnu ulogu i kao pronositelji smrti i uzročnici propasti svijeta. U tom kontekstu, osobito je interesantna zmija, kao simbol smrti (pada) u judeo-kršćanskom religijskom učenju, a zaslužna je i za krađu biljke besmrtnosti mezopotamskom junaku Enkidu. Australski urođenici vjeruju da ih je zmija učinila smrtnima, kao što je slučaj kod više afričkih mitova. Prije je pokazano da se neki bogovi pretvaraju u životinjske oblike, ali mnogi od njih su izvorno obilježeni životinjskim atributima, kao što su bikoglava (istočnosredozemni Hator, Baal, Mitra), riborepa

\footnotetext{
${ }^{187}$ Ibid., str. 60.

${ }^{188}$ Usp. E. Cassirer, Ogled o čovjeku, str. 104-106, 111.

${ }^{189}$ N. Visković, Životinja i čovjek, str. 64.
} 
(kineski Nugua, Fuksi), slonoglava (indijski Ganeša) i sl. božanstva. Neka se božanstva pojavljuju u obliku životinja, kao što je slučaj, primjerice, kod Aditi, majke indijskih bogova koja se predstavlja kao krava. Za razliku od orijentalnih, olimpijski su bogovi antropomorfniji, ali obavezno imaju neke od životinjskih pratioca. Slično tome, u indijskoj mitologiji božanstva imaju životinju za prijevoz, a svaka od njih označava bitnu moć određenog božanstva. Naravno, mitološka upotreba životinja ne zastaje na bogovima, nego se javlja i kao kult određenih životinja, demona, duhova, divova, vila i sličnih bića sa životinjskih svojstvima. Različita životinjska ili poluživotinjska nadnaravna bića ljude uče raznim vještinama i podaruju im kulturna dobra. Također su značajne životinje koje prihvaćaju napuštenu djecu koja postaju heroji, poput usvajanja Zala od strane ptice Simorgh, usvajanje Romula i Rema od strane vučice i sl. ${ }^{190}$

Najviše životinjskih motiva, navodi Visković, očigledno sadrže prirodne religije arhaičkih kultura. Promatramo li takve u Africi, uočit ćemo vrlo blisku vezu čovjeka i životinje do te razine da se životinje promatraju kao ljudi preobučeni u životinje. Takvi su stavovi poduprti vjerovanjem pojedinih plemena da potječu od određenih životinja. Zanimljivo je i vjerovanje, osobito prošireno među američkim urođenicima, da pojedinci imaju svoje dvojnike u životinjama ili vanjske duše koje vladaju njihovom sudbinom, uz što se veže i vjerovanje da se ljudi mogu pretvoriti u određene životinje. Određene životinjske vrste nalaze se pod zaštitom duhova, kojima se lovci obraćaju za dopuštenje i oprost za lov. ${ }^{191}$ Poznati su i postupci sjevernoameričkih Indijanaca prema svojim mrtvima, koje su ostavljali životinjama za hranu, slično kao što su postupali afrički Masai, a tome svjedočimo i u zoroastrizmu. ${ }^{192}$

Visković naglašava da životinje imaju i nezaobilaznu ulogu kao medij magijskih vjerskih obreda, kao posrednici spasenja ili propadanja ljudskih vrijednosti, kao povlašteni predmet žrtvenog darivanja nadnaravnim silama, koje, kako se dade vidjeti iz prethodno navedenog, mogu biti kako antropomorfne, tako i zoomorfne. Magijski rituali uključivali su i proricanje iz ponašanja i organa životinja, ali i postupke crne magije. Mnoge su životinje zahvaljujući takvim vjerovanjima postale omražene. Tu se naročito ističe jarac označen kao zlokobnik i pohotnik, ali i kao onaj od kojeg đavao posuđuje rogove i papke, kojemu se podaju

\footnotetext{
${ }^{190}$ Usp. ibid., str. 64-66.

${ }^{191}$ Usp. N. Visković, Kulturna zoologija, str. 65-66. - Visković se ovdje poziva na studije Ernsta Dammanna (Africa. Le religioni naturistiche) i Irene Nicholsona (Meksička i srednjoamerička mitologija). Dodajmo tome i jedan izvještaj o zoomorfizmu kod kojega se teško može pronaći antropomorfističko podrijetlo: »U totemizmu čovjek ne gleda na sebe kao na potomka određene životinjske vrste. (...) U mnogo slučajeva ta se veza osjeća i izražava kao identičnost. (...) Etnolog Karl von den Steinen izvještava kako su pripadnici totemskog klana jednog indijanskog plemena tvrdili da su oni jedno sa životinjama od kojih su potekli; izrijekom su tvrdili da su vodene životinje ili crvene papige.«(E. Cassirer, Ogled o čovjeku, str. 113).

${ }^{192}$ Usp. N. Visković, Kulturna zoologija, str. 66-67.
} 
vještice i sl. Često su bile ozloglašene i crne mačke, svinje, žabe krastače, muhe itd. S druge strane, postojali su i različiti zoo-fetiši, odnosno amuleti kojima su se pripisivala magična svojstva, a danas kao neka vrsta amuleta služe i znakovi zodijaka. ${ }^{193}$ No isto tako nailazimo i na posve ambivalentna tumačenja istih životinja u različitim tradicijama:

»U mitsko-vjerskim pričama i narodnim vjerovanjima zmija je od svih životinja najviše simbolički 'opterećena' i na njoj se ujedno savršeno potvrđuje mudra ambivalentnost temeljnih kulturnih simbola. Kao životinja koja je najbliža zemlji i kojoj je prijeko potrebna sunčeva toplina, ona je istodobno i ktonska sila mračnih nagona i uranska sila obnove života. Zato je zmija motiv najviših bezvrijednosti i najviših vrijednosti, smrti i života, spoj suprotnih psihičkih, etičkih i religijskih motiva, te stoga i simbol prvotnog jedinstva svijeta. U mnogim kulturama ona je među najstarijim božanskim likovima i obično uz svojstvo ljute opasnosti nosi i blagotvorne moći plodnosti zemlje i majke, besmrtnosti, liječenja, čuvara blaga, znanja i predviđanja. Demonsko zlo u njoj prelazi tako u životorodno dobro. «194

Prekid kako s idolatrijom, tako i sa zoomorfnim poimanjem božanstva, stupa na historijsku pozornicu, navodi Visković, s monoteističkom židovskom vjerom. Ipak, nije riječ o potpunom iščeznuću animalnih elemenata, što se ponajprije očituje u prakticiranju obrednih žrtvovanja životinja, s kojima će konačno raskinuti kršćanstvo. Ni ono ne gubi u potpunosti doticaj s animalnim, što se ogleda u povezivanju goluba s Duhom Svetim, janjeta s Isusom, zatim s povezivanjem određenih životinja uz evanđeliste: bika s Lukom, orla s Ivanom, lava s Markom. Nasuprot Starom zavjetu, koji još ističe životinje kao relevantan faktor, primjerice u priči o Noinoj arki, Novi zavjet povećava odmak od životinja, pokazivajući sve veću ravnodušnost prema njima. Odnos prema životinjama u judaizmu, koji će se posredstvom kršćanstva proširiti čitavim Zapadom, analogan je autoritarnom odnosu Boga prema čovjeku. Bog je prema Bibliji ljude učinio gospodarima svih živih bića. Ali ipak, postoje dva bitno drugačija naglaska pri stvaranju i pri čovjekovom padu. Kod prvoga Bog ljude u Edenskom vrtu upućuje čak na vegetarijanstvo, dajući im da uživaju plodove bilja, dok kod drugoga nastaje oštriji pristup, u kojemu životinje imaju strahovati pred čovjekom, a čovjekov »jelovnik« se proširuje i na mesne namirnice. Štoviše, u Edenskom vrtu životinje su bile pošteđene i

\footnotetext{
${ }^{193}$ Usp. ibid., str. 62, 67-70, 76.

${ }^{194}$ Ibid., str. 258-259. - »Dvoznačnost i spoj suprotnosti u značenjima zmije lijepo izražava štap kaducej, simbol medicine, oko kojeg se jedna nasuprot drugoj ovijaju dvije zmije - jedna kao prijetnja otrova i druga kao obećanje lijeka koje otrov sadrži.« (N. Visković, Stablo i čovjek, str. 325.) »Ikonografska kružna figura uroborosa, zmije što grize svoj rep, znači okultistima i alkemičarima kozmički sklad, ciklički spoj suprotnosti, vječno obnavljanje prirode. Spoj negativnog i pozitivnog u zmijskom simbolizmu jest ispravno shvaćanje onoga što je zmija u prirodi: istodobno opasnost i vrijedna karika u lancu života. Ipak, zmija je i u dubljoj mitskoj i u svakodnevnoj svijesti nadasve zlo - manihejski izraz već spomenutih strahova, predodžba praiskonskih sila i vjerskih potreba za demonskim.« (N. Visković, Kulturna zoologija, str. 264-265.)
} 
međusobnog nasilja. Ta rajska harmonija fragmentarno se pojavljuje i nakon Pada u opisima pokoravanja zvijeri pustinjacima i svecima, što je ujedno i oslikavanje budućeg rajskog stanja. ${ }^{195}$ Riječ je o Izaijinom proroštvu, o kojemu Visković kaže:

»A u nekom budućem rajskom vremenu ponovno neće biti divljih zvijeri i zavladat će novi mir (pa i vegetarijanstvo) među stvorenjima na Zemlji: 'krava i medvjedica zajedno će pasti, mladunčad njihova skupa će ležati, lav će jesti slamu kao govedo' (Iz 11,7); 'vuk će prebivati s jagnjetom, ris ležati s kozlićem, tele i lavić zajedno će pasti, a djetešce njih će vodit' (Iz 11,6).«196

Bez pretenzije za ulaženjem u ozbiljnija teološka razmatranja, ovdje nam se čini zanimljivim primijetiti da s Isusom dolazi jedan novi naglasak u poimanju Boga, koji je sve manje osvetoljubljivi bog, a sve više bog ljubavi. Čini se da već u tome postoji osnova da se, slijedeći gore navedenu analogiju, autoritarni odnos čovjeka spram životinja pretvori u odnos ljubavi, kao svojevrsni prijelazni stupanj k ponovnom postizanju rajske harmonije o kojoj govori Izaija. Pa ipak, kaže Visković, i Biblija sadrži ponešto brige za životinje, iako s jasnim antropocentričnim ili teocentričnim značenjem. Bog nije čovjeka postavio u Edenski vrt da tamo bude despot, nego da ga obrađuje i čuva. On, također, u potopu ne ostavlja na životu samo Nou i njegovu obitelj, nego i po par od svake vrste životinja pa potom i s njima sklapa novi savez, kao što to čini i s čovjekom. Nije ni čudo što će kasnije Noina arka postati jedan od ekologističkih i animalističkih simbola. ${ }^{197}$ Ako se tome uputi kritika da se i dalje radi o starozavjetnim motivima, možda je uputno spomenuti detalj Isusova rođenja u štali, koji se tako rađa u istim uvjetima kao životinje. Visković u tu svrhu spominje apokrifni spis koji se pripisuje Pseudo-Mateju, u kojem vol i magarac pružaju priprostu ljubav tek rođenom Kristu, a tome se može pribrojati i jedan koptski rukopis, koji Isusu pripisuje uključenje svih bića u veliku Božju obitelj. Kršćansku je kulturu, međutim, bitno odredio Petrov stav $(2 \mathrm{Pt} 2,12)$ da su životinje po svojoj prirodi određene da budu hvatane i ubijane. Pa ipak, postoje mnoge iznimke od njega. Tu su ponajprije značajni pustinjaci koji druguju i razgovaraju sa životinjama, osobito afektivan odnos prema životinjama sv. Kevina, zaštitnika životinja, a možda je najpoznatiji ekoetički pristup Franje Asiškog. Isto tako, životinje uzvraćaju za dobrostivost tih iznimnih ljudi. Možda je najpoznatiji slučaj sv. Jerolima koji liječi šapu lavu i time stječe njegovo prijateljstvo i zahvalnost, a sličan mit može se pronaći i u antičkim izvorima (Plinije). U kršćanskim legendama ističe se lik jelena, posebice $u$ »čudu križa među jelenjim rogovima« koje se veže

\footnotetext{
${ }^{195}$ Usp. N. Visković, Kulturna zoologija, str. 96-99.

196 Ibid., str. 104.

${ }^{197}$ Usp. ibid., str. 102-103.
} 
uz više svetaca. Čak se i sam Krist javlja u obliku jelena u trenutku obraćenja sv. Eustahija, a čuvena je i legenda u kojoj se budući svetac Hubert odriče ubijanja gonjenog jelena kada se ovome među rogovima ukaže raspelo. ${ }^{198}$

Visković ističe da, iako Kur'an rjeđe od Biblije spominje životinje, islamska kultura posjeduje djelo u cijelosti posvećeno životinjama, štoviše, djelo upravo o razmatranju životinjskih patnji i čovjekovoj krivnji spram njih. Riječ je o već spomenutoj arapskoj enciklopediji iz 10. st. napisanoj od strane tajnog filozofskog saveza Iskrene braće (IhvanusSafa) iz Basre, koja pokušava sakupiti sva područja znanja, pomiriti ih s Kur'anom, ali i približiti istine svih religija jedinstvenoj istini, odnosno Bogu. Pritužba životinja na maltretiranje od strane čovjeka, koja čini sadržaj tog djela, pripada prvim historijskim primjerima etički, ali i ekološki (pritužbe na uništenje staništa) argumentirane obrane neljudskog života. Riječ je upravo o tome da su u sporu životinja s ljudima argumenti prvih sadržajniji i uvjerljiviji, a različite ljudske razloge za podčinjavanje životinja ove lako i vješto odbacuju. ${ }^{199}$

Jedno od pitanja koje se često usko veže uz religiju odnosi se na postojanje duše kod životinja. Visković u razradi tog problema kreće od nekih očitih primjera pripisivanja duše životinjama, od animizma, preko isprepletenosti ljudske i životinjske duše u kontekstu reinkarnacije (pa i metempsihoze kakva postoji kod Pitagore ili Platona), sve do manje jednostavnih pripisivanja duše živim bićima kod Aristotela i Tome Akvinskoga. Za potonje životinja ima dušu, shvaćenu kao životnu moć osjeta i kretanja, ali ne i kao besmrtnu. ${ }^{200}$ Kod Aristotela se, doduše, interpretatori nisu slagali oko besmrtnosti duše. Još je Aleksandar iz Afrodizije tvrdio da je duša kod Aristotela smrtna, da bi kršćanski pristalice Averroesa njegovo tumačenje aktivnog uma držali sukladnim dogmi o besmrtnosti individualne duše. ${ }^{201}$ Međutim, stvari se po tom pitanju ni u samom Svetom pismu ne bi pokazale toliko jasnima kad bi se pozornije pristupilo njegovu tumačenju:

»Biblijska, starozavjetna, hebrejska riječ za dušu, 'nephesh', doslovce 'dah' ili 'biće koje diše' (u grčkim prijevodima: 'psyche'), označava život, životni dah, svojstven kako ljudskim, tako i ne-ljudskim bićima. Brojni primjeri iz Biblije potvrđuju kako je 'nephesh' i životinjska duša, i životinjska i ljudska duša, i duša pojedinca, osobe, i animalni nagon, i ljudska umna sposobnost, kao i osjećajnost i emocionalnost. Širok

\footnotetext{
${ }^{198}$ Usp. ibid., str. 338-342. - S obzirom na potonju legendu, Visković kaže: »Graniči s crnim humorom to što se mjesečnik francuskih lovaca zove Saint Hubert.« (Ibid., str. 342).

${ }^{199}$ Usp. ibid., str. 110-111, 113.

${ }^{200}$ Usp. ibid., str. 344-345.

${ }^{201}$ Usp. Branko Bošnjak, »Aristotelova psihologija i filozofija života«, u: Aristotel, O duši / Nagovor na filozofiju, preveo Darko Novaković (redigirao Branko Bošnjak), Naprijed, Zagreb 1996., str. ix-xlii, ovdje str. xxiv.
} 
spektar značenja, ali jedno shvaćanje u njihovoj podlozi. U svakom slučaju, ovo shvaćanje duše - koje je kasnije zamućeno različitim interpretacijama i tek je kao takvo imalo svoju povijest utjecaja podrazumijeva i tjelesno duševno jedinstvo i jedinstvo živoga/oduševljenoga bez obzira na različitost načina bivanja kod različitih živih bića. $\ll^{202}$

Prorok u tom duhu kaže:

»Jer zaista, kob ljudi i zvijeri jedna je te ista. Kako ginu oni, tako ginu i one; i dišu jednakim dahom, i čovjek ničim ne nadmašuje zvijer, jer sve je ispraznost. I jedni i drugi odlaze na isto mjesto; svi su postali od praha i u prah se vraćaju. Tko zna da li dah ljudski uzlazi gore, a dah zvijeri silazi dolje k zemlji?« (Prop 3, 19-21) $)^{203}$

Pored toga, kako primjećuje Élisabeth de Fontenay, judaizam za razliku od kršćanske novozavjetne tradicije zajedno s propisima koji se odnose na žrtvovanje životinja sadrži i one koji se tiču njihove zaštite. Tako je čak dopušteno kršiti pravila sabata u slučaju da životinji zatreba pomoć. Upravo će ove propise neselektivno odbaciti sveti Pavao, kao ključna figura u formiranju kršćanske teologije. ${ }^{204}$ Jedan od razloga za postupno smanjenje brige o životinjama u »velikim etičkim religijama«, nasuprot na početku odsječka spomenute mitske svijesti arhaičnog čovjeka, svakako možemo tražiti u njihovu racionalnom, a ne više emotivnom prilaženju prirodi, pa se ono božansko u njoj ne ogleda više u »obilju njezina života, nego u jednostavnosti njezina reda«. ${ }^{205}$ Tako i ne treba čuditi što je usprkos nadmoći etičke argumentacije životinja naspram ljudi u spomenutom sporu na kraju presuđeno u korist ljudi: »Sastavljači Ihvanu-s-safa koristili su spor za izlaganje svojih znanja i uvjerenja o ljudskoj zajednici i o prirodi, ali kao da nisu znali ili se nisu usudili dati etička rješenja koja bi se temeljila na iznijetim sudskim dokazima«. ${ }^{206}$

\section{II.2.1.3. Umjetnost}

Prve materijalne tvorevine s umjetničkim obilježjima, navodi Visković, nalazimo kod Kromanjonca, koji se umjetnički izražava urezivanjem, modeliranjem, crtanjem i oslikavanjem, u obliku piktograma, ideograma, čak i psihograma. Zasigurno je tadašnji čovjek umjetnički

\footnotetext{
${ }^{202}$ H. Jurić, Etika odgovornosti Hansa Jonasa, str. 293.

${ }^{203}$ Dio ovog izvatka iz Biblije citira i Visković u: N. Visković, Kulturna zoologija, str. 338.

${ }^{204}$ Usp. Boris Sirilnik [Boris Cyrulnik], Elizabet de Fontene [Élisabeth de Fontenay], Piter Singer [Peter Singer], I životinje imaju prava. Intervjui koje je vodila Karin Lu Matinjon u saradnji s Dejvidom Rozaneom, preveo Dušan Janić (redigirala Jasna Šamić), Akademska knjiga, Novi Sad 2018., str. 134.

${ }^{205}$ Usp. E. Cassirer, Ogled o čovjeku, str. 134.

${ }^{206}$ Usp. N. Visković, Kulturna zoologija, str. 116.
} 
obrađivao i neke lakše obradive materijale, poput drva i kože, ali do takvih ostataka nije moguće doći. Često prvu pomisao na prahistorijsku umjetnost predstavlja oslikavanje zidova pećina, od kojih su najpoznatije Lascaux u današnjoj južnoj Francuskoj i Altamira u današnjoj sjevernoj Španjolskoj. Ono što obilježava te prve poznate tragove ljudske umjetnosti prevlast je životinjskih motiva. Naime, prema Andréu Lerois-Gourhanu, u dotad istraženoj paleolitskoj predmetnoj i pećinskoj umjetnosti čak 78,5\% slučajeva sačinjavaju životinje. Ne samo da se životinje pojavljuju u toj mjeri, nego se one prikazuju krupnijima, dovršenijima, izražajnijima od čovjeka, ali i u središnjem položaju. Životinje tadašnjem čovjeku zaokupljaju pažnju kao važan izvor prehrane i zaštite od hladnoće, a vjerojatno je i da su ga fascinirale kao uzori moći, plodnosti, ljepote i savršenstva, pa kao takve postaju predmet kulta i umjetnosti. Sama motivacija tih oslikavanja ostaje upitna, od čisto estetske (Bataille), preko magijskog i mimetičkog pridobivanja životinja u svrhu lova (Breuil), ali čini se da tu postoje problemi kako kompleksnosti tih radnji, što baca sumnju na oslikavanje kao isključivo estetsku »razonodu«, tako i nesrazmjera između broja određenih životinja na zidovima i broja njihovih nađenih kostiju. Pećinska umjetnost mogla je služiti i inicijaciji u spolni život, tj. status odraslosti (Freeman). Kako ovdje nije mjesto za razradu ovih problema, tek ćemo još spomenuti poznatu teoriju o oslikanim pećinama kao svetištima (Lerois-Gourhan). ${ }^{207}$

Posebno privilegirana životinja u umjetnosti je ptica. Kako navodi Visković, nijedno živo biće ne očarava koliko ona, u svojoj nebeskoj neobuzdanosti (a i samim čudom leta), svojom blagošću, krhkom ljepotom, ljubavnim igrama, brigom za mlade i sl. Nije ni čudo da ih, stoga, osobito vole maštoviti i senzibilni ljudi: djeca, starci, svetci i umjetnici. Za potonje, ona je osobito inspirativna zahvaljujući svojem glasanju, koje se čovjeku javlja kao predivna muzika. ${ }^{208}$

»... Vivaldi citira češljugara, Beethoven u 'Pastoralnoj simfoniji' slavuja, Puccini crvendaća u operi 'Butterfly'. Prave ornito-skladbe dugujemo tek Olivieru Messiaenu, koji se desetljećima učio prepoznavanju ptičjih glasova, da bi u klavirskom 'Katalogu ptica', orkestarskom 'Vitraj i ptice' i operi 'Franjo Asiški' dao transkripciju preko 300 vrsta pijeva.«209

Generalno uzevši:

\footnotetext{
${ }^{207}$ Usp. N. Visković, Životinja i čovjek, str. 40-42. - Za Lerois-Gourhanovo istraživanje na koje se Visković poziva vidi: André Lerois-Gourhan, Religije prethistorije. Paleolitik, prevela Melita Wolf, Naprijed, Zagreb 1968., str. 91. U daljnjem tekstu autor izlaže detalje studije.

${ }^{208}$ Usp. N. Visković, Životinja i čovjek, str. 234.

${ }^{209}$ Ibid., str. 234.
} 
»Sve do srednjega vijeka umjetnost Zapada bila je izrazito simbolizirajuća, naročito u njezinim religijskim i političkim ulogama, i u njoj su animalni motivi bili osobito česti, ali i tada su životinje bile sastojci realističkih kompozicija i prikaza ljepote svakodnevlja - npr. lovnih i poljodjelskih radova kod majstora Buvine i Radovana, ili pak ornamentalna sredstva - kao u ukrašavanju rukopisa. U renesansnoj i modernoj umjetnosti one su sve važniji dio pejzaža i domaćih ambijenata, pa čak i samostalna tema umjetničkih djela - sjetimo se djela Brueghela, Dürera, Pisanella, Carpaccija, animalista 19. i 20. st., te nebrojenih zooprotagonista u književnosti i filmu. Kod nekih umjetnika zoomotivi su jasno emotivno ili etički 'angažirani', npr. kod pisaca Münthea i Garyja, slikara Marcksa i režisera Flahertyja. «210

Tako u filmu, piše Visković, nalazimo sve načine doživljavanja životinja, od ravnodušnosti, ekonomskog »obzira«, afektivnosti, fantaziranja, pa do znanstvenog, etičkog i ekološkog. One su prvenstveno doživljavane kao puki objekti ili u najboljem slučaju nosioci sporednih uloga. No ponekad igraju ulogu snažnih simbola sudbinskih sila i psihosukoba, ali i romantičnih težnji za povratkom prirodi. Naravno, nailazimo i na pojavljivanje životinja u filmu kao protagonista, pri čemu one nose poprilično antropomorfne osobine, najčešće pozitivne ili negativne moralne karaktere. ${ }^{211}$ Kinematografija se tako najčešće »koristila životinjama na upadljivo antropocentričan način - kao sredstvima za kulise i odvijanje ljudskih radnji, ili kao lutkama što osjećaju i čine tek ono što osjeća i čini čovjek. Same po sebi, kakve jesu u vlastitom svijetu $i$ s 'problemima' toga svijeta, one sve donedavno kinematografiji nisu bile zanimljive. ${ }^{212}$

Temeljni poticaj za uzimanje potonjeg u obzir svakako je ekološka kriza, pri čemu se u filmu znanost i etika susreću putem medija umjetnosti i to prvenstveno radi sudbine samih životinja. ${ }^{213}$ Moralni senzibilitet spram njih u ovom je pogledu rezultirao i razmatranjem mogućnosti životinjina bivanja subjektom umjetnosti. Ovdje se ne možemo dublje upuštati u tu raspravu, no pokušat ćemo problematiku oslikati tek jednom crticom iz domaće animalističke literature. Kako navodi Suzana Marjanić, životinju kao subjekta umjetničkog djela implicitno karakterizira Vlasta Delimar. Komentirajući svoj performans Šetnja Lady Godiva, Delimar govori o konju Petku, na kojemu je jahala, kao o konju »profesionalcu«, što će reći da ga se treba karakterizirati kao glumca u toj sceni. No, slijedom određenja životinje u avangardnoj i postavangardnoj umjetnosti od strane Miška Šuvakovića kao objekta, subjekta i simbola, Marjanić, što dijelom primjećuje i Vlado Martek, drži da se Petko tu nalazi još i u ulozi objekta, s obzirom na to da se umjetnica njime služi, te univerzalnog simbola historijskog arhetipskog

\footnotetext{
${ }^{210}$ N. Visković, »Šest načina odnosa prema životinji«, str. 12.

${ }^{211}$ Usp. N. Visković, Kulturna zoologija, str. 302-306.

212 Ibid., str. 311.

${ }^{213}$ Usp. ibid., str. 312.
} 
značenja bijelog konja, tj. žive skulpture konja i gole jahačice kao inverzije muških spomenika. S druge strane, ona ukazuje i na problematičnost određenja redatelja Romea Castelluccija o vlastitom kazalištu kao događaju prirode (zahvaljujući povratku životinja na scenu) od strane redatelja Romea Castelluccija. Naime, »zooetička niša ne može opravdati navodni 'prirodni' povratak scenske životinje« s obzirom na to da se životinja na sceni ne pojavljuje samovoljno. ${ }^{214}$ Premda je u potonjem naglasak stavljen na moralnu problematičnost, čini se da sa sumnjom u prirodnost životinjine prisutnosti u umjetničkom činu dolazi i sumnja u njezino bivanje subjektom u njemu. Marjanić ipak ističe da se životinja može pojavljivati kao subjekt na sceni, za što posebno ističe primjer psa Capa iz predstave Timbuktu redatelja Boruta Šeparovića u okviru projekta Montažstroja. ${ }^{215}$ No čak i negativan odgovor na pitanje o životinjinom umjetničkom subjektivitetu ne bi značio da ne možemo govoriti o više ili manje antropocentričnoj umjetnosti:

»Kazalište je ipak medij gdje je ne samo najteže dovesti životinje na scenu, nego i najviše antropocentrična umjetnost. Ali ima i od toga izuzetaka. Peter Hall je 1984. postavio u Londonu Orwellovu Životinjsku farmu s glumcima travestiranim u životinje. Oliver Perrier je 1991. predstavio svoj 'théatre avec bestiaux' u kojemu seljaci 'postaju glumci svojih vlastitih historija sa svojom kulturom, sa svojim životinjama: svinjama i teglećim konjima' (Liberation, 27. srpnja 1991.). Patrice Chérauxa zahtijeva da se Hamlet u papinskom dvoru Avignona snabdije pravim konjem. Jacques Livchine postavlja u Théatre de l'Unité u Parizu happening gdje psi 'igraju' za auditorij sastavljen od pasa u pratnji njihovih gospodara (Autrement 56/1984, str. 198-200). «116

Životinje su u umjetnosti svakako najzastupljenije u basnama, a osobito su interesantne političke poruke koje one u njima nose. Već je u tom pogledu, navodi Visković, znakovito što te priče o međuljudskim odnosima moći nastaju u vremenima strahovlada, a da se one najčešće mogu tumačiti političkim prilikama tvrdi i Carl Schmitt. Basnama ovdje treba pridodati i eksplicitno politički nastrojenu »životinjsku epiku«, za što najpoznatiji primjer predstavlja Batrohomiomahia (Boj žaba i miševa), vjerojatno parodija Homerove Ilijade, u vezi čega Visković postavlja pitanje radi li se o prvom historijskom antiratnom tekstu. ${ }^{217}$

\section{II.2.1.4. Politika}

\footnotetext{
${ }^{214}$ Usp. Suzana Marjanić, Topoi umjetnosti performansa. Lokalna vizura, Durieux - Hrvatska sekcija AICA, Zagreb 2017., str. 257-258, 263-264.

${ }^{215}$ Usp. ibid., str. 256; Suzana Marjanić, »Zooscena i kao etička pomutnja: primjeri s hrvatske performerske i kazališne scene«, Kroatologija 1 (2010) 1, str. 169-182, ovdje str. 170-174.

${ }^{216}$ N. Visković, Kulturna zoologija, str. 304.

${ }^{217}$ Usp. ibid., str. 148-150.
} 
Temu upotrebe životinje unutar okvira političke teorije, akcije i ideologije, osobito zanemarenu u okviru propitivanja međuodnosa i međuprožimanja čovjeka i životinje, Visković započinje Aristotelovim određenjem čovjeka kao političke životinje, jednim od ključnih mjesta zapadne političke misli. Zanimljivo je kako to rodno određenje čovjeka kao životinje, sa svojim specifičnim, vrsnim razlikama (ponekad izraženima upravo u njegovim nedostatnostima, kao što je to slučaj kod Gehlena), poprima kod Voltairea, u zapadnoj misli neočekivan, zaključak da je u politici čovjeku zacrtan zadatak da se izjednači sa životinjama u njihovoj obdarenosti (od strane prirode) $\mathrm{u}$ hrani, odjeći i pokrovu. ${ }^{218}$

Pored Aristotelove Politike, životinjski element po pitanju političke vladavine zadobiva značajno mjesto u okviru još jednog kapitalnog djela zapadne misli - Platonove Države. Visković ističe spor Sokrata i Trazimaha po pitanju značenja usporedbe vladara s pastirom u odnosu na njihove podanike (stado), u kojem se kod prvoga ističu dobrohotniji zaključci o tom odnosu. Ostala Platonova djela također koriste takve manje ili više metaforičke elemente. Tako u Državniku govori o istinskom državničkom umijeću koje, za razliku od tiranije, skrbi za »stado dvonožaca, koji se rado pokoravaju«. Biblija također sadrži poznate slike pastira i stada kao gospodara (zemaljskog i nebeskog) i podanika. Domestikacija životinja tako se preslikava na domestikaciju ljudi, pri čemu svoju ulogu igra i narativ tobožnje voljnosti životinja da stupe u odnos podaništva. ${ }^{219}$

„Svijet politike, naime, ne ostaje na tome da o ljudima misli i govori kao o životinjama: u njemu se također zbiljski postupa s ljudima kao s marvom, sa psima čuvarima, s parazitima koje treba istrijebiti itd., a osim toga i neke stvarne životinje stoje u posebnim i značajnim odnosima s moćnicima i s podvlaštenima. $\ll^{220}$

Odnosi životinja u prirodi nerijetko se prepoznaju u samoj politici, pa su u tim slučajevima metafore sve manje metaforične, barem u onom smislu u kojem sagledavamo te odnose:

»Riječ je zapravo o teorijskim izrazima drevnog iskustva, već iskazanog u Ezopovoj basni o vuku i janjetu i u izreci 'veća riba jede manju ribu', da i među ljudima, ne bitno drukčije nego u animalnom svijetu, na kraju krajeva vlada zakon jačega. Nije slučajno da moćnici oduvijek sebe zamišljaju i predstavljaju kao orlove, lavove okrunjene grivama, tigrove, vukove i lisice - sve redom predatori, mesožderi, 'plemenite',

\footnotetext{
${ }^{218}$ Usp. ibid., str. 132-133.

${ }^{219}$ Usp. ibid., str. 134, 184

${ }^{220}$ Ibid., str. 132.
} 
'mudre' ili naprosto agresivne i grabežljive zvijeri koje vladaju nad masom zastrašenih, glupih i pokornih podanika goveda, ovaca, pasa i magaraca, te nad prljavim i štetočinskim pukom svinja, štakora, zmija, crva, parazita itd. $\ll^{221}$

Vulgarni politički jezik nerijetko je pronalazio svoje pristojno opravdanje $\mathrm{u}$ znanstvenim teorijama. Kako ističe Visković, biološke i etološke spoznaje prenosile su se, osobito u 20. st., na znanosti o ljudskom društvu, a tako i na politologiju. Teza koja se u tom pogledu ponekad isticala, a koja glasi da je moć temeljni element u odnosima među životinjama, u oblicima agresivnosti, predacije, hijerarhije i teritorijalnosti, dobila je svoju primjenu u svijetu kulture, ekonomije i politike. Drugi su autori primjećivali drugačije obrasce životinjskog ponašanja, pa je tako Petr Kropotkin prirodne osnove morala i potrebe za izgradnjom novih, anarhističkih političkih zajednica nalazio u nagonima društvenosti i suradnje. ${ }^{222}$

Osim u svrhu opravdanja (nekad i kritike) postojećih političkih odnosa, zoomorfizacija se, naglašava Visković, često usmjeravala protiv političkog neprijatelja, koji se nazivao onim životinjama za koje se držalo da su prljave, niske, zle i sl. Isto tako, ono služi i za huškanje masa, što je naročitu surovost dosegnulo u dugotrajnom europskom prakticiranju antisemitizma, koje je svoj vrhunac doživjelo u nacističkom i sličnim režimima. ${ }^{223}$ No i u znatno blažem obliku, životinje često postaju sredstvo ponižavanja u politici. Tako Visković, komentirajući političku klimu u prvom sazivu Hrvatskog sabora, navodi:

\begin{abstract}
»Na prvi pogled, mogli bismo se pohvaliti da su životinje u našoj politici jako prisutne. Kad ne bi bilo te odurne i znakovite činjenice da se one i u Saboru i općenito u našoj politici spominju samo u pogrdnom i prezirnom smislu. No, i to je precizan pokazatelj kvalitete odnosa naših političara, i ne samo političara, prema prirodi uopće. To pokazuje, uz mnoge druge stvari, da su naši političari odnedavno prestali biti čisti seljaci, kod kojih je ipak bilo stanovitog poštovanja životinja, ali da još nisu postali građani, koji su ravnodušni na sve životinje osim pasa i mačaka, pa stoga oni životinje spominju samo s prezirom i stidom izrođenih i frustriranih seljaka. $\ll^{224}$
\end{abstract}

Tako ova, gotovo kovačićevska primjedba, o srdačnijem, ali i dalje okrutnom selu, kao i o bezdušnom gradu, o gradsko-seoskim »dvospolcima«, otkriva puno više od pogrdnog instrumentaliziranja životinja u političkom jeziku. U hrvatskom slučaju, kulminaciju tih

\footnotetext{
${ }^{221}$ Ibid., str. 136-137. - »Daljnja analiza simbolike moći, od Ezopa do Krilova, od Romana o Liscu do novijeg narodnog folklora, od Platona do Machiavellija, pokazuje da najviše i najlegitimnije oblike vlasti predstavljaju orao i lav, da problematične ali nužne vidove politike oličava lisica, a da legitimnu ili tiransku vlast izražava vuk.« (Ibid., str. 137).

${ }^{222}$ Ibid., str. 142-143.

${ }^{223}$ Usp. ibid., str. 146-147.

${ }^{224}$ N. Visković, Sumorne godine, str. 94.
} 
životinjskih političkih zloporaba predstavlja jedna izjava tadašnjeg predsjednika Tuđmana, koja se istovremeno (što prema Viskoviću vjerojatno ne bi bilo slučajno) javlja kao anti-demokratski i autoritativni stav par excellence. To je upravo

»vrhunac današnje hrvatske političke filozofije, majstorska sinteza životinjskih stanja vladajućih i oporbenjaka u jednom malom narodu na povijesnom raskršću. Evo riječi tog istinskog klasika našeg nacionalnog duha: 'Što znači to da u Zagrebu oporba ima 60\% glasova? To je kao da vam jedan seljak kaže da ima u svom dvoru 60 komada živine. Da li je to praščad ili telad? Da li su to kokoši ili guske? Gdje će svaki razborit seljak i čovjek znati da nasuprot takvom jatu jedan par rasnih konja, ili rasnih krava, vrijedi više negoli čitavo to jato.' Pazite na preciznost i slojevitost te vrhunske sinteze naše političke zbilje! Tu su teorijski iskazane sve one empirijske kokoši i guske, sve one svinje, s isprikom svinjama, i uz to još nedorasla stoka kao telad, dakle sav onaj puk (bože sačuvaj narod!) koji je posljednjih godina imao tako presudno negativno mjesto u Saboru i na usporednim bojištima. Kao zora je bistro da naš klasik nije kompilator, da je stvaralaštvo njegove sinteze dvostruko. Prije svega, on prvi otkriva sav taj živinarski puk u samoj hrvatskoj metropoli - u Zagrebu. Pri tome su koze i psi tek prividno izostali iz sinteze, i to zato da se ne bi, asocijacijom na Šimine [Đodan] i Vicine [Vukojević] filozofske priloge, koji su dakako dio te velike sinteze hrvatske politike, pozornost TV slušateljstva skrenula od povijesnog pitanja zagrebačke skupštine živina na slična ali vanpovijesna pitanja istarsko-riječkih skupština rogatih i splitske skupštine dalmatinera. I zatim, naš klasik prvi otkriva da se nasuprot svekolikom tom živinskom puku, zastupljenom od 60 komada živine, nalazi, za sreću Hrvatske na povijesnom raskršću, jedna elita rasnih konja i rasnih krava koja smije i može i štoviše mora, jer vrijedi neizmjerno više od čitavog onog mješovitog jata, upravljati kao rasna manjina ne samo provincijskim istarsko-riječkim i dalmatinskim pukom nego i nadasve pukom naše nacionalne metropole. Krajnji je dokaz za to da tako nešto zna svaki 'razboriti' seljak, dakako s izuzetkom pokojnog Pankretića i ostatka pravih seljaka, pa onda čak i svaki 'razboriti' neseljak - a to su, vidjeli smo, oni koji nisu više ni pravi seljaci niti dozreli građani. I ne treba dalje tumačiti, što bi zapravo bilo drsko, taj krunski moment moderne hrvatske političko-animalističke filozofije. On hegelijanski konačno iskazuje uzvišenost ovog povijesnog trenutka i rasnih bića koja ga vode. $\ll^{225}$

Kako pokazuje Visković, fizičke životinje, osim što su važna materijalna sredstva vladajućih, također igraju ključnu ulogu u političkoj simbolici. Statusu društvenog stada podređenih ljudi odgovara posjedovanje »neplemenitih« domaćih životinja, dok se gospodarima obično pridodaju »plemenite« životinje poput psa i konja, a uz potonjeg se naročito vežu simbolička značenja. Zanimljiv je i slučaj praznovjerja o boravku šestorice gavrana u londonskom Toweru kao garanciji čvrstoće monarhije, kojega se Englezi nakon devetsto godina još uvijek drže. Vladare, moćnike i različite političke tvorevine obilježava

${ }^{225}$ Ibid., str. 99-100. 
mnoštvo simboličkih životinja. Još i prije zastava i grbova životinje čine sadržaj identitetskih simbola pojedinaca, plemena, klanova i raznih drugih skupina. Vrijedilo bi spomenuti i mnoštvo životinjskih simbola još na najstarijim vladarskim pečatima, kao i na metalnom i papirnatom novcu. Međutim, životinje su osobito prisutne na grbovima, gdje su pored geometrijskih likova i nebeskih tijela najzastupljenije. Radi se najčešće o stiliziranim životinjama, koje gube mnoga prirodna obilježja, a nerijetko je riječ o fantastičnim životinjama. Osobito su privilegirani lav i orao, koji nose vrijednosti patrijarhalnih kultura. U tom smislu je zanimljivo i to što mačaka, svojevrsnih predstavnica ženstva, nema u grbovima. Simboliziranje izostanka njihova podaništva remetilo bi gospodsko-podaničke odnose moći koje grbovi oslikavaju. Orao i lav spajaju se u fantastičnog grifona, spoja zemaljske i nebeske moći, ali i razuzdanosti i umjerenosti. To nije slučajno, jer se grifoni često nalaze na grbovima pripadnika visokog plemstva, čija je razuzdana samovolja donekle ograničena vlašću i vjernošću caru ili kralju. $^{226}$

\section{II.2.1.5. Jezik}

Prema Viskoviću, intuicija da životinje govore vodila je ljudsku želju da razgovara sa životinjama, što onda čini sadržaj mnoštva legendi. Često se u narodnim pričama radi o povlastici razumijevanja životinjskog jezika koju udjeljuju nadnaravne sile. Sposobnost razumijevanja životinjskog jezika čini ključni element nekih društvenih uloga, kao što su to one vračeva i šamana. Naravno, fikcija obiluje životinjama koje razgovaraju, naročito u bajkama i basnama. Razgovor sa životinjama danas se najviše zadržao u praksi tepanja i govorenja kućnim ljubimcima. ${ }^{227}$

Čovjek, nastavlja Visković, imenuje širok spektar životinja, naročito one koje su mu bliže i korisnije. Ta očekivana tendencija još je očitija po pitanju imenovanja životinjskih dijelova, mladunčadi, kretanja, glasanja itd. Nerijetko je i onomatopejsko nazivlje pojedinih životinja. Različito nazivlje istih procesa kod čovjeka i životinje (npr. umrijeti/preminuti nasuprot uginuti/krepati - pri čemu je pčela jedina iznimka ${ }^{228}$ ) ponekad je i prije našeg vremena nailazilo na prosvjede nekih mislilaca, primjerice Schopenhauera. ${ }^{229}$

\footnotetext{
${ }^{226}$ Usp. N. Visković, Kulturna zoologija, str. 145-146, 156-157, 160, 162, 200.

${ }^{227}$ Usp. ibid., str. 119-120.

${ }^{228}$ Pčeli se, štoviše, ponekad pridaje i atribut besmrtnosti. (Usp. P. Krstić, Filozofska životinja, str. 92.) Za još neke primjere visokog simboličkog pozicioniranja pčele vidi: ibid., str. 91-94.

${ }^{229}$ Usp. N. Visković, Kulturna zoologija, str. 121-122.
} 
No, s druge strane, kao što je slučaj kod antropomorfizacije, jezik predstavlja povlašteno mjesto zoomorfizacije. Postoje, kako ističe Visković, mnogi primjeri jezične zoomorfizacije ljudskih ponašanja, čovjeku značajnih pojava, ali i njega samoga. Posredstvom asocijacija na životinje osobe se nazivaju različitim zooantroponimima. Donekle je prijeporna motivacija takvog nazivlja. Ona može biti rezultat direktnih asocijacija kakve postoje u fiziognomici, rezultat različitih zanimanja koje su preci obavljali, a mogu potjecati i od drevnih totemističkih odnosa. Zoonimi su rašireni i u nazivlju igara, plesova, vremenskih razdoblja, biljaka (kod kojih postoji i obrnut proces), nebeskih tijela, naselja itd. Životinjama inspirirano nazivlje ljudskih karaktera i ponašanja osobito je prošireno, pri čemu poseban oblik zadobiva iskazivanje psihičkih, običajnih i moralnih situacija, dok se takvo kolektivno iskustvo o ljudskim postupcima i naravi očituje u narodnim poslovicama. ${ }^{230}$ Jezik erotike također je preplavljen životinjskim figurama, što uključuje ljubavni govor, epitete, nazivlje spolnih organa i snošajnih položaja itd. ${ }^{231}$

Prema Viskoviću, jezik je prožet životinjstvom, ali tu se ne radi samo o ljudskom, nego i o životinjskom jeziku. Dakako, svjestan jačine te teze, Visković je donekle ublažava tvrdeći da se o jeziku kod životinja može govoriti »u stanovitom smislu«. Riječ je ponajprije o činjenici da postoji raznolika moć znakovnog komuniciranja kod mnogih životinjskih vrsta - izmjene informacija o spolnom, prehrambenom, obrambenom i sličnim oblicima ponašanja. ${ }^{232}$

\section{II.2.1.6. Imaju li životinje kulturu?}

Ako životinje imaju jezik, onda se postavlja pitanje imaju li i kulturu, uz koju se on blisko veže? Ovo se pitanje nastavlja na započetu raspravu o kvalitativnim odnosno kvantitativnim razlikama između čovjeka i životinja. Ovdje ujedno nadopunjujemo crtice o Viskovićevu određenju kulture, a obogaćujemo i raspravu o kulturi samoj, koja ide u smjeru ukazivanja na višeznačnost koja pripada tom terminu.

Poveznica ove problematike s jezičnom jasno se pokazuje na mjestu gdje Visković iznosi stav da »ljudski jezik nije samo učenjem stečena sposobnost, jer je i genetski određen, te da s druge strane komuniciranje životinja nije samo nagonska sposobnost - jer se i u njemu

\footnotetext{
${ }^{230}$ Usp. ibid., str. $124-127$.

${ }^{231}$ Usp. Nikola Visković, »Jezik i životinja«, u: Suzana Marjanić, Antonija Zaradija Kiš (ur.), Kulturni bestijarij, Hrvatska sveučilišna naklada - Institut za etnologiju i folkloristiku, Zagreb 2007., str. 355-368, ovdje str. 365366.

${ }^{232}$ Usp. N. Visković, Kulturna zoologija, str. 117.
} 
ponešto stječe učenjem i prenosi kao 'kultura' «. ${ }^{233}$ Ovdje se pojam kulture promatra u vidu samog načina prenošenja, što smo pri pitanju samog definiranja kulture istaknuli kao jedan od načina njezinog definiranja, premda ne onakvoga kakvog u ovom radu slijedimo. Visković upravo na taj način postavlja stvari kada govori da kulturna zoologija ima obuhvatiti i zoologiju kulture, dakle spoznaju bioloških osnova i obrazaca naučenog ponašanja, koja će onda uključivati i razmatranje inteligencije i jezika u tom svjetlu, a takve spoznaje već donose antropologija i etologija. Naime, ako prihvatimo određenje kulture kao »skup ponašanja koja su društveno naučena i prenošena«, tada postoji osnova za tvrdnju da životinje ne predstavljaju samo važan element u izgradnji ljudske kulture, nego da »u stanovitoj mjeri one same imaju svoju kulturu«. Visković drži da se u ovakvim zaključcima radi vjerojatno o najdubljim, ali ujedno i, usprkos pridavanju velike važnosti etologiji, najspornijim osnovama kulturne zoologije. $^{234}$

Dakle, uzmemo li kulturu kao bitno određenu procesom učenja i prijenosa određenih obrazaca, čini se da bismo postojanje kulture trebali pripisati i nekim ne-ljudskim živim bićima. Visković navodi više primjera kojima bi se moglo doći do takvog zaključka:

\footnotetext{
»Primjerice, ptići moraju od roditelja učiti svojevrsni pjev svoje vrste i 'dijalekt' svoje uže skupine; neki majmuni služe se različitim i naučenim krikovima za uzbunu protiv predatora sisavaca, ptica grabljivica i zmija, te glasovnim i gestikulacijskim porukama za druge ciljeve; svojim 'plesom' kraj košnice pčele pokazuju jedne drugima, strukturom leta, pravac i udaljenost cvijeća za pašu - ali ne sve nagonski i jednako, nego djelomično na 'konvencionalne' načine, koji se razlikuju među rasama i geografskim populacijama i koji se u svakoj zajednici uče. $\ll^{235}$
}

Ovakvi bi fenomeni bez sumnje potpadali pod pojam kulture ako bi ga shvatili onako kako ga poima Frans de Waal: »Kultura naprosto znači da su znanje i navike stečene od drugih - često, ali ne uvijek, od starije generacije - što objašnjava zašto se dvije grupe iste vrste mogu ponašati drugačije. ${ }^{236}$ Naravno, sama definicija prvi je kamen spoticanja. Da se ovdje ne radi o jednostavnom problemu, očituje se i u Viskovićevu stavljanju pojma kulture pod navodnike u jednom od ovdje navedenih citata, kao i o naglašavanju problematičnosti ovih pitanja, kondicionalnim zaključcima i sl.

\footnotetext{
${ }^{233}$ Ibid., str. 118.

${ }^{234}$ Usp. ibid., str. 21.

235 Ibid., str. 118.

${ }^{236}$ Frans de Waal, The Ape and the Sushi Master. Cultural Reflections of a Primatologist, Basic Books, New York 2001., str. 6 .
} 
Međutim, kada Visković ovdje priča o jeziku, on ga primarno ne poima »prema kriterijima apstraktnosti, simboličnosti, artikuliranosti i kreativnosti, predodređujući ga tako kao jedino ljudsku osobinu«, nego je skloniji tome da, poput etologa, uvrsti »u širu gradaciju jezične djelatnosti i neke vidove životinjskog komuniciranja ${ }^{237}$ Ovaj bi detalj mogao potvrđivati postojanje tek kvantitativnih razlika između čovjeka i životinje, tako i obesmišljavanje pojma kulture kao čovjeku specifičnog načina bivstvovanja. On bi tada bio bitno različit od pojma kulture kojeg smo u ovom radu odlučili slijediti. No upitno je koliko apstraktnost ili artikuliranost mogu važiti samo kao kvantitativne razlike. Kako tvrdi de Fontenay, ne može se naprosto tvrditi da pojava artikuliranog govora donosi tek nešto više (kvantitativno). Pozivajući se na antropološka istraživanja Mauricea Godeliera, usprkos nalaženju imaginacije, simbolike i sposobnosti prijenosa kod primata, oni »ne mogu mijenjati ukupnu strukturu odnosa specifičnih za njihovu vrstu«, dok ljudski jezik, koji je »do beskonačnosti razvio svijet simbolike«, omogućava ljudima da stvaraju nove materijalne i idealne stvari. ${ }^{238} \mathrm{Uz}$ to, teško da možemo životinjama pripisati Viskovićevo ranije navedeno određenje kulture kao otprirođivanja. No imajući u vidu da čovjekovo ontološko razlikovanje od životinje, ako i postoji, ne treba biti vremenski vječno, možemo konstatirati da u takav krug kulture potencijalno mogu ući i životinje, tj. da i one jednom mogu destruktivno djelovati (onda i moralno vrednovati svoj odnos) spram prirode. Rudimentarni oblici onoga što sada nazivamo kulturnim koje nalazimo kod viših životinja svakako to obećavaju. Time se ne samo potvrđuje na početku spomenuto postojanje sive zone između kulture i prirode, nego se nailaženjem na slične obrasce ponašanja kod čovjeka i životinje potencijalno širi krug prirodnog, a smanjuje onaj kulture određene kao specifično ljudskog načina bivstvovanja. Pitanje je samo bi li pripisivanje otprirođenja ne-ljudskim (dakle, prirodnim) bićima u momentu kad se i ako se za to steknu uvjeti bila kontradikcija ili samo izraz autodestruktivosti prirode, no sigurno je da bi takav rezultat doveo u pitanje smislenost samog pojma kulture. ${ }^{239}$

Čini se da još uvijek ima smisla kulturu pripisivati isključivo čovjeku (ali istovremeno ne i svakom Homo sapiensu), barem u ovom trenutku. Međutim, ovdje izneseni elementi sive zone nisu nimalo beznačajni, ne samo kao područja daljnjeg promišljanja ovih problema, nego

\footnotetext{
${ }^{237}$ N. Visković, Kulturna zoologija, str. 118. - Uže ili strože poimanje jezika drži nešto jezikom samo onda ako sadržava rekurzivne strukture, a njih, prema Noamu Chomskome, Marcu Hauseru i Tecumsehu Fitchu, mogu imati samo ljudi. (Usp. L. Svendsen, Razumijemo li životinje?, str. 20.) »Rekurzivnost znači da jedna fraza može sadržavati drugu frazu istog tipa, npr. 'Znam da ti vjeruješ da tvoj pas razumije što misliš'.« (Ibid.)

${ }^{238}$ Usp. B. Sirilnik, E. de Fontene, P. Singer, I životinje imaju prava, str. 106-107, 113.

${ }^{239}$ Koliko god ekstravagantnim za sada ta mogućnost izgledala, pojam kulture došao bi pod upitnik i iz obrnutog smjera, naime, ako bi se otkrilo postojanje otprirođujućih bića iz vanzemaljskih prostora.
} 
i kao ukazivanje na potrebu za aktualnim promatranjem životinje kao puno kompleksnijeg bića nego što se to često smatralo.

\section{II.2.2. Materijalni aspekt}

Materijalno-upotrebni ili ekonomski pristup razmatranju uloge koju životinja ima u ljudskoj kulturi Visković označava kao onaj u kojemu je »životinja objekt naših materijalnih potreba prehrane, odijevanja, rada i prometa, sirovina za proizvodnju, liječenja, pa i zabave. Životinja je tu jednaka svakoj drugoj upotrebljivoj stvari - biljci, zemlji, vodi, kamenu, tek sredstvo naše fizičke egzistencije, našeg biološkog i ekonomskog egoizma i prečesto okrutnosti. ${ }^{240}$ Ovdje će, stoga, ukratko biti obrađen ekonomski aspekt upotrebe životinje, pri čemu ćemo u pravilu slijediti Viskovićeve spise. Okrutnost spram životinja kojom rezultira ovakav odnos bit će obrađena u posebnom odjeljku.

Usprkos tome što postoji sva sila kulturoloških i sl. istraživanja o čovjekovoj materijalnoj upotrebi životinja, Visković ističe da postoji i očit nedostatak historijskih i teorijskih sinteza po tom pitanju. Prisutne su, dakle, brojne spoznaje o pojedinačnim, konkretnim i lokalnim načinima iskorištavanja životinja, a nedostaje ono što bi trebao biti upravo primarni zadatak takvih istraživanja - spoznaja cjeline, odnosno pravilnosti upotrebe životinja od strane čovjeka. To i ne bi bilo toliko začuđujuće da se ne radi o fenomenima koji sačinjavaju većinu odnosa između ljudi i životinja. ${ }^{241}$

Čovjek, nastavlja Visković, svestrano upotrebljava životinje, od kojih neke služe za više svrha, a neke samo za jednu. Svestrana upotreba životinja može postati razvidnom iz tablica koje pokazuju polivalentnost upotrebe određene životinje ili pasmine za više svrha, kakva je ona etnologa Françoisa Sigauta. Ipak, čini se da postoji još prostora za napredak u takvom poslu, koji bi se moglo popuniti izradom sinkroničkih i dijakroničkih uvida u čitav raspon upotrebe životinja u različitim kulturama. Tu se ne radi tek o puko spoznajnom interesu, nego i o mogućoj potkrijepi teze o sve pasivnijoj (konzumacija u obliku hrane ili sirovine, za razliku od rada, prometa ili različitih vrsta simboličke inspiracije) ulozi životinja u kulturi. ${ }^{242}$ Pokazat će se da to nije niti malo beznačajno pitanje ni s vrijednosnog aspekta.

\section{II.2.2.1. Prehrana}

\footnotetext{
${ }^{240}$ N. Visković, »Šest načina odnosa prema životinji«, str. 11.

${ }^{241}$ Usp. N. Visković, Kulturna zoologija, str. 29.

${ }^{242}$ Usp. ibid., str. 30-32.
} 
Ostajući u okviru propitivanja materijalno-upotrebnog čovjekova pristupa životinji, vrijedi navesti nekoliko stvari koje Visković zamjećuje po pitanju prehrane životinjskim mesom i ostalim životinjskim proizvodima. Prehrambena upotreba životinja ne zadržava se na razini same materijalne upotrebe, nego je zastupljena i u duhovnim praksama i pristupima. Ona sačinjava neke kultne postupke, umjetničke teme, odraz je različitih privilegija, tema je etičkih razmatranja. Raznolikosti prehrambene upotrebe životinja u različitim ljudskim kulturama postoje na više razina. Čovjek nije samo najobuhvatniji svejed, nego i jede životinje pripremljene na više načina (sirove, termički obrađene, sušene itd.), u različitim kombinacijama, zatim različite dijelove životinje, kao i njihove različite proizvode (jaja, mlijeko, med itd.). Pritom izrastaju mnoge gastronomske kulture pojedinačnih skupina, koje su selektivne u izboru prehrane životinjskog podrijetla, toliko da se pripadnici tih skupina gnušaju jedenja onoga što se nalazi izvan selektiranog, a ponekad ga i tabuiziraju. ${ }^{243}$ Kompleksnost prožimanja raznih pristupa razvidna je na svim razinama kulturne zoologije, kako se dade vidjeti i na ovom primjeru. Propitivanju same životinje i čovjekova odnosa spram nje možemo pristupiti iz raznih perspektiva. Jedan od pristupa je i onaj upotrebni, koji se opet grana na više modusa. Prehrana je svakako jedan od primarnih načina čovjekove upotrebe životinja. Ipak, prehrana ne staje samo na zadovoljenju gladi, nego iz nje proizlazi mnoštvo kulturnih elemenata, pristupa i postupaka: umjetnički prikazi, uključujući na izvjestan način i gastronomiju, razni privilegiji, socijalni status, ali i etička problematika. Međutim, neke od tih postupka pronalazimo već pri prvobitnom grananju pristupa životinji, jer uz upotrebni pristup, kao zasebne možemo navesti i onaj etički i onaj umjetnički. Premda ovakav pristup ne slijedi logička pravila razdiobe, on je svakako slikovitiji po pitanju prikaza zamršenosti čovjekova odnosa spram životinje, a ova kompleksnost sama je dio sveobuhvatnosti ovog odnosa, koji kulturna zoologija pretendira reflektirati.

Promatrajući načine osnovnog pribavljanja prehrambenih proizvoda životinjskog podrijetla, Visković ističe da divljač postaje vrlo neznatan dio mesne prehrane. Domaće životinje, čija se produktivnost povećava intenzivnim uzgojem i selekcijom, neusporedivo su zastupljenije u ljudskoj prehrani, što se posebice može pratiti od prve prehrambene revolucije u 19. i 20. st., kada se intenzivira farmski uzgoj svinja, goveda i peradi. ${ }^{244}$

Prehrambena upotreba životinje bitno utječe i na našu sliku o njoj:

\footnotetext{
${ }^{243}$ Usp. ibid., str. 33-34.

${ }^{244}$ Usp. ibid., str. 37-38.
} 
»... u ljudskoj prehrani životinja ne samo što gubi svoju biološku i psihološku individualnost (ona je samo objektna kategorija 'govedo', 'svinja', 'fazan', kokoš') nego često gubi i fizičko jedinstvo; naime, ne nabavlja se i ne jede čitavo govedo, čitava svinja, pa često ni čitava kokoš, već mesni 'položaji' tih životinja - but, prsa, leđa, biftek, vrat, koljeno, noga, krilo, batak, mekani dijelovi kukaca, pa onda iznutrica - srce, jetra, mozak, bubrezi, crijeva itd. S druge strane, malo je životinjskog mesa koje se jede prirodno, tj. sirovo $(\ldots) \ll^{245}$

No prehrana mesom ne olakšava se samo ovom višestrukom obradom, nego i čitavim kulturnim i simboličkim aparatom koji stoji iza te prakse. ${ }^{246}$ Jedan od tih elemenata koji Visković, pozivajući se na Mitologike Claudea Lévi-Straussa, ističe, pronalaženje je važnih značenja koje indijanski mitovi pripisuju opoziciji sirovo-kuhano, pa tako »pripremanje hrane na vatri, kao prometejsko vladanje vatrom, označava prijelaz u kulturu«. ${ }^{247}$

\section{II.2.2.2. Domestikacija}

Domestikacija ili udomaćivanje životinja jedan je od ključnih elemenata u izrastanju kulture. Kako govori i Visković, ona ključno utječe ne samo na biološki svijet, nego i na prijelaz čovjeka iz prahistorije u civilizaciju, prelazak iz stanja potpuno prirodnog načina zadovoljavanja prehrambenih potreba lovom i sakupljanjem plodova u specifično ljudski način proizvođenja hrane. Domestikacija tako nije tek »kultiviranje životinja, nego također, kao jedno od najznačajnijih povijesnih zbivanja, i samokultiviranje čovjeka pomoću životinja koje on proizvodi. $\ll^{248}$

Domestikacija započinje krajem paleolitika, prije 10 do 15 tisuća godina, uspješno obuhvaćajući 20 do 30 vrsta, da bi prije 2 tisuće godina uglavnom završila po pitanju domesticiranja novih vrsta. ${ }^{249}$ Iako je njen nastanak označavao upravo jedan od ključnih povijesnih momenata za ljudsku kulturu, od njenih početaka do danas proizvela je i neke od bitnih promjena na životinjama i biosferi kao takvoj, što se onda posljedično odnosi i na samog

\footnotetext{
245 Ibid., str. 47.

${ }^{246}$ Za to je osobito instruktivna studija Nicka Fiddesa Meso. Prirodni simbol, prevela Suzana Kovačević, Naklada Jesenski i Turk, Zagreb 2002.

${ }^{247}$ Usp. N. Visković, Kulturna zoologija, str. 47.

${ }^{248}$ Usp. ibid., str. 183.

${ }^{249}$ Usp. ibid., str. 187. - Sam pojam domestikacije nije jednostavan kako se na prvi pogled čini. Između divlje i domesticirane životinje postoje međustupnjevi zatočavanja, prilagođavanja, pripitomljavanja itd. Kod samih domesticiranih životinja stvari također nisu jednoznačne, što se ponajprije uviđa na razlici između životinja koje služe za ekonomsku dobit (stoka) i onih koje služe za zabavu (kućni ljubimci). Visković ulazi u sve te probleme pozivajući se na znanstvenike kao što su: Raymond Pujol, Geneviève Carbone, Isidore Geoffroy Saint-Hilaire, Charles Cornevin, Renato Thévenin, Heini Hediger, François Sigaut, Jean-Pierre Digard i dr. (Usp. ibid., str. 183187.)
} 
čovjeka. Visković te promjene smješta u četiri grupe. Prvo, domestikacija u pravilu dovodi do iščeznuća predaka domesticiranih vrsta. Drugo, mnoštvo fizičkih i psihičkih svojstava gubi se ili zadobiva drugačiji izgled uslijed uzgojnih postupaka. Naravno, kada se govori o onom dijelu domesticiranih životinja koje isključivo služe čovjekovu ekonomskom interesu, očekivano je da će se razvijati one osobine životinja koje su ekonomski probitačne. Značajne promjene fizičkog izgleda prate i promjene u ponašanju životinja, najčešće u obliku gubitka nagona za bijeg i teritorijalnost, neurotičnih reakcija, apatičnosti i sl. Spolne karakteristike životinja ne mijenjaju se samo u kvantitativnom smislu (ranije sazrijevanje, veći prirod), nego i u kvalitativnom, tako da, primjerice, gube prirodne periode plodnosti. Zahvaljujući nedostatku opasnosti od predatora, životinjama slabe osjetila, a i mozak im je u prosjeku $20 \%$ lakši od divljih srodnika. Treće, sve intenzivnije manipuliranje domesticiranim životinjama, koje sve više poprima oblike genetičkog inženjeringa, uzrokuje nestanak nekih prirodnih genetičkih svojstava, ali i sve veću ovisnost životinje o čovjeku, a time njihovu slabiju sposobnost opstanka izvan tog odnosa. Konačno, četvrto, uslijed hiperspecijalizacije i odabiranja određenih rasa koje nose trenutnu ekonomsku korist, zapostavljaju se autohtone, otporne i genetički vrijedne rase. $^{250}$

»Poput životinja i biljaka u civiliziranom svijetu, i čovjek je jedno sve više produktivno i zbrinuto (udomaćeno) biće, ali istodobno i baš zbog toga sve rizičnije biće, sve manje utemeljeno u sigurnim prirodnim mehanizmima preživljavanja i sve zavisnije od vlastitih i oskudnih tvorevina. Dakle, čovjeku gospodaru događa se uglavnom isto što i njegovim porobljenim životinjama... uključujući slabljenje moći osjetila, tjelesne podražaje i neotpornost na slobodu u divljini.«251

Domesticirane životinje bitno utječu na mnoge kulturne prakse, a sama ekonomska vrijednost zadobiva upravo tu jedno od svojih historijskih izvorišta:

»U shvaćanjima mnogih naroda, od drevnih mezopotamskih do srednjoazijskih do današnjih plemena istočne Afrike, stoka je pravo 'blago', 'glavnica', 'kapital' (lat. capita, stočna glava), tako da od indoeuropskog peku, što znači stoka, i latinskog pecus, što znači ovca, dolazi izraz pecunia, naziv za obiteljsku imovinu i kasnije za novac. $\ll^{252}$

Naravno, domestikacija nije imala velik značaj samo za prehrambenu upotrebu životinja, nego i za razne ostale. Čovjek, kao nespecijalizirano biće, ne koristi samo kamenje

\footnotetext{
${ }^{250}$ Usp. ibid., str. 190-193.

${ }^{251}$ Ibid., str. 202-203.

${ }^{252}$ Ibid., str. 14.
} 
ili drveće kao svoje alate, nego za to koristi i domesticirane životinje. Kako tvrdi Visković, čovjek je svoju slabost i usporenost nadoknađivao snagom volova, brzinom konja i sl. Životinjsko krzno, koža ili vuna služe za izradu mnogih predmeta, a nerijetko su, kako je to slučaj i kod prehrane, bili pokazatelji staleških ili klasnih razlika. Životinje su tvorile materijal za kulturu i u obliku nekih predmeta bez kojih bi njeni putovi bili nezamislivi. Riječ je o proizvodima poput pergamene (najčešće od janjeće kože), na kojoj se pisalo perima, pri svjetlosti od ulja (primjerice sobova). Tu su još neizostavni i muzički instrumenti od životinjske kože, različiti talismani od životinjskih zubiju, različita ratnička oprema poput opruga za lukove itd. Štoviše, bez konja je do početka 20. st. bio nezamisliv ratni sukob, a prije toga i prenošenje vijesti, za što su svoju ulogu ponegdje igrali i golubovi pismonoše. ${ }^{253}$

\section{II.2.3. Maltretiranje}

Prema osnovnoj podjeli kulturne zoologije, prikaz ubijanja, mučenja i uopće maltretiranja životinja sačinjava jedan od njenih osnovnih elemenata. Ovdje ćemo dijelom i nastaviti na prethodno poglavlje, dakle na razmatranje materijalno-upotrebnog pristupa životinji, ponajprije zato što je o toj temi gotovo nemoguće govoriti, a da se izbjegne promišljanje o maltretiranju životinja. U dosadašnjem smo se tekstu na nekim mjestima indirektno susretali s njime, primjerice kada smo razmatrali posljedice koje domestikacija ima za životinju. Međutim, nismo se upuštali u bilo kakve prosudbe o moralnoj opravdanosti takvog postupka. To nećemo učiniti ni u ovom poglavlju. Govoriti o mučenju i ubijanju životinje nije isto što i govoriti o moralnoj ispravnosti takvih postupaka. Može se pak reći da je ovdje riječ o pripremanju terena za moralno ispitivanje. Taj ćemo teren pokušati proširiti onoliko koliko ova vrsta rada dopušta, kako ne bismo stekli uvid samo u posebne načine maltretiranja životinja, nego i u razloge različitih oblika te većeg i manjeg intenziteta takvih postupka.

\section{II.2.3.1. Rat}

Ne čini se uobičajenim da poglavlje o maltretiranju životinja započinje problemom njihove upotrebe $\mathrm{u}$ ratne svrhe. No upravo je znakovito započeti s njime, s obzirom na to da se tu uvelike otkriva posvemašnji zaborav prirode. Rat je, naime, paradigma i najočitiji izraz međuljudskog nasilja, dakle, ubijanja, mučenja i raznih vrsta maltretiranja ljudskih bića. Unutar

\footnotetext{
${ }^{253}$ Usp. ibid., str. 15-16.
} 
te ultimativne tragedije, čovjek uglavnom zaboravlja na svoje žive supatnike, koje je bez njihova pristanka uveo u nju. Takav način promatranja smrti i maltretiranja životinje, koji ovima ne pripisuje oznaku tragedije, ne odudara bitno od česte percepcije tih pojava i u svim drugim njenim modifikacijama. Izmiješanost konjskih i ljudskih leševa na bojnom polju ukazuje na zajedničku sudbinu životinje i čovjeka, naročito u slučaju prisilnog novačenja, što onda dodatno predočava propust u zanemarivanju pridavanja pažnje životinjskoj ratnoj žrtvi. Stoga se ovdje čini potrebnim odmah naglasiti i kratko se osvrnuti na njega.

To, dakako, nije Viskovićev propust, koji među rijetkima posvećuje pozornost tom pitanju. Prema njemu, čovjek nije samo biće koje izravno napada, muči i uništava, nego i takvo biće koje obavlja te radnje i posredstvom životinja. Kao učestala ratna žrtva u prvi plan dolazi konj, koji tako dobiva i svoje mjesto u umjetničkim prikazima, primjerice na slikama Paola Uccella i Théodora Géricaulta. Tu nije samo riječ o konjima, nego i o devama, slonovima, psima, kao i onima koji indirektnije sudjeluju u sukobu, poput volova koji su vukli ratne sprave, golubova kao »obavještajnih agenata« itd. Naravno, životinje stradavaju u ratnim sukobima i onda kada nisu instrumentalizirane za njih. Osim toga, posredstvom eksperimentiranja pokušava se doći i do nekih novih upotreba životinja za ratne svrhe. Tako se pse i svinje koristi radi ispitivanja učinaka oružja, majmune kao predmete eksperimentiranja radi ispitivanja učinaka bojnih otrova, bakteriološkog i atomskog oružja itd. ${ }^{254}$

Neke se ratne naprave usmjeravaju ubijanju životinja kao krajnjem cilju. To je jedan od razloga zbog kojih Foer smatra da je za naš odnos s ribama rat najadekvatniji opis. Riječ je tako o radaru, dubinomjeru, u mornarici razvijenim navigacijskim sistemima i sl. ${ }^{255} \mathrm{Ni}$ Visković ne govori samo o maltretiranju životinja u svrhu međuljudskog ratovanja, već sâmi suvremeni čovjekov odnos spram prirode naziva ratom. Kako kaže, nasilje i mir prirodna su stanja svakog živog bića, jer ona ne opstaju bez nasilnog potiskivanja i konzumiranja drugih živih bića, kao što onda kada su im osnovne potrebe podmirene žive u razdobljima nenasilja, tj. mira. No u odnosu s drugim živim bićima, čovjek ne vrši više tek ograničeno nasilje, već provodi »totalni, neprekidni $i$ istrebljujući rat«. Među vanjske frontove tog rata spadaju i zatiranje bogatih biotopa te teška onečišćenja vode, zemlje i zraka (pa posljedično i klimatski poremećaji), a manipulacija genetičkim sastavom organizama otvara i unutarnji front, tj. unutarnju agresiju spram živih bića. ${ }^{256}$

\footnotetext{
${ }^{254}$ Usp. ibid., str. 204-206.

${ }^{255}$ Usp. Jonathan Safran Foer, Eating Animals, Back Bay Books - Little, Brown and Company, New York Boston - London 2009., str. 33, 35.

${ }^{256}$ Usp. N. Visković, Sumorne godine, str. 241-243.
} 
Kako pučka misao ponekad zaključuje, nije čudno ako ratni veteran postaje lovac, jer nije lako stati s ubijanjem. Ona na generičkoj razini ima puno dublje značenje od plitke šale. No lov je djelatnost toliko bogata značenjima da je ne treba promatrati samo u spomenutom odnosu, nego i u pogledu (ne)mogućnosti čovjeka da nakon milenijā lova naglo stane s njime i da, što je svakako značajnije, raskrsti sa svim značenjima koje lov u sebi sadržava.

Lov, kako navodi Visković, ne treba ograničiti samo na djelatnost hvatanja i ubijanja ne-ljudskih životinja od strane one ljudske, jer on uključuje i predaciju jedne životinje na drugu (ne nužno ljudske na ne-ljudsku), kao i napade ne-ljudskih na ljudske životinje. Ovdje osobito ima smisla govoriti u pojmovima ne-ljudske i ljudske životinje, s obzirom i na neka određenja lova Joséa Ortege y Gasseta, na kojeg se Visković poziva (premda ne simpatizira njegovu normativnu poziciju spram lova). Lov se, štoviše, javlja i u relacijama čovjek-čovjek, kako je to bio slučaj u nekim krajevima Južne Amerike kada su Europljani lovili urođenike. ${ }^{257} \mathrm{U}$ tom je pogledu ilustrativan i uvod filma Seljačka buna 1573., u kojem feudalci vrše lov na kmeta po istom obrascu kako se on vrši nad divljom životinjom: motivi lovaca (zabava) su isti, kao i bespomoćnost/nevinost lovine. ${ }^{258}$ Motivi se, dakako, ne ograničavaju samo na zabavu. Malo je koji oblik maltretiranja toliko simbolički prožet koliko lov, jer on »nije samo sredstvo materijalnog opstanka čovjeka, već oduvijek istovremeno i sredstvo tajnih moći, zadovoljstva, ugleda i slave u društvenoj zajednici. To je ujedno primordijalni način odnošenja čovjeka prema životu u prirodi, pa je stoga prožet elementarnim porivima, osjećajima i značenjima biološke i kulturne naravi. «259

»Uz skupljanje jestivih biljaka i životinja, lov je prvo specijalizirano zanimanje i djelatnost presudna za razvoj ljudske inteligencije, jezika, tehnike i organizacije zajednice. «260 No lov također izražava, navodi Visković, »muške vrline«, a tako i čitav simbolizam seksualnosti (lov na ženu, ispaljujuća faličnost), ali s jasnim agresivnim, pa i sadističkim porivima, kako o tome svjedoče psihoanalitičari. U tom se ključu može čitati i paradoksalna lovačka ljubav prema žrtvi. Razdvajanje lova od sakupljačke djelatnosti uvodi na historijsku pozornicu prvu podjelu rada među spolovima, ali i hijerarhijsko ustrojstvo unutar samih

\footnotetext{
${ }^{257}$ Usp. N. Visković, Kulturna zoologija, str. 163-164.

${ }^{258}$ Usp. Hrvoje Jurić, »Hrvoje Jurić - 1. međunarodni prosvjed za zabranu lova / Oslobođenje životinja«. Dostupno na: https://www.youtube.com/watch?v=lqkjj4Yp5cQ (pristupljeno 6. 2. 2019.).

${ }^{259}$ N. Visković, Kulturna zoologija, str. 164.

${ }^{260}$ Ibid., str. 14.
} 
lovačkih zajednica i kasnije nejednakost prisvajanja divljih životinja. S obzirom na to, ne treba čuditi što su se skoro sva lovačka sredstva upotrebljavala i za bilo kakvu vrstu lova na ljude. Same ceremonije i pompe koje su pratile mnoge velikane u lov i iz lova nalikovale su upravo ratnim pohodima, a već u prvoj knjizi o lovu, u Ksenofontovu Kinegetikosu, lov se potiče u svrhu odgoja ratnika. ${ }^{261}$

Pored toga, lov je ključan u okviru totemističkih i šamanskih praksi. Šamani se ponekad i sami animaliziraju načinom života, maskiranjem, mimikom, pa i spajanjem sa ženkom životinjskih duhova. Ne treba zanemariti ni osjećaj straha i odgovornosti spram ubijanih životinja kod arhaičnih lovaca, koji »nedostaje ili slabi u civiliziranom lovstvu«, a koji je često prožet vjerovanjima u besmrtnost duše divlje životinje ili u postojanje zaštitnika divljači. To ne znači da su takva vjerovanja isključivala neke bizarne prakse, poput, primjerice, molitva naroda Anu (sjeverni Japan) žrtvovanom medvjediću kojeg su doslovno dojili da im se, pored zagovora kod bogova, ponovno vrati kako bi ga opet mogli žrtvovati. ${ }^{262}$ Konkretna patnja koju životinje doživljavaju u pogledu ovakvih praksi varira od slučaja do slučaja, ali svakako ostavlja posljedice na onoga tko vrši nasilje: »U totemističkom poretku životinja totem se ponekad ne lovi i ne jede, ili onaj tko to čini mora moliti dozvolu, oprost ili podvrgnuti se obredu čišćenja i ispaštanja krivnje - a takvi obredi postoje općenito, pokazuju etnolozi, i u kasnijim lovačkim zajednicama. $\ll^{263}$

Za razliku od ostalih predatora, nastavlja Visković, koji se ograničavaju na uži krug lovljenih životinja, čovjek je jedina vrsta koja lovi univerzalno. No on istovremeno ima izrazito slabe biološke predatorske moći, tako da je ona sva, i u sredstvima i u metodama, umjetna, kulturna, tehnološka. U predgrađanskom stupnju njegove kulture, ekonomska, magijska i statusna funkcija lova nisu bile dovoljne da ugroze ekosistem, za razliku od kasnijeg masovnog lova u komercijalne i razonodne svrhe: 264

»Komercijalizacija i omasovljenje lovstva u modernim društvima imali su kobne posljedice za svijet faune, jer su pokidali tisućljetne ekološke i kulturne ravnoteže između lovaca i lovljenih - kako neposredno količinom ubijenih i uhvaćenih životinja, tako i posredno, prekidima prehrambenog lanca i uznemiravanjem životinja u prirodnim ponašanjima i nadasve u reprodukciji. $\ll^{265}$

\footnotetext{
${ }^{261}$ Usp. ibid., str. 164-165, 167, 170-171.

${ }^{262}$ Usp. ibid., str. 165, 168-170.

263 Ibid., str. 42.

${ }^{264}$ Usp. ibid., str. 165-166, 174.

265 Ibid., str. 174.
} 
»Dodatni činilac u negativnom utjecaju lovstva na svijet faune jest stalno usavršavanje preciznosti, dometa, jačine i brzine vatrenog oružja, koje toliko povećava ubojitu moć lovca da je posve poremećena ona približna ravnoteža između mogućnosti napadača i mogućnosti bijega životinje koja je u samoj biti lova (i o tome piše Ortega y Gasset). A pokušaji da se fatalni učinci masovnosti lova i usavršavanja vatrene moći lovaca nadoknade umjetnim uzgojem i planskom repopulacijom divljači, od fazana do jelena, malo mijenjaju u odnosima lovstva prema fauni i ujedno kriju jednu novu opasnost - ugrožavanje genetske izvornosti autohtonih vrsta. $\ll^{266}$

Pored svega toga, naglašava Visković, lov je postao i ekonomski nefunkcionalan, uz iznimku ribolova, koji ne trpi toliki pritisak ljubitelja životinja, a postoji i opća neosjetljivost na stradanja morskih životinja. Teško je iznaći opravdanje za kopneni lov, s obzirom na to da se za one vrijednosti koje se lovom imaju prakticirati lako pronalaze alternative ( $\mathrm{tj}$. ciljevi koje branitelji lova ističu obično su ispravni, no sredstva nisu). Lov, tako, nikako nije nužno sredstvo čovjekove prehrane, a njemu svojstveni društvenost i rekreacija mogu se postići »foto-lovom« (uz spoznajne i ekonomske prednosti). ${ }^{267}$

\section{II.2.3.3. Zabava}

Među načinima zabave koji uključuju životinje najčešće se ističu zoološki vrtovi. Kako čitamo kod Viskovića, zbirke žive faune postoje od davnih vremena, najčešće kao posjedi vladara koji služe njegovu uveličavanju i zabavi. Moderni zoološki vrtovi nastaju u vrijeme kada se dvorske menažerije otvaraju javnosti, najprije u Beču 1752. Iako su danas neki zoološki vrtovi na Zapadu uspjeli oponašati neke od prirodnih habitusa njihovih stanara, postoje sporovi po pitanju njihova maltretiranja. Iako je zabava jedna od ključnih funkcija zooloških vrtova, njima se mogu nadodati još tri funkcije koje služe kao opravdanje njihova postojanja: obrazovanje posjetilaca, znanstvena istraživanja koja bi vodila dobrobiti životinja i zaštita ugroženih vrsta. Protivnici zooloških vrtova, međutim, ističu nepobitne činjenice o fizičkim i psihičkim stradanjima koje mnoge divlje životinje trpe kada se nasilno odvajaju od svog prirodnog staništa i zajednice. Također poriču mogućnost odgojne, obrazovne, znanstvene funkcije s obzirom na neprirodnost životinjskog ponašanja unutar zoološkog vrta. Ne samo što zoološki vrtovi kod posjetilaca stvaraju pogrešne predodžbe o životu životinja, nego ih i navikavaju na trajno nasilje. Također, nema razloga zašto bi baš zoološki vrtovi bila mjesta brige oko razmnožavanja ugroženih vrsta. Postoje i blaži (realističniji) načini pristupa ovom

\footnotetext{
${ }^{266}$ Ibid., str. 175-176.

${ }^{267}$ Usp. ibid., str. 176-181.
} 
problemu, koji mogu tolerirati držanje onih vrsta u zoološkim vrtovima kojima se takvo okruženje ne bi ozbiljnije odrazilo na kvalitetu života, dakle, životinja koje se lakše pripitomljavaju, ne pate od suženog prostora i čovjekove blizine. Tu se svakako mogu uključiti i domaće životinje koje stanovnici gradova nemaju gdje vidjeti. ${ }^{268} \mathrm{Na}$ taj način bi se na bezbolniji način ostvarivala odgojno-obrazovna funkcija zooloških vrtova, naime, učenje o životinji, uz istovremeno afektivno razvijanje odnosa s njom, naročito kod djece. Ta se funkcija u svakome slučaju ne može umanjiti takvom preinakom zooloških vrtova.

Drugi upečatljiv način maltretiranja životinja u svrhu zabave korištenje je životinja u cirkusima, arenama i sl. Dok su cirkuske priredbe puka zabava, pa tako izloženije napadima za neopravdano instrumentaliziranje životinja, neke zabavne priredbe zadobile su obilježje tradicije te vrve simboličkim značenjima. Najpopularniji primjer takve priredbe je borba bikova - korida ili tauromahija. Iako je i ona naširoko napadana kao neopravdano maltretiranje životinje, tradicijska ukorijenjenost daje snagu njenim braniocima. Tako se ona, usprkos prosvjedima, još uvijek održava u mnogim zemljama.

»Jedni je oduševljeno brane kao drevnu antagonističku umjetnost sjajna ceremonijala, ljepote torerosa $\mathrm{i}$ torosa, duboke simbolike (arte honda) sudara divlje ktonske snage s ljudskom hrabrošću i tehnikom. To Jung psihoanalitički tumači kao duhovno svladavanje životinjskih sila u čovjeku. Tvrdi se još, ne jako uvjerljivo, da bi bez corride izumrla pasmina iberijskih divljih bikova. Nasuprot tome, mnogi u corridi vide bijedno masakriranje jedne kratkovidne, zastrašene, bijesom pomućene i proračunato iznurene životinje od skupine po gotovo svemu nadmoćnih ljudi.«269

Kako tvrdi Visković, iako se borbe od strane čovjeka nahuškanih životinja, u koje od pamtivijeka spadaju još i borbe pasa, pijetlova i goveda, u nekim društvima smatraju odbojnima i neprihvatljivima, one se zapravo i dalje odvijaju pred našim očima, ali u drugim oblicima. To se često događa u lovu, a različita takmičenja u utrkama također možemo svrstati pod svojevrsne borbe u širem smislu, u kojima životinje doživljavaju pretjerana naprezanja i mogućnosti povreda. Ostanemo li samo na borbi bikova, odnosno koridi, dovoljno govori brojka, iz vremena kada Visković piše Životinju i čovjeka, od 13.000 ubijenih (ili bolje: žrtvovanih) bikova godišnje, i to samo u arenama Španjolske. ${ }^{270}$

U ovu skupinu možemo ubrojiti i kategoriju kućnih ljubimaca, iako se to na prvi pogled čini neobičnim i neprimjerenim. Takav je prigovor dijelom svakako opravdan, ali ipak nije u

\footnotetext{
${ }^{268}$ Usp. ibid., str. 209-218.

${ }^{269}$ N. Visković, Životinja i čovjek, str. 370.

${ }^{270}$ Usp. ibid., str. 366-369.
} 
potpunosti. Ovaj odsječak s razlogom je stavljen u ovo poglavlje, upravo kako bi se odbacila nedovoljno kritička pretpostavka o paradigmatskom značenju fenomena kućnih ljubimaca za dobrobit životinja. Dakako, stvari tu nisu jednoobrazne, nego imaju više obličja koje valja rasvijetliti.

Kako čitamo kod Viskovića, kućni ljubimci postaju nova kategorija domaćih životinja onda kada zamire njihova utilitarna uloga. Naravno, o fenomenu kućnih ljubimaca može se govoriti puno prije modernog doba kod dokonih pripadnika viših klasa. Međutim, tek razvojem modernih gradova i modernizacijom sela izrasta jedna nova osjećajnost koja veliki dio stanovništva veže uz kućne životinje lišene svoje drevne utilitarne uloge. ${ }^{271}$

Ipak, čini se da se utilitarna uloga takvih životinja samo mijenja, a ne nestaje. Osvrćući se na uzroke povećanja broja kućnih ljubimaca, Visković govori o siromašenju međuljudskih osjećajnih spona u urbanim naseljima, čežnji za izgubljenom prirodom, medijskom populariziranju životinjskog carstva, ali i animalističkim apelima za brigu o životinjama. Postoje i gotovo patološke potrebe za pažnjom kućnih životinja, gdje bi ove služile kao kompenzacija različitih frustracija, kao potvrda važnosti autoritarne osobe, kao osnaživanje snobovskog ponašanja u obliku posjedovanja plemenitih pasmina itd. Neki parovi bez djece kućne ljubimce koriste kao kompenzaciju. Zapanjujući su razmjeri širenja obožavanja kućnih ljubimaca, koje Kathleen Szasz s pravom naziva petišizmom. Naravno, ne radi se samo o čudnim i pomalo sumnjivim pojavama, nego i o uzajamnom obogaćivanju obiju strana. Životinje, s jedne strane, zadobivaju karakteristike osobe, tako da ih se smatra članom obitelji, dobivaju imena, imaju posebnu zdravstvenu njegu, pokapaju se na zasebnim grobljima itd. S druge strane, osim procvata nekih privrednih djelatnosti vezanih uz prehranu i njegu ljubimaca, druženje s njima ima višestruke koristi za čovjekovo mentalno i fizičko zdravlje, pa se ono koristi i u terapeutske svrhe. ${ }^{272}$

Ovdje još nije u potpunosti jasno kako u ovim odnosima nastaje maltretiranje životinja, osim u činjenici njene instrumentalizacije. Prema Viskoviću, već je diskriminacija unutar kruga životinja koje društvo prepoznaje kao kućne ljubimce problematična. Riječ je o golemim nejednakostima sličnim onima među samim ljudima, što nipošto nije slučajno. Na dnu ljestvice nalaze se odbačenici, ulični psi i mačke, česte žrtve gladi, smrzavanja, progona, pogubljenja u

\footnotetext{
${ }^{271}$ Usp. N. Visković, Kulturna zoologija, str. 280-281.

${ }^{272}$ Usp. ibid., str. 282-287. - Ovdje se Visković djelomično poziva na analize Aarona Katchera, Alana Becka i Sergea Moscovicija. Dodajmo tome da posebnu zaslugu u istraživanju benefita interakcije s ljubimcima ima Boris Levingston, kao preteča onoga što će se kasnije zvati antrozoologijom, disciplini koja proučavanja interakcije čovjeka i životinje, posebno posvećenoj interakciji individua. (Usp. John W. S. Bradschaw, »Anthrozoology«, u: Daniel S. Mills, The Encyclopedia of Applied Animal Behaviour and Welfare, CABI, Wallingford 2010., str. 2830, ovdje str. 28.)
} 
šinterajima ili u znanstvenim eksperimentima. Iznad njih se nalaze kućne životinje među kojima postoje velike nejednakosti u tretmanima koje dobivaju od vlasnika: od afektivne topline i materijalne sigurnosti do potpunog zlostavljanja. Postoje i one kućne životinje koje se obasipaju luksuzom koji njima nije potreban i koji ih eventualno može još više udaljiti od prirode i ostalih životinja. Nadalje, velik je problem i taj što kućni ljubimci sve više pate od istih bolesti kao i čovjek. Postoji i problem koji je već spomenut pri raspravi o domestikaciji, taj da povećanjem broja kućnih ljubimaca opada broj vrsta i jedinki divljih životinja. Hrana za životinje ne dobiva se samo iz klaonica, koje su problem za sebe, nego traže i izlov velike količine divljih životinja, poput kitova, pingvina ili klokana. Pored problemā uzrokovanih neprimjerenošću svijesti gospodara potrebama njihovih ljubimaca, pri čemu je njihovo napuštanje najgora stvar koja im se može dogoditi, ni gradske vlasti često ne poduzimaju napore adekvatne smanjenju patnji gradskih životinja. Tako se često više napora ulaže u hvatanje i istrebljenje uličnih pasa i mačaka nego u gradnju skloništa i edukaciju te prisilu vlasnika da se brinu o svojim životinjama. Jedan od prvih koraka u toj edukaciji osvještavanje je toga da životinje ne smiju služiti kao puki predmet zabave, ako je već cilj ne nanositi im nepotrebnu patnju. ${ }^{273}$

Stoga se upravo puko instrumentaliziranje životinje često pokazuje kao radnja koja najizglednije vodi k maltretiranju životinja. Zabava čini jedan od paradigmatičkih primjera puko instrumentalne upotrebe životinja, pa ipak ona rjeđe dolazi u prvi plan pri propitivanju tog problema. Okviri u kojem se on primarno promatra oni su znanstvenih eksperimenata i industrijskih farmi, ujedno povlaštenih mjesta etičke rasprave o moralnom obziru spram ili glede životinje. Oni će u ovom poglavlju biti tematizirani sukladno njegovu nazivu, dok etičku raspravu ostavljamo za kasnije.

\section{II.2.3.4. Znanstveni eksperimenti}

Poglavlje Životinje i čovjeka pod naslovom »Znanstveni masakri« Visković započinje na šokantan način:

»'Nekoliko pasa polio sam uljem i zapalio. Drugima sam u rasporene utrobe ulijevao vrelu vodu, držao šape pod acetilenskim plamenom, mužjacima gnječio mošnice, lomio nožne kosti. Nekima sam izvadio oči, izudarao crijeva i ubacio eter u dušnik. U jednoga sam pucao revolverom kalibra 30, u drugoga revolverom kalibra $32 . . . '$

\footnotetext{
${ }^{273}$ Usp. N. Visković, Kulturna zoologija, str. 286-290.
} 
Ovo nisu riječi nekog imbecila, ili jednog od onih uličnih huligana što polijevaju benzinom i žive spaljuju mačke. Riječi su to iz studije doktora G. Crilea 'Surgical Schock' (New York, 1899) kojom taj učenjak izvještava o svojim pokusima sa 148 pasa radi simulacije i proučavanja traumatskog šoka.« 274

Iako se radi o izvještaju starom više od stotinu godina, prakse u znanstvenim laboratorijima nekih zemalja nisu se radikalno promijenile. No ne treba zanemariti regulaciju koja je u nekim drugim zemljama znatno ublažila ove postupke, pored čega se ponegdje ograničio broj žrtvovanih životinja, testiranje se sve više radi na glodavcima, a manje na razvijenijim sisavcima, pojedini proizvođači kozmetike odustaju od upotrebe živih životinja u svrhu ispitivanja svojih proizvoda itd. ${ }^{275}$

Bez obzira na regulaciju, i dalje se znanstveni eksperimenti pokazuju izuzetno okrutnima, naročito onda kada nisu usmjereni čovjekovim vitalnim interesima. Tu je prije svega riječ o testiranju novih proizvoda koji se koriste u svakodnevnom životu. Oni se mogu isprobavati oralno, dakle, tako da se životinje prisiljava da gutaju razne supstancije, koje ne trebaju biti jestive (primjerice, ruž za usne), zatim da inhaliraju ili se uranjaju u izvjesne spojeve, a izvode se i dermatološki testovi nadraživanjem kože te testovi ubrizgavanjem određene tvari u krvotok. ${ }^{276}$ U eksperimentima se ponekad nadražuju i oči životinja, za što je najpoznatiji primjer, prenosi Visković, nadraživanje očiju kunića (Draizeov test), a kao pogodne kandidate za ovaj eksperiment čini ih to što nemaju žlijezde suznice. Jedan od poznatijih testova toksičnosti onaj je pod imenom DL 50 (Dose letal 50\%) u kojemu se određenom uzorku određenih životinja daju određene tvari koje se žele testirati, kako bi se nakon smrti polovice skupine došlo do mjere toksičnosti te tvari za čovjeka. ${ }^{277}$ Preživjele životinje, naravno, ne ostaju zdrave. ${ }^{278}$

Eksperimentalna psihologija obiluje mučnim eksperimentima nad životinjama, odnosno izazivanju i promatranju raznih psihopatoloških stanja kod životinja. Životinje se u njima »izoliraju, lišavaju sna, odvajaju od majke, izlažu elektrošokovima i drugim mučenjima radi izazivanja i ispitivanja straha, šoka, depresije i agresije «. ${ }^{279}$ Osobito se okrutnima čine, kako

\footnotetext{
${ }^{274}$ N. Visković, Životinja i čovjek, str. 336.

${ }^{275}$ Usp. ibid., str. 338.

${ }^{276}$ Usp. Peter Singer, Oslobođenje životinja, preveo Neven Petrović, IBIS grafika, Zagreb 1998., str. 43-44.

277 Usp. N. Visković, Životinja i čovjek, str. 336; P. Singer, Oslobođenje životinja, str. 43-44. - Neovisno o eventualnoj zastarjelosti podataka koje Visković navodi 1996. godine (kada je izdana knjiga Životinja i čovjek) ili Singer godinu dana prije (ovdje referirano izdanje knjige Oslobođenje životinja), nema sumnje da se životinje u znanstvenim eksperimentima i danas ozbiljno maltretiraju.

${ }^{278}$ Usp. P. Singer, Oslobođenje životinja, str. 43.

${ }^{279}$ N. Visković, Životinja i čovjek, str. 336. - Pri tome je poseban pokazatelj bešćutnosti i bezobzirne manipulacije »mučenje pasa iz vrste beagle, poznatih po dobroćudnosti, radi toga da ih se, izluđene od patnji, prisili na agresiju « (Ibid.)
} 
prenosi Singer, eksperimenti Harryja Harlowa i Stephena Suomija na mladim majmunima. Naime, oni su stvorili umjetnu »majku-monstruma« koja bi različitim intenzitetom maltretirala majmuna koji se, bez obzira na to, privijao uz nju, da bi kasnije razvijali pravu »majkumonstruma«, odnosno izluđenu majmunicu koja bi maltretirala, čak i ubijala svoje dijete. S takvim se ispitivanjima nije stalo, nego su eksperimenti počeli hraniti sami sebe. ${ }^{280}$

»Reite i njegovi kolege su eksperimentirali na čimpanzama zato što je relativno malo eksperimentalnog rada provedeno na velikim čovjekolikim majmunima, kada se stvari usporede s običnim majmunima. Oni očito nisu osjećali nikakvu potrebu da sebi postave osnovno pitanje - zašto bismo uopće trebali na životinjama raditi ikakve eksperimente koji uključuju maternalnu deprivaciju. Oni čak nisu pokušali ni opravdati svoje eksperimente tvrdeći da su oni korisni za ljudska bića. « ${ }^{281}$

Česta su, isto tako besmislena, psihološka istraživanja s elektrošokovima koji se iz različitih razloga daju štakorima ili psima. Ako ti eksperimenti i nisu bili besmisleni, onda su njihovi rezultati, po riječima samih eksperimentatora, najčešće trivijalni ili očiti, uglavnom znanstvenim žargonom izraženo ono što smo već na neki način znali ili što smo mogli lako saznati i bez eksperimentiranja. ${ }^{282}$ Znanstvena racionalnost u tim slučajevima doseže jedan od svojih najiracionalnijih momenata.

\begin{abstract}
»Dovoljno je znati da se u svakom društvu i svake godine na životinjama testira tisuće proizvoda: ne samo radi ispitivanja toksičnosti lijekova, nego i mogućih štetnih učinaka deterdženata, parfema, šampona, dezodoransa, make up sredstava, krema za sunčanje, duhana, boja, maziva za strojeve, krema za cipele i parkete, gnojiva i insekticida, crnila za pisanje, plastičnih posuda za hranu, bojila za hranu i pića, antifriza... Svakoga tjedna nastaje poneki novi lijek is gotovo svakim se obavljaju pokusi na desetinama i stotinama miševa i štakora, pa i pasa, mačaka i majmuna. Pri tome različiti proizvođači ponavljaju testiranja istovrsnih proizvoda i lijekova, budući da među njima nema dovoljno suradnje i objavljivanja rezultata pokusa, ili zato što se propisi o provjeri škodljivosti tumače tako da treba testirati svaki proizvod, makar on bio sastavom identičan ili bitno sličan već iskušanima. $\ll^{283}$
\end{abstract}

Visković podsjeća da su životinje nekoć učestalo bile žrtvovane u vjerske svrhe, a žrtvovanje životinja za znanstvene svrhe prakticirali su i antički učenjaci (poput Erazistrata, Aristotela i Hipokrata). Danas je patnja žrtvovanih životinja u znanstvene, industrijske i vojne svrhe višestruko intenzivirana u usporedbi s antičkim dobom, a o njima ne ovise samo mnoga

\footnotetext{
${ }^{280}$ Usp. P. Singer, Oslobođenje životinja, str. 25-28.

${ }^{281}$ Ibid., str. 28.

${ }^{282}$ Usp. ibid., str. 39-40.

${ }^{283}$ N. Visković, Životinja i čovjek, str. 339.
} 
otkrića nego i materijalno blagostanje suvremenog svijeta. ${ }^{284}$ Naime, to je blagostanje (svako ne čitavog svijeta, niti čitavih društava) uglavljeno unutar kapitalističkog načina proizvodnje, koji generira više ovakvih žrtvovanja. Ne samo što je unutar tog okvira poželjno da sve vrste potreba kojima tržište može doskočiti rastu, nego se stvara i okrutna konkurencija koja zahtijeva više okrutnosti spram životinja, u vidu bespotrebnih ponovnih ispitivanja određenih supstancija koje su u drugim pokusima pokazale razinu štetnosti. Znanstvena se iracionalnost tu preklapa s ekonomskom.

Rasprava pak postaje puno osjetljivija po pitanju eksperimentiranja nad životinjama u svrhu liječenja ljudi. Gotovo se svi lijekovi, navodi Visković, prije upotrebe iskušavaju na velikom broju laboratorijskih životinja. Neki u sumnju dovode smislenost takvih pokusa, s obzirom na neke važne razlike u fiziologiji čovjeka i drugih životinja, ali i fatalnim primjerima upotrebe lijekova koji su prošli testiranja na životinjama, poput Talidomida, Oprema, Practola itd. ${ }^{285} \mathrm{~S}$ druge strane, oslanjanjem samo na testiranje na životinjama, izgubili bismo neke vrijedne proizvode poput inzulina, koji kod zečeva i miševa, za razliku od ljudi, može izazvati deformacije. ${ }^{286}$ Visković pak ne zauzima pozicije koje idu u krajnosti, pa kao osnovne probleme suvremenog eksperimentiranja na životinjama ističe: »a) kako ograničiti životinjske pokuse na zaista nužne svrhe; b) kako spriječiti njihova nepotrebna ponavljanja i patnje životinja u njima, c) kako postići strogi javni nadzor nad pokusima, i d) kako zamijeniti neke ili sve zoopokuse novim, alternativnim tehnikama ${ }^{287}$ Na drugom mjestu ipak ističe nešto određeniji i radikalniji stav da se eksperimenti na životinjama danas »)još mogu opravdati, uostalom kao i dobrovoljna podvrgavanja ljudi eksperimentima, samo u najznačajnijim medicinskim (ne u privrednim, vojnim, obrazovnim) istraživanjima za koja još nema zamjenskih tehnika i uz najstrože jamstvo bezbolnosti ${ }^{288}$

\section{II.2.3.5. Industrijske farme i klaonice}

\footnotetext{
${ }^{284}$ Usp. ibid., str. 336-337. - Valja svakako spomenuti i žrtvu koju je kuja Lajka podnijela za znanost u bespućima svemira, naročito zato što se tu radi o još jednom svrsi radi koje se maltretira životinja, naime, ideologiji. Povodom Lajkinog bespovratnog leta u svemir književnik Dino Buzzati piše: »Zbogom, dakle, dragi psiću. Nećeš više režati, ni imati štenad, ni travnjak, ni loptu, ni gospodara. Okončat ćeš u groznoj samoći i ne znajući da si junak Povijesti, Simbol Napretka, Pionir Svemira. Još jednom je čovjek iskoristio tvoju nevinost, zloupotrebio te, da bi se osjetio većim i važnim. « (Citirano prema: ibid., str. 337.)

${ }^{285}$ Usp. ibid., str. 337, 340.

${ }^{286}$ Usp. P. Singer, Oslobođenje životinja, str. 46.

${ }^{287}$ N. Visković, Životinja i čovjek, str. 341.

${ }^{288}$ Nikola Visković, »Zakašnjelo i površno«, Tvrtka (1997) br. 15, str. 57-63, ovdje str. 62.
} 
No paradigmatičan primjer posvemašnje okrutnosti spram životinja predstavljaju industrijske farme za intenzivan uzgoj životinja. To pak ne znači da su, kako naglašava Visković, tradicionalni načini uzgoja životinja moralno neproblematični. Premda oni životinjama osiguravaju veću mogućnost ostvarenja potreba za društvenošću i kretanjem, one se i tu najčešće kastriraju bez anestezije, žigošu užarenim željezom, odrezuju im se rogovi, zubi i repovi, nasilno ih se kljuka, mladunčad se rano odvaja od majke te se konačno njihov prijevoz i ubijanje odvijaju u stravi i bolu. ${ }^{289}$

\begin{abstract}
»Nedvojbena etička problematičnost suvremenog industrijsko-intenzivnog uzgoja sastoji se u tome što s njima nastaje sustav mučilišta, nije pretjerano reći koncentracionih logora, gdje se radi maksimalizacije proizvodnosti i profita agrobiznisa živa bića srozavaju na razinu neživih objekata i izlažu najgorima patnjama. (...) Tim bijednim stvorenjima ne odgovara više naziv 'domaće životinje', jer su ona daleko od bilo kakvih domaćinskih odnosa - to su, zapravo, neke nove 'tehnološke životinje' ili životinje-mašine, što se rađaju, rastu, oplođuju, iskorištavaju i kolju u posve neprirodnim uvjetima mehaniziranih pogona dostojnih fantastičnih priča užasa. «290
\end{abstract}

Mnoštvo je primjera koji zorno prikazuju sav taj užas, a ovdje ćemo, ilustracije radi, istaknuti samo nekoliko njih koje prenosi Visković. U halama ovih industrijskim pogonima smještena je ogromna količina životinja. Kratki život ovih životinja (obično nekoliko mjeseci) izložen je visokoj temperaturi, amonijaku iz njihova izmeta i umjetnom osvjetljenju. Prostori u kojima se nalaze jedva im ili im uopće ne daju priliku da se pokreću, što izaziva frustraciju mnoštva nagona, među ostalim i onog socijalnog. Tako se i majčinski nagon osujećuje ranim odvajanjem mladunčeta (odmah ili nekoliko dana nakon poroda). Životinje na industrijskim farmama suviše su često umjetno oplođivane, a one koje se ne oplođuju kastrira se bez anestezije. U svrhu dobivanja poželjnijeg mesa, životinje su nerijetko izložene dodatnim maltretiranjima. Tako se, primjerice, teladi uskraćuju izvori željeza (u travi). Stres koji vlada u industrijskim postrojenjima izaziva psihička oboljenja kod životinja, a šteta koju time mogu prouzročiti svojim brojnim sustanarima potiče prakse odsijecanja kljunova pilićima, repova, ušiju i zubiju svinjama i sl. ${ }^{291}$

\footnotetext{
${ }^{289}$ Usp. N. Visković, Kulturna zoologija, str. 223.

${ }^{290}$ Ibid., str. 223-224. - Foer industrijsko postrojenje za uzgoj životinja opisuje kao »matematičku orkestraciju«, gdje osim samih životinja nema ničega što bi se moglo nazvati prirodnim. Štoviše, u takvim postrojenjima pažnju zaokuplja efikasnost i vladavina stroja, a životinje izgledaju kao njegove ekstenzije. Potrebno je uložiti trud da bi se stekao drugačiji dojam. (Usp. J. S. Foer, Eating Animals, str. 88.)

${ }^{291}$ Usp. N. Visković, Kulturna zoologija, str. 224-225.
} 
»Uza sve te muke, koje se pažljivo i uspješno prikrivaju od javnosti - kako ne bismo bili šokirani spoznajom cijene patnje proizvoda koje konzumiramo, dolaze još i torture straha, žeđi, gladi $i$ ozljeđivanja u masovnom željezničkom, kamionskom i brodskom prijevozu životinja, gdje se prečesto ne poštuju ni vrlo slabe zaštitne mjere koje postavljaju nacionalna i međunarodna pravna pravila, te najzad i patnje u serijskim postupcima klanja.« ${ }^{292}$

Način funkcioniranja suvremenih klaonica u tančine opisuje Timothy Pachirat, koji se u tu svrhu zaposlio u jednoj američkoj klaonici goveda. Njihovo ubijanje otpočinje dolaskom pred radnika koji ih imobilizira i puca im zračnim pištoljem u glavu (čime čelični vijak prodire u lubanju i brzo se povlači). No snaga, kut i lokacija udarca ponekad nisu dovoljno snažni, pa životinja ne pada u nesvijest, nego snažno krvari i divlje mlatara, a radnik je pokušava ponovno pogoditi. Potom se vješaju za jednu nogu i provode do drugih radnika, a jedan od njih drugom vrstom pištolja (engl. captive-bolt handgun) puca u glave onim kravama koje pokažu znakove svjesnosti. Tek onda dolaze do radnika koji ih sjeku - tehnički, ubija ih tek rezanje karotidne arterije i vratnih vena. No prije ovog procesa životinje se ponekad sruše već u kanalima koji vode mjestu gdje njihovo ubijanje treba započeti, bilo zbog bolesti ili iscrpljenosti, bilo zbog mnoštva električkih udara od strane radnika koji ih njima tjeraju da brže prolaze kroz kanale. S druge strane, neke dođu svjesne do spomenutih rezača, a u tom slučaju (ako ovi ne zaustave čitavu proizvodnju da bi drugi pucač ispravio svoj propust) događaju se nesavršeni rezovi (jer postoji velika mogućnost ozljede po rezače kada su suočeni sa životinjom koja se svjesno bori za život), pa se nakon električnih stimulansa (kako bi srce pumpalo, tj. izbacivalo krv) svjesnim kravama odsjecaju repovi, noge i sl. ${ }^{293}$

Premda je patnja ovih bića golema, ne treba zanemariti ni da su ljudi koji rade u ovoj industriji »žrtve, jer im njihovo okrutno zaposlenje, u koje su često prisiljeni, može nanijeti doživotne rane «. ${ }^{294}$ Radnici na industrijskim farmama izloženi su otrovnim plinovima koji im zadaju respiratorne probleme, neurološke degeneracije, reproduktivne disfunkcije, napadaje. ${ }^{295}$ Human Rights Watch je, prenosi Foer, u ovim postrojenjima detektirao sistematsku povredu ljudskih prava. Osim što u lošem postupanju spram životinja radnici ponekad slijede naredbe nadzornika, oni i sami imaju potrebu liječiti svoje frustracije na njima. S druge strane, radnici

\footnotetext{
${ }^{292}$ Ibid., str. 225-226.

293 Usp. Timothy Pachirat, Every Twelve Seconds. Industrialized Slaughter and the Politics of Sight, Yale University Press, New Heaven - London 2011., str. 53-60, 144-145, 147-149. - Za način na koji proces ubijanja funkcionira kod peradi vidi: J. S. Foer, Eating Animals, str. 132-133.

${ }^{294}$ Tomaž Grušovnik, Etika živali. O čezvrstni gostoljubnosti, Univerzitetna založba Annales, Koper 2016., str. $142-143$.

${ }^{295}$ Usp. Melanie Joy, Zašto volimo pse, jedemo svinje i nosimo krave. Uvod u karnizam, prevela Dunja Farkaš, Dvostruka duga - Prijatelji životinja, Čakovec - Zagreb 2012., str. 76
} 
u klaonicama imaju najvišu stopu fizičkih ozljeda (godišnje 27\%). ${ }^{296}$ Oni su i na tim mjestima skloni maltretirati životinje više no što proces njihova ekonomičnog klanja zahtijeva. Neke od konkretnih slučajeva prenosi Melanie Joy. Ona tvrdi i da se radnici uslijed rutinizacije i aktivacije obrambenih mehanizama naviknu, tj. otupe na nasilje, što rezultira gomilanjem psihičkog nemira, onda i traumatiziranjem, ovisničkim i nasilnim ponašanjem. ${ }^{297}$ No maltretiranje životinja odražava se na ljude i na druge načine:

»Ali etička problematičnost okrutnog manipuliranja domaćim životinjama nije jedini nedostatak intenzivnog industrijskog uzgoja. Sva bijeda toga proizvodnog sustava raspoznaje se kada shvatimo koliko je on opasan i s gledišta ljudskih - ekonomskih, ekoloških i zdravstvenih interesa.«298

Ekološke posljedice intenzivnog uzgoja životinja sve su više prisutne u javnosti, dok se u doba kada Visković piše svoje animalističke tekstove one gotovo ne spominju, ne toliko zbog nedostupnosti takvih podataka, koliko iz strategije ekologističkih pokreta u pogledu održavanja podrške u javnosti, premda bi »uklanjanjem masovnog intenzivnog uzgoja nestao jedan od najvećih izvora zagađenja prirode i dio oslobođenih površina bi se vratili flori i fauni«. ${ }^{299}$ Visković već tada prenosi da se u svrhu ovakvog industrijskog uzgoja troši 40\% proizvedenih žitarica, ${ }^{300}$ tj. da se vrši razbacivanje proteina po računici: iz jednog hektra obradive zemlje može se dobiti čak 10 do 20 puta više biljnih nego mesnih proteina. Tako veliki omjeri vrijede i u pogledu drugih hranjivih sastojaka, kao i u pogledu utroška fosilnih goriva. Ekološki se problemi vezani uz intenzivan uzgoj životinja mogu nabrajati gotovo u nedogled: utrošak i zagađenje vode, onečišćenje zemlje, uništenje šuma, klimatske promjene, fekalije. Tu su, naravno, i spomenuti zdravstveni problemi, uslijed pretjerane upotrebe antibiotika, hormona i generalno loših uvjeta na ovakvim farmama. Konačno, zahvaljujući državno-bankovnim potporama agrobiznisu i jeftinim cijenama njegovih proizvoda, sitna i srednja seljačka gospodarstva doživljavaju propast. ${ }^{301}$

Međuprožimanje ekoloških, zdravstvenih i ekonomskih problema koji prate intenzivan industrijski uzgoj životinja može se ilustrirati problemom životinjskog izmeta. Kako iznosi Jonathan Sebastian Foer na primjeru Sjedinjenih Američkih Država, životinje na farmama

\footnotetext{
${ }^{296}$ Usp. J. S. Foer, Eating Animals, str. 231, 254.

${ }^{297}$ Usp. M. Joy, Zašto volimo pse, jedemo svinje i nosimo krave, str. 49-50, 83-84.

${ }^{298}$ N. Visković, Kulturna zoologija, str. 227.

${ }^{299}$ N. Visković, »Zakašnjelo i površno«, str. 60.

300 Aktivist PETA-e Bruce Friedrich naglašava da ovakve velike brojke i postotci o konzumaciji žitarica ne uključuju i posebno značajan problem da životinjska agrikultura troši $98 \%$ od ukupno 225 tona na svijetu proizvedene soje. (Usp. J. S. Foer, Eating Animals, str. 211.)

${ }^{301}$ Usp. N. Visković, Kulturna zoologija, str. 226-231.
} 
proizvedu 130 puta više izmeta od ljudi, pri čemu nema ni infrastrukture ni federalnih smjernica za njegovo zbrinjavanje. Pored amonijaka, metana, ugljičnog monoksida, cijanida i drugih štetnih tvari za ljudsko i ne-ljudsko zdravlje, ovaj izmet sadrži više od sto patogena štetnih za ljude. Djeca odrasla blizu industrijskih farmi svinja imaju duplo veću šansu od ostale da razviju astmu. Izmet se kao zdravstveni i ekološki problem javio onda kada su uzgajanje životinja preuzele korporacije, koje su, za razliku od tradicionalnih farmera, cijenu zagađenja prebacili na javnost. Naime, korporacijama je plaćanje kazni za onečišćenje jeftinije nego odricanje od postojećeg tvorničkog sistema. Ilustracije radi, korporacija Smithfield kažnjena je 1997. za 7.000 povreda zakona pod imenom Clear Water Act, za što je kažnjena dotad rekordnom kaznom za ovakve prijestupe u iznosu od 12,6 milijuna dolara, iznosom koju ona zaradi u svega 10 sati. Spomenimo još i to da je zahvaljujući neodgovornom odlaganju izmeta u 22 američke države do 2009. (godine kada je izdana Foerova knjiga na koju ovdje referiramo) zagađeno čak oko $56.000 \mathrm{~km}$ rijeka. ${ }^{302}$

Intenzivan se uzgoj brani prvenstveno kao »neizbježna posljedica goleme potražnje proizvoda od domaćih životinja u suvremenom prenapučenom i urbaniziranom svijetu«, no stvar je u tome što takva potražnja »nije nikakva društvena neminovnost, nego najvećim dijelom posljedica jednog ekonomskog opredjeljenja i njegovog uvjetovanja prehrambenih ponašanja stanovništva«. ${ }^{303}$ Ovdje se pak otvara prostor za puno dublje sagledavanje moralnog problema, koje se ne svodi na puko zadovoljenje postojećih preferencija, nego propituje i njihove izvore, na što ćemo se posebno osvrnuti u usporedbi Singerove i Reganove etike, kao i u okviru propitivanja istinskih ljudskih potreba.

\section{II.2.3.6. Istrebljenje vrsta}

Bjelodano je, prenosi Visković već konsenzualno utvrđen znanstveni stav, da Zemlja u našem dobu, pored barem pet razdoblja izumiranja vrsta živih bića, ulazi u novo, sada više ne prirodno uzrokovano, doba iščezavanja vrsta. Ono bi se, štoviše, moglo pokazati i kao najstrašnije, čemu bi mogle voditi suvremene prakse uništavanja šuma, kemijskog zatrovanja tla, vode i zraka, pretjerane urbanizacije i gradnje cesta, isušivanja močvara, rasta ljudskog stanovništva i ekspanzivne poljoprivrede, prekomjernog lova, ali i gore obrađivanog množenja domesticiranih životinja. ${ }^{304}$

\footnotetext{
302 Usp. J. S. Foer, Eating Animals, str. 174-179.

${ }^{303}$ N. Visković, Kulturna zoologija, str. 231-232.

${ }^{304}$ Usp. N. Visković, Životinja i čovjek, str. 300.
} 
»Istovremeno, u uništavanju svega izvornog života sudjeluju i stotine milijuna kućnih miljenika, nadasve pasa i mačaka, koji pomažu svojim gospodarima da mesožderski tamane i divlje i domaće životinje. Od toga holokausta živih bića izuzeto je malo vrsta kojima tehnološka civilizacija zasad pogoduje - žohari, štakori, golubovi, vrapci, galebovi...« ${ }^{305}$

Naravno, zaključuje Visković, iščeznuće mnogih vrsta živih bića vjerojatno prijeti i čovjekovu opstanku, ali i kad ne bi bilo tako, valja imati na umu moralne, estetske i druge konzekvence ovakvih praksi. Naprosto bi okruženost tehniziranom kulturom, tj. našim »jednoličnim artefaktima, strojevima i domesticiranim stvorenjima proračunatog, pitomog i servilnog ponašanja« bila znak konačne osamljenosti i bijede koje »egzistenciju lišavaju temelja smisla $\ll^{306}$

\section{II.3. KULTURNA BOTANIKA}

Nastanak botanike kao znanstvene grane biologije, kako u jednom enciklopedijskom članku sažimlju njegovi autori, svoje osnove ima u preokupaciji biljkama najranijih kultura iz koje je proizašlo bogato znanje kakvo je i samo imalo elemente znanstvenih činjenica. Za osnivača botanike smatra se Aristotelov učenik Teofrast, čija su djela o morfologiji, klasifikaciji i prirodnoj historiji bilja važila za neupitna u mnogim narednim stoljećima. Njegovu se autoritetu u Europi pridodao tek onaj Pedanija Dioskorida iz 1. st., koji je po pitanju medicinske botanike vrijedio sve do 15 . st. Tek s izumom optičke leće botanika doživljava ponovni poticaj za istraživanja svih, a ne samo medicinski korisnih biljaka, pa se u 17. st. osobito ističe Gaspard Bauhin, a nakon njega i čitava plejada botaničara s kojima se u 18. st. (kada se već vrše istraživanja s mikroskopom) botanika pretvara u laboratorijsku znanost. $U$ tom je vremenu nezaobilazan spomenuti Linnéov doprinos, kao i utjecaji Darwina i Georga Mendela za razumijevanje i izgradnju teorije evolucije i genetike. Kao i zoologija, botanika sve više ulazi u interdisciplinarni dijalog, zahvaljujući i ekologiji koja se na početku upravo javlja kao subdisciplina botanike. ${ }^{307}$

\footnotetext{
${ }^{305}$ Ibid., str. 309.

${ }^{306}$ Usp. ibid., str. 309.

${ }^{307}$ Usp. Michael J. Pelczar, Rita M. Pelczar, William Campbell Steere, »Botany«, Encyclopcedia Britannica 11. 2. 2020. Dostupno na: https://www.britannica.com/science/botany (pristupljeno 17. 5. 2020.). - Pored toga, premda ni moderna ekologija nema jasne početke, upravo se Teofrast također može držati njezinom pretečom, s obzirom
} 
Viskovićeva je kulturna botanika, kao što je bio slučaj i kod kulturne zoologije, bitno sveobuhvatnija od one znanstvene. Zapravo, kulturna botanika ni po čemu se ne razlikuje od kulturne zoologije osim po predmetu ispitivanja. Tako se i red ispitivanja u kulturnoj botanici ne razlikuje bitno od onoga provedenog u kulturnoj animalistici. ${ }^{308} \mathrm{U}$ tri temeljne točke sažeto je da kulturna botanika ispituje:

\begin{abstract}
»A) važnost biljnog svijeta u biosferi i za opstojnost čovjeka; B) ljudsko ignoriranje i uništavanje divljeg bilja i sebičnu brigu za sve manji broj privrednih biljnih vrsta; i C) potrebu moralne i pravne brige za preostalo biljno blago - sve to kao program jednog interdisciplinarnog znanstvenog projekta koji možemo nazvati kulturna botanika. $\aleph^{309}$
\end{abstract}

Takav sažeti opis ni izbliza ne otkriva čitavo bogatstvo pristupa kulturne botanike biljnom svijetu. Klasična botanika i ekologija otkrivaju tek dio prve (a u izvjesnoj mjeri i druge) točke ispitivanja, što već samo po sebi ukazuje na široku pretenziju ovog projekta. Visković je svjestan veličine tog »zalogaja«, pa osim ograničavanja svog područja (ili, bolje, fokusa) ispitivanja na stabla kao najviši oblik biljnog života, zadaje sebi zadatak nabačaja tek nekih od prvih odgovora i hipoteza po navedenom redu ispitivanja. Uz to, zadatak kulturne botanike teži je od onoga kulturne animalistike jer postoji još veća oskudnost istraživanja na planu uloge bilja (stabala) u materijalnoj i duhovnoj povijesti čovječanstva. Najsvjetliju točku u kulturološkim istraživanjima čovjekova odnosa spram bilja, analogno slučaju kulturne animalistike, predstavlja etnobotanika, međutim njena učestala ograničenost na istraživanja urođeničkih i arhaičnih kultura ne zadovoljava pretenzije kulturne botanike, naime, ne obuhvaća cjelokupnu kulturnu sliku o bilju. ${ }^{310}$ Bez obzira na to, određenje etnobiologije koje nude Balee i Brown u enciklopedijskom članku o etnobotanici odgovara zadatku kulturne botanike, naime kao "proučavanje sveukupnosti odnosa koji su bilo kada postojali između ljudskih bića i biljaka«. ${ }^{311}$ Dio kulturne botanike koji se odnosi na stabla, obuhvaća sljedeće skupine pitanja:

\footnotetext{
»- stablo kao antropološka tema, s upotrebama i uzgojem drveća za ljudsku hranu, građevinski materijal, sirovine, lijekove, urbana rješenja;

- stablo kao nadahnuće u etimologiji, pismu, toponomiji i antroponimiji, računanju vremena;
}

\footnotetext{
na to da je prvi opisao međuodnose živih bića jednih s drugima i s ne-živom okolinom. (Usp. Robert Leo Smith, Stuart L. Pimm, »Ecology«, Encyclopcedia Britannica 7. 2. 2019. Dostupno na: https://www.britannica.com/science/ecology /pristupljeno 17. 5. 2020./.)

${ }^{308}$ Usp. N. Visković, Stablo i čovjek, str. 28.

${ }^{309}$ Ibid., str. 28.

${ }^{310}$ Usp. ibid., str. 28, 49.

${ }^{311}$ Ibid., str. 31. - Visković se referira na: W. Balee - J. Ch. Brown, »Ethnobotany«, u: Encyclopedia of Cultural Anthropology 2, N. York, 1996, str. 399.
} 
- stablo kao predmet religijskog kulta, magije, narodnih običaja, vjerovanja i uopće simbolike;

- stablo kao predmet estetskog doživljaja - u prirodi, vrtlarstvu, likovnim umjetnostima i književnosti;

- stablo kao model spoznaje i klasifikacije;

- ljudsko uništavanje te moralno-pravna zaštita stabala i šuma.«112

Već osnovno određenje kulturne botanike kao refleksije odnosa kulture spram biljnog života uključuje u sebi i samu pozitivnu znanost botanike, ali isto tako i sociologiju spoznaje, koja kao refleksija o pokretačkim interesima znanja (tako i onog znanstvenog) čini jednu od središnjih tema kulturne botanike i kulturne zoologije. ${ }^{313}$ Stoga se čini da su navedene skupine pitanja još uvijek preuske za obuhvaćanje punog značenja kulturne botanike.

Pokušaj odgovora na pitanje »što je stablo čovjeku $i$ što je čovjek stablu« smislen je jedino »pluridisciplinarno«, uvidom iz perspektive različitih znanosti, umjetnosti, religija i sl. ${ }^{314}$ Kulturna botanika Nikole Viskovića pruža model cjelokupnog, pluriperspektivnog istraživanja ove teme. Naravno, usprkos njegovu polihistorskom interesu i znanju, nije moguće da jedna osoba široko obuhvati svu širinu i dubinu postavljenog zadatka. Metoda koju s obzirom na to Visković izabire jest obrada ove problematike na ekstenzivan način, radije »reći ponešto manje o mnogim stvarima«, negoli »reći nešto više o malom broju stvari«, čime priprema teren stručnjacima u posebnim znanstvenim područjima za produbljavanje iznesene problematike, ali "pod uvjetom da su kadri i voljni za interdisciplinarne i sintetičke uvide «. ${ }^{315}$ Već je na počeku određeno da se ovdje radi o »interdisciplinarnom znanstvenom projektu«, premda kao i kulturna zoologija nije svedena samo na suradnju odvojenih znanosti, nego uključuje i široku paletu neznanstvenih pristupa u cilju stvaranja sveobuhvatnog uvida u suodnos čovjeka i ostatka živog svijeta. Stoga ćemo, usprkos Viskoviću, njegov projekte prije označavati kao pluriperspektivne negoli interdisciplinarne ili pluridisciplinarne. Važnost ove oznake i njena prednost pred ostalim određenjima poput multidisciplinarnosti ili interdisciplinarnosti pokazat će se na kraju rada, u nalaženju metodoloških sličnosti ovih projekata s onim integrativne bioetike.

Ovdje ćemo materiju kulturne botanike izložiti na sličan način na koji smo izveli pregled kulturne zoologije. Počinjemo, dakle, od znanstvenog pristupa, koji u sebi uključuje i pojedine filozofske refleksije, zatim dajemo prikaz važnosti bilja za duhovnu kulturu, a preko materijalno-upotrebnog pristupa završavamo na tematiziranju nanošenja štete bilju, tj. stablu.

\footnotetext{
${ }^{312}$ N. Visković, Stablo i čovjek, str. 32.

${ }^{313}$ Usp. ibid., str. 48.

${ }^{314}$ Usp. ibid., str. 30.

315 Ibid., str. 33.
} 
Iako je osnovni okvir ispitivanja isti, pojedine se ovdje istaknute teme razlikuju od onih kojima smo se bavili u prikazu kulturne zoologije.

\section{II.3.1. Duhovni aspekt}

Kako se u kulturnobotaničkim spisima Visković usredotočuje na stablo, tako će se i ovaj prikaz u prvom redu baviti njime, ali neće potpuno ispustiti iz vida cjelinu biljnog svijeta, što će naročito doći do izražaja u ovom poglavlju. Očekivano je da takvo ispitivanje započne definicijama, pa ovdje započinjemo od one stabla, zapravo $o$ onoj stabla, pri kojoj Visković daje neke vrijedne upute za shvaćanje čitavog njegovog djela:

»Svaka je definicija jedan kulturni čin, izraz nekih ciljeva i nečije volje. Zbog toga je svaka definicija, pa i definicija stabla, drva ili drveća (lat. arbor), uključivši razlikovanje njih od grma (lat. frutex), s jedne strane konvencionalna - jer je uvjetovana društvenim običajima i svrhama znanstvene sistematike, a s druge strane ponešto neadekvatna - jer neizbježno pojednostavljuje svoj predmet, zahvaćajući samo najveći dio relevantne pojavnosti i zanemarujući granične slučajeve. «16

Ovdje ponovno nailazimo na probleme definicije i klasifikacije kakve smo imali i kod kulturnozoološkog razmatranja. Visković nikada ne poriče neizbježnost izvjesne mjere čovjekova antropocentrističkog nastrojstva, za što ovi problemi možda sačinjavaju najjasnije primjere. Do sličnog će zaključka, kako ćemo vidjeti kasnije, Visković doći i pri svojim etičkim razmatranjima.

Premda Visković ne želi ulaziti u pitanja botanike, klasifikacije drži izuzetno zanimljivima s obzirom na njihovu uvjetovanost praktičnim svrhama (pa bile to i znanstvene svrhe), a u tom pogledu pripadaju kulturi, tj. mijenjaju se s njezinim razvojem. Pučka razlikovanja nastaju iz različitih motivacija, no neka od njih ukazuju na važne osobine biljaka, pa ih usvajaju i znanstvenici, ali ona imaju vrijednost i kada ih botaničari ne usvajaju, s obzirom na to da mnogo govore o percepciji okoliša ljudi u izvjesnim vremenima na izvjesnim prostorima. ${ }^{317}$

Kulturna značenja koja se pridaju biljkama, naglašava Visković, tijesno su povezana i sa značenjem biljaka za čitavu biosferu. Da biosfera nije samo rezultat procesa u anorganskoj materiji, nego da ona sama bitno utječe na stvaranje vlastite anorganske osnove, najvidljivije je na primjeru biljaka, osobito stabala, koje utječu na nastajanje plodne zemlje i uvjeta pogodnih

\footnotetext{
316 Ibid., str. 56.

${ }^{317}$ Usp. ibid., str. 192, 197.
} 
za razvijanje viših oblika života, od kojih je stvaranje atmosfere među važnijima. Stvaranjem te »'placente' svih viših organizama na Zemlji«, zahvaljujući procesu fotosinteze, ne prestaje ključna uloga biljaka u biosferi. Dovoljno je još spomenuti njihovu nezaobilaznu ulogu u sprečavanju erozija tla, skladištenju i pročišćavanju vode, reguliranju klimatskih uvjeta, prehrambenom lancu itd. ${ }^{318}$

Filozofi i znanstvenici ponekad su pripisivali biljkama psihički život. Kako navodi Visković, prije aristotelovske podjele na vegetativnu, osjetilnu i duhovnu dušu, poneki su predsokratovci, primjerice Anaksimandar i Empedoklo, držali da nema načelnih razlika između tih vrsta oduševljenosti. Međutim, još su neki renesansni filozofi poput Bruna, čak i prosvjetitelji poput Maupertiusa, držali da biljke posjeduju svojevrsni psihički život. Takve predodžbe pojavljuju se i u 19. st., primjerice kod fizičara i psihologa Fechnera. Spomenuta aristotelovska tročlana podjela nije doživjela značajnije uzdrmavanje sve do evolucionističkog obrata. Međutim, ni nakon toga u znanstvenoj zajednici nisu dobro prolazile teorije poput one o živčanom sustavu i pamćenju kod biljaka biologa Bosea ili teorije Whitmana, Tompkinsa i Birda, koje su kod biljaka prepoznavale sličnu razinu kompleksnosti života. ${ }^{319}$

\footnotetext{
»Pretpostavimo li da je zaista razumno odustati od pretjeranih analogija između životinjskog psihizma i navodnog biljnog psihizma, ipak nam izgleda teško prihvatljiv stav da biljke kao živa bića na neki način ne osjećaju zadovoljstva i stradanja, a pogotovo da ni u kom slučaju nije moguće govoriti o njihovu ponašanju. Neka eksperimentalna istraživanja moći komuniciranja biljaka, osobito ona Amerikanca Davida Rhoadesa i Južnoafrikanca Woutera Van Hovena (...), podupiru drukčiji pristup i dokazuju da stabla na svoj način komuniciraju kad su napadnuta.«320
}

Sudeći po suvremenoj popularno-znanstvenoj literaturi, čini se da je Visković ovdje u bitnome u pravu. Istaknut ćemo tek neke detalje iz knjige Daniela Chamowitza Što biljke znaju, kojoj se kao pripadnoj ovom žanru obraćamo zahvaljujući našem ograničenom znanju iz botanike, a bez pretenzije da dajemo bilo kakav konačan sud po ovom pitanju. Chamowitz prepoznaje štetu koju su Tompkinsova i Birdova istraživanja prouzročila u vidu neopravdanog zaziranja znanstvenika od istraživanja ponašanja bilja. Naročito zato što se $u$ takvom istraživanju može doći do iznenađujućih, a ipak čvrsto utemeljenih rezultata. Biljke, naime, posjeduju više osjetilnih svojstava analognih životinjskima. One moraju na izvjestan način biti svjesne svog okružja kako bi preživjele. Još su Darwin i njegov sin dokazali rudimentarni vid

\footnotetext{
${ }^{318}$ Usp. ibid., str. 51-54.

${ }^{319}$ Usp. ibid., str. 23-25.

${ }^{320}$ Ibid., str. 25.
} 
kod biljaka, a pokazalo se čak i da raspoznaju boje. Iako biljke nemaju živčani sustav, postoje neki zajednički biljno-životinjski elementi, kao što je, primjerice, receptor za plavu svjetlost kriptokrom. Jedna od njegovih uloga kod biljke je koordinacija vanjskih svjetlosnih signala i unutarnjeg (cirkadijalnog) sata. Biljkama se može pripisati i nešto što je analogno njušenju, a što se može opaziti upravo u načinu na koji biljke komuniciraju, što je u prethodnom citatu istaknuo i Visković. Riječ je o feromonskim porukama zrakom od stabla napadnutog nekim nametnikom prema zdravim stablima, koja zatim pokreću vlastite obrambene mehanizme. Biljke, također, registriraju dodire, što ne znači da osjećaju bol. Možda su najbolji pokazatelj toga biljke mesožderke, u kojima je razvijena električna aktivnost. Međutim, po svemu sudeći, biljke nemaju nešto nalik sluhu, jer im je, čini se, registriranje zvukova evolucijski nepotrebno. Ipak, biljke imaju još neke začuđujuće sposobnosti, poput svojevrsnih »gravireceptora« u vršku korijena i u stabljici, a još više fascinira njihova izvjesna sposobnost pamćenja. Naime, svojevrsno pohranjivanje informacija dokazano je kod graška, kao i nešto analogno kratkoročnom pamćenju kod venerine muholovke, a osobito je zanimljivo morfogenetsko pamćenje, kod kojega podražaj utječe na budući rast biljke (tako primjerice pupoljci rastu dalje od ranjenog lista). Kod biljaka se pojavljuje i epigenetsko transgeneracijsko pamćenje, a utjecaj stresa iz okoliša na nasljedne promjene otkriće je koje u izvjesnom smislu vodi obnovi lamarkizma. Ipak, radi se o otkriću koje nije općeprihvaćeno. Naravno, kod svih tih oblika pamćenja radi se o proceduralnom, a ne o semantičkom i epizodnom pamćenju. Slijedom toga, može se kazati da biljke posjeduju anoetičku svijest. ${ }^{321}$

Međutim, i u pretjeranim, odviše antropomorfnim teorijama, Visković uviđa nekoliko vrijednih poruka:

\begin{abstract}
»Prvo, one su jedno vedro estetsko iskustvo susreta pjesničkog nadahnuća i naučne metode (...). Drugo, one su jedno pametno znanstveno iskustvo temeljne istine da je zbilja toliko nepregledna da prema njoj treba ispovijedati skromno priznanje naše nemoći shvaćanja, što onda dopušta i postavljanje maštovitih hipoteza u tom polju nepoznatog. Treće, te su ideje dobrodošlo etičko iskustvo koje potvrđuje toliko puta provjerenu moralnu i religijsku praksu da se utemeljenje i zaštita osnovnih vrijednosti, u ovom slučaju biljaka i života općenito, smije i može dostići pomoću nekih fikcija - u nedostatku drugih načina njihova utemeljenja i očuvanja. $\ll^{322}$
\end{abstract}

Stablo, tvrdi Visković, ima povlašteno mjesto u simbolotvorstvu, čemu svjedoči i prostor koji dobiva u rječnicima simbola (u pravilu najveći). Sama priroda simbola ukazuje na

\footnotetext{
${ }^{321}$ Usp. Daniel Chamowitz, Što biljke znaju. Čudesno putovanje u osjetilni svijet biljaka, prevela Aleksandra Barlović, Planetopija, Zagreb 2013.

${ }^{322}$ N. Visković, Stablo i čovjek, str. 24-25.
} 
to da ovo nije niti malo zanemariva činjenica, pošto simboli slikovito i sublimirano izražavaju zbiljske odnose i vrijednosti određenih zajednica. ${ }^{323}$

Moguće je, usprkos manjkavostima klasifikacije, istaknuti nekoliko važnih svojstava po kojima se većina stabala razlikuje od ostatka biljnog života. To su, navodi Visković, u prvom redu veličina, visina i dugovječnost. Ono je, generalno, najveće, najviše i najdugovječnije živo biće. Upravo su ta svojstva izazivala začuđenost i strahopoštovanje kod arhaičnih ljudskih zajednica, koje je s vremenom sve više blijedilo. Nije, stoga, čudno što su stablu bila pridavana značenja magičnoga, vječnoga, mudroga, svetoga i transcendentnog, pa tako imamo snažne simbole kozmičkog stabla, stabla života, stabla spoznaje i sl. ${ }^{324}$

Biljke se generalno usko vežu uz predstavu samog života. Visković ističe sve aspekte te predstave, koji se očituju u plodnosti (pri čemu osobitu vrijednost ima cvijet koji uz ovu ideju vezuje život, užitak i ljubav), ritmu godišnjih doba i sveopćeg kružnog, obnoviteljskog životnog poretka, rađanja i smrti, ljekovitosti i besmrtnosti. ${ }^{325}$

»Biljka je najneposredniji temelj svakoga života - spoj sunca, zraka, zemlje i vode koji održava sva bića na Zemlji. Svojom silnom proizvodnjom tvari, koja se u beskonačnost ponavlja izvornom snagom prirodnih procesa, ona izaziva simboličke slike rodnosti, erotske moći i ljubavi, te odatle ona sveprisutna vjerovanja o biljnim afrodizijacima, o magičnim moćima biljke da spaja muškarca i ženu, o 'stablu života' i 'stablu spoznaje' koji fizički i duhovno rađaju čovjeka.«326

Ovdje se ne smije zanemariti bogato životno, organsko obilježje koje se pridaje znanju kao onome što čovjeka »duhovno rađa«, a upravo je takav sintetički i harmonični pristup promatranju duhovnog i organskog nešto čemu Visković stalno teži, ili bolje: što s lakoćom izlazi iz njegova bogatog stila. Osobit je upravo ovaj obrat klasične (također znakovite) metafore o porađanju znanja, koju najslikovitije opisanu nalazimo kod Sokratove majeutičke metode, inspirirane primaljskom vještinom.

Nije, stoga, čudno što su stari Grci, koji su gajili bitno bogatiji senzibilitet spram života i prirode od naših suvremenika, filozofske škole osnivali u vrtovima, pri čemu Visković navodi poznati primjer peripatetičkog učenja u Akademovu gaju, zatim vrt kao mjesto za Epikurovu i

\footnotetext{
${ }^{323}$ Usp. ibid., str. 294.

324 Usp. ibid., str. 57-60.

${ }^{325}$ Usp. ibid., 296-298.

${ }^{326}$ Ibid., str. 296-297. - »U tradicionalnoj kineskoj misli stablo i drvo imaju najviša simbolička značenja. Śtoviše, jedinstvena je osobina kineske filozofije, po kojoj se ona znakovito razlikuje od zapadnjačke filozofije toliko udaljene od prirode, poimanje drva kao osnovnog elementa svijeta - uz vodu, vatru, zemlju i metal. Radi se uistinu o jednostavnom i dubokom uvidu da je drvo sinteza zemlje, vode, zraka i sunčeve vatre: zemlje koja ga hrani mineralima, vode koja ga napaja od korijena do krošnje, zraka koji mu daje kisik i ugljik, vatre koja je životodarno sunce i skrivena potencija drva.« (Ibid., str. 332.)
} 
Teofrastovu školu, kao i Sokratovo ukazivanje na prikladnost sjene platane za filozofiranje u Platonovu Fedru. Vrt, šuma i prisutnost stabla uopće podrazumijevaju se kao adekvatan ambijent za filozofiranje i meditaciju, što se ogleda u tvrdnji svetog Bernarda da od bukava i hrastova nema boljih učitelja, u smokvi pod kojom Buddha doživljava prosvjetljenje ili u jabuci koja potiče Newtonovo znanstveno prosvjetljenje. Trajnost i struktura stabla neodoljivo ukazuju na ideal formiranja znanja. Poznata je Descartesova metafora o ustroju filozofije i znanosti kao stabla, kao i Porfirijevo stablo koje u toj biljci nalazi idealan nacrt za logičko uređenje misli. S druge strane, nedostatnost stabla, kao slike jednosmjerne, hijerarhijske sistematizacije znanja, dokazana je u postmodernoj misli Deleuza i Guattarija, pa je ono zamijenjeno modelom podzemne biljke, rizome, kako bi se ukazalo na pružanje znanja u mnoštvu pravaca. Na tu se ideju pozivaju i suvremeni ekologisti i antiglobalisti. ${ }^{327}$

Dugovječnost stabla i njegova »uspravnost što asocira na uzlet duhovnosti« pridaju mu, zaključuje Visković, simbole svjedočanstva, pamćenja i znanja. Ne radi se tek o mitološkim predodžbama, nego i o nekim suvremenim sasvim konkretnim osnovama za ovakve predstave, poput »svjedočenja« godova debla o klimatskim promjenama na Zemlji. Pored navedene osnove za predočavanje logičkog sistema, genealoško stablo pruža sistematičan uvid u historiju familije, a i u znanstvenom se klasifikacijskom stablu razlikuju pojedine znanstvene grane. ${ }^{328}$

\section{II.3.1.1. Antropomorfizam i fitomorfizam}

Antropomorfizacija biljaka i fitomorfizacija ljudi znatno je manje zastupljena u ovim odnosima nego u relaciji čovjeka i životinje, što je razumljivo s obzirom na bitno veću bliskost u potonjem odnosu. Konačno, čovjek je po svom bitnom određenju životinja, a ne biljka, iako postoje važna svojstva koja s njome dijeli, poput rasta ili razmnožavanja, ali i života samoga. Ako ljudski potencijali uslijed izostanka kulture ostanu neostvareni, tada je to biće de facto životinja, ali ne i biljka. Čak je i nazivanje određenih nesretnika biljkama, kao jedan od danas najčešćih oblika fitomorfizma, pogrešno, jer biljke za razliku od njih posjeduju neke bitne razlike, poput autotrofnog hranjenja, čak se i uspješnije kreću, a u svakom slučaju samostalnije žive.

\footnotetext{
${ }^{327}$ Usp. ibid., 635-638. - Deleuze i Guattari zapadnjačkim stabljikastim filozofskim sistemima suprotstavljaju i sljedeću sliku: »Istok pokazuje drukčiji lik: više odnos prema stepi i prema vrtu nego odnos prema šumi i polju; poljodjelstvo gomolja (...)« (Citirano prema: ibid., str. 684.)

${ }^{328}$ Usp. ibid., str. 309-310.
} 
Pa ipak, antropomorfizacije biljaka, tj. stabala i fitomorfizacije čovjeka nije nedostajalo u ljudskoj kulturi. Primjerice, La Mettrie u kratkom djelu znakovita naziva Čovjek biljka nabraja i fitomorfno izražava izvjesne analogije između jednog i druge. ${ }^{329}$ Fitomorfizacija svoj izvor nalazi i u mnogim, nerijetko na prvi pogled neuočljivim, asocijacijama između čovjeka i stabla. Kako navodi Visković, uspravnost i složenost (razvedenost) stabla adekvatne su čovjekovoj fizičkoj uspravnosti i duhovnoj složenosti (razvedenosti). Tako indijska tradicija rast ljudskog tijela promatra $\mathrm{u}$ analogiji s biljkom (stablom), $\mathrm{s}$ tom razlikom da je korijen biljke dolje, a čovjeka gore. Blisku vezanost čovjeka i biljke potvrđuju slični ili isti sanskrtski izrazi za ljudske i biljne dijelove. ${ }^{330}$ Zorni prikaz te poveznice možemo uočiti iz jedne upanišade:

»Kao stablo koje natkriljuje šumu, takav je doista i čovjek:

kose su mu lišće, a koža kora.

Pod kožom kola krv, a pod korom sok.

Zato iz rane teče krv kao sok iz zasječena stabla.

Meso mu je unutarnja kora, a živci vlakna.

Kosti su mu unutarnje drvo, a srž kosti ko srčika biljke.

Posječeno stablo ponovno izraste iz korijena.

A iz kojeg korijena dalje raste smrtnik kada ga presiječe smrt? «331

Fitomorfne metafore objašnjavaju čitav čovjekov životni krug, češće i efektivnije negoli one zoomorfne, od porijekla (loze), preko rođenja, rasta, umiranja pa do smrti, kako to oslikava i navedena upanišada. Prema Viskoviću, čovjek je kao i stablo u svojoj mladosti zelen, snažne je ili slabe građe, razgranat ili kržljav, plodan ili jalov. Takve metafore oslikavaju i odgojni proces u kojem se »drvo savija dok je mlado«. Također, vrline se ukorjenjuju, a poroci iskorjenjuju, a ta oznaka ima značenje i u pogledu pripadnosti pojedinca tradicijskom tlu odnosno odmetništvu od njega. Mnogi mitovi govore o nastanku čovjeka iz stabla, a narodne uzrečice fitomorfnim slikama opisuju uvjetovanost njegova podrijetla (npr. »jabuka ne pada daleko od stabla $\ll) .{ }^{332}$

Osim što stablo, naglašava Visković, često vrijedi kao simbol jedinstva i vječnosti prirode, u obličju kozmičkog ili stabla života, ono je »kao biće silne i antropomorfne

\footnotetext{
${ }^{329}$ Usp. Julien Offray de La Mettrie, »Čovjek biljka (1748.)《 u: Julien Offray de La Mettrie, Čovjek stroj / Rasprava o duši / Čovjek biljka, preveo Josip Balabanić, ArTresor naklada, Zagreb 2004., str. 255-279, ovdje str. 255-267.

${ }^{330}$ Usp. N. Visković, Stablo i čovjek, str. 67-68. - Ovdje se Visković poziva na Rawsona i Afanaseva.

${ }^{331}$ Ibid., str. 68.; Čedomil Veljačić, Razmeđa azijskih filozofija, sv. 1, Sveučilišna naklada Liber, Zagreb 1978. str. 136.

${ }^{332}$ N. Visković, Stablo i čovjek, str. 68-69.
} 
uspravnosti i složenosti« protagonist brojnih antropogenih mitova, čovjekov predak koji se nerijetko metamorfozom ponovno vraća u stablo. Također, drveća se vežu uz čovjekovo rađanje i posmrtni život, primjerice tako da u njih ulaze duše pokojnika. Konačno, pojedine se vrste shvaćaju kao muška ili ženska bića, a ponegdje se stabla i vjenčaju, kako međusobno, tako i s ljudima. ${ }^{333}$

Visković se znatno manje direktno osvrće na antropomorfizaciju biljaka, za što jedan od razloga leži i u znatno manje značajnim praktičkim posljedicama tog kulturnog čina. To pak ne znači da po njih pogubnih posljedica nije bilo. Prije opisano kažnjavanje životinja imalo je svoju paralelu i u slučaju biljaka koje ne daju ploda, potaknuto pojedinim mjestima iz Svetog pisma. ${ }^{334}$ Antropomorfizacija stabla pripisuje se i jednom njegovu stanju koje je posljedica njegova kažnjavanja, naime, kako sam Visković izvan ovog konteksta primjećuje, stabla u gradovima ponekad nazivamo »stresiranima $\ll^{335}$ - kažnjenima u tom okružju, dakle, na isti način kao i čovjek.

Međutim, puno češće nailazimo na afirmativna fitomorfna i antropomorfna oslikavanja duboke povezanosti čovjeka i biljaka, naročito u arhaičnoj svijesti. Tako, primjerice, »Frazer izvještava kako su u plemenu Dieri u Australiji o poglavici totema, što se sastojao od jedne posebne vrste sjemena, njegovi ljudi govorili kao da on jest sama biljka koja daje to sjeme. «336

»Upadljivo je, premda u literaturi ipak nedovoljno zamijećeno, da u mitovima, legendama, pričama, bajkama i u svakodnevnom iskustvu stablo veoma rijetko ima negativno značenje - kao nevoljeno, nesretno ili zlo biće, kao arbor infelix i arbor mala, te da je ono redovito jedno sretno, prijateljsko i voljeno biće, arbor felix i arbor bona. To je još jedna potvrda velikih razlika (...), ali ovoga puta u prilog drveća, između naših percepcija životinja i stabala. Posljedica je to činjenice da je gotovo svako stablo čovjeku mnogostruko korisno, a veoma rijetko po bilo čemu štetno.«337

Da je stablo generalno obilježeno pozitivnim svojstvima svjedoči i etimološka osnova pojedinih riječi u mnogim indoeuropskim jezicima:

»Također je znakovito da iz [pretpostavljene indoeuropske] praosnove *dorw-potječu izrazi koji u nekim jezicima označavaju pozitivna prirodna i psihička svojstva čvrstoće, snage, zdravlja, hrabrosti i vjernosti

\footnotetext{
${ }^{333}$ Usp. ibid., str. 306-308.

${ }^{334}$ Usp. E. P. Evans, Životinje pred sudom, str. 12-13.

${ }^{335}$ Usp. N. Visković, Stablo i čovjek, str. 712.

${ }^{336}$ E. Cassirer, Ogled o čovjeku, str. 113.

${ }^{337}$ N. Visković, Stablo i čovjek, str. 310-311. - Fitonimi su tako, navodi Visković, u toponomiji nešto prisutniji od zoonima. U tom pogledu nam mogu puno toga reći o prirodnoj prošlosti, ali i o materijalnoj i duhovnoj kulturi pojedinih predjela. Slično vrijedi i za prisutnost biljaka, a naročito stabala, u antroponimiji. (Usp. ibid., str. 190190.)
} 


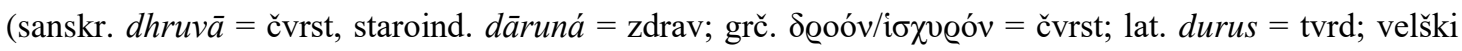
$d r u d=$ hrabar; gotski triggwa $=$ istinito; starogermanski trūen $=$ vjera; eng. trust $=$ povjerenje itd.), a što su sve svojstva što se pripisuju i drveću $(. ..) \ll^{338}$

Ne treba, stoga, čuditi ni učestalo kulturno vezivanje stabla uz nadnaravno, što osobito oslikava starogermansko jezično jednačenje stabla i vjere.

\section{II.3.1.2. Mit i religija}

U pogledu simbolizacije vegetativnog, interesantan je, kako pokazuje Visković, primjer smjene vladavine grčkih božica majki muškim bogovima i vrijednostima (tehnikama ratovanja, proizvodnje i vladanja). Tako novom suverenu Zeusu biva posvećen hrast njegove majke Reje, dok se Posejdonu posvećuje jasen Zeusove pomajke Adrasteje. Riječ je o najvrjednijim grčkim stablima po pitanju graditeljstva i naoružanja. No grčkim se bogovima nerijetko posvećivalo i drugo drveće i bilje (maslina Ateni, šipak Heri, lovor Apolonu, loza i bršljan Dionizu, topola i vrba bogovima podzemlja i sl.), što pak predstavlja simboličke tragove »nekadašnjih bitno vegetativnih funkcija helenskih nebesnika«, a slučaj nije drugačiji ni u svim ostalim arhaičnim mitovima. Tako su i egipatski Izida i Oziris, na mit o kojima se Visković osvrće putem Plutarhova djela (koji ga, što je zanimljivo s obzirom na gore rečeno, promatra kao vjersko zastranjenje), prvenstveno sile biljnog života. Oziris se, štoviše, može tumačiti i kao »izvorno bog-stablo«, kako to radi J. H. Philpot. ${ }^{339}$

Impresivnost, vitalnost te zahvalnost i strahopoštovanje spram stabla, naglašava Visković, često rezultira njegovim simboliziranjem besmrtnosti, vječnosti ili ciklusa ponovnih rađanja. Besmrtnost se pak ne veže isključivo uz vazdazelena drveća. Tako u Kini breskva predstavlja izvor besmrtnosti bogova, a u europskim se mitovima kao simbol vječnosti provlači jabuka. Stabla su također često simbol svetoga, što se posebno odnosi na šume, s obzirom na to da njihova tajnovitost, visina debala te »lukovi njenih hvoja neodoljivo podsjećaju na hram«. Nije slučajno da su zelene grane i cvijeće oduvijek prisutni u vjerskim obredima, zahvaljujući mirisima kao predstavi čistoće i puta u svetost, što sve zajedno stablo klasificira kao numiozno biće. Ne čudi, stoga, što gotovo sve vjerske tradicije imaju rajske vrtove. ${ }^{340}$

Stablo je u Bibliji, navodi Visković, mjesto ljudske sudbine, počevši od stabla života i stabla spoznaje dobra i zla u Edenskom vrtu. Preplitanje simbolike koju nosi kušanje plodova s

\footnotetext{
${ }^{338}$ Ibid., str. 107.

${ }^{339}$ Usp. ibid., str. 299-301, 304-306.

${ }^{340}$ Usp. ibid., str. 308-309, 312.
} 
potonjega, kojim započinje čovjekov izgon iz raja, tj. istočni grijeh, ovdje je osobito zanimljivo. Spoznaja u biblijskom jeziku ima isto značenje kao i spolni čin (što je slučaj u više jezika: sanskrtu, grčkom, francuskom), pa zabrana jedenja plodova s tog stabla označava kako zabranu slobodnog moralnog rasuđivanja, tako i nesputanog spolnog užitka, premda eden na hebrejskom znači užitak. Upravo će zmija, kao simbol plodnosti i mudrosti, nagovoriti prve ljude da se usprotive Jahvinoj zapovijedi. ${ }^{341}$

»Taj falusoidni gmaz je sama čovjekova 'grešna' težnja da ovlada spolnim zadovoljstvom i 'ohola' želja, koju nose Prometej i Buda, Odin i Faust, za potpunom slobodom i sveznanjem. Zmija napasnica je uistinu moć i izazov samoostvarenja čovjeka kao bića slobode. $\ll^{342}$

Visković naglašava da su dvije životinje osobito simbolički vezane uz stablo: ptica i zmija, prva kao »viša«, biće duhovnog svijeta, druga kao »niža«, biće mračnog, nagonskog svijeta - što ističu mnogi autori, kao što su A. J. Vensinck, J. Fergusson, J. W. Locher itd. Zanimljivo je da su zmija i stablo, usprkos mnogim sličnostima i poveznicama (primjerice, presvlačenja kože i mijenjanje lišća i kore kao znameni besmrtnosti), najčešće u vrijednosnom i simboličkom antagonizmu. ${ }^{343}$

»Voda i vatra, te ptica i zmija, antagonizirani su parovi sila. Pa ipak, njihovo srodstvo sa stablom potvrđuje istinu koju mitovi nose: da stablo kao coniunctio oppositorum sjedinjuje sve te suprotnosti, upravo onako kao što drvo sjedinjuje osnovne elemente svijeta. Zato se stablo toliko često i simbolički snažno poima kao neposredni izraz ili središte kozmičke cjeline. Zbog toga se i religijski obredi žrtvovanja i pročišćenja izvode u spoju vatre, vode i bilja - izgaranjem zelenih grana na oltarskoj vatri i posipanjem vode, ulja ili vina na vatru ili na vjernika, dok je žrtvena ptica uzor duševne čistoće. « ${ }^{344}$

\footnotetext{
${ }^{341}$ Usp. ibid., str. 342, 476.

${ }^{342}$ Ibid., str. 342. - Zmiju je kao simbol slobode promatrao i Augustin. Kako Predrag Krstić piše: »U kontekstu ove teološko-ideološko-realcrkvenopolitičke borbe s liberalnijim herezama svoga doba koje su, ovako ili onako, zastupale slobodu, on je upravo zmiju promovirao u onu sablasnu kreaturu koja u Knjizi postanka simbolizira njenu nepoželjnu iluziju. Ljudskim bićima naprosto nije dana slobodna volja: ni u kom pogledu nikada nije bilo namijenjeno čovječanstvu da bude slobodno, već nam je Bog dopustio da griješimo da bi nam na osobnom iskustvu bilo dokazano da 'naše stvarno dobro jest dobrovoljno ropstvo'.« (P. Krstić, Filozofska životinja, str. 14.)

${ }^{343}$ Usp. N. Visković, Stablo i čovjek, str. 323-324, 467.

${ }^{344}$ Ibid., str. 325. - »Antagoniziranje stabla i zmije moglo bi biti i izraz patrijarhalnog potiskivanja ženskih moći, koje narod često vezuje uz zmijsku rodnost, dok ih patrijarhalna ideologija prokazuje kao demonske moći grijeha i krađe besmrtnosti u likovima velikih božica majki, Innane i Eve. Da je takvo suprotstavljanje 'ideološko' pokazuje i to što postoje sretniji doživljaji i posve drugačije simbolizacije zmija: kineski, indijski, meksički i drugi mitovi, te pučke bajke, govore o mudrim i solarnim zmijama koje na ljudska dobročinstva uzvraćaju savjetima, liječenjem i darovima rodnosti i blaga.« (Ibid.) - U judeo-kršćanskoj tradiciji, zmija je označena kao sotonsko, od Boga prokleto biće, kao što biva i od nje zavarana Eva: »u mukama ćeš rađati, žudnja će te mužu tjerati i on će gospodariti nad tobom« (N. Visković, Kulturna zoologija, str. 258, 261). Ova biblijska slika povezuje u sebi sve elemente koji se čine problematičnima u predstavi zmije, a s obzirom i na njeno simboličko obilježje plodnosti i žene. U isti mah prokletima bivaju i zmija i žena, i to na račun u osnovi pozitivnih svojstava: dok za ženu prokletstvo postaje plodnost, za zmiju »vrlo funkcionalan način kretanja postaje u Bibliji kaznom: 'po trbuhu svome puzat ćeš i zemlju
} 
Pučka predaja, navodi Visković, stvorila je eshatološku legendu o jedinstvu edenskog stabla i Kristova križa, tj. stabla života. Tako Isus, kao novi Adam, vraća na jednom drvu besmrtnost koju su ljudi izgubili na drugom. Njegov križ u srednjovjekovnoj ikonografiji ponekad ima upravo oblik stabla. ${ }^{345}$

Štovanje drveća u vrijeme stjecanja prevlasti od strane kršćanstva u Europi bilo je, tvrdi Visković, toliko snažno da su kršćanske vlasti ulagale mnogo napora da se ono suzbije, naravno, i direktnom sječom svetog drveća. No koliko je god srednjovjekovnim kršćanima šuma predstavljala prostor zvijeri i sastajalište vještica, ona je sačuvala svoju svetu ulogu u vidu boravišta isposnika. Pored toga, kršćanstvo je ponekad radilo ustupke u pogledu prihvaćanja nekih pučkih običaja štovanja stabla ili podizanja hramova na mjestima poganskih svetišta. ${ }^{346}$

Na Zapadu je, naglašava Visković, kao božansko i kraljevsko stablo (čemu se kod životinja paralela može naći u orlu i lavu) osobito važio hrast. To ne čudi s obzirom na njegovu robusnost (latinski naziv hrasta lužnjaka upravo je Quercus robur), izdržljivost, starost, uopće »dostojanstven lik«, a konačno i na vrsnoću njegova drva. Upravo se hrast u indoeuropskim religijama tako posvećuje vrhovnim nebesnicima ili gromovnicima (s obzirom na to da se »munja rado druži s hrastom i s gorskim visovima«), poput slavenskog Peruna, grčkog Zeusa, baltičkog Perkunasa, germanskog Thora itd. ${ }^{347}$

Naravno, diljem Zemlje postoje pojedina stabla ili šume uz koje se vežu brojni mitovi, a ovdje se, zbog ograničenosti prostora, osvrćemo samo na nekoliko primjera od pregršt onih koje Visković nudi u Stablu i čovjeku. Tako je u Mezopotamiji, odakle dobivamo prve informacije o stablima života kao izvorima plodnosti i kozmičkim stablima kao okosnicama svijeta, osobito zanimljivo stablo Huluppu, koje na obali Eufrata stoji od stvaranja svijeta. ${ }^{348}$

»Priča o stablu Huluppu ima mnogo zajedničkog s kasnijim hebrejskim mitom o Edenu, vrtu sa stablima života i spoznaje. U oba slučaja stablo je prvotno biće stvaranja, ono daje spoznaju spolnosti i oko njega se odvija temeljni odnos žene i muškarca. S tom važnom razlikom što u sumerskom mitu tjelesna ljubav kao sveti pokretač plodnosti pobjeđuje zmiju i Lilith, dok u hebrejskom Edenu pobjedu odnose zmija ili demonska Lilith, izazvavši tjelesnu ljubav kao grijeh i prokletstvo - što je promjena značenja koja potječe od patrijarhalne naravi biblijske poruke. «349

\footnotetext{
jesti svega života svog', a uz to će joj ljudski rod 'glavu satirati, a ti ćeš mu vrebati petu' (Post 3,15) «. (Ibid., str. 258.) Njihovo zajedničko prokletstvo upotpunjeno je gospodstvom čovjeka-muškarca nad objema.

${ }^{345}$ Usp. N. Visković, Stablo i čovjek, str. 323-354.

${ }^{346}$ Usp. ibid., str. 315-316.

${ }^{347}$ Usp. ibid., str. 368.

${ }^{348}$ Usp. ibid., str. 325-328.

${ }^{349}$ Ibid., str. 328.
} 
U Kini se, piše Visković, a jasno je s obzirom na proizvodne potrebe, osobito štuje dud Fu sang mu, kao kolijevka sunca i hermafrodit koji prethodi podjeli jina i janga, onda i stablo na kojem se sunce također odmara, breskva besmrtnosti Ruo mu, konačno i okosnica svemira, stablo obnove Jian mu. Indijsko, izokrenuto kozmičko stablo, za koje vedski tekstovi govore da povezuje nebo sa zemljom, naziva se Ašvattha. Pomoću njega božanska se energija materijalizira u svijetu, dok se, s druge strane, materijalno ponovno uzdiže u duhovnost. U židovskoj Kabbali postoji pak i sasvim fantastično, apstraktno mitološko, nevezano uz posebnu vrstu, poput Ašvatthe izvrnuto stablo sefirota. ${ }^{350} \mathrm{U}$ ovom je pogledu osobito interesantna sljedeća činjenica:

»Ma koliko bila silna simbolika stabla, a obično i dublja od simbolike drugih biljaka i životinja, u mitskoj, književnoj i folklornoj tradiciji je ipak upadljivo manje fantastičnih stabala u usporedbi s fantastičnim životinjama. (...) možda je to tako i zbog činjenice što su stabla već sama po sebi dovoljno čudesna da im ne treba pridavati neke nove maštovite atribute. « ${ }^{351}$

Dio te čudesnosti svakako čini i njihova ljepota, kojoj se Visković posvećuje više nego ljepoti životinje, s obzirom na nešto širi dijapazon ljudskog stvaralaštva po tom pitanju.

\section{II.3.1.3. Ljepota i ostale estetičke kategorije}

Premda Visković ljepoti stabla pridaje čitavu glavu unutar Stabla i čovjeka, on naglašava da se tu ne radi o estetičkoj raspravi. Uostalom, kako kaže referirajući na Nietzscheovu raspravu o apolonijskom i dionizijskom, ljepota ne predstavlja jedinu estetičku kategoriju ili vrijednost. Na ovoj razini razmatranja ističe tek da su »lijepo i druge estetske vrednote ono što nam se u nekom predmetu sviđa i što nas od njega zanosi nezavisno o njegovoj moralnoj ili ekonomskoj vrijednosti«, što drži bliskim Kantovu određenju. Njegov je cilj naprosto iznijeti i opisati svojstva stabla ili šume koja pobuđuju estetske doživljaje: lijepo, uzbudljivo, dramatično, uzvišeno, izražajno, čudesno, radosno itd. ${ }^{352}$

Stablo se kao predmet estetskog doživljaja pojavljuje u tri situacije:

»a) stablo u 'čistoj', 'divljoj' prirodi,

\footnotetext{
${ }^{350}$ Usp. ibid., str. 333-334, 336, 360.

${ }^{351}$ Ibid., str. 319. - Ovdje se Visković referira i na razloge većeg posvećivanja pažnje životinjama nego biljkama, a na koje ćemo se osvrnuti kasnije.

${ }^{352}$ Usp. ibid., str. 537.
} 
b) stablo u vrtlarski obrađenoj prirodi,

c) stablo u umjetničkom, likovnom i književnom djelu. «353

Ad a) Prva situacija, tvrdi Visković, temeljna je u odnosu na ostale dvije i predstavlja njihov predmet. Ona odaje primarna ili neposredna estetska svojstva stabla, a lijepo u prirodnom doživljavamo prije i neovisno o njegovom umjetničkom prikazivanju, no to opet ne znači da umjetničko posredovanje ne utječe na doživljaj prirodne ljepote. Ova svojstva nalazimo na samom stablu, ali i onda kad je pod utjecajem drugih pojava (tmina, mjesečina, vjetar, svjetlost, sjena, magla, kiša, mraz, snijeg itd.). Primamo ih uglavnom vizualno, ali i posredstvom sluha, mirisa i dodira. Stablo draž dobiva i od životinja koje ga nastanjuju konačno, ptice predstavljaju izvor zvučne ljepote šume. ${ }^{354}$

Po općoj ocjeni, navodi Visković, stabla zadivljuju već svojom organskom cjelinom, izuzetnim dimenzijama, složenošću i uspravnošću, kao cjelina »moćnog stupa, pruženih krakova i pokretne mase lišća«. Stabla su po liku piramidalna, šiljasta, stupasta, globulozna, kišobranasta, čupasta, elegantna, ali i ona nepravilna su dojmljiva. Potonje potvrđuju najmaštovitiji izrazi koje stalni udari vjetra daju stablima, za što kao sredozemni primjer mogu poslužiti »grčevita iskrivljenost smokve i masline «. ${ }^{355}$

»Kad nam po svemu dragi M. Kišpatić kaže (Iz bilinskog svieta, Zagreb, 1884, III, str. 199) da maslina, grbava i nepravilna, 'nije ni najmanje lijepo stablo', onda je to možda jedan sud iz akademske građanske estetike s kojom se ne može složiti ona osjećajnost koja u maslini i smokvi nalazi omiljene predmete slikarskog (van Gogh, Ignjac Job) i općeg estetskog doživljaja. Taj sud nije u skladu ni s tradicijom sredozemnih vrijednosti, koja cijeni 'divnu maslinu u dolini' (Sir 24, 14). 'Provansa je slikarski raj i njeno stablo, maslina, stablo slikara', kaže A. Huxley (...)« «56

Ljepotu stabla, nastavlja Visković, sačinjavaju i složenost i raznolikost strukture svakog od njegovih elemenata, raznih oblika debla, tekstura kore, rasporeda listova i nebrojenih oblika cvatova i plodova. Osobito je dojmljivo jedinstvo tvrdoće i starosti drvenih dijelova stabla te mekoće i mladosti lišća, cvjetova i plodova. Zanosna su i raznobojnost i mijene boja različitih dijelova stabla. Usprkos dugovječnosti, mijena prožima sve osobine stabla, a čak i njegova polagana smrt izlaže njegovu »golu i ponekad elegantnu i moćnu arhitektoniku«. ${ }^{357}$

\footnotetext{
353 Ibid., str. 538 .

${ }^{354}$ Usp. ibid., str. 538-539, 543-544.

355 Usp. ibid., str. 539-540. - »Uredni i melanholični izgled smreke možda ima za posljedicu da engleska riječ spruce znači istovremeno i 'smreka' i 'dotjerano'.« (Ibid., str. 540.)

356 Ibid., str. 654-655.

${ }^{357}$ Usp. ibid., str. 540-542.
} 
»Pokraj toga, razumije se, postoji i odnos uzajamnog uzdizanja između stabala i ljudskih tvorbi kakve su građevine, skulpture i umjetno osvjetljenje. Volumen zgrade i visoki zid naglašavaju siluetu svakog stabla koji uz njih stoji, poput one piramidalne primorske somine (gluvača, Juniperus phoenicea) kraj atenskog Partenona. Rimska palača Barberini i ladanjski dvorac Wilton house u Wiltshireu ističu plastičnu snagu cedrova iz njihovih perivoja. Klaustar i mramori iz Museo Nazionale Romano savršeno uokviruju tamne čemprese koje je tu navodno zasadio Michelangelo. Isto tako, volimo vidjeti smokvu i bršljan kako grle ruševine. Hortikulturni arhitekt Humphry Repton tvrdio je da četinjače odgovaraju klasičnim zgradama a zaobljene krošnje listača gotičkim zdanjima. No to je već tema što izlazi iz estetike prirode i pripada estetici umjetnog i umjetničkog.«358

Ad b) Na pola puta između estetike prirodnog i umjetnog stoje rezultati vještine i umjetnosti vrtlarstva. Vrt je »spoj prirode s estetskim i tehničkim djelom, a u mjeri u kojoj taj preobražaj utječe na percepciju šireg prirodnog i urbanog prostora on je još i dio krajolika. (...) Zadovoljstva koja vrt daje višestruka su: estetski i simbolički doživljaji, ekonomska korist, iskazivanje moći (status symbol), razonoda i odmor, druženje u ugodnom ambijentu i radost promatranja života«. ${ }^{359} \mathrm{U}$ pogledu jednog širokog sagledavanja onoga estetskog prisutnog u vrtu, Visković kritizira Kantove i Hegelove analize vrtlarstva, iako je priklonjeniji stavovima prvoga:

»I. Kant u Kritici rasudne snage (...) određuje vrtlarstvo kao umjetnost najbližu slikarstvu, budući da je ovo 'umjetnost lijepa prikazivanja prirode', a vrtlarstvo 'umjetnost lijepa sastavljanja njenih produkata'; takvo je određenje uglavnom točno, no problematično je mišljenje da je vrtlarstvo kao 'lijepo sastavljanje tjelesnih stvari dano samo za oko, kao slikarstvo', jer vrt se percipira, za razliku od slike, i nosom (biljne arome), i uhom (glasanje ptica, šum vode i vjetra), i kožom (svježina od bilja i voda), čak i okusom, ako se posegne za kojim plodom - te je stoga doživljaj prirode u vrtlarstvu neusporedivo potpunije i svestranije nego li u slikarstvu i bilo kojoj drugoj umjetnosti. Za razliku od Kanta, koji visoko cijeni umjetnost vrtlarstva, Hegel vrtlarstvo ne ubraja u pet 'pravih umjetnosti', već o njemu kaže da je 'nesavršena umjetnost' i samo ga usputno spominje u svojoj Estetici - dosljedno svom shvaćanju, toliko dalekom našem senzibilitetu, da 'ideal predstavlja u sebi savršeno lijepo, dok je priroda nesavršeno lijepa' (a vrt je očigledno toliko prepun prirode!) (...) « ${ }^{360}$

Višefunkcionalnost, raznovrsnost njegovih fizičkih sastojaka i činjenica da je vrt »uistinu pravi mikrokozmos prirode i kulture« ukazuju na potrebu njegova interdisciplinarnog

\footnotetext{
${ }^{358}$ Ibid., str. 544

${ }^{359}$ Ibid., str. 545.

${ }^{360}$ Ibid., str. 656.
} 
shvaćanja, a uloga tehničkih znanja vrtlarstvo čini najsličnijim arhitekturi, »jer se arhitektura dovršava vrtom a vrt se arhitektonski oblikuje«. ${ }^{361}$

\footnotetext{
»Biološka, estetska i simbolička snaga stabla zaista je temeljni činilac ove iluzije savršena svijeta, tj. one bitno umjetne i krhke konstrukcije od bilja, vode, svjetla, boja, mirisa, hlada i mira, koju ljudska čežnja za ljepotom, ljubavlju, obiljem, zdravljem i dokonošću (otium) traži i pronalazi u vrtu kao idealizirane prirode, izgubljena raja ili utopije zlatnoga doba. (...) Posvuda u svijetu vrtlarstvo (hortikultura) stvara iluzije božanskih paradeisos, savršenog Edena, nebeskih Elizejskih poljana i divlje veselih Arkadija pomoću zelenih, cvjetnih, voćnih i sjenovitih gajeva, s čistim vodama i svakovrsnim životinjama, gdje čovjek konačno može pronaći predah blažene sreće. (...) K tome se od Sumera do Rima to mjesto užitka i plodnosti neizbježno vezuje i za spolnost, pa su mu onda božanski zaštitnici Inanna, Aštarta, Adonis, Prijap, Faun, Venera i Flora. Svako stvaranje vrta možemo tumačiti kao novi pokušaj Genesisa, stvaranja svijeta, u dimenzijama jednog mikrokozmosa ljepote, obilja i užitka.« ${ }^{362}$
}

Pored toga, tipovi vrtova kroz historiju, naglašava Visković, kao malo što govore o načinu čovjekova odnosa spram prirode. Tako su se kineski vrtovi, zahvaljujući budističkim i taoističkim shvaćanjem jedinstva čovjeka i prirode, odlikovali minimalnim nasiljem nad prirodom, pa ti vrtovi nemaju geometrijsko oblikovanje, simetriju i predvidljivost kakvu imaju oni srednjoazijski ili europski. Slično vrijedi i za japanske vrtove, čije se neformalističko oblikovanje može pripisati utjecaju šintoizma i budizma. Europski su vrtovi najviše umjetničke dosege postigli u razdoblju od renesanse do kraja vladavine plemstva. Tada se ne teži oponašanju prirode, već se ona koristi gotovo kao puka materija, oblikuje se strogo geometrijski i upotpunjuje s toliko umjetničkih artefakata kakvih ni u jednom drugom vremenu u hortikulturi nije bilo. Tek se u 18. st. događa »jedan od najdubljih estetskih i etičkih obrata u povijesti vrtlarstva« s engleskim neformalnim ili pejzažnim vrtom (landscape garden), koji se uskoro širi izvan Engleske, a čime se poziva na vrtlarstvo koje poštuje i oponaša prirodu te napušta pejorativno shvaćanje šume kao simbola barbarstva ili ekonomskog resursa. Ovom je obratu, među ostalim, kumovala promjena osjećajnosti europskog čovjeka spram prirode, u vidu nalaženja paralele između tiranije nad ljudima i prirodom, $\mathrm{tj}$. u uvjerenju da se »slobodan čovjek mora emotivno i razumno uskladiti sa slobodnom prirodom«, kako to opisuje Keith Thomas i kako se može iščitati iz Rousseauove filozofije. Naravno, razlike stilova vrtnih tvorevina također su rezultat geografske sredine, kulturnog sustava, ljudskih potreba i društvenih odnosa

\footnotetext{
${ }^{361}$ Usp. ibid.

362 Ibid., str. 546-547.
} 
moći. Potonje se posebice izražavalo u tome što su vrtovi uglavnom privatni, posebice do 19. stoljeća kada, usporedno s urbanizacijom i demokratizacijom, nastaju javni parkovi. ${ }^{363}$

Upravo je u pogledu potonjih, onda kad se uzme u obzir ono što je u ovoj točci navedeno, promicanje poznavanja čitavog simboličkog spleta koji se uz vrtove veže od izuzetne važnosti za promicanje senzibiliteta spram prirode i njezinih jedinki. Na tom su polju također angažirane, ili posjeduju izuzetan potencijal za to, različite druge umjetničke forme.

Ad c) Pored bivanja temom likovnog izraza, drvo u likovnim umjetnostima služi i kao materija. Tako je drvorezbarstvo prvi umjetnički način obrade drva, a predstavlja i jedan od izvora kiparstva, oduvijek biva elementom arhitekture, a usko se veže i sa slikarstvom, onda kada se rezbarena površina pokriva bojama, ali i bez toga drvo umjetničkom djelu daje ljepotu svog tkiva i svojih boja. ${ }^{364}$

Visković tvrdi da premda izgleda kako pejzaž i biljke u likovnoj umjetnosti na većoj važnosti dobivaju tek s renesansom i modernim dobom, imamo li ornamentiku u vidu, otkriva se da su biljke bile i starija i raširenija umjetnička tema. Stablo se pak u ornamentici najčešće javlja u pojedinim dijelovima, kao lišće, cvjetovi, plodovi ili grančice, dok čitavo stablo puno veće priznanje dobiva u slikarstvu, gdje s vremenom postaje sve povlašteniji predmet likovnog izraza. U funkcionalnom smislu, stablo i šuma javljaju se kao simbolički motivi, kao scenski dodaci glavnoj temi, kao dio krajolika ili kao samostalni likovni predmet, a različite upotrebe mijenjaju se kroz historiju, tako da su ranije prve dvije, a kasnije druge dvije upotrebe bile prevladavajuće. Indikativno je, primjerice, da u 19. st., uslijed velikog rasta gradova i nostalgije za prirodom, pejzaž postaje glavna tema umjetničkog interesa. ${ }^{365}$

\footnotetext{
»Sve te uloge stabla u likovnim umjetnostima nisu bile predmet znatnije pozornosti ni historije ni teorije umjetnosti. Za simbolizam stabla zanimaju se opća teorija simbola i religijska ikonografija, ali sama estetika jedva - jer ona u svojim raspravama o krajoliku redovito ostaje na razini generičnosti prirodnih pojava, tj. bez naročito razrađenih osvrta na drveće. (...) Kritičari, historičari, a i sama publika, kao da ne zamjećuju značaj stabla (i drugih elemenata prirode) onako kako ga zacijelo vide, dakako izvan teorijske refleksije, umjetnici kada tumače prirodu. To je jedna od posljedica činjenice da su moderna estetička
}

\footnotetext{
${ }^{363}$ Usp. ibid., str. 547-548, 555-556, 560, 565-566, 665-666. - U pogledu privatnih vrtova, valja primijetiti i sljedeće: »Historijska i kulturološka literatura izrazito zanemaruje pučko vrtlarstvo, premda je ono oduvijek brojčano dominantno i s ulogama u ekonomiji i u životu obitelji koje nisu nevažne. To prešućivanje ima bitno isto značenje, zacijelo staleško i klasno, kao i prešućivanje dominantne uloge drva općenito i drvenog graditeljstva u historijskoj i kulturološkoj literaturi«. (Ibid., str. 659.)

${ }^{364}$ Usp. ibid., str. 575-577. - Tu još možemo pridodati ksilografiju, slikanje na drvenoj podlozi, intraziju, korištenje drveta kao okvira za slike, palete za slikarske boje, za izradu glazbenih instrumenata, kazališta itd. (Usp. ibid., str. 578-580.)

${ }^{365}$ Usp. ibid., str. 581, 584.
} 
razmatranja češće usmjerena na stilsko-formalne osobine umjetničkog djela i da zanemaruju njegovu tematsku stranu. «366

Visković kroz čitav kulturnobiološki opus glavnu težnju stavlja upravo na ovu tematsku stranu, pokušavajući naglasiti važnost prirodnog sadržaja za formiranje, osmišljavanje, predočavanje onog kulturnog. Pri tome on nikada ne zanemaruje kompleksan međuodnos kulturnog i prirodnog, pa tako ni u umjetnosti:

»Danas je pomalo suvišno upozoravati na istinu da djelo umjetnika nije imitacija, već tumačenje, selekcioniranje i konstituiranje predmeta njegova djela, ali i na istinu da je umjetnik ujedno nadahnut nečim iz predmeta što on smatra estetski zanimljivim, te da on uvijek oslikava barem nešto od objektivnih osobina toga predmeta - načelno jednako kao što interpretator glazbene kompozicije mora poštivati neka osnovna značenja glazbene notacije, ili kao što pravnik tumači mora poštivati neka osnovna jezična i društveno-ciljna značenja zakonskog teksta i odgovarajućeg društvenog odnosa. «367

Premda se u konkretnom tekstu ne vodi tim postupkom (ostavljajući njegovo provođenje upućenijima), Visković drži da se, kao i u slučaju likovne umjetnosti, mogu detektirati četiri osnovna načina na koja se stablo ili šuma javljaju u književnosti: »ili kao simbol nekih ideja, ili kao dio scenarija glavnog predmeta naracije, ili u opisu pejzaža, ili, konačno, kao glavna tema - ovo posljednje gotovo isključivo u poeziji ${ }^{368}$

Od svih primjera koje Visković navodi u prilog ispoljavanja senzibiliteta za vrijednost šume ili pojedinih stabala u književnosti, osobito vrijedi istaknuti riječi liječnika Astrova, Čehovljeva alter ega u drami Ujak Vanja, koje su »prava lekcija iz ekologije i bioetike«: 369

»Ti možeš ložiti svoje peći i tresetom, a staje graditi od kamena. Dopuštam čak da se i šume sijeku kad je za to nužda, ali čemu da se istrebljuju? Ruske šume padaju pod sjekirom, ginu milijarde drveta; pustoše se životinjska legla i ptičja gnijezda, pličaju i sahnu rijeke, nepovratno iščezavaju najljepši pejzaži, i sve to samo zbog toga, što lijeni čovjek nema smisla za to da se sagne i iz zemlje izvadi gorivo. Čovjek mora biti zatucani barbar, kad može u svojoj kući spaljivati toliku krasotu i uništavati ono, što nije kadar sam da stvori. Čovjek je nadaren razumom i stvaralačkom snagom, da umnoži ono, što mu je dano, ali do sada on nije stvarao, nego rastvarao. Šuma imade sve manje i manje, rijeke presušuju, divljač je poizginula, klima je iskvarena, a zemlja biva svaki dan sve bjednija i ružnija. (...) možda je doista sve to samo

\footnotetext{
366 Ibid., str. 584. - U nastavku Visković navodi pregršt primjera i komentara vezanih uz svaku od ove četiri upotrebe (vidi: ibid., str. 585-605), čemu slijedi pregled upotrebe stabla u slikarstvu Hrvatske Duška Kečkemeta (vidi: Duško Kečkemet, »Stablo u slikarstvu Hrvatske«, u: Nikola Visković, Stablo i čovjek. Prilog kulturnoj botanici, Izdanja Antibarbarus, Zagreb 2001., str. 606-617).

${ }^{367}$ N. Visković, Stablo i čovjek, str. 654.

368 Usp. ibid., str. 618.

369 Usp. ibid., str. 624.
} 
naklapanje jednoga čudaka; ali kad prolazim mimo seljačkih šuma, koja sam ja spasio od sječe, ili kad čujem, kako šumi moja mlada šuma, zasađena mojim vlastitim rukama, onda dolazim do spoznaje, da je u izvjesnoj mjeri i klima u mojoj vlasti, pa bude li čovjek i nakon tisuću godina sretan, bit će u tom i dio moga truda. $\ll^{370}$

Ovaj ulomak ne objedinjuje samo mnoštvo elemenata bioetičke nastrojenosti, nego i oslikava uzvišenu vrijednost umjetničkog pristupa zbilji, koji, upravo zbog ove uzvišenosti nad onim kratkoročnim i pragmatičnim, uspijeva da »prodrma« i ostale sfere u kojima se ljudsko znanje formira. Naime, ako ćemo utopičnošću nazivati ono što ne nalazi rješenje u puko postojećem (o čemu više kasnije), onda je Čehov ovdje utopijski mislioc par excellence (pokazujući istovremeno potencijal umjetnosti da bude utopijska misao), koji izvrsno rastvara tobože nužne imperative čovjekova bezobzirnog i neselektivnog iscrpljivanja resursa (koje, ako su živi - neovisno kako su živi - Čehov nikako ne promatra kao puke resurse) kao puko kontingentne, uvjetovane lijenošću spram probijanja neutabanih staza, nedostatkom senzibiliteta za živo i znanja o važnosti specifičnog živog za čovjeka, ali i za životinje. Čehovljev argument, naime, nije (niti to od njega kao umjetnika smije biti zahtijevano) etički, nego prvenstveno estetički, što je u izvjesnoj mjeri blisko i Viskovićevu pristupu - naročito u pogledu neograničavanja na estetičke elemente, nego uviđajući (istovremeno i predviđajući) znanstvenu činjenicu čovjekova utjecaja na klimu, uz ocrtavanje moralne odgovornosti spram budućih pokoljenja.

Konačno, sam se Čehov ovdje naziva čudakom, tj. oslikava način na koji ga društvo zapelo u puko postojećem - moglo bi se reći u Platonovoj pećini (usprkos Platonovoj kratkovidnosti) ili u suvremenom nedostatku uvida u vrijednost umjetničkog senzibiliteta sagledava. Takvom bismo umjetniku mogli pridružiti i esej Pismo slonu ${ }^{371}$ i roman Korijeni neba Romaina Garyja. U potonjem glavni junak Morel, držeći zaštitu slonova jednim od uvjeta same humanosti, u istom duhu i s još snažnijim mišljenjem s onu stranu postojećeg (što se u onome što slijedi ogleda, primjerice, u totemu napretka), kaže: »Ali, ded' objasnite ovim skučenim mladićima da ne treba samo ići naprijed, već da se treba još opteretiti i slonovima, vezati sebi za nogu đule ovih razmjera - smatrat će vas za luđaka - što vi, uostalom, i jeste. « ${ }^{372}$ Potrebu da se obuhvate još veći razmjeri implicitno podrazumijeva Tin Ujević, kada uspoređuje ubijanje bilja i djece:

\footnotetext{
${ }^{370}$ Ibid., str. 624-625.

${ }^{371}$ Visković ovom eseju posvećuje poglavlje »Pismo slonu« u knjizi Životinja i čovjek, str. 317-320.

${ }^{372}$ Romen Gari [Romain Gary], Korijeni neba, prevela Milica Carcaračević, Svjetlost, Sarajevo 1960., str. 213.
} 
»I što rade svi oni koji nemaju ideala, za koje nema ideje ni pravde ni društva ni čovječnosti? Oni koji ne znaju što je ženstvo i ljubav, što je svebratstvo, svejednakost, čovječanstvo, rad, opća sloboda? Oni sijeku loze po vinogradima, pucaju u stabla, kidaju glave suncokretima, čupaju cvijeće. Ubijaju stabla kako ubijaju nejaku djecu. $\ll^{373}$

Na istom je tragu i Predrag Lucić kada u prikazu Viskovićeva Stabla i čovjeka govoreći o biljkama piše da »nadmeni samoživi antropocentrik u njima ne vidi ništa osim drvetine. Baš kao što ni u čovjeku počesto ne nalazi ništa osim čovjetine. « ${ }^{374}$

\section{II.3.1.4. Gospodstvo}

Stablo zauzima zapaženo mjesto ondje gdje se čovjek često tretira kao »čovjetina« - u politici. Riječ je, ponajprije, o štapovima moći: »Uistinu, kao što se pastirskim štapom upravlja stadom, prvim ekonomskim blagom, tako se gospodskim štapovima upravlja porodicom, narodom i vjerničkom pastvom. «375 Štapovi raznih oblika, kasnije i sublimirani, poput kraljevskog žezla, oduvijek su, navodi Visković, bili znak dominacije i nadređenog položaja u društvu, a nekada su, kao u antičkom Rimu, različiti štapovi označavali različite djelatnosti, tj. društvene razrede. Elegantnu repliku štapa predstavlja i plemićev mač, a pojedini viši redovi vojske koriste zapovjedne palice. Pored spomenutog pastirskog štapa, najdublje osnove tih sredstava moći predstavljaju koplje i strijela ratnika te batina i šiba: ${ }^{376}$

\footnotetext{
»Bitno ista figura moći djeluje i kada se po kaznenom načelu pravednosti suum cuique tribuere neposlušniku, neprijatelju i delinkventu dijele batine, kada se čovjeka na kolac nabije, kada mu se motkom garrote kosti lome, kada se na grede križa pribija. (...)

Štapovi aristokratske vlasti nestaju u republikanskom pokretu, s izuzetkom barjaka i ponegdje degradirane maršalske palice, no zato se istom pojavljuju sveprisutan policijski pendrek i palice cricketa, hockeya i pola otmjene gospode. Ugledni građani nose srebrom optočeni gospodski štap (...), a roditelj i učitelj još uvijek primjenjuju brezinu šibu strogosti istine i discipline. K tome je ponuda 'mrkve i batine' vazda bila i ostala nepotrošno načelo imperijalne politike - od pax romana do pax americana. «377
}

Štap je, također, naglašava Visković, »univerzalno sredstvo i oznaka muške vladavine«. Moć koju predstavlja štap dolazi u »neizbježan odnos s falusom«, pa tako »Dioniz-Bakho i sin

\footnotetext{
${ }^{373}$ N. Visković, Stablo i čovjek, str. 628.

${ }^{374}$ Predrag Lucić, »Knjigom na pilu«, Feral Tribune 2. 5. 2002., str. 95.

375 N. Visković, Stablo i čovjek, str. 412.

${ }^{376}$ Usp. ibid., str. 413-415.

${ }^{377}$ Ibid., str. 414.
} 
mu Prijap izlažu falus, izvor plodnosti i muške vlasti, koji se i danas pučki i književno naziva štapom, fr. verge, tal. verga, eng. stick i rod«. Premda kulturne razlike ne mijenjaju štap kao izraz muške dominacije, jednakost spolova u pogledu upotrebe moći štapa pojavljuje se u magiji te uopće u područjima koja su izvan ili na rubu zakonitosti. Ženske »uzurpacije štapa« protežu se od božice Ištar i čarobnice Kirke, sve do vještica koje jašu metle ili motke, vila što čaraju prutićima i narodnih ljekaruša koje »istjeruju dječje i životinjske bolesti šibom koju Nijemci zovu Lebensrute ${ }^{378}$

Visković navodi da sve od prutova mantičara, augura, druida, preko Mojsija, Arona, izraelskih starješina, pa do biskupova savinutog štapa, on predstavlja neizostavan element u vjerskom univerzumu. Ako je vjerovati psalmu, štap i palica pripadaju i samome Jahvi. Tako su štapovi i sredstva autoriteta i čudesnih moći kod svetaca, poput sv. Silvestra, sv. Vlaha, sv. Nikole itd., čime se ponovno potvrđuje karizmatska i magična snaga stabla. ${ }^{379}$

\footnotetext{
»Nadolaskom moderne tehnologije i gospodstva novca, koji priskrbljuju nove temelje autoritetu i vlasti, uveliko se gubi značaj toljage, štapa, palice, pruta, skiptra, kolca i sličnih artefakata, s iščezavanjem njima odgovarajućih društvenih uloga. (...) I tako izgleda da moć otkinutih izdanaka stabla danas preživljava, uz biskupske štapove koje većina vjernika i ne primjećuje, još samo u invalidskim štakama, u štapovima slijepaca i u lijeskinim (vrbinim ili trninjim) rašljama za otkrivanje podzemnih voda i zračenja (...) Kod ovih posljednjih posrijedi je bitna povezanost drva i vode koju tako jasno pokazuju vrbe i topole uz riječne obale ili svetački štapovi i vilinski prutići što udarcem o stijenu rađaju izvore.

Pa ipak, ne stoji li još uvijek izvan svakog kruga dominacije nevina moć putničkog štapa, po mogućnosti od sretna tisina drva, koji nas prati u susretima s prirodom. « ${ }^{380}$
}

Pored dominacije lišenog putničkog štapa i ponekih ostataka sublimiranih oblika stabla kao simbola dominacije nad ljudima, ono se u sve većem obimu svodi na puku materijalnu upotrebu, koja već zaista, bez potrebe značajnijeg simboličkog posredovanja, izražava dominaciju čovjeka nad prirodom. Tako se i samo drvo obara na stablo, pri čemu je »osobito sjekira, sa svojom drvenom ručkom i metalnim sječivom stvorenim energijom drvenog ugljena, oduvijek glavni krvnik drveću i šumama«. ${ }^{381}$

\section{II.3.2. Materijalni aspekt}

\footnotetext{
${ }^{378}$ Usp. ibid., str. 413, 415.

${ }^{379}$ Usp. ibid., str. 414, 524.

${ }^{380}$ Ibid., str. 416.

${ }^{381}$ Ibid., str. 145 .
} 
Slijedeći zadanu strukturu ispitivanja u izvjesnoj smo mjeri učinili prijestup spram boljeg razumijevanja simboličkog tumačenja stabla:

»... tek spoznaja zbiljskog značaja stvari i njihovih osobina, primjerice značaja i osobina drveća u biosferi i u ljudskoj prehrani, stanovanju, ovladavanju vatrom, liječenju, radu i znanju, otvara put punijem razumijevanju mitskih, legendarnih, religijskih, običajnih, umjetničkih, filozofskih i političkih simbola koji se za te pojave vezuju. Simbolička značenja uzdižu se do najviših ideja, ali izvori su im redovito (i) u svojstvima zbilje. $\ll^{382}$

Stoga nije slučajno da Viskovićev red ispitivanja ide s materijalno-upotrebnog pristupa na onaj simbolički, tj. duhovni. Međutim, ni kod nas se ne radi o slučajnom poretku ispitivanja, s obzirom na to da glavni naglasak stavljamo na etički problem, koji se prirodno nastavlja na predstavljanje materijalne upotrebe kako biljaka, tako i životinja, upotrebe koja najviše šteti tim živim bićima. Nadamo se da se ovakvim preokretanjem neće puno izgubiti na boljem razumijevanju prethodno izvedenoga. No uobičajen prikaz poremetit ćemo još jednim ekskursom, naime, kratkim prikazom Viskovićeva razmatranja drva kao materije, ekskursom s obzirom na to da nas problematika narednog potpoglavlja dijelom vraća na neka od početnih poglavlja ovog rada.

\section{II.3.2.1. Zaborav drva kao materije}

Drvo svakako predstavlja »jedan od temelja materijalne kulture - a time, razumije se, i duhovne«, a Visković tvrdi da se, počevši od pretpostavke potkrepljene historijskokomparativnim i etimološkim istraživanjima o dominaciji drva kod prapovijesnog čovjeka, ali i kasnije, može govoriti o drvenom dobu koje je prethodilo kamenom i metalnima. Što se tiče potonjih, neovisno o dominaciji određenog materijala, epoha se može nazivati prema onom karakterističnom kao novootkrivenoj sirovini, no valja imati na umu da je drvo osnova vladanja vatrom, nužnom za proizvodnju metalnih artefakata, tako da su metalna doba »na posredan način također bila, s obzirom na energiju kojom se do njih dolazi, drvena doba «. ${ }^{383}$

Dok je ovdje epohalna vrijednost drva zanemarena ne samo u pogledu primarnog sredstva, nego i u pogledu sredstva za proizvođenje sredstva, s druge se strane vrijednost samih oruđa za razvoj čovjeka prenaglašava:

\footnotetext{
382 Ibid., str. 293.

${ }^{383}$ Usp. ibid., str. 106-109.
} 
»Uvjerljiva Mumfordova kritika prenaglašavanja uloge oruđa u prahistorijskoj kulturi i uopće svođenja tehnike na oruđe zaista pogađa i prečestu tvrdnju antropologa, pozitivistički opsjednutih kamenokošćanim nalazima i velikim strahom od teorijskih zaključivanja, da je 'industrija oblutaka najstarija industrija...', a to znači i njihovo previđanje značaja i prvenstva drva u ljudskom radu.« «84

Štoviše, isto se tako zanemaruje uloga kamenja kao sredstava za proizvođenje oružja i oruđa od drva. Ako je vjerovati Louisu Leakeyju, u najdavnijim vremenima premoć kamena nad ostalim materijalima bila je više prividna negoli stvarna, što se očituje u samim kamenim nalazima pronađenima u najstarijim paleolitskim lokalitetima čiji oblik navodi na zaključak da su služili obradi drva. ${ }^{385}$ To neuvažavanje materijalne uloge drva nije slučaj u nekim drugim kulturama, kao u kineskoj, gdje ono sačinjava jedan od pet osnovnih elemenata:

»Takvu postavku ne nalazimo u europskoj filozofiji, gdje se tradicionalno spominju samo vatra, zrak, voda i zemlja, uz zaborav organskih tvari, koje su prvenstveno biljne. Međutim, u samom osvitu europske kulture, u grčkom jeziku i grčkoj filozofiji, primarna važnost drva je ipak iskazana na taj način što je izraz $\check{\lambda} \eta$ (hile) početno značio 'šuma' i 'drvo' i ujedno 'materija' uopće. Jednako je s latinskim izrazom sylva, koji znači i 'šuma' i 'materija'. Prema tome, iako zapadna filozofija ne pridaje drvu vrijednost primarnog elementa svijeta, kao što čini kineska filozofska misao, ona ipak dolazi do jedne smislene i značajne identifikacije i homonimije koja izražava ovu temeljnu kulturnu činjenicu: da je drvo prva, najlakše obradiva i najčešća materija, materijal, 'građa' ili sirovina ljudskoga rada. Pri tome je znakovita i srodnost između riječi materies $=$ drvo i grč. $\mu \eta ́ \tau \varrho \alpha=$ maternica, lat. mater $=$ majka, mater, i lat. matrix $=$ žena bremenita ili dojilja, jer je drvo matica ljudskog materijalnog stvaranja kao što je žena matica života. « ${ }^{386}$

Međutim, naglašava Visković, sama materija u zapadnoj metafizici ima podređen značaj u odnosu na formu. Štoviše, ona se svodi na potpunu neodređenost, ne-biće, a kod Plotina nalazimo i da u njoj nema ništa od Dobra, tj. da predstavlja nužnost zla. Spomenuto vrijedi za nju kao takvu. Ona pak biva usavršena onda kada prima formu i pojam, kao što u stoičkom učenju, kako Visković pokazuje na primjeru Seneke, razum i božanstvo kao počela prirode daju život i oblik mrtvoj i bezobličnoj materiji. ${ }^{387}$

»Ta ideja o 'bezobličnoj materiji', kojoj razum 'daje život', jest jedno tipično i drsko, menschliches allzu menschliches, teleološko i teološko hipostaziranje razuma, koje ne vidi i ne želi vidjeti da materija ima po sebi svoje izvorne oblike, a biljka i drveće još i svoj izvorni život, pa stoga ne mora čekati da je razum

\footnotetext{
${ }^{384}$ Ibid., str. 110. - Citat unutar ovoga odnosi se na F. Facchinijevu knjigu Stazama evolucije čovječanstva, a spomenutu Mumfordovu kritiku Visković ukratko iznosi u bilješci br. 363. (Vidi: ibid., str. 237.)

${ }^{385}$ Usp. ibid., str. 109.

${ }^{386}$ Ibid., str. 110.

${ }^{387}$ Usp. ibid., str. 111.
} 
konstituira, tim više što su prirodni oblici i sam život razumu dobrim dijelom nedostupni, nespoznatljivi, nerazumljivi, nad-razumni.« $\ll^{388}$

Visković ove i neke kasnije primjere uvrštava u fenomen »zaborava ili kulturnog podcjenjivanja prirode, pa i šume i drveta, prve tvari ljudskog rada«. On zaborav drva u znanosti (historiji, arheologiji, sociologiji, ekonomiji, pravu) drži istovjetnim zaboravu »malog čovjeka« u istim znanostima, ponovno s izuzetkom etnologije. ${ }^{389}$ No ocjena je ovdje preoštra, barem s obzirom na suvremena gibanja u većini spomenutih znanosti. Tako u historiji barem od rada interdisciplinarno usmjerene škole Anala započinje rast interesa za svakodnevicu »malih ljudi«, na koju je naročito u trećoj generaciji stavljen jedan od glavnih naglasaka, a nije zanemaren ni odnos čovjeka spram prirodne okoline. ${ }^{390}$

\section{II.3.2.2. Gorivo i oružje}

Za samo rađanje i određenje čovjeka, kako kaže Visković, ključne su upravo prve upotrebe drva, u vidu izrađivanja oruđa i oružja, ali možda prije svega u ovladavanju vatrom, koju osim čovjeka sva bića doživljavaju kao prijetnju. Antropološki je neupitno da se savladavanje vatre predstavlja »nužan pogon svake kulture«, a da se njime čovjek rađa, odslikava se i u jeziku. Tako Grci i Rimljani vezuju vatru sa seksualnim činom dajući slične nazive dijelovima drvenog kresiva i muškom odnosno ženskom spolnom organu, a već je pokazano kako se drvo kao materies povezuje s mater. Kulturno se rađanje čovjeka, tj. zadobivanje njegove specifičnosti spram ostatka prirode, iz vatre posebno odnosi i na termičku obradu hrane. Kako tvrdi antropolog Charleton Coon, upravo je kuhanje najvjerojatnije zaslužno za čovjekovo izvlačenje iz prvobitne životinjske egzistencije. ${ }^{391}$

\footnotetext{
${ }^{388}$ Ibid., str. 111.

${ }^{389}$ Usp. ibid., str. 111-112.

${ }^{390}$ Potonje je osobito zastupljeno u knjizi Fernanda Braudela Sredozemlje i sredozemni svijet u doba Filipa II. (sv. 1, prevela Đurđa Šinko-Depierris, Izdanja Antibarbarus, Zagreb 1997.; sv. 2, prevele Mirna Cvitan Černelić i Jagoda Milinković, Izdanja Antibarbarus, Zagreb 1998.). No i sam Visković u jednom ranijem tekstu daje drugačiji uvid u ovu problematiku, odajući priznanje među ostalim i ovoj školi za aktualiziranje animalističke problematike: »Na osnovama prije postavljenih premisa darvinizma, potrebe povratka prirodi o kojoj piše Keith Thomas u 'Man and the Natural World', starijih i novijih učenja o moralnim dužnostima čovjeka prema ne-ljudskim bićima, teorija o životinjskom ponašanju Lorenza i drugih etologa, kao i obnove historijske metode u školi Anala, od sedamdesetih godina nastaju sve brojnije studije o životinjstvu u etici, filozofiji, religiji, narodnim običajima, umjetnosti, ekonomiji, jeziku i drugim oblicima života pojedinih naroda i epoha.« (N. Visković, »Uvodna riječ«, str. 5-6.) Međutim, na drugom mjestu u Stablu i čovjeku, usprkos priznanju zasluge za otvaranje historijskih istraživanja brojnim prije marginaliziranim temama, ustvrđuje da pripadnici ove škole »ne stižu ili jedva stižu do zaključka da bi historičarski interes morao obuhvatiti biološke osnove ljudskog života, inherentne vrijednosti prirode i načine upotrebe i uništavanja prirode u svim vidovima ljudskoga djelovanja - od religije do ekonomije«. (N. Visković, Stablo i čovjek, str. 17.)

${ }^{391}$ Usp. N. Visković, Stablo i čovjek, str. 112-113.
} 
Drvo, nastavlja Visković, upaljeni plamen nadalje hrani sobom, a hrana se na otvorenoj vatri spravlja i do dan danas. Dugo je služilo i da bi osvjetljavalo putove, kako kopnene, tako i morske (svjetionici), a na vatri potpaljenoj drvom zasniva se i mnoštvo zanata u historiji. Kao gorivo za proizvodne svrhe veliku važnost ima i drveni ugljen. Čovjek pored toga iz zemlje uzima i neka druga goriva biljnog podrijetla, tj. fosilizirano bilje. ${ }^{392}$

Dok se danas vode ratovi oko potonjega, drvo je dugo vremena bilo neizostavan materijal za oružje. Visković tako pored kamena spominje toljagu kao prvo pračovjekovo oružje (koje koristi i čimpanza). Nadalje je nastajalo mnoštvo drvenog oružja, od sulice, koplja, bumeranga, ratne sjekire i oklopa, preko ratnih sprava kao što su opsadne kule, ovnovi i baliste, dok se konačno u modernom oružju sve više gubi te se svodi, primjerice, na kundake puški. Isto tako, gradovi su se nekoć branili kako palisadama, tako i drvenim gradskim vratima i pokretnim mostovima. ${ }^{393}$

»Pored svih tih ubojitih artefakata, čovjek od stabla pravi (kao što to čini od psa, konja i zvijeri) i mnoga druga sredstva mučenja i ubijanja. Zaista, samo dijabolična ljudska ingenioznost može od stabla načiniti batinu, vješala, stup i kotač za mučenje, križ za razapinjanje, lomaču za spaljivanje, panj za odsijecanje glave i udova, krvnički malj, kolac za nabijanje, okvire giljotine, klade (...) «394

\section{II.3.2.3. Liječenje}

Naravno, stablo se uvelike koristilo i u upravo suprotne svrhe, naime, u svrhu liječenja. Visković, ponavljajući misao Isidora Seviljskog, tvrdi da su biljke bile prvi lijekovi, no one su, što su znali već Aristotel i Plinije, lijekovi stariji od čovječanstva, s obzirom na to da su se njima liječile i životinje. Na to ukazuju i suvremeni istraživači, poput Jane Goodal, a Eloy Rodriguez ističe kako je mnoštvo lijekova biljnog podrijetla otkriveno zahvaljujući promatranju životinja. Biljni su preparati u toj mjeri bili važni za lijekove da su prve znanstvene spoznaje o biljkama nastajale uglavnom iz potreba medicine, pa se i znanost botanike prvotno izučavala na medicinskim studijama. Tako su prvi botaničari bili liječnici, a prvi botanički vrtovi nasadi ljekovitih biljaka kraj medicinskih učilišta i na samostanskim posjedima. ${ }^{395}$

»... današnja etnobotanika potvrđuje i revalorizira ono što je oduvijek poznato: da su učena znanja herboristike uglavnom zapisana stoljetna iskustva pučkog ljekarstva, pa zato etnobotaničari sada pozivaju

\footnotetext{
${ }^{392}$ Usp. ibid., str. 113, 117-118.

${ }^{393}$ Usp. ibid., str. 120-121.

394 Ibid., str. 122.

${ }^{395}$ Usp. ibid., str. 167; N. Visković, Životinja i čovjek, str. 179.
} 
na sustavno ispitivanje toga iskustva, naročito onih tradicionalnih znanja o ljekovitim biljkama koja čuvaju domoroci u tropskim krajevima i koja su danas pod dvostrukom opasnošću nestajanja šamanskih znanja i uništavanja biodiverziteta u prašumama.« «396

To je tek jedan od brojnih primjera kako kulturni i biodiverzitet najčešće rastu i padaju jedan s drugim. Naime, već nam je iz sadašnje herbalističke literature jasno da gotovo nema stabla čiji dijelovi nemaju bilo ljekovite, bilo preventivne učinke, ${ }^{397}$ a isto je tako sigurno da sva ta znanja nisu sakupljena i u potpunosti valorizirana od strane zapadne medicine, pa je u tom svjetlu istovremeno i medicinski i ekološki zadatak očuvanje kako biljnih vrsta, tako i različitih nezapadnih naroda i plemena.

\footnotetext{
»Može se samo maštati koliko se i kakvih moćnih lijekova krije u još gotovo neistraženom biljnom blagu našeg planeta, pa onda i s tog gledišta razumjeti zabrinutost znanstvenika, a tek odskora i političara, koji su na Konferenciji o okolini i razvoju u Rio de Janeiro 1992. pozvali na uzbunu zbog sadašnjeg barbarskog uništavanja tropskih prašuma, koje uz druga neprocjenjiva biološka i kulturna dobra sigurno sadrže i veliki dio budućih resursa lijekova svjetske medicine. $\aleph^{398}$
}

Biljke, tvrdi Visković, svakako imaju i povoljan utjecaj na čovjekovo psihičko zdravlje. Isto tako, pretjerana privrženost biljkama u ovom pogledu može voditi, kao što je to slučaj i kod životinja, mada znatno rjeđe, mizantropiji. Jedan od takvih primjera zasigurno je onaj s konca Rousseauova života, kada je ovaj u »biljkovanju« pronalazio spas od ljudske zlobe. ${ }^{399}$

\section{II.3.2.4. Kultiviranje}

Kratak prikaz malog dijela materijalne upotrebe drveća služilo je tek da oslika Viskovićev pristup, u koji spada i sagledavanje nepreglednih načina na koje se drvo koristi u kućanstvu, gradu, privredi, pismu, gotovo na svim poljima kulture. No umjesto prepuštanja tom nabrajanju, čini se da je za svrhu ovakvog rada uputnije da se pruži usporedni uvid u kultiviranje biljaka, kao što je u prijašnjoj glavi bio slučaj sa životinjama.

Premda je drveće, navodi Visković, najviše iskorištavano u divljem ili poludivljem (šumarski uzgoj) stanju, jedan manji dio od sveg potpuno domesticiranog bilja spada na drveće, a uglavnom se radi o voćkama. Kod onih korisnijih biljaka nastaje i sve veći broj umjetnih

\footnotetext{
${ }^{396}$ N. Visković, Stablo i čovjek, str. 168.

${ }^{397}$ Usp. ibid., str. 168.

398 Ibid., str. 173.

${ }^{399}$ Usp. ibid., str. 173.
} 
varijeteta, tj. sorti, a procesi križanja, kao i u slučaju životinja, dovode do prorjeđenja ili istrebljivanja izvornih oblika. U pravilu se kod biljnih vrsta koje čovjek mijena smanjuje njihova veličina, a povećava plodnost i veličina plodova, no pored toga, čovjek kultiviranjem i introdukcijom mijenja sastav biotopa, čime oštećuje izvorne biocenoze, a širenjem prostora pod uzgojenim (introduciranim ili ne) vrstama nestaju mnoge divlje vrste biljki i životinja. ${ }^{400}$

Kulturna vrijednost biljaka osobito leži u činjenici što čovjek, naglašava Visković, kultiviranjem biljaka, kao i životinja, mijenja samog sebe. Taj proces »njega samoga odprirođuje, kultivira i domesticira«, kako govori i P. J. Wilson (u knjizi The Domestication of the Human Species). Premda je na domestikaciju čovjeka više utjecao uzgoj žitarica, postoji i mišljenje kakvo je ono Miše Kišpatića, o odlučujućoj ulozi voćki za nastajanje višeg stupnja sjedilačke kulture. Mišljenje je pak pretjerano, no »zacijelo sadrži dio istine«. Pored toga, o izvjesnim tipovima vegetacije u velikoj mjeri ovisi i oblikovanje kultura, civilizacija i naroda. Uzgojem i domestikacijom čovjek s nekim biljnim i životinjskim vrstama ulazi u odnos simbioze, za razliku od ranijeg parazitiranja na njima (tek sakupljanja plodova divljih biljki). ${ }^{401}$

»... od vremena neolita niti čovjek može postojati kao kulturno biće bez tih zarobljenih biljaka i životinja, niti ove mogu kao vrste izmijenjene uzgojem opstati bez stalne ljudske njege. I kao što loza i voćke brzo podivljaju čim čovjek prestane o njima brinuti, tako bi i čovjek podivljao kada bi napustio uzgoj prirode i na njemu utemeljene kulturne zasade. ${ }^{402}$

No ovdje treba uočiti jednu pogrešku u zaključku. Ako je neka praksa vodila izvjesnom poželjnom rezultatu, čak i da je jedino ona njemu mogla voditi, to nikako ne znači da je njeno daljnje izvršavanje uvjet održavanja tog rezultata. Pri tome se radi o pogrešci izjednačavanja proizvodnog uzroka i nužnog uvjeta održavanja čega u postojanju, što se najlakše može ocrtati odnosom roditelja i potomka - premda je prvi proizvodni uzrok drugome, to ne znači da prvi za daljnju egzistenciju drugoga predstavlja nužni uvjet. Pored toga, ovakva tvrdnja, po pitanju životinja, nije u potpunosti konzistentna s nekim drugim Viskovićevim zaključcima, o kojima nešto kasnije. Ovdje je dovoljno utvrditi da, pored problematičnih tvrdnji ove vrste, Visković dobro uviđa čitavu kompleksnost istovremenog kultiviranja čovjeka i onoga što on kultivira, a to posebno sumira u sljedećem:

»Dakle, s jedne strane, uzgojem i seljenjem biljaka čovjek mijenja biljni svijet, kao što svojim poljoprivrednim, industrijskim i urbanim širenjem uništava mnoga biljna izvorna staništa u ekosistemu.

\footnotetext{
${ }^{400}$ Usp. ibid., str. 93-95, 101-102.

${ }^{401}$ Usp. ibid., str. 102-103.

402 Ibid., str. 102.
} 
S druge strane, kultiviranjem biljaka naglo se ubrzava povijesno vrijeme i izbijanje čovječanstva iz njegove prirodne matice: čovjek ustaljuje stanovanje na određenom mjestu, osniva tu svoj dom, silno razvija podjelu i specijalizaciju rada, tehnička sredstva, umijeća i radnu disciplinu, produbljuje spoznaju prirode i moć predviđanja njenih tokova, razvija urbano-politički život, diferencira kulturne sustave, stvara viškove hrane i drugih proizvoda koji mu omogućuju sigurniju i bogatiju egzistenciju, stalnu spolnu aktivnost, brzu reprodukciju, duži život, slobodno vrijeme i umjetnost, obrazovanje i znanost, trgovinu, veću osobnu slobodu i intenzivnije odnose između ljudskih zajednica. Sa svim tim čovjek stječe i moć razaranja prirode, koju u velikoj mjeri uistinu prakticira, ali istodobno i snagu moralne svijesti koja mu nalaže kako bi se trebao odgovorno ponašati prema sebi, prema drugim ljudima i prema prirodi. «403

\section{II.3.3. Maltretiranje}

Već se sama domestikacija može promatrati kao izvjesni vid maltretiranja. Do tog zaključka Visković dolazi i posredstvom uviđanja onoga što smo ocrtali u poglavlju »Zaborav prirode«, u vidu Baconove upute o ovladavanju prirodom, poduprte Božjim nalogom, koji onda bezobzirnost modernog doba spram ne-ljudskog života veže i uz onu srednjovjekovlja:

»U rano moderno doba, spojem prosvjetiteljstva i utilitarizma, na Zapadu je zavladalo istinsko oduševljenje za postupke domestikacije biljaka i životinja - kada su učeni ljudi u tome vidjeli neumitnu zakonitost napretka čovječanstva i ostvarenje Božje volje da čovjek pripitomi i ukloni divlju prirodu. Ovo drugo shvaćanje sadrži već srednjovjekovna kršćanska ideja da je zadatak čovjeka domesticirati, tj. učiniti pitomim i plodnim biljni i životinjski (dakako, i vlastiti ljudski) svijet po božjoj volji i radi vlastite probitačnosti i slave. $\ll^{404}$

Visković potonje potkrepljuje biblijskim motivima potpomognutim usporedbama neplodnosti drveća $s$ poganinom te domestikacije stabala $\mathrm{s}$ Kristovom misijom spašavanja pogana, kakve je izvodio Rabano Mauro. Danas pak tehnološki »napredak«, dovodeći prosvjetiteljski program domestikacije na prag potpune realizacije, »razara i kvari sve segmente prirode oko nas«, a nekadašnju divlju prirodu svodi na umjetnu, po mjeri čovjeka podešenu prirodu. Tome kumuje i to što gotovo čitavo naše znanje o drveću, kao i generalno o živim bićima, pored neznatne motivacije njihova poštovanja, služi njihovu pukom iskorištavanju. Tako sve do izbijanja suvremene ekološke krize običan čovjek koliko i znanstvenik prema prirodnim bićima ima »gotovo isključivo utilitaristički odnos ili ne-odnos ravnodušnosti«. 405 Pa ipak:

\footnotetext{
${ }^{403}$ Ibid., str. 102.

${ }^{404}$ Ibid., str. 104.

${ }^{405}$ Usp. ibid., str. 104, 235.
} 
»... još je uvijek živa i usrećuje nas misao, možda samo luda nada, da bi u jednoj boljoj budućnosti sva ljudska znanja i moći mogli poslužiti, i bez mogućeg odricanja čovječanstva od eksploatacije jednog dijela prirode, dubljem poznavanju vrijednosti prirodnih bića i mnogo odgovornijem suživotu s njima po mjeri ne samo naših, već i njihovih potreba. Tada bi posve kultivirani čovjek bio onaj koji se prema bilinstvu i životinjstvu odnosi, pa i uz određenu mjeru njihova nužnog uzgoja i iskorištavanja, ne kao sebičan i bezobziran izrabljivač i zatirač, već kao subjekt koji poštuje i štiti svaki život, a naročito divlji život na Zemlji. A to znači ne samo odustati od sadašnjeg prekomjernog uništavanja života, nego odustati i od njegove neopravdane, prekomjerne domestikacije. $\aleph^{406}$

Za početak, valja nešto konkretnije sagledati načine na koji su biljke maltretirane, a kao i Visković ovdje se ograničavamo tek na stabla. Ona stradavaju, navodi Visković, na dva osnovna načina, od prirodnih procesa i od ljudskog djelovanja, pri čemu svakako ne treba zanemariti ni njihovu kombinaciju u pogledu čovjekova intenzivnog upliva u prirodu, pa time izazivanje ili intenziviranje prirodnih procesa koji se pogubno odražavaju na stabla. Ovi se načini propadanja odvijaju na razinama biosistema (zajednica stabala), vrsta drveća te pojedinačnih stabala. ${ }^{407}$ Iako Visković razmatra sve ove načine stradavanja drveća, mi se ovdje ograničavamo na one neposredno i posredno antropogene.

\section{II.3.3.1. Uništavanje šuma}

Obaranje šuma najstariji je i najteži (s najdalekosežnijim posljedicama) način ljudskog utjecaja na drveće. ${ }^{408} \gg$ Civilizacija se uistinu gradila, od Kine i Indije do Mezopotamije, Rima i sve do danas, istodobno pomoću šuma i protiv šuma. ${ }^{409}$ Kako prenosi Visković, historičari (primjerice John Perlin) ukazuju i na to da su neke civilizacije (Mezopotamije, Krete, Mikene itd.) propadale zahvaljujući iscrpljivanju drvne materije. Štetu ranim civilizacijama Sredozemlja nanosila je i erozija tla kao posljedica pretjerane sječe šuma. Sječe su vršene u svrhe ogrjeva, poljoprivrede, metalurgije, ispaša te namjerno ili slučajno izazvanim požarima. Upravo sredozemna vegetacija predstavlja »najbolji svjetski primjer razornog utjecaja civilizacije na spontane biljne (i životinjske) vrste«, tj. njihovom zamjenom kultiviranim

\footnotetext{
${ }^{406}$ Ibid., str. 104-105.

${ }^{407}$ Usp. ibid., str. 687. - Ovdje se, kao i u mnoštvu drugih aspekata, mogu pronaći analogije sa stradavanjem životinja. (Usp. ibid., str. 791.)

${ }^{408}$ Usp. ibid., str. 691.

${ }^{409}$ Ibid.
} 
vrstama, ovdje masline, voćaka i loze. No europske šume osobito stradavaju između 10. i 13. stoljeća, u dobu nazvanom »veliko krčenje «. ${ }^{410}$

Bez da ulazimo u daljnji historijski prikaz uništavanja šuma kakav Visković poduzima, bit će dovoljno ukazati da je današnje veliko krčenje prvenstveno zabrinjavajuće u pogledu tropskih šuma. Kako on tvrdi, njihovo je uništavanje vjerojatno »najteža i najsudbonosnija tragedija našeg doba«. Ne radi se tek o iscrpljivanju drvne materije, nego i o najtežim biološkim, klimatskim i geološkim štetama, poput asimilacije ugljikova dioksida i proizvodnje kisika, poremećaja režima padavina, ugrožavanja biodiverziteta, brzog iscrpljivanja tla itd. Nakon ovog »najvećeg biocida u povijesti čovječanstva«, koji uključuje upravo sva živa bića nastanjena na tim prostorima, Visković predviđa da su sibirske tajge iduće veliko šumsko područje na meti masovne sječe. ${ }^{411}$

»Uz to što uništavanje tropskih šuma ubrzava zagrijavanje atmosfere (efekat staklenika) i izaziva erozije, pustinje i poplave, ono uzrokuje nenadoknadivi gubitak genetskog potencijala flore i faune. Do toga katastrofalnog procesa dolazi zbog susreta profitno-potrošačkih interesa razvijenih društava za jeftinom sirovinom i potrebe nerazvijenih društava da rasprodajom svojih neprocjenjivih bogatstava dođu do sredstava za preživljavanje i razvoj. (...)

Slabo je poznato da se najveća prostranstva šuma u svijetu danas nalaze u Sibiru i da sada ona dolaze na nišan multinacionalnih korporacija za eksploataciju drva (japanska Itoh, koreanska Hyundai, američka Louisiana Pacific, Georgia Pacific, europska Weyerhaeuser) koje su već opustošile znatan dio tropskih šuma. $\ll^{412}$

Postoje, naravno, i primjeri afirmativnog odnosa spram šuma. Tako, navodi Visković, u Europi prekretnicu čini prijelaz s 19. na 20. st., kada se deforestacija smanjuje, da bi od polovice 20. st. do njegova kraja nastupilo čak podvostručenje šumskog fonda. Tome su kumovala tri faktora: djelomična zamjena drva u energetici i građevinarstvu drugim izvorima i materijalima, trend napuštanja poljoprivrednih površina te racionalnija, plantažna eksploatacija domaćih šuma, no ujedno i eksploatacija vaneuropskih šuma. ${ }^{413}$ Potonje je važno naglasiti zbog lažnog osjećaja »europske zelene čistoće«, koji se onda (nikako lišeno ideologije) intenzivira usredotočenošću na proizvodnju, a zanemarivanjem potrošnje Europljana.

Konačno, treba naglasiti i da sadašnje osjetno kvalitativno poboljšanje stanja europskih i sjevernoameričkih šuma prati sada dvostruko kvalitativno pogoršanje njihova stanja: gubitak

\footnotetext{
${ }^{410}$ Usp. ibid., str. 691-692, 695.

${ }^{411}$ Usp. ibid., str. 704-707.

${ }^{412}$ N. Visković, Životinja i čovjek, str. 303.

${ }^{413}$ Usp. N. Visković, Stablo i čovjek, str. 703.
} 
biodiverziteta flore i faune u šumskim biotopima (...) i propadanje šuma zbog onečišćenja okoliša «. ${ }^{414}$ Šume umjerenog pojasa propadaju zbog onečišćenja zraka, tla i voda, posebice u vidu kiselih naslaga (kao sretnijeg termina za ono što se kolokvijalno naziva kiselim kišama), a čovjekov je nemaran odnos spram vlastitog okoliša uzrok i sve većim i češćim šumskim požarima, osobito na Sredozemlju (gdje se šumske površine, za razliku od kontinentalne Europe, smanjuju). ${ }^{415}$

\title{
II.3.3.2. Uništavanje vrsta
}

Svaka od ovih praksi usmjerenih protiv šuma, navodi Visković očiglednu činjenicu, često znači i ugrožavanje izvjesnih vrsta stabala. No obrnuto svakako nije nužno. Primjerice, pojedine vrste stradavaju s obzirom na nemogućnost prilagodbe novoj okolini, kao što je slučaj $\mathrm{s}$ nekim tropskim biljkama koje čovjek prenosi u umjerene ekosisteme. Pored toga, antropogenim preseljenjem biljnih vrsta prenose se i biljne biotske bolesti. Introdukcija, usprkos teškoćama u prilagođavanju, predstavlja i dobar način osiguravanja opstanka preseljavanim vrstama, s obzirom na stalno ugrožena izvorna staništa. ${ }^{416}$

\begin{abstract}
»Civilizacija ima prema biljnom i životinjskom svijetu općenito dva usporedna i djelomično suprotna učinka: s jedne strane, ona pogoduje širenju i razmnožavanju jednog manjeg broja biljnih i životinjskih vrsta izvan njihovih prirodnih staništa, i to uglavnom vrsta koje su čovjeku korisne i drage i koje on uzgaja, a s druge strane, ona uništava mnogo veće populacije biljnih i životinjskih vrsta u nezaustavljivom ljudskom pohodu na prirodu. Ta dva procesa, koji podjednako izražavaju ljudski utilitarni, sebični i antiekološki odnos prema okolnom svijetu, dosad su bila bolje zapažena u odnosu na životinje - od kojih se malo vrsta domesticira i upotrebljava, a mnogo više istrebljuje; no potpuno isti procesi djeluju, iako su slabije uočeni, u odnosu na biljke - koje se također mnogo više istrebljuju nego što se domesticiraju i upotrebljavaju. $\ll^{417}$
\end{abstract}

Autohtona stabla, navodi Visković, kao i sve su biljke osobito ugroženi na otocima (gdje se vrste genetički udaljuju u dugoj odvojenosti od kopna i postaju endemi) pod udarima kolonizatora. Tako se na tropskim otocima (čak i na većim otocima kao Madagaskaru ili kontinentima poput Australije) sjeklo drveće radi pretvaranja zemlje u poljoprivrednu te su

\footnotetext{
${ }^{414}$ Ibid., str. 703. - »Takve tendencije u stanju šuma, tj. njihovo površinsko povećanje i opadanje njihova zdravlja, izražavaju zapravo jedno od temeljnih proturječja tehnološki razvijene civilizacije Zapada: opći porast kvantiteta i istodobno djelomično opadanje kvaliteta života.« (Ibid., str. 709.)

${ }^{415}$ Usp. ibid., str. 708-710.

${ }^{416}$ Usp. ibid., str. 689, 711, 713, 715.

${ }^{417}$ Ibid., Stablo i čovjek, str. 714.
} 
lokalne vrste flore i faune ozbiljno nastradale uvođenjem stranih. No treba imati na umu i da stabla zauzimaju manji dio ugroženih biljki. Razloge za to Visković pronalazi u općenito gledano češćem kultnom štovanju stabla nego drugih biljki, u stvaranju mnogih njihovih zbirki u botaničkim vrtovima i arboretumima (naročito egzotičnih vrsta) od renesanse naovamo te u ekonomiji šumarstva (naročito u klimatski umjerenim područjima). Potonje se, naravno, odnosi samo na šumu, ne i na močvarne, riječne, prerijske, brdske, primorske biotope. ${ }^{418}$

Favoriziranje izvjesnih vrsta stabala, navodi Visković, dovodi do sveopćeg kobnog opadanja biodiverziteta, kako opadanjem raznolikosti biotopa, tako i opadanjem broja vrsta i drugih varijeteta $\mathrm{u}$ postojećim biotopima. Pri tome valja zamijetiti razliku između tradicionalnog ekstenzivnog korištenja šuma, koje se sastoji u povremenoj sječi za potrebe gradnje, ogrjeva, prehranu stoke i sl., te modernog šumarstva, gdje gospodarski račun diktira intenzivniju eksploataciju izvjesnih tržišno poželjnih vrsta drva i gdje šumska mehanizacija naveliko uništava šumsku floru. Rezultat potonjeg su biološki osiromašene i sve više monokulturne (plantažne) šume. Usporedno se razvijaju i procesi umjetne hibridizacije drveća i njegova kloniranja. ${ }^{419}$

»... nove tehnologije klonskog uzgajanja i današnji silan razvoj stvaranja transgenih biljaka (koji na Zapadu već osvajaju proizvodnju žitarica i drugih jestivih plodova), zacijelo će još više zaoštriti sve te nevolje u voćnoj i šumarskoj arborikulturi. Točna je tvrdnja da su 'od davnina sve plemenite sorte voćaka i vinove loze zapravo klonovi - razmnožene su aseksualno, cijepljenjem (navrtanjem) izdanaka osobito vrijedne biljke na prikladnu podlogu', ali pri tome kao da još nedostaje kritička masa svijesti da će najnovije primjene genske tehnike još više ojačati tržišno monopolni položaj 'oplemenjenih sorti' i ugroženost preostale raznolikosti voćaka (i drugog bilja, a sutra i šumskog drveća). « ${ }^{420}$

Tako se ljudsko »oplemenjivanje« sve bjelodanije pokazuje kao osiromašenje, kako neljudskog života, tako i ljudskih ekonomskih odnosa, kulturne raznolikosti (znanja) i posredovanja prirode, sve više svedivog na tehnološko, a pokazat će se da ovo potonje kumuje i osiromašenju kritičkog moralnog imaginarija od sveobuhvatnih i dugoročnih implikacija djelovanja do njegova upražnjavanja u susretu s drugim, individualnim živim bićem.

\section{II.3.3.3. Uništavanje jedinki}

\footnotetext{
${ }^{418}$ Usp. ibid., str. 716-720.

${ }^{419}$ Usp. ibid., str. 720-722.

${ }^{420}$ Ibid., str. 723-724. - Navod unutar citata preuzet je od Ž. Kućana. (Usp. ibid., str. 811.)
} 
Visković, naravno, pažnju posvećuje i pojedinim stablima, kao zasebnom organizmu koji »stremi životu i dobrostanju«. Tako je svako obaranje i potreskivanje stabla kakvim alatom njegovo stradavanje, tako i lomljenje grana, tucanje kore, a ono nastupa i u naizgled nevinim radnjama poput pribijanja oglasa čavlima na debla ili ispisivanja imena na korama. Pored same smrti (ili njezina začetka u crvotočinama), kao posljedice se javljaju nepravilan rast, skraćeni životni vijek i različita oboljenja. Biljna oboljenja, jasno, mogu imati antropogene uzroke. Izuzev prije spomenutih antropogenih učinaka na biljna oboljenja, putem onečišćenja zraka, tla i vode, može se naprosto raditi o nebrizi za biljke, kao i o njihovu smještanju u nepovoljne prostore. Posebno je uočljivo stradavanje pojedinih stabala u gradovima, kao »najlakše prepoznatljivih stradalnika suvremene civilizacije«. U suvremenim se gradovima preslikava položaj drveća u makrovizuri šume - kvantitativno je bolji, ali kvalitativno lošiji. ${ }^{421}$

Naravno, sve što je prije rečeno o maltretiranju skupina stabala može se pridodati ovom šturom uvidu u maltretiranje jedinki. Međutim, ono može nastupiti i u praksama koje nisu naprosto rezultat neobazrivosti spram izvjesnih vrsta i jedinki, nego i onda kada je, čak i u afirmativnom kulturnom okruženju i naizgled paradoksalno, briga spram njih na djelu. Primjerice, prije smo naveli poveznicu između japanske sklonosti spram prirode i minimalne intervencije u oblikovanje vrta, no, s druge strane, neke odlike japanske tradicionalne kulture vode postupcima koji nemaju tako zdrav odnos spram živoga:

»Tako će bonsai ne samo nastajati dugotrajnom selekcijom smanjivanja, nego će se sve vrijeme njegova života stalno krojiti i siliti na ovakav ili onakav neprirodni rast i oblik - upravo kao što monah i samuraj nastaju u strogoj i stalnoj asketskoj disciplini duha i tijela, no s tom razlikom što je stablu ta neprirodna disciplina izvana nametnuta, dok je kod monaha i samuraja slobodna samodisciplina.

(...) Naime, paradoksalno je da ljubav Japanaca spram prirode, koja se često očituje i u njihovu odbijanju da vrtna stabla i grmove podrezuju i kroje u figure, živice i blokove drvoreda po umijeću ars topiaria, ipak miri s nasilnim postupcima uzgoja kućnih bonsai stabalaca. Taj paradoks još jednom potvrđuje istinu da je ljudska ljubav prema prirodi (i prema životinjama, pa i čovjeku), obično posesivna i sebična, te da ne znači uvijek njihovo puno poštovanje. Štoviše, s etičkog gledišta može se reći da svaka veća manipulacija biljem u vrtlarstvu, koliko god bila vođena osjećajima za (po nečijim mjerilima) lijepo i savršeno, ipak znači nepoštovanje biološkog bića biljke i naprednijih načela bioetike o vrijednosti i potrebi očuvanja toga bića. Uistinu, još jednom je u pravu Nietzsche kada kaže: 'mi smo tako neotesani da je i naša nježnost prema cvijeću i životinjama skoro uvijek ubitačna.' «" ${ }^{422}$

\footnotetext{
${ }^{421}$ Usp. ibid., str. 711-712, 724.

${ }^{422}$ Ibid., str. 558. - U bilješci Visković navodi da kod starog japanskog pisca Yoshida Kenkôa nalazimo negativnu kritiku uzgoja bonsai stabala, koji divljenje spram njih izjednačuje sa zanimanjem za invalide. (Usp. ibid., str. 662.)
} 
Ovdje se, kao i u prijašnjem osvrtu na maltretiranje životinja, pokazuje da sâmo prepoznavanje maltretiranja izvjesnog živog bića zahtijeva istančanu bioetičku senzibiliziranost, ali i da ova senzibiliziranost ne može uvijek nastupiti spontano, nego biva i produktom načela poštovanja. Drugim riječima, premda uvid u čovjekov bespoštedan odnos spram živih bića služi kao »vještački nalaz« za »presudu« po pitanju njegove moralne ispravnosti (pa onda i za izvjesne pravne korake), sami su principi prema kojima sudimo konstitutivni za »vještačenje«. O kakvim se pak principima radi naširoko će biti raspravljano u nastavku. 


\section{III}

\section{VISKOVIĆEVA (BIO)ETIČKA POZICIJA}

U ovom dijelu rada načinit ćemo jedan širok pregled etičke problematike koji će se najčešće voditi Viskovićevim promišljanjima na tom polju. Izvršit ćemo analizu Viskovićeva poimanja etike, od tradicionalne međuljudske, do one biocentričke. Tu ćemo analizu proširiti kritičkim propitivanjem teorija i misli pojedinačnih autora koji su bitno utjecali na formiranje Viskovićeve pozicije. Kronološki, prvi je na putu tog propitivanja marksizam, koji obilježava Viskovićevu misao od njenih početaka, a usprkos kasnijem kritičkom odstojanju u okviru biocentričke etike, on se iz njegove misli i djela ne gubi do dana današnjeg. Pa ipak, ovdje ćemo pokušati izvesti i neke bitne poticaje koji iz marksizma mogu doći za izgradnju jednog sveobuhvatnog bioetičkog pristupa. To će uslijediti nakon spomenutog propitivanja etičkih pristupa kojima Visković pokušava popuniti rupu koju su tradicionalna etika i marksizam ostavili po pitanju moralnog obzira spram prirode, tj. ne-ljudskih živih bića. Prije čitavog tog izvođenja, bit će potrebno u najkraćim crtama i u najopćenitijem smislu naznačiti određenja morala i etike, a njihovo proširenje i dodatno pojašnjavanje provlačit će se do kraja ovog rada.

\section{III.1. Moral i etika}

Etika spada u korpus najstarijih filozofskih disciplina, a svakako i najvažnijih. Ona je u svom osnovnom određenju filozofska refleksija morala. Specifičnost te discipline je ta što sam njen predmet posjeduje sebi vlastitu refleksiju. Moralna je refleksija osobito naglašena kod onih etika koje moralno djelovanje utemeljuju u umu, pri čemu je ona Kantova paradigmatska. Jasnu formulaciju moralne i etičke refleksije, a tako i samih pojmova morala i etike, nalazimo kod Čovića:

»Otkad postoji, čovjek je zaokupljen promišljanjem mjerila prema kojima se treba ravnati i prosuđivanjem ispravnosti svojih postupaka. Tu normativnu dimenziju ljudskog djelovanja nazivamo moralom. Moral nije posebna vrsta djelovanja nego samo posebna dimenzija djelovanja u kojoj svaki 
ljudski čin zadobiva vrijednosnu kvalitetu i postaje moralno određenim činom. Moralna prosudba ispravnosti postupka odvija se u zatvorenoj strukturi samog čina koju tvore tri elementa: prosudba odluka - izvedba. Tu djelovanju imanentnu refleksiju kojom se procjenjuje moralna ispravnost nakane nazivamo moralnom refleksijom. $\ll^{423}$

Moralna refleksija, nastavlja Čović, konstruira sam moralni čin. Za razliku od praktičke zadaće koju ona vrši, uz moral se nadovezuje i teorijska refleksija koju nazivamo etičkom, dakle ona koja objašnjava moralni fenomen. U svom širem značenju, etika postoji otkad postoji ovakva vrsta refleksije (objašnjavalačka) nad moralom, dok u užem značenju govorimo o etici tek od kad ona postoji kao filozofska disciplina (od Aristotela). ${ }^{424}$

U pokušaju odgovora na pitanje u čemu se sastoji ispravnost odnosno neispravnost moralnog čina, tj. kojem od ovih dijelova moralne refleksije treba dati primat, diferencirale su se različite etičke teorije. Kasnije će se neke od njih djelomično analizirati u sklopu kritičkog razmatranja određenih pozicija koje reflektiraju pojedine bioetičke teme. No ovdje vrijedi odmah istaknuti da sva ova tri elementa igraju važnu ulogu u moralnoj refleksiji, odnosno moralnom činu koji ona konstruira. Prosudba je svakako sine qua non moraliteta, a ta kvalifikacija je očita s obzirom na njen nedostatak kod ne-ljudskih, ali i nekih ljudskih živih bića nesposobnih ili još nedoraslih za moralno suđenje. Kad bi se ostalo tek pri samom sudu, ne bi bilo moguće govoriti o moralitetu, jer je ono u svojoj biti praktički usmjereno, tj. usmjereno na djelovanje pod vidom promišljanja o njegovoj ispravnosti. Stoga je odluka za određeno djelovanje također neizostavna iz moralne refleksije, odnosno moralnog čina. Naravno, odluka također može ostati bez konkretnog izvršenja. Ona, naime, jasno upućuje na određeno djelovanje, ali ne može obećati da će ono biti izvršeno. Međutim, s obzirom na to da je izvršenje zacrtane radnje ono što bi ona imala kao na djelovanje upućena misao pokrenuti, trud na postizanju te radnje joj je implicitan. Ukoliko odluka ne vodi trudu na postizanju prethodno promišljene djelatnosti, utoliko se prije radi o ostajanju u samom promišljanju, a ne zaista o odluci, koja bi trebala biti premosnica između misli i radnje. Naravno, radnja se ne može izolirano prosuđivati kao ispravna i neispravna ako ne stoji pod kontrolom moralnog djelatnika, odnosno može se kao takva promatrati samo s obzirom na njegovu mogućnosti ovladavanja njome - s obzirom na to »koliko je njega« doista »u njoj«. Izvedba, stoga, nije

\footnotetext{
${ }^{423}$ Ante Čović, »Pojmovna razgraničenja: moral, etika, medicinska etika, bioetika, integrativna bioetika«, u: Ante Čović, Marija Radonić (ur.), Bioetika i dijete. Moralne dileme u pedijatriji, Pergamena - Hrvatsko društvo za preventivnu i socijalnu pedijatriju, Zagreb 2011., str. 11-24, ovdje str. 12.

${ }^{424}$ Usp. ibid., str. 12-13.
} 
moralno relevantna ako bi se promatrala kao procjena gotovih rezultata, nego samo utoliko ukoliko bismo je poimali kao trud na samoj izvedbi.

S obzirom na navedeno, čini se da ne možemo doista ukazati na moralnu relevantnost nekog određenog dijela strukture moraliteta, strukture koja je bitno isprepletena. Stoga su gore i različiti nazivi za moralni fenomen, moralna refleksija i moralni čin, poimani kao istoznačnice. Svaki od tih elemenata promatran izolirano izlazi iz same sfere moraliteta. Promišljanje može biti i moralno irelevantno teorijsko razmatranje, odluka nepopraćena promišljanjem pripadna je i životinjama, kao i izvršenje. Pa ipak, čini se da je, u slučaju potrebe, moguće istaknuti upravo odluku kao središnji i najrelevantniji element moraliteta. Naime, tu govorimo o moralnoj odluci, a ne o onoj prije navedenoj, pa time ona, kao premosnica, bitno podrazumijeva i prosudbu i izvršenje u onom smislu kakvog smo istaknuli (trud na izvršenju). Kako smo pokazali, bez i jednog i drugoga ona prestaje biti moralna odluka. Promišljanje, naime, i u moralnom smislu može ostati puko promišljanje (ono čemu možemo pripisati Hegelov ironičan naziv lijepa $d u s ̌ a$, , pri čemu se često pretvara u licemjerje, ali ne i nužno, jer se može odnositi i na radnju koja neće biti odmah izvršena, dok izvršenje može poprimiti onaj oblik u kojemu se nastrojstvo čovjekove volje ne uzima za relevantno (što je odlika nekih od konzekvencijalističkih teorija morala). Čini se da je upravo ovaj kontekst o kojem govorimo presudan za razumijevanje Kantove čuvene misli: »Nigdje na svijetu, štoviše, uopće ni izvan njega ne da se zamisliti ništa što bi se bez ograničenja moglo smatrati kao dobro osim dobre volje. $\ll^{425}$

Ova kratka razrada oslikava ono što etika zapravo jest - refleksija o moralnom fenomenu. Ovdje, naime, nisu razrađeni neki drugi važni etički elementi, kao što je temeljni princip morala, ali njih ostavljamo za kasnije.

Naznačimo još samo jedno od ključnih pitanja etike, ono o kandidatima za moralni obzir. U svom klasičnom obliku etika je u pravilu bila antropocentrična, dakle pripisivala je moralni obzir samo (određenim ili svim) ljudima. Iako su oduvijek postojala pojedina etička učenja koja su moralni obzir nastojala proširiti izvan antropocentričnih okvira, ona su, barem na Zapadu, bila marginalna te nisu bila osobito utjecajna. Širenje moralnih obzora na ne-ljudska živa bića snažniji prodor doživljava tek krajem 20. st., a čini se da nezanemariv utjecaj na takva kretanja imaju ekološka kriza i uvelike povećana mehanizacija, tj. tehnološko posredovanje ne-

\footnotetext{
${ }^{425}$ Immanuel Kant, Osnivanje metafizike ćudoređa, preveo Viktor D. Sonnenfeld, Feniks, Zagreb 2003., str. 11. Veći dio teksta od početka poglavlja »III.1. Moral i etika« do ovdje prenesen je iz rada: Josip Guć, »Moralitet i legalitet u Kantovoj etici«, Theoria 63 (2020) 2, str. 17-40, ovdje str. 20-21. Vidi čitav rad u svrhu dubljeg razmatranja Kantova poimanja moralne ispravnosti.
} 
ljudskih živih bića, koje je, s jedne strane, dodatno umanjilo čovjekovu empatiju spram njih, ali je, s druge strane, izazvalo zabrinutost kod onih koji su na nju bili nešto osjetljiviji i onih koji su imali općenito izraženiji senzibilitet za promjene koje su od industrijske revolucije nadalje zadesile Zapad. Takva etička učenja sve češće nasuprot antropocentrizmu ističu razne inačice šire shvaćenih centrizama (patocentrizam, biocentrizam, ekocentrizam) kao alternative klasičnom poimanju bića koja ulaze u okvir čovjekova moralnog obzira.

\section{III.2. Međuljudska etika}

Premda je biocentrička etika ono što je najprepoznatljivije kod Viskovića i čime je on zaslužio posebno mjesto u razvoju bioetike na našim prostorima, etika u svom klasičnom ili tradicionalnom obliku nije promakla njegovu interesu. Njegova razmatranja etičkog problema usmjeravaju se u dva pravca koja razvija u, uvjetno rečeno, dvama svojim stvaralačkim razdobljima. Prvo je ono socijalističko, u kojemu kao marksistički mislioc razmatra etičkopravne probleme u kontekstu marksističkog nauka, kao i realnih okolnosti u okviru postojećeg, prvenstveno jugoslavenskog, a onda i šireg europskog i svjetskog društva. U drugom će razdoblju pažnju posvetiti prvenstveno temama koje nadrastaju uski krug tradicionalne etike, razmatranju koje u većoj mjeri napušta ove okvire i posvećuje se holističkom sagledavanju suodnosa prirode i kulture, u kojima se sada eksplicitno iznose pitanja moralnog obzira prema ne-ljudskim živim bićima. Govorimo, naime, o temama, poljima razmatranja i interesa, a ne o načelnim razlikama u tim razdobljima, tako da to odvajanje nema značenje različitih nazora, nego sveukupno razmatranje polazi od iste osnovice i istog temeljnog stava prema problemu moraliteta.

Uostalom, kako u djelu, tako i u životu, Visković je ostao dosljedan određenom misaonom kontinuitetu. Socijalističku misao, koju u pravilu ne prihvaća dogmatski, nikada niti ne napušta. Slično stoji i s brigom o ne-ljudskim živim bićima, za koje se zanima gotovo od samoga početka svog života, što je kulminiralo u dva kulturnobiološka kapitalna djela koja danas imamo na raspolaganju.

Kada govorimo o marksizmu i etici ulazimo u kompleksan problem odnosa samih klasika marksizma prema moralitetu. Sagledavanje tog odnosa ključna je prethodna radnja za prikazivanje Viskovićeve etičke pozicije, ali ona je ključna i za perspektivu etike kao etike 
nakon trijade Kant-Hegel-Marx. Prvi će svojim utemeljenjem etike postati nezaobilazna referenca svakog etičkog razmatranja koje će mu uslijediti, dok druga dvojica, svaki na svojoj način, dovode u pitanje moralitet kao takav. Uzmemo li u obzir enorman utjecaj koji su Hegel i Marx imali, svako daljnje etičko promišljanje, naročito ako želi ostati na Kantovu tragu, mora se osvrnuti na njihove kritike, koje zasigurno označavaju jedan od najvećih destabilizacijskih elemenata u čitavoj historiji etike kao filozofske discipline.

\section{III.2.1. Marksizam i etika}

S obzirom na razmjere koje bi upravo navedena rasprava ovdje mogla zauzeti, ograničit ćemo se na propitivanje nekih osnovnih teza koje su u jednoj originalnoj sintezi Hegel-Marxove misli nastale u zagrebačkoj filozofiji prakse. Još određenije, osvrnut ćemo se na ideju ukidanja (prevladavanja) etike (prisutnu na specifičan, ali ne i posve različit način i kod Hegela i kod Marxa) razvijenu u filozofiji Milana Kangrge, jednog od najistaknutijih zagrebačkih praksisovaca, kako su članovi spomenute škole obično nazivani (prema časopisu Praxis). Ona nam je osobito interesantna i s obzirom na jednu kratku polemiku između Viskovića i Kangrge, ali i kao uvod razmatranju Viskovićeva promišljanja nekih kategorija osobito naglašenih kod praksisovaca.

\section{III.2.1.1. Prevladavanje etike u filozofiji prakse Milana Kangrge}

Moto Kangrgine knjige Etika ili revolucija, koji sažeto oslikava njegovu misao, glasi: »Što je manje revolucije, to je više etike. $\aleph^{426}$ Iako to naslov možda sugerira, predstavljena se disjunkcija ne može shvaćati naprosto kao isključujuća, jer tu se ne radi o izboru između dvije potpuno neovisne i odvojene koncepcije, nego je prije na djelu, kako naglašava Kangrga, »prerastanje etike u revoluciju, to jest njezino revolucionarno ozbiljenje«. Etika se u obliku apstraktne protuteže postojećoj stvarnosti javlja kao »puka kompenzacija ljudskog«. Tako i sam moto knjige postaje jasniji: što je više potrebe za etikom, to je manje zbiljske izmjene stvarnosti, odnosno revolucije. ${ }^{427}$ On upravo u Marxovoj misli uviđa usmjerenje k iščezavanju uvjeta morala, odnosno onoga što generira potrebu za njim, pri čemu nije riječ o brisanju onog pozitivnog u etičkoj misli, nego upravo o njegovu ozbiljenju. ${ }^{428}$

\footnotetext{
${ }^{426}$ Milan Kangrga, Etika ili revolucija, Naprijed, Zagreb 1989., str. 7.

${ }^{427}$ Usp. ibid., str. 7-8.

${ }^{428}$ Milan Kangrga, Razmišljanja o etici, Hrvatsko filozofsko društvo, Zagreb 1970., str. 82.
} 
Kangrgina se kritika etike uvelike oslanja na Hegelovu kritiku moralnosti, ali svakako i na misao cjelokupne klasične njemačke filozofije te onu Marxovu. To pak ne znači da tim konceptima ne pridonosi razvijanjem vlastite, u značajnoj mjeri originalne pozicije. Pri tome, u kontekstu nasljedovanja Kanta, Hegela i Marxa, stalno treba imati na umu da:

»Kangrga, naime, ne pristupa Marxovoj misli nekom izvanetičkom ili antietičkom linijom razmišljanja, nego transetičkim putem dvostrukog prekoračivanja, u prvom redu horizonta kantovske etike uz pomoć Hegelove dijalektike, te u drugom koraku kontemplativne zaokruženosti Hegelova apsolutnog znanja uz pomoć Marxove ideje o ozbiljenju filozofije, koja opet ulazi u širi koncept usvajanja jedinstva bitka i trebanja. $\ll^{429}$

U traganju za prevladavanjem apstraktne suprotstavljenosti bitka i trebanja, Kangrga kod Marxa uviđa njihovo drugačije jedinstvo od onoga kod Hegela, upravo zbog toga što Hegelova pozicija stremi dovršenosti, umrtvljenju trebanja u bitku, dok Marxova pozicija to jedinstvo sagledava kao stalno i konkretno građenje svijeta i smisla, pri čemu etička sfera nije posebna teorijska, apstraktna sfera. Takvo jedinstvo nije ništa drugo do izgradnja slobode, odnosno povijesne mogućnosti drugačijeg. Iako takvo jedinstvo stremi otvorenosti i budućnosti, ono je istovremeno i vraćanje iskonskoj mjeri čovječnosti. ${ }^{430}$

Kangrga naglašava da se pri tome ne može raditi o jednoj »etici revolucije«. Revolucija prekoračuje horizont etike, koja ostaje pri onom postojećem. Samim time, u »etici revolucije« postojeće bi postalo kriterij za buduće, pa se takva sintagma javlja kao proturječje, jer se u tom horizontu revolucija nužno javlja kao nemoralna zato što nastupa »s onu stranu postojećeg «. ${ }^{431}$ Da etika ostaje u horizontu sadašnjosti pokazuje se i u tome što ona daje gotov sistem moralnih normi, koje bi važile za svako buduće djelovanje. ${ }^{432}$

Kangrga ističe da sâm moralni apel ništa ne postiže te na viši rang postavlja »istinsku ljudsku akciju« koja ide na destrukciju starog, a u samom tom aktu i na konstrukciju novog svijeta. ${ }^{433}$ On u blisku vezu dovodi pojmove budućeg, utopijskog, vremena, povijesti, prakse, svijeta i revolucije (re-evolucije). To se, primjerice, ogleda u određivanju čovjekove prirode:

\footnotetext{
${ }^{429}$ Ante Čović, »Etički kriticizam u djelu Milana Kangrge«, Filozofska istraživanja 24 (2004) 3-4, str. 667-677, ovdje str. 672.

${ }^{430}$ Usp. M. Kangrga, Razmišljanja o etici, str. 81-82. - Kangrga drži da je čovjekovo postajanje čovjekom stalna borba, u kojoj čovjekov otvoreni horizont prema budućnosti ne znači gubljenje, tumaranje, proizvoljno izabiranje, nego uvijek stremi k fundamentalnom čovještvu, pa stoga »čovjek jest to što jest prije time što ostaje, negoli time što postaje.« (Hrvoje Jurić, »Kangrgina riječ o zavičaju«, Filozofska istraživanja 24 (2004) 3-4, str. 757-762, ovdje str. 758.)

${ }^{431}$ M. Kangrga, Etika ili revolucija, str. 15.

${ }^{432}$ Usp. ibid., str. 132.

${ }^{433}$ Usp. M. Kangrga, Razmišljanja o etici, str. 62.
} 
»Misliti na sredstvo zadovoljenja (= svrha, ono unutrašnje, subjektivno) znači biti već nužno u dimenziji budućeg. Time čovjek kao čovjek već svagda iznova 'starta' s budućnošću iz svojega bitka kao nedostatka. Zato što je po svojoj prirodi (= biti) nedostatno biće, čovjek 'ima' ili bolje: jest budućnost (= bitno budućnosno biće kao otvorenost za ono utopično još-ne), ili povijest kao povijesni čin koji otvara polje njegove mogućnosti, time što neprekidno (a to i jeste upravo stalno prekidanje s postojećim bitkom kao pukim nedostatkom) iznova treba da postaje, ili da se samo održi u onome što već jest (produkcija i reprodukcija ne više kao - životinjska - evolucija, nego baš kao - re-evolucija).« «34

Kao još jedan problem etike Kangrga ističe njezinu nesposobnost da obuhvati cjelokupnu ljudsku praksu. Ona se kao takva ograničava na pojam praxisa, ali ne i na totalitet ljudskog života koji osim njega uključuje i klasične pojmove poiesis, tehne i theoria, totalitet koji iskazuje moderni pojam prakse. Potonji bi, naime, odgovarao samo jednoj reinterpretaciji Kantove etike, ali nikako samorazumijevanju njene intencije, nego prije razumijevanju njenih rezultata koji dovode u identitet pojmove moralnosti i ljudskosti. ${ }^{435}$ Tako kod Kanta »etika ne samo da prerasta u revoluciju, nego je sama već zbiljska misao revolucije«, odnosno »napor za dokučivanjem, uspostavljanjem ili proizvođenjem jednog iz temelja novoga, to jest tek sada čovjekova svijeta, odnosno svijeta kao takvoga. «36 $^{436}$ To je dodatni razlog zašto etika, kao parcijalna, ne može suditi o revoluciji, kao univerzalnoj.

Glavni je, dakle, problem etike što ostaje pri moralnom sudu, a ne ide na njegovo djelatno izvršavanje. Ipak, to ne znači da je ona potpuno bezvrijedna, što se jasno izražava u samom poticaju svijesti da uvidi potrebu za ukidanjem opstojećeg. ${ }^{437}$ Dovođenjem etike do njenih krajnjih konsekvenci, što upravo Kant radi, ${ }^{438}$ ona se potvrđuje kao »misao revolucije« ili kao »bitni i nezaobilazni moment ili ferment revolucije same«, dok se u prerastanju etike u revoluciju nalazi njen povijesni smisao. ${ }^{439}$ Kangrga visoko cijeni dosege građanskog društva, koji čine pretpostavku onom socijalističkom. Osim što u njemu prepoznaje povijesnu snagu napretka čovječanstva (a nakon toga i onu njegovu historijsku stranu, odnosno pretvaranje iz revolucionarne u reakcionarnu snagu), visoko cijeni i mislioce njemačke klasične filozofije. Samim time, veliku pozornost posvećuje Kantu, bez čijeg povijesnog obrata u mišljenju ne bi

\footnotetext{
${ }^{434}$ Milan Kangrga, Praksa - vrijeme - svijet. Iskušavanje mišljenja revolucije, Nolit, Beograd 1984., str. 173.

${ }^{435}$ Usp. M. Kangrga, Etika ili revolucija, str. 10-11.

${ }^{436}$ M. Kangrga, Praksa - vrijeme - svijet, str. 31.

${ }^{437}$ Usp. M. Kangrga, Razmišljanja o etici, str. 73.

$438 \gg$ Upravo je Kant bio taj koji je do posljednjih konsekvencija doveo tu etičko-moralnu poziciju i upravo zato u klasičnom obliku izgradio etičku nauku kao takvu! « (M. Kangrga, Etika ili revolucija, str. 71.) Iz toga slijedi dalekosežan stav da je etika kao takva poslije Kanta, povijesno i filozofski, nemoguća. (Usp. Milan Kangrga, Etika i sloboda. Uvod u postavljanje etičkog problema, Naprijed, Zagreb 1966., str. 35.)

${ }^{439}$ Usp. M. Kangrga, Etika ili revolucija, str. 16.
} 
bila moguća misao jednog Fichtea ili Hegela, a u konačnici i jednog Marxa. Visoki respekt koji Kangrga pridaje Kantovoj misli u prvom redu cilja na njegovu etiku, odnosno uspostavljanju primata praktičkog uma:

\begin{abstract}
»Onog časa kada Kant u taj svijet uvodi svoj pojam spontanosti koji je upravo moralno-etički sumišljen, dakle po principu slobode, a zatim i pojam primata praktičkog uma, onda se upravo time omogućuje to tzv. prvobitno uspostavljanje svijeta s onu stranu postojeće, znanošću spoznate, fiksirane i manipulirane danosti koja (u liku bitka) još nije moralna, dakle ljudska, nego bi to tek trebala da bude ili postane (da bude ljudski svijet mogućnosti slobode).« ${ }^{440}$
\end{abstract}

Kantova misao predstavlja za Kangrgu duhovni početak revolucije. Upravo osamostaljenje etike od metafizike koje se tu događa predstavlja početak povijesnog mišljenja, u kojemu se etika konačno mora ukinuti. Ono otvara jedno eminentno, samoodređeno ljudsko područje života. Dakle, po principu spontanosti, upravo iz Ničega, rađa se svijet (kao ljudski, inače ne bi bio svijet) $\mathrm{u}$ jedinstvenom povijesnom činu. ${ }^{441}$ Kangrga se tako nastavlja na poznatu Marxovu misao o Kantu kao misliocu Francuske revolucije:

»To, da sloboda uopće može imati neki kauzalitet, ili što je isto - kao što bi rekao Kant - da ono Ja kao akt spontanosti može započeti jedan novi (sada već eminentno ljudski) poredak u svijetu, jest jedna teza koja iskazuje više od svoje vlastite formulacije. Ona svoj izvor ima u revoluciji (upravo: francuskoj revoluciji!) i sama je najdublje revolucionarna. Ona artikulira ne samo mogućnost jednog novog poretka u svijetu, nego ujedno mogućnost jednog novog svijeta (= njegova proizvođenja), i to tako radikalno, jasno i konsekventno mišljeno i domišljeno, da Kant njome nalazi razrješenje osnovnog pitanja suvremene povijesti: odnosa prirode $i$ slobode (kojim je preokupirana čitava njemačka filozofija). Jer, koliko je god on filozofski zastao na dualizmu prirodnog i slobodnog (što se imenuje suprotnošću bitka $i$ trebanja), Kant je ipak nepogrešivom slutnjom dospio do spoznaje kako upravo i jedino revolucija sjedinjuje prirodu $i$ slobodu! «42

Ipak, prema Kangrgi, Kantova pozicija ostaje ograničena jer se čovjekovo ozbiljenje shvaća kao progres u beskonačnost. On tu beskonačnost shvaća kao beskonačnost sadašnjeg i prošlog, odnosno kao apsolutiziranje postojećeg. ${ }^{443}$ Revolucija, dakle, spada u jednu potpuno drugačiju dimenziju od etike, pa tako:

\footnotetext{
${ }^{440}$ Ibid., str. 20-21.

${ }^{441}$ Usp. ibid., str. 53-55.

${ }^{442}$ Ibid., str. 84.

${ }^{443}$ Usp. Milan Kangrga, Etički problem u djelu Karla Marxa. Kritika moralne svijesti, Naprijed, Zagreb 1963., str. 20.
} 
»... insistiranje na etici kao etici znači zapravo u svojoj biti zahtjev za ostajanjem u okvirima klasnog društva, tako da se onda na tim pretpostavkama ono etičko-moralno stalno iznova pojavljuje i potvrđuje, i tako obnavlja kao puko ideološko. $\ll^{444}$

Stoga se, tvrdi Kangrga, čitava praktička filozofija, uključujući tu osim Kantove etike i Fichteovu te Hegelovu filozofiju, treba pretvoriti u filozofiju prakse, odnosno u svjesno, revolucionarno mijenjanje svijeta. Drugim riječima, kako to ističe Marx, filozofija se ima ukinuti tako da se ozbilji (dakle, aufheben kao verwirklichen, a ne verschwinden), pa samim time i etika, kao njen dio. 445

Etika ne uspijeva pokazati kako bi se realno trebao izgraditi moralan čovjek, jer ostaje samo pri negiranju svega opstojećeg, odnosno u apstraktnoj negaciji i vječnoj podvojenosti bitka i trebanja. ${ }^{446}$ No Kangrga na ovom mjestu ipak proizvoljno tumači bit moralnosti kao puke negacije opstojećeg, što promašuje bit gotovo svake, a u svakom slučaju Kantove etike. Etika pokušava iznijeti formalnu paradigmu ispravne moralnosti (trebanje), koja vrijedi, nasuprot Kangrginu i Hegelovu ${ }^{447}$ stavu, bez obzira na njeno konkretno ostvarenje. Paradigma ne postaje suvišna uslijed moralno ispravnog ponašanja. Ako je, naime, u trenutku ostvarena, ne znači da se u drugom trenutku neće djelovati protivno njoj.

Kangrga tvrdi i sljedeće: kako se principi djelovanja ne mogu izvlačiti iz puke faktičnosti, niti iz morala konkretnog društva, oni se iznalaze u samoj praksi smislenog transcendiranja postojećeg. Moralno se tu ipak zadržava kao indignacija nad postojećim i nada u mogućnost drugačijeg. Samim time ono se nadaje kao prvi i neophodan poticaj na djelovanje koje ima uslijediti. ${ }^{448} \mathrm{Na}$ ovom mjestu Kangrgina pozicija postaje donekle proturječna. Pitanje iznalaženja principa za djelovanje navodi ga da prizna moralnome njegovo (ovdje upravo ključno) mjesto za nadilaženje postojećeg, bez obzira na njegovu nedostatnost za izvršenje

\footnotetext{
${ }^{444}$ M. Kangrga, Etika ili revolucija, str. 16.

${ }^{445}$ Usp. M. Kangrga, Etički problem u djelu Karla Marxa, str. 142.

${ }^{446}$ Usp. ibid., str. 222.

447 »Dovršenje moralnosti valja međutim odložiti $u$ beskonačnost, jer kad bi ono zbiljski nastupilo, onda bi se ukinula moralna svijest. Moralnost je naime samo moralna svijest kao negativna bit, za čiju dužnost ima osjetilnost samo negativno značenje, pa joj je samo neprimjerena. U harmoniji pak iščezava moralnost kao svijest ili zbiljnost moralnosti, kao što u moralnoj svijesti ili zbiljnosti iščezava njezina harmonija. Zato se dovršenje ne da zbiljski postići, nego se mora zamisliti samo kao apsolutni zadatak (...)« (Georg Wilhelm Friedrich Hegel, Fenomenologija duha, preveo Milan Kangrga, Naklada Ljevak, Zagreb 2000., str. 392-393.) »Uvažimo li dakle ovo najviše dobro kao bit, onda svijesti uopće nije ozbiljno stalo do moralnosti. Jer u tom najvišem dobru priroda nema drugog zakona nego što ga ima moralnost. Prema tome otpada moralno djelovanje, jer djelovanje postoji samo pod pretpostavkom nečega negativnoga, što se radnjom ima ukinuti. Ako li je pak priroda primjerena moralnom zakonu, onda bi se djelovanjem, ukidanjem postojećega povrijedio taj zakon.« (Ibid., str. 401.) Time prema Hegelu dolazimo do toga da, »budući da je moralno djelovanje apsolutna svrha, to se apsolutna svrha sastoji u tome, da moralnog djelovanja uopće ne bude« (ibid., str. 401), pa je moguće samo jedno »međustanje nesavršene moralnosti« (ibid., str. 404).

${ }^{448}$ Usp. M. Kangrga, Razmišljanja o etici, str. 83.
} 
same radnje. Sama praksa očito mora biti određena moralno, jer inače pati od problema gubljenja barem onog dijela izgrađivanja smisla koji pruža moral u vidu poželjnosti izvjesnog djelovanja. Upravo se problem kriterija ispravnog djelovanja kod Kangrge pokazuje posebno problematičnim. Kako bi oslikali njegovu poziciju, navest ćemo sam zaključak interesantnog hipotetskog dijaloga »Razgovor o etici«:

»Stoga mi, poštovani kolege sugovornici, nemojte govoriti ni o kakvoj etici i moralu, nego pokušajte svojim vlastitim djelom pridonijeti ukidanju i revolucioniranju onih društvenih i ljudskih uvjeta, iz kojih izrasta ovaj postojeći ili bilo kakav drugi moral, koji uvijek opravdava, sankcionira i konzervira postojeći društveni poredak. A tu je istovremeno sadržan i kriterij vašeg djela, koji međutim, kao što sam rekao, nije više isključivo etički ili moralni, nego revolucionarno-kritički i ljudski. Moralne ocjene idu mimo čovjeka koji je iza sebe ostavio čitav stari poredak i hijerarhiju vrijednosti i koji se bori za jedan ljudski društveni poredak i smisleniji čovjekov opstanak. «449

Kriterij ispravnosti djelovanja, prema ovom navodu, nalazi se u stupnju prevladavanja postojećeg, pri čemu se u sveobuhvatnom, revolucionarnom djelovanju ostvaruje smisleni ljudski život. Samim time, nikakvi kriteriji ne mogu biti dani, jer upravo time što su dani ostaju u horizontu postojećeg. U tom duhu Kangrga navodi:

»Bio bi međutim veliki nonsens zahtijevati da se pokaže kriterij po kojem netko jest čovjek (odnosno to postaje) ili (ratni) zločinac (odnosno to ostaje)! To bi naime bila u biti cinička (i pokvarena) sofisterija! (ili tipična znanstveno-objektivistička pedanterija). «450

Zločinac tako potvrđuje zločinačku, a ne ljudsku prirodu, jer je ljudsko određeno kao nešto buduće, nešto što stalno postaje, a ne nešto što je poput zločinaštva bezbrojno puta već bilo na djelu. ${ }^{451}$ Ovakav argument, koji sve prošlo, već viđeno označava kao neispravno, pokazuje se duboko problematičnim. Naime, može se pružiti vrlo banalan (ali isto tako djelotvoran) primjer ponašanja kakvo se teško pokazuje kao loše, a puno je puta viđeno, npr. pružena pomoć čovjeku u nevolji u stilu dobrog Samaritanca, što ne znači da se ne treba raditi na tome da potrebe za dobrim Samaritancem uopće ne bude, u čemu leži poanta Kangrgine ideje da etike ima što manje. Ne vidimo zašto se i potonje nastojanje ne bi postavilo kao moralni imperativ, umjesto da se moralni fenomen ograničava samo na popravljanje situacije unutar okvira postojećeg. Uostalom, usprkos Kangrginu odbacivanju normativizma, njegovo

\footnotetext{
${ }^{449}$ Ibid., str. 135-136.

${ }^{450}$ M. Kangrga, Etički problem u djelu Karla Marxa, str. 234.

${ }^{451}$ Usp. ibid., str. 234.
} 
shvaćanje istinske, autentične čovjekove biti vrlo je blisko etičkom normativizmu. ${ }^{452}$ Odbijanje određivanja kriterija »po kojem netko jest čovjek« ukazuje s jedne strane na bitnu proturječnost njegove misli, a s druge na realnu opasnost od proizvoljnog tumačenja istinske ljudske biti.

»Nepostojanje moralne paradigme - kao što je dosadašnje povijesno iskustvo pokazalo, i kao što aktualna praksa desupstancijaliziranog suvremenog svijeta bjelodano pokazuje - otvara mogućnost za opravdanje bilo kojih, pa i najneljudskijih postupaka.«453

Osim navedenih problema, čini se da Kangrga ima problem s uviđanjem usmjerenosti i biti etike, kako one Kantove, tako i etike uopće, čega smo se već u radu dotakli. To se dobro ocrtava u sljedećem Kangrginu navodu:

»Nije dakle riječ o anuliranju moralnog stava i opredjeljenja u konkretnim uvjetima našeg života i ovog svijeta u cjelini nego o njegovoj - nedovoljnosti, čak i uz pretpostavku najčišće moralne čežnje i najdosljednijeg moralnog karaktera. Jer, čak ako se svi složimo u tome, što je to zapravo moralno uopće, kao i u ovom našem povijesnom trenutku, ili još 'konkretnije': u ovoj našoj sredini i ovom našem suvremenom kretanju - moralnost htijenja, ili moralnost čina, ili čvrstoća moralnoga karaktera, ili moralno opredjeljenje, itd. nipošto po sebi samima još nisu garancija da će ovaj patos osim privatiziranog očuvanja moralnog integriteta ('unutrašnjosti', 'savjesti', 'principijelnosti', 'neuznemirenosti', 'čistoće', 'neprljanja ruku' itd.) pojedinca, čak i 'pod svaku cijenu i usprkos svemu', i baš zato, rezultirati izlaženjem tog istog moralnog pojedinca - 'na agoru', kako bi to rekao Hegel, a kako to s druge strane potvrđuje i povijesno iskustvo i ova naša aktualna situacija danas. « ${ }^{454}$

Kangrga se na ovom mjestu opasno približava puko konzekvencijalističkom pristupu etici, koji u potpunosti zanemaruje nastrojstvo volje pri djelovanju. Ta kritika leži na tobožnjoj nedjelotvornosti moralnog stava. Naravno da je moralna svijest kao takva nedjelatna, naprosto zato što je svijest, međutim moralni stav direktno i jasno upućuje na djelovanje i na »prljanje ruku«. Moralna svijest nikako ne može ostati čista ako je nedjelatna, jer se njezin nosioc upravo tako ponaša nemoralno. Uz to, čista dužnost stoji kao paradigma, a ne kao očekivano ponašanje - stvar je u stremljenju k njoj. Da »dobra volja« nije Hegelova nedjelatna »lijepa duša«, ${ }^{455}$ potvrđuje jedan značajan navod iz Kantova Osnova metafizike ćudoređa:

\footnotetext{
${ }^{452}$ Usp. Mislav Kukoč, Enigma postkomunizma, Hrvatsko filozofsko društvo, Zagreb 1997., str. 122.

${ }^{453}$ Ibid., str. 127.

${ }^{454}$ M. Kangrga, Razmišljanja o etici, str. 85-86. - »Lovori pukog htijenja su suhi listovi koji se nikad nisu zelenili.« (Georg Wilhelm Friedrich Hegel, Osnovne crte filozofije prava, preveo Viktor D. Sonnenfeld, Veselin Masleša, Sarajevo 1989., str. 220.)

$455 »$ Nedostaje joj snage ospoljavanja, snage, da se pretvori u stvar i da podnese bitak. Ona živi u strahu, da će krasotu svoje unutrašnjosti uprljati radom i opstankom; a da bi očuvala čistoću svoga srca, ona izbjegava dodir sa zbiljnošću, pa istrajava u svojeglavoj nedjelotvornosti (...)« (G. W. F. Hegel, Fenomenologija duha, str. 425-426.)
} 
»Ako bi zbog osobite nesklonosti sudbine ili zbog slabe opremljenosti maćuhinske prirode toj volji potpuno i nedostajala moć da provede svoju namjeru; ako kraj svog najvećeg stremljenja ipak ništa ne bi postigla i ako bi preostala samo još dobra volja (dakako ne samo kao pusta želja, nego kao naprezanje svih sredstava, ukoliko su u našoj vlasti): ona bi ipak još blistala sama za sebe poput dragulja, kao nešto što ima svoju vrijednost u samome sebi. Korisnost ili besplodnost ne može toj vrijednosti ništa ni dodati ni oduzeti. $\ll^{456}$

Već smo spomenuli kako Kangrga umnogome slijedi Hegelovu kritiku Kantove etike, pa se u tom svijetlu otkriva još jedan značajan problem u Kangrginu odbacivanju etike »kao etike«. Naime, mnoge proturječnosti koje Hegel pronalazi u Kantovoj etici proizlaze iz pogrešnog shvaćanja nužne nemoralnosti postojećeg (bitka), koncepta koji Kangrga prihvaća i na kojemu se uvelike gradi i njegova vlastita filozofska (spekulativna) pozicija. Međutim, dok to tumačenje može u određenoj mjeri i u izvjesnom smislu odgovarati Hegelovoj filozofiji, ${ }^{457}$ teško ga je pripisati Kantovoj etici. U njoj bi određenje bitka kao nemoralnog bilo naprosto nemoguće. Naime, »ako bi se što apsolutno (i u svakome pogledu i bez daljnjeg uvjeta) imalo biti dobro ili zlo, ili bi se kao takvo imalo smatrati, onda bi to bio samo način djelovanja, maksima volje, a prema tome samo djelatna osoba, kao dobar ili zao čovjek, ali ne neka stvar koja bi se tako mogla nazvati. « ${ }^{458}$

Stoga možemo ustvrditi da: »Ono postojeće (bitak), prema Kantu, naprosto ne može biti kategorizirano u domeni dobra i zla, ono je moralno indiferentno, tj. izlazi izvan okvira etičkih promišljanja. $\ll^{459}$ Upravo takav pristup spašava etiku od proturječnosti koje u njoj nalazi Hegel, pa slijedom njega i Kangrga, te ukazuje na put koji bi trebala slijediti, ako stremi ozbiljnom izgrađivanju same sebe, pa samim time i izgrađivanju čovjeka.

\section{III.2.1.2. Visković i marksizam}

Visković se u svom prvom razdoblju profilira prvenstveno kao marksistički mislioc. Međutim, kako je već naznačeno, taj ga okvir nije zadržao na dogmatskim pozicijama. Njegovo

\footnotetext{
${ }^{456}$ I. Kant, Osnivanje metafizike ćudoređa, str. 12 (podcrtao J. G.).

${ }^{457}$ Tako Kangrga navodi: »Bitak kao takav za Hegela i jest ono zlo! « (M. Kangrga, Etika ili revolucija, str. 340.) To može proizaći iz sljedeće Hegelove tvrdnje: »Ono prirodno je, svakako, po sebi prostodušno, niti je dobro niti zlo, ali ono prirodno koje se odnosi na volju kao slobodu i kao njeno znanje, sadrži određenje onog neslobodnog i stoga je zlo.«(G. W. F. Hegel, Osnovne crte filozofije prava, str. 248.)

${ }^{458}$ Immanuel Kant, Kritika praktičkog uma, preveo Viktor D. Sonnenfeld (redigirao Milan Kangrga), Naprijed, Zagreb 1990., str. 98.

${ }^{459}$ Emil Kušan, »Aspekti i implikacije Kantova pojma slobode«, Filozofska istraživanja 32 (2012) 1, str. 79-91, ovdje str. 87.
} 
drugo razdoblje označavat će odmak od marksizma, barem po pitanju tema kojima se bavio. Štoviše, nekad će se činiti kao da je prebacivanjem fokusa na probleme kojima se bavi u okviru kulturne biologije potpuno zanemario, pa i odbacio marksističku filozofiju. Da tomu nije tako bit će dokazano samim njegovim djelovanjem, prije svega ponovnim uključenjem u politički život putem pristupanja Radničkoj fronti, stranci s kraja hrvatskog lijevog političkog spektra.

Visković se problemima ljevice bavi od ranih dana. Već smo u biografiji iznijeli kako se još kao školarac susreo s marksističkom literaturom. Kasnije reflektira o političkim zbivanjima u Jugoslaviji (odnosno Hrvatskoj) i svijetu, posebno se osvrće na problem nove desnice i konzervativne revolucije u Europi, na pitanje sveučilišta, kao i na samu marksističku političku misao. Konačno, kroz političku prizmu progovara i o ekološkim problemima, koje ponekad promatra unutar okvira socijalističke ili ekosocijalističke misli.

Ovdje nam je osobito interesantan Viskovićev odnos prema marksizmu, koji ćemo ukratko tematizirati, bez pokušaja iscrpnije kritike. Kako marksizam predstavlja jednu sveobuhvatnu misao, dotaknut ćemo više tema kojima se, naročito u svojoj prvoj fazi, Visković bavio. Naravno, uglavnom ćemo izostaviti one teme kojima se iscrpnije bavimo u ostalim poglavljima ovog rada.

Visković jasno ukazuje na to da njegova integralna teorija prava svoje filozofske $\mathrm{i}$ sociološke osnove ima u marksizmu - kao što i svaka teorija prava implicitno ili eksplicitno podrazumijeva izvjesne filozofske i sociološke premise. Filozofske bi pak osnove pored antropologije i metodologije sačinjavale vrijednosne orijentacije te kritike prava. Pojam (čovjeka kao bića) prakse čini osnovu marksističke antropologije, a pod ovim se, usprkos nesuglasicama, podrazumijeva da je čovjek pored prirodnog također i stvaralačko biće, a predmet njegova rada kao opredmećenje njegova rodnog života. On sam je povijesno biće, koje svoja svojstva vlastitom djelatnošću stječe, mijenja, gubi i vraća, a preobražavajući prirodu i podnoseći njen otpor postaje (samo)svjesno biće. Opredjeljujući se između povijesnih mogućnosti biva bićem slobode i vrednovanja. Upravo je budućnost osobito značajna za određenje čovjeka - on je »prije svega ono što on može i treba da bude«. ${ }^{460}$

»... praksa je svjesna i slobodna djelatnost kojom čovjek u granicama situacije i kao društveno biće preobražava prirodu i sama sebe radi zadovoljenja svojih prirodnih i ljudskih potreba. Pod praksom se ne podrazumijeva isključivo materijalna djelatnost, nego osjetilno-afektivno-misaoni totalitet egzistencije. $\ll^{461}$

\footnotetext{
${ }^{460}$ Usp. N. Visković, Pojam prava, str. 52-54. - U citiranom odsječku na kraju Visković prenosi Petrovića. ${ }^{461}$ Ibid., str. 55
} 
Visković se također osvrće na postavku o uvjetovanosti nadgradnje bazom, označavajući njezino pojednostavljivanje u dogmatskom marksizmu kao izvanpovijesno. Oslanjajući se na Petrovićeve uvide, tvrdi da u raznim momentima historije neki faktori imaju veću ili manju težinu, pa je u primitivnim zajednicama vladao onaj biološki, s napretkom proizvodnih moći materijalno-proizvodni, tj. ekonomski, koji u budućnosti može izgubiti dominaciju. $^{462}$

»Postavku o društvenoj osnovi i nadgradnji valja dakle tumačiti u duhu dijalektičko-povijesnog i aktivističkog poimanja čovjeka i društva - polazeći od povijesnog razvoja prakse ili egzistencije čovjeka koji, stvarajući društvenu zbilju, neprekidno preobražava i odnose pojedinih segmenata te zbilje. U tome je implicirana i spoznaja da je ukupna aktuelna društvena djelatnost $u$ jednom vremenskom trenutku uvjetovana ukupnom povijesnom praksom ili dostignutom razinom materijalno-duhovne kulture, a da je odnos značajnosti u međuuvjetovanju osnovnih tipova društvene djelatnosti i uopće društvenih pojava povijesno promjenljiv $(. ..) \ll^{463}$

Kritiku posebice valja uputiti »marksističkim skolastičarima«, kojima je »važno dokazati pravovjernost i poznavanje tekstova Učitelja, a ne istražiti i kritički spoznati stvarnost kakva jest! « ${ }^{464}$ A stvarnost o kojoj Visković govori poprilično je problematična. Njegovo reflektiranje te stvarnosti osobito je intenzivno u osamdesetim godinama 20. st., razdoblju koje je osobito krizno u Jugoslaviji. Međutim, već način na koji su se odvile historijske revolucije pod marksističkim stijegom, kao i njihova ostvarenja, nisu pokazali svoju vjernost ključnim emancipatorskim intencijama marksističke misli.

»... slabosti dosadašnje marksističke političke teorije (jednostrani interes za osvajanjem države, utopistički sindrom, etatistička redukcija i dualizam društva-država, eurocentrizam i skolastička citatologija ravnodušna prema stvarnosti) nisu ni slučajne ni čisto epistemološke greške, već zakonite zablude i ideologijske pozicije nastale u jednom izrazito nepogodnom, nesretnom povijesnom zbivanju radničkih revolucija. Radi se o revolucijama koje su buknule i razvijale se u krajnje zaostalim ekonomskim, političkim i kulturnim prilikama, sa subjektima (manjinsko i nespremno radništvo te njegovo birokratsko predstavništvo) i metodama (nasilje, odsustvo demokratskih institucija, hegemonistički izvoz revolucije) koji su bili posve drukčiji ne samo od onoga što su klasici marksizma pretpostavljali, što za čitavu stvar i nije bitno, nego i od onoga što su sami revolucionari u XX. stoljeću željeli i smatrali optimalnim uvjetima za izgradnju socijalizma.« ${ }^{465}$

\footnotetext{
${ }^{462}$ Usp. ibid., str. 59-60.

463 Ibid., str. 60.

${ }^{464}$ N. Visković, Politički ogledi, str. 46.

465 Ibid., str. 47.
} 
Ovdje postaje još jasnije da se Visković ne drži dogmatski klasika marksizma, što ne znači da nije privržen njihovoj misli. Naprotiv, on uviđa da »natezanjem Marxovih (Engelsovih, Lenjinovih i dr.) tekstova« činimo medvjeđu uslugu autoritetima, nanoseći štetu kako njima, tako i našim mogućnostima za izgrađivanje novoga. ${ }^{466}$ Visković drži da se zatvaranje mogućnosti promišljanja i izgrađivanja nečeg novoga očitovalo i u nespremnosti marksista da podrobnije razviju teoriju o strukturi političkog sistema, koncentrirajući se na pitanja rušenja buržoaske i postavljanje nove vlasti, svodeći marksističku teoriju na teoriju revolucije (Bobbio). Otud i nedostatak promišljanja pitanja demokracije, građanskih prava i sloboda, kao i neopravdano podcjenjivanje građanske politološke misli. Upravo je »skolastička citatologija« marksiste držala podalje od refleksije suvremene situacije uzdajući se u sveobjašnjavalačku snagu klasika marksizma. »Ideološkim 'trebanjem' očaranim« i od stvarnosti odvojenim marksistima, tako su se pred nosom odvijale proturječnosti u kojima je »utopistički sindrom« nalagao nužnost brzog revolucionarnog rušenja klasnog društva i države, dok je u zemljama realnog socijalizma zapravo prevladavao etatizam, koji bi trebao biti prva žrtva tog marksističkog sna. ${ }^{467}$

Komentirajući knjigu Komunistički pokret na raspuću Adama Schaffa, Visković pruža još neke od važnih elemenata za razumijevanje vlastite političke misli. On ne želi potpuno diskvalificirati dosadašnje (prije seljačke i partijske negoli) proleterske revolucije, koje upravo zbog »forsiranog marša« kojime se nadoknađuju neke zaostalosti (industrijalizacija, prvobitna akumulacija) naziva predsocijalističkima, odnosno zakašnjelim tipom građanskih revolucija sa socijalističkim intencijama. Na tom trnovitom putu pojavljuju se mnogi problemi koje Schaff ističe, poput potrebe da državna vlast »brani revoluciju« od »mirne unutrašnje kontrarevolucije« prvenstveno putem autokratizma i nasilja. Prema Viskoviću, radi se o nužnoj i tragičnoj »logici zaostalosti« kojoj su bez ostatka podlegle dosadašnje proleterske revolucije. On ne odbacuje ni mogućnost da taj »forsirani marš« potpuno pervertira društvene odnose i bespovratno uništi šanse ostvarenja građanskog društva, kao uvjeta za razvitak socijalizma, međutim, dojma je da se u takvu krajnost ipak nije došlo. ${ }^{468}$ Premda na nekim mjestima izgleda kako Visković »štedi« spomenute nasilne revolucije, ovakvo promatranje stvari u tadašnjim uvjetima (do sada izneseni stavovi potječu iz tekstova od 1983. i 1986. godine) i iz vizure jednog marksista nisu lišeni odvažnosti. Radi se svakako i o promišljenim stavovima, koji se

\footnotetext{
${ }^{466}$ Usp. ibid., str. 46.

${ }^{467}$ Usp. ibid., str. 42-43.

${ }^{468}$ Usp. ibid., str. 53-56.
} 
prvenstveno očituju u svjesnosti potrebe ostvarivanja ideja građanskog društva kao preduvjeta izgradnji socijalizma:

»... izbijanje revolucije ovisi o zrelosti civilnog društva ( $t j$. o autonomiji privrednih $i$ kulturnih kolektiviteta i građana) i o ulozi države u društvenom razvoju. Ova postavka ima, dakako, znatno šire teorijsko značenje - jer se tiče svih građanskih i svih kasnijih proleterskih (namjerno ne kažemo socijalističkih!) revolucija. Naime, njena objašnjavajuća moć sastoji se u sljedećoj hipotezi: što je u jednoj zemlji civilno društtvo zaostalije, to je veća vjerojatnost (ne i nužnost) da će se u njoj socijalni sukobi potiskivati državnom silom, nagomilavati i najzad eksplodirati u nasilnu revoluciju koja će poroditi novu etatističko-autokratsku vladavinu. $«^{469}$

Visković osobito kritički nastupa i prema prilikama u Jugoslaviji. Tako se gotovo izruguje iluziji o nestanku vlasništva u »društvima socijalističke revolucije«, među koja spada i ono jugoslavensko, ističući da u njima još uvijek prevladava upravo izrabljivački odnos pojedinaca koji se ne ponašaju drugačije od vlasnika sredstava za proizvodnju, čime se održavaju osnove za klasnu podjelu društva. ${ }^{470}$ Radi se o, kako piše još 1985., ideološkom zamagljivanju klasnog aspekta. Slijedeći etimologiju termina »privatno« (lat. privare - lišiti), drži da je svako vlasništvo, bilo ono grupno ili individualno, privatno, dok god označava ovlaštenje nekog (nekih), odnosno lišavanje nekog drugog subjekta (subjekata) raspolaganja stvarima i radom. ${ }^{471}$ Toga su lišeni ponajprije radnici :

\footnotetext{
»Sadašnje stanje u nas i u drugim društvima socijalističkih revolucija jest takvo da proizvođačka klasa ima najmanji udio u podijeljenim vlasničkim moćima i ovlaštenjima, pa onda i u podijeljenoj političkoj moći, te da su široki njezini dijelovi još uvijek podčinjeni i eksploatirani od ostalih subjekata vlasništva i vlasti. Dolazi i do 'prelijevanja viška rada' ili specifičnih oblika eksploatacije i između privilegiranih i deprivilegiranih dijelova same proizvođačke klase. Proces oslobođenja radničke klase jest dijalektički i u tom smislu što on posreduje novim oblicima dominacije i izvlaštenja. Ti oblici principijelno mogu biti i povijesne neizbježnosti u stvaranju uvjeta za oslobođenje, ali su istovremeno institucije koje teže da se perpetuiraju, da izmaknu političkoj i pravnoj kontroli i da se konstituiraju u novi klasnoslojevski blok s kontrarevolucionarnim učincima. Za radničku klasu, međutim, revolucija se nastavlja, ona mora stalno iznova razotkrivati i nastupati protiv tih posredujućih institucija i njihovih mistifikacija. To je tada zadatak i permanentne marksističke kritike postojećih odnosa i klasne borbe. « ${ }^{472}$
}

\footnotetext{
${ }^{469}$ Ibid., str. 73.

${ }^{470}$ Usp. ibid., str. 84.

${ }^{471}$ Usp. ibid., str. 107.

472 Ibid., str. 111-112.
} 
Odavde je također očito da je upravo marksizam ishodište njegovih kritika. To je očito i na onim mjestima kada kasnije svoju poziciju ne naziva eksplicitno marksističkom, premda je očito da ona sadrži neke elemente koji su razvijani u toj filozofiji:

»Nazvao bih je radikalno-kritičkom ili libertarskom. Pazite, ne liberalnom nego libertarskom! To je pozicija, na Zapadu, Noama Chomskog i Pierrea Bourdieua. To je mogućnost radikalne kritike svega vladajućeg. Tu se sloboda ne definira kao tržišna i novčana sloboda niti se Europa počinje i završava stvarati s jedinstvenim novcem i jedinstvenom vanjskom i policijskom politikom Schengena. « ${ }^{473}$

No marksizam za njega predstavlja, kako govori u jednom intervjuu iz 1990., neisključivu i nedoktrinarnu misao »koja je trajno valjana kritika socijalnih nepravdi i otuđenosti «. ${ }^{474}$ Tako i 2015. godine tvrdi da »vrijedi još uvijek biti marksist zbog barem dvije temeljne odrednice Karlove filozofije: nesumnjiv opstanak i produbljenje otuđenja čovjeka i nesumnjiv opstanak i produbljenje eksploatacije čovjeka po čovjeku«. ${ }^{475}$ Moglo bi se reći da je Viskovićeva mladenačka čileanska epizoda sačinjavala jedan od presudnih utjecaja na ovakvo poimanje. Govoreći o na početku spomenutom trockističkom kružoku, naglašava da su revoluciju i socijalizam poimali »prije svega etički, kao odgovor na skandal bijede i tlačenja naroda $\ll .{ }^{476}$

\section{III.2.2. Viskovićevo pozicioniranje u okviru tradicionalne etike}

Prikazu etičke pozicije koju Visković zastupa i kritike na njen račun trebamo prije samog izvođenja pripomenuti nekoliko stvari. Prije svega, stalno treba imati na umu obuhvat koju Viskovićeva misao pruža i njegovo svestrano zanimanje za silnu širinu tema pa u tom svjetlu ne treba očekivati njegovo koncizno ulaženje u sve razine etičke problematike. Samim time, spomenuta kritika neće prvenstveno ići na račun Viskovića kao teoretičara morala (što on svakako nije, barem ne primarno), već prije na račun različitih etičkih pozicija na koje se on

\footnotetext{
${ }^{473}$ Nikola Visković, »Nikola Visković: Smiljko Sokol i Ivan Milas žestoko su se oduprli mojem prijedlogu da životinje uđu u Ustav Republike Hrvatske!«, Globus 30. 7. 1999., intervju (razgovarao Drago Hudelist), str. 3437, ovdje str. 35 .

${ }^{474}$ Usp. N. Visković, Sumorne godine, str. 24. - Moguće je da su ovakvoj formulaciji kumovala i njegova »duhovna 'očišćenja' od onih teorijskih i partijskih dogmi i utopija što ih je nosio, najvećim dijelom situacijski određen zaostalošću građanskog društva Istoka, komunizam Treće internacionale«. (Ibid., str. 13.) No svakako kod Viskovića u teorijskom pogledu ne nalazimo prisutnost nečega što bismo mogli u pejorativnom smislu nazivati ortodoksnim marksizmom.

${ }^{475}$ Nikola Visković, »Prof. dr. sc. Nikola Visković«, u: Mirko Banjeglav (ur.), Hommage Zoranu Malenici, Redak, Split 2016., str. 377-379, ovdje 379. - Ovdje se radi o riječi koju je Visković održao na komemoraciji Zoranu Malenici.

${ }^{476}$ N. Visković, Sumorne godine, str. 77.
} 
poziva (što obrađujemo u posebnom odjeljku). To, naravno, ne znači da nećemo vrednovati Viskovićevu etičku poziciju, ali ipak smatramo da pojedine negativne kritike ne narušavaju vrijednost šireg koncepta koji on nudi unutar kulturne zoologije i kulturne botanike, a koji pruža neizmjerne doprinose etičkoj poziciji (promatranoj prvenstveno u okviru integrativne bioetike), koji bi imali svoju vrijednost čak i u slučaju kad bi čitavo Viskovićevo uže etičko teoretiziranje bilo neodrživo.

\section{III.2.2.1. Moral kao poredak}

Ono što predstavlja posebnu teškoću u razmatranju Viskovićeve etičke pozicije u prvom razdoblju njegova stvaralaštva njena je uska vezanost uz pravo. Nije riječ o tome da se moral izjednačuje s pravom. Problem je što on moral često razmatra kao društveni fenomen, a ne na onaj način na koji smo ga prikazali na početku ove glave. On se, stoga, definira kao poredak: »Ukupnost svih moralnih normi nazivamo moralni poredak ili moral.« ${ }^{477}$ Visković ovdje moral smješta u klasifikaciju društvenih normi, zajedno s pravnim i običajnim normama. To se određenje dodatno pojačava time što od pravnih i moralnih normi odvaja one običajne, $s$ obzirom na to da prve proučavaju odnose koji su za opstanak i dobro funkcioniranje određene vrste društva značajniji. Oni stoga imaju funkciju strogog usmjeravanja djelovanja, a moral ima važnost u još dubljem smislu jer čini ljudski suživot ostvarivim. Neki od moralnih odnosa toliko su važni za društvo da je potrebno izvršiti dupliranje normiranja, tj. pojačavanje primarno moralnog usmjerenja onim pravnim. ${ }^{478}$

Međutim, neka distinktivnija određenja morala koja se bliže vežu uz njegovo poimanje u okviru filozofijske etike, očitovat će se u nastavku, gdje je riječ o razlikama između morala i prava. Visković tablično navodi te razlike, raspravljajući tek o nekima od njih. Tako po pitanju namjere drži da moral obilježava zahtjev za stvarnom ili »čistom« namjerom adresata u pogledu zaštićene vrijednosti. Moralni djelatnik ima uvid u svoje namjere, a ujedno je i adresat i ocjenjivač moralnih zapovijedi. Položaj adresata u moralu više je autonoman, dok je u pravu više heteronoman. Međutim, tvorac moralnih normi je teško odrediv (globalna zajednica, skupine i pojedinci), a način njihova stvaranja spontan i neformaliziran. Također, pravne norme teže međusobnom neproturječju, dok moralnima to u znatno manjoj mjeri polazi za rukom, jer se proturječja ne nalaze samo između različitih subjekata, nego i kod moralnih normi istog

\footnotetext{
${ }^{477}$ Nikola Visković, Država i pravo, Birotehnika, Zagreb 1995., str. 122.

${ }^{478}$ Usp. ibid., str. $115-117$.
} 
subjekta. Samo u moralu pojedinci mogu stvarati vlastite norme, pošto je svaki pojedinac, zapravo, moralni tvorac. ${ }^{479}$

Proturječnosti koje ovdje nalazimo (primjerice u istovremenoj mogućnosti autonomne i heteronomne tvorbe moralnih normi) mogu biti rezultat Viskovićeve primarne koncentracije na pravnu znanost, kao i udžbeničkog izvora prema kojemu smo izveli ovaj kratki prikaz. Međutim, proturječnost ovdje proizlazi i iz (ili prvenstveno iz) činjenice što se ovdje radi o deskriptivnoj, a ne o normativnoj refleksiji. Tu onda može ulaziti sve ono što se nominalno označava kao moral, od javne moralnosti, moralnosti kao poretka koji služi održavanju društva i odražava njegove vrijednosti (što je bitno heteronomija), do autonomno izgrađivanog morala (koji sa strane filozofske etike jedini označava moral u punom smislu riječi). Ovakvo razmatranje, stoga, nećemo uzimati u obzir u daljnjoj raspravi, jer se ovdje primarno bavimo etikom kao normativnom disciplinom, ali svakako je valjalo ukazati na ovaj detalj, kako ovaj isječak u Viskovićevim razmišljanjima ne bi naišao na pogrešnu recepciju.

\section{III.2.2.2. Kontinuitet i diskontinuitet moralnog poretka}

U sklopu rasprave o odnosu socijalizma i morala Visković je dao instruktivnije ideje o svom poimanju etike koje se ne ograničava na deskriptivne uvide. Radi se prvenstveno o tek nekoliko stranica posvećenih ovoj temi u članku »O pravednosti«(1983.). Iako i ovdje Visković govori o moralu kao o poretku, čini se da ipak bliže dolazi filozofskom promišljanju morala u normativnom smislu. Pored kontinuiteta i diskontinuiteta kao ključnih elemenata u ovom razmatranju, kao što je vidljivo i iz naslova, treći važan element u njemu je prevladavanje, koji je osobito interesantan u vidu usporedbe s principom Aufhebung razvijanog u okviru zagrebačke filozofije prakse.

Visković polazi od stava da nešto kao specifični »socijalistički moral«ne postoji. Time s jedne strane odriče održivost snažnim stavovima nekih marksista o kvalitativno novom moralu koji bi trebao nastupiti u komunističkom društvu, ali s druge strane nipošto ne poriče postojanje i važenje samog morala u tom kontekstu. Štoviše, postoji povijesni moralni kontinuitet, i to kao jedna od bitnih osobina ljudske kulture. Naime, ova i ne može opstati ako ne usvoji trajan i u bitnome nepromjenjiv fundus moralnih vrijednosti. ${ }^{480}$ Moral se ovdje, kao i prije, javlja u službi održavanja zajednice, ali ovdje poprima univerzalniji vid kao jedan opći fundus u osnovi neizmijenjenih vrijednosti.

\footnotetext{
${ }^{479}$ Usp. ibid., str. 118-120.

${ }^{480}$ Usp. N. Visković, Politički ogledi, str. 32-33.
} 
To pak ne znači da etika stalno barata $\mathrm{s}$ istim moralnim uputama u svakom dobu čovjekove povijesti. Visković određeni diskontinuitet u moralnom razvoju objašnjava putem prevladavanja. Time se konačno pokušava razjasniti i ono što se s moralitetom događa ili ima dogoditi u socijalističkoj revoluciji i komunističkom društvu:

»Moralni poredak u novim uvjetima socijalističke revolucije (ali isto tako i u buržoaskom društvu nasuprot feudalnom te $\mathrm{u}$ feudalnom društvu nasuprot prethodnim formacijama itd.) ne ide putem potpunog raskida ni s tradicionalnim, ni s građanskim moralitetom: on zadržava zatečena vrijednosna načela i mijenja ih samo u smislu prevladavanja, tj. očuvanja i nadogradnje k višim oblicima humanih društvenih odnosa. $\ll^{481}$

Međutim, potrebno je uočiti kako prevladavanje ovdje nema isti značaj i istu snagu kao prevladavanje moraliteta u djelu zagrebačkih filozofa prakse, premda se ponekad čini drugačije. Tako Visković, ne odudarajući značajno od pozicije praksisovaca, navodi:

»Novum koji donosi socijalizam sastoji se upravo u potpunom poopćenju, ozbiljenju i dovršavanju tih načela u izmijenjenim, višim oblicima ljudskog života do kojih se dolazi ili barem smatramo da treba doći u jednom novom društvenom sistemu. $\ll^{482}$

Ovdje prevladavanje kao ozbiljenje i dovršenje ima jasan oblik principa Aufhebung, ali ipak se od tog teško ostvarivog principa radi određeni odmak ponovnim uvođenjem trebanja, tamo gdje je ono prema klasičnom konceptu imalo biti prevladano. Tu se, naime, ne treba raditi o proturječju, pošto se socijalizam ovdje može shvatiti prije kao regulativna ideja, stanje potpunog ozbiljenja moralnih načela. Takav koncept zasigurno bi odskakao od Marxove filozofije, ali Visković i nema pretenziju da isključivo dosljedno njegovoj misli izgrađuje etiku. Ovdje socijalistička misao u svakom slučaju obuhvaća širi krug od samog marksizma.

Bitna razlika naspram shvaćanja prevladavanja moraliteta kod praksisovaca je ta da ovdje nema naznaka toga da se moralitet ukida u revolucionarnoj praksi, niti da etika kao filozofska disciplina izgubi na svojoj relevantnosti. Druga bitna razlika je u tome što se u Viskovićevu konceptu prevladavanje može odnositi na svaki diskontinuirani moment na povijesnom putu moraliteta, pa tako, prema marksističkoj shemi razvoja povijesti, buržoaski moralitet prevladava feudalni, a feudalni onaj robovlasnički. To pak ne znači da se moralitet $u$ bitnome mijenja, nego da su na dijelu određene tendencije koje su sadržane u njegovoj suštini. Radi se o tendencijama univerzalizacije, autonomizacije i pluralizma te racionalizacije.

\footnotetext{
481 Ibid., str. 32.

482 Ibid., str. 33.
} 
Premda te tendencije, prema Viskoviću, ne pokazuju strogu linearnost, u povijesnom se razvoju očituje pravilo širenja važenja moralnih načela na sve veći broj ljudi, kako u smislu moralnih subjekata, tako i objekata. Nadalje, moralna načela sve više gube na svojoj heteronomiji, podložnosti autoritetu i tradiciji, te dobivaju autonoman oblik, a njihova zasnovanost sve se više pomiče s transcendencije, tradicije i emocije na sam um. ${ }^{483}$ Posljedično nastaje i pluralizam etičkih promišljanja:

»... razvija se autonomnija moralna svijest razvijenih ljudskih ličnosti koje se same određuju i grupno koegzistiraju pod djelomično različitim etičkim kodeksima ali istovremeno spontano postižu jednu nužnu zajedničku osnovu moraliteta u onoj mjeri u kojoj su im zajednički biološki, ekonomski, urbani i drugi objektivni aspekti njihova društvenog bića, i tako se autonomizacija i pluralizam moralnog života iskazuju kao sve punije ostvarenje slobode, mogućnosti stvaralaštva i demokratskih društvenih odnosa. «484

Moralitet, prema Viskoviću, nije indiferentan prema materijalnim uvjetima, iako zasigurno nije njima potpuno determiniran. Upravo taj napet odnos jedinstva moraliteta $\mathrm{i}$ različitosti materijalnih okolnosti rezultira različitim etičkim preformulacijama, kao što, primjerice, u socijalističkoj misli vrline hrabrosti i radne pravednosti dobivaju različita obogaćenja u pogledu pitanja klasne borbe, tehnologije, otuđenja itd. ${ }^{485}$ Taj stav o otvorenosti etike novim problemima bitan je faktor koji će autoru omogućiti prijelaz na propitivanje bioetičkih problema koje otvara naše doba.

Konačno, u ovom se tekstu otvara perspektiva i za jedno obogaćenije značenje morala. Uz pojašnjenje kako prevladavanje funkcionira u etičkom okviru, Visković navodi i sljedeće:

»Samo preuzimanjem i zatim dovršavanjem općečovječanske moralne prakse socijalizam može izvršiti svoju zadatu civilizacijsku funkciju daljnjeg pomicanja granica slobode, dostojanstva i stvaralaštva čovjeka k njegovim najvišim rodnim mogućnostima $(. ..) \ll^{486}$

Socijalizam je, stoga, u svojoj ideji bitno moralna ideja i to takva koja stremi širenju mogućnosti i bogatstva čovjekova samoostvarenja. Ovo će se mjesto pokazati dosta važnim u nekima od završnih poimanja moralnog problema, ali i u pogledu marksističkog obogaćivanja etičke problematike. Od jedne ograničene pozicije razmatranja moraliteta kao društvenog

\footnotetext{
${ }^{483}$ Usp. ibid., str. 33-34.

484 Ibid., str. 34.

485 Usp. ibid. - Sam je put dovršavanja općečovječanskog moralnog poretka jedan od vidova povijesnog razotuđenja čovjeka. (Usp. ibid., str. 33.)

${ }^{486}$ Ibid., str. 33.
} 
poretka, ovdje smo došli do puno šire i plodnije ideje. Taj će se raspon proširiti do neslućenih granica u pogledu širenja etičkog horizonta.

\section{III.3. Širenje etičkog horizonta}

\section{III.3.1. Granice marksizma}

Na pitanje označava li sam socijalizam konačno dovršenje moralnog poretka, polazeći od nekih izdvojenih gore iznesenih navoda moramo zaključiti potvrdno, bez obzira na moguću besmislenost suda o dovršivosti moraliteta. Treba, međutim, zamijetiti da se kod socijalizma može govoriti samo o dovršenju »općečovječanske moralne prakse«. Međutim, premda to Visković ovdje direktno ne izriče, iz njegovih je kasnijih radova jasno da se tu ne može govoriti o dovršetku moraliteta uopće, upravo zato što bi on tako ostao tek »međučovječanski«, zato što još ne bi izašao iz antropocentričnih okvira. Ovdje ne dolazi do proturječja upravo i samo u slučaju da se »općečovječanska« shvati ne samo u pogledu aktera, nego i u pogledu zahvaćenih (ne nužno i isključivih) recipijenata moralne prakse, dakle, kao »međučovječanske«.

Marksizam svoju definitivnu granicu doseže tamo gdje se otvara problem moralnog obzira spram ostatka živog svijeta. On, prema Viskoviću, još uvijek stoji na liniji prosvjetiteljskog instrumentalnog odnosa prema potonjem. Svakako je preuzetno samom Marxu pripisivati krivnju za neuviđanje posljedica takvog odnosa, s obzirom na to da on i nije mogao predvidjeti razorni utjecaj industrije kakvog mi uviđamo danas, što objašnjava nedovođenje nekih slutnji o uništavanju zemlje, odnosno potkopavanju izvora bogatstva, do krajnjih konzekvenci. ${ }^{487}$ Naravno, neuviđanje nama suvremenih ekoloških problema nije tek neminovno (s obzirom na nemogućnost uvida) ograničenje klasičnog marksizma, nego i »svake druge misli 19. i početka 20. stoljeća «. ${ }^{488}$ To pak ne znači da ograničenja ne postoje u samom poimanju izvjesnih odnosa i fenomena koje može olakšati ili otežati suočenje s ovom krizom.

Prema tumačenju Alfreda Schmidta, Marxov se pojam prirode od drugih koncepcija razlikuje u njegovu društveno-povijesnom karakteru. Svaki je iskaz o prirodi, pa tako i spoznajnoteorijski i prirodoznanstveni, relativan s obzirom na tehnološko-ekonomski način

\footnotetext{
${ }^{487}$ Usp. N. Visković, Stablo i čovjek, str. 17.

${ }^{488}$ Usp. N. Visković, »Prof. dr. sc. Nikola Visković«, str. 378.
} 
ljudskog prisvajanja, tj. društvene prakse. Uzeta sama za sebe, priroda je za čovjeka ništa, puki potencijal zadobivanja vrijednosti, tj. ostvarenja u čovjekovoj obradi. No odnos nije toliko jednostavan, već prije posrednički, jer se priroda za Marxa ne može u potpunosti svesti na povijesne procese njenog prisvajanja. ${ }^{489}$

»Ako je priroda društvena kategorija, onda u isto vrijeme važi i obrnuti stav da društvo predstavlja prirodnu kategoriju. Iako za materijalista Marxa priroda i njeni zakoni postoje neovisno o svakoj ljudskoj svijesti i volji, iskazi o njoj se uopće mogu formulirati i primijeniti samo uz pomoć društvenih kategorija. Bez ljudskih napora za savladavanje prirode, o pojmu prirodnih zakona se ne može misliti.«490

No bez obzira na to što, kako ističe Schmidt, ljudi u proizvodnji postupaju kao i sama priroda, oni oslobađaju »usnule potencije« prirode, »pretvarajući mrtvo Po-sebi u živo Za-nas«, Marx kasnije ne govori ni o kakvoj »resurekciji« prirode. Ona ima isključivo služiti ljudima, koji trebaju ovladati njome »tehnološkim sredstvima uz najmanji utrošak rada i vremena«. ${ }^{491}$

„Svakako bi bila rđava romantika da se zaboravi da su i stanju za kojim je Marx težio još potrebne funkcije instrumentalnog uma. Međutim, time što se 'finalizira', što se podvrgava uistinu ljudskim svrhama, on gubi - to je činilo Marxovu nadu - svoj ograničeni karakter; vladavina nad prirodom se oslobađa prokletstva da je istovremeno vladavina nad ljudima, da perpetuira slijepu prirodnu historiju. « ${ }^{492}$

O opravdanosti ove nade govorit će i neki drugi marksisti. Međutim, premda ćemo o tome i o nekim drugim potencijalima marksizma kao plodnih momenata za izgradnju bioetike ukazati kasnije, ovdje valja navesti i neke Viskovićeve inicijative koje također stoje na tragu takve reinterpretacije ovog emancipatorskog učenja, ako ne samog marksizma, onda socijalističke misli uopće. Tako, primjerice, tvrdi da je pripadao:

»... onim ljevičarima koji su sedamdesetih godina dospjeli do spoznaje jednog novog i danas temeljnog sistema izrabljivanja, nasilja i socijalne konfliktnosti - izrabljivanja i nasilja nad prirodom iznad mjere njene izdržljivosti, te konfliktnosti između produktivističkih potreba ljudi da se tako odnose prema prirodi i njihovih sadašnjih i budućih potreba (potreba budućih generacija) za prostim opstankom. Taj uvid je vodio uvjerenju da upravo demokratski socijalizam, pojmljen sada kao ekosocijalizam, znači jednako nužan odgovor na taj egzistencijalni odgovor čovječanstva kao što je od 18. i 19. st. on bio nužan i

\footnotetext{
${ }^{489}$ Usp. A. Šmit, Pojam prirode u Marksovom učenju, str. 24, 42, 89.

${ }^{490}$ Ibid., str. 89.

${ }^{491}$ Usp. ibid., str. 97, 190.

492 Ibid., str. 241.
} 
nesumnjivo u cjelini uspješan odgovor na izazov klasne nepravde i potrebe modernizacije zaostalih društava. « ${ }^{493}$

Nekoliko elemenata za taj put eksplicitno je prisutno i u nekim njegovim posljednjim političkim potezima i zamislima. Tako je pri spomenutom pristupanju Radničkoj fronti naglasio kako je tu stranku potrebno »pozelenjeti«. ${ }^{494}$

No Visković pak ne sprovodi značajnije teorijsko povezivanje izvjesnih marksističkih elemenata $\mathrm{i}$ onih vezanih uz bioetičku problematiku. S druge strane, tamo gdje povezuje socijalističku misao s onom »zelenom«, isključivo se drži antropocentrične perspektive, perspektive koja njega svakako ne zadovoljava.

\section{III.3.2. Antropocentrizam i biocentrizam}

Već je u prikazu Viskovićevih promišljanja u okviru tradicionalne etike očito da je poopćenje ili univerzalizacija jedna od ključnih tendencija povijesnog puta moraliteta:

»Povijest morala ukazuje se kao postupno širenje kruga jednako uvažavanih subjekata putem poopćavanja ili univerzalizacije moralnih pravila, dužnosti i ovlaštenja - iz čega slijedi i poopćavanje političkih i pravnih pravila, dužnosti i ovlaštenja. To znači i smanjenje vrsta i broja bića koja su samo sredstva za nečije ciljeve te povećanje vrsta i broja onih koji se smatraju vrijednostima i ciljevima po sebi. $\ll^{495}$

Na ovom je mjestu vidljivo kako se moralna univerzalizacija (u pogledu kandidata za moralni obzir) više ne kreće isključivo linijom čovjeka, već ona obuhvaća i širi krug životnih oblika, odnosno izvan kruga moralnog obzira ostaje sve manje »vrsta i broja bića«. Tu stojimo na novom, širokom području etičkog ispitivanja, a istovremeno i na gore spomenutoj granici marksizma, kao i cijele tradicije antropocentrične etike. Promatrajući iz perspektive pravne znanosti, Visković insistira da na ovu počnu utjecati sve brojnije koncepcije ekološke etike i bioetike, a njihova konvergencija (potrebna s obzirom na to da bioetika tada još uvijek pretežito stoji u antropocentričnim granicama) u »jedinstvenu etičku brigu o životu« ima pravnicima služiti kao »jedan od najutjecajnijih aksioloških izvora prava«. ${ }^{496}$

\footnotetext{
${ }^{493}$ N. Visković, Sumorne godine, str. 13.

${ }^{494}$ Usp. B. Pavelić, »Nikola Visković pristupio RF-u: 'Hrvatska ljevica treba se udružiti u frontu'«.

${ }^{495}$ N. Visković, Kulturna zoologija, str. 315.

${ }^{496}$ N. Visković, »Ekologija i pravo«, str. 465.
} 
Već se u Viskovićevim marksizmom nadahnutim radovima mogao primijetiti odmak od dogmatskih pozicija, zatvorenih za novovrsno promišljanje moralnog problema, što je jasno i iz navedene principijelne otvorenosti etike novim izazovima. Ona svakako ostaje otvorena i za teorijske dosege drugih znanstvenih disciplina, pa novi izazovi i nova saznanja stvaraju jedan od ključnih poticaja ili pokretača šire moralne univerzalizacije. Tako se poraz uskog etičkog antropocentrizma ne događa tek u glavi filozofa, nego je rezultat različitih promišljanja i reakcija na izazove stvarnosti i znanstvena otkrića.

\begin{abstract}
»Do odlučujuće kritike etičkog antropocentrizma dolazi 1970-ih godina uz nove spoznaje o ponašanju $i$ svijesti životinja (etologija), o uništavanju prirode i životinjskih vrsta (ekologija), o patnjama životinja (psihologija i zoofilija) i o prijetnjama životu od tehnoloških manipulacija (bioetika). Ta četiri izvora novih iskustava stavljaju radikalno u pitanje vladajuću ravnodušnost prema ne-ljudskim bićima ili 'drugim životinjama'.« ${ }^{497}$
\end{abstract}

Novi pogled na narav životinja navodi nas na savjesniji uvid u naš odnos prema njima kao takvima. Tome se svakako pridodaje ponovno promišljanje čitave tradicije međusobnog utjecaja čovjeka i ostatka živih bića. Time se baca novo svjetlo na postojeći poredak kao diskriminirajući, kako tvrdi Visković, ne više (u idealnom vidu) prema ljudima druge rase, roda, vjere ili nečeg drugog, već prema svim drugim vrstama živih bića, kao apriorno isključenima iz moralnog obzira. Premda je jasno da je s gnoseološke strane, kako kaže D'Agostino, životinja nama zatvorena zbilja, u smislu da smo osuđeni na njihovo promatranje iz ugla čovjeka, ne znači da ih ne možemo, uviđajući neke njihove potrebe i interese, pojmiti kao vrijednosti po sebi. Ne može se poreći da se kod njih ne mogu uvidjeti neki egzistencijalni interesi zajednički ljudskima, na temelju čega oni mogu postati nosiocima moralnih prava. To je, naime, zahtjev elementarne pravednosti - jednakima dati jednako, a nejednakima nejednako, u srazmjeru njihove jednakosti odnosno nejednakosti. Upravo je stoga vladajući (antropocentrični) moralni poredak još uvijek diskriminatorski i nepravedan. ${ }^{498}$ Komentirajući Univerzalnu deklaraciju o pravima životinja (1978.) Visković tvrdi:

\footnotetext{
${ }^{497}$ N. Visković, Kulturna zoologija, str. 321. - Zoofilija ovdje ne označava seksualni odnos sa životinjom, već naprosto naklonost ili prijateljstvo sa životinjom. Ono uobičajenije značenje Visković jasno osuđuje. Tako navodi »nekoliko erotoposa koji su nedvojbeno nemoralni - svako nasilje bez pristanka, prevara i upotreba maloljetnika i neuračunljivih osoba. A po mom sudu, kao prijatelja životinja, nemoralna je i zoofilija - jer predstavlja napad na životinju.« (Nikola Visković, »Cijela je ljudska kultura protuprirodna«, Slobodna Dalmacija 25. 3. 2006., intervju /razgovarao Damir Pilićl, str. 32-33, ovdje str. 33.)

${ }^{498}$ Usp. N. Visković, Kulturna zoologija, str. 316-317.
} 
»Tako predlagana životinjska prava iz Deklaracije pravedno su slična nekim temeljnim ljudskim pravima. Pravedno su slična - u onoj mjeri koliko je čovjek prirodno jednak ostalim životinjama i koliko su ove jednako ugrožene kao i čovjek, pa stoga trebaju biti na sličan način i zaštićene, jer pravedno je jednako postupati s onima koji su, i onoliko koliko su, po nekim bitnim osobinama jednaki. ${ }^{499}$

Prema Viskoviću, ovdje se »pravo jednakosti u održavanju života, slobode i blagostanja prema zakonima egzistencije svake vrste« javlja kao temeljno prirodno pravo u ime kojega su vođene sve velike bitke protiv nepravde i diskriminacije, a koje će isto tako voditi borbi za prava biljnih vrsta, ${ }^{500}$ čak i za prava nekih dijelova ne-žive prirode. Tako se, tragom prijedloga Univerzalne deklaracije o pravima prirode Michela Serresa, pojam prirodnog prava ne smije više ograničavati na čovjeka, a namjesto totalnog čovjekova gospodstva nad prirodom treba nastupiti ugovor čovjeka s prirodom. Upravo to predstavlja »put od porobljene prirode k prirodi pomirenoj s čovjekom «. 501

Ovdje već uočavamo implicitan odmak od poimanja moraliteta kao poretka u službi društvene stabilnosti, koja od proširenja našeg moralnog horizonta profitira tek u pogledu brige o prirodi kao ljudskom okolišu, ali ne i od brige spram prirode kao takve ili spram pojedinih živih bića, s obzirom na to da bi se u pogledu potonje (dakle biocentričke paradigme) zahtijevalo obzirno djelovanje spram drugih živih bića koje može rezultirati odricanjem od nekih ljudskih interesa, čak i onda kada je propuštanje takvog djelovanja ekološki neugrožavajuće za čovjeka. Može se reći da bioetička perspektiva Viskoviću otvara bolji uvid u bit moraliteta ili ga barem tjera da nehotice slijedi njegovu nit.

Jedno od ključnih obilježja ovog koncepta je da prijelaz s antropocentrizma na biocentrizam ne predstavlja kvalitativan skok, već on logički slijedi zahvaljujući moralitetu inherentnoj tendenciji univerzalizacije. Međutim, kad govorimo o antropocentrizmu i o biocentrizmu, zasigurno ne govorimo o dva monolitna koncepta. Visković u vezi prvoga navodi »antropocentrično i etnocentrično pravilo«:

»... dopušteno je upotrebljavati i ugrožavati biljni i životinjski život, koji je uvijek samo objekt, kadgod je to čovjeku od bilo kakvog interesa, a i ljudski život kadgod je to u interesu neke (porodične, plemenske, političke) zajednice; nedopušteno je upotrebljavati i ugrožavati samo onaj biljni i životinjski život koji je

\footnotetext{
${ }^{499}$ Ibid., str. 390.

${ }^{500}$ Ovdje se kreće od pretpostavke da su »osnovna moralna pitanja i odgovori u pogledu ljudskog ponašanja spram životinja i spram biljaka bitno identični, premda se u njihovim izvođenjima javljaju značajne razlike u odnosu na ta dva 'carstva života'« (N. Visković, Stablo i čovjek, str. 732). »Sve što vrijedi za životinje načelno vrijedi i za biljke. Jedne i druge treba štititi iz četiri razloga: jer stradaju i pate, jer su lijepe i jer su dio biosfere. I, na kraju, jer su nama korisne.« (N. Visković, »Nikola Visković: Smiljko Sokol i Ivan Milas žestoko su se oduprli mojem prijedlogu da životinje uđu u Ustav Republike Hrvatske! «, str. 37.)

${ }^{501}$ Usp. N. Visković, Kulturna zoologija, str. 390-393.
} 
nečija imovina i/ili priznata simbolička vrijednost u određenoj zajednici, odnosno ljudski život ako je to u interesu te zajednice. $\ll^{502}$

Ovakav pristup mogao bi se, prema Viskoviću, nazvati »'apsolutni' ili 'neumjereni' antropocentrizam«, koji ne drži ni do čega osim do dobra čovjeka. S druge bi strane "'relativni' ili 'umjereni antropocentrizam' « bio onaj koji, ne zanemarujući interese i vrijednost drugih bića, čovjeku priznaje neke povlastice pred njima, imajući istovremeno u vidu da je čovjek jedini sposoban racionalno spoznavati, odnosno etički rasuđivati. Tu se radi o neminovnostima, koje Visković zasigurno ne odbacuje, ali ipak preferira antropocentrizmom nazivati apsolutni pristup. ${ }^{503}$ No bez obzira na to, tvrdi da je gotovo nemoguće da čovjek ne gleda antropocentrički na ono što ga okružuje, jer je sve što on o tome zna posredovano njegovom sviješću i njegovim iskustvom, »nikako se ne može desubjektivizirati«. ${ }^{504} \mathrm{Uz}$ bitnu ogradu umjerenog antropocentrizma, Visković se opredjeljuje za biocentrički pristup, koji opisuje »biocentričkim i ekocentričnim pravilom«:

»... dopušteno je upotrebljavati i ugrožavati biljni i životinjski život, koji nije samo objekt nego također i vrijednost po sebi, samo u mjeri koliko je nužno za samoodržanje i samoobranu čovjeka i samih biljnih i životinjskih zajednica, tj. uz uvjet da za to ne postoje druga sredstva, a isto tako upotrebljavati i ugrožavati ljudski život samo u nužnoj obrani; nedopušteno je upotrebljavati i ugrožavati biljni i životinjski život za one svrhe (suvišne prehrane, gradnje, odijevanja, zabave, sporta, kozmetike itd.) koje nisu egzistencijalno nužne na određenom stupnju civilizacijskog razvoja. $\ll^{505}$

Biocentrizam, kao »etičko rasuđivanje koje misli na dobro svih živih bića i nastoji rješavati sukobe interesa među njima tako da a priori ne nadredi svako i bilo koje dobro čovjeka svim dobrima ne-ljudskih bića«, ${ }^{506}$ skladno se odnosi spram umjerenog antropocentrizma. Visković smatra da je iz samog pravila jasno da ono nema pretenziju postaviti vrijednost svih živih bića na isti rang. U realističnim okvirima ono je maksimalno altruistično. Naime, priznavajući biološku nužnost samoodržanja i samoobrane, čovjeku daje prednost spram drugih živih bića, međutim iza te granice čovjek, kao jedini »aktivni moralni subjekt«, odnosno jedino biće obdareno umom i sposobno moralno suditi, ima moralne i pravne dužnosti obzira, zaštite, pa i poštivanja drugih živih bića kao »pasivnih moralnih subjekata«. ${ }^{507}$

\footnotetext{
502 N. Visković, Stablo i čovjek, str. 728.

${ }^{503}$ Usp. ibid., str. 811.

${ }^{504}$ Usp. Nikola Visković, »Nakaradno je da naša etika uopće ne tretira životinje«, Novi list 30. 5. 2009., intervju (razgovarao Neven Šantić), str. [u prilogu Pogled] 10-11, ovdje str. 11.

${ }^{505}$ N. Visković, Stablo i čovjek, str. 730.

506 Ibid., str. 812.

${ }^{507}$ Usp. ibid., str. 730.
} 
»Ovdje smo očigledno pred novom etičkom paradigmom suprotnoj onoj vladajućoj antropocentričnoj. Radi se o pristupu koji se može nazvati biocentrična etika: etika kojoj je život u središtu pozornosti i koja zahtijeva neposrednu zaštitu svakog života kao vrijednosti po sebi, a ne samo posrednu zaštitu živih bića kao vrijednosti koje su sredstvo za neke vanjske svrhe. $\aleph^{508}$

Konačno, pitanje je na koji način utemeljiti jednu biocentričku etiku. Temeljni Viskovićev stav po tom pitanju možemo prepoznati u Kulturnoj zoologiji gdje eksplicitno postavlja ovaj problem, barem po pitanju moralnog obzira spram životinja:

\begin{abstract}
»Na ta pitanja danas se u bioetici i ekološkoj etici daju različiti pozitivni odgovori, koje ovdje nećemo izlagati. Među njima su i oni visokih teorijskih dometa što utemeljuju priznanje bitne jednakosti i etičke relevantnosti svih oblika života (pa i anorganske prirode kao pretpostavki života) na holističkom poimanju svijeta kao 'biotičke zajednice' (Aldo Leopold) ili kao jedinstvenog organskog bića, globalnog Geja-organizma (James Lovelock). Međutim, intuiciji milijuna ljudi je dostupnije i za poticanje zoofilije jednostavnije ono utemeljenje biocentrične etike koje daje većina suvremenih pobornika priznanja moralne relevantnosti i zaštite životinja: sva živa bića bitno su jednaka po tome što mogu živjeti bolje ili lošije s obzirom na njihove biološke, etološke i društvene potrebe, i što sva imaju sposobnost (prema nekim autorima samo ona fiziološki razvijenija, npr. kralješnjaci) osjećaja boli, patnje i zadovoljstva. Dakle, biocentrična etika temeljila bi se na postavci da je minimalna funkcija svakog normativnog poretka, moralnog i pravnog, omogućiti što veće blagostanje svih živih bića kao najviših vrijednosti, i što je moguće manju mjeru njihova stradanja i patnje. $\ll^{509}$
\end{abstract}

Ovdje nailazimo na nekoliko problema. Prije svega, riječ je o proturječju između biocentričkog i patocentričkog utemeljenja etike, tj. kriterijā za kandidate moralnog obzira. Dok se u izvjesnom smislu može govoriti o blagostanju svih živih bića, s obzirom na njihov bolji ili lošiji život, zadovoljavanje ili neuspjeh težnje za ostvarivanjem, već smo istaknuli da je besmisleno, štoviše kontraproduktivno, govoriti o osjećaju boli i patnje kod biljaka. Drugi je problem taj što Visković često nije sasvim jasan po pitanju temelja na kojima počiva moralni obzir spram čovjeka, a u analogiji s kojima utemeljuje onaj spram ne-ljudskih živih bića. Naime, u pogledu potonjih, kojima se uglavnom bavi, čas nalazimo na poštivanje, a čas na suosjećanje kao temelj. Međutim, ovdje ipak za pojašnjenje i opravdanje ovih kontradikcija i manjkavosti u etičkom teoretiziranju valja primijetiti dva elementa. Prvi je Viskovićev stav da holističke teorije poput Leopoldove i Lovelockove pružaju dublje utemeljenje (»visoke teorijske domete«) moralnog obzira spram svih živih bića, pri čemu se čak u izvjesnom smislu

\footnotetext{
${ }^{508}$ N. Visković, Kulturna zoologija, str. 323.

${ }^{509}$ Ibid., str. 324.
} 
otvara prema fiziocentrizmu (premda najčešće u izvjesnom smislu ostaje na biocentičkim pozicijama uočavajući da anorganska priroda ima vrijednost kao pretpostavka života) ${ }^{510}$ Drugi vrijedan element isticanje je relativnog značaja nastavka navedenog citata u kojem se ističe navedena kontradikcija, time što ga označava kao prikladnog intuiciji. Time upućuje na to da njegovo etičko »teoretiziranje« prije svega ima značaj razvijanja bioetičkog senzibiliteta.

Međutim, u daljem tekstu Visković ne uspijeva ostati na liniji ovakvog razmišljanja, dajući punu podršku patocentičnim utilitarističkim pozicijama, kojima onda ozbiljno dovodi u pitanje koherentnost čitavog svog biocentričnog etičkog utemeljenja. Tako ističe da je Benthamova pozicija uvažavanja patnje kao bitnog elementa jednakosti svih živih bića [sic!] i kriterija njihove moralne ravnopravnosti, temelj za racionalno, a ne tek na temelju simpatija, ${ }^{511}$ utemeljenje moralnih i pravnih načela u korist ne-ljudskih živih bića. Uvažavajući, nadalje, Singerovu patocentričku poziciju, barem ne proširuje opravdanje moralnog obzira spram neosjetilnih živih bića. ${ }^{512}$ Naravno, proturječja su ovdje očigledna. Ne samo da patnja ne može biti kriterij prema kojemu bismo mogli moralno uvažiti biljke, nego ova dvojica i nemaju biljke u vidu pri utemeljenju svoje patocentričke pozicije.

Što se biljaka tiče, Visković smatra da im se nesumnjivo mogu pripisivati određen interes, slijedeći argumentaciju Christophera Stonea, interes da opstanu. Međutim, slijedeći Stonea Visković dotiče krajnost pripisivanja prava i entitetima poput šuma, oceana i rijeka, tj. prirodi uopće. ${ }^{513}$ Osim što se Visković značajno manje trudi da utemelji razloge moralnog i

\footnotetext{
${ }^{510}$ Visković navodi kako zaštita šuma postupno gubi neposredno utilitarni karakter, no to ne znači da napušta antropocentričko viđenje šume kao vrijedne za ljudski, a ne primarno za okoliš svih živih bića. (Usp. N. Visković, Stablo i čovjek, str. 754-755.) »Za tu promjenu možemo zapravo reći da i nije prvenstveno posljedica autonomnog sazrijevanja bioetičke spoznaje i moralne svijesti, već iznuđena posljedica sadašnje ekološke krize, koja naprosto sili javno mnijenje i šumarsku struku da konačno prihvate neke odgovornosti prema ugroženoj prirodi zbog interesa opstanka 'budućih generacija čovječanstva', a tek stidljivo ili čak nesvjesno ide tragom onih altruističkih ekološko-etičkih istina koje je npr. pred pola stoljeća ocrtao prvak američkog pokreta prirodnog konzervacionizma Aldo Leopold. A bioetika nosi imperativ da u našim odnosima s prirodom, pa i šumama, 'treba napustiti mišljenje da je pristojna upotreba zemlje jedan isključivo ekonomski problem. Svako pitanje treba postaviti u terminima etičke i estetičke ispravnosti, jednako kao i ekonomske korisnosti. Ispravno je ono što teži održavanju integriteta, stabilnosti i ljepote biotske zajednice, a neispravno ono što teži drugačijem.' Tek ovo načelo poštovanja biotske zajednice otvara ekologizmu i posebice profesiji šumarstva put prema jednoj budućoj etici staranja za svaki život i zbog njega samoga.« (Ibid., str. 755). Valja primijetiti da ovdje Visković u pozivanju na Leopolda ima biocentrički motiv, kao i da zagovara upravo suizgradnju nauka, struka i znanosti, konkretno etike i šumarstva, čemu ćemo se posebno posvetiti kasnije.

$511 »$ Pri tome se o biofilima uopće ustrajno održava otrcano i zapravo podcjenjivačko shvaćanje da su oni 'ljubitelji životinja' ili 'ljubitelji biljaka' - što je, sukladno vladajućoj etičkoj i ekološkoj nekulturi, temeljno nerazumijevanje činjenice da bitna motivacija i svrha biofilije, ekologizma i bioetike nije ljubav prema svakom obliku života, što je psihološki i nemoguće postići (čak prema svim ljudima), već poštovanje i staranje za svaki oblik života u granicama njegovih prirodnih potreba i mogućnosti« (Ibid., str. 26.) Singer će reći kako: »Mi ne 'volimo' životinje. Jednostavno želimo da se s njima postupa kao s nezavisnim, osjetilnim bićima kakva ona i jesu, a ne kao sredstva za ljudske ciljeve - kao što se postupalo sa svinjom čije je meso završilo u sendvičima naše domaćice.«(P. Singer, Oslobođenje životinja, str. x.)

${ }^{512}$ Usp. N. Visković, Kulturna zoologija, str. 328-329.

${ }^{513}$ N. Visković, Stablo i čovjek, str. 787.
} 
pravnog obzira spram biljki nego što je to slučaj sa životinjama, čini se da se obzir spram biljki često stapa s obzirom spram čovjekove prirodne okoline uopće. Međutim, i pri navođenju potrebe za zaštitom anorganske prirode najčešće se ističe njena uloga kao osnovice na koju se život oslanja. Teško je tu govoriti o točno određenom »-centrizmu«, ponajprije zbog nedostatka argumentacije u prilog nekima od teza.

Mnogi izloženi nedostatci u Viskovićevoj teoriji mogu se smatrati takvima ako se ne odstupa od uvriježenog značenja pojedinih pojmova poput osjetilnosti. Već smo, naime, pri letimičnom pogledu na znanstveno određenje biljke došli do zaključka da ona posjeduje mnoga obilježja analogna osjetilnosti, tj. da posjeduje strukture analogne našoj (životinjskoj) osjetilnosti. Visković pak ide korak dalje i pripisuje im osjetilnost u pravom smislu riječi. Štoviše, u okviru rasprave o definiciji života drži je upravo jednom od njegovih bitnih odrednica:

»U ovim našim pokušajima definiranja izostala je osjetilnost. To je vrlo značajno, ne samo zbog Benthama i Singera, koji osjetilnost opravdano stavljaju u osnovu. Osim njih, i Schopenhauer patnju smatra jednom od osnova etike. Nama je značajna ova osjetilnost zbog toga što sve što je živo osjeća. Hoćemo li to nazvati bolom ili nekako drugačije, svejedno je. Nesumnjivo je da svaki put kad dirnete neko živo biće, od mikroba (koji se također mogu dodirnuti), do svake biljke, da ne govorimo o životinjama, ono se trgne, osjeti da smo ga dodirnuli te reagira. Kako ćemo tu reakciju zvati? Hoćemo li pojam patnje zadržati samo za čovjeka? Hoćemo li patnju vidjeti kao intenzitet reakcije koji sadrži svijest, koju možda druga bića nemaju? To nije važno, radi se samo o stupnjevanosti životnih oblika. Za našu temu je značajno da sve što je živo jest osjetljivo, a sve što je osjetljivo treba dodirivati posebnom pažnjom, posebnim marom, posebnom tremom. Naravno, mi se dodirujemo, i mikrobi nas i mi njih. Tu se krije pitanje koje mi se čini krucijalnim: sukob ili odnos interesa, ili odnos dodirivanja. Tko koga, kojim intenzitetom i kojim pravom smije dodirivati. Moramo se dodirivati, samo se moramo uljudno i etički dodirivati. «14

Nije, ipak, svejedno kako ćemo nešto nazvati, jer u etičkom kontekstu nikako nije isto prouzrokovati bol i utjecati na nečiju osjetilnost (pa bilo to i neobazrivo). Kako bilo, ovdje se pojašnjava smislenost inspiriranja autorima poput Benthama ili Schopenhauera po pitanju uvažavanja osjetilnosti svakog živog bića, a istovremeno se postavlja ključna ograda od zapadanja u potpuni egalitarizam (u naglašavanju stupnjevitosti) u kojem bi nemoguće bilo reflektirati kome dati prednost u stalnom »sukobu interesa« između živih bića (o čemu nešto kasnije). Pa ipak, na pojedinim mjestima Visković postavljanjem suosjećanja za temelj morala, istovremeno (iako možda toga nije svjestan) odriče refleksivnost moralu:

\footnotetext{
${ }^{514}$ N. Visković et. al., »Rasprave«, str. 623.
} 
»Kad bih se ja pitao na čemu se temelji moral, na čemu se temelji dobro prema drugom živom, i ne samo živom nego i neživom biću u smislu uvjeta života, tzv. prema neorganskom svijetu, rekao bih da se ono temelji na suosjećanju. Moral se sastoji u tom minimalnom, a sve ostalo je dogradnja (...). Tko nema taj minimum, a to je osjećaj za bol, za strah od smrti, za strah uopće, za patnju i slabost, tko za to nema osjećaj, nema sućuti, njemu trebaju neki autoriteti koji će to nametnuti.« ${ }^{515}$

Suosjećanje kao prirodni osjećaj igra snažnu ulogu u moralu, ali je istovremeno vrlo nezgodan pojam za baratanje u etičkoj teoriji. On se, upravo kao prirodni osjećaj, ne da naložiti imperativom, nego se ili prirodno nadaje ili se ne nadaje. Pored toga, ono često može voditi, nasuprot plemenitim intencijama onih koji ga zagovaraju, izrazito diskriminatorskim praksama. Ako je suosjećanje temelj moralnog »suđenja« ( $\mathrm{u}$ navodnicima s obzirom na to da ono isključuje suđenje u pravom smislu riječi) i djelovanja, tada opravdanima mogu postati privilegiranje ljudi ili ne-ljudi koji iz bilo kojeg razloga prijaju moralnom djelatniku, a nema ničeg očekivanijeg od toga da nam, primjerice, čovjek koji priča našim jezikom bude prijatniji i izaziva kod nas veće suosjećanje od čovjeka iz neke potpuno strane kulture (koji će možda izazivati i strah). Kod morala ne može biti riječ naprosto o osjećaju, nego uvijek o refleksiji o tome tko i zbog čega zaslužuje moj moralni obzir. Naravno da u ovo »zbog čega« pripada i nečija osjetilnost, ali fenomen su-osjećanja potpuno je druga stvar. Ono ipak ima važnu ulogu u moralu, ali prvenstveno kao »pomoćno sredstvo«, sredstvo olakšanja moralnog djelovanja ili kao pomoć u prijemčivosti za osvještenje postojanja moralne dužnosti prema drugome.

Iako je bilo potrebno iznijeti kontekst u kojem Visković razvija svoje ideje i koristi određene termine, mi ćemo ovdje zadržati klasično, uz ljudske i ne-ljudske životinje vezano poimanje osjetilnosti, da se ne bismo iskakanjem iz njega izložili potencijalnoj kritici. Sličan terminološki problem, ali s većim utemeljenjem, očituje se i kod određenja moralnog subjekta i objekta.

\section{III.3.3. Subjekti i objekti moralnih i legalnih prava}

Visković se jasno postavlja u tradiciju mišljenja koja govori o moralnim pravima, kao specifičnim pravima pored onih legalnih. Kritiku onih koji ne misle da takva prava mogu postojati (konkretno Freya) jer, za razliku od legalnih prava, kod morala ne postoji nešto kao

\footnotetext{
515 Ibid., str. 648.
} 
zahtjev među subjektima, Visković odbija tvrdeći da se moral i pravo ne razlikuju u pogledu postojanja zahtjeva i sankcija, nego samo u pogledu načina njihova postavljanja. ${ }^{516}$

\begin{abstract}
»Ne-ljudska živa bića nemaju ili nemaju dovoljno onih svojstava svijesti koja nazivamo razumom, uračunljivošću i slobodom odlučivanja, a koja su po općem uvjerenju nužna za utemeljenje moralnih $i$ pravnih dužnosti (obaveza) i moralne i pravne odgovornosti. U etici je nesporno da je samo čovjek biće razuma i da samo on ima shvaćanje o ispravnom i neispravnom, te da je stoga samo on aktivni etički subjekt. ${ }^{117}$
\end{abstract}

Tradicionalna etika, nastavlja Visković, drži da zbog navedenih razloga ne-ljudska živa bića ne mogu imati ni moralna ni legalna prava (ovlaštenja), tj. subjektivna prava, dakle niti ono što naziva pasivnim etičkim subjektivitetom. Osnove za odbijanje takvog stava nalaze se već u samorazumljivosti pripisivanja moralnih i legalnih prava djeci i mentalno zaostalim ljudima, kojima svakako nedostaje uračunljivosti i slobode odlučivanja. Riječ je, stoga, o uvjerenju koje proizlazi tek iz čovjekove moćničke pozicije. Kao protuargument može se postaviti ideja korelativnosti/simetričnosti prava i dužnosti, na što Visković odgovara da korelativnost ne vrijedi tako da isti subjekt mora biti sposoban imati i prava i dužnosti. Korelativnost postoji u onom smislu u kojem pravo jednog subjekta implicira dužnost drugoga, a obaveznog subjekta ne može biti bez ovlaštenog subjekta (nosioca prava). ${ }^{518}$

Ovdje bi valjalo ukazati na način na koji Visković shvaća pravne subjekte i objekte, kako bi bilo jasnije određivanje moralnih prava, tj. onih koji su nosioci moralnih prava. Tu se radi o onome što se u pravu promatra kao pitanje pravnih odnosa. Visković navodi četiri elementa koji sačinjavaju pravni odnos: pravni subjekti, pravna obveza, pravno ovlaštenje (subjektivno pravo) i pravni objekt. Među njima osnovnu ulogu igraju pravni subjekti, zbog kojih pravo uopće i postoji - kako bi se zadovoljili njihovi interesi. Za pravni odnos potrebna su barem dva pravna subjekta, što nije slučaj u moralnom odnosu, gdje čovjek može biti u odnosu sam sa sobom (primjerice, u odnosu samopoštovanja). ${ }^{519}$ Iako u udžbeničkoj definiciji

\footnotetext{
${ }^{516}$ Usp. N. Visković, Kulturna zoologija, str. 369.

${ }^{517}$ Ibid. - Ovdje, kao i na drugim mjestima, zanemarujemo Viskovićevo nerazlikovanje uma i razuma. Sudeći po kontekstu, ovdje bi se prije radilo o umu, kao spoznajnoj moći na kojoj možemo temeljiti moralno suđenje, jer je razum, u klasičnom Kantovu određenju, takva spoznajna moć koja se zadržava na svođenju osjetilnih zorova pod svoje kategorije (pojmove). To ne znači da na drugim mjestima nećemo uvažavati ovu bitnu razliku.

Pa ipak, usprkos instruktivnosti ovog razlikovanja, iz same Kantove vizure ne možemo reći da se ovdje radi o pogrešci, jer se može govoriti i o razumu u širem, općem smislu: »Ali riječ razum uzima se i u posebnom značenju: naime, budući da se on kao član podjele s druga dva člana podređuje razumu u općem značenju, a kao viša sposobnost spoznaje (promatrana materialiter, tj. ne samo za sebe, nego u odnosu na spoznaju predmetā) sastoji se od razuma, moći suđenja i uma.« (Immanuel Kant, Antropologija u pragmatičnom pogledu, preveo Željko Pavić, Naklada Breza, Zagreb 2003., str. 82.)

${ }^{518}$ Usp. N. Visković, Životinja i čovjek, str. 369-370.

${ }^{519}$ Usp. N. Visković, Država i pravo, str. 178, 192.
} 
navodi su pravni subjekti »ljudi i društvene tvorevine koji imaju pravne obaveze i pravna ovlaštenja s obzirom na neke pravne objekte«, nedugo zatim u bilješci tvrdi:

\begin{abstract}
»Pojam 'pravni subjekt' ne ograničava se samo na ljude pojedince i organizacije kao nosioce pravnih obaveza i pravnih ovlaštenja. Još od antičkih prava priznaje se svojstvo pravnih subjekata i određenoj imovini koja je namijenjena nekim humanitarnim, obrazovnim i sličnim svrhama, a njome upravlja jedno upravno tijelo - zaklada. Međutim, nema zapreka da se i pojedina kulturna, prirodna dobra ili životinje proglase zaštićenim dobrima sa svojstvom pravnog subjekta, pri čemu bi takvi subjekti mogli biti samo nosioci pravnih ovlaštenja, ali ne i pravnih obaveza. $\ll^{520}$
\end{abstract}

Visković u tom pogledu ističe dva značajna suda Hansa Kelsena: da je subjekt prava »personificirano jedinstvo jedne skupine pravnih normi« te da su »čovjek i subjekt dva potpuno različita pojma ${ }^{521}$ Analogno tome, subjekt morala trebao bi biti personificirano jedinstvo jedne skupine moralnih normi, što znači da bi određivanju subjekta morala, pa onda i naših dužnosti spram njega, prethodilo utvrđivanje moralnih normi. To odgovara Reganovu stavu po pitanju ovog slijeda, koji slijedeći Johna Stuarta Milla piše da valjanost određenog moralnog prava »mora ovisiti o njegovoj usklađenosti s moralnim principima čija je valjanost neovisno ustanovljena ${ }^{522}$

S druge strane, navodi Visković, pravni objekti predstavljaju vrijednosti zbog kojih pravni subjekti uopće i stupaju u pravne odnose. Vrijednosti su u pravnom pogledu shvaćene u širem smislu, kao društvene vrijednosti i dobra, kao duhovne i materijalne vrijednosti. Ne samo pravnih, nego i običajnih i moralnih odnosa ne može biti (bili oni i najduhovniji) bez objekta, predmeta ili razloga. Pravne norme raspodjeljuju pravne objekte u skladu s vladajućim shvaćanjem pravednosti. Pravne objekte čine: prirodna dobra, ljudske duhovne i materijalne tvorevine, ljudske radnje činjenja i ljudske radnje nečinjenja (i nečinjenje je, naime, radnja). Međutim, pravnim objektom često postaje i sam čovjek. Iako je u ideji, frazama i političkopravnim deklaracijama čovjek isključivo pravni subjekt, tj. ne može biti pravni objekt, to je s deskriptivnog aspekta neodrživa ideja, iako ima smisla govoriti o čovjeku kao isključivo pravnom subjektu u obliku preskriptivnog suda (suda trebanja, a ne bitka). Već su njegove radnje činjenja i nečinjenja pravni objekti, a može se govoriti samo o mjeri u kojoj je on subjekt odnosno objekt, što je rezultat njegove ovisnosti o drugim ljudima (razina prisile da obavlja

\footnotetext{
${ }^{520}$ Ibid., str. 192.

${ }^{521}$ Usp. N. Visković, Kulturna zoologija, str. 381.

522 Tom Regan, The Case for Animal Rights, University of California Press, Berkeley - Los Angeles 1983., str. 270.
} 
teške i ponižavajuće poslove i sl. - koliko se pravne subjektivnosti još dade naći, primjerice, u prostituciji?). ${ }^{523}$

\begin{abstract}
»Općenito je ljudska egzistencija, to je objašnjeno od Hegela i Marxa, do Heideggera i Sartrea, subjektivitet koji se stalno otuđuje od sebe i postvaruje (postaje više ili manje stvar) u odnosima među ljudima, no u državno-pravnom poretku je to otuđenje i postvarenje naročito snažno i grubo. Kulturni razvoj prava ide $\mathrm{k}$ tome, makar u nekih dijelovima svijeta, da se unutar samog pravnog poretka postavlja sve više i što djelotvornijih zapreka (ljudska prava i njihova sudska i druga zaštita) prisili, nasilju i bijedi iz kojih neprestano izviru odnosi postvarenja - kako bi čovjek bio čovjeku što više subjekt, a što manje (čini se nemoguće da nikako ne bude) objekt. « ${ }^{524}$
\end{abstract}

Kao što i čovjek očito može biti pravnim objektom, nema ničega začuđujućeg u tome da se $u$ isti razred uvode i životinje i biljke. One prema gornjoj klasifikaciji pripadaju prirodnim dobrima. Međutim, pitanje je trebaju li one pripadati tom razredu, odnosno isključivo tom razredu?

Čak se ni oni koji misle da životinje zaslužuju obzir, navodi Visković, ne slažu u tome je li smisleno ili potrebno pridavati životinjama prava, kao pasivnim moralnim i pravnim subjektima - subjektima s pravima, ali bez dužnosti, za razliku od aktivnog subjekta koji ima i jedno i drugo). Pod aktivnim subjektima misli se na uračunljive osobe, koje imaju subjektivne interese i mogu shvatiti pravne i moralne norme, kao i poduzimati radnje za koje snose odgovornost. Pasivni subjekti bića su sa suprotnim odlikama. Oni, dakle, nisu uračunljivi, ne mogu poduzimati neke ili sve moralne i pravne radnje zahvaljujući nemogućnosti njihova shvaćanja, pa su, stoga, ograničeno ili potpuno neodgovorne. U pogledu moraliteta, aktivni i pasivni subjekti razlikuju se onako kako Tom Regan razlikuje moralne agente (djelatnike) i moralne pacijente (trpnike), dok u pravnom aspektu postoji analogna podjela na djelatno sposobne i djelatno nesposobne subjekte. Još jedna razlika spram aktivnih subjekata je ta što se kod pasivnih subjekata štite njihovi objektivni interesi, dakle interesi formulirani od strane drugih subjekata. Visković subjektivnim interesom naziva subjektovo shvaćanje vlastitih potreba i, s time povezano, subjektovo postavljanje vlastitih ciljeva. Objektivni interes se, za razliku od ovoga, odnosi na shvaćanje potreba nekog drugog subjekta i postavljanje ciljeva u njihovu korist. Time nosioc takvog interesa ostaje njegov subjekt. Naime, klasična je postavka (Nelson) da samo ona bića koja imaju interese mogu imati i prava, a oni koji životinjama odbijaju mogućnost moralnih i legalnih prava (Frey) interes interpretiraju kao subjektivni

\footnotetext{
${ }^{523}$ Usp. N. Visković, Država i pravo, str. 196-199.

524 Ibid., str. 199.
} 
interes. Ne samo da životinje imaju interese kao objektivne interese, nego čak postoje naznake da imaju i subjektivne interese (na što pokušavaju ukazati neki etolozi, a Regan na polju etike). ${ }^{525}$

Visković pri iznošenju spomenutog problema razmimoilaženja animalista po pitanju pripisivanja moralnih i legalnih prava životinjama ističe da protivnici takvog pristupa ili slijede shvaćanje po kojemu se životinjama ne daje mogućnost posjedovanja interesa ili smatraju da pripisivanje tih prava nema osobitu važnost u borbi za njihovu zaštitu. Kako smo vidjeli, Visković odbija ispravnost prvog razloga, a za drugi se obraća, po njemu odlučujućem, argumentu Silvane Castignone, prema kojoj se uz ideju prava veže predodžba o sigurnoj i izvornoj zaštiti od strane pravnog poretka, ali i uslijed odgoja postaje inhibicija koja povećava šanse odustajanja od povređivanja subjekta prava. Ako i nije nužno pripisivati prava životinjama, izgleda da je to barem pragmatički oportuno. Stoga Visković u ovom pogledu jasno staje na stranu Regana, a ne Singera koji odbija važnost ideje pripisivanja prava životinjama, prihvaćajući je tek kao ustupak suvremenoj moralnoj retorici. ${ }^{526}$ Općenito, što se moralne zaštite životinja tiče:

»Premda je Reganova teorija o 'animal rights' općenito povoljnija osnova za opravdanje bolje zaštite životinja, te je utoliko argumentativno jača od Singerove teorije koja ne operira sa životinjskim ovlaštenjima, njena kolebljivost u određivanju kruga životinja koje su inherentne vrijednosti, 'subjekti života' i subjekti ovlaštenja (kolebljivost koja je posljedica psihofizičkih kriterija za određenje 'subjekata života'), pokazuje se kao stanovita slabost u usporedbi sa Singerovom jasnijom i po obuhvatu širom teorijom 'bola, patnje i zadovoljstva'. Međutim, razlike u praktičkim zaključcima nisu velike (...)« «27

Reganu, za razliku od Viskovića, pragmatičnost pripisivanja prava ne igra važnu ulogu, no njegova se teorija u svakom slučaju za potonjeg (ako bi se isključio problem obuhvata moralnog obzira) javlja kao superiornija Singerovoj i s obzirom na poštivanje kao temelj moralnog obzira. Naime, prerastanje iz antropocentričke u biocentričku etiku zahtijeva poštivanje svakog života bez utilitarnih motivacija. ${ }^{528}$

\footnotetext{
${ }^{525}$ Usp. N. Visković, Kulturna zoologija, str. 371-372.

${ }^{526}$ Usp. ibid., str. 373-376. - »Uz to, taj imperativ poštovanja i zaštite svih elemenata biosfere može dobiti, a mi smatramo i da treba dobiti, svoj najprimjereniji pravnički izraz, tj. svoje najčvršće jamstvo pravne zaštite, u proširenju normativne kvalifikacije 'subjektivnog prava' na ne-ljudska bića: tako da pravni status biljke i životinje ne bude samo 'objekt prava' (odnosno 'zaštićeni objekt prava'), nego prvenstveno 'subjekt prava' ili određeno središte interesa života koje ima prema čovjeku neka svoja prava koja je zabranjeno i kažnjivo (osim u spomenutim izuzetcima) povrijediti.« (N. Visković, »Ekologija i pravo«, str. 466.)

${ }^{527}$ N. Visković, Kulturna zoologija, str. 377.

${ }^{528}$ Usp. ibid., str. 236.
} 
Osim što se Visković služi različitim, u nekim elementima kontradiktornim etičkim pozicijama, ovdje se ponovno koleba između utemeljenosti argumentacije i pragmatičnosti, koja ovdje označava jasnoću i snagu za postizanje cilja - zaštite životinja. Sudeći po navedenom, izgleda da je dio razloga za prihvaćanje Reganove strane po pitanju ideje prava životinja upravo utilitaran (što bi se moglo nazvati svojevrsnim »meta-utilitarizmom«). To kolebanje dodatno otežava prihvaćanje njegove etičke argumentacije, ali i odražava više puta spomenuti utjecaj pravne znanosti na nju. $U$ tom je pogledu zanimljiv njegov komentar Univerzalne deklaracije o pravima životinja (1978.), koja usprkos tome što nema

»... pozitivnopravnu snagu, sadrži jedan široki i realističan popis prirodnih prava odnosno moralnih ovlaštenja svih ili samo nekih kategorija životinja koje su od čovjeka ugrožene. Kao etički odgovor na vladajuću ravnodušnost prema stradanjima životinja, koje su posvuda još predmeti svakakvih zloupotreba, Deklaracija je realistična u tom smislu što ne odlazi u drugu krajnost - u radikalne animalističke zahtjeve, utopističke u odnosu na mogućnosti i nažalost tvrdo ukorijenjena raspoloženja čovječanstva, koji niječu bilo kakvu ljudsku upotrebu životinja i traže obvezatno vegetarijanstvo u jednom svijetu koji bi trebao biti obnovljeni zemaljski raj. Deklaracija je stoga kompromis između sukobljenih interesa čovjeka i životinje - kompromis što zadovoljava ljudske prehrambene i ekonomske potrebe na račun nekih životinja, ali pri tome štiti opstanak i blagostanje svih životinjskih vrsta i jedinki od bezobzirnog i nerazumnog ljudskog nasilja. $\ll^{529}$

Ona se po njegovu mišljenju pokazuje dobrim prilogom za odgovor na pitanje koja moralna i pravna ovlaštenja trebaju pripasti životinjama. ${ }^{530}$ No konkretno odgovarajući na ovo pitanje, Visković nije suviše pragmatičan:

»Dakle, svim biljkama i svim životinjama trebalo bi priznati, s izuzetcima koji su nužni za opstanak drugih biljaka, životinja i čovjeka, pravo na život, pravo na slobodu, pravo da ne budu zlostavljeni, pravo na zaštitu njihova okoliša i pravo na uzdržavanje ako su obuhvaćene ljudskim ambijentom i/ili uzgojem. $\ll^{531}$

Slijedom priznavanja, primjerice, prava na život, nema razloga da se vegetarijanstvo ne nametne kao moralna i pravna dužnost onim ljudima kojima jedenje životinja ne predstavlja vitalni interes, tj. nije nužno za opstanak. No imajući na umu zahtjev za pripisivanjem prava biljkama, Visković navodi teorijsku dilemu (kakvu je zapazio još Tommaso Campanella) o dužnosti obrane i biljnog života u vidu apsolutne obrane života - ne predstavlja li njihovo

\footnotetext{
${ }^{529}$ Ibid., str. 383-384.

${ }^{530}$ Usp. ibid., str. 384.

${ }^{531}$ N. Visković, »Ekologija i pravo«, str. 466.
} 
isključivanje iz moralnog obzira u veg(etarij)anskom zagovorništvu još jedan stupanj specizma? Takvo pitanje pak nema ništa sa zahtjevom odustajanja od biljne prehrane. ${ }^{532}$ Shvatimo li ovo kao provokaciju obrani vegetarijanstva, pa pristane li se čak i na nemogućnost stupnjevanja životā koje vrijedi spašavati, nesumnjivo je da mesnom prehranom ugrožavamo ne samo životinjske živote, nego i više biljnih života. Banalno je, ali nažalost potrebno ponavljati, da životinje koje se konzumiraju i same moraju nešto jesti. Masovno oduzimanje prava živih bića na život, ali i ostalih gore nabrojana prava, osobito se intenzivira industrijskim uzgojem životinja, pa tako »masovni uzgoj stoke, svinja i peradi uzrokuje teška onečišćenja prirode i živih organizama, a ujedno oduzima staništa divljim životinjama«, a uz to »troši polovinu svjetske proizvodnje žitarica na tov privrednih životinja ${ }^{533}$ Pored ovdje i ranije nabrojanih razornih učinaka, spomenimo još samo zastrašujući podatak da industrijska farmska postrojenja uzrokuju 18\% emisija stakleničkih plinova, a klimatskim promjenama doprinose više no sav transport na Zemlji. ${ }^{534}$ Naravno, problem jedenja životinja ne sačinjava jedini primjer sukoba interesa između čovjeka i životinje.

\section{III.3.4. Sukobi interesa}

Prije spomenuto biocentričko i ekocentričko pravilo, kao osnovno za Viskovićevu bioetičku poziciju, u osnovi je opterećeno sukobima interesa onih bića prema kojima imamo moralni obzir. On prije svega tvrdi da u takvim situacijama ne postoji nešto kao gotov pravilnik djelovanja, nego se pod vidom tog osnovnog pravila zasebno mora promišljati svaki konkretni problem.

\footnotetext{
»Dakako da su u tim sukobima nemoguća posve objektivna ili nesporna rješenja (odluke) - pa će onda zavisno o ovakvom ili onakvom rješenju, u apstraktnim rasuđivanjima i u pojedinačnim slučajevima (case decision), dolaziti do različitih poimanja dopuštenog li nedopuštenog u primjeni samog biocentričnog i ekocentričnog pravila. Jer, uistinu, nema etičkog pravila koje nije podložno slobodi rasuđivanja, etičkim
}

\footnotetext{
${ }^{532}$ Usp. N. Visković, Životinja i čovjek, str. 424. - Visković usprkos vlastitom karnivorstvu priznaje da nije dosljedan, pa da s obzirom na to osjeća krivnju, te tvrdi da, iako se može reći da je čovjek prirodno svejed, on bi se kao racionalno biće trebao suzdržati od jedenja mesa. (Usp. N. Visković, »Nikola Visković: Smiljko Sokol i Ivan Milas žestoko su se oduprli mojem prijedlogu da životinje uđu u Ustav Republike Hrvatske! «, str. 36; Nikola Visković, »Potičući množenje ljudi, Vatikan ugrožava biosferu«, Globus 28. 2. 2003., intervju /razgovarao Miljenko Jergović/, str. 70-72, ovdje str. 71.)

${ }^{533}$ N. Visković, Životinja i čovjek, str. 423.

534 J. S. Foer, Eating Animals, str. 58. - Ova se teza iznosi u opsežnoj studiji Livestock's Long Shadow. (Usp. Livestock's Long Shadow. Environmental Issues and Options, Food and Agriculture Organization, 2006., str. xxi. Dostupno na: http://www.fao.org/3/a-a0701e.pdf /pristupljeno 4. 1. 2020./.)
} 
dvojbama i argumentaciji, a to pogotovo vrijedi za ovo toliko zahtjevno i ljudskoj destruktivnosti bitno suprotstavljeno (stoga i možda konačno na neuspjeh osuđeno) pravilo biocentrične etike. « ${ }^{535}$

Da je riječ o nemogućnosti pružanja gotovih odgovora na sukobe interesa pokazuje se onda i kada se iznađu izvjesna mjerila za njihovo prosuđivanje. Visković tako pojedine sukobe interesa ljudi i životinja provlači kroz mjerila koja proizlaze iz Univerzalne deklaracije o pravima životinja:

»a) razlikovanje vitalnih interesa (bitnih ili osobito važnih za održavanje i kvalitetu života) i nevitalnih interesa, te davanje prednosti vitalnim interesima nad nevitalnim interesima - bez obzira jesu li subjekti jednih i drugih ljudi ili životinje;

b) razlikovanje interesa psihofizički razvijenijih bića i interesa psihofizički nerazvijenijih bića, te davanje prednosti interesima razvijenih bića nad interesima nerazvijenijih bića kada među njima nastupe sukobi vitalnih interesa odnosno nevitalnih interesa;

c) nedopustivost potpunog žrtvovanja vitalnih interesa čitavih vrsta nerazvijenih bića radi ostvarenja vitalnih interesa razvijenijih bića, jer bi to vodilo istrebljenju žrtvovanih vrsta. $\ll^{536}$

Visković ukratko iznosi moguće, često teško razrješive prijepore koji u okviru ovih mjera mogu nastupiti i već nastupaju. Ad a) Jasno je da ubijanje životinja za jelo, njihovo korištenje u medicinskim eksperimentima ili uklanjanje »štetnika« ugrožava vitalni interes životinja, no predmet je spora ugrožava li odustajanje od tih praksi ljudske vitalne interese. Animalisti čak tvrde da su te prakse za čovjeka štetne. $A d b$ ) U slučaju izjednačenih vitalnih odnosno nevitalnih interesa pristupa se razmatranju psihofizičke razvijenosti, no ona uvijek ide na stranu čovjeka, što radikalni animalisti drže specističkim moralom. Sam Visković potvrđuje da je ovdje još uvijek na djelu »eufemizacija odnosa moći«, ali ujedno i »reformistička dobra volja u okvirima postojećih materijalnih mogućnosti i stanja svijesti«. Ako ništa drugo, takav pristup barem donekle otklanja ravnodušnost spram ovih problema. Pored toga, ovo mjerilo služi u odvagivanju između dvije životinje, ali kao osobito se problematično javlja ako nastupa između dvoje ljudi ili ako se psihički razvijenija životinja suprotstavi duševno oboljelom čovjeku u slučaju potrebe eksperimentiranja. U ovom su sukobu na stranu životinje stali Singer, Donald Van der Ver (koji se drži ovdje predstavljenog slijeda ovih dvaju mjerila razrješenja sukoba), ali i Regan, no on tek hipotetički, s obzirom na to da se uopće protivi pokusima nad životinjama. $A d c$ ) Posljednje u nizu mjerila možda će se tek ubuduće pokazati problematičnim. Do sada su čak i oni senzibiliziraniji spram životinja ovima uglavnom, kada se radi o pitanju

\footnotetext{
535 N. Visković, Stablo i čovjek, str. 731.

${ }^{536}$ N. Visković, Kulturna zoologija, str. 400-401.
} 
života i smrti, omogućavali tek da »ulaze u čamac ako ima mjesta« koje čovjek nije popunio no što uraditi ako se radi o posljednjem živom primjerku izvjesne životinjske vrste? ${ }^{537}$

Ovakvim se pak razmatranjima ne zaokružuje problem sukoba interesa, ponajprije zato što u njima nije dovoljno podrobno reflektirano što su uopće ljudski interesi. U kontekstu njihova kontrastiranja onima biljaka i životinja prije svih možemo istaknuti onaj samoodržanja, koji, naravno, ne pripada samo čovjeku. Kao i sva druga živa bića, ističe Visković, čovjek uništava i prisvaja određene oblike života zbog samoodržanja i samoobrane. Konstantan prirodni fenomen ubijanja i oštećivanja Visković naziva »biološkom činjenicom«, ili »biološkom razinom« ubijanja i oštećivanja, koja poprima sasvim specifičan oblik pojavom čovjeka, kao ubijanje i oštećivanje na »biološko-antropološkoj razini«. Prva razina nije podložna moralnom sudu, naprosto zato što bićima koja u tom sukobu participiraju nedostaje razum [sic!] kao konstitutivan za moral, nego se to događa tek onda kada se ubijanje i oštećivanje podignu na »biološko-antropološku razinu«, gdje takve radnje poprimaju i obilježje »moralne činjenice ${ }^{538}$ Međutim, ta druga razina vodi i značajnom proširenju čovjekovih interesa i potreba.

\begin{abstract}
»I tako se u materijalnoj zbilji i u vladajućim idejama stalno potvrđuje istina da je civilizirani čovjek, za razliku od biljaka i životinja, čiji napadaji na okolni živi svijet služe samo biološkom održavanju i samoobrani jedinke i vrste, jedino biće prepotentne tehničke moći i prejakih zahtjeva za 'dobrim životom', koje u svom povijesnom 'napretku' neprestano i neuračunljivo uvećava uništavanje i iskorištavanje svih oblika života, uključujući samoga čovjeka, daleko preko vlastitih bioloških potreba samoodržanja i samoobrane. Radi se zapravo o tome da čovječanstvo svojom pre-moćnom tehnologijom porađa (i nameće se pitanje: nije li to njegov neotklonjivi fatum?) takve kulturne potrebe čije zadovoljenje traži mnogostruko veća žrtvovanja prirode i života od onoga što traže njegove osnovne biološke potrebe - pa se onda događa ne samo to da takve kulturne potrebe sve više ugrožavaju druga bića i čak njegov vlastiti biološki život, nego i da u čovjeku vrlo sporo sazrijeva svijest o tim opasnostima i o poželjnosti ograničenja svojih razornih prohtjeva prema prirodi i prema samom čovječanstvu. Sazrijevanje takve svijesti otežavaju dakako i samoopravdavajući procesi racionalizacije (u čemu odlučujuće sudjeluju prirodne i društvene znanosti), koji sve ljudske prohtjeve što ugrožavaju prirodu, ma koliko bili zbiljski nepotrebni, neracionalni, obijesni ili nakazni, prikazuju, vrlo širokim tumačenjem 'principa realnosti', kao egzistencijalno nužne u smislu samoodržanja.« «39
\end{abstract}

Čovjek s kulturom, dakle, izgrađuje čitav novi krug potreba i interesa uz one prirodne. Štoviše, same »njegove biološke potrebe nisu više onako 'objektivne' i ograničene kao u

\footnotetext{
${ }^{537}$ Usp. ibid., 397-398, 401-407.

${ }^{538}$ Usp. N. Visković, Stablo i čovjek, str. 727-728.

${ }^{539}$ Ibid., str. 729-730.
} 
animalnom svijetu, jer ih kultiviranje čini značenjski znatno 'subjektivnim', možemo reći i ideološkim, pa samim tim vrlo oštrim i nepredvidivim «. ${ }^{540} \mathrm{Ne}$ samo to, nego one stalno rastu dovodeći u sve veću opasnost ostatak živog svijeta:

\begin{abstract}
»To nije više ono ograničeno međuvrsno nasilje, koje je svakom biću nužno i dovoljno za preživljavanje i za njegovu mjeru prirodne slobode, već pravi, štoviše totalni, neprekidni i istrebljujući rat jedne prepotentne vrste, kojoj zacijelo nedostaje ravnoteža između moći i etičke samokontrole, protiv svih drugih zajednica života na svijetu. (...) Osobina je tog totalnog rata da u njemu zapravo nema više ni privremenoga mira, primirja, jer hipertrofirane potrebe prepotentnog Homo sapiensa pritišću bez predaha ekosistem $(\ldots) \ll^{541}$
\end{abstract}

Ovdje se nalaze poticaji za promišljanje široke palete problema. Naime, jesu li novi zahtjevi za dobrim životom zapravo zahtjevi za, kako Visković naznačuje, »dobrim životom«, tj. radi li se samo o iluziji dobrog života? Jesu li potrebe koje tehnološki razvoj donosi uistinu prave ljudske potrebe? Osim toga, postavlja li takav poredak nepromjenjivu realnost koja zadaje jedine moguće okvire mišljenja i djelovanja? Jesmo li, u konačnici, slobodni u formiranju naših potreba? Na ova ćemo se pitanja, u raznim formama razmatrana kroz marksističku misao, vratiti nešto kasnije.

\title{
III.3.5. Filozofski i teorijski utjecaji
}

Prije konačnog kritičkog osvrta na Viskovićevu etičku poziciju, potrebno je uvidjeti domašaje etičkih teorija koje on drži osobito relevantnima za problem moralnog obzira spram drugih živih bića. Radi se, prvo, o onima Arthura Schopenhauera i Jeremyja Benthama, koji spadaju među pionire zagovaratelja moralnog obzira spram životinja u novom vijeku, premda ćemo se mi ovdje podrobnije baviti samo prvim. Nadalje, riječ je o dvije animalističke pozicije u suvremenoj filozofiji, Singerovoj (unutar koje ćemo se kratko osvrnuti i na Benthamovu) i Reganovoj. Konačno, kako smo vidjeli, Visković vjerojatno drži da je teorijski najispravniji put onaj koji pružaju holističke teorije kakva je ona Alda Leopolda, pa ćemo se u ovom pregledu osvrnuti samo na prvu. Pri tome neće biti na odmet promotriti i dubinsku ekologiju Arnea Næssa, kao svojevrsnog Leopoldova nastavljača, kako i sam Visković kaže,${ }^{542}$ premda ne iznosi

\footnotetext{
${ }^{540}$ N. Visković, Sumorne godine, str. 238.

${ }^{541}$ Ibid., str. 242.

$542 »$ Važne su i razlike (prvo formulirane od Norvežanina Arna Naessa) između radikalnog ekologizma ili deep ecology, koja nastavlja holističke ideje Alda Leopolda, i umjerene ekologije ili shallow ecology, koja općenito ne odstupa od antropocentrično utilitarne 'zaštite ljudske okoline', environmentalizma, ambijentalizma.« (N. Visković, Životinja i čovjek, str. 402.) Kao opravdanje uvrštavanja Næssa u ovaj pregled poslužit će i teza koju
} 
naširoko načela ni jednog ni drugog, niti argumentira u prilog njima. Naravno, tu se svakako mogu pridodati i imena Alberta Schweizera, Jamesa Lovelocka i drugih autora koje Visković spominje, ali zadržat ćemo se na navedenima, kako radi ekonomičnosti teksta, tako i zbog izvjesnog slijeda u argumentaciji koji želimo pružiti putem analize filozofskih i drugih pozicija odabranih autora. Naime, ovaj će pregled istovremeno sadržavati kritiku navedenih pozicija. Pri tome će, kako to u etici često biva, u našim komentarima često biti prisutna »avet« Kanta, kao nezaobilazne figure etike kao filozofske discipline. To, naime, nije naš proizvoljan umetak, već proizlazi iz živog zanimanja većine navedenih autora za Kantovu etičku misao, a svakako je i inače slučaj da se većina autora u oblasti etike direktno suočava s njome.

\section{III.3.5.1. Arthur Schopenhauer}

Schopenhauer će svoju etiku izvesti na dva načina u dva spisa. Prvi se odnosi na njegovo stožerno djelo, metafizičku raspravu Svijet kao volja $i$ predstava (Welt als Wille und Vorstellung), u kojoj etika predstavlja kraj, a istovremeno i vrhunac sistema. Drugo ključno djelo u ovom kontekstu, O temelju morala (Preisschrift über die Grundlage der Moral), čitavo je, kako je vidljivo iz samog naslova, posvećeno etici, odnosno zasnivanju morala. Ne treba posebno naglašavati neizostavnu Kantovu ulogu u Schopenhauerovu filozofiranju. Recimo samo, vezano uz raspravljani kontekst, da je odnošenje prema Kantu ključno i u etici, tako da će u oba navedena djela Schopenhauer značajna poglavlja posvetiti upravo kritici njegove filozofije, ali uz što će više puta istaknuti njenu neizmjernu vrijednost, naročito u poredbi s njegovim nastavljačima u okviru klasičnog njemačkog idealizma. Tu kritiku ne namjeravamo iznositi u čitavom opsegu, nego ćemo se na nju osvrnuti jedino u slučaju kritičkog propitivanja same Schopenhauerove etičke pozicije. Prije toga, ukratko ćemo prikazati tri za nas važna vida te pozicije: empirijsko i metafizičko izvođenje te konkretno tematiziranje čovjekova odnosa spram životinja.

U raspravi $O$ temelju morala Schopenhauer etiku izvodi empirijski, naglašavajući da takva forma etike predstavlja ispravan put za razliku od onog imperativnog, zasnovanog na trebanju. On si za cilj postavlja empirijsko pronalaženje radnji kojima propisujemo moralnu

\footnotetext{
ćemo kasnije isticati u ponešto drugačijim kontekstima: »Ali ono što je zaista novo i umnije u razvijenoj bioetici i u tzv. 'dubinskoj ekologiji' (deep ecology) jest načelno poštivanje svakog života i odustajanje Homo sapiensa od njegovog dosadašnjeg pretjeranog, pljačkaškog i nepoštenog odnosa prema prirodi, a što znači i priznanje da se imperativ očuvanja prirodne okoline čovjeka mora uravnotežiti s imperativom očuvanja prirodnih okolina medvjeda, kita, slona, ptice i leptira, šumskih, močvarnih i prerijskih biotopa itd., kao samostalnih vrijednosti koje treba zaštititi koliko je god moguće, neovisno o njihovoj ljudskoj upotrebljivosti. (...) I tek nas takva etika konačno uvodi u moralnu punoljetnost.« (N. Visković, Sumorne godine, str. 215-216.)
} 
vrijednost. Kako je egoizam čovjekova osnovna pobuda koja izrasta na osnovi volje za životom, glavna je zadaća moralne pobude njegovo svladavanje. To je moguće samo tako da krajnji cilj moje volje postane onaj drugi, a njegovo dobro na isti onaj način na koji sam kao egoist želio svoje dobro, što zahtijeva svojevrsno identificiranje s njim. Međutim, kako ja ne mogu postati onaj drugi, to identificiranje može biti sprovedeno samo putem spoznaje (što znači predstave) o njemu, a radi se o stvarnom postupku, fenomenu koji svakodnevno nalazimo u iskustvu i koji se time postavlja kao fundament etike - sažaljenje (Mitleid). On je osnova za dvije kardinalne vrline, pravičnost i čovjekoljublje, iz kojih proizlaze sve ostale. ${ }^{543}$

Etika je, međutim, nemoćna po pitanju promjene određenog karaktera, pošto je on urođen i neiskorjenjiv. Ipak je moguće manipulirati ljudskim radnjama, ali samo na način zavođenja i prevare, pa se tako motivima »može iznuditi legalnost, ali ne moralnost «, tj. nije moguće utjecati na istinsko htijenje drugog čovjeka, nego samo na njegovo djelovanje. ${ }^{544} \mathrm{U}$ tom smislu on ističe Kantovo shvaćanje odnosa slobode i nužnosti, prema kojemu je, kako to Schopenhauer tumači, nužnost smještena u djelovanju, dakle predstavi, dok je sloboda u samom bitku, dakle stvari o sebi. ${ }^{545}$ Odgovornost stoga leži u onome što netko jest, a ne u onome kako netko djeluje, pošto je samo to djelovanje uvjetovano nepromjenjivim karakterom.

Schopenhauer ističe kako je jasno da dobar karakter pristupa drugome tako da smanjuje razliku između sebe i njega. Ipak, egoistički stav sasvim je moguć unutar svijeta kao predstave, u kojem se razlika između mene i drugoga jasno očituje, tako da je empirijski potpuno prihvatljiva. Štoviše, prostor i vrijeme ne pripadaju stvari o sebi, nego predstavi ili pojavi, a upravo na njima počiva mnoštvo i različitost (tako predstavljamo jednu individuu prostorno pored, vremenski iza druge i sl.). Biće po sebi (Wesen an sich) stoga je jedno. ${ }^{546}$

\footnotetext{
»Prema tome, praktička mudrost, činjenje onog što je pravo i dobro, susrela bi se s najdubljim učenjem teorijske mudrosti koja je najdalje dospjela, a praktički filozof, tj. onaj pravični, onaj tko čini dobro i onaj plemeniti, djelom bi izražavali isto saznanje koje je rezultat najveće pronicljivosti i najtegobnijeg istraživanja teorijskog filozofa. « ${ }^{547}$
}

Ono jedno, stvar o sebi, kod Schopenhauera je volja. Čovjekova spoznaja ne može ići dalje od predstave, predstave same volje. Tu se radi o svjetskoj Volji, dok je volja iskušena u

\footnotetext{
${ }^{543}$ Usp. Artur Šopenhauer [Arthur Schopenhauer], O temelju morala, prevela Veselka Santini, Bratstvo-Jedinstvo, Novi Sad 1990., str. 136-140, 149-150.

${ }^{544}$ Usp. ibid., str. 194, 200-201.

${ }^{545}$ Usp. ibid., str. 118.

${ }^{546}$ Usp. ibid., str. 212-214.

${ }^{547}$ Ibid., str. 217.
} 
unutarnjem čovjekovom čulu tek predstava te Volje, tu se ona približava našim spoznajnim moćima u najvećoj mogućoj mjeri. Sama ljudska spoznajna moć jedna je od objektivizacija Volje, koja je u svojoj osnovi nezasitna težnja ili žudnja, koja stalno nadvladava svaki svoj stupanj. Volja se stoga izjednačava s voljom za životom, a kako se sav bitak od nje u suštini ne razlikuje, tako je on sam život. Njeno bitno obilježje je i sloboda, kao neovisnost o načelu razloga, pa tako sloboda i ne pripada živim bićima po sebi, već se kod njih može raditi tek o »fizičkoj slobodi« (fenomenalna sloboda u kojoj nema fizičkih zapreka) ili »intelektualnoj slobodi« (u kojoj nema zapreka duševnih bolesti i sl.), ali nikako o »slobodi htijenja«. Naime, čovjekovi voljni činovi javljaju se nužno, iz uzajamne igre karaktera (naslijeđenog od oca) i motiva (ovisnog i o inteligenciji, naslijeđenoj od majke). Svatko kao inteligibilan karakter, prije rođenja, vrši izbor među različitim karakternim obrascima: egoist, zlobnik/okrutnik, pravednik ili asket/svetac. Kako je volja za životom nezasitna, stoga i nezadovoljiva, na svijetu prevladava patnja, izlazak iz koje je u najvećoj mjeri moguć za svetački, odnosno asketski karakter. Svi prethodni nisu ništa više do potvrđivanje volje za životom, koja vodi patnji, dok posljednji transcendira predodžbeni svijet i nalazi svoje spasenje u negaciji vlastitog karaktera. U njemu volja niječe vlastitu bit. Tako soteriološki interes Schopenhauerove filozofije u najvećoj mjeri dolazi na vidjelo u njegovoj etici. ${ }^{548}$

Čitava Schopenhauerova etička teorija istovremeno je primjenjiva na životinje, koju je, kako tvrdi, racionalistička filozofska tradicija isključila iz moralnog razmatranja, poričući pri tom svijest životinja o njima samima, koja se dokazuje već na razini bezgraničnog egoizma prisutnog u svakoj životinji. Toj zapadnjačkoj sofistikaciji, koja za njega ima svoju osnovu u židovstvu, pridolazi i izvještačeno jezično razdvajanje istih radnji ili stanja kada se pripisuju čovjeku i kada se pripisuju životinji. ${ }^{549}$

\begin{abstract}
»Mora se biti uistinu neosjetljiv na sva čula ili totalno otrovan kloroformom foetor Judaicus-om, pa da se ne spozna da je ono glavno kod životinje i kod čovjeka - isto, i da ono što njih razlikuje ne leži u primarnome, u principu, u arhéu, u unutrašnjem biću, u jezgru obaju pojava, što je i kod jednog i kod drugoga volja individue, nego samo u sekundarnom, u intelektu, u stupnju spoznaje moći koja je kod čovjeka po pridošloj sposobnosti apstraktnog saznanja, nazvanoj um, neusporedivo viša, ali je ipak dokaziva samo posredstvom većeg cerebralnog razvitka, dakle, samo prema somatskoj različitosti jednog jedinog dijela - mozga - i to njegovog kvantiteta. $^{550}$
\end{abstract}

\footnotetext{
548 Sadržaj ovog pasusa referira se na sljedeći prikaz Schopenhauerova djela: Jörg Salaquarda, »Arthur Schopenhauer«, prevela Darija Domić, u: Ozren Žunec (ur.), Suvremena filozofija I, Školska knjiga, Zagreb 1996., str. 35-81.

${ }^{549}$ Usp. A. Schopenhauer, O temelju morala, str. 182-183. »Da se jedan kartezijanac nađe u kandžama tigra, najjasnije bi postao svjestan kakvu oštru razliku ovaj postavlja između svoga Ja i Ne-ja.« (Ibid., str. 183.)

${ }^{550}$ Ibid., str. 184-185.
} 
Kako je sažaljenje jedina osnova morala, tako nema razloga, tvrdi Schopenhauer, da se za onoga tko je okrutan spram životinja drži da je dobar čovjek - sažaljenje prema životinjama dolazi iz istog izvora iz kojega ono dolazi pri moralnom odnosu spram drugog čovjeka. Pa ipak sažaljenje nad životinjama dolazi do izvjesne granice kad patnja čovjeka dođe u konflikt $\mathrm{s}$ patnjom životinje. Naime, kako sposobnost za patnju ide ukorak s razvojem inteligencije, nekad će nanošenje boli životinji izazivati manju patnju kod životinje nego kod čovjeka, primjerice u slučaju mesne prehrane, što ne znači da i tada životinja ne bi trebala biti ubijena na što bezbolniji i brži način. ${ }^{551}$ Ovdje se očito radi o predrasudi, koja doduše može biti nadiđena iz same Schopenhauerove etike. Međutim, ova pati od brojnih drugih problema.

Kritika može krenuti od nedostataka Schopenhauerove kritike Kanta. U prvom redu, čini se da on mnoge pojmove proizvoljno tumači, a svakako izvan konteksta u kojima ih koristi Kant. Dovoljno je ukazati na njegovo razumijevanje nužnosti i slobode. Primjerice, Schopenhauer ne prihvaća sud da je dužnost »nužnost djelovanja iz poštivanja zakona«, jer neizbježnost, koja bi pri nužnosti imala biti na djelu, po samom Kantovom priznanju tu nije. ${ }^{552}$ Međutim, ovdje je ipak riječ o tome da djelovanje nije prirodno, već praktički nužno, što znači da se nužno formira na određeni način ako slijedi zapovijed čistog praktičkog uma. Kant ne tvrdi da se to događa neizbježno (u terminima prirodnog kauzaliteta), nego prije govori o paradigmi savršenog moralnog djelovanja, koja se kao praktički zakon poštuje kada je na djelu ispunjavanje dužnosti, dok je poštovanje uopće besmisleno u pogledu prirodnih zakona (gravitacija djeluje na nas poštovali je mi ili ne). Općenito, možemo se složiti s Jovanom Babićem, koji tvrdi da Schopenhauerovo »razmatranje pojma nužnosti, u relaciji poštovanja zakona, sadržanoj u dužnosti, (...) oblik je naturalističke redukcije na empirijski smisao, a svođenje tog smisla na mogućnost iznalaženja jezičnog prijevoda u riječi 'poslušnost' tako je teorijski skučeno da se teško može shvatiti drukčije do kao odstupnica u onu lagodnu objektivizaciju i hipostaziranje značenja riječi«. ${ }^{553}$

Schopenhauer izjednačava volju i htijenje te prvoj ne pripisuje uže značenje »umnog svrhovitog htijenja«. Do neke razine može se prihvatiti da htijenja nisu u čovjekovoj vlasti, ali to ne znači da čovjek ne može umski kontrolirati instinktivno nadolazeća htijenja i da ne može za njih na toj razini biti odgovoran. Na ovoj instinktivnoj, dakako, on ne može biti odgovoran. Ali kako tu ne može biti odgovoran, nego se odgovornost prebacuje na nekakvo začudno

\footnotetext{
${ }^{551}$ Usp. ibid., str. 185-186, 188.

552 Usp. ibid., str. 72.

553 Jovan Babić, »Pogovor«, u: Artur Šopenhauer [Arthur Schopenhauer], O temelju morala, prevela Veselka Santini, Bratstvo-Jedinstvo, Novi Sad 1990., str. 224-232, ovdje str. 225.
} 
odlučivanje o karakteru pred ulaženje duše u svijet pojava (uz što se veže još jedan paradoks, naime, nasljeđivanje karaktera od oca), tu i nema smisla govoriti o moralnosti, koja svakako podrazumijeva slobodu volje, ne nužno i »slobodu htijenja«. Iz posvemašnje nemogućnosti mijenjanja karaktera i stvarnosti, proizlazi Schopenhauerov defetistički i antiživotni zaključak, koji je također besmislen ako se zadaje kao moralna paradigma. Stoga nema osnove za moralni prijezir prema bilo kakvim radnjama. Takva etika u svakom slučaju ne nudi uputu za izgradnju boljeg svijeta, osim mogućim praktičnim uputama kako da se neslobodna bića zavaraju kako bi radila na općem dobru misleći da zadovoljavaju svoje egoističke prohtjeve.

Takva tumačenja ipak su rezultat bitno drugačijih filozofskih pozicija ove dvojice autora. Ta se razlika u etici pokazuje radikalnom. Već trenutak u kojem Schopenhauer odbija trebanje, kako bi moralni problem problematizirao isključivo sa stajališta bitka, radikalno odvaja ove pozicije, koje više ni u kom slučaju ne mogu pronaći zajednički jezik.

Schopenhauerov stav prema životinjama zasigurno izaziva izvjesnu simpatiju, pa i intuitivno prihvaćanje. Međutim, zaštita životinja, kao i svako drugo moralno pitanje, ne smije izbjeći osnovanom i više ili manje sistematskom, odnosno širem etičkom uvidu. Ukoliko prihvaćamo ovakvo tumačenje moralnosti u obziru spram životinja, utoliko ne možemo tek tako izbjeći filozofiju iz koje ta misao proizlazi. Već amputacija slobode volje čini nemogućim utemeljenje naše moralne obvezatnosti spram životinja ili bilo koga drugoga. Pored toga, moralna pobuda kakva se u ovoj etici zagovara zapravo je, »iako sam Schopenhauer tvrdi da je suprotna egoizmu, i sama u njemu zasnovana: ona proizlazi iz neprijatnosti koju u nama proizvodi prizor tuđe patnje, i sažaljenja koje ta neprijatnost proizvodi «. ${ }^{554}$ Mada eventualno možemo govoriti o razlici koju spoznaja o jedinstvu bića po sebi donosi u naš odnos spram životinja, Schopenhauerova etika u konačnici je briga za čovjeka, i to, zapravo, samog izvršioca djelovanja, koji, da stvar bude gora, nije njegov subjekt.

S obzirom na ove nedostatke, zasigurno snažna intuicija da je naš odnos sa životinjama moralno relevantan radi same životinje morat će pronaći svoje opravdanje unutar neke druge etičke teorije ako ne želi ostati tek puka intuicija.

Ipak, bez obzira na cjelinu Schopenhauerove misli, moguće je izolirati neke elemente koje bi valjalo propitati u drugačijem kontekstu. To se ponajprije odnosi na razmatranje sličnosti čovjeka i životinje, koja svakako ne smije biti zaobiđena u razmatranju mogućnosti čovjekova moralnog obzira spram ne-ljudskih živih bića. Pored toga, od izuzetne je vrijednosti Schopenhauerov sud o jezičnoj manipulaciji u pogledu imenovanja životnih funkcija, koji

${ }^{554}$ Ibid., str. 231. 
otvara jednu širu i cjelovitiju perspektivu moralnog obzira spram životinja. Prihvaćanje ovih elementata ne povlači za sobom nužnost prihvaćanja ostatka teorije.

\section{III.3.5.2. Peter Singer}

Jedan od najpoznatijih predstavnika animalističkog pokreta i jedna od najzaslužnijih osoba za poticanje javnog i znanstvenog dijaloga o moralnoj dimenziji čovjekova odnosa spram životinja zasigurno je australski filozof Peter Singer. Za osvještavanje šire javnosti o bijednom položaju životinja na farmama za intenzivan uzgoj i drugim ustanovama, Singerov je doprinos neizmjeran, kako u aktivističkom, tako i u spisateljskom/teorijskom angažmanu.

Singerova je zooetička pozicija utilitaristička, no on svoj utilitarizam koncipira nešto drugačije od klasičnoga, time što »najbolje posljedice za najveći broj« ne promatra (samo) u kontekstu ugode i boli, nego u kontekstu promicanja interesa (preferencija) određenom djelatnošću pogođenih individua. ${ }^{555}$ Radi se o utilitarizmu preferencija, prema kojem »djelovanje suprotno preferenciji bilo kojeg bića - osim ako tu preferenciju ne prevagnu suprotne preferencije - jest pogrešno «. ${ }^{556}$ Ključno načelo njegove etike načelo je jednakosti, u ovom kontekstu, jednakosti uvažavanja interesa. Pri tom nije relevantno čiji je interes u pitanju, nego se interes uzima u razmatranje sam za sebe, neovisno o svim karakteristikama njegova nosioca, osim same karakteristike imanja interesā. 557

»Načelo jednakog uvažavanja interesa djeluje poput vage, nepristrano važući interese. Prave vage prednost daju onoj strani na kojoj je interes jači ili gdje je nekoliko interesa kombinirano kako bi prevagnuli manji broj sličnih interesa; ali vage ne uzimaju u obzir čiji su interesi što ih one važu. «558

Singer tvrdi da će interesi uzeti zasebno rezultirati time da snažniji interesi ili snažnije potrebe imaju veću težinu, tako da je, primjerice, opravdano trošiti veća sredstva za invalide nego za ostale ljude, pošto su velike potrebe prvih značajnije od manjih potreba drugih. Međutim, Singer ne ograničava svoje razmatranje na ljudske interese i njihove sukobe. Iz same osnove formulacije temeljnog načela jednakog uvažavanja interesa jasno je da se ono ne odnosi samo na njih (premda bi bilo tako kad bi samo ljudi imali interese), nego na interese svih bića koja ih mogu imati. Kao što je u slučaju pridavanja veće težine pravima interesa vlastite rase

\footnotetext{
${ }^{555}$ Usp. Peter Singer, Praktična etika, preveo Tomislav Bracanović, KruZak, Zagreb 2003., str. 10.

556 Ibid., str. 72.

${ }^{557}$ Usp. ibid., str. 16-17.

558 Ibid., str. 16.
} 
očigledno kršenje načela jednakosti, pa se pejorativno naziva rasizmom, tako je i pridavanje veće težine interesima vlastite vrste također kršenje tog načela, te mu se može pripisati pejorativan naziv specizam. ${ }^{559}$ Naravno, Singerov se utilitarizam u svom osnovnom nastrojstvu ne razlikuje radikalno od klasičnog, hedonističkog utilitarizma, pošto sama ugoda sačinjava bitan segment interesa onih bića koja ih mogu imati. Ugoda i patnja često su u centru rasprave o životinjskom životu i čovjekovu moralnom obziru spram njega, pa tako i za Singera označavaju jedan od ključnih segmenata tog problema, prema kojima ne iznosi bitno različit stav od Benthamova: ${ }^{560}$

\begin{abstract}
»Primjena načela jednakosti na nanošenje patnje, barem u teoriji, prilično je jasna. Bol i patnja su loši i treba ih spriječiti ili minimizirati, neovisno o rasi, spolu ili vrsti bića koje pati. Koliko je bol loša ovisi o tome koliko je jaka i koliko dugo traje, ali boli jednake jakosti i trajanja jednako su loše, bilo da ih osjećaju ljudi ili životinje. $\ll^{561}$
\end{abstract}

\title{
S druge strane:
}

»Kada krenemo razmatrati vrijednost života, ne možemo toliko uvjereno reći da je život život i jednako vrijedan, bilo da je ljudski ili životinjski. Ne bi bilo specistički smatrati da je život samosvjesnog bića, sposobnog za apstraktno mišljenje, za planiranje budućnosti, za složene komunikacijske radnje, i tako dalje, vrjedniji od života bića bez tih sposobnosti. ${ }^{562}$

Samosvijest, prema Singeru, nije osobina koja se ekskluzivno pripisuje ljudima, niti je ona pripadna svim ljudima. Potonje je jasno već na primjeru dojenčadi i ozbiljno mentalno zakinutih ljudi. Izjednačavajući pojmove osobe i samosvjesnog bića, Singer ukazuje na bitnu razliku između bivanja osobom i pripadanja vrsti Homo sapiens. ${ }^{563}$ Osobom mogu bivati i neka ne-ljudska bića, za što su često najbolji primjer čovjekoliki majmuni. Tako Singer, na temelju njihove mogućnosti prepoznavanja sebe u ogledalu, zaključuje o postojanju samosvijesti kod tih životinja. To podupire i poznatim slučajevima učenja znakovnog jezika kod čimpanze

\footnotetext{
559 Usp. ibid., str. 40, 43-45. Termin specizam skovao je 1970. Richard D. Ryder, a Singer ga je uvelike popularizirao.

${ }^{560}$ Već kod Benthama nalazimo danas sve prošireniju usporedbu rasizma i specizma. (Usp. Jeremy Bentham, An Introduction to the Principles of Morals and Legislation, sv. 2, W. Pickering, Lincoln's-inn Fields - E. Wilson, Royal Exchange, London 1823., str. 235-236.) Potonji se ogleda i u praksi diskriminacije životinja usprkos »na sliku čovjekovu« postavljenim kriterijima dodjeljivanja moralnog statusa (o čemu nešto kasnije): »No odrasli je konj ili pas neusporedivo racionalnija, kao i promjenljivija životinja od djeteta starog dan, tjedan ili čak mjesec dana. No pretpostavimo da je slučaj obrnut, što bi se time dobilo? Nije pitanje: mogu li one misliti? niti: mogu li one govoriti?, nego: mogu li one patiti?« (Ibid, str. 236.)

${ }^{561}$ P. Singer, Praktična etika, str. 46-47.

562 Ibid., str. 47.

${ }^{563}$ Usp. ibid., str. 66.
} 
Washoe i gorile Koko, pa čak i pripisivanjem pojmovnog načina mišljenja ne-ljudskim samosvjesnim životinjama, na što ga navodi njihova sposobnost shvaćanja vremenske dimenzije (planiranje, predostrožnost i sl.), kao i prevarantsko ponašanje (podrazumijeva samosvijest i svijest o svijesti drugih). ${ }^{564}$ Posjedovanje vremenske dimenzije, sposobnosti bića da sebe vidi u vremenu, karakteristika je nenadomjestivih bića, dok ona bića koja to nisu prije nalikuju »posudama za držanje određene količine sreće«. Premda su i njihovi interesi relevantni u etičkom računu, ne može se govoriti o njihovu interesu da nastave živjeti. ${ }^{565}$

Hijerarhizacija moralno relevantnih bića, odnosno postavljanje demarkacijskih linija svjesnosti i samosvjesnosti, za Singera ne predstavlja specistički čin, premda je i sam svjestan da on tome može nalikovati. Iako životne ugode svakom živom biću znače sve, to ne treba značiti da u nepristranoj poziciji ne bismo izabrali život s većim stupnjem razvitka svijesti i većim rasponom doživljaja, odnosno život samosvjesnog bića. ${ }^{566}$ Međutim, ovdje teško možemo govoriti o utemeljenom argumentu, već prije o slutnji, i to o čovjekovoj slutnji. Naime, koliko god znanstvenim metodama mogli proniknuti u to »kako je biti ne-čovjek«, one su uvijek ograničene našom uvjetovanošću »bivanja čovjekom«. Čini se, stoga, da nije moguće iznalaziti nepristrane principe za prosudbu vrijednosti određenog oblika života. Najviše što možemo učiniti u tom smjeru ono je što čini i sam Singer, naime, iznaći dovoljno formalne principe, temeljene na onome što čovjek promišlja kao vrijedno (što je nužno vezano uz ono njemu pripadno), a što ne obećava potpuno ekskluziviranje Homo sapiensa. Iako formulacija principa u izvjesnoj mjeri i ne mora biti specistička, ona može imati neke bitno specističke elemente.

Ipak, neuobičajeni naglasci u Singerovoj etici nisu prošli neopaženo, dapače, često su izazivali popriličnu buru u akademskoj, ali ne samo u akademskoj javnosti. ${ }^{567}$ Singerovi stavovi koji su naišli na široko negodovanje ponajprije su oni vezani uz odvagivanje vrijednosti života nesamosvjesnog Homo sapiensa s jedne i odrasle životinje s druge strane, pri čemu, dosljedno njegovim etičkim principima, prednost mora biti na strani potonje (pa i u slučaju znanstvenog eksperimentiranja, ukoliko je ono nužno). ${ }^{568} \mathrm{~S}$ druge strane, široki obuhvat Singerove etike u pogledu adresata moralno relevantnog djelovanja ostavlja prostor za zaključke koji nisu skandalozni u ovom pogledu, ali otvaraju neke druge probleme. Tako je »neophodno voditi

\footnotetext{
${ }^{564}$ Usp. ibid., str. 83-88.

${ }^{565}$ Usp. ibid., str. 95. »Za nesamosvjesno biće smrt je prestanak doživljaja, na prilično isti način kao što je rođenje početak doživljaja. Smrt ne može biti oprečna interesu za nastavkom života, ništa više nego što rođenje može biti u skladu s interesom za započinjanjem života. « (Ibid.)

${ }^{566}$ Usp. ibid., str. 80-81.

567 Ilustrativan primjer za burnu reakciju izvan akademske javnosti otkazivanje je Singerovih predavanja u Njemačkoj, zbog nekih njegovih provokativnih stavova. Singer to iskustvo opisuje u dodatku knjige Praktična etika naslovljenom »Kako sam bio ušutkan u Njemačkoj«. (Usp. ibid., str. 257-274.)

568 Vidi npr.: ibid., str. 45-46, 89.
} 
računa o senzibilnosti onih što su bliski čovjeku o kojemu je riječ, i o njihovoj volji. Ako je, na primjer, riječ o djetetu ili o ocu tog i tog, treba voditi računa o onima koji ga vole i brinu se o njemu kao poštovanoj osobi, koji su svjesniji od drugih životinja u sličnim situacijama.«569 Naime, odvagivanjem interesa svih onih koji su pogođeni određenom radnjom nije teško moralno presuđivati na štetu ranjivih društvenih skupina, poput, primjerice, osamljenih beskućnika.

Usprkos Singerovoj sigurnosti u svoju poziciju kao onu koja otklanja i posljednji u nizu diskriminatorskih -izama, to ipak ne može biti samorazumljivo iz njegove pozicije. Kako piše Günther Pöltner:

„Specijesistički prigovor ne živi samo od nedosljednosti nego je sam neka vrsta višeg rasizma: na mjesto vrste homo sapiens stupa naime vrsta posjednika samosvijesti, čiji pripadnici odlučuju o tome kojim se individuama priznaje, a kojima se ne priznaje pripadanje vrsti.« ${ }^{570}$

Premda je ova ocjena donekle pretjerana, ona sadrži uputstvo upravo na onaj klimavi moment prisutan u više pozicija koje se postavljaju tobože nasuprot specizmu.

Kako možemo vidjeti, premda Singerova koncepcija na prvi pogled ide u smjeru zaštite mogućih žrtava diskriminacije, na kakvoj god osnovi se ona gradila, uklanjanja predrasuda, zaštite životinja, kao i u smjeru zaštite slabijih uopće (primjerice invalida), jedno staloženije promatranje može na površinu iznijeti mnoge problematične zaključke, na koje ćemo se dodatno osvrnuti unutar sljedećeg odsječka, posvećenog jednoj od ključnih osoba i teoretičara animalističkog pokreta Tomu Reganu.

\section{III.3.5.3. Tom Regan}

Tom Regan je, kao i Singer, pružio osobit doprinos animalističkom pokretu, kako u aktivističkom promicanju životinjskih prava, ${ }^{571}$ tako i teorijski, naročito u jednom od klasičnih djela animalističke literature Zastupanje životinjskih prava (The Case for Animal Rights). U

\footnotetext{
${ }^{569}$ B. Sirilnik, E. de Fontene, P. Singer, Iživotinje imaju prava, str. 45.

570 Günther Pöltner, »Spezies, Identität, Kontinuität, Potentialität. Bemerkungen zu philosophischanthropologischen Voraussetzungen einer Bioethik«, u: Ante Čović, Thomas Sören Hoffmann (ur.), Integrative Bioethik. Beiträge des 1. Südosteuropäischen Bioethik-Forums, Mali Lošinj 2005, Akademia Verlag, Sankt Augustin 2007., str. 36-37; citirano prema: Ante Čović, »Biotička zajednica kao temelj odgovornosti za ne-ljudska živa bića«, u: Ante Čović, Nada Gosić, Luka Tomašević (ur.), Od nove medicinske etike do integrativne bioetike, Pergamena - Hrvatsko filozofsko društvo, Zagreb 2009., str. 37.

${ }^{571} \mathrm{U}$ tom pogledu osobito se ističe njegov govor iz 1988. u Los Angelesu pod naslovom »Mač pravde, buktinja uma« (»The Sword of Justice, the Torch of Reason«), koji mnogi drže najvećim govorom u povijesti animalističkog pokreta, a dostupan je na: https://www.youtube.com/watch?v=wfLbUWEew-M.
} 
ovom kratkom pregledu morat ćemo izostaviti mnoge važne uvide za izgradnju njegove pozicije, kako bismo se koncentrirali na nekoliko ključnih točaka u cilju osvjetljavanja mogućih putova za konzekventnije utemeljenje moralnog obzira spram životinja.

Regan smatra da se određenim životinjama trebaju, kako naslov njegove knjige glasi, dati upravo moralna prava, uz koja idu i jasne ljudske moralne dužnosti. Njegova deontološka etička orijentacija prirodno ga je teorijski (iako nikako u aktivističkom angažmanu) okrenula protiv Singera, a ovaj pregled možemo započeti upravo iznošenjem te poprilično oštre kritike, usprkos mnogim zajedničkim ciljevima.

Za Reganov odnos spram utilitarizma uputno je obrazložiti što on misli pod pojmom interesa, jednim od centralnih pojmova Singerove etike. On govori o dva bitno drugačija značenja toga pojma: može se govoriti o interesu preferencije (preference-interest) s jedne strane, te o interesu blagostanja (welfare-interest) s druge. Prvi bi se odnosio na imanje interesa za nešto, mentalno stanje koje može biti epizodno ili dispozicijsko, dok bi se drugi odnosio na nešto što je $u$ interesu određenog bića. Potraga za onim što se preferira i njegovo dosezanje, zadovoljavanje $u$ tom procesu te pripadanje onoga što traže njihovu interesu (tj. da je ono u njihovu interesu) sačinjavaju osnovnu strukturu dobrog života i za čovjeka i za životinju. Važno je i da Regan u ovom kontekstu primjećuje kako škoditi (harm) nije isto što i povrijediti (hurt). Dok bi se drugo odnosilo na nanošenje patnje, prvo se istovremeno odnosi i na deprivaciju koje žrtva ne treba biti svjesna. ${ }^{572}$

Reganova kritika Singerova utilitarizma uvelike se veže uz upravo izneseni problem poimanja interesa. Tako on na Singerovu tezu o pogrešnosti ubojstva spram samog individuuma kojeg se ubija s obzirom na nepoštivanje njegove preferencije da nastavi živjeti, odgovara da moralni trpnici (oni koji zaslužuju moralni obzir, ali nisu u stanju moralno suditi za razliku od moralnih djelatnika), nemaju koncept smrtnosti, a time ni preferenciju da nastave živjeti. Time Singer nije uspio u namjeri da prevlada manjkavosti hedonističkog utilitarizma, jer ne uzima u obzir interes blagostanja. Regan tvrdi i da je Singerova teza o nemogućnosti pripisivanja statusa zamjenjivih kutija (replaceable receptacles) samosvjesnim živim bićima također neodrživa, vodeći se Hartovom kritikom da takva tvrdnja ne može proizlaziti iz utilitarizma preferencija. Stoga su u tom okviru i samosvjesna bića zamjenjive kutije preferencija. Tu ne staju problemi sa Singerovim poimanjem utilitarizma, koji si ga samoporiče time što princip jednakosti drži osnovnijim od principa korisnosti. Utilitarizam nije utilitarizam ako ne derivira svaki princip morala iz koristi. ${ }^{573}$

\footnotetext{
${ }^{572}$ Usp. T. Regan, The Case for Animal Rights, str. 87, 93, 97.

${ }^{573}$ Usp. ibid., str. 207-209, 213.
} 
Reganova kritika pogađa Singera i tamo gdje se njihovi aktivistički interesi slažu. Naime, Regan dovodi u sumnju mogućnost zaštite životinja na temelju Singerove etike. Potonja odlučno zagovara veganstvo na temelju argumenta da intenzivni uzgoj životinja služi samo užitku okusa, pri čemu žrtvujemo najvažnije interese drugih bića u svrhu zadovoljenja naših trivijalnih interesa. Pitanje je kako utilitarist može suditi o moralnoj nedopustivosti neke radnje na temelju njene svrhe kada bi se u okviru vlastite teorije trebao zanimati samo za posljedice, a ne za svrhe određenog čina. Konzenkvencijalistički račun koji bi se u prosudbi opravdanosti intenzivnog uzgoja životinja izveo mogao bi se okrenuti upravo u korist takve prakse. Naime, ovdje ne govorimo samo o gotovom obroku, nego i o golemom broju ljudi uključenom u mesnu industriju. Tu ne treba računati samo s kapitalistima, radnicima i njihovim obiteljima, nego is odvijanjem čitave svjetske ekonomije u kojoj mesna industrija nije niti malo sporedan element. U svakom slučaju, ne čini se tako izvjesnim da bi napuštanjem industrijske proizvodnje mesa zbroj interesa svih uključenih bilo veći. Na ovom tragu utilitarizam u određenim kalkulacijama može opravdati ne samo ono što se pojavljuje kao specizam, nego i ono što se javlja u raznim drugim oblicima $»$-izama ${ }^{574}$

Pozicija koju Regan zastupa prije svega pokušava ukazati na inherentnu vrijednost onih živih bića koja naziva subjektima života (subject-of-a-life), a radi se o kriteriju koji ukazuje na relevantnu sličnost moralnih djelatnika i trpnika. Radi se o individuama koji imaju vjerovanja i želje, zatim percepciju, pamćenje, svijest o budućnosti, emocionalni život, interese (u oba navedena smisla), sposobnost da iniciraju radnje, psihofizički identitet i uopće mogućnost dobrog ili lošeg života logički (što ne znači kauzalno) neovisno o njihovoj korisnosti drugim živim bićima. Ovdje se ne radi o intrinzičnoj vrijednosti, koja se veže uz iskustva, doživljaje individua, nego o vrijednosti koje individue imaju same po sebi, čime prestaju biti puke kutije za ono što ima intrinzičnu vrijednost (poput užitka ili preferencije). Inherentna se vrijednost ne može javljati u stupnjevima, pa se uz pretpostavku njena pripisivanja moralnim djelatnicima i na temelju mogućnosti da se moralnim djelatnicima i moralnim trpnicima može škoditi na relativno slične načine, inherentna vrijednost mora pripisivati i potonjima. Međutim, kriterij subjekta života treba se uzimati kao dovoljan razlog posjedovanja inherentne vrijednosti, što je osobito važno s obzirom na postojanje mnoštva graničnih primjera. ${ }^{575}$

Stoga se kao osnovni moralni princip postavlja princip poštivanja (the principle of respect):

\footnotetext{
574 Usp. ibid., str. 220-223, 227.

${ }^{575}$ Usp. ibid., str. 235-236, 239-240, 243, 246.
} 
»Trebamo tretirati one individue koje imaju inherentnu vrijednost na način koji poštuje njihovu inherentnu vrijednost. «576

Ovaj princip osnova je Reganove etike iz kojeg se onda deriviraju svi ostali principi. Ovdje nećemo ulaziti u tu daljnju razradu jer bi nam oduzela suviše prostora, nego ćemo tek uzgred ukazati na neke konzekvence tog principa u razmatranju problema koji se vežu uz ovu poziciju. Ali prije toga svakako valja pobliže razjasniti za Regana važno svojstvo moralnog obzira spram subjekata života, naime, posjedovanje moralnih prava.

Regan drži da su moralna prava, poput inherentne vrijednosti, univerzalna - ako individua ima određena prava, ista prava imaju i sve one individue koje su u relevantnom smislu iste kao $\mathrm{i}$ ona, tj. u pripisivanju moralnih prava nema stupnjevanja. Također, ona se bitno razlikuju od legalnih prava s obzirom na to da u njihovu određivanju nema proizvoljnosti i nisu rezultat kreativnog čina pojedinca ili grupe, kako je slučaj kod potonjih. Važan teorijski poticaj za ideju moralnih prava Regan dobiva od Johna Stuarta Milla, koji drži da imati pravo naprosto znači imati nešto što je društvo dužno čuvati kao pripadno posjedniku prava. Osnova za validnost moralnog prava, kako je već istaknuto, nalazi se u njegovoj sukladnosti moralnom principu čija je validnost neovisno uspostavljena. ${ }^{577}$

Regan jasno ističe da životinje nemaju autonomiju u kantijanskom smislu, ali im se svakako može pripisati nešto što bi se zvalo »autonomija preferencije« (preference autonomy). Nekome se takva vrsta autonomije može pripisivati ako ima preferencije i sposobnost da inicira djelovanje kako bi ih zadovoljio. ${ }^{578}$ Ovakav način promatranja proizlazi iz Reganova stava da određene razlike između čovjeka i životinje treba sagledavati u stupnjevitom (more-or-less view), a ne u isključivom smislu. Tako na primjedbu da se ne može govoriti o tome što životinja vjeruje i želi zbog njene nemogućnosti da posjeduje koncept neke stvari, Regan odgovara da to sa stupnjevitog aspekta ne stoji. Naime, u strogom smislu nemaju ni svi ljudi isti koncept neke stvari, jer jedni o njoj znaju više (primjerice, znaju njen kemijski sastav) od drugih. Stupnjeviti pristup, koji bi ovu pojavu tumačio kao razumijevanje u većoj ili manjoj mjeri, pokazuje se boljim zato što objašnjava samu mogućnost postupnog povećanja razumijevanja određenog koncepta. Istina je da se naš koncept određene stvari uvelike razlikuje od onog životinje, ali on može naći zajedničko mjesto u preferencijskom vjerovanju (preference-belief). Naime, pas vjeruje da kost stoji u nekom odnosu spram njegovih želja ili preferencija, pa je stoga i izabire. Ako koncept $\mathrm{x}$-a shvatimo kao »naše vjerovanje o $\mathrm{x}$-u«, tada nema zapreke da ga u ovom slučaju

\footnotetext{
576 Ibid., str. 248.

${ }^{577}$ Usp. ibid., str. 267-270.

${ }^{578}$ Usp. ibid., str. 84-85.
} 
pripišemo psu. S obzirom na to da je preferencijsko vjerovanje također dio našeg koncepta kosti, može se tvrditi da i mi i životinje (barem viši sisavci) imamo isti koncept kosti, ali ne u isključivom, nego u stupnjevitom smislu. ${ }^{579}$ Čini se da ovime ne bivaju isključene ni kvalitativne ni kvantitativne razlike između čovjeka i životinje, s obzirom na stupnjevitost odnosno različite nazive oblika autonomije, vjerovanja i sl.

Međutim, ono što je donekle kontroverzno kako u Reganovu, tako i u Singerovu pristupu značajkama životinja, problem je pripisivanja samosvijesti. Za Regana je samosvijest implicirana samom intencionalnošću:

»Djelovati sada kako bi se ostvarilo zadovoljenje njezinih želja u nekom budućem vremenu, za individuu A je moguće samo ako pretpostavimo da je samosvjesno barem u mjeri u kojoj A vjeruje da će upravo njezine želje biti te koje će se zadovoljiti u budućnosti kao rezultat onoga što ona čini sada. Drugim riječima, intencionalno djelovanje moguće je samo za one koji su samosvjesni. «580

Ovdje, kao i u prije spomenutim Singerovim uporištima za pripisivanje samosvijesti životinjama, nailazimo na probleme u razumijevanju same samosvijesti. Usporedimo li pojmove koje oni imaju u vidu pri korištenju ovog termina s pojmom samosvijesti u klasičnoj filozofiji, jasno će se uočiti značajna razlika. Ukratko, klasični je pojam samosvijesti puno »teži«. On zahtijeva da subjekt postane sebi objektom u puno strožem smislu nego što je ovdje slučaj, naime, u smislu da subjekt kao takav, on kao on, a ne kao instanca određenih težnji i potreba, sebi postane objektom. Komentirajući rasprave oko poznatog testa s ogledalom, koji smo spomenuli u prikazu Singerove etičke koncepcije, Christine M. Korsgaard primjećuje da čak i ako životinja koja prolazi taj test prepoznaje samu sebe kao subjekta svojih doživljaja

\footnotetext{
${ }^{579}$ Usp. ibid., str. 49-51, 54-60. - Uzmemo li u obzir neke druge primjere, možda bi se moglo ići i dalje od pripisivanja tek preferencijskog vjerovanja životinjama. Fascinantan primjer predstavljaju golubovi koji imaju začuđujuću »sposobnost razlikovanja Picassovih i Monetovih slika. No to nije sve: Kada bi golubovima pokazali Braqueove, Matisseove, Céssaneove i Renoireove slike, oni bi svrstali Braquea i Matissea uz Picassa, dok bi Céssanea i Renoira svrstali uz Moneta. Iz perspektive povijesti umjetnosti, to je nevjerojatno točan izbor, a mnogi posjetitelji muzeja imaju lošije oko za slike od tih ptica. No mi uopće ne znamo što točno golubovi opažaju na tim slikama da im to omogućava razlikovanje slikara. Znači li to razlikovanje da golubovi imaju sposobnost poimanja? To ovisi o tome kako definiramo pojam. Ljudi bez dvojbe znaju svrstati objekte bez ikakvog pojma o njima. Mogli bismo nekoj osobi dati zadatak da sortira dijelove zastarjelih računala i naučiti je da na zasebnu hrpu sortira tiskane pločice, makar ta osoba nemala pojma o tome što su tiskane pločice. S druge strane, možemo reći da dotična osoba zapravo ima pojma o tiskanim pločicama, ali to je poimanje priprosto i sastoji se od sljedećih karakteristika: 'Tiskana pločica uglavnom je zelene boje i po njoj se protežu tanke bakrene niti.' To je poimanje koje ne sadrži ni trunku znanja o funkciji tiskane pločice u računalu, no svejedno je riječ o pojmu. Ako je i takva sposobnost razlikovanja dovoljna za imanje pojma, razumno je pripisati golubovima sposobnost poimanja, premda ne znamo koji sadržaj pojmova njima omogućava razlikovanje slikara. Ako je, dakle, takva sposobnost razlikovanja dovoljna za poimanje, a budući da takve sposobnosti razlikovanja nalazimo kod niza životinja koje nemaju svoj jezik, iz toga proizlazi da jezik nije nužan preduvjet za stvaranje pojmova.« (L. Svendsen, Razumijemo li životinje?, str. 62-63.)
}

${ }^{580}$ T. Regan, The Case for Animal Rights, str. 75. 
(iskustava) to ne znači da sebe prepoznaje kao subjekta svojih stavova, odnosno vjerovanja, emocija i želja. Potonji, koliko znamo, nisu dio životinjina svijeta, nego »leće kroz koje ona vidi svijet ${ }^{581}$

U svakom slučaju, čini se da Reganova deontološka pozicija pruža bolje uporište za utemeljenje zooetike od obaju prethodno razmatranih primjera. On, uostalom, oštro nastupa i spram starog diskursa o moralnom obziru glede životinja u vidu okrutnosti, čiju zabranu ne drži dovoljnom za utemeljenje negativne dužnosti spram životinje. Naime, ne znači da netko ne udovoljava moralnoj dužnosti ako pri nanošenju patnje životinji ne uživa u tom činu. Iz istog je razloga ljubaznost nedovoljna za utemeljenje pozitivne dužnosti. Ukratko, mentalna stanja, motivi i intencije nisu važni u pogledu naših dužnosti spram onih koje ju zaslužuju. ${ }^{582}$ Ovime Regan s »plodnom vodom izbacuje dijete«, potpuno zanemarujući nastrojstvo volje kao konstitutivno za moralitet. Tako u kantovskom pogledu uopće ne dopire do razine moraliteta, nego ostaje na onoj legaliteta, ${ }^{583}$ tj. procjene same radnje koja, kako smo vidjeli na početku ove glave, nikako nije dovoljna za objašnjenje moralnog čina.

\section{III.3.5.4. Aldo Leopold}

Kako bi se moralni obzir proširio izvan kruga ljudskih i ne-ljudskih životinja, tj. kako bi on obuhvatio i druga bića, valja posegnuti za autorom koji među prvima zagovara ekocentričnu etiku. Riječ je o američkom konzervacionistu (štoviše, pioniru tog pokreta) Aldu Leopoldu, čija je misao utjecala na mnoge ekološke aktiviste, a imala je presudan utjecaj i na promišljanja »oca bioetike« Vana Rensselaera Pottera. Ona je prvenstveno sadržana u Ljetopisu pješčanog okruga (A Sand County Almanac), prvotno objavljenom 1949., u kojem je izveo etiku zemlje (the land ethic), posebice $\mathrm{u}$ istoimenom poglavlju.

Konzervacionizam, prema njegovu mišljenju, nema budućnosti ako nije spreman da se suoči s »našim abrahamskim konceptom zemlje«, tj. s idejom da je ona roba u našem vlasništvu. Osnovni je pak koncept ekologije da je zemlja zajednica, a samo njegovim usvajanjem moguće ju je tretirati s ljubavlju i poštovanjem (što predstavlja etičku ekstenziju ekologije), kao i ubirati

\footnotetext{
${ }^{581}$ Usp. Christine M. Korsgaard, »Reflections on the Evolution of Morality«, The Amherst Lecture in Philosophy 5 (2010), str. 1-29., Dostupno na: http://www.amherstlecture.org/korsgaard2010/, ovdje str. 17-18. - Za pregled problematičnih vidova zrcalnog testa, koje autora navode da ustvrdi da je on besmislen po pitanju detektiranja samosvijesti, vidi: L. Svendsen, Razumijemo li životinje?, str. 67-70.

${ }^{582}$ Usp. T. Regan, The Case for Animal Rights, str. 198-199.

${ }^{583} \mathrm{O}$ primatu moraliteta spram legaliteta, štoviše, o nemogućnosti da se legalitet konstituira bez moraliteta, vidi: J. Guć, »Moralitet i legalitet u Kantovoj etici«.
} 
estetske plodove (Leopold kaže upravo esthetic harvest, dakle, »estetska žetva«) iz nje. ${ }^{584}$ Potrebno nam je, dakle, proširenje etike, no ono se može sagledavati i kao filozofski i kao ekološki podvig:

\begin{abstract}
»Proširenje etike, što su do sada izučavali samo filozofi, zapravo je proces ekološke evolucije. Njegove sekvence mogu biti opisane kako u ekološkim, tako i u filozofskim terminima. Jedna etika, ekološki, ograničenje je slobode djelovanja u borbi za egzistenciju. Jedna etika, filozofski, razlikovanje je društvenog od protudruštvenog ponašanja. Ovo su dvije definicije jedne stvari. Ona ima svoju osnovu u tendenciji međuovisnih individua i grupa da razviju načine suradnje. Ekologist ove naziva simbiozama. ${ }^{585}$
\end{abstract}

Prva se etika, drži Leopold, bavila relacijama između individua, kasnije se bavila odnosima individue i društva, no nemamo etiku koja bi se usmjerila na čovjekovu relaciju spram zemlje, kao i životinja i bilja koji iz nje izrastaju, relaciju koja je još uvijek strogo ekonomska. Širenje etike i na nju evolucijska je mogućnost, ali ekološka nužnost. Naime, sva je etika do sada razvijana na osnovi toga što individua pripada zajednici međuovisnih članova. Etika zemlje samo širi granice zajednice, pri čemu zemlja uključuje kako tlo, tako i vode, biljke i životinje. Stoga bi članovi te zajednice, kao i zajednica sama, trebali biti tretirani s poštovanjem, što ne isključuje potrebu za izmjenom ili upravljanjem »resursima«, ali ni ne poriče njihovo pravo na kontinuiranu egzistenciju (koliko je moguće, u prirodnom stanju). ${ }^{586}$

Da je čovjek, tvrdi Leopold, dio biotičke, a ne tek neke svoje izdvojene zajednice, jasno pokazuje i ekološka interpretacija historije. Premda se često opisuju kao ljudski podvizi, mnogi povijesni događaji predstavljaju interakciju ljudi i zemlje. Karakteristike potonje odlučile su o ishodima uvelike kao i karakteristike ljudi. ${ }^{587}$ Leopold ovdje kao da anticipira tezu o anorganskoj prirodi kao subjektu, čemu ćemo se posvetiti kasnije.

Leopold ističe kako su čovjekove intervencije u zemlju različitog reda od evolucijskih promjena, pri čemu se efekti tih intervencija ne poklapaju nužno s čovjekovim intencijama, tj. ne mogu biti u potpunosti predviđeni. Može li se zemlja priviknuti na taj novi red i mogu li antropogene promjene biti vršene s manje nasilja? Različiti biomi, naime, imaju različit nivo tolerancije, no smanjena kompleksnost pri obnovama zemlje svakako se može uočiti na svjetskoj razini. Sposobnost zemlje da se samoobnavlja može se nazvati njezinim zdravljem.

\footnotetext{
${ }^{584}$ Usp. Aldo Leopold, A Sand County Almanac. And Sketches Here and There, Oxford University Press, New York 1968., str. xiii-xiv.

585 Ibid., str. 202.

${ }^{586}$ Usp. ibid., str. 202-204.

${ }^{587}$ Usp. ibid., str. 205.
} 
Konzervacija predstavlja naš pokušaj njegova razumijevanja i očuvanja, a etika zemlje nalaže razvijanje ekološke savjesnosti i individualne odgovornosti za njega. ${ }^{588}$ Osnovni je princip jednostavan:

»Nešto je ispravno kada stremi očuvanju integriteta, stabilnosti i ljepote biotičke zajednice. Ono je pogrešno kad stremi nečemu drugome. $\aleph^{589}$

On kaže da je »namjerno predstavio etiku zemlje kao produkt društvene evolucije jer ništa tako važno kao što je etika nije napisano«, pa je tako i Dekalog »evoluirao u duhovima misleće zajednice, a Mojsije mu je napisao privremeni sažetak za 'seminar'«. ${ }^{590}$ Ovdje zaista i ne nailazimo na razrađenu etičku poziciju, nego prije svega na neke važne upute u pogledu unakrsnog razvoja senzibiliteta (prijemčivosti) i moralnog obzira spram onoga što nas okružuje. Tako i sam Leopold tvrdi da intelektualni rast slijedi širenje etičkih granica, kao i da je konzervacija »popločana dobrim namjerama koje se pokazuju uzaludnima, ili čak opasnima, jer je lišena kritičkog razumijevanja bilo zemlje, bilo njezine ekonomske upotrebe«. Etika zemlje intelektualni je koliko i emotivni proces. ${ }^{591}$

Usprkos intelektualnom usvajanju opasnosti ljudskog djelovanja, pa i razvoju etičkih pozicija u desetljećima nakon Leopolda, čini se da još nije vrijeme za pisanje »seminara« koji bi odražavao postojeći etos poštivanja zemlje. Prisiljeni smo, stoga, u ovom pogledu pisati preskriptivne »seminare« (pisati, zapravo, etiku, a ne bilježiti etos). Pitanje je samo trebaju li oni uključiti baš čitavu zemlju, i ako trebaju, na koji način to valja izvesti. S obzirom na kratki, esejistički pokušaj Leopoldova predstavljanja etike koja obuhvaća čitavu organsku i anorgansku prirodu, čini nam se da kritički osvrt ima više smisla pružiti na razrađeniju ekoetičku poziciju kakva je ona Næssova.

\section{III.3.5.5. Arne Noess}

Dubinska ekologija jedan je od pokreta koji su se razvili uvidom u posvemašnju razornost tehnološkog napretka, odnosno uvidom u svu širinu (a ovdje bitno i dubinu) ekološke krize. On »službeno« nastaje 1973., kada Arne Næss uvodi termin dubinske ekologije u članku »The shallow and the deep, long-range ecology movement. A summary« (»Plitki i dubinski,

\footnotetext{
${ }^{588}$ Usp. ibid., str. 218-219, 221.

589 Ibid., str. 223-224.

590 Ibid., str. 225.

${ }^{591}$ Usp. ibid.
} 
dalekometni ekološki pokret. Sažetak«). ${ }^{592}$ Ovaj norveški filozof, osim uvođenja samog termina, izgrađuje osebujan koncept ekozofije. »Premda je Næss uvijek ohrabrivao druge da izgrade svoju verziju ekozofije, njegov je pečat ostao dominantan u cijelom kasnijem razdoblju dubinske ekologije. «593

U gore spomenutom članku, u kojemu zasniva samu dubinsku ekologiju, Næss daje neke osnovne smjernice za izgradnju misaonog koncepta tog pokreta. On se, kako je jasno već iz naslova članka, formulira u opoziciji spram plitke ekologije, koja se protiv zagađenja ili prekomjernog iscrpljivanja resurasa bori samo s aspekta blagostanja ljudi, i to pretežito onih iz razvijenog svijeta. Dubinska ekologija, s druge strane, u osnovi odbija pojednostavljenu sliku »čovjeka-u-okolišu« u prilog sveobuhvatne, što ovdje znači relacijske slike. Naime, intrinzična relacija dvaju bića bitno utječe na samo određenje tih bića. Na to se nastavlja načelni biosferni egalitarizam, načelni jer nema smisla poricati da je određena razina međusobnog nasilja nužna. ${ }^{594}$

Næss je zajedno s Georgeom Sessionsom formulirao platformu dubinskoekološkog pokreta u osam točaka. Prva točka odnosi se na pridavanje intrinzične vrijednosti svem ljudskom i ne-ljudskom životu, pri čemu se potonje odnosi i na »živuću zemlju«, tj. na rijeke, krajolike, ekosisteme i sl. Stoga, ovaj koncept ne zastaje tek na pojedinim živim entitetima. Iz toga proizlazi da druga točka bez kontradikcije govori o intrinzičnoj vrijednosti bogatstva i raznolikosti životnih formi (život, dakle, ne čine samo pojedinačna živa bića), pri čemu (prema trećem načelu) ljudi nemaju prava ovima naškoditi, osim u slučaju zadovoljenja vitalnih potreba. Spomenimo još i sedmu točku, prema kojem kvaliteta života ima prednost pred visokim životnim standardom. ${ }^{595}$

Næss je koncept u koji je ugradio ove točke nazvao ekozofijom. Riječ je o filozofiji shvaćenoj kao »životna filozofija«, ne toliko ona akademska, koju primjenjujemo na pitanja vezana uz naš odnos s prirodom. Paralelno postavlja i koncept ekofilozofije, kao studije

\footnotetext{
${ }^{592}$ Usp. Arne Naess [Arne Næss], Ecology, community and lifestyle. Outline of an ecosophy, preveo David Rothenberg, Cambridge University Press, Cambridge 1989., str. 27. - Ovaj je članak uključen u knjigu: Arne Naess [Arne Næss], Deep Ecology of Wisdom. Explorations in Unities of Nature and Cultures. Selected Works, Springer, Dortrecht 2005., str. 7-12.

${ }^{593}$ Tomislav Markus, Dubinska ekologija i suvremena ekološka kriza. Jedan bioekološki pogled, Hrvatsko sociološko društvo - Institut za društvena istraživanja - Filozofski fakultet, Zavod za sociologiju Odsjeka za sociologiju, Zagreb 2006., str. 32.

${ }^{594}$ Usp. A. Naess, Ecology, community and lifestyle, str. 28. - Kasnije će reći da je s apstraktnim izrazom načelni biosferni egalitarizam vjerojatno napravio više štete nego koristi (Usp. A. Naess, Deep Ecology of Wisdom, str. 68.) Isto tako: $\gg$ Veoma malo pobornika [dubinske ekologije] koristi termin biosferni egalitarizam, što je dobro s obzirom na to da je prirodno riječ egalitarizam interpretirati u apsolutističkom smislu, kao apsolutnu jednakost ili vrijednost u svakom pogledu, u smislu koji nikada nisam imao na pameti i koji svakoga mora učiniti nekonzistentnim grešnikom. «(Usp. ibid., str. 547.) Ovoj ćemo se temi vratiti uskoro.

${ }^{595}$ Usp. A. Naess, Ecology, community and lifestyle, str. 28-29.
} 
zajedničkih problema ekologije i filozofije, pri čemu ekološki pristup dovodi do uvida u međudjelovanje i međuovisnost svih stvari. Ekofilozofija je nešto što se izučava, dok je ekozofija naš vlastiti vrijednosni kod u ophođenju s prirodom, koji se razvija upravo u našim vlastitim konkretnim situacijama. Stoga i sam Næss izlaže svoju ekozofiju, koju proizvoljno naziva »ekozofijom T«. ${ }^{596}$

Ključan filozofski utjecaj na Næssa, koji on često spominje, predstavlja jedna od ključnih figura novovjekovnog racionalizma - Baruch de Spinoza. Osobitu težinu nosi njegov pojam prirode: „Sve dok se zadržavaju važeći pojmovi prirode umjesto Spinozine Nature ili ostalih širokih, temeljitih pojmova prirode, položaj ekologije u okviru prirodnih znanosti ide u prilog plitko-ekološkom pokretu. «97 On, stoga, odbija i tumačenje partikularnih prirodoznanstvenih opisa prirode kao cjelovitih, naročito s obzirom na njihovu težnju k fiksaciji onoga što bi se prije moglo opisati Heraklitovom sintagmom »sve teče«. ${ }^{598}$ Uz to, u njegovu se djelu očituje potreba uključenja različitih perspektiva u sagledavanje ovih problema. Osim spoznaja koje donose prirodne znanosti, poput ekologije, i neizostavne filozofske refleksije, ovdje se uključuju i neke drugačije perspektive koje sve više gube svoj utjecaj u stvaranju slike svijeta. To se, primjerice, odnosi na neka shvaćanja u klasičnim svjetskim religijama, koja imaju značajnu vrijednost $u$ promišljanju trenutne situacije. ${ }^{599}$ Izričit zahtjev za interdisciplinarnošću, koja prerasta u transdisciplinarnost, odnosno u nadilaženje razlika kako bi se uspostavio jedinstven uvid, Næss formulira na sljedeći način:

\footnotetext{
»Ekopolitička situacija je takva da je potrebno potaknuti podršku stručnjaka različitih profesija, dok se s druge strane moraju učiniti napori $\mathrm{u}$ asimiliranju njihovih uvida u cjelinu koja nije samo interdisciplinarna, već također uključuje artikulaciju dubokih osnovnih stavova.« ${ }^{600}$
}

U takvom spletu svakako nije moguće oštro odvajati teorijski i praktički vid problema:

»Što je veća spoznaja naše združenosti s ostalim bićima, to je veća identifikacija, te će naša briga biti veća. « ${ }^{601}$

\footnotetext{
596 Usp. ibid., str. 36-37.

597 Ibid., str. 39.

${ }^{598}$ Usp. ibid., str. 50.

${ }^{599}$ Usp. ibid., str. 175. - Tu je njemu osobito interesantno šire sagledavanje sebstva kao Sebstva u nekim religijama (usp. ibid.), uloga čega će postati jasna u nastavku rada. Što se judeokršćanske perspektive tiče, tu Næss ističe način na koji Bog i prije stvaranja čovjeka blagosilja sve drugo stvorenje, izričući tako vrijednosne sudove kojima pridaje intrinzičnu vrijednost svemu postojećem, pri čemu ništa nije stvoreno naprosto kao sredstvo. (Usp. ibid., str. 184.)

${ }^{600}$ Ibid., str. 195.

${ }^{601}$ Ibid., str. 175.
} 
Prema Næssu, razlika činjenica i vrijednosti, koja nekad može biti korisna, nije ništa drugo do proizvod apstraktnog mišljenja. Takva apstrakcija je i razlikovanje mišljenja od emocija. Međutim, to ne znači da dubinski ekolozi ne bi trebali izgrađivati jasne norme, ponajprije u svrhu rasprave s oponentima. Doduše, nesporazumi češće izbivaju oko ontologije, a ne same etike. Naime, moguće je da se etička načela preklapaju, ali u njihovoj primjeni nastaju razmimoilaženja upravo zbog različitih ontologija. Primjerice, oba sugovornika mogu koristiti termin 'šuma', ali to nikako ne znači da oni referiraju na iste entitete. ${ }^{602}$ Problemi te vrste osobito su prisutni u kontekstu ekologije. Međutim, nije tek riječ o korisnosti razumijevanja ontologije u svrhu razrješavanja naših etičkih razmirica, nego je stvar u tome da bitak ovdje određuje naše trebanje, čime se jasno odbacuje potreba za otklanjanjem naturalističke pogreške:

»Naša mišljenja o tome što jest ili treba biti učinjeno izrazito su ovisna o hipotezama o tome kako je svijet organiziran. Primijenjeno na ekološke odnose, ovo implicira da su naše norme ovisne o našim vjerovanjima o relacijama međuovisnosti unutar biosfere. ${ }^{603}$

Centralni pojam Næssove ekozofije, koji je i nama od osobite važnosti, jest Samoostvarenje (Self-realisation), pojam koji on drži za logički krajnji element ekozofije T. Radi se o osebujnom pojmu, koji se može sagledavati kao vrsta savršenstva, istovremeno kao proces i kao krajnji cilj, kao osobno samoostvarenje i kao ono zajednice, konačno i kao razotkrivanje totaliteta stvarnosti. Kao što se iz ovoga može iščitati, Samoostvarenje (s velikim početnim slovom) nije isto što i samoostvarenje (s malim početnim slovom). Dok se potonje odnosi na individualistički i utilitaran pristup (samoostvarenje kao ego-ostvarenje legorealisation $\left./{ }^{604}\right)$, prethodno se odnosi na ono što se nekad nazivalo »'univerzalno sebstvo', 'apsolut', 'ātman' itd.« Riječ je, dakle, o dubinskoj identifikaciji individue s drugim životnim formama, koja ide još dalje od poticajne Spinozine ideje samoistrajavanja, a ona pretpostavlja razvijanje sebstva koje uključuje sva druga ljudska bića. ${ }^{605}$ Næss će izravno dati do znanja da se njegov koncept Samoostvarenja može pratiti upravo od Spinozina isticanja istrajavanja u samome sebi (perseverare in suo esse), ${ }^{606}$ no ono se ne bi trebalo shvaćati u plitkom smislu

\footnotetext{
602 Usp. ibid., str. 60, 63-66.

${ }^{603}$ Ibid., str. 74.

${ }^{604}$ Tek bi se u tom pogledu samoostvarivanje kao moralni princip moglo tumačiti, kako to primjerice radi Kai Nielsen, u egoističkom ključu. (Usp. Kai Nielsen, »Alienation and Self-Realization«, Philosophy 48 (1973) 1, str. 21-33, ovdje str. 30-31.)

${ }^{605}$ Usp. A. Naess, Ecology, community and lifestyle, str. 84-85.

${ }^{606}$ Usp. ibid., str. 166. - »Svaka stvar, ukoliko do nje stoji, trudi se da istraje u svome biću.« (Baruh de Spinoza [Baruch de Spinoza], Etika. Geometrijskim redom izložena i u pet delova podeljena, prevela Ksenija Atanasijević, Beogradski izdavačko-grafički zavod, Beograd 1983., str. 109.) Upravo težnja izvjesne stvari da istraje u svome
} 
pukog samo-očuvanja, nego i u pogledu stremljenja slobodi, vrlini i moći. Ipak, termin samoostvarenja bolji je od onog samo-istrajavanja, s obzirom na to da izražava aktivnost i kreativnost, a ne pasivno očuvanje, tj. defenzivan stav. ${ }^{607}$

Prema Næssu, sve žive forme imaju »univerzalno pravo« da žive i da se razvijaju, pravo koje ne može biti kvantificirano, tako da bi jedna forma imala veće pravo od druge. Autor ovdje koristi termin »pravo« jer, kako kaže, ne poznaje bolji izraz da bi objasnio ono na što misli. ${ }^{608}$ Pri tom:

»Jednako pravo razvoja [unfolding] potencijala kao princip nije praktička norma o jednakom ponašanju spram svih životnih formi. Ono predlaže smjernicu koja ograničava ubijanje, a općenitije ograničava opstrukciju ostvarivanja potencijala u drugima. $\ll^{609}$

Næss ne zaobilazi pitanje sukoba Samoostvarenja jednog i drugog bića, do kojih, bez obzira na razinu identifikacije, mora doći. No potreba izbora koja se tu nameće ne znači da bi neko biće imalo veću, a neko drugo manju inherentnu vrijednost. Ono što trebamo uraditi u tom slučaju ne profilira se kroz manju ili veću inherentnu vrijednost jednoga ili drugog bića, dakle, ne u gradaciji vrijednosti, nego u gradaciji naših obaveza. Tako ljudi imaju strože moralne obaveze spram ljudskih negoli ne-ljudskih živih bića, roditelji spram svoje negoli spram djece drugih ljudi, ljudi spram onih drugih ljudi koji žive u blizini negoli spram onih koji su im miljama daleko. ${ }^{610}$ Teze u nastavku dodatno osvjetljavaju njegovu poziciju:

\footnotetext{
»Moja je intuicija da je pravo na život jedno te isto za sve individue, koje god vrste bili, no bez obzira na to, vitalni interesi naših najbližih imaju prioritet. Pravila koja funkcioniraju kada se interesi sukobe uključuju dva važna faktora: vitalnost i blizinu. Veći vitalni interes ima prioritet nad onim manje vitalnim, a onaj bliži nad udaljenijim - u prostoru, vremenu, kulturi i vrsti. Blizina derivira svoj prioritet iz naših posebnih odgovornosti, obaveza i uvida kao ljudskog bića među ljudskim bićima.«
}

»Nadalje, tu je, naravno, relevantnost patnje: je li patnja od $A$ manja nego ona od $B$ ? Ima li $A$ kapacitet za patnju?«

\footnotetext{
biću, tvrdi Spinoza, »nije ništa drugo nego stvarna suština same stvari«. Ovdje ne treba zanemariti i to da su pojedinačne stvari (tek) modusi izražavanja božjih atributa. (Usp. ibid., str. 110.)

${ }^{607}$ Usp. A. Naess, Deep Ecology of Wisdom, str. 389, 631.

${ }^{608}$ Usp. A. Naess, Ecology, community and lifestyle, str. 166-167. - »Uspoređujući Reganov pristup s mojim, držim da je potonji više aposterioran i manje elitistički. Pripisivanje prava životinjama često se događa među 'običnim' ljudima, tj. ljudima bez određenog formalnog obrazovanja. Moje je korištenje termina prava vođeno njihovim, prije no onim od strane ljudi vještih u pravu ili filozofiji.« (A. Naess, Deep Ecology of Wisdom, str. 298.) ${ }^{609}$ A. Naess, Ecology, community and lifestyle, str. 167.

${ }^{610}$ Usp. A. Naess, Deep Ecology of Wisdom, str. 98.
} 
»Jasno, zahtijeva se mjera obuzdavanja određenih formi i stilova života u korist drugih - u korist onih s visokim stupnjem simbioze ili, općenitije, dobrim potencijalima za koegzistenciju.«

»Za kompleksnost, u kvalitativnom smislu mnogostranosti stila života i manifestacija života uopće, slobodno se može reći da se povećava od praživotinja do kralježnjaka. Povećana kompleksnost čini povećanje diverziteta mogućim. Maksimalno ostvarenje stoga implicira maksimalni razvoj nivoa kompleksnosti i maksimalni diverzitet na svakom nivou. « ${ }^{611}$

Næssova ekozofija pokušava doprijeti dublje od klasičnih pojmova, pa tako pojmove poput solidarnosti ili vjernosti naziva »plitkima« naspram identifikacije, koju on zahtijeva. Identifikacija koja se ovdje zagovara nosi svojstvo spontanosti, pa se tako zajednički interes shvaća spontano i internalizira. Na taj način solidarnost ili vjernost prestaju biti moralni zahtjevi u klasičnom smislu, jer naviru spontano. Tada Samoostvarenje jednoga bitno ovisi o Samoostvarenju drugoga. ${ }^{612}$ To se može uvidjeti i u Næssovoj formulaciji najosnovnijih normi i hipoteza:

$» N 1$ : Samoostvarenje!

H1: Što je Samoostvarenje više postignuto od strane bilo koga, šira je i dublja identifikacija s ostalima.

H2: Što je viši level Samoostvarenja postignut od bilo koga, to je njegovo daljnje povećanje više ovisno o Samoostvarenju drugih.

H3: Potpuno Samoostvarenje bilo koga ovisi o Samoostvarenju sviju.

N2: Samoostvarenje za sva živa bića! «613

Samoostvarenje je pojam koji otvara prostor širokom krugu razmatranja ispravnog ponašanja. Čini se da u tom svjetlu može pomoći i osvjetljenju pogubnosti razdvajanja klasičnih pojmova theoria, praxis i poiesis. Ta kruta razdioba ušla je i u pojedine sastavnice, tako da se unutar praxisa etika i politika razdvojila već od doba Machiavellija i Hobbesa, da bi se onda i ekonomija odvojila kao zaseban način čovjekova djelovanja. Štoviše, ekonomija je prerasla u zasebnu, autonomnu silu vođenu zasebnim unutarnjim zakonitostima. Næssov pojam Samoostvarenja upravo sadrži potencijal da deziluzionira takvu sliku svijeta. Što se ekonomije tiče, on se osobito trudi ukazati na ništavnost suvremene slike o kvaliteti života (a takvoj iskrivljenoj slici pristaje i poseban naziv, naime »životni standard«) projektiranu kroz bruto nacionalni proizvod:

${ }^{611}$ Ibid., str. 67, 69, 292, 293.

${ }^{612}$ Usp. A. Naess, Ecology, community and lifestyle, str. 172.

${ }^{613}$ Ibid., str. 197. Hipotezu H3 Næss precizira na sljedeći način: »'Potpuno Samoostvarenje bilo koga ovisi o Samoostvarenju svih bića koja su u načelu sposobna za Samoostvarivanje.' U svrhu sažetosti u istraživanju, ta su bića u nastavku nazivana 'živa bića'. Mi definiramo 'živa bića' na taj način.« (ibid., str. 199). 
„Stoga je BNP u izvjesnom smislu vrijednosno neutralan kvantitet: mjera aktivnosti, ne aktivnosti nekakve vrijednosti. Upravo je to prvi argument protiv neprestanog rasta. BNP ne daje nikakvo jamstvo smislenosti onoga što se stvara. Rast u BNP ne implicira bilo kakav rast u pristupu intrinzičnim vrijednostima i napredak u pravcu Samoostvarenja. « ${ }^{614}$

Kako bi se dospjelo do onoga što čini istinsku kvalitetu života, a ne tek visok standard života, Næss predlaže istraživanje kvalitete života (life quality research) kao novu društvenu znanost, odnosno dubinski intervju kao adekvatnu istraživačku metodu. Time bi se iza privida konvencionalnog mišljenja o tome što ljudi žele došlo do njihovih istinskih želja. ${ }^{615}$

Međutim, upravo se na ovom mjestu očituje nemogućnost izjednačavanja bitka i trebanja koje stoji u pozadini ovakvih razmišljanja. Premda primamljivim izgleda ideja da se deskripcijom istinske, duboke čovjekove želje može doći do onoga što bi vrijedilo kao normativno, ona se ipak pokazuje varljivom. Bez da ulazimo u zakučaste probleme psihoanalize, ovdje ćemo se osvrnuti na jedan detalj iz filma Stalker redatelja Andreja Tarkovskog, interpretacija kojega nam može osvijetliti ovdje promatrani problem. Riječ je o izvjesnoj »sobi« u kojoj se ostvaruju najdublje želje onoga tko u nju uđe. To je bio slučaj s likom nadimka Dikobraz, koji je u »sobu« ušao s namjerom da u život vrati nedavno preminulog brata, no pokazalo se da je njegova istinskija želja bila bogaćenje, tako da se potonja ostvarila. ${ }^{616}$ Ovdje se ključnim pokazuje spomenuto Reganovo razdvajanje interesa-za i uinteresu. »Sobu« u Stalkeru možemo tumačiti kao alegoriju za opasnost kojoj se izlažemo ako slijedimo naš interes-za u svoj njegovoj dubini. Ne samo da je uzimanje svjesnog aspekta interesa-za često problematično pri njegovu uzimanju u etički »račun«, već se i nesvjesni aspekt (u psihoanalitičkom smislu dublji, istinskiji) pokazuje duboko problematičnim (odnosno još dublje problematičnim). Dikobrazova »istinska« preferencija bila je bogaćenje, a ne bratov život. Dublja je problematičnost u tome što on tu preferenciju ne može svjesno kontrolirati, stoga ni biti odgovoran za nju, čime moralna prosudba čina pogonjenog njome gubi na smislenosti. Međutim, ovaj moment može zadobiti na moralnoj relevantnosti ako se pitamo gdje su izvori Dikobrazove duboke preferencije. Čini se da takva preferencija često dolazi iz materijalnih, odnosno proizvodnih i sl. odnosa unutar društva, pa se, stoga, kao dužnost nalaže (prije nekim drugim ljudima, negoli Dikobrazu) da se sudjeluje u stvaranju okolnosti koje neće rađati takvim formiranjem sfere nesvjesnog. No usprkos tome što bismo ove izvore mogli

\footnotetext{
${ }^{614}$ Ibid., str. 112.

${ }^{615}$ Usp. ibid., str. 122-123.

${ }^{616}$ Andrej Arsenijevič Tarkovski, Stalker, Mosfilm, 1979.
} 
detektirati u proizvodnim i sl. odnosima unutar društva, pa bi se kao dužnost nametala njihova izmjena, nije moguće izvoditi normativne zaključke iz pojedinčevih preferencija, ma koliko duboke bile. Riječ je o tome da se pojedincima trebaju uklanjati zapreke uviđanju i prakticiranju njihovih istinskih potreba ili interesa, no tako da se njihovoj autonomiji prepusti da sami iznalaze ono što je u njihovu interesu. Premda je Tarkovski, čini se, pokušao fenomenom »sobe« ukazati na čovjekovu inherentnu nemoć, tj. nemogućnost potpunog oslanjanja na vlastite moći, pa stoga potrebovanje božanske milosti, ovdje bismo htjeli ukazati da i izbacivanjem božanstva iz »jednadžbe« još uvijek imamo spasonosnu (ne u smislu vječnog spasenja, nego ovozemaljskog autentičnog života) dispoziciju uma, odnosno morala utemeljenog na njemu. Riječ je o tome da se norme uspostavljaju prije naših najdubljih želja, koje ne samo da mogu voditi nečemu što će narušavati naše ili samoostvarenje drugih živih bića, već su i bitno uvjetovane našim nesvjesnim, čijoj konstituciji društvena sredina može bitno naškoditi.

Næssova filozofija također pati od nekih pretjeranosti, poput koncepta života koji obuhvaća - sve! Zaista je teško pronaći nešto postojeće, a što ne bi pripadalo tom konceptu. Tu se očituje ključan utjecaj Spinozine filozofije u pokušaju obuhvaćanja svega postojećeg pod jedan princip, ali takva stajališta o bitku možemo nalaziti i u osnovama zapadnog mišljenja, u grčkoj filozofiji, gdje se bitak, kako se već spomenulo, shvaćao kao život. Ontološko ustrojstvo prisutno u konceptima dubinskih ekologa može se sažeti na sljedeći način:

\footnotetext{
»... ne postoji čvrsta ontološka podjela na polju egzistencije. Drugim riječima, svijet naprosto nije podijeljen na nezavisno postojeće subjekte i objekte, niti u stvarnosti postoji bifurkacija na ljudska i neljudska područja. Umjesto toga, svi su subjekti konstituirani od njihovih odnosa. U mjeri u kojoj percipiramo granice, podbacujemo u dubinskoekološkoj svijesti.« ${ }^{617}$
}

Premda je prožetost odnosima sveg bića nešto što ne treba dovoditi u pitanje, pitanje je koliko je opravdano zanemarivati neke bitne razlike između organske i anorganske materije, te koliko to posvemašnje izjednačavanje može biti plodno za etičku teoriju. Nadalje, ima li smisla pridavati anorganskoj materiji atribut samoostvarenja? U slučaju da prihvatimo postavku da Samoostvarenje može postojati samo ako potiče svako pojedino samoostvarenje, zar već u tome nije na izvjestan način sadržano da se u konačnici mogu samoostvarivati samo pojedinačna bića? Ako tomu nije tako, čini se da vrijednost ili dostojanstvo individue ne može doći na svoje, čime čitava teorija postaje etički sumnjiva. Čini se da koncepti koji pretendiraju na obuhvaćanje

${ }^{617}$ Warwick Fox, »Deep Ecology: A New Philosophy of Our Time?« The Ecologist 14 (1984) 5-6, str. 194-200, ovdje str. 196. 
čitave zajednice života (što ovdje zapravo znači: zajednice postojanja) kao nosioca imanentne vrijednosti stvaraju više problema nego koristi. Naime, ako se dade pokazati da je moralni obzir spram živih bića smislen, tada je na osnovi univerzalizacije lako utvrditi da naš odnos spram prirodnog svijeta treba stubokom izmijeniti. To se onda neizravno odnosi i na brigu oko očuvanja ugroženih vrsta, zaštite rijeka i sl., ali radi živih (bića koja se mogu samoostvarivati) bića, a ne radi anorganske materije same.

Foxov se pokušaj odstranjivanja svake podjele, tvrdi ekofeministkinja Val Plumwood, metafizičkim ujedinjenjem ljudi s kozmičkom cjelinom, pokazuje kao neadekvatna osnova za izgradnju etike životne sredine. Razlog leži u tome što se svaki vid ljudskog odnosa s prirodom javlja kao jednako istinit, eksploatacija prirode isto koliko i njeno očuvanje mogu ilustrirati to jedinstvo. S druge strane nema razloga da se ljudsko sebstvo više razlikuje od nekog njegova artefakta negoli od prašume. Autorica ne ističe slučajno potonji primjer. Naime, kako dubinski ekolog John Seed drži da naša nemogućnost razlikovanja od prašume vodi k postajanju njenih potreba našima, ona ne vidi kako isto tako ne bismo mogli neke naše potrebe smatrati njenima. Stoga nije dovoljno prepoznati samo naš kontinuitet $s$ prirodom, nego i pojmiti našu razdvojenost od nje kako bismo uvidjeli i »razdvojenost potreba stvari u prirodi od naših potreba«. 618

Premda bi se spomenute konzekvence mogle povući iz Næssove misli, naročito upotpunjene tezama kakva je gore spomenuta Foxova, kritičku oštricu prema njoj ipak bi trebalo ponešto otupiti s obzirom na neke njezine eksplikacije koje barem naglašavaju nezaobilaznost onog individualnog, premda se time ne rješava problem inherentne vrijednosti apstraktnih entiteta kakav je vrsta. Tako po pitanju onoga što bi životna forma, kao ono što ima inherentnu vrijednost, trebala značiti, Næss naglašava:

»Izraz 'svaka životna forma' može biti interpretirana kao sinonimna 'svakom individualnom živom biću i svakoj vrsti'. Ono što je, ili treba biti, isključeno interpretacija je 'svake žive forme' kao sinonimne 'svakoj vrsti (ne svakom individualnom živom biću)'.«619

Bez obzira na spomenute nedostatke, ovakva ekozofija posjeduje izuzetnu vrijednost za daljnja promišljanja nekih problema. Pojam samoostvarenja (možda s manjom pretenzijom od

\footnotetext{
${ }^{618}$ Usp. Val Plamvud [Val Plumwood], »Priroda, sopstvo i rod: feminizam, filosofija životne sredine i kritika racionalizma«, prevela Svetlana Bogdanović, u: Jelena Đurić, Srđan Prodanović, Predrag Krstić (prir.), Životna sredina. Moralni i politički izazovi, Službeni glasnik - Institut za filozofiju i društvenu teoriju, Beograd 2012., str. 57-85, ovdje str. 69-72.

${ }^{619}$ A. Næss, Deep Ecology of Wisdom, str. 95. - Još snažniji naglasak na individualnom izražava kad kaže: »Ne isključujem mogućnost samoostvarivanja kolektiva, ali preferiram misliti samo o određenim bićima, određenim ljudskim bićima, žabama, rudarskim glistama.« (Ibid., str. 294.)
} 
onog s velikim početnim slovom) otvara prostor za moguće utemeljenje moralnog obzira pored klasičnih kategorija poput autonomije, praktičkog zakona, interesa, moralnog osjećaja itd., premda to ne mora voditi njihovu isključenju. Pored toga, Næssova misao nosi značajnu vrijednost u buđenju senzibiliteta za probleme o kojima govori, no nedovoljna je za racionalno utemeljenje našeg moralnog obzira.

Međutim, istaknimo samo još jedan od problema na koji nailaze pozicije poput Næssove. Radi se o bježanju u suprotne krajnosti izvjesnog čovjekova nastrojstva spram svijeta u svrhu njegove radikalne izmjene. Naime, svojevrsno idealiziranje spontanosti prirodne samoregulacije, kao reakcija na novovjekovni imperativ čovjekova ovladavanja prirodom, lako može zaboraviti na potrebu stalnog čovjekova povijesnog samonadilaženja. Tako Næss u pozivanju na Spinozu zanemaruje suštinsku nepromjenjivost metafizičke slike svijeta potonjega, ali i to što u okviru čitavog sistema postoje još do kraja neprevladane mehanicističke pretpostavke, počevši od toga da su nama spoznatljivi atributi jedinstvene supstancije tek mišljenje i protežnost, pa se tako ni ono što bi se konvencionalno nazivalo prirodom ne bi dalo razumjeti izvan okvira kvantiteta. To primjećuje Kangrga kad piše da kod Spinoze »posljedica ne sadržava nikad nešto više ili drugo od onoga, što je već sadržano u jednom ili više njenih uzroka zajedno. To je kvantitativno određenje pojma uzroka, i tu nema i ne može biti kvalitativnih promjena«. ${ }^{620}$ Time se pak vraćamo na probleme istaknute u okviru propitivanja zaborava prirode. Štoviše, oni se, u izvjesnom smislu, još više intenziviraju kod Spinoze:

\begin{abstract}
»I Spinoza je, kao i Descartes, prvu i osnovnu sigurnost $\mathrm{i}$ istinitost spoznaje našao u matematici i geometriji, ali kod njega je, na jednom višem stupnju, čitava ta problematika u osnovi svojoj postavljena sasvim drugačije i obuhvatnije. Kod Descartesa je matematski, geometrijski red primarno metodski, spoznajnoteoretski ideal, a kod Spinoze naprotiv ontološka pretpostavka, koja je sama osnova i bit mehaničke racionalističke koncepcije svijeta. «21
\end{abstract}

Ove bismo, Næssu suprotne naglaske po pitanju Spinozine metafizike trebali također imati na umu pri zadatku sveobuhvatnog uvida u svu širinu koju bioetička problematika rastvara. Tako ćemo u nastavku pokušati, uz pomoć i kritiku Viskovićevih teza (i onih autorā na koje se oslanja, koje su ovdje već iznošene), izvesti bioetičko gledište koje neće »izbacivati

\footnotetext{
${ }^{620}$ Milan Kangrga, Racionalistička filozofija. I odabrani tekstovi filozofa, Nakladni zavod Matice hrvatske, Zagreb 1982., str. 68-69.

${ }^{621}$ Ibid., str. 70. - Dodajmo još jedan Kangrgin uvid koji možemo vezivati uz problem novovjekovne metode u pogledu zaborava prirode: »Jer svaki je modus ili konačna stvar sagledan s dva aspekta: pod atributom mišljenja i atributom protežnosti, pa je osnovni nagon za samoodržanjem usmjeren s jedne strane na njegovo znanje, a s druge strane na njegovu $m o c ́$, a to je na koncu po Spinozi jedno te isto, jer upravo znanje = moć, što je osnovna lozinka prirodnonaučnog razuma od Bacona pa nadalje sve do u 18. stoljeće.« (Ibid., str. 81.)
} 
dijete s plodnom vodom «, time što bi zanemarilo kako samovrijednost živih bića, tako ni stalan zahtjev čovjekove samotranscendencije, bez koje ni koncepti posvećeni obrani ove samovrijednosti ne bi bili ni mogući.

\section{III.4. Kritički osvrt i pokušaj doprinosa utemeljenju biocentričke pozicije}

Premda je kritički osvrt na pojedine Viskovićeve (bio)etičke stavove već dan u prethodnom, ovdje ćemo ih pokušati u izvjesnoj mjeri sve obuhvatiti, nudeći istovremeno prijedloge za zaokruživanje njegovih pojedinih misaonih pozicija u koherentniju cjelinu, posebno njegovo zastupanje marksizma i biocentričke etike. Potonju ćemo, imajući na umu uvide u njezine manjkavosti i kontradikcije u Viskovićevim spisima, pokušati čvršće utemeljiti u pojmu samoostvarivanja, ponešto različitom od onog Næssova, koji se istovremeno može shvatiti kao njegova kritika i kao njegova korekcija. Kao uvod u to, ponovno ćemo otvoriti problem moralnog subjektiviteta ne-ljudskih živih bića, služeći se jednom Viskoviću već upućenom kritikom.

\section{III.4.1. Može li ne-ljudsko živo biće biti moralni subjekt?}

Za dodatno osvjetljavanje osnovanosti pripisivanja moralnog subjektiviteta ne-ljudskim živim bićima, instruktivno je sagledati Kangrginu reakciju na tu tezu. S obzirom na to da ona $u$ bitnome odražava stav tradicionalne etike po ovom pitanju, njezino kritičko preispitivanje može pomoći barem u pogledu prikladnosti određene terminologije.

U odgovoru na intervju Nikole Viskovića »Stiže nas osveta životinja«, odgovoru s obzirom na to da se u tom intervjuu osjeća prozvan, Milan Kangrga oštro reagira prvenstveno na jedan navod:

»Našim etičarima i filozofima uglavnom je ispod časti govoriti o prirodi i o životinjama kao o etičkim vrednotama, odnosno subjektima. Kod nas je etika u tom smislu 'zapela' na kantovsko-hegelijanskom viđenju da životinje nemaju svijesti i duh, pa ih samim tim ne treba ni uzimati u etička razmatranja. Izvan Hrvatske, međutim, mnogi su se etičari i filozofi bavili ili problemom odnosa čovjeka prema životinjama, 
od principa sućuti Arthura Schopenhauera, preko Hansa Jonasa i Alberta Schweizera i njegove teorije integralne obrane života, pa do Petera Singera koji je prevođen i kod nas. « ${ }^{622}$

Kangrgina reakcija je u mnogim aspektima pretjerana, prvenstveno u pogledu nepotrebne osornosti spram ovog navoda u kojem se nalazi osobno uvrijeđen, iz kojega proizvoljno tumači Viskovićeve intencije, a u konačnici ga i vrijeđa pripisujući mu nacionalističke stavove. ${ }^{623}$ To je ovu situaciju dovelo do obostrane uvrijeđenosti i prekida svake daljnje diskusije. U ovom poglavlju namjeravam ponovno otvoriti zamrli spor, ne kako bih »tjerao pravdu« između »poniženih i uvrijeđenih«, nego kako bih pokušao odgovoriti na pitanje: može li se (i ako može, u kojem pogledu) ne-ljudska živa bića odrediti kao moralne subjekte, ne odbacujući klasične filozofske kategorije (na koje se Kangrga dijelom oslanja), ali ni suvremenu tendenciju uključenja ovih bića u moralni horizont (koje je proponent Visković)?

Srž Kangrgine kritike je u sljedećem:

»Za gospodina su Viskovića, dakle, priroda $i$ životinje ne samo etičke vrednote (njem. Werte), nego - on kaže u identitetu: odnosno subjekti! Odatle slijedi zaključak - do sada vjerojatno najoriginalniji u historiji! - kako su priroda i životinje moralni subjekti! Tko bi sad znao ili dokučio, što gosp. Visković razumije pod onim 'moralni', a što pod onim 'subjekti'?! Po svemu sudeći, on ni sâm ne zna što je rekao?! Zašto se gosp. Visković nije potrudio - kad već govori i piše o etičko-moralnoj problematici - da bar zaviri u bilo koju i bilo kakvu etiku, kako bi dokučio bar to, kako ni priroda, ni životinje nisu i ne mogu biti moralni subjekti (jer nisu ni subjekti, te bi ga baš u tome mogli podučiti upravo Kant i Hegel, koje on nije ni čitao!). $\ll^{624}$

Iz prethodno navedenog je jasna »pravnička obojenost« Viskovićeva poimanja moralnog subjektiviteta, ali i njegova koherentnost, pa tako nije osobito teško razaznati »što gosp. Visković razumije pod onim 'moralni', a što pod onim 'subjekti'«. No radi li se ovdje ipak o nespretnom i neopravdanom korištenju pojma 'subjekt'?

\footnotetext{
${ }^{622}$ Nikola Visković, »Stiže nas osveta životinja«, Feral Tribune 28. 10. 2005., intervju (razgovarala Tena Erceg), str. 20-21, ovdje str. 21; Milan Kangrga, Filozofske rasprave, Euroknjiga, Zagreb 2008., str. 294.

${ }^{623}$ M. Kangrga, Filozofske rasprave, str. 294-298 (ovaj je Kangrgin odgovor u ovoj publikaciji naslovljen »Životinje nisu moralni subjekti (ni objekti)«). - Optužba za nacionalizam zaista je apsurdna ako se u obzir uzme Viskovićevo, po njega nimalo bezopasno, zalaganje za splitske Srbe koji su za vrijeme posljednjeg rata na različite načine maltretirani, od izbacivanja iz stanova, do zločina u Lori. Uostalom, Kangrga je zbog svojih antirežimskih istupa sudski gonjen od iste osobe kao i Visković - Vladimira Šeksa. O nekorektnosti Kangrgina napada dovoljno govori činjenica da je redakcija Feral Tribunea, najsnažnijeg antirežimskog glasila svog vremena, odbila objaviti ovaj njegov tekst, pa je on prvotno tiskan u beogradskoj Republici. (Vidi: ibid., 294.)

${ }^{624}$ Ibid., str. 295.
} 
Imamo li u vidu rječničke i enciklopedijske natuknice, subjekt se obično promatra kao nositelj svijesti i spoznaje, ali i kao nositelj radnje, stanja, svojstva i sl. ${ }^{625}$ Tek bi dio ovog drugog značenja, ako zanemarimo ono posuđeno iz prava, moglo donekle izvući Viskovićevo određenje pasivnog moralnog subjekta, ali uz korekciju da se radi o subjektu zasluge moralnog obzira, a ne morala uopće. Prvo značenje, radije spoznajnoteorijsko negoli ontološko, ukazuje na to da je za pridavanje pridjeva 'moralni' subjektu nužna njegova sposobnost osvještavanja moraliteta. Ako bismo pak aktivitet uzeli kao nužan uvjet bivanja subjektom, kod termina 'pasivni subjekt' radilo bi se o kontradikciji, isto kao što bi se kod termina 'pasivni objekt' radilo o pleonazmu.

No pripisivanje moralnog subjektiviteta ne-ljudskim živim bićima u potonjem bi se pogledu možda i dalo spasiti upravo referiranjem na za Kangrgu nezaobilaznog klasika Immanuela Kanta. Naravno, radilo bi se o jednom novom tumačenju stare ideje ili samo jednog njenog fragmenta. Naime, polazi se od ideje da bi kod Kanta kao moralnog subjekta mogli odrediti suzakonodavca moralnog zakona. No ako ti suzakonodavci mogu biti samo racionalna bića, onda je besmisleno odliku moralnog subjekta propisivati ne-racionalnim bićima. Ovdje se racionalnost i moralna subjektivnost međusobno uvjetuju, a potonja izjednačuje sa sposobnošću moralne odgovornosti. Kangrga često ide i korak dalje, pristupajući iz historijske perspektive, tj. ne sagledavajući čovjeka kao apstraktno biće, pa tako za njega odgovor na pitanje o subjektu moralnosti ne može naprosto glasiti: čovjek. Kako tvrdi u svojoj Etici: »Na pitanje, dakle, tko je subjekt (nosilac) moralnosti (...) mogli bismo odgovoriti samo tako da je taj zbiljski nosilac kroz čitavu historiju do danas bio i ostao jedino vladajući sloj (stalež, klasa, kasta), a većina čovječanstva bila je samo mogući objekt moralnosti.« ${ }^{626}$ No idemo li već deskriptivnim putom, teško je uvidjeti u čemu bi se sastojao interes čovječanstva ili bilo kojeg njegova dijela da $\mathrm{u}$ direktni moralni obzir uključi ne-ljudska živa bića. Time se ovakvo shvaćanje moralnosti čini preuskim, u izvjesnom smislu reduciranim na odnose moći, što ne znači da istovremeno ne

\footnotetext{
${ }^{625}$ Vidi npr.: Vladimir Filipović, »Subjekt«, u: Vladimir Filipović (ur.), Filozofijski rječnik, Nakladni zavod Matice hrvatske, Zagreb 1989., str. 318; A. Mišić, Rječnik filozofskih pojmova, str. 250; »Subjekt«, Hrvatska enciklopedija. Dostupno na: http://www.enciklopedija.hr/natuknica.aspx?id=58573 (pristupljeno 3. 11. 2019.).

${ }^{626}$ Milan Kangrga, Etika. Osnovni problem i pravci, Golden Marketing-Tehnička knjiga, Zagreb 2004., str. 111. - No ne treba zanemariti ni povijesni razvoj ovog fenomena kakav Marx i Engels dijagnosticiraju u Njemačkoj ideologiji. Osim što drže da je vladajuća materijalna sila istovremeno i vladajuća duhovna sila, gdje u samoj vladajućoj klasi nastupa podjela rada između duhovnog (ideolozi) i materijalnog (tobože pasivni usvajači ideja, ali zapravo aktivni članovi), novoj je klasi pri pretenziji i nastupanju na mjesto vladajuće potrebno svoj interes prikazati kao zajednički svim članovima društva. Time vladajuće misli postaju sve apstraktnije, tj. sve općenitije. No širenjem osnove svoje vladavine samo se produbljuje sukob nove vladajuće i nove podređene klase. (Usp. Karl Marx, Friedrich Engels, »Njemačka ideologija«, preveo Stanko Bošnjak, u: Karl Marx, Friedrich Engels, Rani radovi, Naprijed, Zagreb 1989., str. 355-428, ovdje str. 393-396.) Tako se i proces poopćavanja u moralnom progresu kakav detektira Visković kroz ovu vizuru može promatrati kao proizvod svake nove vladajuće klase koja njime sve efikasnije (posebice ako zakazuju njezini ideolozi) pila granu na kojoj sjedi.
} 
pruža vrijedan uvid u stalno prisutnu mogućnost manipuliranja moralom, barem u njegovu sadržajnom pogledu. Naravno, i ovo shvaćanje za tumačenje subjektiviteta zahtijeva posjedovanje dispozicije za osvještenje moraliteta.

No moralna subjektivnost isto tako može biti tumačena bitno drugačije ako se u središte stavi upravo pojam suzakonodavstva. Ako su pak ne-ljudska živa bića ona koja utječu na naše shvaćanje načina na koji treba djelovati, tada u izvjesnom smislu sukreiraju (makar ni u kom pogledu ne osvještavaju) sadržaj moralnog zakona - onda kada svoju volju dovodimo pred moralno sudište, za nas ne bi bili relevantni samo artikulirani zahtjevi koji proizlaze iz volja drugih autonomnih bića, nego i nijemi zahtjevi neracionalnih bića.

\section{III.4.1.1. Samoostvarivanje}

No odakle proizlazi ovaj nijemi zahtjev neracionalnih bića i što nas obavezuje da ga uzmemo u moralni obzir? Držimo li se u Kantove etike, moramo ustvrditi da je utemeljenje moraliteta moguće samo u umu, ili barem primarno u njemu, a u svakom slučaju nikako bez njega. Samim time, barem koliko za sada znamo, jedino moralno djelatno biće može biti čovjek. Samo utemeljenje moraliteta stoga je antropocentrično, međutim, ono to nije nužno, nego je prije određeno našim trenutnim spoznajama o opsegu bića koja su posjednici uma. Stoga bi za Kantovu poziciju namjesto antropocentrizma prikladnije bilo, kako to radi Allen W. Wood, isticati naziv logocentrizam. ${ }^{627}$ Kako bilo, tu se ne može raditi o biocentričkom utemeljenju samog moraliteta, jer bi to značilo da svako živo biće, uz posjedovanje uma s kojim može biti dionik u moralnom su- i samozakonodavstvu, posjeduje sposobnost moralnog djelovanja. Sâmo ovo utemeljenje igrat će kod Kanta ključnu ulogu i u određivanju čovjeka kao jedinog bića spram kojega se mogu imati direktne moralne dužnosti:

»Sudeći po samom umu, čovjek nema druge dužnosti doli prema čovjeku (prema samome sebi ili nekome drugome); jer njegova dužnost spram bilo kojeg subjekta jest moralno primoravanje subjektovom voljom. Primoravajući (obavezujući) subjekt mora, dakle, kao prvo, biti osoba, kao drugo, ta osoba mora biti dana kao predmet iskustva; zato što čovjek treba djelovati u skladu sa svrhom njezine volje, što se može zbiti samo u međusobnom odnosu dvaju egzistirajućih bića (jer puka mišljevina ne može postati uzrok postizanja neke svrhe). No uza svo naše iskustvo nije nam osim čovjeka poznato nijedno drugo biće koje bi bilo sposobno za obavezu (aktivnu ili pasivnu). Prema tome, čovjek ne može imati dužnost ni prema kojem drugom biću osim prema čovjeku, a ako ipak zamišlja da takovu dužnost ima to se zbiva

${ }^{627}$ Usp. Allen W. Wood, Onora O'Neill, »Kant on Duties Regarding Nonrational Nature«, Proceedings of the Aristotelian Society, Supplementary Volumes 72 (1998), str. 189-228, ovdje str. 189. 
zahvaljujući svojevrsnoj dvosmislenosti pojmova refleksije, te je njegova tobožnja dužnost prema drugim bićima samo dužnost prema samome sebi; na taj nesporazum navodi ga to što svoju dužnost glede drugih bića brka s dužnošću prema tim bićima. «228

Vodi li utemeljenje moraliteta u umu istovremeno i tome da izravni moralni obzir može biti pridavan isključivo umnim bićima? Premda se intuicija tomu često opire, ono što nam ona govori mora se na određeni način konceptualizirati i racionalno opravdati ako želi zadobiti »pravo građanstva«. U pokušaju razjašnjenja ovog pitanja pokušat ćemo uraditi odmak od uskoće same etičke teorije koja neke ontološke pretpostavke ponekad uzima zdravo za gotovo. Jedna od takvih pretpostavki postojanje je suviše velikog ontološkog jaza između čovjeka i drugih živih bića.

Čini se da sukladno sve bogatijim znanstvenim uvidima u strukturu živih bića taj jaz postaje sve manji, no on ponekad u usko znanstvenim okvirima promatranja prirode zastrani u redukcionističke krajnosti. Međutim, razmatranja o smanjenju tog jaza bila su pružena i s raznih filozofskih pozicija. Nama je ovdje osobito interesantna ona Jonasova, koji u svojoj filozofijskoj biologiji pruža bitno različite uvide u neke temeljne ontološke pojmove od onih koji su prevladavali u novovjekovnoj filozofiji. On u svoju filozofiju života pokušava sjediniti i filozofiju duha i filozofiju organizma, naglašavajući kako su već u onom organskom sadržani nagovještaji onog duhovnog, a da je duhovno (u što spada i sama sloboda) uvijek i dio organskog. Naime, Jonas tvrdi da se već metabolizam kao osnovna razina organske egzistencije može promatrati kao prva forma slobode. Stalna prijetnja smrti (nebitka) s kojom se živo biće (bitak) suočava, tjera bitak da se stalno afirmira kao briga, a nebitak se u njemu utjelovljuje. Bitak se tu ne promatra kao gotovo stanje, nego kao stalna mogućnost. Forme relacije, poput forma/materija ili sloboda/nužnost, od kojih je temeljna bitak/nebitak, određuju život koji je u svojoj biti relacija, a relacija implicira transcendiranje, odnosno kretanje preko samoga sebe. ${ }^{629}$

»Velike kontradikcije koje čovjek otkriva u sebi - sloboda i nužnost, autonomija i ovisnost, sebstvo i svijet, relacija i izolacija, kreativnost i smrtnost - imaju svoje rudimentarne tragove čak i u najprimitivnijim formama života, svaka neizvjesno balansirana između bitka i nebitka, te svaka već obdarena internim horizontom 'transcendencije'. ${ }^{630}$

\footnotetext{
${ }^{628}$ Immanuel Kant, Metafizika ćudoređa, Matica hrvatska, preveo Dražen Karaman, Zagreb, 1999., str. 226. - Za detaljnije sagledavanje utemeljenja moralnih dužnosti glede životinja kod Kanta vidi: I. Eterović, Kant $i$ bioetika, str. 193-215.

${ }^{629}$ H. Jonas, The Phenomenon of Life, str. 1-5.

${ }^{630}$ Ibid., str. xxiii.
} 
Živi se organizam ne može naprosto svesti na puku materiju, među ostalim i s obzirom na to da je »samog sebe izuzeo iz opće integracije stvari u fizičkom kontekstu, postavio se nasuprot svijetu i uveo tenziju 'biti ili ne biti' u neutralnu sigurnost egzistencije ${ }^{631} \mathrm{~S}$ druge strane, kao osnovnu grešku kartezijanstva (što onda nije ostalo samo na tom filozofskom usmjerenju) uviđa u »poricanju organskoj realnosti principijelne i najočitije karakteristike, naime, da ona u svakoj individualnoj instanci izlaže težnju za vlastitom egzistencijom i ostvarenjem [fulfilment] ili činjenicu da život želi samoga sebe«. ${ }^{632}$

Implikacije Jonasove filozofijske biologije veoma su značajne za ponovno promišljanje nekih starih i novih moralnih problema. Njenu snagu za formiranje biocentričke etike istaknuo je Hrvoje Jurić, uklapajući je istovremeno u okvir integrativne bioetike. Riječ je o slijeđenju Jonasova koncepta u kojem se pored klasičnog značenja trebanja kao naloga za ljudsko djelovanje, trebanje utemeljuje i iz »nijemog zahtjeva« samog bića čija samovrijednost proizlazi iz činjenice života kao samopotvrđivanja. Stoga se trebanje, ogrješujući se sada o zabranu izvođenja trebanja iz bitka, mora uspostavljati i s obzirom na jedno takvo biće. Drugi bitan aspekt ovog koncepta čovjekov je odnos s okolišem, u kojemu je često zanemarivana praktička, odnosno moralna komponenta. Osvještavanje tog propusta mora ići u smjeru etičkog tematiziranja tog odnosa, a ne samo ontološkog ili spoznajnoteorijskog. ${ }^{633}$

»Osim fizičkih predispozicija i tehničkih sposobnosti, čovjek ima i moralne dužnosti koje se ne mogu ograničiti samo na jedno područje njegova činjenja, nego moraju 'pokrivati' čitavo područje njegove moći. « ${ }^{334}$

Spomenuti nam pojam »nijemog zahtjeva« živog bića koje se u relaciji bitka i nebitka afirmira, uzimajući u obzir i neka njegova druga iznesena obilježja, otvara prostor za razmišljanje o svojevrsnom primoravanju koje nam dolazi od tih bića da ih uzmemo u moralni obzir. Ona svakako nisu naši su-zakonodavci u formiranju moralnog zakona na način na koji to

\footnotetext{
631 Ibid., str. 4.

632 Ibid., str. 61.

${ }^{633}$ Usp. H. Jurić, Etika odgovornosti Hansa Jonasa, str. 292, 300. - Osnovne konture Jonasovih koncepata na kojima se grade ovi Jurićevi mogu se pronaći u: H. Jonas, The Phenomenon of Life, str. 282-284. Tu se upućuje na izgradnju etike na osnovi ontologije, a slična misao nalazi se i tamo gdje Jonas eksplicitnije govori o nijemom zahtjevu prirode: »... neki nijemi apel za očuvanje njezinog integriteta izgleda da polazi od te punoće životnog svijeta koji je u opasnosti. Hoćemo li čuti taj apel, treba li da priznamo njegovo pravo kao obavezno jer ga sankcionira priroda stvari, ili ćemo u njemu gledati samo jedan naš sentiment koji možemo uvažiti ako to hoćemo i ukoliko ga sebi možemo priuštiti? Prva alternativa, uzeta ozbiljno u njezinim teoretskim implikacijama, prisilila bi nas da daleko proširimo onaj spomenuti preokret mišljenja i da ga prenesemo iznad učenja o djelovanju, to znači etike, sve do učenja o bitku, to znači do metafizike, u kojoj, na koncu konca, mora da se zasniva svaka etika.« (Hans Jonas, Princip odgovornost. Pokušaj jedne etike za tehnološku budućnost, preveo Slobodan Novakov, Veselin Masleša, Sarajevo 1990., str. 24.)

${ }^{634}$ H. Jurić, Etika odgovornosti Hansa Jonasa, str. 300.
} 
može drugo umno biće. Međutim, sasvim je jasno da iz težnje i samopotvrđivanja određenog bića proizlazi egzistencijalni zahtjev koji isto tako sačinjava dio moralnog zahtjeva koje umno biće upućuje drugom čovjeku. Stoga bi se i taj zahtjev u izvjesnom smislu, na analogan način, mogao tumačiti kao moralni zahtjev.

Taj zahtjev proizlazi iz onoga što ovdje nazivamo samoostvarivanje. Kod čovjeka, tu bi se, pored ostaloga, radilo o zahtjevu da se bude suzakonodavac moralnog zakona, a to znači da maksima kojom se određeni subjekt vodi mora (moći) i od svakog nasuprot stojećeg zahtijevajućeg subjekta biti prihvaćena kao opći zakon. Moralno ponašanje koje se ovdje odvija upravo je ostvarivanje čovjekove slobode. Uzevši pojedinca u suodnos sa svima drugima, njegova se sloboda odvija na način da se ona odvija i kod svakog drugog suzakonodavca moralnog zakona. Sama sloboda, osim što je konstituens moraliteta (ratio essendi moralnog zakona prema Kantu ${ }^{635}$ ), pokazuje se i kao način čovjekova samoostvarivanja. Ideja slobode tu je forma njegova samoostvarivanja, onaj okvir u kojem se ono može odvijati, što onda svakako ne isključuje sadržaj (koji ne treba biti izravno moralno relevantan), nego ga upravo putem univerzaliziranja forme omogućuje.

Samoostvarivanje, međutim, nije samo ljudska značajka - ono postoji kod svakog živog bića. Stoga se po analogiji s čovjekovim samoostvarivanjem i ono drugih živih bića može promatrati kao vrijednost u sebi. Naročito ako imamo u vidu vrijednost koju pridajemo određenim segmentima ključnima za naše samoostvarivanje, a koje nalazimo i kod ne-ljudskih živih bića (rast, hranjenje, izbjegavanje bola itd.). »Nijemi zahtjev« živih bića koji moralno trebanje mora uzimati u obzir proizlazi upravo iz tog samoostvarivanja, odnosno samopotvrđivanja (kao izraza samoostvarivanja), koje je svojstveno samo živim bićima. Pošto je »nijemi zahtjev« ne-ljudskih živih bića upravo »nijem«, njihovo sudioništvo u moralnom zakonodavstvu mora se uzeti tek analogno i u određenoj mjeri - dakle, kao da bi mogli artikulirati svoj zahtjev za samoostvarivanjem i njime obavezati umno biće, jer je nekakva analogija prema određenim aspektima zahtjeva umnog bića upravo suviše očita i snažna.

Kako samoostvarivanje ne može opstojati samo kao apstraktni pojam, nego je uvijek pripadno pojedinačnom živom biću, tada se na temelju njega živim bićima može pripisivati vrijednost po sebi. Naime, svođenjem slobode (shvaćene kao autonomije volje) na formu samoostvarivanja ona se ne obezvređuje. Osim što je se na ovaj način pokušava »zadržati na zemlji«, odnosno interpretirati je na način da je se očuva od bijega u apstrakciju, čija bi vrijednost lebdjela iznad konkretnog bića u čijem samoostvarivanju ona dobiva mjesto, ona

${ }^{635}$ Usp. I. Kant, Kritika praktičkog uma, str. 32. 
zadržava najviši značaj u tom samoostvarivanju koje je kao takvo samoostvarivanje čovjeka kao kompletnog bića. Drugim riječima, potpuno čovjekovo samoostvarivanje ne može se zamisliti kao rast u slobodi, a da on istovremeno ne bude popraćen rastom i održavanjem $u$ onom prirodnom. Određena razina organskog razvoja ključna je i u mogućnosti slobode, tako da se on ne može izostaviti iz »računa« samoostvarivanja čovjeka.

Već je iz do sada navedenog jasno da je nemoguće izbjeći određenu hijerarhizaciju samoostvarivanja, u kojem bi ono pripadno samosvjesnom čovjeku bilo vrjednije od onog pripadnog ne-ljudskim živim bićima. To pak nikako ne govori da svaka ljudska svrha nadilazi one koje ima životinja ili biljka. Dužnost poštivanja samoostvarivanja određenog živog bića nalaže nam da odstranimo neke vlastite svrhe koje nisu ključne za naše vlastito samoostvarivanje, ako one dolaze u koliziju s onima koje su ključne ne-ljudskom živom biću. Sva sukobljavanja samoostvarivanjā treba promatrati u vidu temeljnog određenja ispravnog moralnog djelovanja koji bi se mogao formulirati na sljedeći način: Moralno ispravno djelovanje ono je djelovanje koje stremi omogućavanju samoostvarivanja svakom biću kojemu je samoostvarivanje svojstveno.

Stremljenje se ovdje može tumačiti dvojako. Prvo, ovdje slijedimo jednu od ključnih poruka Kantove etike, da vrijednost (u smislu ispravnosti) moralnog djelovanja leži u nastrojstvu volje. Ako bismo stremljenje uklonili iz ovog principa, tada bi radnja koja usprkos uloženom trudu ne uspijeva stajati na putu spomenutog omogućavanja, koje je kao nastrojstvo sadržano u volji koja je pokreće, bila moralno pogrešna. Takvo određenje protivilo bi se samoj biti moralnog djelovanja, koje proizlazi iz volje kao praktičkog uma, a ne iz same radnje, jer su potonje sposobna činiti i živa bića koja nemaju sposobnost moralnog djelovanja. Drugo, imajući u vidu i nesvršene termine koji slijede stremljenju, ovaj princip ukazuje na nemogućnost idiličnog scenarija u kojem svako živo biće dobiva priliku za samoostvarivanje. Tu kao jedina za moralno djelovanje sposobna bića moramo preuzeti nezahvalnu dužnost odvagivanja vrijednosti samoostvarivanja određenih živih bića, koja se ne može unaprijed propisati nekakvom materijalnom etikom, odnosno popisom vječno važećih pravila.

Čini se da je 'samoostvarivanje' ovdje prikladniji termin od 'samoostvarenja', naročito u pogledu ljudskog bića. Ne može se, naime, zamisliti nekakav konačan oblik čovjeka čiji su potencijali ostvareni, a smisao dosegnut - čovjek je bitno nedovršivo biće. Njegovo samoostvarivanje leži u rukama njegove autonomije (sloboda je, kako je rečeno, specifična forma njegova samoostvarivanja), stoga njegov sadržaj ne može biti propisan od izvanjskih faktora, osim onih koji se tiču njegova opstanka kao prirodnog bića. To znači i da djelovanje spram takvog bića, ukoliko želi biti moralno ispravno, mora omogućavati to samoostvarivanje, 
a nikako mu nametati nekakav njegov gotov sadržaj. Što se životinja i biljaka tiče, na njih se tradicionalno gledalo kao na dovršiva bića nasuprot čovjeku kao nedovršivom, dok imajući u vidu gore iznesene Jonasove interpretacije možemo uvidjeti da i one žive u stalnom transcendiranju postojećeg, ali svakako na bitno siromašniji način u usporedbi s čovjekom. Ako se neke njegove ocjene $\mathrm{i}$ čine pretjeranima (u pogledu pripisivanja određenih pojmova neljudskim bićima, poput slobode), svakako se plodnim pokazuje dodatno osvjetljavanje uvida da živa bića nisu puki strojevi potpuno utopljeni u prirodni kauzalitet. Ne-ljudska živa bića u svakom slučaju posjeduju specifične načine samoostvarivanja, koje su ljudi dužni poštovati u onoj mjeri u kojoj je to moguće.

Poštivanje samoostvarivanja ne-ljudskih živih bića, kako se to može činiti, ne narušava moralni obzir spram čovjeka. Upravo suprotno, ono lakše uspijeva utemeljiti moralne dužnosti spram (a ne tek glede) nekih ljudskih bića koja su zadavala probleme u tumačenjima nekih klasičnih etika, naime mentalno oštećenih ljudi ili djece. ${ }^{636}$ S̆to se potonjih tiče, ovaj koncept otvara prostor za rasprave o potencijalnosti, kao i o odgoju, u koje ovdje nećemo zalaziti. Osim toga, on se legitimira i time što osvjetljava i eksplicira sam pojam slobode. Naime, pojam samoostvarivanja nalaže promatranje slobode kao bitno moralno obilježene, dakle kao odgovorno i ozbiljno shvaćena zadatka koji proizlazi iz praktičkog uma. Čovjek nije slobodan naprosto onda kada nije sputan u slijeđenju proizvoljnih preferencija, jer tako ne bi bilo ništa manje razloga da se sloboda pripiše leopardu ili lastavici. Takvoj bi »slobodi« nedostajao ključni element - mogućnost moralnog suđenja i djelovanja, pa time i odgovornosti. Zato se ni u etičkom diskursu koji se bavi samo ljudskim bićima ne može ostati samo pri dovođenju u odnos pojedinih proizvoljnih preferencija.

Ovaj koncept otvara prostor za pluriperspektivno sagledavanje određenih problema. To se posebice očituje u pokušaju odgovora na pitanje: što ima biti samoostvarivanje za svako određeno živo biće? U kontekstu ne-ljudskih živih bića, nije moguće pristupiti ovom pitanju bez pomoći određenih prirodnih znanosti, naročito biologije. Filozofska kontemplacija samostalno ne može ponuditi odgovore na pitanja o ponašanju živih bića, njihovim sposobnostima i mogućnostima, doživljajima i razinama svijesti, o razlučivanju anorganske od organske prirode itd. Sva su ta pitanja ključna u određivanju smislenosti i vrsti našeg moralnog obzira spram određenih bića.

\footnotetext{
${ }^{636} \mathrm{U}$ tom smislu Tom Regan s pravom tvrdi da zalaganje za moralni obzir spram životinja ide u prilog, a ne na štetu onih ljudi koji nisu sposobni za moralno odgovorno djelovanje (Usp. T. Regan, The Case for Animal Rights, str. 156.)
} 
Kada se pitamo o čovjekovu samoostvarivanju, tu problemi postaju bitno kompleksniji. Radi se o pitanju s kojim se rve gotovo čitava povijest filozofije, ali i različiti svjetonazori, religija, mit, umjetnost itd. Premda filozofija daje onaj središnji konceptualni okvir za promišljanje ove teme, nikako ne smijemo iz tog promišljanja isključiti i te različite perspektive, a sve u svrhu odgovornog propitivanja tog nimalo benignog pitanja. Određenje čovjekova samoostvarivanja ovdje zauzima ključno mjesto, koje se onda odnosi i na određenje svih drugih samoostvarivanja, pošto smo osuđeni na izvjesni antropomorfizam u određivanju vrijednosti, koje se odvija upravo po važnosti koje igraju u ulozi samoostvarivanja čovjeka, u analogiji s kojim pridajemo vrijednost i samoostvarivanju ne-ljudskih bića. Pitanje samoostvarivanja čovjeka ukazuje i na još jednu ključnu misao, naime, da etiku nije moguće izolirati iz korpusa filozofije, već da ona stalno zahtijeva odgovaranje na ono ključno Kantovo pitanje na koje se svode sva pitanja filozofije: »što je čovjek?«U pokušaju odgovornog pristupa tom stalnom odgovaranju ne smijemo ispustiti iz vida ni one različite perspektive u kojima se znanje formiralo, često još i prije nastanka onoga što zovemo (zapadnom) filozofijom. Ovo pitanje zaista se tiče čitavog čovjeka, njegova društva, njegova svijeta i čitave prirode. Ono se tiče i pitanja istinskog čovjeka, čovjeka u njegovoj prirodnoj i duhovnoj cjelovitosti. Stoga ono provocira jako dalekosežna, pa i revolucionarna pitanja, poput primjerenosti društvenog uređenja ljudskom i ne-ljudskom samoostvarivanju, pitanja »istinskih ljudskih potreba«, kao i pitanja dužnosti izmjene otuđujućih društvenih odnosa i sl. ${ }^{637}$ Ovo će se kasnije pobliže pojasniti u okviru mogućih marksističkih doprinosa bioetici. U tom pogledu valja podsjetiti da i Viskovićeva etička koncepcija unutar tradicionalnog poimanja moraliteta, prožeta marksističkom filozofijom, ima u vidu čovjekovo samoostvarivanje. Ponovimo dva citata (s našim istaknućima) iz kojih se to može iščitati:

»... razvija se autonomnija moralna svijest razvijenih ljudskih ličnosti koje se same određuju i grupno koegzistiraju pod djelomično različitim etičkim kodeksima ali istovremeno spontano postižu jednu nužnu zajedničku osnovu moraliteta u onoj mjeri u kojoj su im zajednički biološki, ekonomski, urbani i drugi objektivni aspekti njihova društvenog bića, i tako se autonomizacija i pluralizam moralnog života iskazuju kao sve punije ostvarenje slobode, mogućnosti stvaralaštva i demokratskih društvenih odnosa. «638

\footnotetext{
${ }^{637}$ Od početka poglavlja »III.4.1.1. Samoostvarivanje« do ovdje u najvećoj mjeri prenosimo tekst iz: Josip Guć, »Samoostvarivanje živih bića i genetički modificirani organizmi u poljoprivredi«, Jahr 10 (2019) 2, str. 361-375, ovdje str. 362-368.

${ }^{638}$ N. Visković, Politički ogledi, str. 34.
} 
„Samo preuzimanjem i zatim dovršavanjem općečovječanske moralne prakse socijalizam može izvršiti svoju zadatu civilizacijsku funkciju daljnjeg pomicanja granica slobode, dostojanstva $i$ stvaralaštva čovjeka k njegovim najvišim rodnim mogućnostima $(. ..) \ll^{639}$

Socijalizam, dakle, podrazumijeva omogućavanje ostvarivanja čovjekovih najviših rodnih mogućnosti, što se slijedom prije iznesenoga može tumačiti kao samoostvarivanje, naročito onda kada su uvjeti za to promicanje slobode, dostojanstva i mogućnosti stvaralaštva. Upravo potonji pojam ukazuje na to da postavljanje nastrojstva $\mathrm{k}$ omogućavanju samoostvarivanja kao osnovnog moralnog imperativa ne znači da se čovjek samoostvaruje isključivo kao moralno biće, nego i kao estetsko, a onda i na brojne druge načine. Među ostalima, tu je riječ i o tjelesnom samoostvarivanju, pri čemu valja posjetiti na još jedan izneseni detalj (ponovno s našim istaknućima) iz Viskovićeva, sada kulturnobiološkog djela, gdje istovremeno stoji najbliže određenju slobode kao specifične forme ljudskog samoostvarivanja:

»Taj falusoidni gmaz je sama čovjekova 'grešna' težnja da ovlada spolnim zadovoljstvom i 'ohola' želja, koju nose Prometej i Buda, Odin i Faust, za potpunom slobodom i sveznanjem. Zmija napasnica je uistinu moć i izazov samoostvarenja čovjeka kao bića slobode.« ${ }^{640}$

Vratimo li se problemu suzakonodavstva i uz njega vezanog moralnog subjektiviteta, valja primijetiti da nijemi zahtjev za samoostvarivanjem time i dalje nije moralni zahtjev, što postaje tek u artikulaciji same moralnosti, kao bitnog obilježja klasično shvaćenog moralnog subjekta, naime, kada on utječe na formiranje sadržaja moralnog zakona. To pak znači da revizija shvaćanja moralnog subjekta koja se ne sastoji tek od preuzimanja i prilagođavanja pravnih kategorija mora imati na umu da se moralni subjektivitet bića koja ne osvještavaju moral može uzimati samo u relativnom smislu. Njegovo obavezivanje, a time i utjecaj koji vrši na formiranje moralnog suda, još ga ne čini subjektom morala u apsolutnom smislu, s obzirom na to da takvo obavezivanje nastaje tek u svijesti onoga tko može biti subjektom morala, koji sam moral može osvijestiti i ravnati se prema njemu. Živo biće time ostaje subjektom samoostvarivanja, a direktno uzimanje u obzir samoostvarivanja kao moralno relevantne kategorije (zahvaljujući zahtjevu koji proizlazi iz njega) otvara izvjesni ponor između klasično shvaćenog moralnog subjekta i moralnog objekta. Stoga se najboljim terminološkim rješenjem čini ono s čime Visković i uspoređuje svoje razlikovanje aktivnog i pasivnog moralnog subjekta, a radi se o Reganovu razlikovanju moralnog djelatnika i trpnika, pri čemu se kao

\footnotetext{
${ }^{639}$ Ibid., str. 33.

${ }^{640}$ N. Visković, Stablo i čovjek, str. 342.
} 
kriterij za uključenje u oba razreda javlja bivanje onime što on naziva subjektom života. Ovdje samo valja nadodati, uvažavajući prvenstveno Jonasovu filozofiju organskoga, potrebu za širenjem pojma subjekta života na svako živo biće. Naime, za razliku od morala, koji bez osvještenja ne nastupa kao moral, pojedinačno živo biće ne mora reflektirati svoj život da bi živjelo - samom prisutnošću života, tj. samoafirmacijom i samotranscendiranjem koje je svojstveno već najprimitivnijem organskom, ono biva njegovim subjektom.

\section{III.4.1.2. Izleti u fiziocentrizam: prava neživog}

U Jonasovoj se filozofiji živo i neživo radikalno razlikuju. To je očito već na razini suodnosa forme i materije. Forma živoga prije je uzrok, negoli rezultat materije od koje se sastoji, dok je kod neživoga materija esencijalna, a forma akcidentalna. Promjenjivi materijalni sadržaji živoga »stanja su njegova trajnog identiteta«, a njegovo bivanje istim ne odvija se naprosto inercijski. Tako se za njega »osnovna sloboda organizma« iščitava iz izvjesne neovisnosti njegove forme o materiji. Trajanje neživog naprosto je ostajanje, a ne reafirmacija (funkcija, briga i postignuće). Materijalna se čestica potpuno identificira putem prostornovremenske pozicije. Ona nema unutarnje, nego samo izvanjske reference. Organski identitet nema supstrata kao referenta za izvanjski identitet. ${ }^{641}$

Jonas također odbija pokušaj svođenja kvalitativne razlike između živoga i neživoga na kvantitativnu razliku (dakle, ne kao razliku u biti, nego kao razliku u stupnju), kako to zaključuje Alfred North Whitehead. Pored ostalog, Jonas ovom pristupu prigovara da zanemaruje nemogućnost razumijevanja života bez smrti, bez koje se duboka anksioznost biološke egzistencije ne može razumjeti, kao i to da je Whiteheadova metafizika »priča o intrinzično osiguranom uspjehu« u kojem je svako postajanje zapravo gotova samorealizacija, a svaki događaj u sebi potpun, jer se inače ne bi bio aktualiziran. ${ }^{642}$ Tako bi neprepoznavanje distinktivnosti živoga ugrozilo i zamutilo i sam pojam samoostvarivanja, koji bitno ovisi o nedovršivosti svake organske egzistencije, tj. njezinoj pozicioniranosti unutar napetosti bitka i nebitka.

Već smo se, kako u okviru Viskovićeve na momente fiziocentričke pozicije (koja, iako se najčešće referira na živa bića, tj. njihove životne uvjete, ipak bez posebnih ograda govori o čitavoj prirodi kao vrijednosti u sebi), tako i u okviru analize Næssove dubinske ekologije, kritički osvrtali na pokušaje uključenja anorganske materije u direktni moralni obzir upravo iz

\footnotetext{
${ }^{641}$ Usp. H. Jonas, The Phenomenon of Life, str. 79-82.

${ }^{642}$ Usp. ibid., str. 95-96.
} 
razloga nemogućnosti njenog samoostvarivanja. Samim time završava svaka priča o pridavanju moralnih prava tim dijelovima prirode, premda to može imati težinu po pitanju dodjele legalnih prava. To nikako ne znači da oni ni u kom pogledu nisu predmet moralnog djelovanja. Naime, kako mnoga živa bića bitno ovise o okolišnim uvjetima, njihovo je zanemarivanje u agresivnoj intervenciji u prirodu rezultat moralno pogrešne nastrojenosti volje.

Stoga se može govoriti o zaštiti okoliša kao o etičkoj temi, ali imajući u vidu gore izneseno, ne bismo se mogli zaustaviti samo na ljudskom okolišu, nego bismo imali dužnost štititi okoliš svakog onog bića koje se samoostvaruje, tj. svakog živog bića.

\footnotetext{
»... ekološka etika i bioetika zahtijevaju, polazeći od principijelne jednakosti svih oblika života i međuvrsne pravednosti, da uz moralne i pravne dužnosti 'zaštite ljudske okoline' djeluju također moralne i pravne dužnosti 'zaštite okoline biljaka i životinja'; pri tome su dakako nužna pravila rješavanja sukoba interesa među oblicima života, prema kojima je neizbježno da čovjek ima neke prednosti u odnosu na druga bića (zbog njegove najviše razvijenosti u stupnjevima života, ali, realistički gledajući, i zato što je on je taj koji pravila piše!), ali ipak ne smije, kao do sada, a priori i neupitno nametati svaki svoj interes svakom interesu drugih bića. «643
}

\section{U tom pogledu Visković s pravom zahtijeva}

\»... načelno poštivanje svakog života i odustajanje Homo sapiensa od njegovog dosadašnjeg pretjeranog, pljačkaškog i nepoštenog odnosa prema prirodi, a što znači i priznanje da se imperativ očuvanja prirodne okoline čovjeka mora uravnotežiti s imperativom očuvanja prirodnih okolina medvjeda, kita, slona, ptice i leptira, šumskih, močvarnih i prerijskih biotopa itd., kao samostalnih vrijednosti koje treba zaštititi koliko je god moguće, neovisno o njihovoj ljudskoj upotrebljivosti.« ${ }^{644}$

Ako se ovdje navedeni biotopi ne gledaju kao vrijednosti u sebi, nego kao vrijedni očuvanja radi navedenih životinja i drugih živih bića koja ih sačinjavaju, tada ova misao pogađa ono što namjeravamo iskazati.

Ovdje se može postaviti pitanje: treba li u etici govoriti o zaštiti prirode ili o zaštiti okoliša? Ako bi potonja uključivala okoline svih živih bića radi samih tih živih bića, onda bi ona bila sasvim adekvatan okvir za raspravu o sadržaju naših moralnih dužnosti na tom području ljudskog djelovanja. Međutim, kako zaštita okoliša često podrazumijeva zaštitu samo ljudskog okoliša, zaštita prirode se nametnula kao alternativa tom antropocentričnom i neopravdanom sužavanju etičkog obzora. Iako je motivacija onih koji naglašavaju potrebu

\footnotetext{
${ }^{643}$ N. Visković, »Ekologija i pravo«, str. 466-467.
}

${ }^{644}$ N. Visković, Sumorne godine, str. 215-216. 
zaštite prirode naspram zaštite okoliša puno češće ispravnija, čini se da i tu poziciju prate određeni problemi. Naime, ako bi zaštita prirode podrazumijevala da čitava priroda, kao cjelina ili kao zbir njenih pojedinih živih i neživih elemenata, zaslužuje izravan moralni obzir, tada se to ne bi dalo opravdati zbog onoga što je gore izneseno. S druge strane, svođenje zaštite prirode na, jednostavno rečeno, brigu o planetu Zemlji, zanemaruje jedan drugi aspekt zaštite prirode koji bi s obzirom na čovjekovo posvemašnje otprirođenje, o čemu smo pisali na početku ovog rada, trebalo biti na djelu.

Kako je već prije istaknuto, Viskovićevo poimanje kulture kao otprirođenja odmak je od romantiziranog određenja kulture kao oplemenjivanja. U okviru rasprave o zaštiti okoliša/prirode kultura može pokazivati više svojih lica, od moralne brige (koja, zapravo, samo iz okrilja kulture može proizaći) do bespoštednog zatiranja. Međutim, kako smo mogli vidjeti iz prije navedenog, to zatiranje nije tek neobazriva briga za vlastiti interes, nego upravo odraz neprijateljskog stava kulture spram prirodnog kao takvog. Stoga, i kad se postavi pitanje o načinu obračuna s ekološkom krizom, čini se da se koncept održivog razvoja najčešće pokazuje kao jalov. On nastavlja prirodu promatrati kao puki resurs ili tek kao sredstvo za profit i održavanje čovjekova blagostanja. Potonje se ne bi trebalo razumjeti kao promicanje čovjekova samoostvarivanja, s obzirom na gore opisanu čovjekovu podređenost svom sredstvu, tj. s obzirom na ugrožavanje same forme tog samoostvarivanja - slobode. Onda kada tehnologija istisne ostale elemente kulture kao ljudskog posredovanja prirodnog, dogodit će se upravo gubitak refleksije o mogućnosti drugačijeg, tj. slobode same, jer ćemo biti zapleteni u slijepi kauzalitet, recimo to tako, »puke tehnološke prirode«. Priroda tu služi tek kao izazov, opasnost koja se ima savladati, no tom se kulturnom borbom protiv sila prirode ne proizvodi ništa drugo do nova prisila, kako su već Horkheimer i Adorno izrazili u misli koju Visković drži jednom od »najdubljih samokritika prosvjetiteljstva«: »Svaki pokušaj da se slomi prirodna prisila uništavanjem prirode samo se još dublje sapliće o prirodnu prisilu. U tome jest put europske civilizacije. $\ll^{645}$

Opasnost nije u samim tehničkim rješenjima za pogubne rezultate našeg nezdravog odnosa prema okolišu, nego u tome da uklanjanje tih rezultata nije zamislivo ako tehnička rješenja izostanu. Ovdje se ogleda i distopičan usud tehnologije, koja, za razliku od kulture, nema potencijal mišljenja iz bitne nedovršivosti svijeta, a što se može promatrati kao nemogućnost mišljenja i djelovanja s onu stranu principa nezaustavljivosti tehnološkog napretka. Tehnološka rješenja svakako neće moći sanirati štetu koja je iz pogubnog kulturnog

${ }^{645}$ N. Visković, Stablo i čovjek, str. 16; M. Horkheimer, Th. Adorno, Dijalektika prosvjetiteljstva, str. 27. 
odnosa prema prirodnom proizašla. Ako u pojedinim slučajevima takav pristup štiti (ljudski) okoliš, pitanje je štiti li doista prirodu? Dok on nema ni snage ni namjere da transcendira okvir koji zadaju principi tržišta i tehnološkog razvoja, ne može se potvrdno odgovoriti na to pitanje, jer ti principi obećavaju samo nastavak narušavanja čovjekove autonomije, a tako i mogućnosti da bitno promijeni svoj odnos prema prirodnome.

Stoga i zaštita okoliša i zaštita prirode u određenom tumačenju imaju svoju specifičnu važnost. Prva u smislu shvaćanja važnosti okolišnih uvjeta za samoostvarivanje svakog živog bića, a druga u pogledu zaštite prirodnosti od tehnološkog nasrtaja, prirodnosti u vidu ključnog korelativa kulture, ali i u pogledu samog samoostvarivanja živih bića. Namjesto upuštanja u prisilje izbora, valja promišljati ono što ove sintagme imaju značiti s obzirom na dosljedan etički pristup, a samim time i djelovati s obzirom na obje.

S druge pak strane, pripisivanje prava i subjektiviteta (i neživoj) prirodi može se sagledati i kroz vizuru filozofije Michela Serresa, na kojeg se referira i Visković, posebice kad u Stablu i čovjeku, pozivajući se na stavove iznesene u Životinji i čovjeku, kaže:

»I tu je već rečeno, na kraju točke 'Životinjska prava', uz izlaganje i obranu načela jedne neantropocentrične ili biocentrične etike, da sve naše stavove o vrijednostima, o moralnom rasuđivanju i o poštovanju životinjskog svijeta treba načelno primijeniti i na biljni svijet. I dalje, mutatis mutandis, da se ti stavovi mogu i trebaju odnositi na cjelokupni, neorganski i organski svijet - upravo u smislu onog 'prirodnog ugovora' o kojemu govore Michel Serres i drugi suvremeni mislioci.« ${ }^{646}$

Serres ovu problematiku ilustrira počevši od slike Dvoboj s toljagama Francisca Goye, na kojoj se dvojica neprijatelja bore u živom blatu, pa tako s većim intenzitetom borbe protivnici sve dublje tonu, tj. sami sebe pokapaju, a da to ne primjećuju. Koncentrirajući se na samu bitku, na same dueliste, ljudi obično zanemaruju stvari, no one nas sve više podsjećaju na svoju prisutnost. Oni obično bitke smještaju u apstraktne prostore, tako i sve konflikte i debate, narative, filozofije, povijest, pa i sve društvene znanosti, čineći tako »spektakl koji zovu kulturnim«. No to ne znači da živo blato ne guta sukobljene strane, da klima i vode, sve »nijeme stvari nekad postavljene kao dekor okruženju uobičajenih spektakala«, koje su tvorile tek maglovitu ideju prirode, silovito ne upadaju u našu kulturu. Štoviše, ono što je nekad bilo lokalno, poput živog blata sa slike, postaje globalno. ${ }^{647}$ Ovdje se zadaje drugačija perspektiva od one Jonasove u kojoj priroda zahvaljujući našem djelovanju postaje povrediva (pa

\footnotetext{
${ }^{646}$ N. Visković, Stablo i čovjek, str. 22.

${ }^{647}$ Usp. Michel Serres, The Natural Contract, preveli Elizabeth MacArthur i William Paulson, The University of Michigan Press, Ann Arbor 1995., str. 1-3.
} 
zahvaljujući našoj moći i objekt naše odgovornosti), ${ }^{648}$ no obje su objedinjene u rečenici: »Globalna povijest ulazi u prirodu; globalna priroda ulazi u povijest: ovo je nešto sasvim novo u filozofiji.« ${ }^{649}$ Drugim riječima, ako u doba Goye svijet nije bio fragilan, on je danas postao takvim, no isto tako poraženi svijet u konačnosti poražava nas. ${ }^{650}$

Nastavljajući se na ovu sliku, Serres naglašava kako konflikt (ili debata) zahtijeva korištenje istih riječi ili koda od strane različitih strana, koje time prihvaćaju preliminarni, najčešće prešutni ugovor, za što je u ovom slučaju znakovit jednoznačan termin 'deklaracija rata'. On razlikuje subjektivne ratove, u kojem se nacije ili države sukobljuju radi privremene dominacije, od objektivnog nasilja, u kojem su svi neprijatelji, premda nesvjesno, združeni u opoziciji spram objektivnog svijeta. Svjesno proglašen sukob je, s obzirom na navedeno, pravni odnos, no objektivno nasilje odvija se bez preliminarnog ugovora. Pred prijetnjom kolektivne smrti moramo stvoriti zakon za objektivno nasilje, paralelno stvaranju povijesti, gdje su kulture spašene ugovorom pretvaranjem subjektivnog nasilja u rat. Sama je povijest započela sa subjektivnim ratom, sada je na redu prirodni ugovor, preliminarni dogovor s objektivnim neprijateljem ljudskog svijeta - svijetom samim - ratom svih protiv svega. Uz to se kao potreba javlja i revizija društvenog ugovora. ${ }^{651}$

Serres ističe kako se ništa značajno u argumentaciji ne mijenja prijeđemo li s rata na ekonomske odnose. Kompeticija ratne operacije vodi drugim sredstvima, poput eksploatacije, robe ili novca. Objektivno globalno nasilje provodi se tvornicama, industrijskim uzgojem životinja, velikim tankerima i sl., također na temelju ugovora i s istim ciljem dominacije nad ljudima. Prešutan ugovor ove vrste nalazimo i među znanstvenicima. Tako u znanosti, zakon anticipira činjenicu utoliko ukoliko subjekt prethodi objektu (i obrnuto). Ugovorom ujedinjeni kolektivitet i ovdje prema svijetu vrši nesvjesno nasilje, putem ovladavanja i posjedovanja, što se dade iščitati s početka znanstvenog i tehnološkog doba (Descartes). Takva filozofija prisutna je kako u industrijskom podvigu, tako i u tobože neutralnoj znanosti, nerazdvojnima u ovom smislu. Time je naš osnovni odnos s objektima reduciran na oblike rata i vlasništva. ${ }^{652}$

Serres nastavlja tvrdnjom da je s idejom društvenog ugovora, kao i Deklaracijom o pravima čovjeka i građanina, golemi opseg stvari sveden na pasivne objekte, koji tek služe stjecanju. No očita je potreba da se priroda učini pravnim subjektom - upravo na ovom pojmu i temeljimo pravo. Uostalom, priroda utječe na ljudsku prirodu, koja onda utječe i na nju,

\footnotetext{
${ }^{648}$ Usp. H. Jonas, Princip odgovornost, str. 21.

${ }^{649}$ M. Serres, The Natural Contract, str. 4.

${ }^{650}$ Usp. ibid., str. 11-12.

${ }^{651}$ Usp. ibid., str. 8, 10-11, 14-15.

${ }^{652}$ Usp. ibid., str. 15, 21-23, 32.
} 
priroda nam daje, ali i oduzima toplinu ili hranu kada je zlostavljamo, pa se može reći da se ponaša kao subjekt. Čovjek se, sa svoje strane, prema njoj ponaša parazitski, a kako se pravo generalno može definirati kao »minimalno i kolektivno ograničavanje parazitskog djelovanja«, čime se postiže ekvilibrij, trebamo revidirati i moderni prirodni zakon, koji izbacuje ne-ljude iz okvira pravnih subjekata prethodno reducirajući »prirodni« na ljudsku prirodu. Tek se uključenjem objekata u razred pravnih subjekata na svim razinama može doći do ekvilibrija između naše trenutne moći i sila svijeta. Prirodni ugovor, stoga, mora biti onaj simbioze i reciprociteta, a to onda znači da poštivanje, pozornost i divljenje imaju zamijeniti ovladavanje i prisvajanje, odnosno znanje ne smije implicirati prisvajanje, niti djelovanje smije implicirati ovladavanje. ${ }^{653}$

Kako je rečeno, priroda, tradicionalno promatrana kao objekt, može se ipak odrediti kao nekakav subjekt. Premda stvari, tj. ne-živa bića, nisu subjekti života (samoostvarivanja), to ne znači da samim time nisu subjekti uopće, naročito imamo li u vidu prije izneseno značenje subjekta »kao nositelj radnje, stanja, svojstva i sl.«. No osvještavanje aktivnosti stvari ponajprije je rezultat djelovanja nas samih. Kako Serres naglašava, globalni objekt (priroda) postaje subjektom reagiranjem na naše djelovanje, a u istom procesu mi sami postajemo objekti, »žrtve vlastitih pobjeda, pasivnost naših aktivnosti«. Ne samo da stvari koje su nekada bile neovisne o nama sada o nama ovise, nego i mi sami ovisimo o stvarima koje su rezultat našeg djelovanja (tehnologija). Tako naš cilj sada prvenstveno ima biti vladanje vladanjem, a ne svijetom. Promatranjem svijeta kao objekta, »osuđujemo sebe da postanemo objekti tog objekta« ${ }^{654}$ Time se zaokružuje spomenuta bejkonovska predstava podvrgavanja objektu (ili, u drugom pogledu, sredstvu) kao posljedici ovladavanja njime.

Našim postajanjem objektom, stoga, nešto drugo (stvari) preuzima ulogu subjekta. Uvidom da subjektima ne bivaju samo samosvjesni ljudi, čak ni samo živa bića, osvjetljava se značajan element po pitanju čovjekove autonomije, tj. prvenstveno radi detektiranja (onda i uklanjanja) onih silnica koje je osujećuju. Time se otvara prostor u kojem je smislenije govoriti o stvarima kao pravnim subjektima, naročito zato što, prema Serresu, a što se osniva na gore

\footnotetext{
${ }^{653}$ Usp. ibid., str. 34-38, 46. - Na pitanje koji to jezik stvari govore da bi se s njima moglo doći do sporazuma, Serres odgovara da se isto pitanje može uputiti i društvenom ugovoru. No ipak kaže da je za ostvarivanje ugovora dovoljno što Zemlja govori u terminima sila, veza i interakcija. (Usp. ibid., str. 39.) Pričati pak ne mogu, naglašava Stone, ni korporacije, koje jesu nosioci legalnih prava. Za prirodne objekte bi isto tako govorili pravnici, kao što sada govore i za vegetativne ljude, ali i zastupajući samosvjesne odrasle (ali pravno nedovoljno upućene) građane. (Usp. Christopher D. Stone, Should Trees Have Standing? Law, Morality, and the Environment, Oxford University Press, New York 2010., str. 8.)

${ }^{654}$ Usp. Mišel Ser [Michel Serres], »Povratak na Ugovor o prirodi«, prevela Milica Šešur, u: Jelena Đurić, Srđan Prodanović, Predrag Krstić (prir.), Životna sredina. Moralni i politički izazovi, Službeni glasnik - Institut za filozofiju i društvenu teoriju, Beograd 2012., str. 109-119, ovdje str. 113-114, 116-117.
} 
spomenutoj činjenici da ugovor prethodi kako znanosti i drugim ljudskim djelatnostima, »prvi nama poznati subjekt je pravni subjekt «. ${ }^{655}$ No ovo isto tako ima označiti pravničku autonomiju po pitanju određenja pravnog subjekta, tako da ukazivanje na subjektivitet koji nije pravni ne predstavlja odlučujući argument po ovom pitanju, što je, zapravo, već ranije jasno izrečeno pri razmatranju Viskovićeva poimanja pravnog subjektiviteta.

Uvjeti za bivanje subjektom legalnih prava, kako navodi Dieter Birnbacher, bitno su fleksibilniji od onih za bivanjem subjektom moralnih prava, zahvaljujući pripadnosti ovih vrsta prava drugačijim »jezičnim igrama«. Za razliku od potonjih, pripisivanje legalnih prava bitno je pragmatično, pa njihova smislenost prvenstveno ima biti suđena njihovom instrumentalnošću. Subjekti ovih prava ne trebaju biti osjećajni, svjesni ni sposobni za djelovanje, pa se mogu pripisivati i onima koji nisu osobe te apstraktnim entitetima, »o čijim se 'interesima' brinu predstavnici djelujući bez eksplicitnog ili implicitnog naloga od strane onoga što predstavljaju«. Premda, dakle, na teorijskoj razini nema zapreke pridavanju pravnog subjektivitetima ne-živim entitetima, za Birnbachera je ono neprihvatljivo na praktičnoj razini. Osim što ne drži nužnim da će se ono voditi većoj zaštiti (mada je izglednije da hoće), on misli da se ciljevi koje pokušavamo s ovim pravima postići mogu ostvarivati i na druge načine. Tako bi se, pored drugih mjera, mogla uvesti i institucija »čuvara«, tj. svojevrsnih zastupnika prirode, kakvu zagovara Stone, bez inzistiranja na jeziku prava prirode. ${ }^{656}$

No imamo li instrumentalnost jezične igre prava u vidu, Stone, među ostalim, nudi argumente o poželjnosti pripisivanja pravnog subjektiviteta prirodnim entitetima na planu snage jezika u pravnoj praksi:

\footnotetext{
»Također je činjenica da nama dostupni vokabular i izrazi utječu na, čak i usmjeravaju našu misao. (...) $\mathrm{Na}$ taj bi način suci koji bi se mogli otvoreno referirati na 'legalna prava okoliša' bili ohrabreni da razvijaju funkcionalno pravno tijelo - dijelom naprosto putem dostupnosti i sile izraza. Pored toga, ovakav bi način govora od strane sudova doprinio popularnim pojmovima, a društvo koje bi pričalo o 'legalnim pravima okoliša' imalo bi nagnuće da formalno donosi okolišno-zaštitničke zakone. « ${ }^{657}$
}

\footnotetext{
${ }^{655}$ Ibid., str. 115.

${ }^{656}$ Usp. Dieter Birnbacher, »Legal Rights for Natural Objects. A Philosophical Critique«, u: Edgar Morscher, Otto Neumaier, Peter Simons (ur.), Applied Ethics in a Troubled World, Springer Science+Buisness Media, Dordrecht 1998., str. 29-40, ovdje str. 33-36, 38.

${ }^{657}$ C. Stone, Should Trees Have Standing?, str. 22-23. - Stone ukazuje i na utjecaj koji promjene u pravnom poimanju institucije vlasništva, od toga da su se nekad mogli posjedovati i ljudi prema stalnom sužavanju tog pojma, utječe na našu svijest i osjećaje. Primjerice, ustanovljenje oporuke ostavilo je traga na našem shvaćanju smrtnosti. (Usp. ibid., str. xi.)
} 
Ovdje govorimo o onome o čemu ćemo kasnije šire raspravljati pod pojmom bioetičkog senzibiliteta. No razvijanje tog senzibiliteta nije jednoznačno poželjno, s obzirom na to da ono, ako nije usmjereno $\mathrm{k}$ ispunjavanju racionalno postavljenih moralnih principa, može voditi do teorijskog apsurdizma, ${ }^{658}$ čime se čitavom skupu onoga što branimo u cjelokupnoj zaštiti prirode lako može pružiti tek medvjeđa usluga. Birnbacher se slaže s time da jezik pravā može inspirirati moralni entuzijazam, $u$ tom pogledu što su prava u pogledu emocija snažniji izraz od dužnosti, no isto tako drži da on može potaknuti intelektualnu konfuziju, primjerice, po pitanju korištenja pojma interesa čak i za apstraktne entitete poput vrste. Problem je i ako legalna prava tumačimo na objektivistički način, time što izvor vrijednosti lociramo u prirodi samoj. ${ }^{659} \mathrm{U}$ tom pogledu treba imati na umu i da se poimanje posjedovanja legalnih prava najčešće pogrešno tumačilo kao prirodna, a ne stvar ljudske, tj. pravne konvencije. ${ }^{660}$

S obzirom na klasično (u suštini ipak antropocentrično) poimanje pravnog subjekta, ${ }^{661}$ svakako valja ukazati i na potrebu da s pojedinih stvari korisnih čovjeku fokus treba prebaciti na čitavu prirodu ili, možda bolje, na one stvari koje igraju ulogu u ljudskom i ne-ljudskom samoostvarivanju. Međutim, takav zaključak i dalje ne govori u prilog pripisivanju moralnih prava ne-živim entitetima, prema kojemu smo se već negativno postavili. No možda je sama rasprava izlišna, naime, možda bi se prije svega trebalo ponovno postaviti pitanje ima li koncept moralnih prava uopće smisla.

\section{III.4.1.3. Smislenost koncepta moralnih prava i sukob dužnosti}

Jezici prava, aktivizma i politike u značajnoj mjeri dopuštaju pragmatičnost, kako bi se njima efikasnije postiglo namjeravano ili kako bi se intenzivirala javna prijemčivost za postojanje izvjesnih problema. No oni bi u konačnici trebali zahtijevati čvrsto uporište koje osigurava smislenost tih namjera i relevantnost problema. Mjesto na kojem bi to trebalo tražiti ono je gdje se ispravnost našeg djelovanja uspostavlja u fundamentalnom smislu. Kao i, uostalom, smislenost. U protivnom bi pravni, politički i aktivistički angažman označavali tek isprazno nastojanje na ostvarivanju proizvoljnih, a možda i anti-humanih (i anti-prirodnih) zadataka, koji obesmišljavaju taj angažman s obzirom na to da se potonji uglavnom formiraju

\footnotetext{
${ }^{658}$ Usp. A. Čović, »Biotička zajednica kao temelj odgovornosti za ne-ljudska živa bića«, str. 35-36.

${ }^{659}$ Usp. D. Birnbacher, »Legal Rights for Natural Objects«, str. 36-37.

${ }^{660}$ Usp. C. Stone, Should Trees Have Standing?, str. 2-3.

661 »... govor o 'interesima' u slučaju organizacija i kompanija ima, u konačnici, nekakvu činjeničnu osnovu s obzirom na to da su ova tijela obično stvorena i održavana za izvjesne precizno definirane ljudske svrhe (...)《 (D. Birnbacher, »Legal Rights for Natural Objects«, str. 36.)
} 
u vidu ostvarenja apstrakcija poput kapitala ili emancipacije apstrakcija poput tržišta, a ne u pogledu ostvarivanja čovjeka i ostalih živih bića. Upravo razdvojenost sastavnica onoga što je Aristotel kao koherentnu cjelinu podrazumijevao pod praktičkom filozofijom vodi tome da pravo i politika vode zasebnim svrhama, a zapravo najčešće ekonomskim i/ili egoističnim. Ponovno osmišljavanje ovih sfera zahtijeva njihovo integriranje, a što podrazumijeva postavljanje fundamentalnog pitanja kao moralnog, dakle, kao pitanja o ispravnosti i krajnjoj svrsi djelovanja. S obzirom na to, etika u strogom smislu ne smije tolerirati pragmatičnost, nego u dosljednom pronalaženju principa djelovanja i načina moralnog obzira spram bića koja ga zaslužuju treba postaviti fundament, referentnu točku za pravo, politiku, aktivizam, a konačno i za ekonomiju.

Ostavljanjem pragmatičnosti na stranu, koncept moralnih prava pokazuje se u najmanju ruku kao suvišan. Naime, ako se moralno pravo postavlja kao personificirano jedinstvo jedne skupine moralnih normi (Kelsen-Visković), tj. tako da valjanost moralnog prava ovisi o njegovoj usklađenosti s neovisno ustanovljenim moralnim principima (Mill-Regan), nailazimo na strukturu u kojoj se na temelju moralnog principa konstruira moralno pravo, da bi onda iz tog prava proizlazila moralna dužnost. No s obzirom na to da već sam moralni princip konstituira moralnu dužnost, koncept prava se ovdje pokazuje kao suvišan korak.

Dublji je pak teorijski problem sukob prava koji neminovno nastupa, naročito ako su sva živa bića posjednici moralnih prava. Kako bi pravo po ovom konceptu bilo konstitutivno za dužnost, onda bi istovremeno bila riječ i o sukobu dužnosti. No ova se sintagma pokazuje problematičnom već od shvaćanja dužnosti kao nužnosti djelovanja iz poštivanja moralnog (praktičkog) zakona, ${ }^{662} \mathrm{~s}$ obzirom na to da bi u slučaju sukoba dužnosti došlo do paradoksa postojanja dviju suprotstavljenih praktičkih nužnosti. Stoga Kant s pravom koristi sintagmu sukob razloga obvezatnosti:

»Sukob dužnostî (collisio officiorum, s. obligationum) bio bi takav odnos u kojemu bi jedna (posve ili djelomice) ukinula drugu. - No kako su dužnost i obaveza općenito pojmovi koji izražavaju objektivnu ili praktičku nužnost stanovitih djelovanja te kako dva suprotna pravila ne mogu istodobno biti nužna, pa kada je dužnost djelovati u skladu s jednim od njih, djelovanje u skladu s drugim ne samo da nije dužnost nego se čak protivi dužnosti, tako sukob dužnosti i obaveza uopće nije zamisliv (obligationes non colliduntur). Ali zato u nekom subjektu i u pravilu što ga on sebi propisuje i te kako mogu biti povezana dva razloga obvezatnosti (rationes obligandi), od kojih jedan ili drugi nije dostatan da bi ga obvezao (rationes obligandi non obligantes), pa onda jedan od njih nije dužnost. - Kada se takva dva razloga

${ }^{662}$ Usp. I. Kant, Osnivanje metafizike ćudoređa, str. 18. 
sukobe, praktička filozofija ne kaže da pobjeđuje jača obaveza (fortior obligatio vincit), nego da pobjedu odnosi jači razlog obvezatnosti (fortior obligandi ratio vincit).« ${ }^{663}$

Stoga je dužnost, u strogom smislu, jedna i formalno određena. S obzirom na uključenje ne-ljudskih živih bića u moralni obzor, koje se koherentno dade obuhvatiti formalnim principom kojim se kao moralno ispravno djelovanje određuje ono koje stremi omogućavanju samoostvarivanja svim bićima kojima je ono svojstveno, ne može se naprosto tvrditi da smo dužni za potpuno samoostvarenje svih živih bića, pa da bi nužan neuspjeh koji u tom slučaju nastupa bio pokazatelj naše potpune ili djelomične moralne neispravnosti. Strogo govoreći, čovjek je odgovoran za nastrojstvo svoje volje, kao i za trud na ispunjenju onoga što moralni sud i moralna odluka donose. Da smo svi krivi, moguće je zaključiti samo s obzirom na slabost volje u većoj ili manjoj mjeri svojstvenoj svakom čovjeku. Nije tako da treba zanemariti obzir spram jednog bića radi drugog, nego u svakom trenutku trebamo imati obzir spram svakog bića koje ga zaslužuje. Tek je u okviru cjelokupnog obzira (koji stalno ima biti na djelu) smisleno govoriti o tome da se radi posvećivanja bogatijem samoostvarivanju jednog bića naruši samoostvarivanje drugog bića, ali to drugo biće time ne izlazi iz obzira. No okolnosti koje uzrokuju sukob razloga obvezatnosti ipak provociraju pitanje hoću li se u stremljenju $\mathrm{k}$ omogućivanju samoostvarivanja svih živih bića konkretnije ili izravnije posvetiti samoostvarivanju ovoga ili onoga bića?

Time etička priča po ovom pitanju nije do kraja zaokružena. Naime, problem kod pristupa nekih etika koje obrađuju problem sukoba je u tome što ne postavljaju neka nužna predpitanja. Primjerice, kako je do sukoba došlo? Odgovor na to pitanje otvara ona mnogo dalekosežnija, koja često mogu dovesti pod moralni upitnik čitavo društveno ili ekonomsko uređenje, način na koji se formira znanje, djelovanje, predrasude pa čak i nesvjesni dio moralnog djelatnika. Izmjena tih sfera tada postaje dužnost pred kojom etika ne smije, kako je to često činila, zatvarati oči. Takav bi se kompleksni splet dužnosti mogao izraziti u obliku jedinstvene dužnosti da je prvi moralni zadatak (ili predzadatak) po ovom pitanju rad na tome da do sukoba razloga obvezatnosti uopće ne dođe. Važno je naglasiti upravo rad na tom zadatku, jer je njegovo potpuno ostvarenje, nažalost, nezamislivo izvan religijskih predodžbi rajskog stanja. Odustajanje od ovog zadatka rezultiralo je situacijom u kojoj je naša moć premašila potencijale naše odgovornosti, kako to jasno detektira Jonas, čime se zapravo progresivno povećavaju spomenuta sukobljavanja. $\mathrm{S}$ druge strane, ovdje valja ozbiljno uzeti u obzir i marksističku kritiku etike, upravo na onim mjestima gdje ona pod kritiku podvodi

\footnotetext{
${ }^{663}$ I. Kant, Metafizika ćudoređa, str. 21-22.
} 
ograničenje etičkog propitivanja na mogućnosti djelovanja unutar jednog samorazumljivog i nepromjenjivog okvira. Ta se neutopičnost etičkog mišljenja danas osobito očituje u koncentraciji na misaone eksperimente, kakav je, primjerice, trolley problem, ili na iznalaženja načina kojima bi se masovno klanje na industrijskim farmama »humaniziralo«.

Međutim, mi na nekim poljima već implicitno uočavamo važnost spomenutog predzadatka, primjerice u djelovanju spram mentalno oštećenih ljudi. Ovo pitanje osobito je kompleksno s obzirom na to da bi princip samoostvarivanja u mogućem sukobu mogao voditi k tome da se naruši samoostvarivanje tih bića pred samoostvarivanjem mentalno neoštećenog odraslog čovjeka. No taj se izbor nikada ne bi ni trebao događati, upravo zato što je izbjegavanje sukoba osnovni predzadatak morala. Ljudska društva u svakom slučaju mogu omogućiti samoostvarivanje barem svih ljudi, tako da je sam dolazak pred ovakav izbor indikator duboko nemoralnih radnji koje su u društvu na djelu i čije je otklanjanje, ponavljamo, predzadatak. ${ }^{664}$

Polazište je, stoga, svakako egalitarističko pravilo - svako biće koje se samoostvaruje nosi vrijednost u sebi, tj. njegov artikulirani ili nijemi zahtjev obavezuje naš praktički um, $i$ uvijek mora biti dio našeg moralnog obzira. Međutim, ono je uvijek samo polazište. Sukobi razloga obvezatnosti, koji nastupaju već kod preživljavanja živih bića u vidu prehrane, iako ne narušavaju samovrijednost svakog od ovih bića, nadaju potrebu izbora među njima. Namećući se neovisno o volji bilo kojeg moralnog subjekta, tjeraju nas da pružimo orijentacijske odgovore za nošenje s njima, a odgovor se nalazi već u ključnom elementu formulacije egalitarističkog pravila - samoostvarivanju, tj. u njegovu aktualnom, možda i potencijalnom, bogatstvu. Treba svakako naglasiti da ono što bismo u ovim situacijama trebali iznalaziti nije neka vrsta algoritma prema kojem bi se moralno djelovanje mehanički ravnalo. Etičar može ponuditi orijentaciju, ali težina moralne odluke u konačnici leži na svakom pojedinačnom moralnom djelatniku.

Jedan od alternativnih pristupa upravo iznesenome, a kakav se očituje i u Viskovićevim refleksijama, pokušao bi očuvati svojevrsni egalitarizam na način da zada granice moralu: svi su jednaki, ali moramo ubijati da bismo jeli ili da bismo se obranili, tj. da bismo živjeli. ${ }^{665}$ Ovakva je tvrdnja problematična upravo zbog tih granica. Moral je normativna dimenzija ljudskog djelovanja koja se odnosi na čitavo njegovo djelovanje, a ne samo na jedan njegov djelokrug. Svako djelo, neovisno u koju kategoriju još spadalo (primjerice ekonomsku ili

\footnotetext{
${ }^{664}$ Ovaj i njemu prethodni pasus u najvećoj su mjeri preuzeti iz: J. Guć, »Samoostvarivanje živih bića i genetički modificirani organizmi u poljoprivredi«, str. 369-370.

665 Tako, primjerice, kaže i da »je samoodržanje (ali dokle i blagostanje?), ma koliko to etički ružno zvučalo, najviša moć života i granica etičkih zabrana«. (N. Visković, Stablo i čovjek, str. 724.)
} 
političku), mora proći moralni filtar. Na spomenuti način, moral se ne postavlja kao normativni vrhunac, nego tu ulogu sačinjava borba za opstanak, a tek kad se ona zadovolji, prepušta normativne uzde moralu. Moral nije moral ako ne zauzima baš tu vrhovnu poziciju, jer u tome upravo leži njegova bit kao procjenjivanja djelovanja kao takvog, a onda i njegova provođenja.

Egalitarističko pravilo ovdje eksplicitno sadrži isključivanje hijerarhije, što nije ništa čudno i što se jasno ogleda u dužnosti izbjegavanja sukoba, ali upravo zbog neizbježnosti pojedinih sukoba ovo pravilo naizgled paradoksalno podrazumijeva, a možda i implicitno sadrži (u tom bi se slučaju moglo odrediti kao princip, a ne tek kao pravilo) posjedovanje svojevrsne hijerarhije samoostvarivih bića, jer će se u suprotnom sukobi razrješavati na nekim drugim: emotivnim, interesnim ili sl. osnovama. Time bi se iskazala upravo neodgovornost spram uvažavanja svakog samoostvarivog bića, jer bi se u slučaju pristranosti koja tu nesumnjivo nastupa, odustalo od bilo kakvog pokušaja utemeljenja, pa onda i opravdanja moralnog obzira spram njih na racionalnim osnovama. Hijerarhija je tu pokušaj nepristranog prilaska sukobu, iako ona, nažalost, nikada neće biti oslobođena ljudskog, nužno u određenoj mjeri antropomorfnog pogleda (već od činjenice da su pojmovi vrijednosti ili bogatstva ljudske kategorije).

No nikakva nas nemogućnost iskakanja iz vlastite antropomorfističke kože ne opravdava da izguravamo ne-ljudska živa bića iz etičke priče, niti da ne preveniramo sukobe s njima. Tu se nikako se ne radi o laganom zadatku. Kao što je iz navedenog jasno, izbjegavanje sukoba nije tek puko nenasilje. Sukob se mora razmotriti sa svih aspekata, a spirala neobuzdanog divljanja moći raskrinkati u njezinu korijenu, kako bi se stvorili uvjeti koji neće generirati daljnje sukobe. U tom bi se pogledu, analogno ekologiji, mogao formulirati neki dubinski pacifizam, koji bi onda označavao nezaobilazni element u samom fundamentu morala.

Zaključak se može oslikati kritiziranim trolley problemom - naš zadatak nije samo davanje orijentacijskih, dakle ne definitivnih, dogmatskih ili algoritamskih odgovora pred dilemom ispravnog usmjeravanja trolejbusa, nego i postavljanje pitanja: zašto se trolejbus uopće našao na tom mjestu te tko ga je i iz kojih razloga tu doveo ${ }^{666}$ Sličnu metaforu u drugom kontekstu, a relevantnom za temu ovog rada, možemo pronaći i u studiji Andreasa Malma Fosilni kapital. Ispitujući razloge prijelaza s vodeničke na fosilnu energiju i perspektive za budućnost, on navodi sljedeće:

\footnotetext{
${ }^{666}$ Rečenica je u najvećoj mjeri preuzeta s: J. Guć, »Samoostvarivanje živih bića i genetički modificirani organizmi u poljoprivredi«, str. 370 .
} 
»Ako je fosilna energija vlak koji se nikada ne zaustavlja, nego uvijek ubrzava, čak i kada se približi litici, zadatak je na vrijeme zakočiti (ili možda iskočiti iz vlaka), a ako postoji vozačica koja to pokušava spriječiti, ona vjerojatno već neko vrijeme sjedi u lokomotivi - moramo saznati tko je ona i kako ona djeluje (možda je to automatski motor, vozilo bez vozača, ali potreba bi ostala ista). Interesi koji su nekoć pokretali vlak možda još uvijek njime upravljaju. « ${ }^{667}$

Prije no što promislimo kako ublažiti posljedice padanja vlaka u provaliju, treba, valjda, odlučno pristupiti uklanjanju podivljale vozačice. Nije, dakle, rješenje u usmjeravanju sila koje nam se nadaju, nego prije svega u njihovu prepoznavanju, raskrinkavanju i, konačno, odbacivanju. Upravo u pogledu mogućnosti i nemogućnosti osujećenja te vozačice, jasno se pokazuje kako naša odgovornost izrasta na istom polju na kojem izrasta naša sloboda.

\section{III.4.1.4. Održivi razvoj kao odgovor na ekološku krizu}

Postojeći načini suočenja s ekološkom krizom iz više su razloga osuđeni na propast. Viskovićev je pristup radikalan: put ozdravljenja (i to ne potpunog) može se pronaći još samo u radikalnim mjerama, promjenom čitavog proizvodnog i potrošačkog stila života, a nikako u aktualnom (kako 1997. kada Visković o ovome piše, tako i danas) pristupu koji pokušava zbrinuti, a ne smanjiti otpad, pronalaziti nove izvore energije, a ne smanjivati njezinu potrošnju, i sl. ${ }^{668}$ Naime, kako navodi na drugom mjestu, riječ je o nesustavnom suočenju »na empirijski način« koji problem rješava od slučaja do slučaja, zanemarujući izvore šteta koje donekle sanira. Među razloge za pesimizam svakako se mogu uvrstiti i zanemarivanje zaštite prirode kao prioritetnog političkog i društvenog pitanja, puka deklarativnost ekozaštitnih nastojanja na međunarodnoj razini, neadekvatan nadzor primjene pravnih normi, nedostatno sudsko sankcioniranje njihova kršenja, nedostatak usvajanja ovih političko-administrativnih nastojanja u moralnu i pravnu kulturu građana itd. Govoreći dalje u kategorijama prava, Visković naglašava i da je jedan od ključnih razloga neefikasnosti suočenja s ekološkom krizom i u pravilu antropocentrično i utilitarno-ekonomističko polazište pravne regulacije. Oslanjanjem na nju upada se u zabludu da je dobrobit čovjeka moguće ostvariti bez dobrobiti drugih bića unutar biosistema. ${ }^{669}$

\footnotetext{
${ }^{667}$ Andreas Malm, Fosilni kapital. Uspon parnog pogona i korijeni globalnog zatopljenja, Fraktura - Institut za političku ekologiju, Zaprešić - Zagreb 2018., str. 25.

${ }^{668}$ Usp. N. Visković, »Zakašnjelo i površno«, str. 60.

${ }^{669}$ Usp. N. Visković, »Ekologija i pravo«, str. 462-464.
} 
»... strategija održivog razvoja danas ima razne varijante, ali gotovo sve one pate od jednog bitnog iako redovito nezamijećenog etičkog i ekološkog nedostatka: izrazito su antropocentrične i čak grubo sebične, beskrupulozne prema ne-ljudskim oblicima života na Zemlji. I kada razmišljaju o strategiji održivog razvoja donekle vode računa o zaštiti nekih vidova ne-ljudskog života (...), ona to ipak čine prvenstveno ili isključivo onoliko koliko se smatra da su ti oblici života uvjet za preživljavanje i blagostanje čovjeka. Odatle i brojne sadašnje rasprave o potrebi očuvanja genetskih potencijala svjetske flore i faune kao neprocjenjivo vrijednih 'resursa' za ekonomsku, medicinsku i drugu eksploataciju prirode od budućih generacija čovječanstva. Potreba za održivim razvojem radi zaštite prirode kao vrijednosti po sebi $i$ radi dobrobiti biljaka $i$ životinja kao naših sustanara na Zemlji još nije stigla na dnevni red razmišljanja suvremenih ekologa i političara - utilitarno obuzetih jedino sudbinom čovjeka... Takav je stav nesumnjivo moralno problematičan i, osim toga, što je opet nezamijećeno, čak i kratkovidan unutar vlastite egoističke logike - jer ne razumije međuovisnost stradanja čovjeka i životinja. « ${ }^{670}$

Spomenuto polazište pravne regulacije, naglašava Visković, uvjetovano je ekonomskim ciljevima koji se uglavnom svode na kratkoročnu rentabilnost, pa su tako pokušaji zaštite prirodne okoline »opterećeni sebičnom i neumnom egocentričnošću jednog subjekta čija tehnološka moć daleko i tragično nadvisuje njegovu društvenu i moralnu uračunljivost «. ${ }^{671} \mathrm{Iz}$ toga proizlazi porazan rezultat da ljudi ekološku krizu najčešće sagledavaju kao tehnički, a ne kao moralni ili strukturalni problem. To je uvjetovano i spomenutim prerastanjem tehnike u tehnologiju, koja ne samo zamjenjuje izvornu prirodu, već također istiskuje ostale dimenzije kulture.

»U ekološkoj krizi pred kojom se nalazimo nisu bitna tehnička sredstva kojima bi se ona mogla ublažiti ili izbjeći, nego su tu bitne temeljne političke odluke prema njoj. (...) Radikalni odgovor na dolazeću ekološku krizu, dio koje je globalno zatopljenje traži najdublju promjenu društveno-ekonomskog sustava, a pogotovo napuštanje sadašnjeg trenda globalizacije po neoliberalnim principima. $\ll^{672}$

Ogledan primjer tehnološkog suočavanja s novovrsnom situacijom onaj je održivog razvoja, najčešće mišljen u pogledu iznalaženja načina kako unutar postojećeg društvenoekonomskog sistema, podrazumijevajući potrebu da se ne ometa stalan ekonomski rast, spriječiti ekološku katastrofu. Ukoliko bi se ovdje pod društveno-ekonomskim sistemom mislilo na neoliberalni kapitalizam, utoliko ne nalazimo načina na koji bi takva ideja održivog razvoja svoj blagoslov mogla pronaći u Viskovićevu djelu.

\footnotetext{
${ }^{670}$ N. Visković, Kulturna zoologija, str. 234.

${ }^{671}$ Usp. N. Visković, »Ekologija i pravo«, str. 463-464.

${ }^{672}$ Nikola Visković, »Političke elite su ekološki nepismene«, Feral Tribune 16. 8. 2003., intervju (razgovarao Toni Gabrić), str. 29-30, ovdje str. 30.
} 
»Neoliberalni projekt ne pogađa samo ekonomski i kulturni život naroda. On također pogađa, a možda i s najtežim, nepopravljivim posljedicama, svijet prirode, ljudski okoliš i zdravstvene standarde kojima je priroda temelj. Merkantilno-tehnokratska utopija o beskonačnom napretku i općoj sreći preko nesputane vladavine profita ima uistinu zločinačke učinke na prirodu: njoj se žrtvuju tropske prašume, s njihovih 90\% biljnog i životinjskog biodiverziteta, njoj se žrtvuju vode i zemlja s nepotrebnim i nekažnjenim zagađivanjem, odnedavno joj se žrtvuje i atmosfera, koju smo tisućljećima smatrali nedodirljivom i neoštetivom, a time i sve klimatske ravnoteže na Zemlji. Njoj se upravo priprema žrtvovanje genetske strukture života, koja je nastajala evolucijom milijunima godina, a sada bi se također trebala upotrebljavati i ugrožavati za produktivno-profitne svrhe. ${ }^{673}$

Premda jasno uviđa razornost ideje beskonačnog ekonomskog rasta, Visković ideologiji održivog razvoja eksplicitno ne pripisuje podrazumijevanje ove ideje, ${ }^{674}$ naprotiv, tada je u izvjesnom smislu promatra više kao »znanstvenu utopiju« koja svjetske moćnike neće prisiliti na smanjenje potrošnje prirode ili uključivanje neke vrste ekološkog poreza na štetu koju proizvode. Štoviše, usvajanje nečega poput ekološkog zakonodavstva vodilo bi trenutnom raspadu »neoliberalne utopije i vladavine«. Uzevši za primjer aktivnosti tadašnje skupine Narod Seattlea usmjerene zaštiti života na Zemlji, tvrdi da su »upravo na tom polju njihovi zahtjevi najumniji i zbilja revolucionarni«, s obzirom na to da se ono što ljudskim djelovanjem još nije uništeno u prirodi dade spasiti samo bitno drugačijim odnosom spram nje, a to podrazumijeva i njegovo uobličenje u sasvim drugačijem međunarodnom ekonomsko-političkom poretku. ${ }^{675}$

\section{III.4.2. Bioetička rehabilitacija marksizma}

Uzmu li se u obzir umnost i revolucionarnost bitne promjene odnosa spram prirode, kao i nužna razornost neoliberalnog kapitalizma, izgleda da nam marksizam može pomoći tek u drugom zadatku, a u prvome čak i odmoći. Kada je riječ o uspostavi obzira spram ne-ljudskih živih bića i prirode uopće, Visković otpisuje gotovo čitav marksizam, spominjući tek uzgred pokoju svijetlu točku. Tu ponajprije ističe Rudija Supeka, kao jednog od prvih društvenih

\footnotetext{
${ }^{673}$ N. Visković, Sumorne godine, str. 286.

${ }^{674}$ Difamaciji dogme ekonomskog rasta s obzirom na njegovu razornost spram prirode i čovjeka (čak i izvan konteksta ekološke krize) osobito su pridonijeli zagovornici koncepta odrasta (eng. degrowth). (Vidi: Giacomo D'Alisa, Federico Demaria, Giorgos Kallis (ur.), Odrast. Pojmovnik za novu eru, prevela Mirta Jambrović, Fraktura - Institut za političku ekologiju, Zaprešić - Zagreb 2016.) Unutar njega se često ukazuje na ideologičnost održivog razvoja: »Održivi razvoj depolitizira iskonske političke antagonizme o vrsti budućnosti u kojoj pojedinac želi živjeti; ekološke probleme čini tehničkima, obećavajući zajednička rješenja i (nemogući) cilj produljivanja razvoja bez nanošenja štete okolišu. « (Giorgos Kallis, Federico Demaria, Giacomo D'Alisa, »Odrast«, u: Giacomo D'Alisa, Federico Demaria, Giorgos Kallis (ur.), Odrast. Pojmovnik za novu eru, prevela Mirta Jambrović, Fraktura - Institut za političku ekologiju, Zaprešić - Zagreb 2016., str. 1-27, ovdje str. 15-16.)

${ }^{675}$ Usp. N. Visković, Sumorne godine, str. 287.
} 
teoretičara koji je kod nas pokazao zanimanje za ekologiju. ${ }^{676}$ No čini se da odustajanjem od potrage za nekim drugim vrijednim marksističkim uvidima za bioetičku problematiku Visković samo gubi na koherentnosti svoje čitave misaone pozicije (koja u ostalim pogledima gleda blagonaklono na marksizam) tamo gdje na njoj može dobiti. Marksizam je, istina, bitno antropocentrično učenje, no kroz čitav svoj razvoj porađa autore čije su misli na ovaj ili onaj način relevantne za problem koji Viskovića primarno zanima. Štoviše, u pojedinim je aspektima važan i za posljednje područje njegova zanimanja - erotiku. Stoga ćemo ovdje, bez pretenzije na cjelovit prikaz, istaknuti pojedine važne elemente marksizma, ne samo kao nadopunu Viskovićeve teorije, nego i kao doprinos bioetici uopće. Pri tome se dijelom vraćamo i na već raspravljani problem ukidanja morala.

Kada govorimo o suvremenom povijesnom trenutku, riječ koja najčešće odjekuje u svijesti jest kriza. Zeleni govore o krizi okoliša, crveni o krizi kapitalizma, klerici o krizi vrijednosti itd. Međutim, moguće je detektirati i jednu, recimo to tako, meta-krizu u ovom univerzumu kriza, naime, onu u kojoj se ovi različiti diskursi o krizi artikuliraju u odvojenim i nepomirljivim oprekama i nastrojenostima jednih prema drugima. Takvo stanje čini sve te pojedinačne i konkretne krize intenzivnijima, a njihovo razrješenje beznadnijim. Također se čini da takva situacija kao jedino rješenje nalaže oštar sukob iz kojeg će izaći određeni pobjednik, kao samostalni pokretač daljnje povijesti. Odriješit obračun sačinjava jedan od važnih momenata čuvenog spisa spomenutih crvenih, naime Manifesta komunističke partije Karla Marxa i Fridricha Engelsa. Odgovarajući na optužbe o destrukciji morala, religije, filozofije, prava, pa i ideja poput slobode, dakle, ideja i institucija koje su u različitim oblicima izdržale turbulentni hod povijesti, njih dvojica ističu da se čitava ta povijest ne sastoji ni od čeg drugoga do klasnih suprotnosti i izrabljivanja koji formiraju određene oblike svijesti, a kontinuitet postojanja klasnih suprotnosti i privatnog vlasništva ukazuje da se ovi oblici svijesti tvore po jedinstvenom obrascu. ${ }^{677}$ Stoga je potrebna korjenita izmjena materijalne stvarnosti: »Komunistička revolucija je najradikalniji prekid s naslijeđenim odnosima vlasništva; nikakvo čudo da ona i najradikalnije prekida s naslijeđenim idejama. « ${ }^{678}$

Najradikalniji prekid s naslijeđenim idejama izuzetno je teška teza, naročito s obzirom na Marxov ponešto »mekši« stav o ovom pitanju, prvenstveno izražen u njegovim ranim radovima, pa se s obzirom na to može donekle tumačiti kao »stilska figura« pripadna

\footnotetext{
${ }^{676}$ Usp. N. Visković, Stablo i čovjek, str. 39; N. Visković, »Ekologija i pravo«, str. 459.

${ }^{677}$ Usp. Karl Marx, Friedrich Engels, »Manifest komunističke partije«, preveo Moša Pijade (redigirao Boris Buden), Ekonomija / Economics 15 (2008) 3, str. 565-596, ovdje str. 583.

${ }^{678}$ Ibid.
} 
programatskom diskursu jednog manifesta. Spomenuti »mekši« stav odnosi se na dijalektički princip ukidanja (Aufhebung), prema kojemu momenti koji se ukidaju ne nestaju, nego se upravo ostvaruju u višoj sintezi. On je jasno izražen u Marxovu Prilogu kritici Hegelove filozofije prava u tvrdnji da filozofija ne može biti ukinuta bez da je se ostvari, niti može biti ostvarena bez da je se ukine. ${ }^{679} \mathrm{Na}$ tom tragu stoji i poznata Marxova jedanaesta teza o Feuerbachu: »Filozofi su svijet samo različito interpretirali, radi se o tome da ga se izmijeni. « ${ }^{680}$

\section{III.4.2.1. Znanstveno-tehnološka racionalnost, osjetila i potrebe}

Čini se da refleksija nad ljudskim djelovanjem danas vapi za njegovom suštinskom promjenom više no ikad. Radi se o tome da čovjekovo djelovanje poprimilo moć nad prirodom kakva je u Marxovo doba bila još nepojmljiva. Ona se nije promijenila samo kvantitativno, nego i kvalitativno, ${ }^{681} \mathrm{u}$ tom smislu da je pred njom, kako tvrdi Jonas, sama priroda postala povredljiva. Međutim, ako se osvještenje te promjene možda i desilo preko noći, preduvjeti za njeno nastupanje nisu, nego imaju svoje korijene barem u počecima formiranja novovjekovne znanosti i filozofije, kod Descartesa i Bacona, kako je već spominjano te iz čega je proizašao zaključak o čovjekovu podređenju vlastitom sredstvu.

S obzirom na to da su taj proces uočili i pojedini marksistički autori izvan konteksta ekološke krize, tj. promjene suštine čovjekova djelovanja, njihovi uvidi mogu dodatno rasvijetliti ovaj problem. Osobitu pažnju poimanju ovog fenomena posvetio je Herbert Marcuse, koji u članku »Some Social Implications of Modern Technology« navodi sljedeće:

»U manipuliranju strojem čovjek uči da je pokoravanje uputama jedini način zadobivanja željenih rezultata. Snalaženje je identično prilagodbi aparatu. Nema mjesta za autonomiju. Individualistička racionalnost razvila se u učinkovitu usklađenost s danim kontinuumom sredstava i svrha. « ${ }^{682}$

\footnotetext{
${ }^{679}$ Karl Marx, »Prilog kritici Hegelove filozofije prava«, preveo Stanko Bošnjak, u: Karl Marx, Friedrich Engels, Rani radovi, Naprijed, Zagreb 1989., str. 90-105, ovdje str. 97. - Tu valja na umu imati reinterpretaciju Gaje Petrovića koji drži da se filozofija može ukinuti »samo tako da se realizira do kraja, potpuno. A potpuno bi se mogla realizirati samo potpuna, zatvorena, završena filozofija kojom završeni čovjek misli sama sebe u svom završenom svijetu. Nezavršena, otvorena filozofija može se ostvarivati (ozbiljivati), ali ne i definitivno ostvariti (ozbiljiti).«(Gajo Petrović, Filozofija i marksizam, Mladost, Zagreb 1965., str. 68.)

${ }^{680}$ Karl Marx, »Teze o Feuerbachu«, preveo Stanko Bošnjak, u: Karl Marx, Friedrich Engels, Rani radovi, Naprijed, Zagreb 1989., str. 337-339, ovdje str. 339.

${ }^{681}$ Usp. H. Jonas, Princip odgovornost, str. 13.

${ }^{682}$ Herbert Marcuse, »Some Social Implications of Modern Technology«, u: Herbert Marcuse, Technology, War and Fascism, Routledge, London - New York 2004., str. 39-65, ovdje str. 46.
} 
Samosvrhovitost ovog aparata nužno vodi k otuđenju. Nije samo, kako tvrdi Marx, proizvod otuđen od radnika, nego je sama njegova djelatnost (proizvodnja) od njega nezavisna, tj. otuđenje se dešava već u njoj. Stoga se radnik ne potvrđuje u svom radu, koji ne služi zadovoljenju potrebe, nego kao sredstvo za potrebe izvan njega, a kod sebe se nalazi tek izvan tog rada. To znači da se čovjek osjeća samoodjelatnim tek u onome što Marx naziva »životinjskim funkcijama«, tj. u održavanju fizičke egzistencije, pri čemu njegov rodni život (svjesna životna djelatnost) postaje sredstvo individualnog života (održavanja) - život postaje sredstvo za život. ${ }^{683}$ Ovdje vrijedi ukazati i na neke dodatne oblike u kojima čovjek doživljava svoju tobožnju samodjelatnost u slobodnom vremenu, tj. privatnoj sferi. U tom kontekstu, kako navode Horkheimer i Adorno:

»Pojedinac ono što treba da čini ne mora više iznalaziti u bolnoj unutarnjoj dijalektici savjesti, samoodržanja i poriva. Za čovjeka kao zaposlenog odlučuje se posredstvom hijerarhije saveza sve do nacionalne uprave, a u privatnoj sferi shemom masovne kulture, koja zaposjeda i posljednja unutarnja kretanja svojih prisilnih potrošača. ${ }^{684}$

U tom pogledu: »Raspoloženje publike, koje navodno i činjenično pogoduje kulturnoj industriji i njezinom sistemu, jest dio tog sistema, a ne njegovo opravdanje. « ${ }^{685}$ Takav je okvir prikladan i za spomenuti Viskovićev stav da intenzivan uzgoj životinja nije neizbježna posljedica potražnje, nego posljedica izvjesnog ekonomskog opredjeljenja, tj. njegova uvjetovanja prehrambenog ponašanja. Ili kako Marcuse tvrdi u knjizi Čovjek jedne dimenzije, proizvodni aparat tendira totalitarnosti ne samo time što determinira društveno potrebna zanimanja, vještine i stavove, nego i individualne potrebe i aspiracije. ${ }^{686}$

\begin{abstract}
»Suvremeno industrijsko društvo tendira totalitarizmu na osnovu organizacije njegove tehnološke baze. Jer 'totalitaran' ne znači samo terorističku političku koordinaciju društva već, također, neterorističku, ekonomsko-tehnološku koordinaciju koja djeluje posredstvom manipuliranja potrebama, dodjeljujući interese. Ona tako sprečava izbijanje efikasne opozicije protiv cjeline. Ne pogoduje totalitarizmu samo određena vrsta vladavine ili načela partije već, također, određeni sistem proizvodnje ili raspodjele koji ne isključuje 'pluralizam' partija, novinskih listova, 'sila protuteže' itd. « ${ }^{67}$
\end{abstract}

\footnotetext{
${ }^{683}$ Usp. Karl Marx, »Ekonomsko-fillozofski rukopisi iz 1844.«, preveo Stanko Bošnjak, u: Karl Marx, Friedrich Engels, Rani radovi, Naprijed, Zagreb 1989., str. 183-336, ovdje str. 248-251.

${ }^{684}$ M. Horkheimer, Th. Adorno, Dijalektika prosvjetiteljstva, str. 215.

${ }^{685}$ Ibid., str. 134.

${ }^{686}$ Usp. Herbert Marcuse, Čovjek jedne dimenzije. Rasprave o ideologiji razvijenog industrijskog društva, prevela Branka Brujić, Veselin Masleša, Sarajevo 1968., str. 15.

${ }^{687}$ Ibid., str. 22-23.
} 
Stoga se kao jedno od ključnih pitanja postavlja ono istinskih ljudskih potreba naspram onih koje generira proizvodni i tehnološki aparat. Za ovaj problem instruktivno je ukazivanje Ericha Fromma na promašaj »velikog obećanja o neograničenom napretku«. Jedan od razloga tog promašaja leži u psihološkoj premisi da zadovoljenje svake želje ili subjektivne potrebe sačinjava cilj života. Radi se o problematičnoj pretpostavci da sâmo postojanje želje konstituira etičku normu, koju ne nalazimo ni u jednom učenju velikih klasičnih mislioca. Naprotiv, oni su prije svega tragali za objektivnim potrebama, dok spomenuta pretpostavka svoje rođenje ima u isključenju etike iz ekonomije u kontekstu kapitalizma osamnaestog stoljeća. Upravo tada postaje jasno da ekonomska mašina postaje autonomna, a njen razvoj samosvrha. ${ }^{688}$

Centralna je Frommova misao u navedenoj knjizi ta da je u suvremenom ljudskom stanju imanje sama bit bivstvovanja. ${ }^{689}$ Nju možemo pronaći formuliranu još u Marxovim Ekonomsko-filozofskim rukopisima, gdje tvrdi:

»Privatno vlasništvo nas je učinilo tako glupim i jednostranim da je neki predmet naš tek onda kad ga imamo, dakle, kad za nas postoji kao kapital ili kad ga neposredno posjedujemo, jedemo, pijemo, nosimo na svome tijelu, nastanjujemo itd., ukratko kad ga upotrebljavamo. Iako privatno vlasništvo shvaća sva neposredna ozbiljenja samog posjeda opet samo kao sredstvo za život, a život, kojemu oni služe kao sredstvo, jest život privatnog vlasništva, rad i kapitaliziranje.

Stoga je na mjesto svih fizičkih i duhovnih osjetila stupilo jednostavno otuđenje svih tih osjetila, osjetilo posjedovanja. $\ll^{690}$

Ovdje valja primijetiti Marxovu usredotočenost na osjetila, tj. na njihovo obogaćivanje $\mathrm{s}$ jedne i otuđenje s druge strane te naglašavanje toga da se čovjek u predmetnom svijetu ne potvrđuje samo mišljenjem, nego i osjetilima. Naime, kako on tvrdi, u subjektivnom smislu nije isto, primjerice, kakvom uhu pristiže muzika. Za nemuzikalno uho ona nema nikakvog smisla, ali ako ona doseže muzikalno uho tada je situacija suprotna. Riječ je o tome da predmet može biti samo potvrđivanje jedne od naših suštinskih snaga (kao naše subjektivne sposobnosti). One se razvijaju putem predmetno razvijenog bogatstva čovjekova bića koje nastaje tek pomoću postajanja njegova predmeta, što ovdje znači očovječene prirode. Stoga Marx i tvrdi da je stvaranje pet osjetila posao cjelokupne svjetske historije. Pri tome on ovim osjetilima pribraja i ona »duhovna, praktička«, poput volje ili ljubavi. ${ }^{691}$ Osjetila, tj. ono što ona proizvode, nisu

\footnotetext{
${ }^{688}$ Usp. Erich Fromm, Imati ili biti?, preveo Gvozden Flego, Naprijed, Zagreb 1979., str. 55-60.

${ }^{689}$ Usp. ibid., str. 67.

${ }^{690}$ K. Marx, »Ekonomsko-fillozofski rukopisi iz 1844.«, str. 279-280.

${ }^{691}$ Usp. ibid., str. 281. - »Za izgladnjela čovjeka ne postoji ljudski oblik hrane, nego samo njeno apstraktno postojanje kao hrane (...) (Ibid, str. 280-281.)
} 
gotova i nepromjenjiva danost, nego bitno ovise o čitavom spletu načina na koje se čovjek potvrđuje u svijetu. Samo njihovo formiranje bitno je stvaralački čin.

Kapitalistički odnosi, dakle, ugrožavaju razvijanje čovjekove osjetilnosti reducirajući je na posjedovanje. U tom je pogledu zanimljivo i Marcuseovo zapažanje o ograničenju libida koje nastupa s mehanizacijom, a na način iščezavanja »krajolika« kao medija libidinoznog iskustva. Tim je iščezavanjem, kao historijskim preduvjetom progresa, dezerotizirana čitava jedna dimenzija ljudske aktivnosti i pasivnosti. Redukcijom okoline koja pruža takvo iskustvo, libido je lokaliziran, a erotsko je iskustvo svedeno na ono seksualno. Tehnološka stvarnost tako limitira djelokrug sublimacije, ali i umanjuje potrebu za sublimacijom. To se odvija tako da se snižava napetost između onoga za čime se čezne i onoga što je dozvoljeno, tako da instinktne potrebe više nije potrebno transformirati. Ali riječ je zapravo o tome da se libidom upravlja, čime se postiže dobrovoljna koordinacija s postojećim, upravo zato što sublimacija sadrži potencijal transcendiranja postojećeg i potencijal oslobođenja, čuvajući svijest o odricanju koje pojedincu nameće represivno društvo, tj. tehnološki i politički aparat. ${ }^{692}$

Ne samo da kapitalistički razvoj u tom pogledu guši čovjekove bogate potencijale i potrebe, nego čak i reducira neke od njegovih osnovnih životinjskih potreba, poput one za čistim zrakom ili za kretanjem. ${ }^{693} \mathrm{~S}$ druge se strane stalno stvaraju umjetne potrebe kako bi ekonomski stroj ponude i potražnje nastavio funkcionirati. Ono što ovaj poredak neslobode čini uznemirujućim spremnost je širokih masa da zadovoljno pristanu na manipulacije samosvrhovito razvijajućeg aparata nad njihovim vlastitim potrebama. Tako Marcuse u Eseju o oslobođenju jasno ističe kako su ove potrebe poput konzumiranja i posjedovanja postale biološke, tako da se ta čovjekova »druga priroda« buni protiv onog što bi ugrozilo njenu potrošačku egzistenciju. On mora kupovati proizvode koji proizlaze iz kapitalističkog aparata proizvodnje i razmjene, jer on tako kupuje bitan dio vlastite egzistencije. Njegova sloboda svodi se na »slobodu« jurnjave automobilom i sl. ${ }^{694}$ Iza ovakvog poimanja slobode i ovakvih potreba stoji jedan poseban tip racionalnosti:

»Ideja učinkovite usklađenosti savršeno ilustrira strukturu tehnološke racionalnosti. Racionalnost se transformira iz kritičke sile u onu prilagodbe i usklađenosti. Autonomija uma gubi svoje značenje u istoj mjeri u kojoj su misli, osjećaji i djelovanja ljudi oblikovani tehničkim zahtjevima aparata koji su sami stvorili. ${ }^{695}$

\footnotetext{
${ }^{692}$ Usp. H. Marcuse, Čovjek jedne dimenzije, str. 81-83.

${ }^{693}$ Usp. K. Marx, »Ekonomsko-filozofski rukopisi iz 1844.«, str. 290.

${ }^{694}$ Usp. Herbert Marcuse, »Esej o oslobođenju«, prevela Branka Brujić, u: Kraj utopije, Esej o oslobođenju, Stvarnost, Zagreb 1972., str. 127-202, ovdje str. 142-143.

${ }^{695}$ H. Marcuse, »Some Social Implications of Modern Technology«, str. 49.
} 
U takvom je okviru otkrivanje vlastitih istinskih potreba nemoguć zadatak. Kako Marcuse pojašnjava u Čovjeku jedne dimenzije:

»U posljednjoj instanci, pitanje koje su istinske, a koje krive potrebe moraju riješiti sami individuumi. No, samo u konačnoj analizi, tj. kad su i ako su oni slobodni da daju svoj vlastiti odgovor. Sve dok su ljudi spriječeni u tome da budu autonomni, dok im se nameću stavovi i dok su objekt manipuliranja (sve do i samih instinkata), njihov odgovor na to pitanje ne može biti prihvaćen kao njihov vlastiti. « ${ }^{696}$

Ugroza autonomije izaziva uznemirenost upravo zbog njene ključne uloge za moralno djelovanje. Stoga čitava ova rasprava zadobiva nezaobilazno mjesto u okviru današnjih etičkih promišljanja. Protivljenje formiranju i održavanju društvenih uvjeta koji generiraju ugrozu autonomije ljudskog bića postavlja se stoga kao moralni imperativ. Dodatnu potvrdu moralnom skandaliziranju suvremene situacije dobivamo uviđanjem prezentiranih načina na koje čovjek svodi sebe i drugog čovjeka na puko sredstvo, upravo posredstvom služenja onome što je sam zamislio kao sredstvo. No treba imati na umu da primarna motivacija ovog posvemašnjeg porobljivanja čovjeka leži u porobljavanju prirode. Upravo u pogledu u kojem Bacon potonje postavlja kao imperativ znanja, Kangrga drži da je sama ideja novovjekovne znanosti »mišljena upravo već građansko-kapitalistički: kao znanstveno-tehnička dominacija nad prirodom, a onda samim time i ljudskom prirodom, tj. čovjekom samim i njegovim društvenim, državnim i životnim uređenjem uopće «. ${ }^{697}$ Neovisno o rješenju dileme o kokoši ili jajetu koja se ovdje potencijalno javlja, kapitalističko uređenje potpuno funkcionira po principima instrumentalne racionalnosti, koja je bitno obilježje znanstveno-tehnološke paradigme znanja. »Pri tom do izražaja dolazi specifični novovjekovni pojam ratio-a, to jest uma (odnosno: razuma) koji se ovom svojom operativnošću i instrumentalnošću potpuno razlikuje od onog emancipatorskog pojma uma što ga Kant uvodi u značenju praktičkog uma (...) « ${ }^{698}$

\section{III.4.2.2. Um, priroda i etika}

Potreba za naglašavanjem uma kao stvaralačke i oslobodilačke moći ukazuje na neodvojivost ovog »idealističkog« sastojka iz određenih materijalističkih filozofija koje teže čovjekovoj emancipaciji. On osigurava onaj zadnji kamen na kojem se temelji čitav smisao

\footnotetext{
${ }^{696}$ H. Marcuse, Čovjek jedne dimenzije, str. 25.

${ }^{697}$ M. Kangrga, Praksa - vrijeme - svijet, str. 22.

${ }^{698}$ Ibid., str. 22-23.
} 
prevladavanja postojećih materijalnih uvjeta te pruža mogućnost racionalnog objašnjenja vlastitog djelovanja. Ali također treba biti svjestan toga da ti materijalni uvjeti u značajnoj mjeri određuju svijest, a što su pojedini fragmenti nabačeni u ovom poglavlju pokušali prikazati.

Etika koja zaista želi biti na tragu svog zadatka mora uključiti materijalistički aspekt u svoje okvire, ako svoj zadatak shvaća kao promicanje ljudske slobode, a naročito ako ovu poima kao specifičnu formu čovjekova samoostvarivanja. Upravo u potonjem pojmu leži bitan doprinos marksističke perspektive promišljanju ispravnog djelovanja. Ona putem kritike suvremenog sputavanja različitih načina ljudskog samoostvarivanja, koji uključuju i one koje je tradicionalna etika često zanemarivala, poput razvijanja osjetilnosti, upire upravo na njegovu vrijednost, istovremeno čineći jasnim da je sloboda ključan uvjet i forma koja ga omogućuje. Vrijednost marksizma u ovom pogledu možda ponajprije leži u osvještavanju načina na koje materijalni uvjeti proizvodnje ne samo neopravdano ograničavaju ljudsko samoostvarivanje, nego i formiraju svijest koja ne prepoznaje o čemu je u tom procesu riječ.

Štoviše, upravo su oni autori koji su pokušavali kod Marxa detektirati etički sistem, kao primarni argument isticali normativni karakter ljudskog samoostvarenja ${ }^{699} \mathrm{U}$ tom je pogledu posebno interesantna pozicija Hilliarda Aronovitcha. Neovisno o tome koliko pogađa po pitanju zbiljske prisutnosti etike kod Marxa, ${ }^{700}$ ona barem može biti vrijedan pokazatelj prisutnosti plodnih elemenata u Marxovoj misli za izgradnju jedne etike.

Kao osnovu za »moralitet samoostvarivanja«, u kojem je misao o moralitetu usredotočena na princip punog i slobodnog razvoja svih individua, Aronovitch ističe Marxovo poimanje ljudske prirode, koja može biti oblikovana od strane čovjeka onda kada ljudi zavladaju okolnostima (umjesto da je obrnuto na djelu). Da to pripada njihovoj prirodi, izražava se i u pojmu čovjeka kao rodnog bića. Aronovitch pruža i vrijedne odgovore na primjedbe temeljenju moraliteta na pojmu samoostvarivanja. Prva bi glasila da ostvarenje nečije prirode mora biti vezano uz funkciju ili namjenu (što ima smisla samo uz pretpostavku nekoga tko ih zadaje, poput boga), no tomu svakako nije tako pojmimo li ovu »prirodu« naprosto kao kapacitet ili sposobnost. Drugi je prigovor da postoji mnoštvo ljudskih sposobnosti, pa nam je, u slučaju prihvaćanja samoostvarivanja kao moralnog principa, potreban neki neovisan moralni kriterij prema kojemu ćemo izabirati među ovima. No Aronovitch tvrdi da su neke sposobnosti fundamentalnije od drugih, tj. da njihovo upražnjavanje, barem do izvjesne mjere, uvjetuje

\footnotetext{
${ }^{699}$ Usp. Anita Lunić, »Održivost teze o Marxovoj etici«, Eidos 2 (2018) 2, str. 115-124, ovdje str. 117. - Navedeni rad pruža dobar pregled ove problematike.

${ }^{700}$ To direktno pokušava opovrgnuti Derek P. H. Allen u: »Does Marx Have an Ethic of Self-Realization? Reply to Aronovitch«, Canadian Journal of Philosophy 10 (1980) 3, str. 377-386.
} 
upražnjavanje praktično svake druge sposobnosti. Ako se u velikoj mjeri ne bi mogle oblikovati okolnosti, ne bi se mogle upražnjavati ni druge sposobnosti - kad bi se pak i pružila prilika za potonje, riječ bi bila tek o slučajnosti, nečemu što ne proizlazi iz djelatnika. No ta fundamentalna sposobnost ne mora biti distinktivno obilježje čovjeka (i druge vrste oblikuju svoj okoliš), ona mu naprosto, kako pridjev kaže, mora biti fundamentalna. ${ }^{701}$ Pri tome je Aronovitch izbjegao potrebu za korištenjem Aristotelova ergon argumenta, kojemu su pribjegli neki drugi marksistički autori u iznalaženju strukture za izvođenje Marxove etike, ${ }^{702}$ čime je otvorio prostor, iako nije zagazio u njega, za moralno uvažavanje ne-ljudskih živih bića.

Samoostvarivanje se, nastavlja Aronovitch, sastoji od samodeterminacije i samoaktualizacije. Prva označava »slobodno i svjesno oblikovanje uvjeta nečijeg života, što omogućava daljnje slobodno i svjesno oblikovanje nečijeg sebstva« - što se ponekad nazivalo pozitivnom slobodom. U tom se pogledu osobito inzistira na (samo)svjesnom usmjeravanju volje, tj. na sagledavanju društvenih i psihičkih faktora koji mogu usmjeravati volju i time djelatnika učiniti neslobodnim. Samodeterminacija je implicitna u svim stremljenjima za ciljevima i svrhama, u suprotnom oni i ne bi bili zaista djelatnikovi. S druge strane, samoaktualizacija naprosto predstavlja daljnje razvijanje sposobnosti i potencijala. ${ }^{703}$

Premda se ovdje opet sužavaju potencijali Aronovitcheva doprinosa moralnom uvažavanju ne-ljudskih živih bića (osim ako se ova struktura odnosi tek na ljudsko samoostvarivanje), već i osvještenje slobode kao specifične forme ljudskog samoostvarivanja otvara prostor, kako smo pokazali, za analogiju po kojoj se moralni obzir može uspostaviti spram svakog živog bića. Za to je potreban i uvid da se mi ne samoostvarujemo tek kao duhovna, nego i kao prirodna bića. Spomenuta Marxova analiza osjetilnosti i razmatranje problematike umjetnih i pravih potreba daju važne priloge tome.

Iako marksisti često nisu imali »sluha« za prirodu, čini se da su pružili uvide koji sačinjavaju jedan važan dio preduvjeta za povratak tog »sluha«. ${ }^{704} \mathrm{Tu}$ se ne radi samo o

\footnotetext{
${ }^{701}$ Usp. Hilliard Aronovitch, »Marxian Morality«, Canadian Journal of Philosophy 10 (1980) 3, str. 357-376, ovdje str. 361-366.

702 »... Nasser smatra kako kod Marxa nedvojbeno nalazimo etičke argumente, i to argumentirane na Aristotelu sličan način. Da bi dokazao ovu tezu, Nasser prvo određuje sadržaj Aristotelovog ergon argumenta (navodim prema: Nasser 1975: 486):

1. Smisleno je i točno reći kako priroda čovjeku određuje posebnu svrhu;

2. Ta svrha se može dokučiti ustanovljavanjem vrste djelatnosti koja razlikuje homo sapiensa od drugih bića;

3. Ta je djelatnost (moralno) dobra za čovjeka. (A. Lunić, »Održivost teze o Marxovoj etici«, str. 122.) Spomenuta se referenca odnosi na: Alan G. Nasser, »Marx's Ethical Anthropology«, Philosophy and Phenomenological Research 35 (1975) 4, str. 484-500.

${ }^{703}$ Usp. H. Aronovitch, »Marxian Morality«, str. 366, 370-371.

${ }^{704}$ Neki marksisti i eksplicitno su izrazili brigu spram prirode, naročito s obzirom na očiglednu činjenicu da kapitalizam generira značajne probleme po ovom pitanju, a koja se može izraziti naslovom knjige pionira američkog ekosocijalizma Joela Kovela Neprijatelj prirode, koji, dakako, aludira na kapitalizam (vidi: Joel Kovel,
} 
stvaranju preduvjeta, nego i o eksplicitnim uvidima nekih filozofa pretežito marksističke orijentacije na probleme odbacivanja i porobljavanja prirodnog, prvenstveno kod pojedinih autora frankfurtske škole (neki od njih su već navedeni u prethodnim poglavljima). U Horkheimerovoj Kritici instrumentalnog uma nailazimo na klasično formuliran problem uzajamne veze podređivanja čovjeka i prirode, u kojem kapitalizam predstavlja tek nastavak jedne tendencije, iako je on podiže na najviši stupanj:

»Ljudsko biće, u procesu svog oslobađanja, dijeli sudbinu svojeg ostalog svijeta. Vladavina prirodom uključuje i vladavinu čovjekom. Svaki subjekt ne samo što mora sudjelovati u podjarmljivanju vanjske prirode, ljudske i neljudske, nego kako bi to učinio, mora podjarmiti i prirodu u sebi samome. Vladavina postaje 'pounutrašnjena' radi vladavine. Ono što se obično označuje kao cilj - zadovoljstvo pojedinca, zdravlje i bogatstvo - dobiva svoje značenje isključivo po svojoj funkcionalnoj mogućnosti. (...) Budući da se podjarmljivanje prirode, unutar čovjeka i izvan njega, odvija bez značajnog motiva, priroda se stvarno ne nadmašuje niti izmiruje, nego samo tlači. «705

Priroda se, međutim, kako to ističu Horkheimer i Adorno, osvećuje za takav tretman. Kultura koja izrabljivački nastupa spram prirode razvija odnos s tijelom kao s predmetom koji se može posjedovati. Taj se predmet, kao mrtvi corpus stavlja u apsolutnu opreku spram duha, kao isprazne moći zapovijedanja. Tim samoponižavanjem čovjeka u corpus priroda se osvećuje za njeno unižavanje u sirovinu od strane čovjeka. ${ }^{706} \mathrm{Na}$ to se mogu nadovezati i prije spomenute detektcije uzajamnog smisaonog osiromašenja manipulatorski nastrojenog subjekta i njegova objekta (prirode) od strane ovih autora, ali i tome bliski Viskovićev također spomenuti sud o lišavanju smisla ljudske egzistencije uslijed instrumentalnog odnosa spram živih bića.

Nije kod frankfurtovaca samo riječ o promatranju prirodnosti kao cjeline ili kao aspektu ljudskog bića, nego i o ulaženju u neke konkretne bioetičke probleme, poput onoga o životinjskom pitanju, ali ne gubeći iz vida čitav opisani sklop. Tako će Horkheimer i Adorno u svojoj Dijalektici prosvjetiteljstva posvetiti jedno poglavlje odnosu čovjeka spram životinje, od čega prvenstveno vrijedi istaknuti prvi pasus:

»Ideja čovjeka u europskoj povijesti izrazuje se u razlikovanju od životinje. Bezumnošću životinje dokazuje se ljudsko dostojanstvo. Ta je suprotnost s toliko jednoglasnosti i ustrajnosti isticana od svih

The Enemy of Nature. End of the Capitalism or the End of the World, Zed Books - Fernwood Publishing, New York - Halifax - Winnipeg 2007.). U tom duhu Rudi Supek odgovara »na poznatu porugu bavarskog konzervativca Franca Josefa Straussa da su 'zeleni kao paradajz, jer kad dozrijevaju, postaju crveni', protustavom: 'Crveni kad dozriju, postaju Zeleni.'« (Rudi Supek, Ova jedina zemlja. Idemo li u katastrofu ili u Treću revoluciju?, Globus, Zagreb 1989., str. 6.)

705 M. Horkheimer, »Pomrčina uma«, str. 68.

${ }^{706}$ Usp. M. Horkheimer, Th. Adorno, Dijalektika prosvjetiteljstva, str. 253. 
prethodnika građanskog mišljenja, od starih Židova, stoika i crkvenih otaca, pa kroz srednji i novi vijek, da je to kao malo koja ideja sastavni dio zapadne antropologije. I danas to je priznato. Behavioristi su samo prividno zaboravili na tu suprotnost. To što na ljude primjenjuju iste formule i rezultate koje razulareni u svojim strašnim laboratorijima iznuđuju životinjama bez obrane pokazuje tu razliku na posebno zao način. Zaključak koji donose na osnovi razmrvljenih životinjskih tijela ne pristaje uz slobodnu životinju nego uz današnjeg čovjeka. Time što zlostavlja životinju navješćuje da on i samo on u čitavom stvorenom svijetu dobrovoljno funkcionira tako mehanički, slijepo i automatski kao što životinje trzaju, vezane da bi ih stručnjak razmotrio. Profesor za stolom za seciranje to trzanje znanstveno definira kao reflekse, mantičar ih je na oltaru tumačio kao znakove svojih bogova. Čovjek ima um koji neumitno djeluje; životinja iz koje izvodi svoj krvavi zaključak ima samo bezimenu stravu, poriv za bijegom, koji joj je onemogućen. «07

Naš je odnos sa životinjama bitno posredovan znanstveno-tehnološkim svjetonazorom, u kojemu se na ovaj ili onaj način još uvijek zadržava mehanicističko razumijevanje stvarnosti, što puno više govori o samom čovjeku negoli o samoj stvarnosti. Sama znanost ne može se smatrati neutralnom s obzirom na njene često nepreispitane pretpostavke i skrivene svrhe, čije slijepo slijeđenje Horkheimer i Adorno s pravom dovode u analogiju s mitološkim predodžbama.

Marksizam ima izuzetnu vrijednost u osvještavanju pogubnosti simbioze instrumentalne racionalnosti i kapitalističkog uređenja po čovjekovo samoostvarivanje. Također, on može osvijetliti potencijalno bogatstvo tog samoostvarivanja, tj. ukazati na cjelovitost ljudskog bića. Kako tvrdi Petrović:

»... čovjek nije samo duh, nego je 'duh' samo jedan 'dio', 'strana' ili 'aspekt' čovjeka. Bilo bi čudno kad bi pitanje o odnosu jednog dijela čovjeka prema materiji ili prirodi bilo osnovno pitanje filozofije. Zar nije važnije pitanje o odnosu cjelovitog čovjeka prema svijetu u kojem živi? « ${ }^{708}$

$\mathrm{Na}$ tom tragu, valja otkloniti i nepomirljivost idealističkog i materijalističkog pristupa. Inspiraciju za to nalazimo, koliko god to izgledalo neobično, kod samog Marxa, a koja se onda naročito očitovala kod marksista poput frankfurtovaca i praksisovaca. ${ }^{709}$ Čak i tamo gdje je

\footnotetext{
${ }^{707}$ Ibid., str. 269. - Ovo dijelom citira i Visković u: N. Visković, Kulturna zoologija, str. 335. Za Adornovo pozicioniranje u pogledu moralnog obzira spram životinja vidi: Christina Gerhardt, »The Ethics of Animals in Adorno and Kafka«, New German Critique (2006) br. 97, str. 159-178.

${ }^{708}$ G. Petrović, Filozofija i marksizam, str. 78. - „Cijelo Marxovo djelo kao borba za čovjeka koji će se realizirati kao biće prakse, ujedno je zalaganje da se i teorijski i praktično provede distinkcija između autentičnog i neautentičnog bivstvovanja.« (Ibid., str. 82.)

709 »Taj je komunizam kao dovršeni naturalizam - humanizam, kao dovršeni humanizam = naturalizam, on je istinsko rješenje sukoba između čovjeka i prirode, između čovjeka i čovjeka, istinsko rješenje borbe između egzistencije i suštine, između opredmećivanja i samopotvrđivanja, između slobode i nužnosti, između individuuma i roda.«(K. Marx, »Ekonomsko-filozofski rukopisi«, str. 275.) »Ovdje vidimo kako se provedeni naturalizam ili
} 
naglašenije materijalist, kao u Njemačkoj ideologiji, koju piše zajedno s Engelsom, očituje se njegovo nepodlijeganje toj jednostavnoj podjeli kada tvrdi da »okolnosti isto toliko čine ljude koliko i ljudi okolnosti «. ${ }^{710}$ Prevedeno u jezik bioetike: nije naš zadatak samo postavljati etičke norme prema kojima valja u novoj situaciji ugroze sveg života postupati, nego i pojmiti te otkloniti materijalne uvjete pod kojima se ta ugroza zbiva, a time i iskrivljenu racionalnost koju oni porađanju.

\section{III.4.2.3. Kakvo ukidanje?}

Konačno se, u duhu ukidanja filozofije, može postaviti ključno pitanje našeg povijesnog trenutka: kakvu filozofiju ukinuti i na koji način? Sagledamo li ukidanje kao dijalektičko u onom smislu u kojem to Marx postavlja u svojim ranim radovima, tada bi valjalo upravo ukinuti današnju etiku koja mora strepiti nad sve neizvjesnijoj i strahovitijoj budućnosti i to kao zahtjev etike same! U svrhu odgovornog upravljanja našeg djelovanja u smjeru konkretnog omogućavanja samoostvarivanja svih živih bića danas je, više nego ikad, potrebno ovladati širokom paletom znanja. Takvo promišljanje prije nije bilo potrebno, naprosto zato što naša moć nije bila u stanju mijenjati uvjete života gotovo svih živih bića na planetu. Ovu promjenu uloge znanja u moralu jasno će izraziti Jonas:

»U takvim okolnostima znanje postaje prvenstvena obaveza koja nadilazi sve što se ikad uzimalo u obzir za njegovu ulogu, i to znanje mora, po veličini, biti izjednačeno s kauzalnim razmjerom našeg djelovanja. Međutim, pošto je činjenica da ono s njim, zapravo, ne može biti jednako po veličini, to jest pošto predskazujuće znanje zaostaje za tehničkim znanjem koje daje moć našem djelovanju, i sama ta činjenica poprima etičko značenje. Jaz između snage prethodnog znanja i moći čina proizvodi jedan novi etički problem. Priznanje neznanja, onda, postaje obratna strana obaveze da se zna, a time dio etike koja mora da podučava onu sve neophodniju samokontrolu naše prekomjerne moći. «111

Moralne dileme koje naše kolektivno djelovanje nameće svakom pojedincu sve više premašuju snage njihova moralnog suđenja, a upravo je dovođenje pojedinaca u takvu situaciju nemoralna radnja. Etika danas prije svega zahtjeva ograničavanje ljudske moći nad ne-ljudskom

\footnotetext{
humanizam razlikuje kako od idealizma, tako i od materijalizma, a istovremeno je njihova istina koja ih ujedinjuje.« (Ibid., str. 324.) Ili kako tvrdi Petrović: »Prema tome, niti je podjela na materiju i duh osnovna podjela cijelog svijeta u kome živimo, niti je to osnovna podjela u okviru čovjeka. Kako onda osnovno pitanje filozofije može biti pitanje o odnosu materije i duha? Nije li pitanje moguće samo uz izvjesne dualističke pretpostavke koje Marxov 'naturalizam-humanizam' isključuje?«(G. Petrović, Filozofija i marksizam, str. 79.)

${ }^{710}$ K. Marx, F. Engels, »Njemačka ideologija«, str. 384.

${ }^{711}$ H. Jonas, Princip odgovornost, str. 23.
} 
prirodom pa upravo stoga zahtjeva da se dio njenih zahtijeva ostvari na način da se ukine potreba za njenom intervencijom po nekim drugim pitanjima.

Ukidanje ove vrste ima svoje granice u tome što donekle promašuje poimanje ljudske slobode. Usprkos Marxu i nekim marksistima, samu etiku nemoguće je ukinuti, ne samo zato što se izgradnja svijeta u kojemu su nestali razlozi za njeno pojavljivanje čini nemogućom, nego i zato što uspjeh izgradnje tog svijeta ne bi garantirao čovjekovo stalno pridržavanje principa ispravnog djelovanja. Stoga se etika ne može potpuno ukinuti, tj. nadići, ali ona si svakako može i treba olakšati. Međutim, ostaju neki važni prostori koji su se za nju otvorili u ovom kriznom razdoblju, pri čemu prvenstveno mislim na one vezane uz moralni obzir spram neljudskih živih bića. Za njih, barem na planu teorije, vrijedi ona čuvena Hölderinova da tamo gdje raste opasnost, raste i ono spasonosno.

Promatramo li pak ukidanje naprosto kao negiranje, onda bismo tako trebali postupiti prema svakoj filozofiji koja izrasta iz pervertiranja racionalnosti proizašle iz tehno-znanstvene paradigme znanja i djelovanja. Ovo sačinjava i dio gore iznesenog zahtjeva, jer je smanjenje ljudske moći upereno prvenstveno protiv ove paradigme, koja zahtijeva njeno intenziviranje. Kako bi njeno negiranje moglo biti izvojevano, potrebno je udružiti sve silnice koje stoje nasuprot njoj. Ne samo udružiti, nego i obogaćivati jedne drugima u pluriperspektivnom dijalogu. Stoga, namjesto programatskog stava spomenutog na početku ovog poglavlja, usmjerenog na najkorjenitiji raskid sa svom povijesno izborenim idejama (što, ponavljam, ne pripada generalnom duhu Marxove misli), treba nastupiti integriranje tih znanja i perspektiva $u$ bioetičku paradigmu, koja ima afirmirati život u svim njegovim oblicima i potencijalima. Taj zadatak zahtijeva kako teorijski, tako i praktički rad, kako idealističke, tako i materijalističke elemente. On zahtijeva mišljenje i življenje slobode. 


\section{DOPRINOS NIKOLE VISKOVIĆA INTEGRATIVNOJ BIOETICI}

\section{IV.1. Nastanak bioetike}

Već smo ranije govorili o tome što je etika (a što moral) kao jedna od osnovnih filozofskih disciplina. No isto se tako tijekom cijelog rada provlači pojam 'bioetika', kao i 'integrativna bioetika', bez da se jasno ukazalo na njihovo značenje. Kako bi to bilo učinjeno, prije svega ćemo se kratko osvrnuti na sam njezin nastanak. Ona, barem za dio bioetičara (kojima i mi pripadamo), ima dvojicu očeva koji su neovisno jedan o drugome skovali termin i pružili definiciju tog pojma. Dugo se smatralo da je otac bioetike američki onkolog Van Rensselaer Potter, koji je početkom 70-ih godina 20. st. po prvi put (kako se tada mislilo) upotrijebio termin 'bioetika'. Međutim, tek se kasnije otkrilo da je formiranje termina i definiranje pojma bioetike još prije Pottera, sredinom 20-ih godina 20. st., izveo njemački teolog Fritz Jahr. Premda se tu ne radi o dva ista pojma, svakako je riječ o kompatibilnim konceptima koji se, zajedno s konceptualiziranjem određenih društvenih kretanja i uz produbljenu filozofsku refleksiju, pokušavaju objediniti u konceptu integrativne bioetike, koji je svoje rođenje i najintenzivniji razvoj doživio na našim prostorima.

\section{IV.1.1. Potterova ideja bioetike}

Svoju početnu koncepciju bioetike Potter je razradio u knjizi Bioetika. Most prema budućnosti (Bioethics. Bridge to the Future), kao i u nekim radovima koji su joj neposredno prethodili. Bioetika tu za Pottera ponajprije znači sintezu etičkih vrijednosti i bioloških činjenica. ${ }^{712}$ Potreba te vrste razvila se zahvaljujući iznimnom povećanju ljudske moći koja posredstvom tehnologije stvara novovrsne prijetnje, prije svega opstanku čovjekova života.

\footnotetext{
${ }^{712}$ Usp. Van Rensselaer Potter, Bioetika. Most prema budućnosti, prevela Ines Radinović, Medicinski fakultet u Rijeci, Katedra za društvene znanosti - Hrvatsko društvo za kliničku bioetiku - Hrvatsko bioetičko društvo Međunarodno udruženje za kliničku bioetiku (ISCB), Rijeka 2007., str. 23.
} 
Ono što zabrinjava jest to što takav tijek događaja ne zaokuplja pažnju znanosti, kako onih prirodnih, tako ni onih humanističkih. Potter upravo u njihovoj razdvojenosti nalazi jedan od ključnih uzroka takvog stanja stvari:

»Ukoliko postoje 'dvije kulture' za koje se čini kako ne mogu razgovarati jedna s drugom - prirodnih i humanističkih znanosti - te ako je ovo dijelom razloga zašto se budućnost čini upitnom, tada bi možda mogli izgraditi 'most za budućnost' izgradnjom discipline Bioetike kao mosta između dvije kulture. «113

Metafora bioetike kao mosta ovdje se koristi kako u smislu izgradnje zajedničkog prostora za dijalog prirodoslovlja i humanistike, tako i u smislu stvaranja znanja koje će osigurati sâmo postojanje budućnosti čovječanstva. Kao što integriranje različitih perspektiva pruža nadu za budućnost, tako i razdvojenost redukcionistički nastrojenih znanosti pobuđuje strahovanje nad njenom izvjesnošću.

»Čovječanstvu je hitno potrebna nova mudrost koja će pružiti 'znanje kako koristiti znanje' za čovjekov opstanak te za poboljšanje kvalitete života. Ovakav koncept znanja kao smjernice za djelovanje - znanje kako koristiti znanje za društvenu dobit - mogao bi se nazvati Znanost opstanka, a zasigurno je preduvjet za poboljšanje kvalitete života. « ${ }^{714}$

Potter se, međutim, čuva zalaženja u krajnosti, ističući vrijednosti kako redukcionističkog pristupa, $\mathrm{tj}$. minucioznog istraživanja visoko specijalizirane znanosti, tako i holizma, koji u prvom redu ima označavati cilj kojemu pojedini redukcionistički pristupi doprinose. ${ }^{715}$ Kasnije će u knjizi Globalna bioetika. Izgrađivanje na Leopoldovoj ostavštini (Global Bioethics. Building on the Leopold Legacy) donekle promijeniti naglasak, ističući kako se treba čuvati pretjerane specijalizacije, a težiti ka harmoniziranju različitih pristupa unutar bioetike u cilju preživljavanja na globalnoj razini. No Potter se pretjeranoj specijalizaciji protivio već znatno ranije, primjerice kada je 1962. predložio osnivanje »Instituta za integrirane studije prirodnih i humanističkih znanosti«, zahtijevajući širenje horizonata znanja. ${ }^{716}$

Bioetika, smatra Potter, mora biti izgrađena interdisciplinarno, pri čemu primarno ima u vidu područja »medicinske bioetike« i »ekološke bioetike«, prvo upravljeno kratkoročnim, drugo dugoročnim uvidima i ciljevima. Osim toga, ovdje je riječ o »evoluiranju etike« od one

\footnotetext{
${ }^{713}$ Usp. ibid.

${ }^{714}$ Ibid., str. 29.

715 Ibid., str. 35 .

${ }^{716}$ Usp. Amir Muzur, Iva Rinčić, Van Rensselaer Potter i njegovo mjesto u povijesti bioetike, Pergamena, Zagreb 2015., str. 62.
} 
međuljudske do razine na kojoj ona širi obzor na čitavu »biološku zajednicu«. ${ }^{717}$ Ono što je kod Pottera važno primijetiti, pored interdisciplinarnog pristupa suvremenim problemima, koji uvođenjem nekih spiritualnih elemenata vremenom postaje sve više pluriperspektivan, isticanje je opreznosti kao jednog od temeljnih načela koja danas imaju vrijediti u našem znanstvenom i drugom ophođenju barem spram drugih ljudi, još u svojim prvim nacrtima bioetike:

»Ono što ja tražim nije ni optimizam niti pesimizam, već informiran realizam koji obuhvaća poniznost: poniznost kojom ćemo priznati da nitko od nas ne zna kako bi društvo trebalo nastaviti dalje, poniznost koja nas tjera da slušamo kako bismo mogli iskoristiti misli drugih. « ${ }^{718}$

Nedugo nakon što je Potter skovao termin 'bioetika', isti se našao u nazivu instituta Joseph and Rose Fitzgerald Kennedy Institute for the Study of Human Reproduction and Bioethics (preimenovanog kasnije u Kennedy Institute of Ethics) koji je pri Sveučilištu Georgetown osnovao André Hellegers. ${ }^{719}$ Upitno je, prema Albertu Jonsenu, je li Hellegers upotrijebio taj termin bez da je znao za Potterovo autorstvo, što ne predstavlja jedinu dubiozu po pitanju nastanka tog termina (koju je Warren Reich »presjekao« tezom o istovremenom rođenju bioetike na dva mjesta, uz priznanje Potterova vremenskog prvenstva). ${ }^{720}$ Kako bilo, ono što je bioetika dobila institucionalizacijom, izgubila je redukcijom na biomedicinsku problematiku, kakva će je obilježiti u narednom dobu, a u velikoj mjeri i dan danas. Ovakvom će ustanovljenju bioetike kao ključna teorijska referentna točka poslužiti knjiga Principi biomedicinske etike (Principles of Biomedical Ethics) ${ }^{721}$ Toma L. Beauchampa i Jamesa F. Childressa, a četiri osnovna principa koja se u njoj promiču: autonomija, dobročinstvo, neškodljivost i pravednost, bit će nazvani Georgetown mantrom. Ovdje nije mjesto da ulazimo u kritiku ove koncepcije, ${ }^{722}$ u svrhu ovog rada bit će dovoljno spomenuti da ona s odricanjem od Potterove šire ideje istovremeno zatvara vrata i uključivanju ne-ljudskih živih bića u etička razmatranja, tj. ostaje na bitno antropocentričkim pozicijama.

\footnotetext{
${ }^{717}$ Usp. Van Rensselaer Potter, Global Bioethics. Building on the Leopold Legacy, Michigan University Press, East Lansing 1988., str. 74, 78.

718 V. R. Potter, Bioetika, str. 192.

${ }^{719}$ Usp. I. Rinčić, A. Muzur, Fritz Jahr i rađanje europske bioetike, str. 83.

${ }^{720}$ Usp. Albert R. Jonsen, The Birth of Bioethics, Oxford University Press, New York 1998., str. 26-27, Warren Thomas Reich, »The Word 'Bioethics': Its Birth and the Legacies Who Shaped It«, Kennedy Institute of Ethics Journal 4 (1994) 4, str. 319-335; Warren Thomas Reich, »The Word 'Bioethics': The Struggle Over Its Earliest Meanings«, Kennedy Institute of Ethics Journal 5 (1995) 1, str. 19-34; I. Rinčić, A. Muzur, Fritz Jahr i rađanje europske bioetike, str. 83-85.

${ }^{721}$ Vidi: Tom L. Beauchamp, James F. Childress, Principles of Biomedical Ethics, Oxford University Press, Oxford - New York 2001.

${ }^{722} \mathrm{U}$ tu svrhu vidi mjesta na kojima se Eterović osvrće na nju u: I. Eterović, Kant i bioetika.
} 


\section{IV.1.2. Jahrova ideja bioetike}

Ako je tzv. Georgetown mantra svođenjem bioetike na novu biomedicinsku etiku promašila Potterovu viziju, onda je još više promašila onu Jahrovu, koja svoju pažnju jedva da usmjerava prema medicini. O nju se pak nije ogriješila, jer se tu radi o otkriću koje je nastalo na prijelazu između 20. i 21. stoljeća i koje prije toga nije imalo utjecaja na razvoj bioetike. Riječ je o otkriću »drugog oca« ili »zaboravljenog djeda« bioetike, njemačkog protestantskog pastora i teologa Fritza Jahra, koji je, koliko zasad znamo, prvi upotrijebio termin, ali i pružio objašnjenje i definiciju pojma 'bioetika'.

Jahrova koncepcija, međutim, polazi od bitno drugačijih problema nego ona Potterova. U njoj nema spomena (jer još nema izravnih saznanja) o opasnostima tehno-znanstvenog napretka i prijetnji opstanku ljudske vrste na Zemlji, a njegov pojam bioetike u namjeri slijedi etimologiju svog termina, ${ }^{723}$ usmjeravajući se prema etici koja u svoj obzor uzima svako živo biće. Tako on, po uzoru na tzv. drugu formulaciju Kantova kategoričkog imperativa, formulira »bio-etički imperativ«: »Poštuj svako živo biće u načelu kao svrhu u sebi i po mogućnosti postupaj s njim kao takvim! « ${ }^{724}$

Ovakav imperativ, međutim, nije samo plod filozofske spekulacije, nego i novih prirodoznanstvenih saznanja, koje Jahr često kombinira s religijskim učenjem. Za razliku od mnogih teologa njegova vremena, Jahr uočava podudarnost prirodoznanstvenih otkrića, naročito nakon Darwinova doprinosa, s naukom Svetog pisma u pogledu bliskosti čovjeka i životinje. Tako on upućuje na često zanemarene biblijske poruke o životinjskoj duši, koje nalazi još u prvoj Mojsijevoj knjizi. ${ }^{725}$ Jahrova otvorenost, s obzirom na historijski kontekst i kontekst njegove profesije, pokazuje začuđujuće razmjere, stavljajući, primjerice, Franju Asiškog i

\footnotetext{
${ }^{723}$ Ovdje se ipak ne radi o potpunoj etimološkoj dosljednosti. Naime, u grčkom jeziku termin bios nije označavao čitav život nego upravo onaj ljudski, odnosno specifične forme njegova života (primjerice bios theoretikos). Tako je, svjesno slijedeći ovo ili ne (a češće se radi o ovom drugom), »bioetika uglavnom sagledavana kao ona koja se bavi novim etičkim problemima vezanima uz ljudski život, tijelo i zdravlje (npr. biomedicinskim istraživanjima, kliničkom praksom, zdravstvom, okolišnim uvjetima itd.), premda su prve i ključne koncepcije bioetike sugerirale nešto drugo.« (Hrvoje Jurić, »From the Notion of Life to an Ethics of Life«, Synthesis Philosophica 30 (2015) 1, str. 33-46, ovdje str. 34.)

${ }^{724}$ Fritz Jahr, »Znanost o životu i nauka o ćudoređu (Stare spoznaje u novom ruhu)«, preveo Amir Muzur, u: Iva Rinčić, Amir Muzur, Fritz Jahr i rađanje europske bioetike, Pergamena, Zagreb 2012., str. 197-200, ovdje str. 200. - Riječ je o prvom članku u kojemu se spominje termin bioetika (njem. Bio-Ethik), zajedno s objašnjenjem pojma koji označava. Ista formulacija nalazi se (zajedno s formulacijom u izvorniku) i u: Fritz Jahr, »Bio-etika: osvrt na etički odnos čovjeka prema životinjama i biljkama«, preveo Amir Muzur, u: Iva Rinčić, Amir Muzur, Fritz Jahr i rađanje europske bioetike, Pergamena, Zagreb 2012., str. 201-205, ovdje str. 205.

${ }^{725}$ Usp. Fritz Jahr, »Smrt i životinje: razmatranje Pete zapovijedi«, preveo Amir Muzur, u: Iva Rinčić, Amir Muzur, Fritz Jahr i rađanje europske bioetike, Pergamena, Zagreb 2012., str. 207-211, ovdje str. $207-208$.
} 
Buddhu u isti red. Međutim, ono što osobito iznenađuje, njegovo je skladno prihvaćanje Darwinova učenja, koje i dan danas najčešće izaziva odbojnost kod kršćanskih teologa.

»... svrhovita i učinkovita zaštita životinja moguća je samo onda kada postoji zadovoljavajuće poznavanje prirode i barem donekle njeno razumijevanje. Jer doista se životinje može samo onda istinski zaštititi ako se donekle poznaje njihova fiziološka i psihološka svojstva i uvjete života. Odatle je glavnim ciljem pokreta za zaštitu životinja da se takva znanja i takvo razumijevanje prirode prema mogućnosti i probudi, proširi i produbi. Takav interes za prirodu neće se potom sam od sebe ograničiti na životinje, već će morati s jedne strane uključiti i biljke, a s druge strane i čovjeka $(. ..) \ll^{726}$

Otvorenim razmatranjem svojstava životinja i biljaka ne možemo zanemariti neka od njih koja nam nalažu dužnost moralnog obzira spram tih bića. Jahr tu u prvom redu misli na osjećajnost, tako da, na Schopenhauerovu tragu, kao istinski moralni motiv ideje zaštite životinja ističe suosjećanje. ${ }^{727} \mathrm{Jahr}$ također iznosi neke za to vrijeme nove spoznaje u biologiji i psihologiji, među koje uključuje i začetke istraživanja o psihologiji biljaka, nalazeći u oduševljenosti svih živih bića osnovu za njihovo uvođenje u moralni obzor. ${ }^{728}$ Taj znanstveni proboj bitno utječe na formiranje etike:

»Od biopsihike je tek jedan korak do bio-etike, tj. do prihvaćanja etičkih dužnosti ne samo prema ljudima, već prema svim živim bićima. Zapravo, bioetika uopće nije otkriće našeg vremena. Već je teolog Schleiermacher proglasio nemoralnim da se život i obličje, tamo gdje ih ima, dakle i kod životinje i kod biljke, uništavaju, ukoliko to nije povezano s razumnom svrhom. Još prije njega je pjesnik Herder od čovjeka očekivao da se, po uzoru na božanstvo koje svojim osjećajem u sve proniče, presadi u svako stvorenje i da s njime suosjeća u onoj mjeri u kojoj je to stvorenju potrebno. Isto zahtijeva i filozof Krause, Schleiermacherov suvremenik, da se svako živo biće kao takvo tretira i da se ne smije uništavati bez svrhe. Jer svi su, biljke i životinje jednako kao i čovjek, ravnopravni - svakako ne u istome, nego svaki u onome što je nužnim zahtjevom za postignuće njegova određenja.« ${ }^{729}$

Problem za Jahrovu poziciju javlja se ako uzmemo u obzir posvemašnju neprihvaćenost teorija o psihologiji biljaka u znanstvenoj zajednici. Međutim, Jahr u nekoliko različitih pozicija koje navodi pruža neke ideje koje bi mogle postati plodnije po pitanju uključenja biljaka u moralni obzor. U njegovu obranu možemo reći da se ovdje mahom radi o kraćim člancima u popularnim ili srednjoškolskim listovima, koji su prije usmjereni nabacivanju različitih pozicija

\footnotetext{
${ }^{726}$ Fritz Jahr, »Zaštita životinja i etika u svom međusobnom odnosu«, preveo Amir Muzur, u: Iva Rinčić, Amir Muzur, Fritz Jahr i rađanje europske bioetike, Pergamena, Zagreb 2012., str. 213-218, ovdje str. 215.

${ }^{727}$ Usp. ibid., str. 213.

${ }^{728}$ Usp. F. Jahr, »Znanost o životu i nauka o ćudoređu (Stare spoznaje u novom ruhu)«, str. 197.

${ }^{729}$ Ibid., str. 198.
} 
za promišljanje naznačenog problema i buđenju senzibiliteta za njega, negoli studioznom izvođenju etičkih principa.

\section{IV.2. Integrativna bioetika kao produbljivanje prvih impulsa}

Kod obaju ovih izvornih bioetičkih pozicija nalazimo izuzetno vrijedne elemente za usustavljenje etičkog promišljanja novovrsne globalne situacije. One se slažu u potrebi interdisciplinarnog pristupa, kao jedinog načina na koji se mogu pružiti smisleni praktički odgovori na tu novu situaciju (Potter) ili kao jedinog prikladnog odgovora na nova znanstvena otkrića (Jahr). Također, obje idu u smjeru širenja našeg moralnog horizonta, iako često nije jasno u čemu se sastoji osnovica njihove etike, odnosno u čemu se utemeljuje moralitet.

Bitni su nedostatci Potterove koncepcije bioetike izostanak njenog filozofskog konceptualiziranja, koji se onda izražava u njenom određenju kao životne mudrosti, u formuliranju »bioetičkog vjerovanja« i sl., te izostanak promišljanja integrativnih faktora između različitih problema i pristupa, tj. izostanak integrativne metodologije. ${ }^{730}$ Bez obzira na to, vizija bioetike koja će osim biomedicinskih problema obuhvatiti i one vezane uz čitavu prirodu te inzistiranje na interdisciplinarnosti i opreznosti važne su Potterove zasade za daljnji razvitak bioetike. Potreba za interdisciplinarnošću implicitna je i Jahrovoj poziciji. Jahr se malo više približava konceptualiziranju svoje etičke pozicije, ali istovremenim pozivanjem na nekoliko autora čije se etike djelomično ili potpuno isključuju (primjerice ona Kantova i ona Schopenhauerova), čini utemeljenje svoje bio-etike izloženim kritici.

Zadatak koji si integrativna bioetika postavlja može se okarakterizirati upravo kao teorijsko produbljenje ovih prvih impulsa. To se osobito očituje na filozofskom planu. Počevši od onog filozofsko-povijesnog, može se reći, zajedno s Čovićem, da nova epoha, koje smo suvremenici od eksplozije atomske bombe nad Hirošimom, s obzirom na dominantni tip znanja zaslužuje naziv bioetičke epohe. ${ }^{731}$ Taj čin, koji je prouzrokovao prvu radikalniju sumnju u znanstveno-tehnološku paradigmu znanja, otvara bioetičku epohu, ali prije nametanjem

\footnotetext{
${ }^{730}$ Usp. H. Jurić, Etika odgovornosti Hansa Jonasa, str. 251-253. - Potter ponekad tek spominje neka područja moguće integracije, ali bez dublje razrade. Tako, primjerice, za područja medicinske i ekološke bioetike kaže: »Međutim, ove se dvije grane bioetike trebaju prikladno preklapati po pitanju individualnog ljudskog zdravlja, kontrole ljudske reprodukcije te držanja spram važnosti stalnog povećanja rasta ljudske populacije.« (V. R. Potter, Global Bioethics, str. 74, 76.)

${ }^{731}$ Usp. A. Čović, Etika i bioetika, str. 65.
} 
teorijskog zadatka izgradnje nove paradigme znanja, negoli njenim spontanim izrastanjem. Za tu izgradnju, kako je već naznačeno, Potter i Jahr daju važne sadržajne i metodološke impulse, ali oni dolaze i iz samih društvenih kretanja. Bioetika tako ne izrasta samo kao intelektualni, nego i kao društveni pokret. Štoviše, početak bioetike možda se prije treba tražiti u potonjem, dakle, u pokretima potaknutima problemima koje je proizveo znanstveno-tehnički razvoj poput zahtjeva građana za većim nadzorom zdravstvenog sustava, ali i anti-nuklearnog pokreta, ekološkog pokreta itd. ${ }^{732} \mathrm{Za}$ nultu točku nastanka bioetike često se uzima osnivanje etičkog komiteta u Seattleu 1962., čija je specifičnost bila mješovito povjerenstvo (koje je pored dvoje medicinara uključivalo sedmoro medicinskih laika ${ }^{733}$ ), kako bi se kompleksan problem sagledao s različitih perspektiva. Tu nije samo riječ o uviđanju granica redukcionističkog znanstveno-tehnološkog znanja:

\begin{abstract}
»Tako sastavljeno povjerenstvo nosilo je dalekosežnu poruku da se moralna pitanja, koja je potencirao znanstveno-tehnološki napredak u medicini, ne mogu više smatrati stručnim potpitanjima niti rješavati u stručnim okvirima. Štoviše, da se ni moralni aspekti stručnih problema ne mogu rješavati izdvojeno, nego da probleme s izrazitim moralnim dvojbama treba rješavati svestrano, uz istodobno sagledavanje svih ili barem glavnih njihovih aspekata. Utoliko je u sastavu i načinu rada prvog bioetičkog komiteta u embrionalnom obliku sadržano metodološko ustrojstvo bioetike i simbolički naznačen bioetički pluriperspektivizam kao način sagledavanja i rješavanja ne samo moralnih nego i općecivilizacijskih problema. $\ll^{734}$
\end{abstract}

Može se reći da integrativna bioetika teorijski usustavljuje i produbljuje ove prve impulse za izgradnju nove paradigme znanja. Odgovorno znanje, koje bi imalo smijeniti paradigmu znanja kao moći, kao ideal nameće potrebu za pluriperspektivnim sagledavanjem određenog problema, pri čemu etička refleksija treba zauzimati središnje mjesto, kao brana bezumnosti, odnosno »teorijskom apsurdizmu«. Već se u samom idealu odgovornog znanja takvo postavljanje nadaje kao nužnost, jer je sama odgovornost etička kategorija.

\title{
IV.2.1. Pluriperspektivizam
}

Jedan od temeljnih tekstova za poimanje pojma 'pluriperspektivizam', naročito u okviru integrativne bioetike $\mathrm{u}$ kojem je on $\mathrm{i}$ nastao, Čovićev je članak »Pluralizam i

\footnotetext{
${ }^{732}$ Usp. Ivana Zagorac, Hrvoje Jurić, »Bioetika u Hrvatskoj«, Filozofska istraživanja 28 (2008) 3, str. 601-611, ovdje str. 601-602.

${ }^{733}$ Vidi: Shana Alexander, »They Decide Who Lives, Who Dies«, Life 9. 11. 1962., str. 102-125.

${ }^{734}$ A. Čović, Etika i bioetika, str. 114.
} 
pluriperspektivizam«. On tu polazi od razlikovanja pojma pluralizma u području filozofije na institucionalni i supstancijalni. Prvi označava »pluralizam filozofskih orijentacija ili misaonih pristupa $\ll$ u pogledu njihove formalne ravnopravnosti i prava na institucionalno postojanje. No supstancijalni pluralizam, ako bi se prihvatilo da svaka filozofska pozicija pretendira na (apsolutnu) istinitost, ne podnosi ovakvu ravnopravnost. ${ }^{735}$

Pluralizmu, nastavlja Čović, blizak je pojam perspektivizma, koji upućuje na relativnost spoznaje, tj. njezinu uvjetovanost historijom i kulturom. Tu je riječ o relativističkom perspektivizmu, onome koji u slučaju izoliranosti spoznajnih perspektiva nužno, kako mu ime kaže, završava u relativizmu. No ako se perspektivizam postavi interaktivno, to ne mora biti slučaj. Naime, ako interaktivnost preraste u integrativnost, ova može dovesti do cjelovite istine. Tek se u ovome obliku supstancijalni pluralizam ili integrativni pluralizam perspektiva filozofski može održati, u obliku pluriperspektivizma. ${ }^{736}$

\begin{abstract}
»Doduše, netko bi mogao zastupati i pluralizam istinâ, samo što bi mu svaka daljnja tvrdnja u najmanju ruku bila suvišna. Istina se može pluralizirati samo 'prema unutra', može se umnogostručavati u svojim aspektima. Monizam istine nužna je pretpostavka svih spoznajnih napora, svih rasprava i polemika, svake izmjene i sukoba mišljenja. Monizam istine odgovara jedinstvu uma.

Unutrašnji pluralizam istine nazivamo pluriperspektivizmom, a sastoji se u mnogostrukosti njezinih aspekata i mnoštvenosti perspektiva u kojima se oni sagledavaju. No, istina nije samo teorijski nego i praktički pojam, ona podjednako sabire spoznajne i egzistentne perspektive. U različitim razvrstavanjima i grupiranjima perspektivâ neizbježne su upravo navedene perspektivne strane, dok se iz njihova međusobnog odnosa, iz uspostavljene konstelacije generira duh vremena i konstituira specifični karakter određene svjetsko-povijesne situacije, koju obično nazivamo epohom. « ${ }^{737}$
\end{abstract}

Upravo perspektivna jednostranost i redukcionizam, tvrdi Čović, predstavljaju ozbiljno ograničenje, ali i znakove dotrajalosti, tj. iscrpljivanja unutrašnjih mogućnosti novog vijeka kao znanstveno-tehnološke epohe. Da se istina ovdje javlja kao praktički pojam sasvim je jasno u pogledu dezorijentiranosti kojom je ova epoha rezultirala, kao i pogubnostima perpetuiranja znanstveno-tehničkog napretka. ${ }^{738}$ Pored toga:

»Perspektivna jednostranost novovjekovlja sastoji se u svođenju istine na njezinu teorijsku stranu, te reduciranje teorijske strane na kontemplaciju činjenica u formi egzaktne znanosti. Amputirana praktička

\footnotetext{
${ }^{735}$ Usp. Ante Čović, »Pluralizam i pluriperspektivizam«, Filozofska istraživanja 26 (2006) 1, str. 7-12, ovdje str. 7-8.

${ }^{736}$ Usp. ibid., str. 8-9.

${ }^{737}$ Ibid., str. 8.

${ }^{738}$ Usp. ibid.
} 
strana istine nadomještena je tehničkom protezom, praktičnom primjenom egzaktno kontempliranih činjenica, da bi u konačnici i sama praktička primjena, tj. tehnika postala područjem znanosti. Time je zatvoren krug novovjekovnog poimanja istine, te uspostavljen znanstveni monoperspektivizam kao duhovno obilježje epohe. « ${ }^{739}$

Upravo su prva bioetička povjerenstva, koja su se suočavala s novom medicinskom situacijom, ona čiji je rad najavio pluriperspektivnu metodologiju. Naime, ona »nisu ništa drugo do institucionalizacija bioetičkog pristupa«, pa se s obzirom na to može tvrditi »da metodološki pluriperspektivizam svoju institucionalnu formu dobiva upravo u laicizmu bioetičkih tijela«. ${ }^{740}$

Dakle, ono što se kroz suočavanje s bioetičkim problemima očitovalo kao potrebno širenje je i produbljivanje različitih, recimo to tako, pristupa koji na ovaj ili onaj način okupljaju više disciplina i koji u konačnici dovode do pluriperspektivnosti. Takvi se pristupi šire od multidisciplinarnosti kao naprostog okupljanja znanosti i djelatnosti relevantnih za bioetička pitanja, preko interdisciplinarnosti kao poticanja dijaloga i nalaženja načina za suradnju tih disciplina i transdisciplinarnosti kao nadilaženja međusobnih razlika u okviru jedinstvenog, bioetičkog pogleda (da teži zbiljskoj, a ne tek mehaničkoj integraciji), sve do pluriperspektivnosti kao objedinjavanja i dijaloškog posredovanja znanstvenih i izvanznanstvenih pristupa. ${ }^{741}$ Kako glasi definicija Hrvoja Jurića, pisana kao leksikonska bilješka:

"pluriperspektivizam (latinski plus, genitiv pluris: više i perspektivizam), u filozofiji, posebice spoznajnoj teoriji, teoriji znanosti i bioetici nazor o karakteru orijentacijskog znanja koje se postiže interakcijom raznovrsnih spoznajnih perspektiva. Budući da se po tom shvaćanju istina može umnogostručavati samo u svojim raznorodnim očitovanjima, p. tu raznorodnost nastoji sagledati integralistički, tj. povezati ju s obzirom na po sebi jednu istinu. Kao filozofski pojam p. je prvi put filozofski artikuliran na simpoziju Hrvatskoga filozofskog društva 'Filozofija i pluralizam' (Zagreb, 2425. XI. 2005). Teorijsko ishodište ideja pluriperspektivizma ima u kategorijalnim razlikovanjima kojima su J. Mittelstraß i F. Kaulbach izrazili potrebu za rehabilitacijom i novim zasnivanjem orijentacijskog znanja u doba znanstvenog redukcionizma. Utvrđujući pojmovnu razliku između '(parcijalnog) znanja o ovladavanju prirodom i društvom' i '(univerzalnog) znanja o orijentiranju u prirodi i društvu', koju terminološki fiksira kao 'uporabno i orijentacijsko znanje', Mittelstraß zaključuje kako je u modernim 'tehničkim kulturama' posve nestao orijentacijski oblik znanja. Na sličan način Kaulbach razgraničava 'objektnu i smisaonu istinu' te se zalaže za rehabilitiranje 'spoznaje koja pruža orijentaciju u svijetu'. Nastavljajući tu liniju mišljenja p. se razvija kao posebno razumijevanje istine i kao metodološka podloga

\footnotetext{
${ }^{739}$ Ibid., str. 8-9. - »Tamo gdje je znanje bez cjeline jednog svjetonazora, ono se cijeni prema svojoj tehničkoj uporabljivosti. Za to je odličan primjer biotehnologija koja je dopustila ekonomsku suradnju (i zato su-kreiranje) znanosti i tehnologije gdje je objektivnost kompromitirana zavodljivim sirenskim zovom kapitala.« (Slavko Amulić, Perspektivizam i pluralizam. Prilog zasnivanju pluriperspektivizma, Pergamena, Zagreb 2019., str. 7-8.) ${ }^{740}$ A. Čović, Etika i bioetika, str. 117.

${ }^{741}$ Usp. H. Jurić, Etika odgovornosti Hansa Jonasa, str. 240-241.
} 
za postizanje orijentacijskog znanja. Za razliku od perspektivizma, koji se u konačnici ispostavlja kao spoznajni relativizam, p. ističe zahtjev za općevažećom spoznajom koja uzima u obzir različite znanstvene uvide (interdisciplinarnost), ali i one neznanstvene, koji se u pozitivnoj formulaciji nazivaju 'kulturnim perspektivama'. U bioetičkoj raspravi, koja se u sklopu posebnog projekta od 2004. vodi u području jugoistočne i središnje Europe, p. je prihvaćen kao metodološko određenje u međunarodnim razmjerima afirmirane koncepcije integrativne bioetike. $\ll^{742}$

Prema Kaulbachu, perspektivistička filozofija otkriva da istina o svijetu nikako nije neovisna o položaju koji spram njega zauzimamo i načinu na koji ga tumačimo te »pod kojim vidom u njemu djelujemo«. Pri tome on ne namjerava uspostaviti relativističku koncepciju, već artikulirati istinu s obzirom na pojmove pozicioniranja, stava prema bitku i njemu odgovarajuće perspektive, a onda i s obzirom na prelaženje s jedne na njoj superiorniju perspektivu. Bitan uvid perspektivističkog mišljenja je i sloboda koju upražnjava, primjerice, slikar dok odabire perspektivu koja će mu objekt dovesti u pogled na optimalan način, no ništa se drugačije ne ponaša ni znanstvenik. Stoga je ovdje odlučujuća namjera. ${ }^{73}$ To otkriva širok prostor mogućnosti koje stoje u osnovi znanstvenog znanja, koje nije osuđeno na metodu kakvu mu je zadala znanstveno-tehnološka paradigma. No kako za sada stvari stoje, pogođenim držimo i Kaulbachovo razdvajanje objektne istine, koja bi pripadala svijetu prirodnih znanosti, te smisaone istine, pripadne svijetu slobode. ${ }^{744}$

»... vidimo da je 'integrativna bioetika' nastala kao pokušaj da se mnoštvenosti života u svim njegovim konkretno-povijesnim samoočitovanjima odgovori polazeći od života samoga. Zbog toga 'metoda' integrativne bioetike ne može biti nikakav prethodno dani znanstveno-teorijski konstrukt; ona svoj pristup životu crpi upravo iz njega samoga, dakle, ne više objektivistički, već smisaono. Tek se zahvaljujući tomu 'integrativna bioetika' uzdiže iznad razine puke pojedinačne znanstvene discipline te na smisaonorazumijevajući način ulazi u sve konkretne probleme čovjekova povijesnog životnog svijeta, ujedinjujući pritom temeljno ontologijsko razumijevanje čovjekova bitka u svijetu s nedodirljivom i nepovredivom (integritas) strukturom života koji time prestaje biti puka, bilo duhovnoznanstvena ili prirodoznanstvena 'kategorija', nego se uvijek iznova pojavljuje kao jamstvo valjanosti bilo koje postignute 'integracije', u odnosu na koju u vodu pada svaki zahtjev za objektivnošću i općim važenjem (Allgemeingültigkeit) bilo koje znanstvene spoznaje. ${ }^{745}$

\footnotetext{
${ }^{742}$ Prema Željko Pavić, »'Pluriperspektivizam' - slučaj jedne natuknice u Filozofskome leksikonu«, Filozofska istraživanja 34 (2014) 4, str. 577-600, ovdje str. 581.

${ }^{743}$ Friedrich Kaulbach, Philosophie des Perspektivismus, sv. 1, Wahrheit und Perspektive bei Kant, Hegel und Nietzsche, Mohr, Tübingen 1990., str. 1-5.

${ }^{744}$ Usp. ibid., str. 16.

745 Ž. Pavić, »'Pluriperspektivizam' - slučaj jedne natuknice u Filozofskome leksikonu«, str. 587.
} 
Prema Kaulbachu, tek smisaona istina, pripadna svijetu slobode, može pružiti orijentaciju u svijetu: »Spoznaja koja pruža orijentaciju u svijetu ima perspektivističko značenje, ona se ne zasniva na znanju o objektivnom bitku svijeta. « ${ }^{746}$

Kako je gore rečeno, kategoriju orijentacijskog znanja uvodi Jürgen Mittelstraß, misleći pod njome ono što smo više puta isticali kroz ovaj rad u vidu kritike instrumentalnog pristupa prirodi, što u konačnici vodi do gušenja kritičkih (što onda znači i emancipacijskih, barem kao njihov uvjet) potencijala racionalnosti:

»... moderna industrijska društva sve se više prezentiraju kao tehničke kulture, s posljedicom rastućeg osobnog nezadovoljstva, još samo (parcijalnim) uporabnim znanjem o prirodi i društvu, a bez (univerzalnog) orijentacijskog znanja $u$ prirodi i društvu; znanost je dopustila unutar društvenoga degradaciju kritičkog i orijentacijskog potencijala pod nametnutom joj paradigmom tehničke racionalnosti. $\ll^{747}$

Stoga se unutar tako strukturirane znanosti ne može kretati ideja bioetike i njezine metodologije koja bi se oslanjala na Kaulbachove i Mittelstraßove ideje. U tom svjetlu i Čović ističe ograničenja označavanja bioetičkog pristupa kao multi- ili interdisciplinarnog, prvenstveno u vidu uklapanja bioetike u postojeći znanstveni sustav koji ona nastoji nadići promjenom strategijskog cilja znanja pa i drukčijim strukturiranjem znanosti. Time što u obzir uzima i ne-znanstvene perspektive, njezino je »metodološko ustrojstvo primjerenije označiti kao pluriperspektivizam. $\ll^{748}$

»'Pluralizam' i 'interdisciplinarnost' predstavljaju puki 'transfer' znanja iz jedne znanosti u drugu, gdje to usvojeno znanje uopće ne suodređuje način spoznavanja znanosti koja ga preuzima, već isključivo služi samo za njezine samopostavljene spoznajne i spoznajno-praktične ciljeve. $\ll^{749}$

Upravo to suodređivanje možemo uvidjeti na pitanju koje se kroz čitav ovaj rad postavlja kao centralno, a to je ono širenja našeg moralnog horizonta na ne-ljudska živa bića. Prije kratkog izvođenja primjene pluriperspektivne metodologije na ovaj problem, ukažimo i na to da se ovdje ne radi, kako Eterović kaže, o metodologiji u klasičnom smislu riječi. Tu je prije riječ o načinu pristupa rješavanju problema, a ne strogo definiranom alatu ili klasičnom

\footnotetext{
${ }^{746}$ F. Kaulbach, Philosophie des Perspektivismus, sv. 1, str. 214. Prijevod i prethodna misao preuzeti od: A. Čović, »Pluralizam i pluriperspektivizam«, str. 10-11.

747 Jürgen Mittelstraß, Wissenshaft als Lebensform. Reden über philosophische Orientierungen in Wissenschaft und Universität, Suhrkamp Verlag, Frankfurt am Mein 1982., str. 7. - Citirano prema prijevodu u: I. Eterović, Kant i bioetika, str. 267.

${ }^{748}$ Usp. A. Čović, Etika i bioetika, str. 117.

749 Ž. Pavić, »'Pluriperspektivizam' - slučaj jedne natuknice u Filozofskome leksikonu«, str. 584.
} 
kanonu pravila i metoda. Nju primarno obilježava stalna otvorenost prema dijalogu, a oslanja se na kritički potencijal, refleksivnost i praktičku razboritost istraživača. ${ }^{750}$

\begin{abstract}
»Jednostavno rečeno, pluralitetu ne možemo izbjeći ni kada je u pitanju etika kao znanost o dobru, jer je dobro pitanje okolnosti i trenutka pa, stoga, i točka gledišta i perspektive. Etičko promišljanje, phronesis, doduše uključuje opća shvaćanja, na primjer znanje da svaka etička vrlina leži u sredini dviju krajnosti. (...) ali je onda presudno da se ta opća shvaćanja ispravno primijene u pojedinačnom slučaju, a to znači: ono što uvjetuje pojedinačna situacija. Važno je u određenom trenutku i okolnostima pronaći ono što je ispravno, jer praktičko znanje ne može biti općeg oblika, nego mora sadržavati znanje ili znanja koja su uvjetovana situacijom, točkom gledišta i perspektivom. « ${ }^{751}$
\end{abstract}

Iluzorno je od bioetike zahtijevati metodologiju kakvu nalazimo u prirodnim znanostima, koja bi pružala »algoritamski mehanizam za uspoređivanje različitih normativnih zaključaka «, ${ }^{752} \mathrm{~s}$ obzirom na to da je isto iluzorno tražiti i od klasične etike, ne samo u pogledu dogovora etičara oko pružanja konkretnih smjernica za ljudski život, nego i u okvirima mnogih etičkih pozicija koje unutar sebe odbijaju algoritamski pristup. Uzme li se u obzir, primjerice, kantijanska pozicija, ovakav bi pristup ozbiljno ugrozio samu autonomiju racionalnog subjekta, čime bi se, zapravo, moralno djelovanje potpuno obesmislilo.

Stoga bi prilaženje bioetičkoj problematici kakva je ona moralnog obzira spram neljudskih živih bića prije svega zahtijevalo preispitivanje samog moralnog subjekta, prvenstveno u pretresanju njegove autonomije - nikako ograničene na pojam autonomije korišten u okviru principalizma - kao preduvjeta njegova moralnog djelovanja, ali $\mathrm{i}$ forme njegova samoostvarivanja. Tu se u istom koraku ispituje njegova sloboda, njegova odgovornost, pa time i odgovornost nas kao vanjskih promatrača za njegovu slobodu i za samoostvarivanje onih bića kojima ta osoba pristupa. Time etika više ne može funkcionirati unutar bjelokosne kule propitivanja djelovanja od moralnih principa $\mathrm{k}$ procjeni konkretnih djelovanja i nastrojstva volje onih koji ih pokreću, nego mora ozbiljno uzeti u obzir druge znanstvene i ne-znanstvene perspektive - čak se i suodrediti s njima. Ona tu ne može zatvarati oči pred determinantama društveno-ekonomskog uređenja, ideologije, određene kulture, nesvjesnoga itd. Praksa razdvojenog razmatranja ovih determinanti, od strane međusobno odvojene sociologije,

\footnotetext{
${ }^{750}$ Usp. I. Eterović, Kant i bioetika, str. 64.

${ }^{751}$ S. Amulić, Perspektivizam i pluralizam, str. 22.

${ }^{752}$ Daniel Adler, Randi Zlotnik Shaul, »Disciplining Bioethics: Towards a Standard of Methodological Rigor in Bioethics Research «, Accountability in Research 19 (2012) 3, str. 187-207, ovdje str. 201. - Osim što ovaj članak pokušava pružiti jednu algoritamsku metodologiju, on pruža dobar pregled nekih drugih (po mišljenju autora mahom bezuspješnih) pokušaja da se uradi isto. $\mathrm{S}$ obzirom na to da ni sam ne pruža model jedne takve metodologije, on više predstavlja puki apel za nečim što je, čini se, neizvedivo.
} 
političke teorije, etnologije, kulturologije, psihoanalize itd., rezultira posvemašnjom dezorijentacijom. Pored toga, etika ne samo da je odbijala dijalog s navedenim disciplinama, što predstavlja još jednu zadanost novovjekovnog razdvajanja prvo etike i politike, a onda etike i ekonomije, nego ih je nerijetko promatrala kao ugrozu, što je, primjerice, slučaj sa psihoanalizom (otkrivanje jedne sfere neslobodnog u jastvu) ili marksističkom ukazivanju na uvjetovanosti kojima su pojedinačne etike bile izložene (što je već ranije raspravljeno). No te ugroze nisu ništa više no ukazivanja na izvjesna ograničenja tradicionalne etike, tj. trebale bi se usvojiti kao prilika za stvaranje jedne transdiscipline kakva je bioetika, u kojoj različite znanosti i ne-znanosti ne stupaju u dijalog čvrsto se držeći svojih tradiranih metodologija, nego pokušavaju sa svoje strane doprinijeti zajedničkom odgovoru na pitanje: što da se radi?

Ono čime etika može zahvaljujući svom instrumentariju doprinijeti ovoj raspravi prvenstveno je izgrađivanje jedne koherentne normativne pozicije - takva je, primjerice, ona koju smo mi ovdje pokušali ponuditi - no, ponavljamo, iluzorno je očekivati da će se oko nje najednom stvoriti konsenzus. Štoviše, kada bi se to i dogodilo, i dalje ne bismo imali algoritam za rješavanje problema. No to novu situaciju u pogledu etike ne čini ništa drugačijom u odnosu na onu staru.

Sljedeći korak u ovom izabranom primjeru sastojao bi se u pronalaženju razloga za uključenje izvjesnih bića u moralni obzir, kao i načina na koji bi se to trebalo odvijati. Tu je uloga prirodnih znanosti neizostavna. No također je neizostavno i na tom koraku razmotriti na koje su načine izvjesna vjerovanja i njezina metodologija izgrađene, pri čemu se lako mogu otkriti, primjerice, ograničenosti i uvjetovanosti mehanicističkog sagledavanja ustrojstva živih bića. Drugo pitanje koje u ovom pogledu treba postaviti je: koliko nam znanost svijeta uopće otkriva? Nastavno na to: postoje li neke perspektive koje nam u izvjesnim slučajevima svijet bolje otkrivaju od znanstvenog načina njegova poimanja? Tu se, pored za filozofiju, otkriva širok prostor za umjetnički senzibilitet. Kako smo pokazali, on je kroz čitavo novovjekovlje čuvao jednu potpuno različitu paradigmu poimanja života i prirode, no pored ove »konzervatorske« uloge, umjetnici su nerijetko prije filozofa i znanstvenika ukazivali na pogubnosti znanstveno-tehničke civilizacije, kao što je slučaj s Huxleyevim Vrlim novim svijetom, ili zornije pokazivali egzistencijalne užase tjerajući nas na revaloriziranje te civilizacije, primjerice, Picassova Guernica. ${ }^{753}$ Vratimo li se bliže problemu otkrivanja

\footnotetext{
${ }^{753}$ Visković efektno koristi motiv Guernice unutar osude borbe s bikovima: »kao da je tauromahija još jedna epizoda u pobjedi razuma i konja nad instinktom i bikom u zapadnoj kulturi. Ali te dvije prastare i iskonske moći, uranska i ktonska, zajedno stradavaju u Picassovoj evokaciji Guernice razorene od nacističkog barbarstva.« (N. Visković, Životinja i čovjek, str. 368.) Ovom tumačenju treba pridodati i jedan stav uredništva Guardiana koji zgodno sažimlje ono što smo pokušali ovdje naznačiti s vrijednošću umjetničkog senzibiliteta: »Ona [Guernica]
} 
bogatstva samoostvarivanja živih bića, treba obratiti pozornost i na ograničenja same znanosti u tom poslu, za što izvrstan primjer pruža Jonasova filozofijska biologija, ali i na sasvim konkretne propuste koje u ovom pogledu nerijetko imaju novoformirane znanosti, poput one koja se naziva animal welfare, a koja lako može previdjeti ugrozu samoostvarivanja koje se već sugerira u pojedinim misaonim eksperimentima o genetičkoj izmjeni kokoši nesilica (kako bi bile zadovoljne s uvjetima u kavezu) ili bikova (s ciljem izazivanja ekvivalenta Downova sindroma). ${ }^{754}$

Konačno, valja sagledati i koje nas kulturne prakse odvajaju, a koje približavaju živim bićima i prisnijem poimanju prirodnoga, na koji se način to odvija i koje su opasnosti i blagodati jednoga i drugoga za formiranje senzibiliteta ključnog za začetak uspostave institucionalne brige o onim bićima koje je naš pluriperspektivni pogled izvojevao. Ne treba posebno ukazivati na važnost kulturoloških, religijskih, etnoloških i sl. perspektiva po pitanju prvoga, kao i ulogu aktivističkog djelovanja te pravne i političke teorije po pitanju potonjeg. Pri svemu ovome stalno valja imati u vidu i uklopljenost našeg odnosa spram prirode i života u širu sliku paradigmi našeg znanja i djelovanja, a tu posebno mjesto zauzima sagledavanje moći kroz prizmu filozofije, feminizma itd.

Tek nakon svega ovoga možemo pristupiti odvagivanju strana u sukobu razloga obvezatnosti, uz spomenuti ključan preduvjet: rad na tome da do sukoba razloga obvezatnosti uopće ne dođe. Odbijanje ovog predzadatka izraz je posvemašnje neodgovornosti. ${ }^{755}$

Stoga bismo ovaj kompleksan splet problema koji nam se u suvremenoj situaciji sve snažnije kao takav nadaje mogli sagledavati samo pluriperspektivno, a ovdje izvedeni primjer mogao bi zadati uputu za tu novu metodologiju:

1) Zadavanje problema.

2) Preispitivanje moralnog subjekta, determinanti koje na njega utječu i iznalaženje načina za otklanjanje onih utjecaja koji osujećuju njegovu autonomiju.

\footnotetext{
je prvi put izložena na svjetskom sajmu u Parizu, navodno kao prikaz znanstvenog progresa, no smrt stotina civila u malom španjolskom gradu dokazala je mračniju stranu tehnologije. (...) U crno-bijeloj tehnici, ovaj komad sadrži hitnost novinske fotografije. Podivljali (flailing) bikovi i konji pokazuju da visceralni užasi rata nisu tek uvreda ljudskoj civilizaciji, nego i životu.« (»In Praise of ... Guernica«, The Guardian 26. 3. 2009. Dostupno na: https://www.theguardian.com/commentisfree/2009/mar/26/pablo-picasso-guernica-spain-war /pristupljeno 3. 11. 2019./.)

${ }^{754}$ Vidi: David E. Cooper, »Intervention, humility and animal integrity «, u: Alan Holland, Andrew Johnson (ur.), Animal Biotechnology and Ethics, Springer Science+Business Media, Dordrecht 2004., str. 145-155, ovdje str. 146.

755 Treba samo zamisliti ovo odbijanje unutar nekih osjetljivih pitanja ljudskog društva da bi se ta neodgovornost zorno pokazala. Ponovimo prije spomenuti primjer drugim riječima: kakvim bi se, primjerice, ljudsko društvo koje ne radi na zbrinjavanju mentalno ozbiljno oštećenih ljudi, nego dopušta da njihovo samoostvarivanje stalno stupa u ozbiljan sukob sa samoostvarivanjem mentalno neoštećenih ljudskih bića moglo nazvati?
} 
3) Pokušaj zadavanja koherentne i formalne normativne (etičke) pozicije koja ne bi ovisila o konkretnom problemu (dakle, ne kazuistički), uz refleksiju nad mogućim van-etičkim utjecajima na nju.

4) Iznalaženje razloga za uključenje izvjesnih bića u moralni obzir i načina na koji se uključuju u njega.

5) Razmatranje kulturnih i društvenih praksi koje potpomažu ili osujećuju bioetički senzibilitet.

6) Osmišljavanje institucionalne (pravne) brige.

Svaki bi od koraka ovog prijedloga za izgradnju integrativno-bioetičke metodologije zahtijevao dijalog, suprožimanje i suodređenje različitih znanstvenih i ne-znanstvenih pristupa, tj. takva bi metodologija na svakom od svojih koraka bila pluriperspektivistička. Rezultat čitave strukture zadavanje je nove paradigme znanja - kao odgovornog i orijentacijskog znanja - za razliku od znanstveno-tehnološke, instrumentalističke paradigme znanja zadane još na počecima modernog mišljenja. Pri tome je za ograničenja odvojenih i pozitivnih znanosti od izuzetne vrijednosti spominjani uvid u postojanje smisaone pored objektne istine, kao i rušenje iluzije o neutralnosti spoznaje kojom je isključivo oslanjanje na objektnu istinu rezultiralo. Tako

»svijest 'nepristranoga promatrača' uopće nije nepristrana: ona je okovana predmetnim i 'smisao' svojega postojanja vidi jedino u proizvođenju predmetnosti u sklopu nadvremenih fizikalnih zakona. Takav je promatrač rob puke predmetnosti. (...)

Rehabilitiranje iskustva i doživljaja na razini ontologijskoga pluralizma i spoznajno-teorijskoga perspektivizma ne samo da isključuje bilo kakvu mjerodavnost 'nepristranoga promatrača', nego i ono što izravno proistječe iz takvoga stava: vrijednosnu neutralnost spoznaje. To je stav potpune ravnodušnosti prema onome što nas susreće u svijetu ili, točnije rečeno, potpuna isključenost mogućnosti susretnutosti $\mathrm{i}$ istinske blizine. $\ll^{756}$

\section{IV.2.2. Bioetički senzibilitet}

Kada je riječ o ravnodušnosti i njenoj suprotnosti u etičkom kontekstu, govorimo o kategorijama koje napuštaju područje racionalnosti i otvaraju ono senzibiliteta. Čini se da upravo u kontekstu bioetike, koja proširuje etičke obzore na sva živa bića, promicanje ovog senzibiliteta postaje izrazitom potrebom. Ovdje se tako otvara zasebna, više puta kroz ovaj rad spomenuta tema bioetičkog senzibiliteta, koja predstavlja još jedan nezaobilazni novum integrativne bioetike.

Pojam 'bioetički senzibilitet' prvi se put pojavljuje u članku »Znanje i moralnost« Ante Čovića, gdje je on kratko određen kao »nova planetarna osjećajnost«, koja bi integrativnim

756 Ž. Pavić, »'Pluriperspektivizam' - slučaj jedne natuknice u Filozofskome leksikonu«, str. 597. 
obzirima (kao i metodologijom) trebala obuzdati opasna zastranjenja redukcionističkog hoda znanosti, štoviše, uspostaviti novu paradigmu znanja. Time se otvara prostor za nastupanje čitave nove epohe koja se, prema dominantnom tipu znanja, može nazvati bioetičkom. ${ }^{757}$ Ovaj pojam tako zadobiva svjetsko-povijesno značenje:

»Naime, proces prelamanja svjetsko-povijesnih epoha podjednako se ogleda u narastanju novog epohalnog senzibiliteta kao i u razvijanju nove epohalne svijesti. Snaga novog senzibiliteta počesto potiskuje ili zakrivljuje racionalni diskurs, te na taj način otežava razvijanje nove epohe racionalnosti. Time je upravo objašnjeno snažno prisustvo teorijskog apsurdizma u raspravama o odgovornosti čovjeka za ne-ljudska živa bića. Utoliko je potrebno uvažiti i vrednovati sve ono što rade i pišu istaknuti borci za životinjska prava, za moralni status životinja, za zaštitu okoliša itd., ali pod uvjetom da se to ispravno protumači kao razvijanje novog senzibiliteta teorijskim sredstvima, te da se na odgovarajući način klasificira u registru znakova vremena. Naime, sav taj radikalizam, funkcionalna pretjerivanja, neutemeljeni stavovi, nelogičnosti, jednom riječju sav taj teorijski apsurdizam može dobiti pozitivan predznak, pod uvjetom da se u registru znakova vremena vodi u rubrici 'znakovi nove epohalne osjećajnosti'. Pritom treba imati u vidu povijesni poučak da se bez potisne snage, koju nosi nova epohalna osjećajnost, ne bi mogla konstituirati nova epoha, ali isto tako da bi bez striktno izgrađene nove epohalne racionalnosti svjetska povijest neizbježno završila u novom barbarstvu. « ${ }^{758}$

Usprkos strogom inzistiranju na racionalnom zasnivanju našeg obzira spram ne-ljudskih živih bića, Čović upravo u širem, svjetsko-povijesnom pogledu, uviđa neizmjernu vrijednost razvijanja senzibiliteta. Ponešto drugačije intonirano određenje bioetičkog senzibiliteta nalazimo kod Ivane Zagorac, koja u knjizi Bioetički senzibilitet drži da taj pojam treba čitati u ključu semantičkog razvoja pojma 'senzibilitet' i njemu bliskih pojmova, povijesno-filozofskog i uopće misaonog nasljeđa te suvremenih okolnosti. Naime, ona pokušava pokazati kako ovaj senzibilitet nije produkt suvremenog doba. ${ }^{759}$ Spomenuta ravnodušnost prema životinjama koja zapravo vrhuni u naše doba (ili malo prije njega) upravo ide u prilog ovoj tezi i vodi k većoj potrebi da se rad na buđenju bioetičkog senzibiliteta postavi kao imperativ.

Kao i Čović, Zagorac također otkriva u ovom senzibilitetu vrlo dalekosežne potencijale:

»Senzibilitet, čini se, otvara šire značenjske mogućnosti i ima potencijal povezivanja kategorija unutar ljudske prirode te čovjeka i prirode općenito. Povezivanje fizičkog i moralnog kroz pojam senzibiliteta, njegova moć ekspanzije izvan ljudskog tijela uz pomoć upisivanja u prirodu, uloga fuzijskog elementa

\footnotetext{
${ }^{757}$ Usp. Ante Čović, »Znanje i moralnost«, Filozofska istraživanja 17 (1997) 4, str. 1049-1064, ovdje str. 10631064.

758 A. Čović, »Biotička zajednica kao temelj odgovornosti za ne-ljudska živa bića«, str. 36.

${ }^{759}$ Usp. Ivana Zagorac, Bioetički senzibilitet, Pergamena - Znanstveni centar izvrsnosti za integrativnu bioetiku, Zagreb 2018., str. 133, 207.
} 
između osjećaja i razuma, njegova teorijska sublimnost i praktična danost, kao i kapacitet za združivanje metafizike i etike, karakteristike su koje su se iz senzibiliteta iščitavale tijekom duge tradicije. Dodatnu snagu pojmu bioetički senzibilitet dodaje upravo njegova specifikacija kao bioetičkog. Prva razina na kojoj možemo promatrati bioetički senzibilitet jest ona praktična - pojačana svijest o međupovezanosti prirode i čovjeka, holistički pristupi razmatranju čovjeka, kao i konstrukcija novih odgojnih ideala koji zagovaraju razvoj cjelokupne osobe, uz druge pokazatelje upućuju na ponovno buđenje senzibilnog aspekta čovjekove prirode. Druga razina, ona teorijska, upućuje na kontinuitet promišljanja senzibiliteta, odnosno na njegovu utemeljenost u (zapadnoj) tradiciji mišljenja. « ${ }^{760}$

Ulozi senzibiliteta u okviru etike možemo pristupiti i na, kako se to može činiti, neočekivane načine. Tako možemo u kantijanskom duhu uvidjeti važnost razvijanja senzibiliteta kakav predstavlja uvjet razvitka moraliteta. Ako, naime, oduzmemo samom senzibilitetu ulogu moralnog arbitra, tj. temelja za zasnivanje moralnih sudova, to nikako ne znači da razvijanje ljudske osjećajne prirode nema svoju ulogu u moralu. To se osobito očituje u Kantovim primjedbama vezanima uz naš odnos prema ne-ljudskim živim bićima. ${ }^{761}$ Sve i kad se ne bi prihvatio Kantov (ipak izrazito) antropocentrični stav po ovom pitanju, njegovo je ukazivanje na važnost razvijanja senzibiliteta u ovom pogledu izrazito instruktivno za svaku etiku koja želi ostati na kolosijeku uma. Naš odgovoran pristup onima koji zaslužuju moralni obzir nije moguć bez izgrađivanja našeg vlastitog karaktera, a svaka izgradnja karaktera zahtijeva, barem u procesu odgoja, razvijanje senzibiliteta, kako u smislu osjećajnosti, tako i u smislu prijemčivosti za uviđanje postojanja određenih problema. Prijemčivost i osjećajnost kao bitni aspekti bioetičkog senzibiliteta očituju se i u sljedećem njegovu određenju:

»U bioetičkom diskursu pojam senzibiliteta opisuje naglašenu osjetljivost prema okolini, implicira moralno reflektirano odnošenje prema ljudskoj egzistenciji i drugim živim bićima, sadrži prosvjetiteljsku naklonost prema slabijima i nezaštićenima, ali i otvara nove horizonte na liniji »starih« pojmova poštovanja, ljubavi i suosjećanja. Bioetički senzibilitet tako se javlja kao bitna sastavnica humanosti uz visoku razinu respekta, ponovno pronalazeći svoje mjesto pored 'hladne' racionalnosti.« ${ }^{762}$

Iako su u ovim refleksijama nabačena mnoga značenja koja bi se mogla pripisati bioetičkom senzibilitetu, ipak se čini da se ona mogu podvesti pod dvije razine, a koje provizorno možemo nazvati individualnom i društvenom. Prva bi se odnosila na važnost razvitka senzibilne čovjekove prirode, koji i unutar etika zasnovanih na umskim principima igra

\footnotetext{
760 Ibid., str. 46.

${ }^{761}$ Kod nas je najopsežniju studiju koja uključuje spomenuti problem izveo Igor Eterović, koji je na temelju čitavog Kantova opusa opovrgnuo mnoge zablude o pretjeranoj apstraktnosti, formalizmu i zanemarivanju osjećajnosti u Kantovoj etici. (Vidi: I. Eterović, Kant i bioetika.)

${ }^{762}$ I. Zagorac, H. Jurić, »Bioetika u Hrvatskoj«, str. 608.
} 
nezaobilaznu ulogu, u svrhu odgovornog postupanja prema svim živim bićima. Druga bi označavala javno djelovanje, uključujući ono znanstvenika, novinara, umjetnika, aktivista, političara, filozofa, teologa i drugih u vidu osnaživanja ovog senzibiliteta, prvenstveno u vidu razvitka prijemčivosti pojedinaca za uviđanje bioetičkih problema i posljedično za rast odgovornosti i angažmana za njihovo rješavanje. Podjela bi se mogla izvršiti i na planu dvaju aspekata bioetičkog senzibiliteta, naime osjećajnosti i prijemčivosti, iako su oba ta aspekta često isprepletena, a i donekle se mogu podvesti pod prvu podjelu, jer individualnu razinu više obilježava osjećajnost, a društvenu prijemčivost. Dakako, ni podjela između individualne i društvene razine nije isključujuća, nego sadržava mnoge zone preplitanja.

U pogledu naše teme vrijedi istaknuti i da se bioetički senzibilitet odnosi na uviđanje problematičnosti našeg odnosa spram ne-ljudskih živih bića, u čemu uviđanje mehaničkog i ravnodušnog nastrojstva spram njih također treba igrati nezanemarivu ulogu. Još više, uvid u načine koji su sprječavali buđenje bioetičkog senzibiliteta ima za nas izuzetnu vrijednost, jer je, s obzirom na rečeno, očito da su oni pokrivali široki duhovni spektar, od znanosti i tehnologije, sve do religije.

\section{IV.3. Plodni elementi Viskovićeva djela za izgradnju integrativne bioetike}

Viskovićev se potencijalni doprinos izgradnji integrativne bioetike prvenstveno može sagledavati na planu bioetičkog senzibiliteta. No sukladnost njegove kulturne biologije i integrativne bioetike primjetna je na više metodoloških i sadržajnih razina. Stoga ćemo nakon izlaganja plodnih elemenata za obogaćivanje ideje bioetičkog senzibiliteta, sukladnost ova dva projekta sagledati i kroz samu Viskovićevu ideju bioetike, a onda i putem refleksije o formiranju znanja, gdje osobitu ulogu igra njegova detekcija otprirođenja znanosti.

\section{IV.3.1. Obogaćivanje koncepta bioetičkog senzibiliteta}

\section{IV.3.1.1. Prisnost kulture prirodi i njene posljedice}

Refleksija nad udaljenošću odnosno bliskošću kulture spram prirode, kao i nad posljedicama koje takva postavljenost ima na uvažavanje i tretman ne-ljudskih živih bića, nije 
ništa drugo do ispitivanje načina na koji se formira (na koji se nekad formirao i na koji se treba formirati) bioetički senzibilitet. Ona, uostalom, zauzima središnje mjesto unutar kulturne biologije, a predstavlja genuini »začin« etičkom razmatranju, kao i jedan od Viskovićevih originalnih doprinosa animalističkim, ekologijskim i bioetičkim promišljanjima.

Ovdje će više biti riječi o udaljavanju čovjeka od animalnog negoli od botaničkog, a za to postoji više razloga. U prvom redu, animalno je segment prirode koji je čovjeku najbliži, ali ujedno i najodbojniji, najviše ga podsjeća na prirodni aspekt njegova bića. Naše zanemarivanje biljnog carstva, naglašava Visković, ne može biti posljedica njegove manje važnosti u biosferi, jer ono to zasigurno nije. Međutim, osim što su biljke u pravilu brojnije i dostupnije od životinja, one su i slabije pokretljive, bezglasne, u manjoj mjeri nadražljive, pa ne čudi što nas manje interesiraju, što je naša empatija spram njih bitno manja i što ih čak rijetko doživljavamo kao živa bića, za razliku od životinje, čije nazivanje u mnogim jezicima ima značenje živoga živo(tinja), anima(l) i sl. Osim toga, biljkama se rijetko pripisuje individualnost. One se, stoga, bitno manje cijene i simbolički koriste još u arhaičnim društvima. ${ }^{763}$

Međutim, iz svega dosad navedenog razvidno je da arhaična društva stupaju u prisniji odnos s prirodom. Vidjeli smo da arhaični čovjek manje bježi od animalnosti kao sastavnice svoje prirode, da je njegovo stvaralaštvo bilo uglavnom posvećeno životinjama, da su stariji mitovi sadržavali više primjera životinja kao protagonista, da je njegova religija bila puno bogatija životinjskim motivima itd. Percepcija ovisnosti o prirodi bila je puno jasnija, a prožetost ljudskog i životinjskog života puno prisnija. Visković, primjerice, ističe kako je razlikovanje među domesticiranim životinjama na korisne i kućne tek rezultat modernog doba, dok je ta razlika u arhaičnim i ruralnim zajednicama puno manje na snazi. Ne samo da su urođenici nerijetko držali u svojim nastambama životinje te im bili vrlo prisni, nego i stočari često razvijaju afektivni odnos prema određenim životinjama. S druge strane, životinje poput psa ili mačke u ruralnim sredinama često imaju važne utilitarne funkcije. ${ }^{764}$

\footnotetext{
»Nasuprot toj činjeničnoj sveprisutnosti životinjskog u povijesti čovječanstva, (...) za naše vrijeme je ipak karakteristično naglo potiskivanje životinja iz mnogih temeljnih ljudskih djelatnosti - iz rada u poljodjelstvu, zanatstvu i industriji, iz prijevoza, iz odijevanja, iz jezične i likovne i vjerske simbolike, te iz drugih oblasti gdje je životinjstvo još donedavno bilo toliko bitno a gdje ga sada zamjenjuju novi tehnički postupci, proizvodi i ideje. Posljedice su toga kako fizičko nestajanje mnogih životinjskih vrsta i rasa što su u prošlosti okruživale čovjeka, tako i činjenica da sve više ljudi životinje općenito doživljava, s izuzetkom svojih ili susjedovih pasa i mačaka, kao nevažna, daleka, apstraktna ili tupa bića, ili pak kao
}

\footnotetext{
${ }^{763}$ Usp. N. Visković, Stablo i čovjek, str. 22-23.

${ }^{764}$ Usp. Nikola Visković, Kulturna zoologija, 186 - 187.
} 
mrske uljeze u vlastitim prostorima, ili kao strane i bizarne izloške zooloških vrtova, a najčešće možda ipak samo preko bifteka i drugih pečenja na tanjuru. « $^{765}$

Čini se da, slijedom ovoga, životinje sve više nestaju iz ljudskih života, ali Visković naglašava da je tu prije riječ o zamjeni njihove upotrebe. Udaljavanje životinja iz temeljnih ljudskih djelatnosti ne znači da stalno ne nastaju njihove nove upotrebe. Kontinuirani industrijski napredak omogućio je iskorištavanje dijelova životinje u ponekad teško zamislivim proizvodima, poput gumenih kotača, papirnatih kutija, guma za žvakanje, lijekova itd. Velika područja upotrebe životinja nastoje se dodatno proširiti genetičkim inženjeringom. ${ }^{766} \mathrm{U}$ svakom slučaju, životinje su najčešće izvan izravne ljudske upotrebe i kontakta.

»S modernim vremenima ekonomski pristup se strukturalno duboko mijenja, ali ne gubi u društvenoj važnosti: u razvijenim društvima nestaju životinje za rad i prijevoz, mijenjaju se funkcije i značaj pojedinih vrsta, a mesna prehrana i odijevanje kožom i krznom industrijaliziraju se - tako da potrošači sada ne vide niti čak misle na životinje, izmrcvarene i skrivene i anonimne, koje konzumiraju. I to je dio cijene civilizacije, jedan od načina čovjekova otuđenja ili odprirođenja. $\ll^{767}$

Jasno je da manja izloženost životinjama psihički olakšava nošenje s njihovim patnjama i vodi tome da životinju ne promatramo kao individuu - okrutnost, naime, preferira apstrakciju. ${ }^{768}$ Neprijeporno je mnogo $»$ mučnije neposredno promatrati mrcvarenje jednog čovjeka (ili jedne životinje) nego slušati o pogibiji stotine tisuća ljudi u Hirošimi (ili više vrsta biljaka i životinja dnevno). Do naših TV ekrana nisu još stigli prizori o svim Hirošimama što se događaju u šumama, morima, rijekama, savanama, planinama i drugim biosistemima. « ${ }^{769}$

Slično kao životinje, i biljke su sve manje predmet našeg izravnog kontakta. Kako ističe Visković, za takav je proces jedan od važnih »krivaca« tehnološka preobrazba poljodjelstva i deagrarizacija društva. Kad se tome pridodaju povećanje ljudske moći i zabluda o neiscrpnosti biljnog svijeta, dobivamo posvemašnju banalizaciju prirode, pri čemu biljno carstvo zadobiva još bezobzirniji tretman od životinjskog. ${ }^{770}$ Duhu Viskovićeva zaborava prirode odgovara i Supekovo upozoravanje na industrijsko nametanje kriterija proizvodnje poljoprivredi. Brineći samo o povećanju proizvodnje i smanjenju troškova, tj. slijedeći »logiku tržišta«, suvremeni

\footnotetext{
765 Ibid., str. 22.

${ }^{766}$ Usp. N. Visković, Životinja i čovjek, str. 250, 252.

${ }^{767}$ N. Visković, »Šest načina odnosa prema životinji«, str. 11-12.

${ }^{768}$ Usp. J. S. Foer, Eating Animals, str. 102.

${ }^{769}$ N. Visković, Životinja i čovjek, str. 303-304.

${ }^{770}$ Usp. N. Visković, Stablo i čovjek, str. 27.
} 
seljak ili farmer zaboravlja na »logiku prirode«, naime gubi intuiciju da prirodu treba poštovati u njenu kretanju. ${ }^{771}$

\begin{abstract}
»Konačno, vidjeli smo koliko su životinje u prošlosti služile u simbolizaciji mitskih, religijskih, heraldičkih, političkih i literarnih ideja. Takve su simboličke funkcije u moderno i suvremeno doba znatno oslabljene, održavajući se uglavnom još samo kao rudimenti nekadašnjih zbiljskih uvjerenja. No u građanskom društvu se istodobno pojavljuje jedno novo polje vrlo učestale, mada i porukama siromašnije animalne simbolizacije: industrijska i tržišna ekonomija. Sada životinjski likovi postaju uspješna sredstva za privlačenje potrošača, tj. oni se pokazuju kao 'dobri za prodaju' proizvoda i usluga.« «72
\end{abstract}

Iako ova nova zastupljenost životinja u kulturi može djelovati pozitivno, problematično je to što upravo profit čini gotovo isključiv uvjet njihova pojavljivanja. Time tržišnotehnološko-znanstveni sklop ponovno dolazi na vidjelo kao dominantan način na koji čovjek sebi posreduje prirodu. Uzmemo li u obzir važnost supstrata u simbolotvorstvu, prateći put od uloge životinje u njome bogatoj »visokoj kulturi« do njezine degradacije u pijuna »masovne kulture« reklamne industrije, jasnijim postaje što je danas život(inja) čovjeku - puko sredstvo, resurs ili potrošna roba (na što upućuje i prije spomenuta sve pasivnija uloga životinja u kulturi) - i što je sukladno tome čovjek životinji i živim bićima uopće, uključujući i sebe sama.

Iako to nigdje kod Viskovića eksplicitno nije tako formulirano, a možda ni izravno mišljeno, u ovim promišljanjima o odnosu kulturnog i prirodnog kao jedan od osnovnih zadataka izniče uklanjanje tehnologije. Naravno, tu se ni u kom pogledu ne misli na uklanjanje tehnike, nego upravo tehnologije kao slike svijeta. Problem koji se s tom slikom javlja je što ona djelomično ili potpuno stupa na mjesto ostalih sadržaja kulture. Iako kultura prema Viskoviću jest otprirođenje, ona istovremeno vapi za onim prirodnim, što možemo čitati i kao potrebu za ponovnim uspostavljanjem zdravih korijena. Između čovjeka i prirode više ne stoji samo kultura kao njegovo specifično posredovanje potonjeg, nego se iz nje rađa tehnologija kao tehnika pretvorena u čovjekovu zvijezdu vodilju, a da pri tom gubi ulogu njegova sredstva. Štoviše, kako smo već pokazali, čovjek se upravo u stanovitom smislu pretvara u sredstvo onoga što je prvotno zamislio kao sredstvo. U tom je kontekstu vrlo »zdravorazumski« pod napretkom razumijevati gotovo isključivo onaj tehnološki.

Iako je tehnika nesumnjivo dio kulture, pitanje je može li se tehnologija uključiti u njen okvir? Ako uzmemo u obzir da kulturu bitno obilježava sloboda, tehnološka se prisila čini neadekvatna tom pojmu, upravo zato što je prisila. Isto tako, ona je jednosmjerno otprirođenje,

\footnotetext{
${ }^{771}$ Usp. R. Supek, Ova jedina zemlja, str. 221-222.

772 N. Visković, Životinja i čovjek, str. 253.
} 
za razliku od kulture koja, barem potencijalno, potrebuje prirodu kao svoje uporište. Prije smo pokazali kako se kultura samouništava posvemašnjom negacijom prirode, pa slijedom ovog izvođenja isto možemo reći za prevladavanje tehnologije nad ostatkom kulture. Kako smo već prije ukazali, ovo tehnološko istiskivanje vodi gubitku refleksije o mogućnosti drugačijeg, odnosno o mogućnosti slobode, uslijed zapletenosti u slijepi kauzalitet »puke tehnološke prirode $\ll$.

Ono o čemu se ovdje radi, a pri čemu Viskovićeva misao pruža važne poticaje, osiguravanje je same mogućnosti promjene našeg odnosa spram drugih živih bića. Pri tome je potrebno odmjereno sagledati različite historijske modalitete tih odnosa, ne kako bi se pronašao gotov recept, nego kako bismo u nekim elementima tih praksi pronašli razloge suvremenih promašaja. Jer, u konačnici, treba biti jasno da »čovjek nikada nije bio obziran prema životinjama, da ih je oduvijek i gotovo sve progonio, mučio, ubijao i jeo. Jedino što u prošlosti nije bio ravnodušan spram njih, kao što jest danas «. ${ }^{773}$ Štoviše, ovdje su nerijetko na djelu oni što smo ih nazvali kovačićevskim »dvospolcima«, ljudi koji su izgubili ambivalentnost »seoske« srdačno-okrutne bliskosti spram životinja, a s obzirom na sačuvanu okrutnost nisu do kraja usvojili ni »gradsku« gotovo jednoznačnu udaljenost od njih, izuzev kućnih ljubimaca. Nikako ne treba zanemariti ni činjenicu da je »širenje kućnog ljubimstva među urbanim srednjim klasama u ranom modernom dobu (...) potaknulo srednje klase da formiraju optimističke zaključke o životinjskoj inteligenciji (...); stimuliralo misao da životinje mogu imati karakter i individualnu osobnost; te stvorilo psihološku osnovu za stav da neke životinje imaju barem pravo na moralni obzir «. ${ }^{774}$ No osnovni je problem u tome što se ovako obogaćeni senzibilitet za život životinje najčešće i ograničava na kućne ljubimce. Premda Visković ne gleda jednostrano na fenomen kućnog ljubimstva, priznajući i da se njime izražava čežnja za izgubljenom prirodom, ${ }^{775}$ osuđuje selektivnost brojnih društava za zaštitu životinja, nazivajući ih u tom pogledu specističkima. ${ }^{776}$ Briga o bliskim životinjama, kako se već pokazalo, nerijetko uključuje potpunu ravnodušnost prema onim udaljenima.

Izostanak kulturnih značenja životinja, smatra Visković, danas teče paralelno ravnodušnosti tolikih razmjera da se čovjek ne obazire na strahote masovnog industrijskog uzgoja životinja (uvjerljivo najgoreg dosad osmišljenog načina maltretiranja životinja), a zahvaljujući posredovanju odnosa sa životinjama automatiziranim tvorničkim procesima koji

\footnotetext{
${ }^{773}$ N. Visković, Kulturna zoologija, str. 23.

774 Ovu tezu historičara Keitha Thomasa citiramo prema: J. S. Foer, Eating Animals, str. 22-23.

775 Usp. N. Visković, Kulturna zoologija, str. 283.

${ }^{776}$ Usp. N. Visković, Sumorne godine, str. 96.
} 
odrađuju najprirodnije funkcije poput hranjenja, reprodukcije i sl. ${ }^{777}$ Već smo prije vidjeli da zamjena prirode tehnostrukturom vodi k neprepoznavanju izvora naših materijalnih dobara, čime opada pridavanje vrijednosti prirodnome. Međutim, priroda se, na što smo već ukazali, »osvećuje« za takav tretman. Tu je pojavu na različite načine uočilo više filozofa. Primjerice, Horkheimer i Adorno u jednom su obuhvatnom smislu sagledavali načine nastupanja ove pojave. Jedan od načina kako se »osveta prirode« odvija ponižavanje je tijela, odnosno samoponižavanje čovjeka u mrtvi corpus. Tako se čovjekovo tijelo pretvara u puku sirovinu, a potiskivanje tjelesnosti samo potiče destruktivnost i okrutnost. Čak se i ljubav spram tijela kakva obilježava (otvoreno ili prikriveno) totalitarno društvo veže uz afinitet prema ubijanju, a stvari stoje slično is afinitetom prema lovu kod ljubitelja prirode. Naime, tijelo je tu promatrano kao da je već mrtvo, što je potpuna suprotnost bojazni prisutne u židovskoj tradiciji da se čovjek mjeri metrom, jer se mjere samo mrtvi za lijes. Na nesvjesnoj razini, manipulatori tijela druge promjeravaju pogledom pogrebnika. ${ }^{778}$ Već smo govorili o tome kako Descartesovo poimanje neduhovne supstancije nosi u sebi sjeme za izrastanje ovakvih posljedica. Međutim, i nakon mehaniziranja prirode, čovjek se neće olako riješiti animalnog:

\footnotetext{
»Istina, životinja će ostati i nakon svega toga uznemirujući ljudski dvojnik, biće odviše slično čovjeku, kojim će se nadasve zbog te sličnosti i dalje baviti svi ozbiljni filozofi i znanstvenici, ali Descartesovo shvaćanje životinje kao bezosjećajnog i glupog mehanizma postat će tijekom stoljeća modelom znanstvene spoznaje i moćnim temeljem isključenja životinjskog s područja etike.«779
}

Ovdje se, međutim, rađa i značajan problem za sam čovjekov moralitet. Zanemarivanjem upozorenja nekih od ovdje navedenih filozofa došli smo do potpunog umrtvljenja savjesti kod znanstvenika. Njihova neosjetljivost za patnje životinja, smatra Visković, nije stvar sadizma, nego etičke nezrelosti. ${ }^{780}$ Tako izvjesne posljedice znanstvenotehnološke paradigme vode gotovo do pada čovjeka ispod razine moraliteta. ${ }^{781}$ Osobit doprinos tome daje posvemašnja partikularizacija znanja, kao i razvoj čovjekove moći koja prerasta granice njegove moguće odgovornosti (Jonas), što je posebice primjetno u pogledu genetičkih manipulacija nad živim svijetom.

\footnotetext{
${ }^{777}$ Usp. N. Visković, Kulturna zoologija, str. 200.

${ }^{778}$ Usp. M. Horkheimer, Th. Adorno, Dijalektika prosvjetiteljstva, str. 253, 255-256.

779 N. Visković, Životinja i čovjek, str. 158.

${ }^{780}$ Usp. ibid., str. 337-338.

781 Ovakvu će ocjenu Kangrga pripisivati rodovsko-plemenskom mentalitetu (primjerice, nacionalističkom), onome koji se još »nije ni našao u horizontu moralnog problema kao takvoga«, za koga »moralna problematika u pravom smislu još uvijek ne postoji«, pa se nositelj ovakvog mentaliteta može označiti kao amoralno biće. (Usp. Milan Kangrga, Šverceri vlastitog života, Republika, Beograd 2001., str. 190-191.)
} 
»Tko može jamčiti da će se genetika koristiti, pa i uz nužne pokuse sa životinjama i ljudima, samo u humane svrhe liječenja bolesti i umjerenih zootehničkih zadataka, a ne i za autoritarnu kontrolu ljudskog nasljeđa i stvaranje životinjskih čudovišta? «782

Čovjekovo otprirođenje popraćeno je i otprirođenjem mnogih bića koja dolaze s njim u kontakt. To se obično promatralo pod pashom oplemenjivanja, tj. kultiviranja, ali kako se čovjekovo otprirođenje radikalizira, tako se granica između oplemenjivanja i stvaranja sve slabije uviđa. Ta se granica još može jasno uočavati kod klasične domestikacije i kod sličnih intervencija u kojima je sama priroda zadavala granice. U tu skupinu još uvijek pripadaju bića kojima čovjek raznim metodama mijenja biološke osobine, ali čini prvi korak prema radikalnom otprirođenju živih bića u vidu genetičkih modifikacija.

\section{IV.3.1.2. Antropomorfizam}

Antropomorfizacija predstavlja izuzetno plodnu temu kojom Viskovićeva misao može obogatiti onu bioetičku, naročito u pogledu bioetičkog senzibiliteta. Kako bi se taj potencijalni doprinos osvijetlio, potrebno je najprije sagledati njegov pokušaj pronalaženja razloga antropomorfizacije životinja:

\footnotetext{
»Između ostalog: 1) nemoć čovjeka da misli i objasni druga bića sasvim izvan analogija s vlastitim stanjima; 2) zbiljska prirodna srodnost čovjeka i životinje po njihovu smještaju i uvjetovanosti u svijetu, po osnovnim nagonima, načinima hijerarhije i komuniciranja, osjetljivosti na bol, patnju i ekološku ugroženost; 3) životna zavisnost lovaca, stočara i ratara o 'korisnim' i 'štetnim' životinjama, koja se transponira u zamišljanje njihovih usluga i opasnosti kao 'dobra' i 'zla'; 4) moralna odgovornost današnjeg čovjeka spram životinja kao bića koja civilizacija zlostavlja i uništava. « ${ }^{783}$
}

Konteksti u kojima se antropomorfizacija životinja zbiva ukazuju na neke ključne aspekte našeg odnosa spram njih, kako ih ovdje Visković izvrsno sažimlje. Naš spoznajni odnos spram životinje ne može izbjeći analogije s nama samima, što je jedan od ključnih uvida koji se djelomično može osloniti i na neke teško osporive srodnosti čovjeka i životinje. Naša ovisnost o njima i utjecaj koji na njih vršimo također igraju ključnu ulogu u njihovu poimanju. Iako je pripisivanje moralnih kategorija unutrašnjem životu životinja, koje potječe od naše ovisnosti o njima, očigledno naivno, uviđanje naših štetnih postupaka spram njih otvara čitav

\footnotetext{
${ }^{782}$ N. Visković, Životinja i čovjek, str. 346.

${ }^{783}$ N. Visković, Kulturna zoologija, str. 53.
} 
jedan novi obzor u kojemu suosjećanje za njihove patnje može voditi k antropomorfizaciji koja ponekad otvara prijepore, kao što je bio slučaj s uspoređivanjem industrijskih farmi s nacističkim koncentracijskim logorima. ${ }^{784}$ Vidjeli smo da se ni Visković ne libi koristiti takvu i metafore poput holokausta i Hirošime za naš odnos spram životinja. ${ }^{785}$

Naravno, kako navodi Visković, postoji i podozrivost od strane biologa, odnosno etologa prema antropomorfizaciji životinja kada je riječ o objektivnoj, znanstvenoj spoznaji njihovih obilježja, neovisno o tome što priznaju nekakve zajedničke biostrukture kod čovjeka i životinje. Psihologija također ima specifičan odnos prema ovom problemu, a on ponekad, naročito ako kreće s biheviorističkih pozicija, vodi u odbacivanje upotrebe antropomorfnih termina. Posljedica toga je odbacivanje prepoznavanja duhovnih i osjećajnih stanja kod životinja. Tu se otvara problem što isti psiholozi na temelju pokusa nad životinjama pokušavaju pružiti zaključke o nekim ljudskim ponašanjima, čime se pretpostavlja značajna srodnost čovjeka i životinje. Visković se ovdje poziva i na Singera, koji, osim isticanja ovog problema, ${ }^{786}$ uviđa još jednu zabrinjavajuću posljedicu nasilnog udaljavanja od antropomorfizacije, naime, prikrivanje užasa koje životinje doživljavaju pretvaranjem jezika u neemotivni tehnički žargon. ${ }^{787}$ Tako je u modernoj znanosti, što je onda nasljedovala i ona suvremena, »zabrana antropomorfizma proširena na zoomorfizam uopće«. ${ }^{788}$

»Za razliku od takvog principijelno odbojnog ili barem suzdržanog stava znanosti prema antropomorfizaciji životinjskog, u etičkim i estetičkim raspravama antropomorfizam se doživljava pozitivno, budući da su analogije i metafore vrijedni postupci etičke argumentacije i umjetničkog stvaralaštva koji potiču emotivne doživljaje, poštovanje i zaštitu životinja kao i estetske doživljaje zbilje. Naravno, i etika odbija analogije s ljudskim koje niječu prirodnu samobitnost, specifičnosti nagona i moralnu ne-odgovornost (pa stoga i nekažnjivost) životinja.« ${ }^{789}$

\footnotetext{
${ }^{784}$ Vidi npr.: Charles Patterson, Vječna Treblinka. Naše postupanje prema životinjama i holokaust, preveo Bernard Jan, Genesis, Zagreb 2005. - Zanimljivo je da jedan primjer svođenja patnje životinja na tehnički žargon, tj. jezična manipulacija u svrhu otupljenja senzibiliteta za njih, u izvjesnom smislu može dovesti i do suprotnih posljedica. Riječ je o nazivu »koncentrirana operacija hranjenja životinja« (engl. Concentrated Animal Feeding Operation), osmišljen od strane okolištaraca, a ne mesne industrije (usp. J. S. Foer, Eating Animals, str. 50), koji je uvelike sličan izrazu 'koncentracijski logor'.

${ }^{785}$ Sadašnje farme za intenzivni uzgoj životinja »pravi su koncentracioni logori, kriminalna mučilišta o kojima većina ljudi nije dovoljno obaviještena« (N. Visković, »Potičući množenje ljudi, Vatikan ugrožava biosferu«, str. 71). Dodajmo još i tvrdnju da uzgoj životinja u agroindustrijskim postrojenjima naziva »ponekad pravim Auschwitzima za životinje« (N. Visković, Politički ogledi, str. 236).

$786 »$ Dakle, središnja se dilema eksperimentatora u psihologiji pojavljuje u osobito oštrom obliku: ili životinja nije poput nas pa u tom slučaju ne postoji razlog za izvođenje eksperimenata, ili nam je pak životinja slična, ali onda eksperiment ne trebamo izvoditi na njoj ako bi se on smatrao sramotnim u slučaju da je napravljen na jednom od nas.« (P. Singer, Oslobođenje životinja, str. 42.)

${ }^{787}$ Usp. N. Visković, Kulturna zoologija, str. 53-55.

${ }^{788}$ H. Jonas, The Phenomenon of Life, str. 10.

${ }^{789}$ N. Visković, Kulturna zoologija, str. 54.
} 
U pogledu potonjeg, ne treba zanemariti činjenicu da je, pored istaknute pragmatične uloge suđenja životinjama, vjerski fanatizam jasno pripisivao moralnu odgovornost životinjama koje su istovremeno shvaćane kao puki objekti čovjekove volje. ${ }^{790} \gg$ Jedna od besmislica iz stare prakse krivičnih progona životinja jest $u$ tome što se ove općenito nisu smatrale moralnim i pravnim subjektima, a ipak ih se pozivalo na odgovornost i kažnjavalo. Tu proturječnost ne može uvjerljivo otkloniti ni ideja da su neke od njih sredstvo demonskih sila. « ${ }^{791}$ Čini se kako se tu ovaj pristup susreće s prije spomenutim biheviorističkim. U oba se životinja naspram čovjeka promatrana iz istog aspekta tretira bitno drukčije. Ona je puki objekt, ali je ipak i moralno odgovorno biće; ona je slična čovjeku u smislu da se rezultati podvrgavanja njenog tijela pokusima mogu koristiti za spoznaje o ljudskom tijelu, ali nad čovjekom se ne smiju vršiti pokusi (ili je tu riječ samo o strahu od zakona koji, nekim slučajem, čovjeka štiti). U svakom slučaju, krajnosti pretjerane antropomorfizacije i njenog potpunog odbacivanja mogu ići u vrlo sličnim smjerovima, koji proizvoljnim određenjima pokušavaju doći do zadovoljenja čovjekovih iracionalnih ili moralno sumnjivih težnji.

Spomenute krajnosti upravo su stoga indikator izostanka bioetičkog senzibiliteta. Neosviještenost i neprijemčivost znanstvenika za uviđanje konkretnih problema u našem odnosu spram drugih živih bića u korelaciji je s odbijanjem antropomorfnog pristupa, a ako on izostaje kao posljedica, tada očito nedostaju i svi navedeni razlozi, tj. ne pojavljuju se u čovjekovoj svijesti. Mišljenje životinja bez analogije s nama rezultat je dugog pretjeranog ekskluziviranja čovjeka iz živog svijeta, što je urodilo već spomenutim paradoksima. U pogledu svođenja čovjeka na jedan njegov određeni aspekt (duhovnost), svako uviđanje zbiljske prirodne srodnosti sa životinjama gubi na značaju, a naročito na mogućnosti etičkih implikacija. Slijedom posvemašnjeg tehnološkog posredovanja životinje, Zapadnjak sve više gubi svijest o životnoj i duhovnoj zavisnosti od nje, što je kao »zaborav prirode« u ovom radu već naglašeno, s konačnom konzekvencom u gubljenju sposobnosti suvremenog čovjeka »da im bude zahvalan i da se spram njih odnosi etički«. Stoga nedostatak isprepletenosti čovjeka i drugih živih bića otežava osvještavanje odgovornosti spram njih.

Međutim, kako je vidljivo iz navedenog, relacija ovdje nije jednosmjerna, jer i naše poistovjećivanje (među ostalim, putem antropomorfizacije, zoomorfizacije, čak i fitomorfizacije) sa živim svijetom osnažuje odgovornost, a što svoju osobito vrijednu primjenu može zadobiti u procesu odgoja. Sklop u kojem se rađa antropomorfizacija pokazuje se vrijednim i zato što među ovim razlozima možemo uvidjeti još jedan kauzalni smjer.

\footnotetext{
${ }^{790}$ Usp. N. Visković, Životinja i čovjek, 296.

${ }^{791}$ N. Visković, Kulturna zoologija, str. 389.
} 
Osvještavanje onoga što označavaju prva tri istaknuta pojma (analogija, prirodna srodnost i zavisnost čovjeka i životinje) vodi osnaživanju senzibiliteta za onaj posljednji i ključni odgovornost. Ali upravo kako bismo osvijestili tu ključnu sastavnicu našeg odnosa spram životinja potrebno je izbjeći one krajnosti antropomorfizacije i zoomorfizacije te dualizma koje Visković ističe.

\section{IV.3.1.3. Senzibilitet i racionalnost}

Upravo navedeno znači da razvijanje bioetičkog senzibiliteta putem antropomorfizacije i zoomorfizacije ima svoju vrijednu ulogu, ali ipak kao priprema završnom činu teorijske konceptualizacije. Sam Visković u okviru kulturne botanike naglašava kako je minuciozni spor oko modusa čovjekove pravne i moralne odgovornosti spram biljnog svijeta manje važan u početnom alarmiranju javnosti, iako jasna izgradnja teorijske pozicije po tom pitanju u konačnici ima veliku važnost. ${ }^{792}$

»Emotivni pristup nije toliko pogrešan koliko nedovoljan. Obično se sastoji u povlašćivanju 'lijepih', 'dobrih' i 'dragih' životinja, kakve su mace, psi, kunići, medvjedi, tuljani itd. Ostale se vrste zaboravljaju. «93 $^{793}$

Usprkos ponešto nesređenom Viskovićevu stavu o utemeljenju moraliteta, čini se da se njegova jasnija pozicija po ovom pitanju otkriva pri objašnjenju prožimanja osjećajnosti i racionalnosti u moralu. Tako tvrdi da »čak prije razuma, drukčiji pristup životinjskom svijetu omogućuje mu simpatetika, suživljavanje. Ako nemate simpatiju ili sućut prema životinji, razum neće biti zainteresiran za životinje. $\ll^{794}$ Ovdje također vidimo da dva ključna aspekta bioetičkog senzibiliteta, osjećajnost i prijemčivost idu ruku pod ruku, da, u izvjesnom smislu, prva stoji u službi druge. Čini se da bi se upravo u tom svjetlu trebalo iščitavati Viskovićevo temeljenje moralnog obzira spram drugih živih bića u suosjećanju. No »za bioetiku je važno, između ostalog, da se ona ne temelji prvenstveno na odviše subjektivnoj moći ljubavi, jer nam neke životinje i biljke nisu i ne moraju biti mile, već da se prije svega zasniva na objektivnijem načelu poštovanja drugoga«. ${ }^{795}$

\footnotetext{
${ }^{792}$ Usp. N. Visković, Stablo i čovjek, str. 789-790.

${ }^{793}$ Usp. N. Visković, »Nikola Visković: Smiljko Sokol i Ivan Milas žestoko su se oduprli mojem prijedlogu da životinje uđu u Ustav Republike Hrvatske! «, str. 36.

${ }^{794} \mathrm{~N}$. Visković, »Nakaradno je da naša etika uopće ne tretira životinje«, str. 11.

${ }^{795}$ Usp. N. Visković, »Potičući množenje ljudi, Vatikan ugrožava biosferu«, str. 71.
} 
U izvjesnom se smislu može reći da senzibilitet omogućuje racionalnosti da se pokrene, da uvidi problem i da ga onda vlastitim sredstvima rješava. Pa premda se Visković ovdje po pitanju objektivnog utemeljenja moraliteta normativno prije priklanja Reganu negoli Schopenhaueru, istovremeno uspijeva pokazati da se senzibilitet i racionalnost ne odnose na odvojene sfere čovjekova pristupa svijetu, ali da oni trebaju igrati svoje specifične uloge kako bi oboje aktualizirali svoje najvrjednije potencijale.

\title{
IV.3.2. Ideja bioetike: Visković - očevi bioetike - integrativna bioetika
}

Paradigmatičan tekst za sagledavanje Viskovićeve ideje bioetike je »Kakva bioetika?«, objavljen 2. 2. 2002. u Feral Tribuneu. ${ }^{796}$ Već se u samom datumu objavljivanja krije dio odgovora na pitanje postavljeno u naslovu - bioetika je okrenuta drugome, svakom drugome! Visković tu okrenutost drugome ponekad dodatno zaoštrava, primjerice u tekstu »Bioetika shvaćena ozbiljno«, gdje moral određuje (ističući kako ne ulazi u preciznija etička razmatranja) kao »rasuđivanje i ponašanje koje stremi dobru drugih - i tek u tom okviru vlastitu dobru«. ${ }^{797}$ Moralitet se najčešće shvaća kao briga za »dobro drugih ljudi«, a ponekad samo za dio njih, pa je u tom smislu, prema Viskoviću, »metaetički rečeno i 'nemoralan', jer više ili manje neopravdano ne priznaje i izbacuje neke 'druge' u svom stremljenju k dobru drugih «. ${ }^{798}$

\begin{abstract}
»Takvo općevladajuće shvaćanje morala možemo nazvati apsolutni moralni antropocentrizam. Po njemu je čovjek ne samo jedini subjekt moralnog rasuđivanja i moralnih obveza, što je nesumnjivo točno i jedino moguće (jer su moral i etika kognitivno, normotvorno i primijenjeno samo ljudska stvar, s obzirom na to da je čovjek jedino biće s mjerom svijesti i slobode koja može uspostaviti poredak moralnost), nego je čovjek još i jedini 'drugi', jedino biće korisnik ili subjekt ovlaštenik dobara koja moralna pravila štite.

Prema takvu shvaćanju morala sva ostala, neljudska bića, životinjska i biljna, kao i svi prirodnoanorganski uvjeti života, nisu korisnici moralnih pravila, i to naprosto zato što mi (gospodari morala) postavljamo samovoljno kriterije moralnosti, pa ih po tim kriterijima ne priznajemo u moralnu kategoriju 'drugih', dakle ni kao moralne subjekte u smislu moralnih ovlaštenika. «"799
\end{abstract}

Prema navedenome, nedosljednost umovanja vodi moralitet u samovolju, pa se bioetika javlja upravo kao potencijalna spasiteljica morala od njegova zapadanja u samovolju. Već je iz rečenoga jasno da Visković bioetiku neće formulirati na tragu njenog prevladavajućeg poimanja

\footnotetext{
796 Tekst je izašao pod naslovom: »Bioetika za početnike« (Feral Tribune 2.2.2012., str. 72-73), a ovdje ga prenosimo pod navedenim naslovom iz knjige Sumorne godine (str. 212-216).

${ }^{797}$ Nikola Visković, »Bioetika shvaćena ozbiljno«, Zarez 21.11.2002., str. 14-15, ovdje str. 14.

798 Ibid.

${ }^{799}$ Ibid.
} 
(naročito u anglo-američkoj tradiciji) kao humane biomedicinske etike, nego da će se približiti intencijama Pottera, Jahra i integrativnih bioetičara.

Što se prvoga tiče, u Viskovićevu se radu »Bioetika i biomedicinsko pravo« iz 1995. nalazi jedna od prvih (iako kratkih) recepcija Pottera u Hrvatskoj. ${ }^{800}$ Visković tu navodi da je Potter skovao termin bioetika, ali u danas zaboravljenom značenju koje je u sebe uključivalo i probleme ekološke etike. Iako se bioetika nakon njega profilirala kao medicinska etika, ona je barem proširila svoje problemsko područje i uvela interdisciplinarnu metodologiju. Naime, etika (ljudskog) života u medicinskom kontekstu nije sama po sebi nešto novo. Može se reći da je bioetika, u navedenom smislu, staro područje pravne i moralne regulacije. Nagli napredak tehnologije uzrokovao je i sve intenzivnije intervencije na području biologije i medicine, tj. intervencije u integritet i kvalitetu ljudskog života. Uz to su i neki stari postupci, koji su postali tehnički lakše izvedivi, otvoreno izašli u javnost te u novom, suvremenom pluralističkom društvu izazvali oštre polemike. Tako je nastalo ono što bi se moglo nazvati »novom bioetikom «. ${ }^{801}$ Ovdje se izvorište bioetike s pravom postavlja jednom nogom u društvene silnice - bioetika je, kako smo vidjeli, ne samo intelektualni, nego i društveni pokret.

Visković u članku »Kakva bioetika?« u svjetonazornom pluralizmu i silini tehnološke intervencije u svijet života prepoznaje ne samo dva temeljna društvena procesa suvremenosti, nego i dva bitna razloga nastanka bioetike. Ona se na početku razvija u duhu tradicionalne, antropocentrične etike, promatrajući svoj problem iz ograničene i sebične perspektive vladajuće ljudske vrste. Kao takva, ona zastaje na prvoj razini bioetičke problematike. ${ }^{802} \mathrm{U}$ vrijeme pisanja navedenog članka, integrativna bioetika pruža tek svoje prve impulse, tako da u našem intelektualnom diskursu uglavnom prevladavaju ovakva poimanja bioetike. Visković, stoga, može kazati:

»Bioetika naših dana nalazi se uglavnom u svojoj početnoj fazi antropocentrizma. To je posve očigledno na primjeru Hrvatske, gdje je ona disciplinarno gotovo zarobljena medicinskim i tehnološkim studijima,

\footnotetext{
${ }^{800}$ Prema našim saznanjima, Pottera prije toga u Hrvatskoj spominje samo Ivan Šegota u svom bioetičkom priručniku iz 1994., gdje prenosi razgovor koji je vodio s Warrenom Reichom: »Da, točno je da je ime nove medicinske etike nastalo u Wisconsonu, u Madisonu, zahvaljujući Vanu Rensselaeru Potteru. Ali ono je također rođeno i ovdje, u Georgetownu, zahvaljujući Andreu Hellegersu (...) Potter je izumio izraz 'bioetika' kombinacijom dviju riječi: 'bio' i 'etika', ali je taj termin ostao marginaliziran sve do Hellegersa. Osim toga, Potter mu je, kako je to sam objašnjavao, dao drugo značenje od onog koje danas ima.« (Ivan Šegota, Nova medicinska etika (bioetika). Priručnik, Medicinski fakultet, Katedra društvenih znanosti, Rijeka 1994., str. 17.)

${ }^{801}$ Usp. Nikola Visković, »Bioetika i biomedicinsko pravo«, Zbornik radova Pravnog fakulteta u Splitu 39-40 (1995) 1-2, str. 67-83, ovdje str. 67-68.

${ }^{802}$ Usp. N. Visković, Sumorne godine, str. 212-214.
} 
umjesto da se po naravi stvari (pitanja života) prvenstveno razvija na filozofskim i sociološkim studijima, a istodobno je pod prejakim utjecajem konzervativnijeg katolicizma. $\ll^{803}$

Iz ovoga se dade iščitati da takvo formiranje bioetike vraća ovu problematiku u neka vremena prije dosegnutog povijesnog trenutka, kada se pitanje o etici života zadržavalo pod autoritarnom religijskom pashom, čineći tako razvijanje same ideje bioetike otežanim, jer se takvim usmjerenjem zatire upravo jedno od njenih izvorišta. Pored toga, zanemarivanjem filozofske perspektive otežava se dosljednost i prihvaćanje sve težine problemā koje bioetika u duhu novog vremena postavlja - ometa se zadatak »shvaćanja bioetike ozbiljno«. Ona se takvom može shvaćati jedino onda kada se podigne na drugu razinu:

»Drugu razinu čine problemi opstanka i kvalitete svih oblika života - ljudskog, životinjskog i biljnog, tj. cjelokupne biosfere, kao uistinu altruističke ili biocentrične etike, koja ozbiljno shvaća značenje svoga korijena $\beta$ íos (= život) i pošteno brine za sva bića na planeti Zemlja. «804

Ako imamo u vidu ovu drugu razinu, onda je jasno da oštra Viskovićeva kritika konzervativnog katoličkog upliva u bioetiku na ovom mjestu pogađa $u$ jedan problem prema kojemu intencija njene oštrice možda i nije bila direktno upućena. Kritika se ne može uputiti samo autoritarnom konzervativno-katoličkom razrješavanju važnih biomedicinskih problema, nego i njegovu generalnom zanemarivanju ne-ljudskog života. Da je tomu tako potvrđuju i današnja kretanja u kršćanskim krugovima Zapada, gdje »pro-life pokreti« i »kultura života« brinu samo za život Homo sapiensa (naročito u njegovoj embrionalnoj/fetalnoj fazi), izbjegavajući breme dosljednosti čak i u samom svom nazivlju i krilaticama (poput često naglašavane »svetosti života«).

Iako bioetika prve faze najčešće ostaje na razini onoga što se eventualno može zvati »humanom bioetikom« u području medicine, njoj se može pripojiti i briga za ekološke vrijednosti, ali isključivo motivirana neposrednim ljudskim interesom, držeći se antropocentričnog značenja »zaštite ljudske okoline«. ${ }^{805}$

»Razumije se, i biocentrično usmjerena bioetika, tj. ona kojoj je središnja briga zaštita svih oblika života, također mora priznati neke razumne prednosti ljudske vrste nad drugim prirodnim bićima - u mjeri koliko čovjek nužno konzumira neke biljke i životinje i zauzima dio njihova životnog prostora, kao što se uostalom i sva druga bića međusobno konzumiraju i prostorno natječu. Takvu relativnu povlasticu

\footnotetext{
${ }^{803}$ Ibid., str. 214.

${ }^{804}$ Ibid. - Ovdje se javlja ponovno javlja gore spomenuti problem vezan uz grčki termin bios.

${ }^{805}$ Usp. ibid., str. 215-216.
} 
čovječanstva ne može racionalno osporiti nikakav etički fundamentalizam. Ali ono što je zaista novo i umnije u razvijenoj bioetici i u tzv. 'dubinskoj ekologiji' (deep ecology) jest načelno poštivanje svakog života i odustajanje Homo sapiensa od njegovog dosadašnjeg pretjeranog, pljačkaškog i nepoštenog odnosa prema prirodi, a što znači i priznanje da se imperativ očuvanja prirodne okoline čovjeka mora uravnotežiti s imperativom očuvanja prirodnih okolina medvjeda, kita, slona, ptice i leptira, šumskih, močvarnih i prerijskih biotopa itd., kao samostalnih vrijednosti koje treba zaštititi koliko je god moguće, neovisno o njihovoj ljudskoj upotrebljivosti. (...) I tek nas takva etika konačno uvodi u moralnu punoljetnost. $«^{806}$

Bioetika se ovdje javlja gotovo kao »novo prosvjetiteljstvo«, buđenje iz samoskrivljene malodobnosti slijepog slijeđenja profita i tehnološkog napretka kao nepreispitanih zvijezda vodilja, kao i iz »dogmatskog drijemeža« nekih često nepreispitanih postavki tradicionalne etike. Bez obzira koliko snažno to buđenje bilo, bioetičko promišljanje za Viskovića ipak ne može otkloniti već naznačene antropocentričke granice, što je osim na ovom mjestu već prije isticano u razradi antropocentrizma i biocentrizma.

Ovdje već nailazimo na niz sličnosti između Viskovićeva i Jahrova bioetičkog nastrojstva. Gotovo se čini da bi u slučaju ranijeg otkrivanja Jahra Visković postavio njegovo etičko učenje kao centralni element svojega. Nije tu riječ samo o slično formuliranim pravilima i imperativima, u okviru kojih se moralno ispravno djelovanje izgrađuje načelnim poštivanjem svakog živog bića, nego i o nekim ključnim zajedničkim poticajima za promišljanje smislenosti moralnog obzira spram drugih živih bića. Tako Visković, kao i Jahr, odlučan moment za rušenje antropocentrizma vidi u znanstvenim dostignućima 20. stoljeća. No pored njih, u Viskovićevu promišljanju, kako smo vidjeli, ključnu ulogu također igra Darwinov evolucionistički zaokret, prvenstveno u pogledu dovođenja u pitanje nesagledivosti jaza između čovjeka i životinje.

Međutim, znanstvena otkrića za Viskovića nisu dovoljna u pokušaju odgovora na pitanje što životinja i biljka jesu. Ono se ne može razriješiti ako se pruži samo odgovor na pitanje što one biološki jesu, nego mu se mora nadodati i odgovor na pitanje što one kulturno jesu. Puninu odgovora, odnosno usmjerenje prema punini odgovora na sva pitanja vezana uz međuodnos čovjeka i životinje odnosno čovjeka i biljke pružaju njegovi koncepti kulturne zoologije i kulturne botanike.

Iako Visković stoji više na Jahrovu nego na Potterovu tragu po pitanju motivacije za bioetičku misao, imajući na umu prvenstveno dužnost brige za sva živa bića, on pritom ne isključuje sagledavanje pogubnosti suvremene situacije. Štoviše, ona se postavlja kao jedno od polazišta za njegova kulturnozoologijska i kulturnobotanička istraživanja. To je naročito

\footnotetext{
${ }^{806}$ Ibid., str. 215-216.
} 
naglašeno kod potonjeg, koje započinje analizom zaborava prirode, odnosno pogrešnom percepcijom naše ovisnosti o njoj. No ovdje je naglasak ipak više usredotočen na nemoralne prakse spram drugih živih bića (ali ne isključujući čovjeka) koje iz suvremene situacije, tj. tehno-znanstvene i pratećih konstelacija proizlaze. To se naročito ogleda u udaljenosti spram drugih živih bića i prirode uopće, kojoj tehnološko posredovanje tog odnosa doprinosi više nego išta u historiji.

Viskovićeva misao ovime, kako je pokazano u prošlom poglavlju, ukazuje da ono što će integrativni bioetičari nazvati bioetičkim senzibilitetom nije nimalo beznačajna stvar. Odnos bliskosti i udaljenosti od prirode odražava način na koji čovjek egzistira, način na koji on sebi posreduje ono što ga okružuje i kako se sukladno tome odnosi spram njega. Tehnološko posredovanje tako potencijalno i aktualno sadrži opasnosti bezobzirnog odnošenja spram onoga što zahtijeva i zaslužuje moralni obzir. Konačno, Viskovićevo nastojanje na promicanju bioetičkog senzibiliteta poprimilo je i konkretne oblike u kontekstu političkog i aktivističkog angažmana, gdje je njegova zasluga, kao i u intelektualnom stvaralaštvu, nemjerljiva. Ne treba ispustiti iz vida ni to da Viskovićevo intelektualno stvaralaštvo nije ostalo samo u knjigama i znanstvenim ili stručnim radovima, nego je razasuto po brojnim člancima u novinama i časopisima namijenjenima široj publici, koji predstavljaju jedan od ključnih kanala putem kojih se potiče rast bioetičkog senzibiliteta. ${ }^{807}$ Posredstvom svih kanala kojima se služio, Visković se osobito obrušio na pogubnosti ne samo tehnološkog, nego i, kako smo vidjeli, tržišnog posredovanja živih bića, a posebice onakvog posredovanja kakvo provodi partikularizirana i otprirođena znanost.

\section{IV.3.2.1. Znanje i moralnost}

Visković je, ako ne prvi, onda sigurno jedan od prvih naših bioetičara koji su prepoznali vrijednost Potterova zasnivanja bioetike nasuprot manjkavosti onog njenog modela koji se razvio neposredno nakon toga. Uz slijeđenje ključne poruke »mostovne bioetike«, naročito u izgrađivanju mosta između prirodnih i humanističkih znanosti, Visković problem na koji se usredotočuje sagledava polazeći iz suvremenog konteksta. Međutim, gotovo se može reći da

\footnotetext{
${ }^{807}$ Dovoljno je ukazati na to da osnovu Viskovićeva temeljnog kulturnozoološkog djela Životinja $i$ čovjek sačinjavaju upravo njegovi članci objavljivani u feljtonu »Životinja i čovjek«, koji je tijekom 1990. i 1991. izlazio u Slobodnoj Dalmaciji. Ne treba zanemariti da su mediji odigrali ključnu ulogu u nastanku bioetike. Tako mnogi za početak formiranja bioetike uzimaju članak »Oni odlučuju tko živi, a tko umire« Shane Alexander, vezan uz spomenuto osnivanje etičkog komiteta u Seattleu 1962. godine. (Usp. I. Zagorac, Bioetički senzibilitet, str. 231; S. Alexander, »They Decide Who Lives, Who Dies«.)
} 
primarna motivacija za to nije ljudski opstanak, nego prije svega čovjekov odnos spram drugih živih bića te odnos kulturnog i prirodnog uopće. Tu je Visković već puno bliži Jahru, koji svoju pažnju usmjeruje na smislenost moralnog obzira spram drugih živih bića. Kod Jahra su, kao i kod Viskovića, etički koncepti nešto razrađeniji nego kod Pottera, ali i Jahrovi i Viskovićevi pate od nedostatnosti, u prvom redu zahvaljujući nabacivanju mislī više autora koje se međusobno isključuju - osim u dijelu zaključaka. Ako takav postupak ugrožava konzistentnost teorijske pozicije, on je barem vrijedan na planu osnaživanja bioetičkog senzibiliteta, koji, kako smo vidjeli, ima nemali značaj kako u formiranju integrativne bioetike, tako i u formiranju kulturne zoologije i kulturne botanike.

Visković ne pokušava samo izgraditi most između humanistike i prirodoslovlja, nego upućuje na prevladavanje otprirođenja znanosti, a u približavanju kulturnog i prirodnog nalazi se put za transdisciplinarno sagledavanje odnosa čovjeka (kulture) i prirode. Kulturna biologija javlja se, stoga, upravo kao transdisciplina, upravljena na prevladavanje različitih redukcionističkih pristupa. Sličan put slijedi i integrativna bioetika. Kod nje se, kao i kod Viskovića, pluriperspektivnost postavlja kao ključna metodološka odrednica, koja vodi jedinstvenom bioetičkom (kulturnobiološkom) pogledu i time barem djelomično transcendira razdvojene discipline, istodobno umanjujući pogubnosti redukcionizma. Lako uočljiva razlika između ovih koncepata svakako je neujednačen, premda umnogome preklapajući opseg promatranja. Izvjesna razlika postoji i u osnovnoj svrsi, međutim i tu se dadu pronaći neke sličnosti koje se ne smiju previdjeti. Viskovićev projekt prvenstveno je enciklopedijski. Njegov cilj je sakupiti znanja, pristupe i svjetonazore koji na bilo kakav način tematiziraju čovjekov odnos spram životinja i biljaka. Integrativna bioetika, s druge strane, sakuplja spomenuta znanja, ali s jasno određenim ciljem, naime da potraži rješenja moralnih problema čije konce tradicionalna etika više nije u stanju pohvatati. Naravno, jedan od ključnih pristupa u Viskovićevu bioetičkom djelu zasigurno je onaj etički, i to ne kao deskriptivni, što bi se možda očekivalo od jednog takvog projekta, već i kao normativni. Etički se pristup u oba kapitalna djela postavlja na kraj, kao svojevrsna kruna izlaganja. To, naime, nije slučajno, jer pregled svih dosadašnjih i suvremenih načina odnošenja ukazuje na bitnu bliskost i međuovisnost čovjeka i drugih živih bića na više kulturnih i prirodnih razina, što zasigurno pruža barem intuitivan poticaj za ponovno promišljanje opsega čovjekove moralne odgovornosti.

Osuda partikularizacije znanosti može se kod Viskovića jasno detektirati neovisno o problemima izraženima u kulturnobiološkim i bioetičkim spisima. Visković naglašava neizbježnost filozofskog propitivanja osnova pravne znanosti, s obzirom na to da znanost uopće, neovisno o osviještenosti te činjenice, »uvijek i nužno izražava određena stanovišta o 
posljednjim osnovama spoznaje i biti pojavnosti«. Osvrćući se prvenstveno na ignoriranje filozofije od strane marksističkih pravnika (premda je marksizmu filozofija imanentna), govori o naivnosti znanstvenika koji drže da mogu nešto tvrditi »bez raspolaganja posljednjim postulatima koji znanju daju karakter sistema« te odbijaju postojanje ikakve poveznice između metafizike i znanosti. ${ }^{808}$

Ovo osobito vrijedi za društvene znanosti, kojima izvjesna ontologija uvijek stoji u osnovi, sa sasvim konkretnim posljedicama. Govoreći o reintegriranju ekonomije u praktičku filozofiju, Lino Veljak navodi sljedeće:

\begin{abstract}
»To objedinjavanje praktičke filozofije s ekonomikom danas se najčešće vrši primjenom rezultata teorije odlučivanja i sličnih područja analitičke filozofije u sferi racionalnog poslovanja ili pak širenjem normativne etike na poslovnu etiku ili 'etiku gospodarstva'. Poteškoća te vrste pristupa (koji se ponekad, kao u slučaju londonske Škole ekonomijskih znanosti, kombiniraju i s derivatima drevnih istočnjačkih filozofija, npr. s Advaitom Vedantom) jest što načelno i strukturalno mimoilaze pitanja vezana uz smisao ekonomijskog i političkog djelovanja, uzimajući zatečene inačice logike gospodarenja prirodom i ljudskim bićima kao neumitne prirodne okvire i neprelazne granice ljudskog djelovanja i potrage za dobrom i srećom. Moglo bi se reći da je upravo izostanak ontologijske dimenzije (u smislu jedne ontologije društvenog bitka) strukturni razlog mimoilaženja pitanja o tomu jesu li zatečeni okviri ljudskog života uistinu prirodni i nužni.«809
\end{abstract}

Pri tome ne treba zanemariti ni sociološku analizu formiranja znanja, pa u tom svjetlu možemo podsjetiti i na Viskovićevo nezadovoljstvo s nedostatkom sociološke dimenzije u početnim domaćim bioetičkim studijama. Naime, kako navodi Karl Mannheim, osnovna je teza sociologije znanja da se izvjesni načini mišljenja ne mogu razumjeti bez analize njihova društvenog podrijetla. To ne znači da tamo gdje je mišljenje određeno pripadnošću nekoj grupi ili orijentaciji u skladu s djelovanjem »nije moguća duhovna, kritička samokontrola«. Stoga je refleksijom moguće steći kontrolu nad čimbenicima u mišljenju. ${ }^{810}$ Drugim riječima, refleksija obećava slobodu (mišljenja), a ako etika u izvjesnom smislu predstavlja nauk o rastu u slobodi, tada se izoštravanje refleksije, ovisno o mogućnostima, javlja kao imperativ. To je osobito važno u suvremenom povijesnom trenutku, s obzirom na ideologijsku zatrovanost mišljenja, njegovo svođenje na instrumentalnu dimenziju, čime se potkopava zadatak odgovornog rada na promicanju samoostvarivanja živih bića.

\footnotetext{
${ }^{808}$ Usp. Nikola Visković, Pravo kao kultura. Egološka teorija prava Carlosa Cossija, Izdavački centar Rijeka, Rijeka 1990., str. 158.

${ }^{809}$ Lino Veljak, Uvod u ontologiju, Naklada Breza, Zagreb 2019., str. 60.

${ }^{810}$ Usp. Karl Mannheim, Ideologija i utopija, preveo Kiril Miladinov, Naklada Jesenski i Turk - Hrvatsko sociološko društvo, Zagreb 2007., str. 12, 15.
} 
»Doduše, i u društvenim znanostima posljednji kriterij istinitosti i neistinitosti mora se pronaći u proučavanju predmeta, a sociologija znanja nije nadomjestak za to. Ali istraživanje predmeta nije izoliran čin; ono se događa u kontekstu koji je obilježen vrijednostima i kolektivno-nesvjesnim voljnim porivima. (...) U društvenim znanostima nova se vrsta objektivnosti ne može postići tako da se vrednovanje isključi, nego tako da ga se bude kritički svjesno i da se ono kontrolira. ${ }^{811}$

Mannheim pojašnjava i nezaobilaznost smisaonog značenja u tumačenju određenog fenomena. Razvoj moderne znanosti eliminirao je razumijevanje smisla, zadajući si zadatak istraživanja isključivo izvanjskih, mjerljivih fenomena, što se osobito očituje u biheviorizmu. Danas je znanstvenicima uvelike iz vida nestao cilj istraživanja. Jedini cilj do kojega je u ovom kontekstu najčešće moguće doći onaj je što neometanijeg funkcioniranja. Tako je svrha psihoanalitičareva liječenja pacijenta tek optimum prilagodbe, bez da se uopće zna što bi taj optimum trebao predstavljati. ${ }^{812}$ „Čak i ako se zauzme posve kauzalno i funkcionalno stajalište, na kraju se samo otkriva koji je smisao izvorno bio skriven u ontologiji od koje se krenulo. « ${ }^{813}$ Tako u osnovi znanstveno-tehnološke paradigme znanja svakako stoji defetizam spram mogućnosti radikalne promjene i u skladu s tim prilagođavanje postojećim okvirima (postizanje optimuma prilagodbe) kao jedini smislen čin (instrumentalno-)racionalnog pojedinca. Ontologija u pozadini zadaje izvjesni, nepromjenljivi oblik ljudske prirode, kao kompetitivnog bića čiji rodni život, kako kaže Marx, služi svrhama individualnog. ${ }^{814}$

Instrumentalna racionalnost, koju smo kritici podvrgli osobito u okviru razmatranja o plodnim elementima marksizma za izgradnju bioetike, naišla je na osudu i kod Viskovića, već u njegovoj prvoj značajnoj knjizi Pojam prava, gdje piše: »Danas je na filozofskom planu i u teoriji ideologije jasno da 'je pozitivizam redukcija smisaono-spoznajnog uma na tehničkoinstrumentalni, na opstojeće orijentirani razum'. ${ }^{815}$ Kasnije je, kako smo vidjeli, pozitivizam naročito podvrgnut osudi u pogledu zaborava prirode. $U$ tom je pogledu bio određen kao tehnokratski usmjeren, pod vidom »nadideologije« beskrajnog materijalnog rasta, čime je, dakle, i sama znanost instrumentalizirana za kolonizaciju prirode i društva. Iako Visković, kako smo ranije prenijeli, tvrdi da se ova kolonizacija ponekad odvija i tek u scijentističke svrhe, čini

\footnotetext{
${ }^{811}$ Ibid., str. 15.

${ }^{812}$ Usp. ibid., str. 30-31, 54.

813 Ibid., str. 31.

${ }^{814}$ Usp. K. Marx, »Ekonomsko-filozofski rukopisi iz 1844.«, str. 250.

${ }^{815}$ N. Visković, Pojam prava, str. 11. - Visković ovdje citira djelo Naturrecht und Positivismus H. Welzela, koji prenosi u originalu: »Positivismus ist die Reduktion der sinnvernehmenden Vernunft auf den daseinsorientieren, technisch instrumentalen Verstand «. Pri tome kaže kako ovakva ocjena dolazi i od strane marksizma i kritičke teorije društva. (Usp. ibid.)
} 
nam se da taj dodatak vrijedi tek u pogledu tobožnje neutralnosti znanosti, no i ona kao postavka vrijedi u svrhu oslobađanja znanosti za bespoštedno manipuliranje prirodom (i društvom) u profitne i političke svrhe. Ona pak nema vrijednost izvan upotrebne funkcije, čemu svjedoči i neposredni nastavak ovih Viskovićevih tvrdnji, naime, da se »svaki teorijski i moralni poziv konačno podređuje utilitarnom instrumentalističko-tehničkom računu«. ${ }^{816}$

\footnotetext{
»Eksponencijalni rast tehnološke moći i instrumentalno-racionalnog (a neumnog) gospodarenja prirodnim resursima, kao bitna osobina našega doba, rađa sada i po prvi put u povijesti univerzalnu krizu prirode i ujedno sve zreliju svijest o općoj ugroženosti života ili barem svijest o ugroženosti vlastitog života. $\ll^{817}$
}

Čimbenici posredovanja prirode sasvim se jasno pokazuju kao čimbenici rata $s$ prirodom, rata koji se »vodi sa svim financijskim i tehnološkim moćima, mobilizacijom svih znanosti i profesija i stotina milijuna radnika, sa strateškim i taktičkim štabovima, $\mathrm{s}$ propagandnim lažima i prešućivanjima «. ${ }^{818}$

Trostruka pogubnost posredovanja prirode - putem suvremene tehnoznanosti, politike i gospodarstva - struktura je koju često nalazimo i u okviru integrativne bioetike. Tehnoznanost sačinjava spregu s, jednako monoperspektivnim i redukcionističkim, ustrojstvima suvremene ekonomije i politike, koji se, primjerice, jasno očituju u spojenim posudama genetičke kolonizacije živog svijeta i neokolonizacije zemalja trećeg svijeta u pogledu patentiranja genoma biljaka kao zajedničkog dobra lokalnog stanovništva, kako to na najbolji način razjašnjava indijska znanstvenica i aktivistica Vandana Shiva ${ }^{819}$ Time se tehnoznanost ne može reflektirati, niti joj se može oponirati, bez uzimanja u obzir ove sprege.

\section{IV.3.3. Postmodernizam i bioetika}

Onda kada pored pozitivnih ističe negativne učinke globalizacije, Visković ih gotovo svodi na ono što naziva tehnološkom i ekonomskom ekspanzijom po osvajačkom programu neoliberalizma. Suvremena globalizacija, jedan od načina širenja partikularne materijalne i duhovne kulture k općoj, sastoji se upravo u otvaranju državnih granica i svih društvenih polja volji međunarodnog kapitala, što vodi ugrozi privrede, kulture i prirode manje razvijenog dijela

\footnotetext{
${ }^{816}$ N. Visković, Stablo i čovjek, str. 16.

${ }^{817}$ N. Visković, »Ekologija i pravo«, str. 458.

${ }^{818}$ N. Visković, Sumorne godine, str. 242-243.

${ }^{819}$ Usp. Hrvoje Jurić, Euforija i eutanazija. Akutni zapisi o kroničnim problemima, Sandorf - Mizantrop, Zagreb 2019., str. 77.
} 
svijeta. Tu je onda riječ i o lišavanju socijalnih prava i zaštite radnoj snazi tih zemalja te rastu njihova duga. Nasuprot prirodnoj poljoprivredi, imperativ profita utječe na intenzivni biljni i životinjski uzgoj, prijeteći tako malim proizvođačima, ali i zdravstveno potrošačima. Konačno, ovakav vid globalizacije ne dovodi ni do mira, što se jasno ogleda u vojnim djelatnostima Sjedinjenih Američkih Država - države koja, uostalom, vlada financijskim kapitalom. ${ }^{820}$

No Viskovićeve učestale osude američkog imperijalizma u nekim su aspektima inkonzistentne s njegovim simpatijama spram postmoderne. Tu imamo u vidu misao jednog od vodećih lijevih kritičara postmodernizma, Fredrica Jamesona, koji drži očevidnim »da je čitava ta globalna, a ipak američka postmoderna kultura unutarnji i nadgradbeni izraz cijelog novog vala američke vojne i ekonomske dominacije širom svijeta: u tom smislu, kao i kroz klasnu povijest, poleđinu kulture čine krv, tortura, smrt i strava«. ${ }^{821}$

No, imamo li u vidu bioetičku problematiku, čini se da postmoderno doba otvara veći prostor za kulturno uvažavanje živih bića od onih ranijih:

\begin{abstract}
»Promjena pripada onome što nazivamo postmodernim duhovnim obratom, a na ovom specifičnom području izazvana je ponajprije krizom ideologije beskrajnog materijalnog progresa na račun tobože nepotrošive prirode koju danas izražavaju, ukratko rečeno, ekološka i bioetička kritika postojeće znanosti, filozofije i morala. U tom spoznajnom i praktičnom obratu događa se i snažan razvoj zanimanja za životinjstvo, čak više, iz razumljivih razloga bliskosti životinjskoga i ljudskog, negoli za bilo koji drugi segment prirodnoga svijeta. U središtima postmoderne svijesti - u Americi, Europi, Australiji i Japanu, znanstvene institucije ozbiljno se usmjeruju na istraživanje uloga životinja u povijesti kulture i istodobno se množe građanski angažmani za priznanje i zaštitu životinja, pa se onda sav taj spoznajni i etički i animalistički aktivizam prenosi i na masovnu kulturu, tisak, film, televiziju, dječju literaturu... $\ll^{822}$
\end{abstract}

Visković je svakako u pravu po pitanju intenziviranja rasprave o ulozi živih bića u kulturi, a onda i o njihovu uključenju u moralni i pravni obzir, koji nastupaju u dobu koje, tek kronološki, uobičavamo nazivati postmodernim. No on se posebno ne osvrće na doprinose ovom problemu koje može iznjedriti postmoderno mišljenje. Stoga ovdje valja ukratko ocrtati način na koji ono pristupa ovom problemu, a kako se radi o izuzetno šarolikoj paleti pristupa, osuđeni smo, s obzirom na gabarite ovog rada, pružiti tek parcijalan uvid u postmoderno, a u tom okviru prije svega etičko nastrojstvo spram uvažavanja živih bića. On svakako ne pokriva

\footnotetext{
${ }^{820}$ Usp. N. Visković, Sumorne godine, str. 281-285.

${ }^{821}$ Fredric Jameson, Postmodernizam ili kulturna logika kasnog kapitalizma, preveo Srđan Dvornik, Arkzin, Zagreb 2019., str. 19. - Može se argumentirati i da Visković indirektno uviđa ovaj problem kada među karakteristike postmodernog doba uvrštava dosad neviđenu kompleksnost, ubrzanost i globalizaciju. (Usp. N. Visković, »Prof. dr. sc. Nikola Visković«, str. 378.)

${ }^{822}$ N. Visković, »Uvodna riječ«, str. 5.
} 
svu njegovu raznolikost, prije je riječ o tome da pokušavamo iznaći određena mjesta koja mogu biti značajna za našu temu.

»Postmodernizam nas uči da besprincipijelna i neutemeljena moralnost omogućava da budemo dobri i blagonakloni jedni prema drugima. « ${ }^{823}$ Ono što se svakako uočava kod mnoštva postmodernih etičara, odbijanje je neutralnih principa. Tako, primjerice, kako sažimaju Jasminka Babić-Avdispahić i Asim Mujkić, Lévinas ističe da se naš odnos s drugima razlikuje od neutralne perspektive koja obilježava naš odnos s predmetima spoznaje. Njegova etika počiva na odgovornosti za Drugoga, koji se javlja kao sugovornik, Lice i transcendencija, a u moralnom se odnosu ne radi o subjekt-objekt odnosu, već o otkriću Drugoga. Upravo u susretu s Licem Drugoga, ovaj mi zapovijeda odgovornost tako da ona prethodi slobodnom pristanku ili ugovoru. Štoviše, moralna superiornost Drugoga određuje intersubjektivni odnos kao neravnopravan, tj. nesimetričan. No opaska s početka zasigurno više odgovara Lyotardovoj misli. On drži da »nije moguće očekivati univerzalne ili beskontekstne kriterije za etičke prosudbe«, da postoji samo njihova pluralnost i da se relevantnima pokazuju samo u izvjesnim pragmatičkim okvirima. Mada ovakav pristup pokušava biti emancipacijski u pogledu odbacivanja dominacije pojedinih jezičnih igara, kritičari tvrde da je on istovremeno i antiemancipacijski. Barem su dva razloga za to, koja ističe Honi F. Haber: neravnopravnost u moći koju jezične igre imaju te činjenica da jezične igre nisu pacifističke. Richard Rorty sa svoje će strane, uz zadržavanje pragmatičkog nastrojstva i odbijanje univerzalnih racionalnih kriterija, rješenje tražiti u imaginaciji, tvrdeći da moralni progres ne leži u povećanom znanju, nego u upravljanju osjećajima. ${ }^{824}$

Kako navodi Bauman, za razliku od moderne etike koja potražuje univerzalnost i utemeljenje, barem u vidu vjere da je takav jedan jednoznačan i ne-aporijski etički kod moguće jednom pronaći, postmoderni pristup etici ne vjeruje u takvu mogućnost. Moderna, vjeruje se, sama pokazuje ispraznost svojih nada, tj. besmislenost svog truda. Štoviše, njezini pokušaji da zajamči moralno držanje boljim okvirima ili bolje formiranim motivima za ljudsko djelovanje polučili su više okrutnosti negoli humanosti. Uostalom, kako su prema postmodernom svjetonazoru moralni fenomeni bitno ne-racionalni, ne-repetitivni, nepredvidljivi, oni ne mogu biti pravilima vođeni fenomeni, tj. nije moguće uspostaviti etički kod. Njegovo bi uspostavljanje zapravo isključilo moralne fenomene iz okvira autonomnog sebstva koje konstruira odgovornost i zamijenilo ga usvojivim znanjem pravila. Moral je, uostalom, nužno aporijski, a moralno se sebstvo prepoznaje upravo po njegovoj nesigurnosti o ispravnosti svog

\footnotetext{
${ }^{823}$ Jasminka Babić-Avdispahić, Asim Mujkić, Etika, Eidos, Zenica 2019., str. 166.

${ }^{824}$ Usp. ibid., str. 171-173, 179-184.
} 
djelovanja. Odbacivanje vjere u univerzalnost ne podupire nužno moralni relativizam. Bauman, naime, izvrće ovu optužbu optužujući etičke kodove za relativizam - upravo moderna društva pod maskom univerzalne etike promoviraju moralnu uskogrudnost. ${ }^{825}$ No uzimajući dio moderne etike za cjelinu, Bauman ne uviđa prostor slobode, kreativnosti i odgovornosti koji se javlja u univerzalističkim etičkim pozicijama koje su formalno određene.

Ista se logička greška nerijetko javlja i pri dovođenju u odnos etike i estetike. Jedan od značajnijih postmodernih animalista, Steve Baker, potonju stavlja ispred prve kada, oslanjajući se na Derridu i Badioua, drži da se etika tiče tek kontrole, regulacije, pasivnosti, tj. izbjegavanja neodgovornih radnji. Alternativa se treba tražiti »u nekoj vrsti poetske invencije, kreativne akcije i imaginativnog raspoznavanja nereguliranih mogućnosti«, što odgovara Lyotardovoj zamisli uloge postmodernog umjetnika. ${ }^{826}$ Naravno, uzmemo li u obzir ono što je o etici govoreno u ovom radu, pogotovo u pogledu njezinog vezivanja uz pojam samoostvarivanja, ovakav je postmoderni pristup (ne-postmodernoj) etici svakako neutemeljen.

Postmodernizam, ističe Gary Steiner, već s primatom raznovrsnosti pred jedinstvom i neprihvatljivošću dominacije jedne perspektive nad drugom, ne dopušta artikulaciju principā koji bi imali obavezujući autoritet. Kritika uma koja se ovdje provodi nije, sljedeći razlikovanje Richarda Wolina, »imanentna«, nego »totalna«, što znači da um nema snagu koja premašuje utjecaj moći ili perspektive, pa time i nema želje za artikuliranjem moralnih principa. ${ }^{827}$

\footnotetext{
»'Gubljenjem' istine ili suštine 'pravednog', 'dobrog', 'čovještva', ne gubimo pravedno, dobro ili čovještvo. Ono što nam se čini da gubimo - stvar po sebi, stvar u svojoj univerzalnoj sveobavezujućoj dimenziji čini se, pokazuju nam postmoderni mislioci, nikada nismo ni imali. Ako pak ne možemo izgubiti ono što nikada nismo ni imali, onda, u suštini, možemo biti samo na dobitku - dobivamo slobodu za samooblikovanje i samostvarenje vlastitih sebstava i zajednica unutar kojih djelujemo.« ${ }^{828}$
}

No pristupi poput Lyotardova i Rortyjeva čine inzistiranje na slobodi upitnim, bilo s obzirom na odbijanje čvršćeg zasnivanja racionalne pozicije s koje bi se moglo suočiti sa silnicama koje osujećuju slobodu (tako da se ta pozicija ne pretpostavi kao jednakovrijedna onoj vezanoj uz ove silnice), bilo da uopće ne postoji spremnost suočavanja s tim silnicama. Tako Rortyjeva »analiza nije eksplicitna u identifikaciji suvremenog kapitalizma kao ključnog izvora ovog problema«, u ovom kontekstu uže formuliranog u pitanje: »što je to što dovodi do takvog osiromašenja i živote nesretnih ljudi u rizik tako da im ostaje još vrlo malo i ponosa i

\footnotetext{
${ }^{825}$ Usp. Zygmunt Bauman, Postmoderna etika, prevela Dorta Jagić, AGM, Zagreb 2009., str. 16-20, 23.

${ }^{826}$ Usp. Steve Baker, Artist | Animal, University of Minnesota Press, Minneapolis - London 2013., str. 65.

${ }^{827}$ Gary Steiner, »Response to Commentators«, PhaenEx 8 (2013) 2, str. 308-325, ovdje str. 311-312.

${ }^{828}$ J. Babić-Avdispahić, A. Mujkić, Etika, str. 184-185.
} 
samopoštovanja ${ }^{829}$ Kada je riječ o Lévinasovoj etici, izgledi slobode tu su još eksplicitnije ugroženi, a svakako i težnje za otklanjanjem ugroze moga (ili nečijeg drugog) samoostvarivanja od strane superiornog Drugoga. ${ }^{830}$

No kada je pobliže riječ o životinjama, Chloë Taylor ističe kako pojedini postmoderni autori jasno naglašavaju da imamo moralnu odgovornost spram njih, primjerice levinasovci koji kao osnovu za nju drže drugost. Nju osobito interesira fukoovska perspektiva (premda se Foucault nije htio nazivati postmodernistom), koja može pružiti vrijedne upute za životinjsku etiku. Tako na tragu ove misli u pogledu »oslobođenja životinja« ne bismo trebali govoriti o njihovu potpunom oslobođenju od odnosa moći (s obzirom na to da ljudske odluke neizbježno utječu na životinje), što ne znači da ne bismo trebali odbaciti prakse spram životinja koje nalikuju onima protiv kojih je u okviru ljudske zajednice pisao Foucault. Pokret za oslobođenje životinja osuđen je na neefikasnost ako ne osvijesti načine na koje moć djeluje u odnosima čovjeka i životinje. Njegova bi misao mogla dobro poslužiti i kao sredstvo za iznalaženje genealogije specizma. ${ }^{831} \mathrm{U}$ tom svjetlu i Tomaž Grušovnik ističe da nijedan postmodernistički ili poststrukturalistički autor nema nešto što bismo mogli nazvati »etikom životinja«, no razmišljanja nekih od njih imaju »neposredne etičke posljedice «. ${ }^{832}$

U ovom bismo pogledu svakako mogli naglasiti važnost izvjesnih poticaja koji dolaze iz etičkih implikacija postmoderne filozofije, no to ne otklanja važnost univerzalnih (što ne znači, koliko god kritika išla u tom smjeru, sadržajnih uputa, nego prije svega formalnih) principa kao etičkog utemeljenja koje neće izvjesnim »malim« naracijama dozvoljavati proizvoljno tumačenje naše dužnosti spram onih koji je zaslužuju (suprotno bi bilo upravo neodgovorno, jer ne bi bilo osnove, primjerice, za osudu i sprječavanje izvjesnih tradicionalnih, prema životinjama okrutnih praksi koje određena zajednica upražnjava i štiti svojom malom naracijom), ali će isto tako jasno progovarati protiv onih silnica koje u pozadini relativističke obrane različitih stilova života i odabira vrijednosti upravo određuju te stilove i odabire (kao i same potrebe), ugrožavajući time samoostvarivanje i subjekata i objekata morala.

Kako bi se pokazalo da se pribjegavanje postmodernističkom okviru za razrješavanje bioetičkih pitanja nerijetko pokazuje kao medvjeđa usluga živim bićima, vrijedi ukazati na još

\footnotetext{
${ }^{829}$ Ibid., str. 187.

${ }^{830}$ Tu je na djelu emancipacija od ovisnosti moje pozicije o držanju Drugoga (usp. Z. Bauman, Postmoderna etika, str. 66-67), no to nije novost spram drugih ne-recipročnih etika, kakvu smo, zapravo, i ovdje zagovarali (uopće bi teško bilo zasnovati biocentričku etiku s recipročnih polazišta). Za Baumanovu obranu postojanja istinske slobode u Lévinasovoj etici vidi i: ibid., str. 109-110, 155-156.

${ }^{831}$ Chloë Taylor, »'Postmodern' Critical Animal Theory: A Defense «, PhaenEx 8 (2013) 2, str. 255-270, ovdje str. 257, 264-266.

${ }^{832}$ T. Grušovnik, Etika živali, str. 50
} 
jedan, širi aspekt ove problematike, pri čemu mislimo na relevantnost Jamesonove kritike postmodernizma i za ono o čemu smo raspravljali u okviru poglavlja »Zaborav prirode«. Jameson posebno razmatra kategoriju uzvišenog, posebno isticanu u moderni od strane Edmunda Burkea, Kanta i Heideggera, a uvijek s bitnom referencom na prirodu. No kakva forma predstave prirode može postojati u postmodernizmu, kada priroda, zapravo, nestaje? Ona pak nestaje zahvaljujući praksi eliminacije enklava pretkapitalističke organizacije od strane kapitalizma našeg vremena, enklava »koje je do sada tolerirao i eksploatirao samo uzimanjem danka«, a radi se o »originalnoj penetraciji i kolonizaciji Prirode i Nesvjesnoga«, u vidu razaranja pretkapitalističke poljoprivrede putem zelene revolucije (da ne govorimo onda i o genetičkoj kolonizaciji koja u trenutku kad Jameson ovo piše još nije u svome kasu) te razvoja medija i reklamne industrije. Što se onda može detektirati kao ono drugo našeg društva (ili, u kontekstu spomenutog poglavlja, kulture) ako to više nije priroda? Prema čemu se, dakle, formira postmoderno uzvišeno? Jameson nije sklon označavanju tehnologije per se kao toga drugoga, s obzirom i na to da tehnologija, s marksističkog gledišta, predstavlja rezultat razvoja kapitala, a ne krajnju određujuću istancu. Pored toga, tehnologija ne izaziva na svakom stupnju razvoja kapitalizma istu vrstu doživljaja uzvišenoga. Marinettijeva futuristička uzbuđenost mašinerijom ne nalikuje predstavljanju mašine u postmoderni, kada je ona prije namijenjena reprodukciji negoli produkciji. ${ }^{833}$

\begin{abstract}
»Stoga tehnologija suvremenog društva nije toliko hipnotična i fascinantna sama po sebi, već zato što se čini da nudi neku privilegiranu reprezentativnu šifru za shvaćanje mreže moći i kontrole koju naš duh i mašta može još teže shvatiti - naime, čitave nove decentrirane globalne mreže trećeg stadija samog kapitala. Taj se figuralni proces može u sadašnjici najbolje promotriti u čitavoj modi suvremene zabavne literature - čovjek je u iskušenju da je karakterizira kao 'visoko-tehničku paranoju' - u kojoj krugove i mreže nekog tobožnjeg globalnog kompjuterskog sklopa u priči pokreću zamršene zavjere autonomnih, ali smrtonosnim uzajamnim zahvatom povezanih konkurentskih informacijskih agencija, s takvom kompleksnošću koja čak nadmašuje kapacitet normalnog čitalačkog duha. Ipak, teoriju zavjere (i njene iskićene narativne manifestacije) valja gledati kao nižerazredni pokušaj da se - putem figuracije razvijene tehnologije - misli nemogući totalitet suvremenog svjetskog sistema. Po mojem sudu, postmoderno uzvišeno se može adekvatno teorijski spoznati samo kroz odrednice tog golemog i prijetećeg, premda samo nejasno uočljivog drugog realiteta ekonomijskih i socijalnih institucija.« ${ }^{834}$
\end{abstract}

\footnotetext{
${ }^{833}$ Usp. F. Jameson, Postmodernizam ili kulturna logika kasnog kapitalizma, str. 59-63.

${ }^{834}$ Ibid., str. 64-65. - S »golemim i prijetećim« i nemogućnošću obuhvaćanja Jameson se nadovezuje na spomenuta Burkeova i (naročito) Kantova poimanja uzvišenog: »Uzvišeno je za Burkea, kao što se sjećate, doživljaj koji graniči sa strahom, časovit bljesak u zapanjenosti, prepasti i strahopoštovanju, doživljaj nečega toliko golemog da posve krši ljudski život; taj je opis Kant zatim učinio finijim, uključivši i pitanje samog prikazivanja, tako da predmet uzvišenoga sada postaje ne samo stvar puke snage i fizičke nesumjerljivosti ljudskog organizma
} 
Jameson kao poseban problem ističe dokidanje distance, naročito one kritičke, u novom prostoru postmodernizma, među ostalim zahvaljujući i koloniziranju spomenutih pretkapitalističkih enklava od strane multinacionalnog kapitala, koje su »kritičkoj djelotvornosti pružale eksteritorijalne arhimedovske oslonce $\ll .{ }^{835}$ Sa zatiranjem i zaboravom prirode, gubljenjem drugoga putem posvemašnje »kulturalizacije« (pa i onda kada se radi o »naturalizaciji«, bilo u socijaldarvinističkom, bilo u dubinskoekološkom pogledu), zasigurno se ne postiže istinsko uvažavanje prirode i živih bića, no isti proces pogubno se odražava i na čovjeka, a u postmodernizmu takvo se što može zgodno sagledati kao nestanak ili smrt subjekta.

\section{IV.3.3.1. Pitanje subjekta}

Postmoderno mišljenje, prema Jamesonu, općenito je osporilo četiri temeljna dubinska modela: frojdovski (latentno/manifestno), egzistencijalni (autentično/neautentično), semiotički (označitelj/označeno) te »dijalektički model bîti i pojave (zajedno s čitavim rasponom pojmova ideologije ili iskrivljene svijesti, blisko povezanih s njim)«. Dubina je tako zamijenjena površinom, a ako se radi o višestrukim površinama, npr. intertekstualnosti, i dalje se ne može govoriti o dubini. Uz dubinski model autentično/neautentično vezana je i suprotnost otuđenje/razotuđenje, koja također biva žrtvom postmoderne, tako da se javlja »smjena otuđenja subjekta raspadanjem subjekta«. »Smrt subjekta« tako se odvija kao kraj individuuma, kraj autonomne građanske monade, a kao protuteža, bilo u moralnom ili empirijskom pogledu, naglašava se decentriranje nekad centriranog subjekta (za kojeg bi poststrukturalizam rekao da je postojao tek kao ideologijsko priviđenje). Visoka moderna podrazumijeva individualnu monadu, kako se može, primjerice, promotriti putem slike Krik Edvarda Muncha, no na ovoj se također iščitava visoka cijena bivanja monadom, zatvorenom spram drugoga. ${ }^{836}$ Moderna misao tako već sadrži kategorije, od kojih je ona otuđenja (posebice kada se razmatra u vidu otuđenja od drugoga, koje ne nastupa odvojeno od samootuđenja) krucijalna, koje se mogu suočavati s izvjesnim problemima rođenima ili barem potenciranima u modernom dobu.

\footnotetext{
s Prirodom, već također i stvar granicā figuracije i nesposobnosti ljudskog duha da pruži predstavu za takve goleme sile.« (Ibid., str. 59.)

${ }^{835}$ Usp. ibid., str. 80-81. - »Ukratko, želim reći da novi prostor uključuje potiskivanje distance (u smislu Benjaminove aure) i neumorno popunjavanje svake preostale praznine i praznih mjesta, do točke na kojoj je postmoderno tijelo (...) sada izloženo perceptualnoj baraži neposrednosti iz koje su uklonjeni svi zaštitni slojevi i sva posredovanja.« (Ibid., str. 97.)

${ }^{836}$ Usp. ibid., str. 30, 33-34.
} 
Postmodernizam se također donekle oslanja na modernu misao. Upravo po pitanju socijalno konstruiranog subjekta, kako u jednoj natuknici Enciklopedije postmodernizma (Encyclopedia of Postmodernism) navodi Tammy Clevell, postmodernisti referiraju na Marxovu i Freudovu misao. Oni se protive kartezijanskom pojmu subjekta, kao strogo ograničenog racionalnog samozakonodavca. Ljudski je subjekt, prema prevladavajućem postmodernističkom stavu, konstruiran društvenim diskursima, lingvističkim strukturama i praksama označavanja. ${ }^{837} \mathrm{No}$, slijedom prije navedenog definiranja subjekta (koje ostaje u izvjesnom smislu tradicionalno), postmodernistički bi nam uvidi mogli prije pomoći u osvještenju istovremenog djelovanja više subjekata kroz krajnjeg izvršitelja djelovanja. To je osobito važno, kako će se uskoro pokazati, u etičkom pogledu, što se može pratiti na planu zamagljivanja autonomije kao regulativne ideje (čime je već opovrgnuta predstava u potpunosti aktualiziranog subjektova samozakonodavstva) našeg odnosa spram drugog ljudskog bića, ali i na planu odgovornosti.

U tom je pogledu osobito važno izbjeći krajnost koja se može vezivati uz ekološkoetičku problematiku, a riječ je o mjeri prožetosti odnosima sveg bića koju smo istaknuli kao eventualan problem u okviru dubinske ekologije (neovisno svrstavamo li ovu u postmodernu). Naime, što bi se dogodilo kada bi se spomenuta Foxova tezu o podbacivanju u dubinskoekološkoj svijesti uslijed prepoznavanja granica primijenila na sam subjekt, tj. kada bi identifikacija pojedinca $\mathrm{s}$ kozmičkom cjelinom nastupila i u pogledu njihova bivanja subjektom? Ono što je tu relevantno za etiku snažnija je osnova za zasnivanje kolektivne odgovornosti, no raste opasnost od zamagljivanja one individualne.

To nas vodi u smjeru Jonasove etike, tj. potrebe za jednom novom etikom uslijed nove dimenzije odgovornosti, gdje se kao sve relevantnije javlja »rastuće područje kolektivnog čina u kojem počinilac, djelo i učinak nisu više oni isti kao u onoj bliskoj sferi«, tj. sferi, kako on kaže, »susjedske etike«. ${ }^{838}$ Neovisno o daljnjim Jonasovim promišljanjima, svakako možemo ustvrditi da se kolektivni čin javlja kao sve relevantniji za etička promišljanja, no to nas ne bi smjelo odvesti u iskušenje pripisivanja (moralne) odgovornosti nečemu što nadilazi volju pojedinačnog umnog bića, izvan koje je, kako je ranije zajedno s Kantom istaknuto, nemoguće zamisliti nešto što bi bilo dobro ili zlo. To pak nikako ne znači da neposredni izvršitelj izvjesnog

\footnotetext{
837 Usp. Tammy Clevell, »Subjectivity«, u: Victor E. Taylor, Charles E. Winquist, Encyclopedia of Postmodernism, Routledge, London - New York 2001., str. 381-383. - Postojala je i reakcija na apsolutiziranje ovih determinanti: »Kao mnogi feministi, kritičari u poljima novog historicizma, postkolonijalizma te gay $\mathrm{i}$ lezbijskih studija odbacuju teoriju pasivnog subjekta, u potpunosti determiniranog kulturom i jezikom. Posljedično, kulturni kritičari uveli su probleme ljudskog djelovanja i individualne odgovornosti te koncepte intersubjektivnosti i zajednice u diskusiju o postmodernom subjektivitetu.« (Ibid., str. 383.)

${ }^{838}$ H. Jonas, Princip odgovornost, str. 21.
} 
djelovanja snosi čitavu odgovornost za njega. U tom pogledu on može biti djelomičan subjekt djelovanja (ili možda, kao pod hipnozom, ne biti samosvjesnim subjektom uopće), uz kojega se kao drugi djelomični subjekti javljaju i različite društvene (ili šire, kulturne) i prirodne silnice. Ove društvene mogu biti i kolektivne (tako da pojedinac sudjeluje u njima), ali i apstraktne (poput uvjetovanja od strane izvjesnog društveno-ekonomskog sistema), no ovima je besmisleno pripisivati odgovornost - ona leži samo u mjeri u kojoj je pojedinac slobodan subjekt ili je trebao/mogao biti slobodan subjekt svog djelovanja (tj. da je samostalan i ima djelovanje pod kontrolom), bilo da se ono vrši »u susjedstvu«, bilo da se uključuje u kolektivan čin, kakav je, primjerice, onaj uzrokovanja klimatskih promjena. U tom pogledu zanemarivanje odijeljenosti subjekata djelovanja (i određivanja naravi i intenziteta njihova bivanja subjektima) vodi u stramputicu ne samo nemogućnosti određenja odgovornosti (pa tako i onih koji su nosioci moći u kolektivu), nego i besmislicama poput pripisivanja odgovornosti bićima nesposobnima za moralno suđenje i djelovanje.

Stoga postoji ozbiljna opasnost posvemašnjeg odbacivanja klasično određenog subjekta, pa se kao alternativa može ponuditi upravo izneseni ocrt načina na koji pojedinac biva subjektom prilikom djelovanja, a posebice uvidom u načine na koji subjektom postaju izvjesne apstrakcije čije se uklanjanje, u svrhu dosezanja autonomije ljudskih bića, uspostavlja kao moralna dužnost, a ne samo kao politički imperativ, što ne znači da etika taj zadatak može obavljati bez politike (i ne samo politike).

Generalno bi se moglo reći da značajni emancipatorski potencijali leže u razotkrivanju neosviještenih determinanti koje uvjetuju naše mišljenje i djelovanje. Ovdje je osobito vrijedno već Spinozino upozorenje (koje ovdje ističemo neovisno o duhu njegove filozofije) da »ljudi misle kako su slobodni samo iz toga razloga što su svjesni svojih radnji, a ne znaju uzroke kojima su određeni«, ${ }^{839}$ a onda i Mannheimov uvid »da se izgledi za relativno oslobođenje od društvene determiniranosti povećavaju proporcionalno uvidu $\mathrm{u}$ tu determiniranost «. ${ }^{840}$ Pojedinici tako nisu tek epifenomeni pluralnih i presjecajućih diskursa ${ }^{841}$ ili nekakvih drugih determinanti, ako ništa drugo onda zato što mogu ove osvijestiti, pronaći načine na koje oni sami nisu u potpunosti subjekti svakog svog djelovanja i kako da to postaju, kao i kako da isto omogućavaju drugima. Postmodernističko cijepanje ili poricanje subjekta u izvjesnom bi se

\footnotetext{
${ }^{839}$ B. Spinoza, Etika, str. 107.

${ }^{840}$ K. Mannheim, Ideologija i utopija, str. 59.

${ }^{841}$ Vidi: Christopher Butler, Postmodernizam. Kratki uvod, preveo Dušan Janić, Šahinpašić, Sarajevo 2007., str. 63-64.
} 
smislu dalo tumačiti kao ishitrena reakcija na ovaj problem, čije se rješenje plaća nemogućnošću zasnivanja autonomije, a onda i smislenosti govora o moralnome.

Ozbiljnija bi se reinterpretacija prije trebala poduzeti na planu supstancije. Jonas je tu svakako zahvalniji sugovornik od dubinskih ekologa. Jedan od ključnih ontoloških problema koji on s pravom ističe onaj je relacije, a on je bitno vezan uz problem supstancije. Naime, Descartesovo određenje supstancije kao onoga što ne zahtijeva ništa drugo da bi egzistiralo isključuje svaku samo-tranzitivnost ili samo-transcendenciju, bez koje je nemoguće pojmiti fizičku relaciju pojedinca spram okoline, a naročito prateću ranjivost. Tako se kao jedan od glavnih zadataka suvremene ontologije zadaje oslobađanje bitka od okova supstancije, a kao jedan od aspekata te zatvorenosti javlja se i problem posvemašnje zabrane antropomorfizma. ${ }^{842}$ Uvažavanje samotranzitivnosti bitno mijenja klasični pojam supstancije, no ne vodi (barem ne nužno) u »razvodnjavanje« ili »razmrežavanje« subjekta.

\section{IV.3.3.2. Viskovićev postmodernizam?}

Viskovićevo poimanje subjekta u svom osnovnom određenju ne odudara od klasičnog poimanja, barem u pravnoj znanosti. U svojim pravnim i etičkim refleksijama Visković se u velikoj mjeri poziva na moderne autore, a one same dio su sustavnog obrazlaganja međuodnosa čovjeka i ostatka živog svijeta i same teže sustavnom ustrojstvu. ${ }^{843}$ Značajan dio tog sklopa sačinjavaju i velike naracije, primjerice, o trendu univerzalizacije moralnih prava i dužnosti te uopće ideja moralnog progresa. ${ }^{844} \mathrm{U}$ suvremenom trenutku ulogu velike naracije svakako igra i, kako ćemo uskoro pokazati, ekološka priča (s kojom se također valja sustavno suočiti), a ne treba zanemariti ni, usprkos njegovim granicama, stalnu prisutnost velike naracije marksizma kao trajno valjane kritike socijalnih nepravdi i otuđenja. Moderne kategorije tako zasigurno ne iščezavaju iz Viskovićeva djela. U svakom slučaju, neke od njegovih osnovnih poruka zasigurno više odgovaraju iznesenim Jamesonovim kritikama postmodernizma negoli teorijama postmodernista.

\footnotetext{
${ }^{842}$ Usp. H. Jonas, The Phenomenon of Life, str. 32.

${ }^{843}$ Sustavnost se može pripisati i njegovim pojedinim knjigama, pa u pogledu Stabla i čovjeka Frane Šago piše: »Znanstveno-kompozicijska osebujnost ove Viskovićeve knjige nije tendencija k njezinoj golemoj voluminoznosti (premda je ona to predmetno-supstancijalno sama po sebi), već je to poglavito strukturirana i, rekoh, smisleno sustavno osmišljena cjelina, štoviše kao jedina i jedinstvena u toj matrici materija, usudio bih se ustvrditi u cijeloj Europi, i ona je stoga novum.« (Frane Šago, »Knjiga 'Stablo i čovjek'. Opus magnum u hrvatskoj i europskoj kulturnoj botanici«, Mogućnosti 50 (2003) 4-6, str. 164-168, ovdje str. 165.)

${ }^{844}$ Bauman ideju moralnog napretka shvaća kao modernističku reakciju na ugrozu univerzalizma postojanjem različitih predodžbi dobra i zla u vremenu i prostoru. (Usp. Z. Bauman, Postmoderna etika, str. 52.)
} 
Može se činiti da njegovo uzimanje u obzir mnoštva »malih naracija« u vidu pojedinih perspektiva arhaičnih zajednica (i uopće različitih kulturnih zajednica), umjetničkih izraza, stavova »malog čovjeka«, aktivističkih skupina itd. navodi na suprotan zaključak. Posebice ako bismo taj kompleks znanja prikazali u obliku »rizome« (Deleuze i Guattari), a ne »stabla« (hijerarhije), što Visković, uzmemo li u obzir sam način prikaza problematike u svojim kapitalnim kulturnobiološkim knjigama, u izvjesnom smislu i radi. ${ }^{845}$ Ovdje bi valjao izvesti kratku usporedbu s feminističkom perspektivom, koju i Visković uvažava. ${ }^{846}$ Ona se u svom postmodernom obliku i dalje dijelom nadaje kao moderna, s obzirom na to da održava barem jednu veliku naraciju. Ona je nužna kako bi se, tvrde Nancy Fraser i Linda J. Nicholson, sam središnji predmet feminističke teorije - »tlačenje žena od strane muškaraca« - mogao ustanoviti, pa tako »učinkovita kritika ove pojave zahtijeva niz različitih metoda i žanrova, tj. minimum velikih pripovijesti«. One se pak ne odriču postmoderne oznake, držeći svoju koncepciju naprosto drugačijom inačicom postmoderne misli od one Lyotardove (čije odbacivanje žanra kritike, poput velikih povijesnih naracija i historijski situirane društvene teorije drže neopravdanim). No ovaj minimum velikih naracija ne bi trebalo voditi izgradnji sveobjašnjavajuće velike društvene teorije, nego bi feministkinje svoj pothvat trebale »shvaćati kolektivno, kao slagalicu čije dijelove nadopunjuju razni ljudi, a ne kao konstrukciju koju se može kompletirati jednim velikim teorijskim zahvatom «. ${ }^{847}$ No čak ako ovo uzmemo i za legitimno korištenje pojma postmodernizma, Viskovićevo uvažavanje različitih perspektiva, uvelike slično integrativnobioetičkom pluriperspektivizmu, ne čini od ovih tek dijelove slagalice koji se slažu pod vidom minimuma velike naracije »tlačenja prirode od strane čovjeka«, nego konstitutivne dijelove velikog teorijskog zahvata s jasnim ciljem - utvrđivanje činjenica, vrijednosti i normi - i jasno određenim ulogama (kako smo vidjeli, primjerice, za antropomorfizam u etici). Ovo je osobito uočljivo na onim mjestima gdje se pojedini

\footnotetext{
${ }^{845}$ Premda bismo samom izvanjskom prikazu možda prije mogli dati obilježje Adornove ideje slobodne refleksije koja se javlja u formi »mišljenja kao enciklopedije«, no ona se iz unutarnje strukture Viskovićevog mišljenja ne bi u pravom smislu riječi dala iščitati upravo zbog Adornove težnje k nesistematičnosti (vidi: P. Krstić, Subjekt protiv subjektivnosti, str. 74-75), a onda to pogotovo vrijedi za rizomsku formu znanja.

${ }^{846}$ Pored prethodno navedenih elemenata u prilog ovome, vrijedi spomenuti i sljedeće: »Možda smo čak na početku jednog šireg, a za mogućnost mijenjanja postojećih stanja zaista neophodnog okupljanja snaga emancipatorskog otpora - jednog saveza mirotvornih, zelenih, ženskih, anarhističkih, antiglobalističkih pokreta, kao i drugih marginaliziranih društvenih skupina, koji bi se temeljio i na spoznaji o bitnoj istovrsnosti uzroka i posljedica nepravednih ratova u društvu i nepravednog rata protiv prirode. Spajanje svih tih sadašnjem svjetskom poretku alternativnih snaga bilo bi optimalno ne samo za otpor ratovima u društvu i ratu s prirodom, već i za solidarno postizanje posebnih ciljeva feminizma, anarhizma, antiglobalizma i drugih pokreta kojima je zajednički otpor protiv društveno strukturiranog (fizičkog, psihičkog, institucionalnog, simboličkog) nasilja.« (N. Visković, Sumorne godine, str. 244.)

${ }^{847}$ Usp. Nancy Fraser, Linda J. Nicholson, »Društvena kritika bez filozofije: susret feminizma i postmodernizma«, prevela Lidija Zafirović, u: Linda J. Nicholson (ur.), Feminizam/postmodernizam, Liberata - Ženski studiji, Zagreb 1999., str. 23-38, ovdje str. $28,34$.
} 
(alternativni) pristupi problemu čovjekova odnosa spram prirode drže važnima za razvijanje (bioetičkog) senzibiliteta, ali se istovremeno označavaju teorijski naivnima.

Visković ne nastupa postmoderno ni onda kada uvažava pojedine elemente misli autora koji tako u izvjesnom smislu postupaju. Takav je slučaj, primjerice, s Nietzscheom i Heideggerom, koje Gianni Vattimo smješta u postmodernu s obzirom na to da odbijaju slijediti modernu logiku razvića ili progresivnog prosvjetljenja predlaganjem kritičkog nadvladavanja. Premda zauzimaju distancu spram zapadnjačkog mišljenja, ne ukazuju na neki istinskiji temelj. ${ }^{848}$ Takvo se nastrojstvo bitno razlikuje od Viskovićeva. No to ne znači da je u Viskovićevu djelu riječ o svaštarenju. Premda je ono pretežito enciklopedijskog tipa, ono nije tek nabrajanje nepovezanih, pa onda potencijalno i proturječnih pozicija o predmetu ispitivanja (iako, kako smo pokazali, ima i takvih slučajeva), nego ono pokušava ukazati na neka od uporišta za jedinstveni zadatak prevladavanja zaborava prirode (što podrazumijeva i njezino moralno uvažavanje) kako bi se nastavljala tendencija sve univerzalnijeg obzira, ali univerzalnijeg zaista u sve više pogleda, pa onda nije dovoljno uočiti samo moralni ili pravni napredak, već se mora »kopati« dublje u historiju neprijateljstva kulturnog spram prirodnog. Ova uporišta pronalaze se i tamo gdje prevladava ovo neprijateljstvo, ne zanemarujući da ono postoji, tj. da je paradigma koja iza njih stoji njime obilježena. No to ne sprječava, u suštini optimističku, potragu za pronalaženjem plodnih elemenata za suočavanjem s ovim zadatkom u svim formama i načinima, u raznim vremenima i prostorima nastajanja ljudskog znanja. Stoga, premda pojedina mjesta Viskovićevih djela sugeriraju suprotno, namjesto ponekad podcjenjivačkog postmodernog stava da valja odbaciti ono što se formiralo pod neadekvatnim paradigmama, kod Viskovića prevladava nešto slično bioeticizaciji filozofije u okviru integrativne bioetike, kao bioetičko čitanje pojedinih autora filozofske tradicije, ${ }^{849}$ no u širem značenju bioetizacije ili kulturbiologizacije čitavog fundusa ljudskog znanja.

\footnotetext{
${ }^{848}$ Usp. Gianni Vattimo, Kraj moderne, preveo Mario Kopić, Matica hrvatska, Zagreb 2000., str. 6. - U pogledu Nietzscheove teze o smrti Boga, Vattimo ističe: »Budući da pojam istine više ne opstoji, budući da temelj više ne funkcionira - jer više nema temelja za vjerovanje u temelj, odnosno u činjenicu da bi se mišljenje moralo 'utemeljivati' -, neće se iz moderne moći izaći kritičkim prevladavanjem, što bi bio samo korak unutar te iste moderne. Tako postaje jasno da treba iznaći neki drugi put. To je čas koji se može nazvati rođenjem postmoderne u filozofiji«. (Ibid., str. 154.)

${ }^{849}$ Usp. H. Jurić, Etika odgovornosti Hansa Jonasa, str. 254. - »U tom smislu bi, primjerice, aktualiziranje i reinterpretacija Aristotelove trijade znanjâ i znanostî mogli biti od velike koristi u raspravama o načelnim, metodologijskim pitanjima bioetike. Budući da se u Aristotelovoj sistematici ne radi samo o suptilnom diferenciranju problemâ, pristupâ i područjâ nego i o uočavanju te razvijanju imanentnih kohezivnih elemenata, ova bi integrativna trijada, ako ništa drugo, mogla biti jedan od poticaja u potrazi za modelima bioetičke pluriperspektivnosti i integrativnosti. Osim toga, pojedini autori i njihova djela, koji se na prvi pogled čine vrlo udaljenima od predmetnog područja bioetike, primjerenim bi pristupom mogli postati inspirativni sugovornici bioetičarima. Sjajan primjer za to predstavlja bioetičko čitanje Kanta kakvo je ponudio Thomas Sören Hoffmann u članku 'O Kantovoj aktualnosti za bioetiku', a vrlo zanimljivi su i radovi Michaela E. Zimmermanna, posvećeni
} 
S obzirom na navedeno, trebalo bi zanemariti mnogo iznesenih indikatora da bi se govorilo o Viskoviću kao postmodernističkom autoru, a on to ne postaje usprkos detektiranju i kritici onoga što znanstveno-tehnološka paradigma znanja, kao, možemo reći, moderni fenomen, sa sobom nosi. Visković ne odustaje od modernih kategorija. Buđenje iz maloljetništva nikada nije gotov proces, a kritičko sazrijevanje je stalan zadatak, koji se u ovom povijesnom momentu prije svega očituje u bioetičkoj problematici.

Treba ipak biti oprezan da se u ocrtavanju totalnosti ekonomske, tehnološke i sličnih mašinerija, čije bismo djelovanje $\mathrm{s}$ obzirom na navedeno držali zanemarenima (time i blagoslovljenima) od strane postmodernog relativizma, upali upravo u postmodernističku, ovdje više pragmatičnu grešku paralize kritičkog potencijala, koja u ovom kontekstu nastupa i onda kada postmoderni autori ispisuju razornu kritiku takvih mašinerija. Ponovno se valja poslužiti Jamesonom:

»Događa se da čim je moćnija vizija nekog sve totalnijeg sistema ili logike - očit je primjer Foucault iz knjige o zatvorima - tim se bespomoćnijim čitalac počinje osjećati. Ukoliko teoretičar pobjeđuje, time što konstruira sve zatvoreniju i strašniju mašinu, upravo utoliko on gubi, jer je time paraliziran kritički kapacitet njegovog rada, a pobude na negaciju i revolt, o pobudama na društvenu transformaciju da i ne govorimo - sve se više doživljava kao uzaludne i trivijalne naspram samog modela. $\ll^{850}$

Ovdje pak treba pozitivno valorizirati Viskovićev, ponekad pretjerano, pragmatički pristup izvjesnim problemima vezanima uz čovjekov bespoštedan odnos spram životinja. Tu se ne bi radilo o ublažavanju moralnog imperativa ili krajnjeg političkog cilja, nego o prepoznavanju izvjesnih prostora u koje se može stupiti i hodati »malim koracima«, ne gubeći iz vida ni nastojanja na ostvarivanju »velikih ciljeva«. S druge se pak strane može govoriti i o problemu razvijanja bioetičkog senzibiliteta, koji krajnje anti-reformističkim nastupom (kao posljedicom bespoštedne, ali isključivo negativne kritike svega postojećeg) rijetko može biti razvijan u suvremenom društvu. Svoj ponegdje pragmatički stav Visković nekad otvoreno opravdava borbom protiv ravnodušnosti.

Viskovića bi se u citatu spomenutom na početku ovog poglavlja moglo optužiti i po pitanju neproblematiziranja uloge masovne kulture $u$ populariziranju animalističke

\footnotetext{
uspostavljanju veza između dubinske ekologije i Heideggerove filozofije, koji su - iako ne pod imenom bioetike - svakako relevantni za ono što je ovdje nazvano bioeticizacijom filozofije.« (Ibid.)

${ }^{850}$ F. Jameson, Postmodernizam ili kulturna logika kasnog kapitalizma, str. 20. - Ovaj fenomen kod Foucaulta Rick Roderick naziva »paradoksom kritičara«. (Rick Roderick, »306 Foucault and the Disappearance of the Human (1993)«, Rick Roderick. Dostupno na: http://rickroderick.org/306-foucault-and-the-disappearance-of-thehuman-1993/ /pristupljeno 14. 5. 2020./.)
} 
problematike, ${ }^{851}$ tj. u cilju osnaživanja bioetičkog senzibiliteta, posebice imamo li u vidu Horkheimerovu i Adornovu kritiku fenomena masovne kulture, koje smo se i ovdje dotaknuli. No ono bi se upravo u pogledu ovog senzibiliteta moglo (barem dijelom) opravdati imamo li na umu dvostruku ulogu masovne kulture kakvu prepoznaje Jameson:

»Usprkos tome što se može smatrati da je funkcija djela koja nastaju iz produkcije masovne kulture legitimacija postojećeg poretka, prema Jamesonu se ne smije zanemariti momenat utopijskog ili transcendentalni potencijal koji im je inherentan. Tako masovna kultura, paradoksalno, na jednoj strani legitimira postojeći poredak čiji je i sama proizvod, dok se, s druge strane, prema njemu kritički i negativno odnosi oživljavajući i izražavajući 'fundamentalne nade i fantazije kolektiviteta'.« ${ }^{852}$

Jamesonov se stav ovdje u izvjesnoj mjeri podudara s Marxovim dvostrukim viđenjem uloge religije kao, s jedne strane, simptoma izvan-religijskog otuđenja, i kao, s druge strane, utopijske nade za razotuđenim svijetom. ${ }^{853}$ Takav neisključivi duh uvelike ohrabruje ne samo aktivističke pristupe, nego i pluriperspektivne teorijsko-praktičke pokušaje izgrađivanja platforme s koje se može nastupati spram postojećih destruktivnih silnica, što, eksplicitno ili implicitno, tvori zadatak kako kulturne biologije, tako i integrativne bioetike.

\section{IV.3.3.3. Integrativna bioetika i postmodernizam}

Jameson je instruktivan i po pitanju čuvenog postmodernističkog odbacivanja velikih narativa. Tako će on, nasuprot Lyotardovu napadu na ove, rehabilitirati pojam 'totaliteta', upravo u svrhu stvaranja uvjeta za mogućnost velikih narativa - za njega je, naime, narativ »uvjet svake historijske refleksije, isto koliko i ono što omogućava projektiranje u budućnost « ${ }^{854}$ Od ideje totaliteta ne odustaje ni Hoffmann kada opisuje integrativnu bioetiku kao »znanost totaliteta«, pružajući istovremeno sasvim jasno protivljenje njenoj pragmatizaciji:

\footnotetext{
${ }^{851}$ Visković na jednom mjestu, kroz lika Andreju svog rukopisa Toposi erotike (o čemu nešto kasnije), popularizaciju animalističke problematike kod djece putem Walta Disneya i masovne kulture stripa drži efikasnijom od onoga što im trenutno u školi pridolazi od strane prirodnih znanosti. Da se radi o donekle tužnoj okolnosti, potvrđuje usporedba takvoga sredstva s ulogom pornografije (za koju inače nema puno lijepih riječi) u pogledu spoznavanja i oslobađanja spolnosti. (Usp. Nikola Visković, »Erotika, pornografija, erotoposi«, Treća 5 (2003) 1-2, str. 158-177, ovdje str. 165.)

${ }^{852}$ Jovan Čekić, »Nastajanje post-humanog kapitalizma«, u: Fredric Jameson, Postmodernizam ili kulturna logika kasnog kapitalizma, preveo Srđan Dvornik, Arkzin, Zagreb 2019., str. 116-227, ovdje str. 170-171. - Čekić se ovdje referira na Jamesonovu knjigu Signatures of the Visible.

${ }^{853}$ Usp. K. Marx, »Prilog kritici Hegelove filozofije prava«, str. 91.

${ }^{854}$ Usp. J. Čekić, »Nastajanje post-humanog kapitalizma«, str. 168. - Zahvaljujući viđenju postmodernizma kao kulturne logike onoga što Mandel naziva kasnim kapitalizmom, Jameson će prisustvo velikih narativa detektirati i u njemu: »S postmodernizmom, po Jamesovom sudu, ne dolazi do kraja metanarativa, kao što to tvrdi Lyotard, već se čitav proces prije može razumjeti kao transformiranje čitavog svijeta u jednu te istu veliku priču, onu o razvoju globalnog kapitalizma.«(Ibid., str. 171.)
} 
»'Integrativna bioetika' se ne shvaća jednostavno kao tehnika rješavanja spornih pitanja koja se dade naučiti, koja se primjerice pojavljuju u području medicine koja u visokom stupnju koristi tehničke naprave koje potiskuju neposredni angažman liječnika, ili se ta pitanja javljaju u području primjene novih tehnologija na čovjeka. 'Integrativna bioetika' se mnogo više razumijeva kao seizmograf žive razmjene između djelovanja na prirodu i njezinih 'odgovora', između ljudske intervencije i sustavne reakcije, između ljudski 'ekscentričnog' činjenja i protufunkcija totaliteta, na koji mislimo pod pojmom 'život'. To stvarno stanje odnosa može se također jednostavno tako izraziti da je u 'integrativno' shvaćenoj bioetici u zadnjoj instanci subjekt dijalektički ukršten sa svojim objektom; da se ovdje ne događa ono inače tako rasprostranjeno 'otuđenje' jednog protiv drugoga i da je 'integrativna bioetika', pravo shvaćena, utoliko znanost totaliteta, a ne specijalna disciplina među drugima. $«^{855}$

No i pored toga, sasvim je jasno da integrativna bioetika zadržava veliki narativ, prvenstveno u vidu filozofsko-povijesnog pristupa (smjena epoha) i znanja (potreba utvrđivanja nove paradigme), no to ne znači da bi trebala biti zatvorena prema poticajima iz drugih velikih narativa, poput, primjerice, marksizma (kako smo već pokazali) ili feminizma (među ostalim, zbog propitivanja paradigme moći). Uostalom, imamo li u vidu fenomen ekološke krize, kao nezaobilazan praktički problem našeg vremena, čini se da reakcija na njega već sama zadaje konačan udarac postmodernističkom odbacivanju velikih narativa. Tako će George Myerson ustvrditi da je suvremena ekološka misao, premda zasigurno mijenja percepciju znanosti, tehnologije i progresa, duboko moderna. On prije svega osporava Lyotardovu dijagnozu iščeznuća univerzalnog meta-jezika (što je u moderni progres, iza kojega je stajao trijumf znanosti), pri čemu znanost više nije u mogućnosti da legitimira neku drugu jezičnu igru, poput ekonomske ili političke. Upravo ekologija tvori veliki narativ za 21. stoljeće, koja, primjerice, legitimira autoritet vlade po pitanju mjera protiv klimatskih promjena. Znanost nije samo izvor objašnjenja izvjesne krize, nego i nužna referentna točka političkog odgovora na nju. Opće je mišljenje da se pojedine krize (kakva je bila ona kravljeg ludila) razbuktavaju upravo zahvaljujući zanemarivanju znanstvenih uvida od strane političara, a uvažavanje tih uvida spada potonjima u dužnost. ${ }^{856}$ Ništa se drugačije ne promatra ni suvremeni eksces (spram globalno prevladavajućeg stava) poricanja klimatskih promjena od strane američkog predsjednika

\footnotetext{
855 Thomas Sören Hoffmann, »Bioetika i mnogostrukost pojmova prirode«, preveo Pavo Filipović, u: Velimir Valjan (ur.), Integrativna bioetika i izazovi suvremene civilizacije. Zbornik radova Prvog međunarodnog bioetičkog simpozija u Bosni i Hercegovini (Sarajevo, 31. III.-1. IV. 2006.), Bioetičko društvo u BiH, Sarajevo 2007., str. 23-33, ovdje str. 25.

${ }^{856}$ George Myerson, Ekologija i kraj postmoderne, preveo Ognjen Čaldarović, Naklada Jesenski i Turk, Zagreb 2002., str. 8, 14-15, 37, 42-43.
} 
Donalda Trumpa, ${ }^{857}$ što se kao eksces artikulira i kroz nepopustljivo povjerenje u znanost od strane aktivista poput Grete Thunberg.

S druge strane, nastavlja Myerson, širina zahvata ekološke velike naracije obuhvaća toliko područja da proizvodi »ekopatologiju svakodnevnog života«. Time se hoće reći da se, kao i u slučaju psihopatologije, stvaraju poveznice između bezopasnih i patologijskih pojava, pa svako ponašanje ima svoje ekološko značenje. Ekopatologija je, poput Freudova totalnog sistema (izvedenog i u Psihopatologiji svakodnevnog života), kadra sve tumačiti univerzalnim meta-jezikom. ${ }^{858} \mathrm{U}$ tom pogledu valja biti oprezan spram redukcionizma, što integrativna bioetika sa svoje strane uspijeva (ili barem postavlja kao zadatak), time što protiveći se onom tehnoznanstvenom, sumnjiči svako redukcionističko usmjerenje u sagledavanju tako kompleksnog fenomena poput života, a što proizlazi i iz neodgovornosti takvog pristupa imaju li se u vidu moralni imperativi spram živih bića.

Stoga bi se moglo reći da izbor između jednostranog insistiranja na izvjesnom velikom narativu i potpunom odbacivanju svakog velikog narativa predstavlja lažnu alternativu:

»I, konačno, nije li izbor između tvrdokorna istrajavanja na tradicionalističkoj patetici (dakle istrajavanja na 'velikim pričama', na onomu što prema misliocima poput Lyotarda valja bez ostatka odbaciti) na jednoj te relativiziranja etičkih normi i estetičkih kanona na drugoj strani jedan uistinu paradigmatičan slučaj lažne alternative? Pri tom biranju između laži patetike i laži nerazlikovanja dobra od zla i lijepoga od ružnoga, dodajmo i to, uopće se ne dovodi (jer već i sama formulacija alternative to onemogućuje) pravi korijen i zbiljski izvor evidentiranoga nadiranja nihilističkog sindroma, a to je samosvrhovitost proizvodnje profita, ona samosvrhovitost koja instrumentalizira i ništi i prirodu i ljudska bića. Ono što se ne može uočiti - ne može se, dakako, ni podvrći kritici niti na bilo koji način dovesti u pitanje. $^{859}$

U ovom je pogledu ideologija neoliberalizma osobito destruktivna, naročito $u$ vidu odbijanja činjenice da ona propagira ili afirmira izvjesnu ideologiju od strane njezinih zastupnika, koji je drže produktom vrijednosno neutralnih ekonomskih i drugih društvenih znanosti. ${ }^{860}$ No, vratimo li se na problem filozofske/ontološke zasnovanosti (društvenih) znanosti, već se kod klasičnih ekonomista mogu uočiti izvjesne ontološke predstave koje bitno

\footnotetext{
${ }^{857}$ Myerson u ovom pogledu vizionarski zaključuje da protivnici ekološkog modernizma ili »demonstranti goriva«, kako ih on naziva, »neće stajati pred vratima, nego unutar Bijele kuće«. (Ibid., str. 75.)

${ }^{858}$ Usp. ibid., str. 51, 54-56.

${ }^{859}$ L. Veljak, Uvod u ontologiju, str. 115.

${ }^{860}$ Usp. ibid., str. 126-127. - Veljak ovdje koristi pojam neoliberizam, tvrdeći da on ne isto što i neoliberalizam dok se kod potonjeg radi o obnovi klasičnog liberalizma, prvi bi imao označavati učenje oblikovano od strane autora poput Friedricha von Hayeka i u okviru čikaške škole (usp. ibid., str. 127). U ovom radu ipak koristimo termin 'neoliberalizam', misleći na ono što Veljak ovdje naziva 'neoliberizam', iz pragmatičkog razloga usvojenosti značenja prvog termina kojim se onda koriste $\mathrm{i}$ autori koje ovdje citiramo.
} 
određuju način na koji pokušavaju izgraditi ekonomiju kao znanost. Prema njima, kako navodi Veljak, ljudska je priroda zadana, a ne povijesno nastala. Takvo stanovište o bitnoj gotovosti svijeta oni dijele s klasičnom metafizikom, a taj se svijet »reproducira u skladu s logikom koju je posve besmisleno dovoditi u pitanje«. U svrhu osvjetljenja ove zasnovanosti tobože neutralne društvene znanosti kakva je ekonomija od osobite je vrijednosti Marxovo ontologijsko poimanje kapitala (kao društveni odnos, pa onda u vidu ontologije društvenog bitka, kako će to kasnije izraziti Georg Lukács), kao entiteta koji se terminologijom klasične metafizike može iskazati kao bitak - »ono jest po kojemu su bića našega svijeta uopće i moguća«. Neposredan izraz ovog društvenog odnosa bila bi roba u dvostrukom pogledu, kao upotrebna i razmjenska vrijednost, a primat potonje uzrok je nužnosti širenja reprodukcije, tj. održavanje logike akumulacije kapitala. ${ }^{861}$

Moć nad znanjem i njegovim plasiranjem sigurno je nezanemariv bioetički problem, no odustajanjem od potrage upravo za čvrstim temeljima znanja, tj. njegovim posvemašnjim (postmodernim) relativiziranjem, gube se i uporišta za borbu protiv te moći.

»... nema nikakve dvojbe da u suvremenoj medicini ima mnogo toga što zaslužuje ne samo temeljitu kritiku nego i osporavanje, ponajprije se to odnosi na evidentirane elemente medicinskog dogmatizma i nedovoljno utemeljene samouvjerenosti medicine, a u još većoj mjeri se to odnosi na različite dimenzije zloporabe medicine (a da se o farmaceutskoj industriji i njezinoj sprezi s medicinom i ne govori), ali ako je iščezla sposobnost razlikovanja ozbiljne medicine od svakojakog šarlatanstva, onda je zapravo nestala i opravdanost kritike etablirane medicine i u onim njezinim aspektima koji zaslužuju kritiku. Na taj se način uspostavlja antitetička solidarnost instrumentalnog dogmatizma s onim relativizmom koji stupa u funkciju afirmacije šarlatanstva. ${ }^{862}$

Veljak rehabilitaciju ideje istine drži jednom od osnovnih zadaća filozofije u našoj epohi. No on pri tome nipošto ne smatra potrebnim izbor između dogmatizma i relativizma. Naprotiv, ova se alternativa javlja kao lažna, štoviše, kao ona koja rađa autodestruktivni nihilizam, pa se ona ima prevladati. Pri tome odbacivanje relativizma ne implicira odbacivanje pluralizma. Ako se pak ima odbaciti relativistički pluralizam Nelsona Goodmana, to ne znači da se trebaju odbaciti neke druge koncepcije, a tu posebno ističe kod nas elaboriranu ideju pluriperspektivizma, spram koje je ovakav relativistički pluralizam »jednoznačno antitetičan «. ${ }^{863}$ Tako Slavko Amulić drži da pluriperspektivizam kao metoda integrativne

\footnotetext{
${ }^{861}$ Usp. ibid., str. 140, 150-153.

${ }^{862}$ Ibid., str. 115-116.

${ }^{863}$ Usp. ibid., str. 117.
} 
bioetike pokušava pronaći sredinu između modernističkog (monoperspektivističkog) totalitarizma i postmodernog relativizma. ${ }^{864}$

\section{IV.3.4. Viskovićevi osvrti na ostale bioetičke probleme}

\section{IV.3.4.1. Medicinska etika}

Biomedicinskim aspektima bioetike Visković se bavi u članku »Bioetika i biomedicinsko pravo« (1995.). Članak je, međutim, preglednog tipa. U njemu se prvenstveno iznose glavni problemi i uz njih vezane dileme koji zaokupljaju »novu medicinsku etiku«, kao i načini na koje ih pravo regulira. Riječ je o medicinski asistiranoj (umjetnoj) oplodnji, pobačaju, znanstvenim i eksperimentalnim istraživanjima nad ljudima, presađivanju organa i tkiva, upotrebi genetike, eutanaziji te pitanju početka i kraja čovjekova života, tj. života osobe. ${ }^{865}$ Premda se ovdje ne radi o iznošenju Viskovićevih normativnih odgovora na pojedina pitanja, vrijedi ukazati tek na dva detalja ove studije.

Iako njezine probleme razmatra odvojeno, medicinsku bioetiku već na sadržajnoj razini nije primjereno izolirati od onoga što bi se u širem pogledu moglo nazvati ekološkom bioetikom:

\footnotetext{
»A važno je još napomenuti, među ostalim radi razumijevanja sudbinske povezanosti svih oblika života i ciljeva ekološke etike i 'globalne bioetike', da su svi ti biomedicinski postupci bili iskušavani i primijenjeni (radi privrednih interesa zootehnologije i medicine i veterinarstva) na životinjama znatno prije nego što su primijenjeni na čovjeka.«866
}

Na drugom mjestu uviđa implikacije vezane uz problematiku »ekološke bioetike« i po pitanju abortusa kada tvrdi da je »prevelik broj ljudi na Zemlji (...) izvor najtežih ekoloških nedaća - sve do iščeznuća vrsta i klimatskih poremećaja. Protiveći se kontracepciji i reguliranom pobačaju Crkva faktički pristaje na propadanje biosfere. ${ }^{867}$

Pozivajući se na Paola Cattorinija, kao nedvojbeno temeljna načela bioetike i biomedicinskog prava nabraja: dostojanstvo pojedinca, autonomiju subjekta, neprinudnost i nekomercijalizaciju, povjerljivost podataka te pravednost $\mathrm{i}$ solidarnost $\mathrm{u}$ primjeni

\footnotetext{
${ }^{864}$ Usp. S. Amulić, Perspektivizam i pluralizam, str. 13.

${ }^{865}$ Usp. N. Visković, »Bioetika i biomedicinsko pravo«, str. 69-83.

${ }^{866}$ Ibid., str. 69-70.

${ }^{867}$ N. Visković, »Potičući množenje ljudi, Vatikan ugrožava biosferu«, str. 71.
} 
biomedicinskih postupaka. ${ }^{868}$ Premda se ovdje radi o »prvoj razini bioetičke problematike« i, uostalom, o ranom spisu u pogledu razvijenosti bioetike, ipak treba primijetiti da se ovakvim pristupom ponavljaju neki propusti koje je sa sobom nosio principalizam. S druge strane, imamo li u vidu američki principalizam, načela koja Visković odobrava šire zahvaćaju bioetičku problematiku utoliko što se protive tržišnom uplivu u ovom području, kako na individualnom (jasnom zabranom komercijalizacije), tako $i$ na društvenom nivou (obavezivanjem na solidarnost).

U socijalnom pogledu Visković primjećuje da je posrijedi izvjesno »neznanje i dvoličnost onih što se odupiru pokusima s ljudima dobrovoljcima: jer nije točno da čovjek ne eksperimentira s čovjekom u medicini $i$ u industriji. Bogata praksa potvrđuje da se zapravo mnogi proizvodi iskušavaju na slabije stojećem stanovništvu i da ni odobreni lijekovi nisu posve neopasni za ljudsko zdravlje «. ${ }^{869}$ Od eventualnog pogrešnog zaključka da postojanje izvjesnih praksi opravdava njihovo daljnje izvođenje, ovdje je važnije ukazivanje na zanemareno eksperimentiranje na socijalno osjetljivijem stanovništvu (koje bi, može se pretpostaviti, sačinjavalo i većinu »dobrovoljaca« ako bi za sudjelovanje u testiranjima postojala financijska naknada). Tabuiranje eksperimentiranja nad ljudima time tek osigurava »kožu« bolje stojećih u društvu, no liberalni pristup (naročito ako je i ekonomski) ne treba voditi bitno drugačijim rezultatima. ${ }^{870}$ Tako uz šire pitanje koje se dotiče eksperimenata nad životinjama: »Zašto čovjek u potpunosti ne bi preuzeo odgovornost za očekivanja i posljedice vlastita napretka, koji se ionako redovito pokazuje razornim za prirodu? « ${ }^{871}$ možemo postaviti i ono uže: Zašto se ta odgovornost ne bi jednakomjerno preuzela od strane svih ljudi?

$\mathrm{Na}$ drugim mjestima Visković otvoreno iznosi vlastite normativne sudove po gore istaknutim pitanjima. Tako izražava afirmativan stav spram eutanazije u pogledu toga što umiranje u dostojanstvenim uvjetima drži osnovnim ljudskim pravom. No pri tome ne isključuje potrebu postavljanja strogih kriterija kako bi se izbjegla zloupotreba (primjerice, pritisak rodbine zbog materijalne koristi), ostavljanja dovoljno vremena za potencijalno pacijentovo predomišljanje i osnivanja liječničkih komisija. Dva su osnovna uvjeta za odobrenje ovog postupka: terminalna faza neizlječive bolesti i nepodnošljiva patnja. Potonje se

\footnotetext{
${ }^{868}$ Usp. N. Visković, »Bioetika i biomedicinsko pravo«, str. 80. - Da se ovdje ne radi tek o deskriptivnom, nego o vlastitom normativnom sudu svjedoči i stav pojedinih renomiranih bioetičara (poput Engelhardta) o dopustivosti komercijalizacije dijelova ljudskog tijela. (Usp. ibid., str. 74.)

${ }^{869}$ N. Visković, Životinja i čovjek, str. 341.

${ }^{870}$ Visković prije ovoga ukazuje samo na primjer zahtjeva gay aktivista Larryja Cramera da se oboljelima od AIDS-a dopusti da budu predmet eksperimentiranja u svrhu pronalaska lijeka protiv njihove bolesti (usp. ibid., str. 341), pa time ne upada u pogrešku previđanja društvenog problema koji nastupa s nejednakom raspodjelom rizika s obzirom na nečije materijalno stanje (no na ovom mjestu taj problem niti ne adresira onako kako smo ga iznijeli). ${ }^{871}$ Ibid., str. 341.
} 
ne odnosi isključivo na fizičku bol (za čije su otklanjanje, uostalom, često i razvijeni lijekovi), nego i na psihičku patnju. Eutanazija bi tako trebala biti potpuno subjektivna kategorija, ovisna isključivo o volji bolesnika, tj. o subjektivnom osjećaju nepodnošljive patnje, dakle, »pitanje nedostojanstva života, a ne fizičke patnje«. No osobit je problem u ovom pogledu što bi odobravanje eutanazije trebalo podrazumijevati pristanak uračunljivog pacijenta, no ovi su u tim situacijama obično »na granici«. No generalno, pravo na život ne bi se trebalo tretirati samo pozitivno, nego i negativno, kao pravo na samoubojstvo. To ne znači da ovaj čin ne nosi sa sobom izvjesne moralne probleme, kao egoistični postupak koji osobito škodi rodbini. ${ }^{872}$

Razmatranje ovih postupaka ne iscrpljuje problematiku suvremene medicinske bioetike, pa tako u navedenom članku, pored suicida, Visković navodi i sljedeće teme: mentalne bolesti, toksikoovisnost, samoubojstvo, suvremena oboljenja, zdravstveno-psihološki tretman staraca, hendikepiranih i djece, estetska kirurgija, a onda i ekonomija zdravstva, ali i sami pojmovi 'zdravlje', 'normalnost', 'bolest', itd. ${ }^{873} \mathrm{U}$ pogledu razmatranja ovih pojmova valja zabilježiti i njegovu kratku opasku da su »zapadna društva često medikalizirala sve fenomene koji su smatrani nepoželjnim «. ${ }^{874}$ Ovakvo se manipuliranje znanošću posebno odnosilo na ono što se obično smatralo seksualnim devijacijama.

\section{IV.3.4.2. Erotika}

»Izrazi 'protuprirodno', 'bolesno', 'nastrano', 'perverzno' i sl. uobičajene su ideološke oznake, što uistinu djeluju kao zastrašujuće diskvalifikacije, za sve kulturne činjenice koje se protive konzervativnom mentalitetu. Pri tome se posebno izraz 'protuprirodno' upotrebljava veoma neobjektivno i selektivno: najprije se ne mari za antropološku istinu da je čovjek po definiciji izrazito neprirodno i protuprirodno biće, tj. biće koje sve više izbija iz prirodnosti i ništi prirodnost, te upravo tako stvara kulturu, a potom se protuprirodnim pogrdno označavaju samo činjenice koje nekome smetaju. $\aleph^{875}$

Pod ovu posve neodrživu moralnu osudu pod imenom protuprirodnosti, navodi Visković, često potpada i homoseksualnost. Da stvar bude gora, etološka istraživanja potvrđuju prisutnost ove prakse i u ne-ljudskoj prirodi, posebno kod razvijenijih životinja. No sve kad bi se poimala kao protuprirodna pojava, homoseksualnost je to "zacijelo u manjoj mjeri od Mozartovog koncerta, od nomenklature tucanja iz Kama Sutre i od svemirskog raketoplana

\footnotetext{
${ }^{872}$ Usp. Nikola Visković, »Nepodnošljiva težina postojanja«, Novi list 18. 7. 2009., izjava (članak napisao Jerko Bakotin), str. 54-55, ovdje str. 55.

${ }^{873}$ Usp. N. Visković, »Bioetika i biomedicinsko pravo«, str. 69-70.

${ }^{874}$ N. Visković, »Nepodnošljiva težina postojanja«, str. 55.

${ }^{875}$ N. Visković, Sumorne godine, str. 265.
} 
Shuttle«. Pored optužbe za protuprirodnost, nepoželjnost homoseksualnosti često se izražavala u vidu društvene opasnosti, tj. prijetnji moralnom poretku zajednice. Ova je tvrdnja, zapravo, djelomično točna, s obzirom na to da »svaka spolna (i politička, vjerska, znanstvena itd.) sloboda dovodi u pitanje odnose gospodstva«, a pored ove vrijedne subverzije, historija homoseksualnosti ne pokazuje neka osobita kriminogena svojstva. ${ }^{876}$

»... pored naturalističkog doživljaja svijeta i pored takvog antinaturalizma postoji i treća, kvazinaturalistička pozicija, ideološki izrazito konzervativna, koja se lažno poziva na prirodu kako bi ocrnila upravo prirodne potrebe tijela i prirodne temelje kulture - nazivajući ih 'prljavim', 'protuprirodnim' i 'perverznim'. Ta zloupotreba pojma prirode se najčešće pokazuje u crkvenoj i malograđanskoj protuspolnoj i protuerotskoj moralci.«877

Riječi iz ovog odlomka pripadaju Andreji, junaku Viskovićeva neobjavljenog rukopisa Toposi erotike, svojevrsnog enciklopedijskog romana čiji su pojedini dijelovi već objavljeni. Premda sama forma ne dopušta da se izvjesni stavovi likova u djelu pripišu Viskoviću, oni se u velikoj mjeri podudaraju s njegovom mišlju, što je očito i iz navedenog odlomka.

Visković drži da je bavljenje toposima erotike u izvjesnom smislu pripadno bioetici, smatrajući da je prijelaz sa zanimanja za životinje i stabla na erotiku logičan. Naša je spolnost bitno životinjska, a razlike koje nastaju njenim kultiviranjem osobito se ogledaju u erotici (dok bi se, primjerice, ljubav u elementarnim oblicima možda mogla pripisati i nekim životinjama). ${ }^{878}$ Pored brojnih poveznica ljudskog i (ostalog) životinjskog, što je pokazano i u kratkoj opasci o prisutnosti potonjeg u jeziku erotike, to se preplitanje odvija i u mitskim zoolikovima, primjerice, kod pretvorbi bogova u životinje koje se seksualno sparuju s ljudima, pri čemu Visković kroz svoje likove suvremene prakse seksualne zoofilije naziva zloupotrebom životinja. ${ }^{879}$ Među neprihvatljive radnje svrstava i voajerizam i ekshibicionizam koji se izvršavaju na silu i prijevaru, ${ }^{880}$ a već je prije spomenuto da postoji »nekoliko erotoposa koji su nedvojbeno nemoralni - svako nasilje bez pristanka, prevara i upotreba maloljetnika i

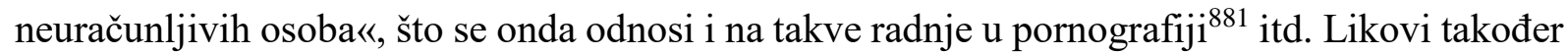
osuđuju pravne propuste svog vremena, primjerice, u suviše uskom pravnom određenju silovanja. Skandaliziraju se, primjerice, isključenja spolnog nasilja nad ženom s kojom je

\footnotetext{
${ }^{876}$ Usp. ibid., str. 266-267.

${ }^{877}$ Nikola Visković, »Spolnost i pravo 1971.«, Zbornik radova Pravnog fakulteta u Splitu 45 (2008) 3, str. 641658 , ovdje str. 643.

${ }^{878}$ Usp. N. Visković, »Potičući množenje ljudi, Vatikan ugrožava biosferu«, str. 71.

${ }^{879}$ Usp. Nikola Visković, »Voljene životinje«, Zarez 3. 6. 2004., str. 15.

${ }^{880}$ Usp. Nikola Visković, »O erotoposu dirkanja«, Zarez 21. 10. 2004., str. 12-15, ovdje str. 15.

${ }^{881}$ Usp. N. Visković, »Erotika, pornografija, erotoposi«, str. 166.
} 
nasilnik u braku, spolnog nasilja nad muškarcem i različitih drugih vrsta spolnog nasilja, pri čemu se ona označavaju kao dio »falokratskog poretka koji vlada tisućama godina, od Hamurabija i Manua do Napoleona i socijalista«. ${ }^{882}$ Općenito, likovi se slažu s Andrejinim zaključkom:

\»... odsustvovanje prava od velike većine spolnih užitaka je etički ispravno! Nema dovoljno jakih razloga da pravna prisila intervenira u takve odnose osim ako su oni nasilje i zloupotreba nemoćnih! U odnosima odraslih, uračunljivih i pristajućih osoba nijedno spolno-erotsko ponašanje ne bi smjelo biti pravno zabranjeno, s izuzetkom onih koje neposredno prijete nečijem životu ili tjelesnom integritetu, jer tu su interesi pojedinaca dovoljno zaštićeni njihovim autonomnim traženjem sreće i moralnim rasuđivanjem! ${ }^{883}$

Širok je spektar moralno neproblematičnih erotskih radnji koje su često uvrštavane u one nemoralne. Tu je primarno riječ o potrebi »onih koji imaju društvenu moć da nadziru spolni užitak, budući da nekontrolirani užitak lako postaje izvor opasnih sloboda, transgresija tabua i prijetnji uspostavljenim i neupitnim međuspolnim, radnim, porodičnim, vlasničkim i političkim odnosima ${ }^{884}$ Briga za očuvanjem postojećih odnosa moći tako ideološki instrumentalizira pojedine kulturne sfere. Ovdje je najčešće riječ o onoj moralnoj. No Andrea detektira više razloga odbijanja masturbacije, počevši od moralnog (grešna pohota), osvrćući se zatim na ekonomski ili utilitarni (nekorisno i neumjereno trošenje vrijednog resursa, tumačenje kakvo će zavladati u građanskoj ideologiji), a konačno i na medicinski (prijetnja fizičkom i psihičkom zdravlju). Historija književnosti i filozofije, naravno, poznaje i zagovaratelje masturbacije, poput nepoznatog autora poeme La Masturbomanie (1820.), koji je »slavi kao najsamostalniji i najfilozofskiji od svih ljudskih užitaka«, pa prije toga d'Argensa, čiji likovi u djelu Thérèse Philosophe (1748.) »razvijaju pravu teorijsku, hedonističku i antinatalitetnu apologiju masturbacije«, a još je kinik Diogen javno masturbirao, žaleći se što istom lakoćom ne može zadovoljiti gladni želudac. ${ }^{885}$

Valja ipak zamijetiti, kako tvrdi jedan od likova Toposa erotike (znakovita zanimanja i imena) asistent prava Nikola, da je po pitanju seksualnosti u suvremenim društvima

\footnotetext{
${ }^{882}$ Usp. N. Visković, »Spolnost i pravo 1971.«, str. 469. - Za ostale primjere pravne regulacije spolnosti i reakcije likova na njezinu opravdanost vidi nastavak članka. ${ }^{883}$ Ibid., str. 656-657.

${ }^{884}$ N. Visković, »O erotoposu dirkanja«, str. 12. - Jedno od upojedinjenja ove potrebe svakako je »održavanje crkvene moći i dominacije nad pastvom preko sputavanja i kulpavilizacije subverzivne snage žudnje $\ll$. (N. Visković, »Spolnost i pravo 1971.«, str. 467.) Erotika se, naime, od pornografije među ostalim razlikuje i time što kod nje razvrat može biti subverzivan spram poretka, koristeći se i kritički nastrojenim humorom. (Usp. N. Visković, »Erotika, pornografija, erotoposi«, str. 160.)

${ }^{885}$ Usp. N. Visković, »O erotoposu dirkanja«, str. 12-14.
} 
»... sve izrazitija autonomija nasuprot heteronomiji, emancipacija žene nasuprot patrijarhalnosti, unutarnja i slobodna kontrola moralnosti prema vanjskoj i prisilnoj kontroli pravnosti, ljubav prema ekonomiji, ovlaštenje užitka prema obvezi prokreacije, radosna spolnost prema grešnoj spolnosti, privatnost prema javnosti... Zato se usporedo s današnjim procvatom svih erotskih intimnosti, koje zapravo i nije moguće efikasno pravno ograničavati, sada počinje gasiti većina nekadašnjih spolnih delikata i psihijatrijskih zala - inkriminacije prostitucije, homoseksualnosti, sodomije, pornografije, fetišizma, ekshibicionizma, voajerstva, i tako dalje, s prepoznatljivom tendencijom da se pravne zabrane svedu samo na tri područja: na spolno nasilje, na spolno zlostavljanje djece i na brak između najbližih srodnika. $\ll^{886}$

Ovdje prepoznajemo i opće tendencije moraliteta koje Visković proteže kroz sve moralno relevantne teme kojima se bavi. Jedna od tih tendencija je i sve veća pluralizacija, no ona se ni ovdje ne promatra posve u relativističkom pogledu. Tako likovi Toposa erotike dolaze do zaključka da bi različiti etički i znanstveni stavovi o seksualnosti trebali biti izloženi slobodnom natjecanju, kako u školi, tako i u javnosti, no teren za tu raspravu treba biti pripremljen od strane prirodnih i društvenih znanosti »prožimanjem bioloških, historijskih, filozofskih, socioloških, etnoloških, pravnih i drugih istraživanja spolnosti u jednom polihistorijskom projektu«, koji bi uključivao i kulturnu botaniku i animalistiku, čime bi se pokazalo međuuvjetovanje biološkog i kulturnog. ${ }^{887}$ Takav bi sintetičan, pluriperspektivan uvid u fenomen seksualnosti mogao sačinjavati treći element kulturne biologije. Pitanjima »što je životinja čovjeku i što je čovjek životinji« te »što je biljka čovjeku i što je čovjek biljci« time se pridodaje pitanje $»$ što je seksualnost kulturi i što je kultura seksualnosti«. ${ }^{888}$

Duboka uklopljenost erotike u bioetičku i kulturnobiološku problematiku utoliko je veća ukoliko seksualnost i tjelesnost snažnije ukazuju na našu prirodnost, koja je također kulturno posredovana i koja pati po sličnim pogubnim kulturnim obrascima kao što je slučaj s prirodnom okolinom. Tako Nikola ističe: »Od Descartesa do Marxa prosvjetiteljstvo je, uz njegovu sjajnu borbu za emancipaciju razuma i čovječanstva, (...) istovremeno žrtvovalo toliko toga od prirode oko nas i u nama! I to traje do danas čak među pragmatskim ili ekonomističkim ekolozima u njihovom načinu brige za ljudsku okolinu «. ${ }^{889}$

\footnotetext{
${ }^{886}$ N. Visković, »Spolnost i pravo 1971.«, str. 657. - Nikola predviđa čak i nastanak oblasti »posebnih ljudskih prava - koju bih nazvao spolna prava i koja će biti osobito važna za neke još zastrašene i uglavnom nevidljive spolne manjine«. (Ibid.)

${ }^{887}$ Usp. ibid., str. 657-658.

${ }^{888}$ Ibid., str. 658.

${ }^{889}$ Ibid., str. 641-642.
} 
»... 'shvaćanje prirode samo kao 'ljudske okoline' uvelike ignorira činjenicu da je sâm čovjek prvenstveno priroda, svojom tjelesnošću i svojom psihom, te da bi stoga prava svijest i istinska briga o prirodi bili ne samo altruistička svijest i briga za sva bića, nego ujedno i staranje o sebi kao biću uvjetovanom vanjskom prirodom i po sebi prirodnomu.' 'U tome se nalaze, shvati Andrea pravac rezoniranja, ignoriranje spolnosti i erotike u njihovoj prirodnosti. Spolnost je uglavnom priroda, dok je erotika, u platonskom smislu erosa, težnja za lijepim i za spoznajom u njoj.' 'Tako je! Uostalom, zar ne osjećamo sreću sličnu spolnom užitku u svakoj ljepoti i spoznaji prirode?'« ${ }^{890}$

Potiskivanje seksualnosti upravo pripada paradigmi kulturnog obračuna s prirodnim koji se u konačnici osvećuje samom čovjeku, a što je u više navrata isticano u ovom radu. Posljedica toga je i dezerotiziranje krajolika, Marcuseova misao koja u ovom pogledu još jednom pokazuje da pojedini marksistički pravci nisu beznadni po pitanju uvažavanja prirodnog na više, pa ovdje onda i na erotskoj razini. No sam je Visković svjestan potencijala da se ova tematika promatra kroz marksističku vizuru, barem onda kada njegov Andrea kaže kako »izgleda čudno da se i takozvani socijalistički moral pridružuje toj diskvalifikaciji erotike i njenih prevratničkih moći ${ }^{891}$

Konačno, erotika se kao dio kulture nosi s istom tendencijom kojom je ova generalno obilježena, naime, potrebom za povratkom prirodi od koje se odvojila. Prema Andrejinim riječima:

»... 'paradoks svake prezrele ili rafinirane kulture, od gurmanstva do likovne umjetnosti, a ne samo erotike: na kraju krajeva ona opet žestoko čezne, svjesno i podsvjesno, za onom od same kulture potisnutom i zabranjenom prirodnošću, a što će onda mnogi nazivati 'dekadencija', 'perverzija', 'ludilo' i 'prljavština'!' 'Dijalektička negacija negacije', šeretski će marksist Nikola, 'povratak kulture u biologiju nakon svog otprirođenja.' 'Dakle', zablista Rita, 'rafiniranu kulturu ponovno privlači sirovost prirode?' 'Da, i do toga je već, na svoj klinički način, bio došao Freud, pa je Marcuse u pravu kad tvrdi da je to pozitivna potencijalnost njegove misli. Nakon što je građanska kultura zanijekala i patologizirala svu širinu libida, proglašavajući je čak 'protuprirodnom', erotika strasno istražuje i iskušava seksualnost kao svoju nagonsku osnovu u hedonističkoj žudnji za svim skrivenim, uzbudljivim i zabranjenim 'prljavim' užicima ne mareći za bilo kakve zapreke moralističkog seksualnog utilitarizma!'«892

Ovladavanje se, prema svemu što je u ovom odlomku rečeno, ponovno javlja kao jedan od osnovnih remetilačkih faktora u pogledu postizanja harmonije kulturnog i prirodnog. Pored onoga što je na ovu temu već izrečeno, može se zaključiti Horkheimerovim i Adornovim

\footnotetext{
${ }^{890}$ Ibid., str. 643.

${ }^{891}$ N. Visković, »Erotika, pornografija, erotoposi«, str. 158.

${ }^{892}$ N. Visković, »Spolnost i pravo 1971.«, str. 644-645.
} 
uvidom nezdravog odnosa u kojem je ovisnost o prirodi sadržana u »ovladavanju prirodom bez kojeg duh ne egzistira«, pri čemu se osobito potencira fenomen žrtvovanja. Naime, čitava je povijest civilizacije zapravo povijest introverzije žrtve. Žrtva pak stalno ukazuje na prohtjeve same prirode, koja se u čovjeku niječe »u svrhu gospodstva nad izvanljudskom prirodom i drugim ljudima«. Utemeljenje jastva gospodstvom čovjeka nad samim sobom u ovom se obliku osvećuje njemu samome. ${ }^{893}$

\section{IV.4. Normativna dimenzija prirode i kulture}

Ovdje sada stižemo na zadnju točku bioetičkog razmatranja kulturnog i prirodnog. Vodeći se tezom da deskripcija nije neovisna o normativnosti, na koju se implicitno i eksplicitno više puta ukazivalo tokom ovog rada, ovdje ćemo, pored djelomičnog sažimanja onoga što svjetlo kulturne biologije može pridodati poimanju prirode i kulture, ponuditi bliže sagledavanje njihova normativnog određenja i normativnosti u njihovu određenju.

\section{IV.4.1. Normativna dimenzija kulture}

Za ono kulturno kod Viskovića vrijedi bitno određenje otprirođenosti. U odnosu prema prirodi, ono je ambivalentno - ono je ništenje prirode, ali i njezino uvažavanje. Izostankom otprirođenja nije moguće uspostaviti ni moralni obzir spram prirode. Već se ovdje otvara mogućnost da kultura, kao čovjeku specifičan način posredovanja, tumači normativno, kakva ona treba biti. Stvari se mogu postaviti i tako da je jedan od zadataka kulture kakva ona treba biti i to da se ona kao takva očuva kao jedini izvor normativnosti. No kako je kultura naslonjena na prirodu, tako se ona ne da očuvati bez očuvanja prirode. Tu ne mislimo da se priroda zaista dade uništiti od strane prepotentnog čovjeka, nego da maltretiranje prirode posredstvom tehnologije (pa onda i suvremene znanosti i kapitala) neizostavno biva maltretiranjem kulture upravo istiskivanjem njezinih vrijednih elemenata od strane tehnologije (pa onda i suvremene znanosti i kapitala) ili preobrazbom ovih elemenata u instrumente potonjih. Kao jedini izvor normativnosti, jasno je da nam kultura igra važnu ulogu u samoj ideji brige o prirodi, koja u suprotnom gubi svoj smisao. No osim pitanja o tome kakva kultura treba biti da zauzme obziran

${ }^{893}$ Usp. M. Horkheimer, Th. Adorno, Dijalektika prosvjetiteljstva, str. 53, 67-69. 
stav spram prirode, postavlja se i pitanje kakva kultura treba biti da bi se samo njezino trebanje (normativnost) očuvalo, da sama ne zapadne u kolotečinu vlastite jednostranosti u njezinu bitku. U tom svjetlu možemo gotovo reći da je u stanju u kojem se kultura našla uznemirujuća upravo potreba da se kultura spasi.

Odgovor na ovo pitanje u jednom od svojih smjerova vodi i suprotnoj perspektivi od maločas spomenute - da bi se u navedenom pogledu spasila kultura, potrebna je priroda. Potrebna je, među ostalim, kao najosnovnije drugo i kao predmet uzvišenoga, jer u suprotnom ovo mjesto zauzimaju ljudski konstrukti čija je neobazrivost spram prirode (a istovremeno i čovjeka) ostavila raščišćen prostor koji su ovi »kolonizirali«, zajedno sa starim svijetom kulture, pa je dijalektika kulture i prirode odstranjena, a na njezino mjesto nastupila u svojoj biti nepromjenljiva, stoga i krnja »kultura« kakva se očituje u oblicima poput tehnologije i kapitala. Njihovo ugrožavanje ljudske autonomije dovoljno govori o pogubnosti takvog procesa. No autonomija je u napadu na prirodu potresena i po pitanju osiromašenja ljudske osjećajnosti, kao preduvjeta, barem ako je vjerovati Kantu, razvijanja autonomije. U širem smislu, osiromašenje i instrumentalizacija osjećajnosti, potreba (svođenje na potrebu posjedovanja i stvaranje umjetnih potreba), čak i erosa (dezerotiziranje okoline), napad je na čovjekovo samoostvarivanje, a istovremeno vodi zatiranju i slabijem uvidu u bogatstvo samoostvarivanja ne-ljudskih živih bića (bilo kao posljedica neizostavnog antropomorfizma, bilo u smislu osujećenja razvitka bioetičkog senzibiliteta).

Dakle, ono mjesto gdje je potreba brige za prirodno kako bi se kultura očuvala možda je ponajprije moral. Tu nije riječ samo o očuvanju onoga što sa stanovišta čovjeka možemo nazvati unutrašnjom prirodom (čovjekova animalnost), nego i vanjskom prirodom. Naime, kako se moral sastoji u promicanju samoostvarivanja, pa onda u slučaju čovjeka posebice promicanja slobode, i kako je sloboda ključno obilježje kulture (bivajući čovjekovim svijetom), degradacija kulture uništavanjem prirode nastupa odstupanjem od onoga što moral zapovijeda, a ovdje zapovijeda upravo obzir prema svim živim bićima.

Ovdje posebno treba imati u vidu i Viskovićevo isticanje važnosti supstrata $u$ simbolotvorstvu, gdje priroda igra važnu, ali sve slabiju ulogu:

»Ali od životinja ujedno zavise pozitivno i fizička i duhovna kultura u tisućama godina pretpovijesti i povijesti, što je razlog zašto su one jedna od osnovnih, nužnih i trajnih briga čovjeka. To je ono što kulturna zoologija mora pokazati. ${ }^{894}$

\footnotetext{
${ }^{894}$ N. Visković, Kulturna zoologija, str. 14.
} 
Upravo se u ovome, kako smo vidjeli, sastoji srž onoga što smo i ovdje prikazali kroz sažeti pregled kulturne zoologije, a isto vrijedi i za kulturnu botaniku i ulogu bilja u ljudskoj kulturi. Pored toga što oni imaju biti briga kulture s obzirom na zabrinjavajuće rezultate njihova iščezavanja kao njezinog supstrata, oni to trebaju nastaviti biti i zbog naše osviještenosti o njima samima, tj. radi održavanja i osnaživanja bioetičkog senzibiliteta.

Normativna dimenzija kulture ogleda se i u onome što se na početku označilo kao duhovna kultura ili kultura u užem smislu, za razliku od civilizacije kao materijalne kulture. Premda Visković ovu razliku ne provodi dosljedno kroz svoja djela, ona bi uvelike pripomogla formulaciji i daljnjem zaokruženju misli koje su kod njega u izvjesnoj mjeri prisutne. Među njima je i ona koju smo označili kao jednu od najvažnijih, a to je doprinos konceptu bioetičkog senzibiliteta u vidu prisnosti prirodi, a onda posebno u vidu namjernog (tehnološkog) posredovanja odnosa spram živih bića (u tom pogledu i sve manje neposrednog uvida u načine njihove materijalne upotrebe) koje rezultira otupljenjem naše senzibiliziranosti za njihove patnje, koje upravo tehnološkim posredovanjem postaju intenzivnije. Način na koji spomenuto razlikovanje ovdje može pripomoći konceptualiziranju problema nalazimo kod Pachirata, koji suvremene klaonice drži upravo egzemplarom funkcioniranja (fizičke, društvene, jezične i metodološke) udaljenosti i prešućivanja kao mehanizama moći u današnjim društvima. Jednu od formi odnosa moći i pogleda nalazi artikuliranu kod Eliasa, koji segregaciju i uklanjanje iz pogleda fenomena koji se drže neukusnima kao i moralno ili fizički odvratnima (poput uriniranja, nagosti, pljuvanja, ali i ubijanja životinja) drži ključnim obilježjima civilizacijskog procesa. Tako se čitav proces objedovanja razvija u smjeru izbjegavanja uvida u njegovu vezu s ubijanjem životinja - noževi se smanjuju, a forma ubijene životinje se izobličuje. Pachirat tako tvrdi da se ono što nazivamo razvojem ili progresom sastoji u prešućivanju i distanciranju od ovih djelatnosti prije no u njihovoj eliminaciji ili transformaciji. ${ }^{895}$ No ako se izvanjski progres o kojem je ovdje riječ s pravom može nazivati procesom civiliziranja, to nikako nije dovoljno da se on nazove kulturalizacijom, ako bi se potonja shvaćala u normativnom pogledu trebanja kulture (kako je to u razlici spram civilizacije shvaćao i Kant) koja bi zahtijevala eliminaciju moralno pogrešnih djelovanja ili njihovu transformaciju utoliko ukoliko bi ona njome prestala biti moralno pogrešna, a s obzirom na vrhovnu normativnu ulogu koju moral ima u kulturi.

\section{IV.4.1.1. Potreba razlikovanja prirode i kulture}

\footnotetext{
${ }^{895}$ Usp. T. Pachirat, Every Twelve Seconds, str. 3-4, 9-11.
} 
Upravo u pogledu oslabljenja senzibiliteta za ne-ljudska živa bića i prirodu uopće, podjela na kulturu i prirodu doživljava sve snažnije kritike. Česta meta kritike je čovjekova prepotentnost, izdizanje u kulturno kako bi se opravdala i intenzivirala dominacija nad prirodnim i sl. No čini se da ta kritika podliježe »pravilima igre« koja su nametnuli oni s moralno sumnjivim motivima nalik upravo spomenutima. Predzadatak negativne kritike kulture trebao bi, naime, biti kritika kulture u fundamentalnijem smislu (bez pozitivnog ili negativnog predznaka) - pokušaj dolaska do odgovora na pitanje što kultura uopće jest i koje su njene posljednje svrhe.

Osnovna greška koju počinjavaju oni koji žele relativizirati pojam kulture, tj. oduzeti mu eminentno ljudsko značenje, jest to što oni kulturu drže maltene empirijskim pojmom kultura bi, prema njima, imala opisivati neke utvrđene obrasce ponašanja kod živih bića, nešto objektivno što možemo zapaziti. Međutim, pojam kulture se u svojoj srži ili u početnom određenju ne odnosi se ni na što objektivno. Čini se da je prije riječ o pojmu proizašlom upravo iz ljudske potrebe da označi onaj aspekt svoje egzistencije koji drži sebi specifičnim. U tome prima facie nema ničega lošega. Kao što na individualnoj razini imamo potrebu osvijestiti (ali i proizvoditi) ono što je nama kao jedinkama autentično (čime ne oštećujemo druge jedinke), imamo istu potrebu i na generičkoj razini. ${ }^{896}$ Potreba bi, naravno, ostala nezadovoljena kada ne bismo imali ikakve čvrste podloge da je zadovoljimo. Međutim, već je rapidan način na koji se čovjek kroz svoju povijest mijenja dovoljan pokazatelj da postoji nekakav aspekt njegove egzistencije koji je različit od ne-ljudskih živih bića - pa makar se to odnosilo samo na kvantitativnu razliku. Kvantitativna razlika bi se činila ozbiljnijom prijetnjom ovom razgraničenju samo onda kad bismo stvari promatrali u izrazito dugim razdobljima (kroz koje bi se onda mogućnosti razvoja drugih živih bića pokazale bogatijima), ali tomu svakako nije tako - možemo se odnositi i uspoređivati s onim drugim samo kao vremenita bića. Stoga ni evolucija u ovom pogledu za nas nema nikakvog značenja - ima samo u onoj mjeri u kojoj nas upozorava da nismo samo naša specifičnost, nego smo i ono što je zajedničko.

No onda kada kod životinja otkrivamo ono što smo držali isključivo kulturnim obrascima, sadržaj našeg pojma kulture se sužava, a kako se širi onaj prirode (naročito one žive, organske, koja nam je svakako relevantnija), tako se širi i ono naše zajedničko s drugim živim

\footnotetext{
${ }^{896}$ Imamo li na umu dvostrukost poimanja kulture/a, kao i usmjerenost tog pojma na označavanje specifičnosti, »neutralnost « ove potrebe podrazumijevana je i onda kada Morin kaže: »Kultura održava ljudski identitet u onome što mu je specifično; kulture održavaju društvene identitete u onome što im je specifično.« (E. Morin /sur. N. Vallejo-Gómez/, Odgoj za budućnost, str. 63.)
} 
bićima. Posljednje pak opravdanje za odvojenost kulture i prirode je moralni obzir, sposobnost koju pripisujemo čovjeku (i to ne svakom čovjeku) kao jedinom (aktivnom) subjektu morala. Širenje kulture do te razine da se i životinjama prizna aktivni subjektivitet u moralu rezultiralo bi time da one, kao i mi, snose odgovornost. Značilo bi to i opravdanje spomenutih kazni za životinje. Značilo bi to, možda, i uvećavanje broja moralnih kodova, pa bismo mi imali svoj moralni kod, čimpanze svoj, žabe svoj, mačke svoj, jer neka ponašanja koja kod životinja ne nailaze na osudu, kod nas nužno nailaze (dovoljno je samo promotriti okrutnu igru mačke s mišom). Kako moral mora težiti univerzalnosti, ako želi biti u skladu s umom kao našom najvišom spoznajnom moći, te kako gubi smisao ako ne sačinjava najviše normativno sudište, višestrukost moralnih kodova je besmislica. Uostalom, što bi u tom slučaju priječilo one koji ne drže ne-ljudska živa bića vrijednima moralnog obzira da takvo suđenje ne proglase vlastitim moralnim kodom? Moralni relativizam bi, stoga, bio neizbježan.

Stvari, dakako, uvijek mogu postati predmetom manipulacije, ali upravo je popuštanje pred manipulacijom jedan od oblika predaje, pored onoga da se dade zavesti njome. Popuštanje pred manipulacijom značilo bi prihvaćanje načina na koji ona operira s pojmovima. Ako bi se sada iz samog postojanja kulturnog povukle implikacije koje kulturno izdižu iznad ne-kulturnog ili prirodnog na način da je potonje ostavljeno na milost i nemilost ovom prvome, tada treba napasti na besmislenost same implikacije. Popuštanje pred manipulacijom upravo bi se odnosilo na okretanje priče u druge pravce, tako da se problem rješava time da pojam kulture širimo na ne-ljudska živa bića u svrhu osujećenja pretencioznosti ljudske vrste. Ili, još gore, time da difamiramo kulturu kao takvu, pa da izlaz tražimo u potpuno prirodnim oblicima življenja (što, zapravo, s obzirom na našu osuđenost na slobodu/kulturu, i nije moguće). Pojam kulture, kako je već naglašeno, ima smisla braniti jer tom obranom ujedno branimo i mogućnost umski utemeljenog moralnog obzira spram živih bića.

\footnotetext{
»Ovu povezanost se mora jasno uvidjeti da bi se primijetilo kako se epohalno značenje integrativnobioetičkih pitanja našega vremena sastoji upravo u tome da postanemo svjesni diskrepancije između 'prve' i 'druge' prirode, dakle, da metodički objektivirane slike prirode više ne držimo za prirodnu prirodu. A ujedno nanovo primjećujemo kao da mi samo kao bića 'stršimo' u sferi prve prirode, da tu sferu ujedno nama svojstveno razumijevamo, štoviše, da je znamo u 'normativnom' smislu cijeniti. « ${ }^{897}$
}

${ }^{897}$ T. S. Hoffmann, »Bioetika i mnogostrukost pojmova prirode«, str. 29-30. 
Ova odvojenost kulture i prirode ujedno štiti od zapadanja u ideološke »naturalizme«, poput socijaldarvinizma, koji, kako smo pokazali, i sami prešutno nameću vlastitu normativnost koja je u konačnici okrenuta i protiv čovjeka i protiv prirode.

\section{IV.4.1.2. Moralna relevantnost pripisivanja kulture ne-ljudskim bićima}

Pripisivanje kulture nekim ne-ljudskim živim bićima (a) ne može služiti antispecističkom argumentu u pogledu kandidata za moralni obzir, a istovremeno (b) ne čini razliku po pitanju našeg moralnog obzira spram ne-ljudskih živih bića.

Ad a) Ako je kultura i samo kultura moralno relevantna kategorija po pitanju kandidata za moralni obzir, onda iz tog obzira isključujemo određen broj vrsta živih bića (što je i dalje specizam), s obzirom na to da se ne može tvrditi da kulturu, ni u najšire poimanom pogledu, imaju sva živa bića, pa čak ni sva osjećajna bića. Premda bismo uz takvo tumačenje pojma kulture i njegovu dosljednu primjenu ukinuli neopravdano ekskluziviranje čovjeka, izvjesnim bićima koja zaslužuju moralni obzir i dalje bi uskratili uključenje u taj razred, pa bismo mogli govoriti samo o pomicanju granica specizma. Naravno, to ne znači da se prisutnost onoga što se pod takvim pojmom podrazumijeva, premda ga mi ne uvažavamo kao takvoga, izvjesnim živim bićima treba poricati.

Ad b) Ako kultura nije jedina moralno relevantna kategorija po pitanju kandidata za moralni obzir, onda ona također ne unosi nikakvu razliku po pitanju odvagivanja sukoba razloga obvezatnosti kad bi se pripisala i nekim ne-ljudskim bićima. Razlog za to leži u proporcionalnosti »liberalno« pojmljenog kulturnog razvoja s ostalim značajkama samoostvarivanja živih bića.

Štoviše, ako se ne bi radilo o striktnoj proporcionalnosti, prenaglašavanje moralne relevantnosti kulture po pitanju odvagivanja sukoba razloga obvezatnosti vodilo bi pogrešnim zaključcima, barem što se ne-ljudskih živih bića tiče. Premda kulturni razvitak, u najširem mogućem smislu, uistinu pridonosi samoostvarivanju, on kod mnogih bića igra bitno manju ulogu od, primjerice, izbjegavanja bola ili neometanog kretanja - kulturna značajka poput učenja od starijih generacija ovdje bi služila prvenstveno kao sredstvo, a ne kao svrha. Kod čovjeka kulturni razvoj također lako može biti podređen spomenutim sastavnicama samoostvarivanja, no ne nužno. Primjerice, neki redovnici svoje samoostvarivanje nalaze u kulturnom razvitku koji im ograničava kretanje, seksualni poriv, pa čak može voditi i do fizičke patnje. 
Time izgleda da široko određivanje kulture nije moralno relevantno bilo u smislu kriterija za pripisivanje moralnog obzira izvjesnom biću, bilo u smislu odvagivanja sukoba razloga obvezatnosti spram bića koja ulaze u moralni obzir. Imamo li u pogledu ovdje zastupanu definiciju kulture kao čovjeku specifičnog načina bivstvovanja, kao i to da se kultura u ovom obliku javlja kao svrha po sebi, ovakva definicija kulture zadobiva moralnu relevantnost utoliko ukoliko ukazuje na bogatije (nažalost neizbježno iz ljudskog, ako se hoće specističkog rakursa) samoostvarivanje ljudskih (misli se, naravno, na samosvjesne Homo sapiense) spram ne-ljudskih živih bića. Pored toga, jedna od ključnih karakteristika (koja sama po sebi nije relevantna za odmjeravanje sukoba razloga obvezatnosti, iako ono bez nje nije moguće) ovako pojmljene kulture, ponovimo, jest sama mogućnost postojanja moraliteta. No treba imati na umu upravo ono što je u Viskovićevu pojmu kulture naglašeno, naime, a to (barem primarno) nije čovjekova privilegiranost, nego njezin razaralački potencijal spram prirodnoga i, što je još važnije, odgovornost spram živih bića. Ona je, dakle, prije obaveza negoli privilegij, a njezin zadatak oplemenjivanja treba ići u smjeru kulturnih, a ne ne-kulturnih živih bića.

Zadatak promicanja samoostvarivanja kulturnih bića ne ograničava se na brigu o njihovoj kulturnoj dimenziji. Kada je dio tog zadatka sprječavanje boli, omogućavanje nesmetanog i zdravog razvoja organizma i sl., tada se brinemo upravo o njihovoj prirodnoj dimenziji. Čovjek se samoostvaruje kao cjelovito biće.

\section{IV.4.2. Normativna dimenzija sagledavanja prirode}

Kako je pokazano, već običan, »zdravi razum «, odnosno svakodnevni jezik, često barata s pojmom prirodnoga kao poželjnoga. Ne treba posebno naglašavati da ovo gledište previđa da ono sâmo, kao jezik kojim je izrečeno i vrijednosni sustav iz kojega proizlazi, nastaje u okviru kulture. Čini se bespotrebnim ukazivati i na to da prirodno stanje podrazumijeva neke odnose koji su neprihvatljivi unutar kulturne zajednice (ili bi to barem trebali biti). Ovakva razumijevanja zanemaruju posredničku »prirodu« kulture. Tu prisutan koncept prirodnosti bitno je kulturno određen, tj. kulturno posredovan, pa ovdje možemo izvrnuti konstrukciju kojom prethodna rečenica završava, nazivajući ovaj fenomen »kulturom prirode«. Međutim, već ovi konstrukti odaju bitnu isprepletenost koja stoji barem u začecima i etimologiji određenja kulture.

$\mathrm{Na}$ ovo posredovanje jasno je ukazivano mnogo puta kroz ovaj rad. Već se sam Viskovićev projekt kulturne biologije sastoji od pokazivanja načina na koje je kultura u mnoštvu svojih sadržajnih varijeteta posredovala prirodu, a glavna mu je intencija usmjerena 
na uspostavljanje normi kako kultura u moralnom i pravnom vidu treba posredovati prirodu. Neodvojivost ovih dvaju aspekata kulturnog posredovanja prirode očituje se i u tome što se kao pitanje ne postavlja samo kako (je) kultura (dosad i kako) treba moralno i pravno posredovati prirodu, nego i kako je kultura dosad pristrano u deskriptivnom vidu posredovala i kako odsad treba u tom pogledu posredovati prirodu.

Ne bismo trebali ići za tim da tumačimo prirodu u skladu s našim normativnim uvjerenjima, nego bismo trebali biti svjesni da izvjesna normativna uvjerenja i ideologije, naše ili izvanjske, oblikuju našu predodžbu o prirodi. To se, primjerice, uočilo u obratu uobičajenog poimanja koje od darvinizma ide k socijaldarvinizmu. Odbacivanjem takvih normi i ideologija valja uvidjeti kako su one oblikovale našu sliku prirode, da bismo shodno tome ponovno proveli deskripciju prirode. Ono pak što se u ovu deskripciju normativno može unijeti, prvenstveno je oprez kao odraz odgovornosti za nimalo benigne rezultate deskripcije prirode. Njihova potencijalna opasnost proizlazi iz puta kulturne motivacije, deskripcije prirode i legitimacije kulturne akcije ovom deskripcijom prirode. U darvinizam-socijaldarvinizam primjeru tako je bila riječ o motivaciji opravdanja kapitalističkih odnosa, koje se putem poimanja prirode kao poprišta stalnog sukoba (»priroda krvavih zubiju i kandži«) naturaliziralo, tj. legitimiralo kao kulturna praksa.

Ti nimalo benigni rezultati ne nose samo opasnost za društvo, nego prvenstveno za samu prirodu, tj. za ne-kulturna živa bića. No tu je prvenstveno riječ o razvijanju senzibiliteta za njihovo moralno uvažavanje. Čisto na teorijskoj etičkoj razini zakrvljenost kandži i zubiju živih bića ne igra ulogu u našoj moralnoj obavezi da stremimo omogućavanju njihova samoostvarivanja.

Tako i pozitivni normativni utjecaj na deskripciju prirode u vidu odgovornosti/opreza ima u konačnici služiti u negativne svrhe. Situacija je donekle paradoksalna, s obzirom na to, proširimo li Mannheimovo upozorenje vezano uz društvene znanosti, da i u prirodnim znanostima nastupamo vrednujući, tako da objektivnost više ne možemo tražiti u posvemašnjem isključivanju vrednovanja, među ostalim i zato što takvi pristupi vode samo razbuktavanju izvjesnog vrednovanja zahvaljujući upravo zanemarivanju njegove konstitutivne uloge, nego njegovim kritičkim osvještavanjem i kontroliranjem. S obzirom na to da je naše promatranje prirode gotovo uvijek, a u znanosti isključivo, kulturan čin, valja imati na umu da je kulturno dobro, kako Visković prikazuje (iako eksplicitno ne izražava slaganje ili neslaganje) 
iz Cossijeva određenja, »i ono što čovjek stvara vrednujući, i sam ljudski akt stvaranja koji je uvijek aksiološki određen $\ll .{ }^{898}$

Pojam prirode u konačnici se postavlja kao stalan zadatak, zadatak koji nije samo spoznajni (deskriptivni), već svakako i normativni. On se utoliko ne može pomišljati izvan stalne dijalektičke napetosti spram pojma kulture, odnosno spram čovjekova samorazumijevanja.

${ }^{898}$ N. Visković, Pravo kao kultura, str. 28. 


\section{ZAKLJUČAK}

Priroda i kultura pripadaju razredu najsamorazumljivijih pojmova, što onda gotovo neizostavno znači i najproblematičnijih. Različite manipulacije njima to najzornije pokazuju, a ni one se zasigurno ne bi događale (barem ne u toj mjeri) da ovi pojmovi ne igraju važnu ulogu u našem i određenju onoga što nas okružuje. U pokušaju odgovornog pristupa odgovoru ovom problemu, a uz pomoć Viskovićevih spisa (iako ih nekad zaobilazeći ili držeći ih se parcijalno), naš je pristup bio uvelike formalan i pojednostavljen - kultura je specifičan način čovjekova posredovanja onoga s čime ulazi u odnos, dok je priroda sve ostalo. No kakvo god bilo razrješenje značenja ovih pojmova, njihov odnos sačinjava dodatni, nepregledan prostor, kojega smo se ovdje tek dotaknuli. Taj je doticaj stalno bio pod pashom normativnog pristupa, kao onoga koji smo ovdje držali za glavni cilj čitavog istraživanja, a što se preklapa kako s Viskovićevim svrhama, tako i s onima integrativne bioetike, kojoj je ovaj rad u izvjesnom smislu imao služiti kao doprinos: prvo, kao ukazivanje na elemente Viskovićeva djela koji nisu samo sukladni ideji integrativne bioetike, nego je mogu na više načina obogatiti, i drugo, kao daljnje prokopavanje puta dosezanja orijentacije spram života tamo gdje je Visković stao, što i jest njegova intencija. Na tom su putu pružena i donekle alternativna usmjerenja razvoju integrativne bioetike, prvenstveno u vidu artikulacije pojmova pluriperspektivnosti i bioetičkog senzibiliteta, a onda i u pogledu pružanja prijedloga etičke teorije (sa samoostvarivanjem kao centralnim pojmom) u duhu njezinih određenja.

Jedno od tih njezinih ključnih određenja predstavlja spomenuta pluriperspektivna metodologija, koju, premda slovom nenaznačenom, nalazimo duhom upriličenu kod Viskovića, čije nam djelo na najbolji način pokazuje kako se moralno suđenje ne može ograničiti tek na primjenu apstraktnih moralnih principa, nego potrebuje pomoć širokog uvida u kulturno posredovanje izvjesne materije. Visković tako »svaku pojavu ili pak splet pojava, odnosno svoje generičko i povijesno mjesto, zatim sustavni red kojim se jedna pojavnost javila i dinamički gibala, nalazi i smješta u najdublju i najširu konfiguraciju široko zamišljenog, znanstvenog i estetsko-etičkog izraženog skupa skupova«. ${ }^{899}$ Prepoznavanje obuhvaćanja svega toga od strane jedne osobe daje nam za pravo da sa Šagom ponovimo, kako je pisao povodom izdanja Stabla i čovjeka, da njezina erudicija »visokog stila najviših europskih intelektualaca,

${ }^{899}$ F. Šago, »Knjiga 'Stablo i čovjek'«, str. 165. 
daje Nikoli Viskoviću mjesto na samom Parnasu, u Panteonu kognitivne intelektualne snage u najširem, selektivno najrelevantnijem i najdubljem kompatibilitetu $\mathrm{s}$ prošlošću, $\mathrm{s}$ aktualizacijom i anticipacijom onog budućeg, a to doista nije stilsko-kritička hiperbola već neporecivi fakt ${ }^{900}$

Osim svestranog teorijskog (metodološkog i sadržajnog) doprinosa orijentaciji u doba posvemašnjeg zaborava prirode i degradacije kulture, Viskovićev osobni pristup suočenju s ovim problemima također može služiti kao uzor. Njegov teorijski trud, oslonjen na iznimnu polihistorsku širinu, prenosi se akademskoj zajednici znanstvenim studijama, ali i čitavoj društvenoj zajednici putem članaka u popularnim časopisima, dnevnom tisku, a ništa manje ni aktivističkim i političkim angažmanom. Visković je tako u mnogočemu zadužio našu (ali i, nadamo se da će se tako pokazati, svjetsku) bioetiku. Zahvalnost na tome svakako ne treba uobličavati u, kako je i sam isticao u slučaju Marxove misli, »citatologiju«, nego upravo u njegovoj kritičkoj recepciji i samostalnom nastavljanju izgradnje onoga što je on započeo. U tom je duhu pisan i ovaj rad, koji se, istina, uvelike oslonio na »citatologiju«, prvenstveno zbog nezasluženo oskudne dosadašnje recepcije, no nadamo se da nije suviše zakazao po pitanju ova dva zadatka.

${ }^{900}$ Ibid., str. 164. 


\section{POPIS LITERATURE}

- Adler, Daniel; Zlotnik Shaul, Randi, »Disciplining Bioethics: Towards a Standard of Methodological Rigor in Bioethics Research«, Accountability in Research 19 (2012) 3, str. 187-207.

- Aleksa, Ratko, »Problemi splitske 'Zelene akcije'«, Vjesnik 4. 8. 1989., str. 4.

- Alexander, Shana, »They Decide Who Lives, Who Dies«, Life 9. 11. 1962., str. 102-125.

- Allen, Derek P. H., »Does Marx Have an Ethic of Self-Realization? Reply to Aronovitch«, Canadian Journal of Philosophy 10 (1980) 3, str. 377-386.

- Amulić, Slavko, Perspektivizam i pluralizam. Prilog zasnivanju pluriperspektivizma, Pergamena, Zagreb 2019.

- Aronovitch, Hilliard, »Marxian Morality«, Canadian Journal of Philosophy 10 (1980) 3, str. 357-376.

- Babić-Avdispahić, Jasminka; Mujkić, Asim, Etika, Eidos, Zenica 2019.

- Babić, Jovan, »Pogovor«, u: Artur Šopenhauer [Arthur Schopenhauer], O temelju morala, prevela Veselka Santini, Bratstvo-Jedinstvo, Novi Sad 1990., str. 224-232.

- Bacon, Francis, Novi organon, preveo Viktor D. Sonnenfeld (redigirao Vladimir Vratović), Naprijed, Zagreb 1986.

- Bačić, Mašenjka, »Heroji mira: Aktivizam pod čizmama HOS-a«, Novosti 9. 8. 2019., str. $22-23$.

- $\quad$ Baker, Steve, Artist | Animal, University of Minnesota Press, Minneapolis - London 2013.

- Batovanja, Vesna, Martin Heidegger. Mišljenje koje se više ne razumije kao metafizika, Naklada Breza, Zagreb 2007.

- Bauman, Zigmunt [Bauman, Zygmunt], Kultura $i$ društvo, preveo Radoslav Đokić, Prosveta, Beograd 1984.

- Bauman, Zygmunt, Postmoderna etika, prevela Dorta Jagić, AGM, Zagreb 2009.

- Beauchamp, Tom L.; Childress, James F., Principles of Biomedical Ethics, Oxford University Press, Oxford - New York 2001.

- Bentham, Jeremy, An Introduction to the Principles of Morals and Legislation, sv. 2, W. Pickering, Lincoln's-inn Fields - E. Wilson, Royal Exchange, London 1823. 
- $\mathrm{BH}[$ Bio-hemeroteka].

- Biblija. Stari i Novi zavjet, preveli Antun Sorić, Silvije Grubišić, Filibert Gass i Ljudevit Rupčić, Kršćanska sadašnjost, Zagreb 1990.

- Birnbacher, Dieter, »Legal Rights for Natural Objects. A Philosophical Critique«, u: Edgar Morscher, Otto Neumaier, Peter Simons (ur.), Applied Ethics in a Troubled World, Springer Science+Buisness Media, Dordrecht 1998., str. 29-40.

- Blekburn, Sajmon [Blackburn, Simon], Oksfordski filozofski rečnik, preveli Ljiljana Petrović et al., Svetovi, Novi Sad 1999.

- Bošnjak, Branko, »Aristotelova psihologija i filozofija života«, u: Aristotel, $O$ duši / Nagovor na filozofiju, preveo Darko Novaković (redigirao Branko Bošnjak), Naprijed, Zagreb 1996., str. ix-xlii.

- Bradschaw, John W. S., »Anthrozoology«, u: Daniel S. Mills, The Encyclopedia of Applied Animal Behaviour and Welfare, CABI, Wallingford 2010., str. 28-30.

- Braudel, Fernand, Sredozemlje i sredozemni svijet u doba Filipa II., sv. 1, prevela Đurđa Šinko-Depierris, Izdanja Antibarbarus, Zagreb 1997.

- Braudel, Fernand, Sredozemlje i sredozemni svijet u doba Filipa II., sv. 2, prevele Mirna Cvitan Černelić i Jagoda Milinković, Izdanja Antibarbarus, Zagreb 1998.

- Bukša, Željko, »Obmana i ignoriranje demokratske javnosti«, Vjesnik 17. 11. 1989., str. 6.

- Butler, Christopher, Postmodernizam. Kratki uvod, preveo Dušan Janić, Šahinpašić, Sarajevo 2007.

- Cassirer, Ernst, Ogled o čovjeku. Uvod u filozofiju ljudske kulture, preveli Omer Lakomica i Zvonimir Sušić, Naprijed, Zagreb 1978.

- Chamowitz, Daniel, Što biljke znaju. Čudesno putovanje u osjetilni svijet biljaka, prevela Aleksandra Barlović, Planetopija, Zagreb 2013.

- Cifrić, Ivan, Bioetička ekumena. Odgovornost za život susvijeta, Pergamena, Zagreb 2007.

- Cifrić, Ivan, Leksikon socijalne ekologije. Kritičko promišljanje, Školska knjiga, Zagreb 2013.

- Cifrić, Ivan, Pojmovnik kulture i okoliša, Visoka škola za poslovanje i upravljanje s pravom javnosti »Baltazar Adam Krčelić«, Zaprešić 2009.

- Clevell, Tammy, »Subjectivity«, u: Victor E. Taylor, Charles E. Winquist, Encyclopedia of Postmodernism, Routledge, London - New York 2001., str. 381-383. 
- Cooper, David E., »Intervention, humility and animal integrity«, u: Alan Holland, Andrew Johnson (ur.), Animal Biotechnology and Ethics, Springer Science+Business Media, Dordrecht 2004., str. 145-155.

- Cottingham, John, »'A Brute to Brutes?': Descartes' Treatment of Animals«, Philosophy 53 (1978) 4, str. 551-559.

- Cvitanović, Ivan; Lerotić, Dada; Miličić, Jure; Trebotić, Matko, »Da ne bude zabune«, Slobodna Dalmacija 27. 3. 1990., str. 18.

- Čekić, Jovan, »Nastajanje post-humanog kapitalizma«, u: Fredric Jameson, Postmodernizam ili kulturna logika kasnog kapitalizma, preveo Srđan Dvornik, Arkzin, Zagreb 2019., str. 116-227.

- Čoloković-Sviličić, Jadranka, »Car, prosjaci i rentijeri«, Slobodna Dalmacija 7. 12. 1989., str. 12.

- Čoloković-Sviličić, Jadranka, »Potemkinova sela ili grad s naličja«, Slobodna Dalmacija 8. 12. 1989., str. 14.

- Čović, Ante, »Biotička zajednica kao temelj odgovornosti za ne-ljudska živa bića«, u: Ante Čović, Nada Gosić, Luka Tomašević (ur.), Od nove medicinske etike do integrativne bioetike, Pergamena - Hrvatsko filozofsko društvo, Zagreb 2009., str. 11-24.

- Čović, Ante, »Etički kriticizam u djelu Milana Kangrge«, Filozofska istraživanja 24 (2004) 3-4, str. 667-677.

- Čović, Ante, Etika i bioetika. Razmišljanja na pragu bioetičke epohe, Pergamena, Zagreb 2004.

- Čović, Ante, »Pluralizam i pluriperspektivizam«, Filozofska istraživanja 26 (2006) 1, str. $7-12$.

- Čović, Ante, »Pojmovna razgraničenja: moral, etika, medicinska etika, bioetika, integrativna bioetika«, u: Ante Čović, Marija Radonić (ur.), Bioetika i dijete. Moralne dileme u pedijatriji, Pergamena - Hrvatsko društvo za preventivnu i socijalnu pedijatriju, Zagreb 2011., str. 11-24.

- Čović, Ante, »Znanje i moralnost«, Filozofska istraživanja 17 (1997) 4, str. 1049-1064.

- Ćurko, Bruno, »Kulturna animalistika Nikole Viskovića - s primjerom vuka (Canis lupus)«, u: Josip Guć, Hrvoje Jurić (ur.), Nikola Visković: pravo - politika - bioetika. Zbornik povodom osamdesetog rođendana, Pergamena - Filozofski fakultet Sveučilišta u Splitu, Centar za integrativnu bioetiku - Pravni fakultet Sveučilišta u Splitu - Znanstveni centar izvrsnosti za integrativnu bioetiku, Zagreb - Split [u pripremi]. 
- Dadić, J., »Na Marjanu opet dobrovoljci«, Slobodna Dalmacija 19. 10. 1990., str. 8.

- D'Alisa, Giacomo; Demaria, Federico; Kallis, Giorgos (ur.), Odrast. Pojmovnik za novu eru, prevela Mirta Jambrović, Fraktura - Institut za političku ekologiju, Zaprešić - Zagreb 2016 .

- Davidović, Blažo, »S rukom u ruci za bolje 'stađune'«, Slobodna Dalmacija 28. 1. 1990., str. 7.

- de Waal, Frans, The Ape and the Sushi Master. Cultural Reflections of a Primatologist, Basic Books, New York 2001.

- Dragičević, M., »Dva modela organiziranja«, Večernji list 7. 6. 1989., str. 5.

- Eagleton, Terry, Ideja kulture, prevela Gordana V. Popović, Naklada Jesenski i Turk, Zagreb 2014.

- Eagleton, Terry, Kultura, preveo Damir Biličić, Naklada Ljevak, Zagreb 2017.

- Elias, Norbert, O procesu civilizacije. Sociogenetska i psihogenetska istraživanja, preveli Silvija Bosner i Marijan Bobinac, Izdanja Antibarbarus, Zagreb 1996.

- Eterović, Igor, Kant i bioetika, Pergamena - Centar za integrativnu bioetiku Filozofskog fakulteta Sveučilišta u Zagrebu, Zagreb 2017.

- Evans, Edward Payson, Životinje pred sudom. Kazneni progon i smrtna kazna za životinje, preveo Hrvoje Gračanin, TIM press, Zagreb 2014.

- F., D., »Tko se od 'zelenih' mora zacrvenjeti?«, Slobodna Dalmacija 26. 3. 1991., str. 11.

- Fiddes, Nick, Meso. Prirodni simbol, prevela Suzana Kovačević, Naklada Jesenski i Turk, Zagreb 2002.

- Filipović, Vladimir, »Kultura«, u: Vladimir Filipović (ur.), Filozofijski rječnik, Nakladni zavod Matice hrvatske, Zagreb 1989., str. 183.

- Filipović, Vladimir, »Subjekt«, u: Vladimir Filipović (ur.), Filozofijski rječnik, Nakladni zavod Matice hrvatske, Zagreb 1989.

- Foer, Jonathan Safran, Eating Animals, Back Bay Books - Little, Brown and Company, New York - Boston - London 2009.

- Fox, Warwick, »Deep Ecology: A New Philosophy of Our Time?«, The Ecologist 14 (1984) 5-6, str. 194-200.

- Fraser, Nancy; Nicholson, Linda J., »Društvena kritika bez filozofije: susret feminizma i postmodernizma«, prevela Lidija Zafirović, u: Linda J. Nicholson (ur.), Feminizam/postmodernizam, Liberata - Ženski studiji, Zagreb 1999., str. 23-38.

- Fromm, Erich, Imati ili biti?, preveo Gvozden Flego, Naprijed, Zagreb 1979. 
- G., L., »Donesite hrane!«, Slobodna Dalmacija 18.-20. 4. 1992., str. 20.

- Gall, Zlatko, »Split se oprao«, Danas 20. 12. 1988., 72-73.

- Gari, Romen [Gary, Romain], Korijeni neba, prevela Milica Carcaračević, Svjetlost, Sarajevo 1960.

- Gehlen, Arnold, Čovjek. Njegova priroda i njegov položaj u svijetu, preveo Aleksa Buha, Veselin Masleša, Sarajevo 1974.

- Gerhardt, Christina, »The Ethics of Animals in Adorno and Kafka«, New German Critique (2006) br. 97, str. 159-178.

- Gretić, Goran, »Heideggerova kritika boljševizma i liberalizma«, Anali Hrvatskog politološkog društva 13 (2016) 1, str. 37-50.

- Grizelj, O. I., »Kresovi 'zelenih'«, Slobodna Dalmacija 24. 6. 1990., str. 32.

- Grušovnik, Tomaž, Etika živali. Očezvrstni gostoljubnosti, Univerzitetna založba Annales, Koper 2016.

- Guć, Josip, »Ekološka kriza između kulture i prirode«, u: Ana Štrkalj, Zoran Glavaš, Sanja Kalambura (ur.), $1^{\text {st }}$ International Conference The Holistic Approach to Environment. Proceedings Book, Association for Promotion of Holistic Approach to Environment, Sisak 2018., str. 211-221.

- Guć, Josip, »Moralitet i legalitet u Kantovoj etici«, Theoria 63 (2020) 2, str. 17-40.

- Guć, Josip, »Nikola Visković, integrativna bioetika i očevi bioetike«, u: Josip Guć, Hrvoje Jurić (ur.), Nikola Visković: pravo - politika - bioetika. Zbornik povodom osamdesetog rođendana, Pergamena - Filozofski fakultet Sveučilišta u Splitu, Centar za integrativnu bioetiku - Pravni fakultet Sveučilišta u Splitu - Znanstveni centar izvrsnosti za integrativnu bioetiku, Zagreb - Split [u pripremi].

- Guć, Josip, »Samoostvarivanje živih bića i genetički modificirani organizmi u poljoprivredi«, Jahr 10 (2019) 2, str. 361-375.

- Guć, Josip, »Viskovićevo tumačenje antropomorfizacije životinje i zoomorfizacije čovjeka«, u: Snežana Voštinarov (ur.), Drugi kongres o zaštiti životinja. Zbornik radova, Animal Rescue Serbia, Beograd 2018., str. 9-12.

- Gudić, Dražen, »Naprid zeleni«, Danas 15. 8. 1989., str. 73-75.

- Hanson, Earl Dorchester, »Zoology«, Encyclopcedia Britannica 13. 3. 2019. Dostupno na: https://www.britannica.com/science/zoology (pristupljeno 21. 4. 2020.).

- Hegel, Georg Wilhelm Friedrich, Fenomenologija duha, preveo Milan Kangrga, Naklada Ljevak, Zagreb 2000. 
- Hegel, Georg Wilhelm Friedrich, Osnovne crte filozofije prava, preveo Viktor D. Sonnenfeld, Veselin Masleša, Sarajevo 1989.

- Heidegger, Martin, »Prevladavanje metafizike«, u: Martin Heidegger, Mišljenje i pevanje, preveo Božidar Zec, Nolit, Beograd 1982., str. 7-40.

- Heidegger, Martin, »Razgovor s Martinom Heideggerom« (razgovarao Danilo Pejović), u: Danilo Pejović, Sistem i egzistencija, Zora, Zagreb 1970., str. 116-127.

- Heisenberg, Werner, Slika svijeta suvremene fizike, preveo Drago Dujmić, Epoha, Zagreb 1961.

- Hoffmann, Thomas Sören, »Bioetika i mnogostrukost pojmova prirode«, preveo Pavo Filipović, u: Velimir Valjan (ur.), Integrativna bioetika i izazovi suvremene civilizacije. Zbornik radova Prvog međunarodnog bioetičkog simpozija u Bosni i Hercegovini (Sarajevo, 31. III.-1. IV. 2006.), Bioetičko društvo u BiH, Sarajevo 2007., str. 23-33.

- Horkheimer, Max, »Pomrčina uma«, preveo Tomislav Ladan, u: Max Horkheimer, Kritika instrumentalnog uma. Iz predavanja i zabilježaka nakon svršetka rata, Globus, Zagreb 1988., str. 3-131.

- Horkheimer, Max; Adorno, Theodor, Dijalektika prosvjetiteljstva. Filozofijski fragmenti, prevela Nadežda Čačinović-Puhovski, Veselin Masleša, Sarajevo 1974.

- Hösle, Vittorio, Filozofija ekološke krize. Moskovska predavanja, prevela Darija Domić, Matica hrvatska, Zagreb 1996.

- M. I., »Hitno mijenjati izborne zakone«, Vjesnik 28. 1. 1990., str. 3.

- Ihvanus-Safa, Razgovor čovjeka sa životinjama, preveo Enes Karić, V.B.Z., Zagreb 2008.

- »In Praise of ... Guernica«, The Guardian 26. 3. 2009. Dostupno na: https://www.theguardian.com/commentisfree/2009/mar/26/pablo-picasso-guernica-spainwar (pristupljeno 3. 11. 2019.).

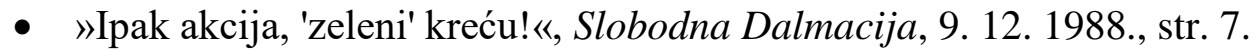

- J., A., »Demonstracija 'zelenih'«, Slobodna Dalmacija 10. 12. 1989., str. 8.

- J., A., »Na meti Marjan i more«, Slobodna Dalmacija 30. 1. 1989., str. 8.

- J., A., »Pitomci najbolji«, Slobodna Dalmacija 23. 4. 1989., str. 6.

- J., A., »Povratak Marjanu«, Slobodna Dalmacija 12. 3. 1989., str. 4.

- J., A., »'Veliko spremanje' Marjanske šume«, Slobodna Dalmacija 5. 2. 1989., str. 7.

- J., A., »'Zeleni' na vrhu Marjana«, Slobodna Dalmacija 19. 3. 1989., str. 13. 
- Jahr, Fritz, »Bio-etika: osvrt na etički odnos čovjeka prema životinjama i biljkama«, preveo Amir Muzur, u: Iva Rinčić, Amir Muzur, Fritz Jahr i rađanje europske bioetike, Pergamena, Zagreb 2012., str. 201-205.

- Jahr, Fritz, »Smrt i životinje: razmatranje Pete zapovijedi«, preveo Amir Muzur, u: Iva Rinčić, Amir Muzur, Fritz Jahr i rađanje europske bioetike, Pergamena, Zagreb 2012., str. 207-211.

- Jahr, Fritz, »Zaštita životinja i etika u svom međusobnom odnosu«, preveo Amir Muzur, u: Iva Rinčić, Amir Muzur, Fritz Jahr i rađanje europske bioetike, Pergamena, Zagreb 2012., str. 213-218.

- Jahr, Fritz, »Znanost o životu i nauka o ćudoređu (Stare spoznaje u novom ruhu)«, preveo Amir Muzur, u: Iva Rinčić, Amir Muzur, Fritz Jahr i rađanje europske bioetike, Pergamena, Zagreb 2012., str. 197-200.

- Jakaša, A., »Više 'zelenih' nego čistoće«, Slobodna Dalmacija 12. 2. 1989., str. 8.

- Jakaša, A., »'Zeleni' još izvan zakona«, Slobodna Dalmacija 29. 6. 1989., str. 10.

- Jakaša, Azra, »Od SKOJ-a do 'Zelenih' - u ilegali«, Slobodna Dalmacija 11. 10. 1989., str. 9.

- Jameson, Fredric, Postmodernizam ili kulturna logika kasnog kapitalizma, preveo Srđan Dvornik, Arkzin, Zagreb 2019.

- Jč., M. »Protestni tjedan za Dioklecijanovu palaču«, Slobodna Dalmacija, str. 10.

- Jonas, Hans, Princip odgovornost. Pokušaj jedne etike za tehnološku budućnost, preveo Slobodan Novakov, Veselin Masleša, Sarajevo 1990.

- Jonas, Hans, The Phenomenon of Life. Toward a Philosophical Biology, Northwestern University Press, Evanston 2001.

- Jonsen, Albert R., The Birth of Bioethics, Oxford University Press, New York 1998.

- Jovanović, Dragan, »Jajce u 'Lavu'«, NIN 4. 2. 1990., str. 28-30.

- Joy, Melanie, Zašto volimo pse, jedemo svinje i nosimo krave. Uvod u karnizam, prevela Dunja Farkaš, Dvostruka duga - Prijatelji životinja, Čakovec - Zagreb 2012.

- Jurić, Hrvoje, Etika odgovornosti Hansa Jonasa, Pergamena, Zagreb 2010.

- Jurić, Hrvoje, Euforija i eutanazija. Akutni zapisi o kroničnim problemima, Sandorf Mizantrop, Zagreb 2019.

- Jurić, Hrvoje, »From the Notion of Life to an Ethics of Life«, Synthesis Philosophica 30 (2015) 1, str. 33-46. 
- Jurić, Hrvoje, »Hrvoje Jurić - 1. međunarodni prosvjed za zabranu lova / Oslobođenje životinja«, YouTube. Dostupno na: https://www.youtube.com/watch?v=lqkjj4Yp5cQ (pristupljeno 6. 2. 2019.).

- Jurić, Hrvoje, »Kangrgina riječ o zavičaju«, Filozofska istraživanja 24 (2004) 3-4, str. $757-762$.

- $\quad$ K., A., »Zeleno oko«, Slobodna Dalmacija 11. 12. 1989., str. 14.

- Kallis, Giorgos; Demaria, Federico; D'Alisa, Giacomo, »Odrast«, u: Giacomo D'Alisa, Federico Demaria, Giorgos Kallis (ur.), Odrast. Pojmovnik za novu eru, prevela Mirta Jambrović, Fraktura - Institut za političku ekologiju, Zaprešić - Zagreb 2016., str. 1-27.

- Kangrga, Milan, Etički problem u djelu Karla Marxa. Kritika moralne svijesti, Naprijed, Zagreb 1963.

- Kangrga, Milan, Etika. Osnovni problem i pravci, Golden Marketing-Tehnička knjiga, Zagreb 2004.

- Kangrga, Milan, Etika ili revolucija, Naprijed, Zagreb 1989.

- Kangrga, Milan, Etika i sloboda. Uvod u postavljanje etičkog problema, Naprijed, Zagreb 1966.

- Kangrga, Milan, Filozofske rasprave, Euroknjiga, Zagreb 2008.

- Kangrga, Milan, Praksa - vrijeme - svijet. Iskušavanje mišljenja revolucije, Nolit, Beograd 1984.

- Kangrga, Milan, Racionalistička filozofija. I odabrani tekstovi filozofa, Nakladni zavod Matice hrvatske, Zagreb 1982.

- Kangrga, Milan, Razmišljanja o etici, Hrvatsko filozofsko društvo, Zagreb 1970.

- Kangrga, Milan, Šverceri vlastitog života, Republika, Beograd 2001.

- Kant, Immanuel, Antropologija u pragmatičnom pogledu, preveo Željko Pavić, Naklada Breza, Zagreb 2003.

- Kant, Immanuel, »Ideja opće povijesti s gledišta svjetskog građanstva«, u: Immanuel Kant, Pravno-politički spisi, preveo Zvonko Posavec, Politička kultura, Zagreb 2000., str. 17 32.

- Kant, Immanuel, Kritika čistoga uma, preveo Viktor D. Sonnenfeld, Nakladni zavod Matice hrvatske, Zagreb 1984.

- Kant, Immanuel, Kritika praktičkog uma, preveo Viktor D. Sonnenfeld (redigirao Milan Kangrga), Naprijed, Zagreb 1990. 
- Kant, Immanuel, Metafizika ćudoređa, preveo Dražen Karaman, Matica hrvatska, Zagreb 1999.

- Kant, Immanuel, Osnivanje metafizike ćudoređa, preveo Viktor D. Sonnenfeld, Feniks, Zagreb 2003.

- Kaulbach, Friedrich, Philosophie des Perspektivismus, sv. 1, Wahrheit und Perspektive bei Kant, Hegel und Nietzsche, Mohr, Tübingen 1990.

- Kečkemet, Duško, »Stablo u slikarstvu Hrvatske«, u: Nikola Visković, Stablo i čovjek. Prilog kulturnoj botanici, Izdanja Antibarbarus, Zagreb 2001., str. 606-617.

- Kirn, Andrej, »Između ontološke i antropološke opasnosti: Martin Heidegger i 'usuda biti'«, Socijalna ekologija 7 (1998) 4, str. 331-341.

- Korsgaard, Christine M. »Reflections on the Evolution of Morality«, The Amherst Lecture in Philosophy 5 (2010), str. 1-29., Dostupno na: http://www.amherstlecture.org/korsgaard2010/.

- Kovel, Joel, The Enemy of Nature. End of the Capitalism or the End of the World, Zed Books - Fernwood Publishing, New York - Halifax - Winnipeg 2007.

- Krstić, Predrag, Filozofska životinja. Zoografski nagovor na filozofiju, Službeni glasnik Institut za filozofiju i društvenu teoriju, Beograd 2008.

- Krstić, Predrag, Subjekt protiv subjektivnosti. Adorno i filozofija subjekta, Institut za filozofiju i društvenu teoriju - I. P. »Filip Višnjić«, Beograd 2007.

- Krznar, Tomislav, Znanje i destrukcija. Integrativna bioetika i problemi zaštite okoliša, Pergamena - Učiteljski studij Sveučilišta u Zagrebu, Zagreb 2011.

- Kukoč, Mislav, Enigma postkomunizma, Hrvatsko filozofsko društvo, Zagreb 1997.

- Kušan, Emil, »Aspekti i implikacije Kantova pojma slobode«, Filozofska istraživanja 32 (2012) 1, str. 79-91.

- Kuštre, Ante, »Koliko je Split 'zelen'«, Nedjeljna Dalmacija 20. 11. 1988., str. 4.

- La Mettrie, Julien Offray de, »Čovjek biljka (1748.)《u: Julien Offray de La Mettrie, Čovjek stroj / Rasprava o duši / Čovjek biljka, preveo Josip Balabanić, ArTresor naklada, Zagreb 2004., str. 255-279.

- La Mettrie, Julien Offray de, »Čovjek stroj (1747.)«, u: Julien Offray de La Mettrie, Čovjek stroj / Rasprava o duši / Čovjek biljka, preveo Josip Balabanić, ArTresor naklada, Zagreb 2004., str. 167-254.

- Leopold, Aldo, A Sand County Almanac. And Sketches Here and There, Oxford University Press, New York 1968. 
- Leopold, Aldo, »The Conservation Ethics«, u: Lloyd C. Irland (ur.), Ethics in Forestry, Timber Press, Portland 1994., str. 251-263.

- Lerois-Gourhan, André, Religije prethistorije. Paleolitik, prevela Melita Wolf, Naprijed, Zagreb 1968.

- Leskur, Jasenka, »Velo Misto sad je čisto«, Slobodna Dalmacija 11. 12. 1988., str. 9.

- Lévi-Strauss, Claude, Strukturalna antropologija 2, preveli Daniel Bučan i Vjekoslav Mikecin, Školska knjiga, Zagreb 1988.

- Livestock's Long Shadow. Environmental Issues and Options, Food and Agriculture Organization, 2006. Dostupno na: http://www.fao.org/3/a-a0701e.pdf (pristupljeno 4. 1. 2020.).

- Ls., J., »Protestni tjedan za gradsku jezgru«, Slobodna Dalmacija 2. 12. 1989., str. 10.

- Lucić, Predrag, »Knjigom na pilu«, Feral Tribune 2. 5. 2002., str. 95.

- Lunić, Anita, »Održivost teze o Marxovoj etici«, Eidos 2 (2018) 2, str. 115-124.

- Lunić, Anita, »Životinja između biopolitike i bioetike: tehnike reguliranja životinjskog tijela i života. Od suđenja životinjama do više-nego-ljudske biopolitike«, u: Josip Guć, Hrvoje Jurić (ur.), Nikola Visković: pravo - politika - bioetika. Zbornik povodom osamdesetog rođendana, Pergamena - Filozofski fakultet Sveučilišta u Splitu, Centar za integrativnu bioetiku - Pravni fakultet Sveučilišta u Splitu - Znanstveni centar izvrsnosti za integrativnu bioetiku, Zagreb - Split [u pripremi].

- Malm, Andreas, Fosilni kapital. Uspon parnog pogona i korijeni globalnog zatopljenja, Fraktura - Institut za političku ekologiju, Zaprešić - Zagreb 2018.

- Mannheim, Karl, Ideologija i utopija, preveo Kiril Miladinov, Naklada Jesenski i Turk Hrvatsko sociološko društvo, Zagreb 2007.

- Marcuse, Herbert, Čovjek jedne dimenzije. Rasprave o ideologiji razvijenog industrijskog društva, prevela Branka Brujić, Veselin Masleša, Sarajevo 1968.

- Marcuse, Herbert, »Esej o oslobođenju«, prevela Branka Brujić, u: Kraj utopije, Esej o oslobođenju, Stvarnost, Zagreb 1972., str. 127-202.

- Marcuse, Herbert, »Some Social Implications of Modern Technology«, u: Herbert Marcuse, Technology, War and Fascism, Routledge, London - New York 2004., str. 3965.

- Marjanić, Suzana, »Pokret za prava životinja u RH: pokušaj pregleda«, Ekonomska $i$ ekohistorija 10 (2014), str. 113-132. 
- Marjanić, Suzana, Topoi umjetnosti performansa. Lokalna vizura, Durieux - Hrvatska sekcija AICA, Zagreb 2017.

- Marjanić, Suzana, »Zooscena i kao etička pomutnja: primjeri s hrvatske performerske i kazališne scene«, Kroatologija 1 (2010) 1, str. 169-182.

- Marjanić, Suzana; Zaradija Kiš, Antonija (ur.), Kulturni bestijarij, Hrvatska sveučilišna naklada - Institut za etnologiju i folkloristiku, Zagreb 2007.

- Marković, Mihailo, »Čovek danas«, u: Čovek danas. Zbornik filozofskih ogleda, Nolit, Beograd 1964., str. 9-30.

- Markus, Tomislav, Dubinska ekologija i suvremena ekološka kriza. Jedan bioekološki pogled, Hrvatsko sociološko društvo - Institut za društvena istraživanja - Filozofski fakultet, Zavod za sociologiju Odsjeka za sociologiju, Zagreb 2006.

- Marx, Karl, »141, Marx Engelsu u Mančester, 18. juna 1862.«, u: Karl Marx, Friedrich Engels, Pisma. Januar 1960 - Septembar 1964, preveli Mara Fran i Ivan Ivanji, u: Dela, sv. 37, Institut za međunarodni radnički pokret - Prosveta, Beograd 1979., str. 229-230.

- Marx, Karl, »Ekonomsko-filozofski rukopisi iz 1844.«, preveo Stanko Bošnjak, u: Karl Marx, Friedrich Engels, Rani radovi, Naprijed, Zagreb 1989., str. 183-336.

- Marx, Karl, Kapital. Kritika političke ekonomije, sv. 1, Proces proizvodnje kapitala, preveli Moša Pijade i Rodoljub Čolaković, Kultura, Zagreb 1947.

- Marx, Karl, »Prilog kritici Hegelove filozofije prava«, preveo Stanko Bošnjak, u: Karl Marx, Friedrich Engels, Rani radovi, Naprijed, Zagreb 1989., str. 90-105.

- Marx, Karl, »Teze o Feuerbachu«, preveo Stanko Bošnjak, u: Karl Marx, Friedrich Engels, Rani radovi, Naprijed, Zagreb 1989.

- Marx, Karl; Engels, Friedrich, »Manifest komunističke partije«, preveo Moša Pijade (redigirao Boris Buden), Ekonomija / Economics 15 (2008) 3, str. 565-596.

- Marx, Karl; Engels, Friedrich, »Njemačka ideologija«, preveo Stanko Bošnjak, u: Karl Marx, Friedrich Engels, Rani radovi, Naprijed, Zagreb 1989., str. 355-428.

- Matić, Zoran, »Mrtvo, mrtvo Jadransko more«, Polet 24. 2. 1989., str. 17.

- Mikulandra, D., »Fronta i sedam patuljaka«, Slobodna Dalmacija 24. 6. 1989., str. 14-15.

- Milivončić, Ivica, »Vode Tuđman i Račan, slijede Savka i Miko«, Slobodna Dalmacija 8. 4. 1990., str. 16-17.

- Mittelstraß, Jürgen, Wissenshaft als Lebensform. Reden über philosophische Orientierungen in Wissenschaft und Universität, Suhrkamp Verlag, Frankfurt am Mein 1982. 
- Mišić, Anto, Rječnik filozofskih pojmova, Verbum, Split 2000.

- Morin, Edgar (suradnik Nelson Vallejo-Gómez), Odgoj za budućnost. Sedam temeljnih spoznaja nužnih u odgoju za budućnost, prevela Ingrid Šafranek, Educa, Zagreb 2002.

- Mumford, Lewis, Mit o mašini, sv. 1, Tehnika i razvoj čovjeka, preveo Nikica Petrak, Grafički zavod Hrvatske, Zagreb 1986.

- Muzur, Amir; Rinčić, Iva, Van Rensselaer Potter i njegovo mjesto u povijesti bioetike, Pergamena, Zagreb 2015.

- Myerson, George, Ekologija i kraj postmoderne, preveo Ognjen Čaldarović, Naklada Jesenski i Turk, Zagreb 2002.

- Naess, Arne [Næss, Arne], Ecology, community and lifestyle. Outline of an ecosophy, preveo David Rothenberg, Cambridge University Press, Cambridge 1989.

- Naess, Arne [Næss, Arne], Deep Ecology of Wisdom. Explorations in Unities of Nature and Cultures. Selected Works, Springer, Dortrecht 2005.

- Nasser, Alan G., »Marx's Ethical Anthropology«, Philosophy and Phenomenological Research 35 (1975) 4, str. 484-500.

- Niče, Fridrih [Nietzsche, Friedrich], Genealogija morala. Polemički spis, preveo Božidar Zec, Grafos, Beograd 1990.

- Nielsen, Kai, »Alienation and Self-Realization«, Philosophy 48 (1973) 1, str. 21-33.

- O'Hear, Anthony, »Culture«, u: Edward Craig (ur.), The Shorter Routledge Encyclopedia of Philosophy, Routledge, New York 2006.

- Oreb, B., »I zelene kacige u Hrvatskoj?«, Slobodna Dalmacija 22. 3. 1992., str. 8.

- Oreb, B. J., »Danas svi na bicikle!«, Slobodna Dalmacija 28. 5. 1989., str. 6.

- Oreb, B. J., »Šokantni eksponati«, Slobodna Dalmacija 27. 5. 1989., str. 8.

- Oreb, B. J., »Uskoro startni brojevi BEM-a«, Slobodna Dalmacija 15. 5. 1989., str. 9.

- Oreb, B. J., »Zadovoljstvo sa zadrškom«, Slobodna Dalmacija 30. 5. 1989., str. 9.

- Oštrić, Zoran, »Ekološki pokreti u Jugoslaviji. Građa za proučavanje razdoblja 19711991.«, Socijalna ekologija 1 (1992) 1, str. 83-104.

- P., A., »Najmlađi sportaši na Marjanu«, Slobodna Dalmacija 9. 4. 1989., str. 4.

- Pachirat, Timothy, Every Twelve Seconds. Industrialized Slaughter and the Politics of Sight, Yale University Press, New Heaven - London 2011.

- Padjen, Ivan, »Viskovićevo integralno poimanje prava: problemi i rješenja«, u: Josip Guć, Hrvoje Jurić (ur.), Nikola Visković: pravo - politika - bioetika. Zbornik povodom osamdesetog rođendana, Pergamena - Filozofski fakultet Sveučilišta u Splitu, Centar za 
integrativnu bioetiku - Pravni fakultet Sveučilišta u Splitu - Znanstveni centar izvrsnosti za integrativnu bioetiku, Zagreb - Split [u pripremi].

- Patterson, Charles, Vječna Treblinka. Naše postupanje prema životinjama i holokaust, preveo Bernard Jan, Genesis, Zagreb 2005.

- Pavelić, Boris, »Nikola Visković pristupio RF-u: 'Hrvatska ljevica treba se udružiti u frontu'«, Novi list 3. 6. 2016. Dostupno na: http://www.novilist.hr/Vijesti/Hrvatska/NikolaViskovic-pristupio-RF-u-Hrvatska-ljevica-treba-se-udruziti-u-frontu (pristupljeno 6.2. 2019.).

- Pavić, Željko, »'Pluriperspektivizam' - slučaj jedne natuknice u Filozofskome leksikonu«, Filozofska istraživanja 34 (2014) 4, str. 577-600.

- Pavlović, Branko U., Filozofija prirode, Naprijed, Zagreb 1978.

- Pejković Kaćinski, M., »Jadran treba zaštitu«, Večernji list 23. 5. 1990., str. 6.

- Pejović, Danilo, Suvremena filozofija Zapada. I odabrani tekstovi, Nakladni zavod Matice hrvatske, Zagreb 1983.

- Pelczar, Michael J.; Pelczar, Rita M.; Steere, William Campbell, »Botany«, Encyclopcedia Britannica 11. 2. 2020. Dostupno na: https://www.britannica.com/science/botany (pristupljeno 17. 5. 2020.).

- Perko-Šeparović, Inge, »Pogrešne percepcije«, Vjesnik 7. 7. 1990., str. [u prilogu Panorama subotom] 22.

- Petrović, Anđelka, »Kakav kruh jedemo«, Nedjeljna Dalmacija 19. 3. 1989., str. 14-15.

- Petrović, Anđelka, »Prodavači kriju narodni kruh!«, Nedjeljna Dalmacija 26. 3. 1989., str. $14-15$.

- Petrović, Gajo, Filozofija i marksizam, Mladost, Zagreb 1965.

- Pilić, Damir, »Professor emeritus Nikola Visković: 'potporni stup splitske ljevice'«, u: Josip Guć, Hrvoje Jurić (ur.), Nikola Visković: pravo - politika - bioetika. Zbornik povodom osamdesetog rođendana, Pergamena - Filozofski fakultet Sveučilišta u Splitu, Centar za integrativnu bioetiku - Pravni fakultet Sveučilišta u Splitu - Znanstveni centar izvrsnosti za integrativnu bioetiku, Zagreb - Split [u pripremi].

- Plamvud, Val [Plumwood, Val], »Priroda, sopstvo i rod: feminizam, filosofija životne sredine i kritika racionalizma«, prevela Svetlana Bogdanović, u: Jelena Đurić, Srđan Prodanović, Predrag Krstić (prir.), Životna sredina. Moralni i politički izazovi, Službeni glasnik - Institut za filozofiju i društvenu teoriju, Beograd 2012., str. 57-85.

- Polić, Milan, »Kultura kao sudbina«, Filozofska istraživanja 28 (2008) 1, str. 3-11. 
- Polić, Milan, Odgoj i svije(s)t, Hrvatsko filozofsko društvo, Zagreb 1993.

- Pöltner, Günther, »Spezies, Identität, Kontinuität, Potentialität. Bemerkungen zu philosophisch-anthropologischen Voraussetzungen einer Bioethik«, u: Ante Čović, Thomas Sören Hoffmann (ur.), Integrative Bioethik. Beiträge des 1. Südosteuropäischen Bioethik-Forums, Mali Lošinj 2005, Akademia Verlag, Sankt Augustin 2007.

- Potter, Van Rensselaer, Bioetika. Most prema budućnosti, prevela Ines Radinović, Medicinski fakultet u Rijeci, Katedra za društvene znanosti - Hrvatsko društvo za kliničku bioetiku - Hrvatsko bioetičko društvo - Međunarodno udruženje za kliničku bioetiku (ISCB), Rijeka 2007.

- Potter, Van Rensselaer, Global Bioethics. Building on the Leopold Legacy, Michigan University Press, East Lansing 1988.

- »Prof. dr. sc. Hrvoje Jurić«, Odsjek za filozofiju Filozofskog fakulteta Sveučilišta u Zagrebu. Dostupno na: https://filoz.ffzg.unizg.hr/nastavnici/hrvoje-juric/ (pristupljeno 21. 2. 2021.).

- „Prof. dr. sc. Nikola Visković, umirovljeni profesor«, Pravni fakultet, Sveučilište u Splitu. Dostupno na: http://www.pravst.unist.hr/ljudi.php?p=26\&s=1008 (pristupljeno 19. 4. 2020.).

- $\quad$ R., Ž., »Četrnaest za«, Slobodna Dalmacija 25. 2. 1989., str. 9.

- Regan, Tom, The Case for Animal Rights, University of California Press, Berkeley - Los Angeles 1983.

- Regan, Tom, »Tom Regan The Sword of Justice, The Torch of Reason«. Dostupno na: https://www.youtube.com/watch?v=wfLbUWEew-M (pristupljeno 22. 8. 2017.).

- Reich, Warren Thomas, »The Word 'Bioethics': Its Birth and the Legacies Who Shaped It«, Kennedy Institute of Ethics Journal 4 (1994) 4, str. 319-335.

- Reich, Warren Thomas, »The Word 'Bioethics': The Struggle Over Its Earliest Meanings«, Kennedy Institute of Ethics Journal 5 (1995) 1, str. 19-34.

- Rifkin, Jeremy, Biotehnološko stoljeće. Trgovina genima u osvit vrlog novog svijeta, prevela Ljerka Pustišek, Naklada Jesenski i Turk - Hrvatsko sociološko društvo, Zagreb 1999.

- Rinčić, Iva; Muzur, Amir, Fritz Jahr i rađanje europske bioetike, Pergamena, Zagreb 2012.

- Roderick, Rick, »306 Foucault and the Disappearance of the Human (1993)«, Rick Roderick. Dostupno na: http://rickroderick.org/306-foucault-and-the-disappearance-ofthe-human-1993/ (pristupljeno 14. 5. 2020.). 
- Rogošić, Željko, »Nagrada ne čeka registraciju«, Večernji list 15. 10. 1989., intervju (razgovarao Želimir Žanko), str. 7.

- Salaquarda, Jörg, »Arthur Schopenhauer«, prevela Darija Domić, u: Ozren Žunec (ur.), Suvremena filozofija I, Školska knjiga, Zagreb 1996., str. 35-81.

- Sartre, Jean-Paul, Egzistencijalizam je humanizam, Veselin Masleša, Sarajevo 1964.

- Ser, Mišel [Serres, Michel], »Povratak na Ugovor o prirodi«, prevela Milica Šešur, u: Jelena Đurić, Srđan Prodanović, Predrag Krstić (prir.), Životna sredina. Moralni i politički izazovi, Službeni glasnik - Institut za filozofiju i društvenu teoriju, Beograd 2012., str. 109-119.

- Serres, Michel, The Natural Contract, preveli Elizabeth MacArthur i William Paulson, The University of Michigan Press, Ann Arbor 1995.

- $\quad$ Singer, Peter, Oslobođenje životinja, preveo Neven Petrović, IBIS grafika, Zagreb 1998.

- Singer, Peter, Praktična etika, preveo Tomislav Bracanović, KruZak, Zagreb 2003.

- Sirilnik, Boris [Cyrulnik, Boris]; de Fontene, Elizabet [de Fontenay, Élisabeth]; Singer, Piter [Singer, Peter], I životinje imaju prava. Intervjui koje je vodila Karin Lu Matinjon u saradnji s Dejvidom Rozaneom, preveo Dušan Janić (redigirala Jasna Šamić), Akademska knjiga, Novi Sad 2018.

- Skledar, Nikola, Čovjekov opstanak. Uvod u antropologiju, Hrvatsko filozofsko društvo, Zagreb 1996.

- Smith, Robert Leo; Pimm, Stuart L., »Ecology«, Encyclopcedia Britannica 7. 2. 2019. Dostupno na: https://www.britannica.com/science/ecology (pristupljeno 17. 5. 2020.).

- Spinoza, Baruh de [Spinoza, Baruch de], Etika. Geometrijskim redom izložena $i$ u pet delova podeljena, prevela Ksenija Atanasijević, Beogradski izdavačko-grafički zavod, Beograd 1983.

- »'Statuti' podvig, Salona ruglo, Zeleni nada«, Slobodna Dalmacija 31. 12. 1988. - 3. 1. 1989., str. 26-27.

- Steiner, Gary, »Response to Commentators«, PhaenEx 8 (2013) 2, str. 308-325.

- Steiner, George, Martin Heidegger. With a New Introduction, The University of Chicago Press, Chicago 1992.

- Stone, Christopher D., Should Trees Have Standing? Law, Morality, and the Environment, Oxford University Press, New York 2010.

- »Subjekt«, Hrvatska enciklopedija. Dostupno http://www.enciklopedija.hr/natuknica.aspx?id=58573 (pristupljeno 3. 11. 2019.). 
- Supek, Rudi, Ova jedina zemlja. Idemo li u katastrofu ili u Treću revoluciju?, Globus, Zagreb 1989.

- Svendsen, Lars Fr. H., Razumijemo li životinje? Filozofijski pristup, preveo Mišo Grundler, TIM press, Zagreb 2019.

- Šago, Frane, »Knjiga 'Stablo i čovjek'. Opus magnum u hrvatskoj i europskoj kulturnoj botanici«, Mogućnosti 50 (2003) 4-6, str. 164-168.

- Šegota, Ivan, Nova medicinska etika (bioetika). Priručnik, Medicinski fakultet, Katedra društvenih znanosti, Rijeka 1994.

- Šlelamov, Sergije, »Pred ekološkim ponorom«, Slobodna Dalmacija 28. 1. 1990., str. 4.

- Šmit, Alfred [Schmidt, Alfred], Pojam prirode u Marksovom učenju, preveo Danilo Basta, Vuk Karadžić, Beograd 1981.

- Šopenhauer, Artur [Schopenhauer, Arthur], O temelju morala, prevela Veselka Santini, Bratstvo-Jedinstvo, Novi Sad 1990.

- $\quad$ T., S., »Prsten oko palače«, Slobodna Dalmacija 27. 1. 1990, str. 9.

- $\quad$ Tarkovski, Andrej Arsenijevič, Stalker, Mosfilm, 1979.

- Taylor, Chloë, »'Postmodern' Critical Animal Theory: A Defense«, PhaenEx 8 (2013) 2, str. 255-270.

- Tirnanić, Bogdan, »Topla voda i hladni vetrovi«, NIN 25.6.1989., str. 12-13.

- Ulfig, Alexander, Lexikon der Philosophischen Begriffe, Bechtermünz, Eltville am Rhein 1993.

- V., E., »Slab odaziv građana«, Slobodna Dalmacija 11. 11. 1990., str. 8.

- Vattimo, Gianni, Kraj moderne, preveo Mario Kopić, Matica hrvatska, Zagreb 2000.

- Veljačić, Čedomil, Razmeđa azijskih filozofija, sv. 1, Sveučilišna naklada Liber, Zagreb 1978.

- Veljak, Lino, Uvod u ontologiju, Naklada Breza, Zagreb 2019.

- Visković, Nikola, »Bioetika i biomedicinsko pravo«, Zbornik radova Pravnog fakulteta u Splitu 39-40 (1995) 1-2, str. 67-83.

- Visković, Nikola, »Bioetika shvaćena ozbiljno«, Zarez 21.11.2002., str. 14-15.

- Visković, Nikola, »Cijela je ljudska kultura protuprirodna«, Slobodna Dalmacija 25. 3. 2006., intervju (razgovarao Damir Pilić), str. 32-33.

- Visković, Nikola, Država i pravo, Birotehnika, Zagreb 1995. 
- Visković, Nikola, »Ekologija i pravo«, u: Bože Vuleta, Ante Vučković (ur.), Odgovornost za život. Zbornik radova sa znanstvenog simpozija održanog u Baškoj Vodi, 1. - 3. listopada 1999., Franjevački institut za kulturu mira, Split 2000., str. 455-476.

- Visković, Nikola, »Erotika, pornografija, erotoposi«, Treća 5 (2003) 1-2, str. 158-177.

- Visković, Nikola, »Jezik i životinja«, u: Suzana Marjanić, Antonija Zaradija Kiš (ur.), Kulturni bestijarij, Hrvatska sveučilišna naklada - Institut za etnologiju i folkloristiku, Zagreb 2007., str. 355-368.

- Visković, Nikola, »Jugoslavija jučer i danas. A sutra?«, Nedjeljna Dalmacija 10. 9. 1989., str. 27-28.

- Visković, Nikola, Kulturna zoologija. Što je životinja čovjeku i što je čovjek životinji, Naklada Jesenski i Turk, Zagreb 2009.

- Visković, Nikola, »Nakaradno je da naša etika uopće ne tretira životinje«, Novi list 30. 5. 2009., intervju (razgovarao Neven Šantić), str. [u prilogu Pogled] 10-11.

- Visković, Nikola, »Nepodnošljiva težina postojanja«, Novi list 18. 7. 2009., izjava (članak napisao Jerko Bakotin), str. 54-55.

- Visković, Nikola, »Nikola Visković: Smiljko Sokol i Ivan Milas žestoko su se oduprli mojem prijedlogu da životinje uđu u Ustav Republike Hrvatske!«, Globus 30. 7. 1999., intervju (razgovarao Drago Hudelist), str. 34-37.

- Visković, Nikola, »O erotoposu dirkanja«, Zarez 21. 10. 2004., str. 12-15.

- Visković, Nikola, Pojam prava. Prilog integralnoj teoriji prava, Logos, Split 1981.

- Visković, Nikola, »Političke elite su ekološki nepismene«, Feral Tribune 16. 8. 2003., intervju (razgovarao Toni Gabrić), str. 29-30.

- Visković, Nikola, Politički ogledi, Književni krug, Split 1990.

- Visković, Nikola, »Potičući množenje ljudi, Vatikan ugrožava biosferu«, Globus 28. 2. 2003., intervju (razgovarao Miljenko Jergović), str. 70-72.

- Visković, Nikola, Pravo kao kultura. Egološka teorija prava Carlosa Cossija, Izdavački centar Rijeka, Rijeka 1990.

- Visković, Nikola, »Prema političkom Savezu zelenih«, Nedjeljna Dalmacija 12. 11. 1989., str. 27.

- Visković, Nikola, »Prof. dr. sc. Nikola Visković«, u: Mirko Banjeglav (ur.), Hommage Zoranu Malenici, Redak, Split 2016., str. 377-379.

- Visković, Nikola, »Spolnost i pravo 1971.«, Zbornik radova Pravnog fakulteta u Splitu 45 (2008) 3, str. 641-658. 
- Visković, Nikola, Stablo i čovjek. Prilog kulturnoj botanici, Izdanja Antibarbarus, Zagreb 2001.

- Visković, Nikola, »Stiže nas osveta životinja«, Feral Tribune 28. 10. 2005., intervju (razgovarala Tena Erceg), str. 20-21.

- Visković, Nikola, Sumorne godine. Nacionalizam - bioetika - globalizacija, Kultura\&Rasvjeta, Split 2003.

- Visković, Nikola, »Šest načina odnosa prema životinji«, u: Nenad Cambi, Nikola Visković (ur.), Kulturna animalistika. Zbornik radova sa znanstvenog skupa održanog 29. rujna 1997. godine u Splitu, Književni krug, Split 1998., str. 11-15.

- Visković, Nikola, »U inat vladajućim idiotarijama«, Zarez 5.6.2003., intervju (razgovarao: Hrvoje Jurić), str. 8-10.

- Visković, Nikola, »Ujedinjavanje 'zelenih'«, Zaštita rada 30 (1989) br. 353, str. 5.

- Visković, Nikola, »Uvodna riječ«, u: Nenad Cambi, Nikola Visković (ur.), Kulturna animalistika. Zbornik radova sa znanstvenog skupa održanog 29. rujna 1997. godine u Splitu, Književni krug, Split 1998., str. 5-7.

- Visković, Nikola, »Većinski protiv razuma«, Borba 2. 2. 1990., intervju (razgovarao Živko Cerović), str. 8.

- Visković, Nikola, »Voljene životinje«, Zarez 3. 6. 2004., str. 15.

- Visković, Nikola, »Zakašnjelo i površno«, Tvrtka (1997) br. 15, str. 57-63.

- Visković, Nikola, »Zašto 'zeleni' u Dalmaciji?«, Slobodna Dalmacija 11. 11. 1988., str. 3.

- Visković, Nikola, Životinja i čovjek. Prilog kulturnoj zoologiji, Književni krug, Split 1996.

- Visković, Nikola et al., »Okrugli stolovi«, u: Bože Vuleta, Ante Vučković (ur.), Odgovornost za život. Zbornik radova sa znanstvenog simpozija održanog u Baškoj Vodi, 1. - 3. listopada 1999., Franjevački institut za kulturu mira, Split 2000., str. 643-667.

- Visković, Nikola et al., »Rasprave«, u: Bože Vuleta, Ante Vučković (ur.), Odgovornost za život. Zbornik radova sa znanstvenog simpozija održanog u Baškoj Vodi, 1. - 3. listopada 1999., Franjevački institut za kulturu mira, Split 2000., str. 621-642.

- Wood, Allen W., O'Neill, Onora, »Kant on Duties Regarding Nonrational Nature«, Proceedings of the Aristotelian Society, Supplementary Volumes 72 (1998), str. 189-228.

- Zagorac, Ivana, Bioetički senzibilitet, Pergamena - Znanstveni centar izvrsnosti za integrativnu bioetiku, Zagreb 2018.

- Zagorac, Ivana; Jurić, Hrvoje, »Bioetika u Hrvatskoj«, Filozofska istraživanja 28 (2008) 3, str. 601-611. 
- "Zelena akcija Split. Naši kandidati za Sabor SR Hrvatske«, Slobodna Dalmacija 19. 4. 1990., str. 29.

- Zimmerman, Michael E., »Rethinking the Heidegger-Deep Ecology Relationship«, Environmental Ethics 15 (1993) 3, str. 195-224.

- Zelena akcija, »Zeleni mir sada, rat - nikada«, Slobodna Dalmacija 15. 3. 1990., str. 11. 


\section{ŽIVOTOPIS AUTORA S POPISOM \\ OBJAVLJENIH DJELA}

Josip Guć rodio se u Splitu 1992. U Podstrani završava osnovnu školu, a u Splitu gimnaziju. Godine 2011. upisuje studij filozofije i povijesti na Filozofskom fakultetu Sveučilišta u Splitu, a magistar edukacije filozofije i povijesti postaje 2016. obranom diplomskog rada Prevladavanje etike kod Hegela i Marxa. Od 2017. zaposlen je kao asistent na Filozofskom fakultetu Sveučilišta u Splitu. Trenutno je voditelj Splitskog filozofskog kruga, tajnik Hrvatskog filozofskog društva i član upravnog odbora Hrvatskog bioetičkog društva. Sudjeluje kao organizator i izlagač na mnogim domaćim i međunarodnim znanstvenim simpozijima i ljetnim školama. Pored prikaza publikacija i simpozija, objavio je sljedeće znanstvene radove:

- Etički aspekti Camusova Pobunjenog čovjeka«, Filozofska istraživanja 37 (2017) 2, str. 271-287.

- $\quad$ Ekološka kriza između kulture i prirode«, u: Ana Štrkalj, Zoran Glavaš, Sanja Kalambura (ur.), $I^{\text {st }}$ International Conference The Holistic Approach to Environment. Proceedings Book, Association for Promotion of Holistic Approach to Environment, Sisak 2018., str. 211-221.

- „Treba li se kritika bojati svojih rezultata?«, Filozofska istraživanja 38 (2018) 2, str. $315-324$.

- $\quad$ »Samoostvarivanje živih bića i genetički modificirani organizmi u poljoprivredi«, Jahr 10 (2019) 2, str. 361-375.

- »Moralitet i legalitet u Kantovoj etici«, Theoria 63 (2020) 2, str. 17-40.

- »Mjesto koride u dvoznačnosti tradicije«, u: Branislava Vičar (ur.), Pojmovanja živalskih smrti: antropocentrizem in (ne)možne subjektivitete, Znanstveno-raziskovalno središče, Annales ZRS, Koper 2020., str. 55-70. 